FACULDADE DE ARQUITETURA E URBANISMO UNIVERSIDADE DE SÃO PAULO

\title{
SÃO PAULO E BUENOS AIRES: URBANISMO E ARQUITETURA 1870-1915
}

RICARDO HERNÁN MEDRANO

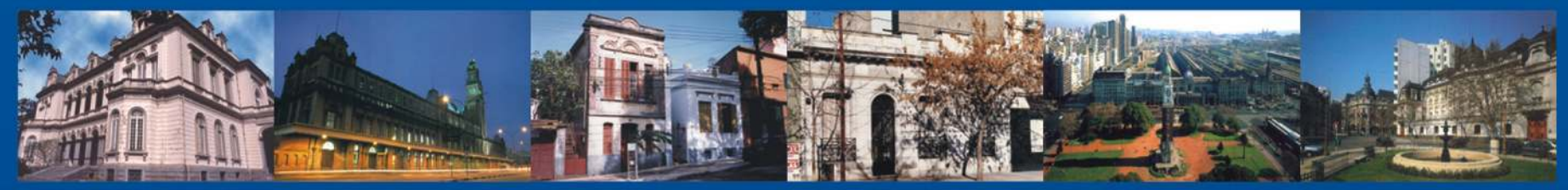


FACULDADE DE ARQUITETURA E URBANISMO UNIVERSIDADE DE SÃO PAULO

TESE DE DOUTORADO

\section{SÃO PAULO E BUENOS AIRES: URBANISMO E ARQUITETURA (1870-1915)}

Ricardo Hernán Medrano autor

Prof. Dr. Nestor Goulart Reis Filho orientador 


\section{AGRADECIMENTOS}

Uma tese é paradoxalmente uma obra solitária e coletiva ao mesmo tempo. Muitas foram as pessoas que me ajudaram neste trabalho, e certamente o nome de várias delas me foge à memória neste momento. Mesmo sabendo do risco de cometer injustiças, não posso deixar de agradecer a aqueles que de uma forma ou de outra contribuíram para que esta tese chegasse ao fim.

Agradeço em primeiro lugar ao meu orientador, prof. Dr. Nestor Goulart Reis Filho, dedicado e solícito em todos os momentos. A convivência quase diária no LAP Laboratório de Estudos da Urbanização, Arquitetura e Preservação - deixou como legado um enorme aprendizado, que está refletido de alguma maneira em cada página da tese. Ter sido seu orientando foi certamente um privilégio.

Não posso também deixar de agradecer à prof ${ }^{\mathrm{a}} \mathrm{Dr}^{\mathrm{a}}$ Rebeca Scherer, que foi minha orientadora na graduação e de quem tenho recebido constante apoio desde então. Sua qualidade intelectual e rigor teórico foram sempre uma referência para os momentos de impasse.

Aos membros da banca de defesa, prof. Dr. Carlos Guilherme Mota, $\operatorname{prof}^{\mathrm{a}} \operatorname{Dr}^{\mathrm{a}}$. Ivone Salgado e prof. Dr. Hugo Segawa,.

Aos membros das duas bancas de qualificação realizadas, $\operatorname{prof}^{a} \operatorname{Dr}^{a}$ Maria Lucia Refinetti, prof. Dr. Antonio Carlos Cabral Carpintero.

À Fapesp, que financiou duas bolsas de pesquisa, nos períodos de março de 1996 a agosto de 1998, e de novembro de 1999 a abril de 2002.

À Mariângela Portela da Silva, pela amizade e companheirismo, e incentivo nos momentos de dificuldade.

Aos colegas do LAP, pela ajuda e pela saudável convivência intelectual nesses anos todos: Ana Paula Koury, Antonio Xavier, $\mathrm{Dr}^{\mathrm{a}}$ Beatriz Piccolotto Siqueira Bueno, $\mathrm{Dr}^{\mathrm{a}}$ Eliza Miki Tahara, Maria Elena Bergamin, Dr $^{a}$ Marta Tanaka, Mônica Silveira Brito, Stepan Chahinian, Yara Reis, Vera Marques, e aos muitos estagiários que passaram pelo laboratório.

À $\operatorname{prof}^{\mathrm{a}} \mathrm{Dr}^{\mathrm{a}}$ Regina Meyer, que gestou os contatos que tornaram possível a viagem à Espanha.

A todos os funcionários da FAUUSP que de alguma forma contribuíram para que esta tese fosse possível, particularmente àqueles das seções que foram mais solicitadas: Biblioteca, Secretaria de Pós-graduação e Laboratório de Programação Gráfica.

Aos professores das diversas disciplinas de pós-graduação que cursei: Gustavo Neves da Rocha Filho, Marta Dora Grostein, Philip Gunn, Murillo Marx, Celso Lamparelli, Lucio Gomes Machado, Paulo Bruna e Jorge Oseki.

Aos funcionários dos diversos acervos e bibliotecas que consultei.

Aos amigos Terezinha de Oliveira Gonzaga, Eduardo Moreno, Antonio Soukef, Alejandro e Elena Mascitti. 
Em Buenos Aires devo agradecer particularmente a Ana Maria Lang, do Instituto de Arte Americana e Investigaciones Estéticas "Mario J. Buschiazzo", que além da amizade, facilitou enormemente minha tarefa, ao indicar caminhos e contactar os pesquisadores locais. Destaco também a ajuda de Adrián Gorelik, Alicia Novick, Alberto de Paula, Clara Hendlin, Horacio Caride, Jorge F. Liernur e Margarita Gutman.

Nesta cidade não posso deixar de reconhecer a eterna dívida que tenho com Ramón Gutierrez, que foi o principal responsável pela minha descoberta da arquitetura latinoamericana, ainda na graduação, e pela decisão de estudá-la. Também aos integrantes do CEDODAL, particularmente a Patrícia Méndez.

Em Barcelona a Jordi Borja, que aceitou ser meu orientador, apesar do tempo escasso de que dispunha. Também a Zaida Muxi, Frances Muñoz, Fernando Alvarez, Andrés Passaro, Laís Bronstein e Pilar Pérez-Calvo.

Em Montevidéu a Carlos Altezor e aos pesquisadores do Instituto de Historia de la Arquitetura, da Universidad de la República. Também a Adela Pellegrino.

Em Porto Alegre a Luis Merino.

Em Salta a Carlos Alberto Puig e María Victoria Alcaráz.

Em Santiago do Chile a Patrício e Gloria Alarcón, e família.

Por último um agradecimento muito especial à minha família, sem cujo apoio teria sido impossível levar adiante esta empresa: meus pais Ricardo Enrique Medrano e Lilia Ines Zanotti de Medrano, minhas irmãs Cecília Ines, Maria Silvina e Veronica Laura. A Pipo e Vaqui. E à minha família na Argentina, que me acolheu em minhas viagens de pesquisa. 


\section{RESUMO}

Neste trabalho é realizada uma comparação entre diversos aspectos da arquitetura e do urbanismo em São Paulo e Buenos Aires, no período de 1870 a 1915. São abordados a rede urbana regional e internacional, as intervenções nas áreas centrais, a habitação das elites, a produção do espaço público, o traçado e a produção habitacional para as camadas médias.

Faz-se uso principalmente de fontes iconográficas e cartográficas, as quais são examinadas através de categorias de análise da organização do espaço intra-urbano.

Identificando-se o que é geral e o que é particular é possível tanto estudar a urbanização na América Latina como avaliar os modelos de explicação para cada núcleo urbano. No primeiro caso através da identificação de regularidades existentes no sistema urbano do continente. Essas mesmas regularidades gerais permitem avaliar os modelos teóricos desenvolvidos para um núcleo urbano em outro, já que havendo condições semelhantes, deveriam valer as mesmas explicações.

Com isto, procura-se contribuir ao estudo da urbanização na América Latina a partir das especificidades, com ênfase particular na arquitetura e no urbanismo em ambas cidades. Também se busca mostrar que para explicar essa materialização de projetos é necessário entender uma articulação de movimentos que vão além das determinações geradas pela nova divisão internacional do trabalho. Estas, embora centrais, respondem pelas generalidades, mas não explicam as especificidades, o que exige uma abordagem que reconheça a existência de outras racionalidades, nas quais são atribuídos papéis específicos aos diferentes espaços e escalas.

Palavras-chave: São Paulo, Buenos Aires, América Latina, História da Arquitetura, História do Urbanismo, Estudos da Urbanização. 


\section{RESÚMEN}

En este trabajo ha sido realizado un estudio comparativo entre diversos aspectos de la arquitectura y del urbanismo en las ciudades de San Pablo y Buenos Aires, en el período de 1870 a 1915. Se enfoca la red urbana regional e internacional, las intervenciones en los áreas centrales, la habitación de las élites, la producción del espacio público, el trazado y la producción habitacional para los grupos medios.

Se emplean, principalmente, fuentes iconográficas y cartográficas, las cuales son examinadas a través de categorías de análisis de la organización del espacio intraurbano.

Por la identificación de lo que es general y lo que es particular es posible estudiar tanto la urbanización en América Latina como evaluar los modelos de explicación para cada núcleo urbano. En el primer caso, a través de la identificación de regularidades existentes en el sistema urbano del continente. Esas mismas regularidades generales permiten evaluar los modelos teóricos desarrollados para un núcleo urbano en otro, ya que habiendo condiciones semejantes, deberían valer las mismas explicaciones.

De esta forma, se intentó contribuir al estudio de la urbanización en América Latina a partir de las especificidades, con particular énfasis en la arquitectura y en el urbanismo, en ambas ciudades. También se intenta mostrar que para explicar esa materialización de los proyectos es necesario entender una articulación de movimientos que van más allá de las determinaciones generadas por la nueva división internacional del trabajo. Estas, a pesar de centrales, responden por las generalidades, pero no explican las especificidades, lo que exige un enfoque que reconozca la existencia de otras racionalidades, en las cuales son atribuidos papeles específicos a los diferentes espacios y escalas.

Palabras-llave: San Pablo, Buenos Aires, América Latina, Historia de la Arquitectura, Historia del Urbanismo, Estudios de la Urbanización. 


\section{ABSTRACT}

This work compares several architectural and urbanistic aspects between São Paulo and Buenos Aires in the period 1870-1915, addressing the regional and international urban network, interventions in central areas, elite housing, the production of public spaces, urban shape and the production of middle-class housing.

This study mostly uses iconographic and cartographical sources, which are studied through the analysis categories of the intra-urban space organisation.

The discrimination between general and particular aspects is essential not only to study urbanism in Latin America through the identification of similarities in the urban system of the American continent, but also to evaluate the explanation models for each urban nucleus. General similarities are important to assess whether a theoretical model developed for one urban nucleus suits another, since the same explanations should apply to similar conditions.

The aim of this work is then to contribute towards knowledge broadening on urbanisation in Latin America based on specificities with focus on the architecture and urbanism of both cities. In order to explain this materialisation of projects, it is necessary to understand the determinations of the new international division of labour, which, albeit of a central nature, can explain generalities, not specificities. The latter requires the acknowledgement of the existence of other rationalisations, in which different spaces and scales are assigned specific roles.

Key-words: São Paulo, Buenos Aires, Latin America, History of Architecture, History of Urbanism, Urbanisation Studies. 


\section{SUMÁRIO}

1. INTRODUÇÃO 1

1.1. A escolha do tema 2

1.2. Pressupostos teóricos 3

1.2.1. Urbanização na América Latina 3

1.2.2. Arquitetura e Urbanismo 10

1.2.3. Conceito de urbanização 12

1.2.4. Relação entre espaço e sociedade 13

1.2.5. A interdisciplinaridade 14

1.2.6. Uma Teoria da Urbanização 15

1.3. Conclusões e proposta 16

1.4. Comentários sobre procedimentos 19

2. CARACTERIZAÇÃO GERAL 21

2.1. O mundo 22

2.2. As sociedades brasileira e argentina 23

2.3. Arquitetura e urbanismo 29

2.3.1. A cidade européia $\quad 29$

2.3.2. A cidade inacabada 32

2.3.3. Infra-estrutura 33

2.3.4. Indústrias 36

2.3.5. Habitação precária 38

3. A REDE URBANA REGIONAL E INTERNACIONAL 40

3.1. Introdução 41

3.2. A rede urbana geral 41

3.3. Migrações 50

3.4. A rede urbana latino-americana 55

3.5. Conclusões 60 
4. INTERVENÇÕES NAS ÁREAS CENTRAIS

4.1. Introdução 63

4.2. Em São Paulo 63

4.3. Em Buenos Aires 66

4.4. Em outras cidades latino-americanas $\quad 67$

4.5. As referências regionais $\quad 70$

4.6. O problema das referências e influências $\quad 72$

4.7. Conclusões 78

5. HABITAÇÃO DAS ELITES

5.1. São Paulo $\quad 82$

5.2. Buenos Aires 84

5.3. Comparação $\quad 86$

6. PRODUÇÃO DO ESPAÇO PÚBLICO: OS PARQUES 88

6.1. Antecedentes 89

6.2. Dois parques 90

6.3. Outros espaços 92

6.4. A vegetação nas residências 95

6.5. A escolha dos sítios 98

6.6. Os sistemas de parques $\quad 99$

6.7. Os quadros profissionais 102

6.8. Conclusões 103

7. TRAÇADO: RUAS, QUADRAS E LOTES 105

7.1. Antecedentes 106

7.2. Aspectos Formais 111

7.2.1. O desenho 111

7.2.2. A área ocupada 114

7.2.3. Alguns agentes sociais $\quad 115$

7.2.4. A legislação 117

7.2.5. As Tipologias resultantes 119

7.3. Conclusões 121 
8. A "CASA DE PORÃO ALTO" E A "CASA-CHORIZO" 123

8.1. Caracterização 124

8.2. $1^{\mathrm{a}}$ Hipótese 132

8.3. $2^{\mathrm{a}}$ Hipótese 134

8.4. $3^{\mathrm{a}}$ Hipótese 135

8.5. $4^{\mathrm{a}}$ Hipótese 136

8.6. Discussão 140

8.7. Conclusões 145

9. CONSIDERAÇÕES FINAIS 146

10. REFERÊNCIAS BIBLIOGRÁFICAS 153 
CAPÍTULO 1

INTRODUÇÃO 


\section{1 - A ESCOLHA DO TEMA}

Antes de identificar a relação entre este tema de estudo e o quadro teórico no qual se insere, é importante destacar alguns aspectos que levaram à sua escolha. Esta é sempre um processo de risco. Para diminuí-lo, é conveniente pautar a escolha pela observação de alguns elementos que permitam vislumbrar boas possibilidades de construção de séries de dados, de tal forma que seja possível uma futura sistematização e conseqüente construção de modelos teóricos. ${ }^{1}$

No caso de São Paulo e Buenos Aires, havia algumas características que em princípio atendiam a esses requisitos.

Nosso período de estudo situa-se entre fins do século XIX e início do XX. Em geral, nos estudos urbanos, esta etapa é caracterizada como o momento em que há uma nova divisão internacional do trabalho, na qual as nações mais desenvolvidas produzem e fornecem produtos industrializados e as menos fornecem matériasprimas. Assim, em países como Brasil e Argentina, estrutura-se uma rede urbana regional em forma de "pé-de-galinha", com foco em cidades situadas junto a portos. Segundo esta visão, é em cidades como São Paulo (que forma um sistema com Santos, onde está o porto) e Buenos Aires onde ocorre a intermediação destes fluxos de mercadorias e capitais.

Em segundo lugar há o fato de que tanto uma como a outra irão se transformar nos principais centros industriais de seus países, e nos maiores núcleos urbanos. Além disso, são em meados do século XIX, pequenas cidades que em pouco tempo irão experimentar um crescimento físico e demográfico acelerado; em ambos casos devido em grande parte à imigração européia. Estes imigrantes, por sua vez, terão grande importância na construção civil e na arquitetura, principalmente os italianos.

A introdução de inovações técnicas também é uma característica marcante nas duas cidades no período. Neste caso, verificamos que apesar de Buenos Aires ser, na virada do século XIX para o XX, razoavelmente maior que São Paulo, inovações como energia elétrica e bondes ocorrem de forma simultânea.

Em resumo, havia algumas condições favoráveis para a análise, já que tanto havia fatores comuns, que permitem a construção de séries, como também diferenças, o que permite avaliar os modelos teóricos elaborados sobre cada cidade.

Há ainda é um fator biográfico, que é o fato de termos morado em ambas cidades. Este também foi um incentivador já que julgamos que esta vivência permitiria em parte evitar um olhar de "estrangeiro" sobre a cultura e o espaço, permitindo, ao menos em princípio, realizar um trabalho mais abrangente do que a simples soma de pesquisadores especialistas em cada cidade.

\footnotetext{
${ }^{1}$ REIS FILHO, Nestor Goulart. Séries e escalas. (inédito).
} 


\section{2 - PRESSUPOSTOS TEÓRICOS}

Existem dois enfoques principais nesta pesquisa. Ambos ficarão mais claros após a apresentação dos referenciais teóricos e do estado atual das pesquisas na área. Entretanto, é importante desde já explicitá-los, com o objetivo de direcionar a leitura.

Primeiramente, pelo fato de tomarmos como objeto duas cidades, estamos necessariamente também abordando o estudo da urbanização na América Latina. Por este motivo iremos apresentar inicialmente um breve quadro da produção teórica sobre esta temática, elencando as principais correntes e a situação atual das pesquisas.

Em segundo lugar, esta pesquisa procura abordar o espaço a partir de uma maior aproximação ao trabalho específico do arquiteto, que é o da arquitetura e do urbanismo. A ênfase no projeto, neste caso, refere-se às ações que procuram a efetiva materialização das iniciativas. Assim sendo, faremos apenas alguns breves comentários sobre esta área de pesquisa, já que como nesta tese daremos ênfase aos aspectos empíricos (o que também explicaremos mais adiante) maiores dados serão colocados durante a exposição.

Além desses dois tópicos, também iremos definir alguns dos principais conceitos e categorias que usamos, e no final, apresentamos um resumo posicionando esta tese em relação às discussões que faremos à continuação, e a explicitação de qual é a tese proposta.

\subsection{1 - Urbanização na América Latina}

A partir da segunda metade do século XIX, principalmente a partir da década de 1870, diferentes partes do mundo passam a estar conectadas em um grau inédito até aquele momento. Nunca antes na história da humanidade regiões distantes milhares de quilômetros estiveram tão fortemente relacionadas, fenômeno este que foi bem descrito e analisado por Hobsbawm, na clássica obra "A era dos Impérios".2

Mais adiante voltaremos a esta questão ao estudar a rede urbana internacional. Mas o fato é que naquele momento a América Latina forma um sistema com uma série de características semelhantes, e é possível identificá-lo como uma unidade frente aos países mais desenvolvidos da Europa.

Os estudos sobre a urbanização na América Latina tomaram particular importância principalmente a partir dos anos 1950. Trata-se de um período em que há uma urbanização acelerada, resultado tanto de intensas migrações rural-urbanas,

\footnotetext{
${ }^{2}$ HOBSBAWM, Eric J. A era dos Impérios. 1875-1914. $7^{\text {a }}$ ed. Rio de Janeiro, Paz e Terra, 1988.
} 
como também de componentes demográficos, como uma alta taxa de natalidade associada à melhoria dos padrões higiênicos que reduzem as taxas de mortalidade.

Não apenas na América Latina dava-se ênfase ao estudo deste continente, com o objetivo de resolver os enormes problemas decorrentes da urbanização, mas era também objeto de interesse em todo o mundo devido, entre outros motivos, às agitações sociais. Hobsbawm, em sua autobiografia, assim coloca este período:

\begin{abstract}
"Após o triunfo de Fidel Castro, e mais ainda depois do insucesso da tentativa dos EUA de derrubá-lo na baía dos Porcos, em 1961, não havia intelectual na Europa ou nos Estados Unidos que não sucumbisse ao feitiço da América Latina, continente onde aparentemente borbulhava a lava das revoluções sociais". ${ }^{3}$
\end{abstract}

Desde essa época, foram desenvolvidas várias linhas teóricas para explicar e auxiliar na formulação de saídas para a superação dos problemas detectados. O quadro das diferentes correntes teóricas é complexo. Felizmente uma recuperação deste conhecimento foi competentemente realizada por Rebeca Scherer. ${ }^{4}$ A partir desta obra, podemos de forma bem resumida dividir esta produção em três grandes linhas principais:

Uma é a linha positivista, derivada da obra de Durkheim. Uma parte dos estudos desenvolvidos baseia-se em pesquisas realizadas na Escola de Chicago (conhecida também como "Escola da Ecologia Urbana"). Uma de suas características principais é a identificação de analogias com a biologia, e a utilização como instrumento dos "tipos médios". Neste caso, verifica-se em que medida os comportamentos se aproximam ou se afastam destes. Como decorrência, tal como na biologia onde todos os seres vivos nascem e morrem da mesma forma em qualquer lugar, todas as sociedades devem percorrer os mesmos caminhos, o que significa que a sociedade Latino-Americana estaria apenas mais atrasada, presumindo como modelo de adiantamento os países europeus. Qualquer desvio desse caminho é considerado patológico. Um exemplo é a chamada teoria da modernização. ${ }^{5}$

A corrente weberiana não utiliza analogias com a biologia, e procede à análise através dos "tipos ideais" (comunidade-sociedade, rural-urbano, etc.). Um dos

\footnotetext{
${ }^{3}$ HOBSBAWM, Eric J. Tempos interessantes. Uma vida no século XX. São Paulo, Companhia das Letras, 2002 , p. 396.

4 Ver o capítulo intitulado "Recuperação sucinta da história da reflexão sobre a urbanização e o planejamento no Brasil e América Hispânica" em: SCHERER, Rebeca. Sistematização Crítica do Conjunto dos Trabalhos. Tese de Livre Docência. São Paulo, FAUUSP, 1994. Ver também da mesma autora: Notas sobre Planejamento e Método. Cadernos de Pesquisa do LAP 10. São Paulo, FAUUSP, nov. dez. 1995. Para uma visão sobre as teorias da urbanização até fins da década de 1960, ver REIS FILHO, Nestor Goulart. Urbanização e Teoria. São Paulo, Edição do autor, 1967. Uma visão mais atual está em: REIS, Nestor Goulart. Notas sobre a evolução dos estudos de História da Urbanização e do Urbanismo no Brasil. Cadernos do LAP 29. São Paulo, FAUUSP, jan. jun. 1999. Uma revisão das teorias sobre a geografia na América Latina pode ser encontrada em LEMOS, Amalia Ines Geraiges de. Modernidade e Metrópoles Latino-americanas. Rio de Janeiro e Buenos Aires. Tese de Livre-docência. São Paulo, FFLCH-USP, 1996.

${ }^{5}$ A respeito das abordagens positivistas afirma esta autora: “... as abordagens positivistas até então vigentes de nada nos serviam. Na medida em que supunham um processo unilinear de evolução, com crescente diferenciação e conducente a um suposto progresso universal, podiam quando muito descrever fenômenos num momento dado mas não permitiam nem explicá-los e menos ainda explicar aqueles que ocorriam de modo diverso dos padrões habituais." SCHERER, Rebeca. História, Teoria e Método nos Estudos de Urbanização. Cadernos de Pesquisa do LAP 10. São Paulo, FAUUSP, nov. dez. 1995, p. 24.
} 
problemas derivados desta linha é que não permite a análise dos processos de mudança. Não será demais lembrar que o conceito de cidade de Max Weber refere-se a uma cidade estática, e não em transformação. ${ }^{6} \mathrm{O}$ Estado não é neutro como no positivismo, mas depende de quais grupos estão no poder, daí o viés voluntarista de muitas destas propostas. Muitos foram os planos propostos a partir desse paradigma, em geral muito elaborados e repletos de informações. Procurava-se com isto passar a idéia de que os dados ali reunidos seriam suficientes para planejar, sem que fosse necessária a participação política. Segundo Scherer, "Identificava-se no capitalismo o avanço da racionalidade, e por esta via supunham-se asseguradas a eficiência e eficácia do planejamento, que era assim legitimado pela ciência e pela tecnologia".

A abordagem marxista, através do método histórico-estrutural permitiu incorporar duas contribuições importantes para a formulação de instrumentos de análise mais adequados à realidade das sociedades latino-americanas: a dimensão ideológica (relações de poder), e a possibilidade da existência de múltiplas racionalidades. Desta forma, é possível formular propostas que tragam implícita a idéia de que as diferentes sociedades podem se desenvolver percorrendo caminhos diversos, e não apenas os mesmos trilhados pelos países mais desenvolvidos. ${ }^{8}$ No âmbito dos estudos urbanos, corresponde à substituição do uso da palavra "evolução" (um único caminho, como na biologia) por "desenvolvimento" (múltiplos caminhos). Além disso, permite situar socialmente a produção das pesquisas, já que neste paradigma não existe objetividade absoluta. Também é diferente a intermediação entre a sociedade e o Estado, pois a sociedade é considerada como formada por classes estruturalmente antagônicas, sendo o Estado um aparelho da classe dominante.

Esta visão teórica permite também introduzir um importante conceito que é o da especificidade nas pesquisas: partimos do princípio de que há um processo e que este é histórico. ${ }^{9}$ Ou seja, os modelos devem ser referidos à lógica da sociedade em análise. Disto decorre, como já colocamos acima, que as possibilidades de intervenção, objetivo final das pesquisas na área de arquitetura e urbanismo, permitem múltiplos caminhos, não necessariamente iguais aos percorridos por outros países (os mais e os menos desenvolvidos).

Para abordar a sociedade desta forma, Rebeca Scherer utiliza o conceito de "formação social", que permite

“... distinguir as peculiaridades presentes nas diferentes sociedades em que pese sua inserção nos macro-sistemas; isto é, dentro do sistema capitalista existem diferentes formações sociais. Essas, embora capitalistas, possuem uma

\footnotetext{
${ }^{6}$ WEBER, Max. The city. Tradução e edição de Don Martindale e Gertrud Neuwirth. Glencoe III, Free Press, 1958.

7 SCHERER, Rebeca. Sistematização Crítica do Conjunto dos Trabalhos. Tese de Livre Docência. São Paulo, FAUUSP, 1994, p. 186.

${ }^{8}$ Marx não trabalhou a questão da relação com a América Latina já que viveu apenas no início deste processo (embora tenha se interessado pelas culturas pré-colombianas, que associou em algum grau ao sistema asiático). Entretanto, esta posição provém do paradigma marxista, já que, segundo Marx, o homem pode libertar-se e criar seu próprio caminho.

9 Para uma recuperação da história das pesquisas sobre urbanização na Faculdade de Arquitetura e Urbanismo da USP, ver SCHERER, Rebeca. Op. cit. e Reis Filho, Nestor Goulart. Algumas Raízes. Origens dos trabalhos regulares de pesquisa sobre História da Arquitetura, da Urbanização e do Urbanismo no Brasil. O Estudo da História na Formação do Arquiteto. São Paulo, Revista Pós Número Especial, 1994.
} 
história que Ihes é própria do ponto de vista das relações sociais internas e das relações específicas com o conjunto do sistema. Assim sendo apresentam traços que Ihes são específicos e que podem, como no caso brasileiro é fácil constatar, combinar desde o capitalismo mais avançado até formas pré-capitalistas, passando por todas as variações que comporta. Alguns aspectos de seu evolver são recorrentes, repetem-se tanto em sua história como na própria história do sistema, outros são emergentes, decorrem de condições específicas surgidas ao longo de seu desenvolvimento."10

Mais adiante abordaremos com maiores detalhes alguns aspectos da organização social em ambos países e cidades. Mas não há dúvida de que em nosso caso estamos tratando de regiões que apresentam algumas particularidades. Por exemplo, o sistema social brasileiro comportou a escravidão até fins do século XIX, quando foi oficialmente abolida. Com isto, uma grande massa de descendentes de escravos passa a formar um segmento social em grande parte marginalizado, situação que perdura ainda hoje.

Nos países hispano-americanos a escravidão variou de uma região para outra. No caso específico da Argentina, a população de origem africana trabalhava principalmente em serviços domésticos. Embora durante a colônia representasse uma parte significativa do total, as sucessivas guerras e epidemias acabaram dizimando-a e no período que nos toca ela era proporcionalmente muito menor do que em São Paulo. O caso deste segmento social é um exemplo de que estamos comparando sistemas sociais diferentes.

A discussão sobre esta produção teórica é extensa e escapa aos objetivos deste trabalho. Mas queremos salientar que durante um determinado período de pouco mais de duas décadas houve intensa preocupação em realizar análises sobre a América Latina como um todo. ${ }^{11}$

A motivação seria a constatação de que havia mais em comum do que diferenças entre os diversos países, o que justificava esta abordagem. Por exemplo, citamos Rofman:

“... existen aspectos fundamentales comunes al sistema económico-social de las unidades nacionales incorporadas a la región que disimulan de manera significativa cualquier diferencia observable en la superficie de los procesos económicos, políticos o sociales que tienen lugar en cada uno de los países. Es por dicha razón que aceptamos a la realidad latinoamericana como una presencia única, pasible de ser estudiada a través de un marco teórico propio." ${ }^{12}$

Após os anos 70, incrementam-se os estudos com enfoque no intraurbano, enquanto perdem força as visões mais gerais. As causas disto podem talvez

\footnotetext{
${ }^{10}$ SCHERER, Rebeca. História, Teoria e Método nos Estudos de Urbanização. Cadernos de Pesquisa do LAP 10. São Paulo, FAUUSP, nov. dez. 1995, p. 23.

11 Para um balanço da historiografia sobre a América Latina até 1985, ver MOTA, Carlos Guilherme. América Latina: em busca da memória comum. Ciência e Cultura 38(1), p. 110-120.

12 ROFMAN, Alejandro Boris. Dependência, estructura de poder y formación regional en América Latina. $2^{\mathrm{a}}$ ed. México, Siglo Veintiuno Editores, 1977.
} 
ser encontradas nos golpes militares que reprimiram diversas abordagens, e pelo pouco resultado prático obtido, desfazendo inclusive um otimismo latente que então existia. ${ }^{13}$ Scherer destaca esta mudança:

"Sob acentuada influência da sociologia marxista francesa, em sua versão eurocomunista, e também inspirados pelo aumento de participação popular nos governos socialistas da Europa ocidental, e ainda em função do contato acadêmico estabelecido nos anos de ditadura, começamos também no Brasil a colocar maior ênfase nos movimentos sociais e na análise dos diferentes setores do capital a nível intraurbano, perdendo de vista aqueles dados estruturais ligados à posição do País na rede internacional e também à modalidade de regulação internamente existente".

Conseqüentemente:

"A ênfase nos estudos passa para o intraurbano com graves prejuízos para a reflexão. Além desta ênfase, na esteira da crítica ao estado autoritário, passa-se da crítica estrutural para a institucional com as discussões sobre descentralização e participação, desligadas de seu componente mais básico de ordem estrutural qual seja a divisão internacional do trabalho." ${ }^{" 14}$

Hardoy também critica a forma desarticulada com que são tratadas as diversas escalas em pesquisas desenvolvidas em importantes instituições, como a CEPAL (Comissão Econômica para a América Latina) e ILPES (Instituto Latinoamericano de Planejamento Econômico e Social):

"Foram poucas as contribuições da CEPAL e do ILPES ao planejamento e desenvolvimento local urbano, que continuou a ser tratado, na maioria dos casos, e apesar da reconhecida gravidade da situação urbana, de maneira isolada com respeito ao planejamento nacional e regional"15

\footnotetext{
${ }^{13}$ Em 1969 dizia Hardoy a respeito de como poderiam ser as cidades latino-americanas no ano 2000: " $\mathrm{La}$ futura forma y estructura interna de la ciudad sólo pueden ser un motivo de especulación y en ellas influirá la tecnología prevaleciente. Es previsible que exista una forma urbana nueva como consecuencia del empleo de inventos conocidos y aún no utilizados y de nuevos descubrimientos. Seguramente existirán veloces sistemas masivos de transporte que permitirán conectar en menos tiempo a puntos distantes de una región urbana cada vez más extensa, la disponibilidad de agua no constituirá una limitación ya que será económica la transformación del agua salada, se habrán adoptado sistemas distintos en la disposición de los residuos, la televisión jugará un rol importante en la comercialización de los productos, plantas atómicas suministrarán energía a los hogares, la industria y el transporte, la construcción se habrá industrializado masivamente, nuevos medios de comunicación permitirán a la población una más simple recepción de conocimientos y la recreación y la educación continua absorberán un porcentaje importante dentro de jornadas con horas menos intensas de trabajo, el mercado de tierras no podrá operar como hasta ahora y el estado habrá intervenido como corrector y conductor del desarrollo urbano." HARDOY, Jorge E.; TOBAR, Carlos. La urbanización em América Latina. Buenos Aires, Editorial del Instituto, 1969, p. 17.

${ }^{14}$ SCHERER, Rebeca. Sistematização Crítica do Conjunto dos Trabalhos. Tese de Livre Docência. São Paulo, FAUUSP, 1994, p. 229.

15 HARDOY, Jorge E. La investigación urbana en América Latina durante las últimas décadas. In: CARRION, Fernando; LINDA, Mario; CORAGGIO, José Luis. La Investigacion Urbana en América Latina:
} 
É importante frisar, entretanto, que a maioria das obras refere-se mais aos aspectos sociais da urbanização (pobreza, incorporação de migrantes rurais, desemprego, marginalidade, etc.) do que aos aspectos físicos. Mesmo quando estes estão presentes, são tratados de forma geral, sem maiores preocupações com o intraurbano, e menos ainda quanto aos aspectos da arquitetura e do urbanismo. ${ }^{16}$

Ao estudar o espaço, trabalhamos em três níveis: a sociedade, a arquitetura e o urbanismo, e a rede urbana em suas diferentes escalas - internacional, nacional e local. ${ }^{17}$ Neste último caso, somente através de mudanças de escala é possível identificar os diferentes fatores que são determinantes para a apropriação, produção, uso e transformação do espaço. ${ }^{18}$

No caso da rede urbana internacional, manifestam-se no período que estudamos alguns fenômenos importantes nas relações capitalistas. O final do século XIX corresponde ao período em que pela primeira vez, na Europa, a produtividade agrícola permite diminuir significativamente as crises de subsistência provocadas pelas variações nas safras. É portanto o momento em que os indicadores sociais, como expectativa de vida e mortalidade infantil, experimentam grandes avanços.

Quanto à relação entre a rede urbana latino-americana e a internacional, certamente ainda há muito que estudar. Ainda hoje faltam trabalhos que se proponham a uma abordagem conjunta de ambas redes. ${ }^{19}$ Mesmo no período em que se enfatizava o estudo da América Latina, esta relação era abordada principalmente quanto às questões de dominação, como evidenciam palavras que eram usuais, como "dependência" e "Imperialismo".

$\mathrm{Na}$ historiografia sobre urbanização na América Latina existem dois trabalhos pioneiros que muito contribuíram para a realização de abordagens conjuntas dos aspectos da arquitetura e do urbanismo, e dos instrumentos das ciências sociais para o estudo da urbanização. Em 1964 surge Evolução Urbana do Brasil, ${ }^{20}$ onde é tratado o período histórico de 1500 a 1720. Nesta obra já estava presente a abordagem dinâmica da urbanização, que supera as limitações de muitos modelos utilizados até então, como os derivados de Max Weber, onde a análise dos fenômenos urbanos é realizada a partir de "tipos", que não são adequados para explicar transformações. Trata-se agora de entender não apenas determinada situação em si, mas sim como ela muda, ou seja, quais os mecanismos de mudança.

Caminos Recorridos y por Recorrer. 3v. Quito, CIUDAD, 1989-1990. vol. 3. p. 9-64. Citado in SCHERER, Rebeca. Op. cit. p. 216.

${ }^{16}$ São exemplos de abordagens de conjunto com ênfase no urbanismo os seguintes trabalhos: El paisaje urbano de América del Sur. In: HARDOY, Jorge E. Las ciudades en America Latina. Seis ensayos sobre la urbanización contemporánea. Buenos Aires, Paidos, 1972; SUÁREZ, Odilia E. El diseño urbano en América Latina. In: HARDOY, Jorge E.; TOBAR, Carlos. La urbanización em América Latina. Buenos Aires, Editorial del Instituto, 1969.

${ }^{17}$ MEDRANO, Ricardo Hernán. Resumos das aulas do Prof. Nestor Goulart Reis Filho na disciplina AUH 237 Urbanização e Urbanismo no Brasil I. Cadernos de Pesquisa do LAP 19. São Paulo, FAUUSP, 1997.

${ }_{18}$ Que Lefebvre, baseado em Marx, chama de "operar un cambio de escala para ir del elemento al todo". LEFEBVRE, Henri. El Materialismo Dialéctico. Buenos Aires, Ed. La Pleyade, 1971, p. 140.

${ }^{19}$ A rigor, estamos estudando a relação entre a rede urbana latino-americana e a européia. Por uma questão de recorte, não estamos considerando a experiência estadunidense, que certamente permitiria incorporar muitos dados interessantes, o que, ao que saibamos, ainda não foi feito.

${ }^{20}$ REIS FILHO, Nestor Goulart. Contribuição ao estudo da evolução urbana do Brasil (1500-1720). São Paulo, Pioneira, 1968 
Outra consideração importante é a de que este processo é social. Isto significa que para entendê-lo, e a arquitetura e o urbanismo produzidos, é necessário compreender a relação entre espaço e sociedade. Reis Filho, no trabalho acima citado, mostra que para explicar a urbanização no Brasil naquele período é necessário analisar a sociedade no seu conjunto. Foi possível assim entender melhor a relação entre as políticas colonizadora e urbana no período, dentro do contexto social (econômico, político, cultural) da época.

Simultaneamente a este trabalho, surge escrita por Jorge E. Hardoy a obra Ciudades Precolombinas. Trabalhando em direção semelhante, verifica as limitações de conceituações quando aplicadas às cidades pré-colombianas, entre elas os dez critérios propostos por Childe para diferenciar uma cidade de uma aldeia prévia. Isto permite aperfeiçoar o conceito de cidade:

"El concepto de ciudad es esencialmente dinámico y evoluciona con el tiempo y el lugar, estando condicionado por el medio ambiente, la estructura socio-económica y el nivel tecnológico de la sociedad a la cual pertenece el observador."21

Em relação ao conceito de especificidade, Hardoy justifica o estudo destas antigas culturas na América pelo fato, segundo sua análise, destes sistemas sociais na época ainda persistirem na América Latina, o que diferencia a organização social neste continente da existente em outros.

Ambos trabalhos acima citados foram pioneiros em questionar a validade de modelos teóricos baseados em outros contextos, em geral europeus, que eram utilizados aqui sem a devida crítica. Mostraram que aqueles não eram adequados para descrever a realidade empírica aqui observada.

Também é importante destacar quão recentes são estes estudos, principalmente quando comparados com outras áreas das ciências sociais: segundo Hardoy, somente em 1972 é que teria sido possível utilizar...

"pela primeira vez uma bibliografia sobre temas regionais e urbanos totalmente composta por autores latino-americanos." ${ }^{22}$

Uma das contribuições recentes mais importantes foi dada por Flávio Villaça, no trabalho Espaço intra-urbano no Brasil. ${ }^{23}$ Embora não chegue à escala da arquitetura e do urbanismo, estuda o intra-urbano de várias cidades brasileiras, e questiona os estudos existentes por utilizarem os mesmos modelos teóricos para tratar tanto o regional como o intra-urbano. Nesta pesquisa mostra que essas duas dimensões seguem lógicas distintas exigindo, portanto, abordagens diferentes.

\footnotetext{
${ }^{21}$ HARDOY, Jorge Enrique. Ciudades Precolombinas. Buenos Aires, Ed. Infinito, 1964, p. 19.

${ }^{22}$ Citado em SCHERER, Rebeca. Op. Cit, p. 209.

23 VILLAÇA, Flávio. Espaço intra-urbano no Brasil. São Paulo, Studio Nobel/Fapesp/Lincoln Institute, 1998.
} 


\subsection{2 - Arquitetura e Urbanismo}

Os estudos sobre arquitetura e urbanismo na América Latina se iniciam muito timidamente no final do século XIX. A partir dos anos 1920 ganharão impulso através, entre outros, de movimentos como o neocolonial, que procurava incorporar elementos autóctones a uma arquitetura que ainda seguia as premissas do ecletismo ou "neos" das décadas anteriores. Também diversos arquitetos ligados ao movimento moderno irão estudar principalmente o período colonial, de forma a encontrar uma continuidade entre a arquitetura desse período e as novas propostas.

Com o correr do tempo, diversos pesquisadores ampliaram este campo de pesquisas, produzindo em muitos casos trabalhos de muita qualidade. Podemos citar, como exemplo, autores como Diego Angulo Iñiguez, Enrique Marco Dorta e Mario J. Buschiazzo, que publicaram em 1955 a magistral obra em três volumes, "História del arte hispanoamericano". ${ }^{24}$ Atualmente o mercado editorial publica anualmente centenas de títulos sobre o tema, e embora ainda falte avançar no sentido da divulgação e distribuição, já foi dado um grande passo em relação às décadas anteriores.

Hoje em dia a melhor obra disponível para uma visão geral dos diversos aspectos da arquitetura e do urbanismo na América Latina, principalmente quanto a informações, é "Arquitectura y Urbanismo en Iberoamérica", de Ramón Gutierrez. Este mesmo autor publicou algumas obras sobre a bibliografia existente, que permitem construir um bom panorama sobre esta questão. ${ }^{25}$

Como já dissemos, a produção na área é extensa, embora ainda sintamos a falta de outros trabalhos críticos sobre a mesma. Uma das correntes mais atuantes é aquela que posiciona as obras a partir dos pontos de vista do "próprio" e do "alheio", o que é feito através de conceitos como "identidade" e "adequado". Ou seja, critica aqueles que produzem a partir de um ponto de vista externo, e não a partir do olhar da América. $^{26}$ Esta é a linha preponderante nos SAL (Seminários de Arquitetura Latinoamericana), que desde 1985 vêm sendo realizados a cada dois anos em diferentes cidades do continente.

\footnotetext{
24 ANGULO IÑIGUEZ, D.; MARCO DORTA, E.; BUSCHIAZZO, Mario J. Historia de arte hispanoamericano. 3v. Barcelona, Salvat, 1945-1956.

${ }_{25}$ GUTIERREZ, Ramón. Notas para uma bibliografia hispanoamericana de arquitectura. 1526-1875. Resistência, Universidad Nacional del Nordeste, 1972; GUTIERREZ, Ramón. La historiografía de la arquitectura americana. Entre el desconcierto y la dependencia cultural. 1870-1985. Buenos Aires, Revista Summa 215/216, agosto 1985; GUTIERREZ, Ramón; MARTíN, Marcelo. Bibliografía iberoamericana de revistas de arquitectura y urbanismo. Madrid, Instituto Español de Arquitectura; Ediciones de las Universidades de Alcala y Valladolid, 1993; GUTIERREZ, Ramón; MÉNDEZ, Patricia. Bibliografía de arquitectura y urbanismo en Iberoamérica, 1980-1993. Alcalá de Henares, Instituto Español de Arquitectura, Universidad de Alcalá y Valladolid; Buenos Aires, Centro de Documentación de Arquitectura Latinoamericana (CEDODAL), 1996.

${ }^{26}$ Isto fica evidente nos títulos de numerosos artigos. Tomemos, por exemplo, o livro TOCA, Antonio. Nueva arquitectura em América Latina: presente y futuro. México, Gustavo Gili, 1990. Constam, entre outros, os seguintes títulos: "Uruguay. Busqueda de una arquitectura apropriada"; "Propriedad y ajenidad en la arquitectura latinoamericana"; "Hacia una modernidad apropiada: obstáculos y tareas internas"; "Por una arquitectura apropiada y apropiable"; "Arquitectura e identidad en la Argentina".
} 
Segundo Ramon Gutierrez, seu principal impulsionador, a questão está em

que...

"Uma das formas mais evidentes de alienação cultural é o desconhecimento das próprias circunstâncias históricas, já que não se pode valorizar algo que se desconhece, nem tão pouco defendê-lo ou respeitá-lo. "27

Portanto, busca-se...

“... una lectura de la cultura desde América y con un horizonte que ensueña la recuperación de la dimensión continental como eje integrador. Esto implica reconocer las similitudes y las diferencias, aceptar los niveles de interdependencia $y$ autonomía y, sin aislarse, intervenir protagónicamente en el diálogo universal de las culturas." 28

Um exemplo é o caso da arquitetura praticada pela Espanha na América: esta é resultado de um processo de "seleção" e "síntese", tomando elementos de várias culturas da Espanha. Não há nada tão espanhol na Espanha como a arquitetura hispano-americana. Assim ele pergunta: ¿Como podría explicarse América mirando simplemente lo que hay em España? ${ }^{29}$

Esta visão tem certamente produzido uma ação importante no sentido da conscientização de profissionais e estudantes de arquitetura quanto à necessidade de desenvolver uma consciência crítica a respeito das idéias e da produção arquitetônica em relação às condições locais, embora talvez ainda falte avançar quanto ao rigor das conceituações usadas.

Entretanto, isto não impede que ainda seja comum que se dê grande destaque apenas para um número reduzido de obras arquitetônicas e urbanísticas, geralmente localizadas nas áreas freqüentadas pelas camadas sociais mais opulentas. E que em geral os modelos de explicação estejam baseados na busca de referências européias, seja de obras (como as reformas de Paris e Viena), ou de autores que teriam influenciado os arquitetos e urbanistas que participaram das intervenções aqui realizadas (Haussmann, Sitte, Howard, Hénard, Stübben, etc.). Se bem estas relações possam efetivamente ser identificadas no espaço, aplicam-se a apenas uma parte do espaço produzido, principalmente às obras realizadas nas áreas centrais, no caso do urbanismo, e da arquitetura dos grandes edifícios públicos e privados construídos então. Nos capítulos 4 e 5 estudaremos esta questão com maiores detalhes.

\footnotetext{
${ }^{27}$ GUTIERREZ, Ramón. Arquitetura latino-americana. Textos para reflexão e polêmica. São Paulo, Nobel, 1989 , p. 51.

${ }^{28}$ GUTIERREZ, Ramón (coord.). Arquitectura latinoamericana en el siglo XX. Barcelona, Lunwerg, 1998, p. 32.

29 GUTIERREZ, Ramón. El laberinto de la enajenación. La historia de la arquitectura própria escrita con ojos ajenos. In: MARCONDES, Neide; BELLOTTO, Manoel. Laberintos e nós: imagem ibérica em terras da América. São Paulo, Unesp/Imprensa Oficial, 1999, p. 77.
} 


\subsection{3 - Conceito de Urbanização}

É importante a partir deste momento conceituar o que é urbanização. Entendemos que esta se inicia no final do neolítico, quando uma parcela da população passa a viver em um núcleo urbano, possibilitado pela produção de um excedente social que permite a uma minoria viver sem precisar ela própria produzir seus alimentos. ${ }^{30}$ Isto é chamado de complementaridade assimétrica. ${ }^{31}$ Trata-se de um ciclo que estamos assistindo encerrar-se, principalmente nas nações mais desenvolvidas onde a porcentagem de população urbana tende a 100\%.

Segundo Reis Filho:

"Ocorre um processo de urbanização quando em uma sociedade existe uma divisão social do trabalho, em caráter permanente, de sorte que uma parcela ponderável da população deixa de se dedicar à produção de alimentos e passa a depender, para a sua subsistência, dos produtos do trabalho da outra parcela, aos quais tem acesso por meio de troca ou por apropriação direta.,32

Com base nesta conceituação, este último autor, no referido trabalho "Evolução Urbana do Brasil", não enfoca mais apenas a cidade, ou o núcleo urbano, mas o processo de urbanização e a rede urbana, substituindo as abordagens baseadas na relação cidade/campo pela urbano/rural, o que permitiu entender melhor a inserção da rede urbana brasileira na rede mundial. Quando nos referimos a cidade e campo, estamos nos referindo a elementos físicos, objetos. Utilizar urbano e rural significa incorporar a dimensão social.

Outros autores que trabalham com abordagens semelhantes também propuseram conceitos de urbanização. Segundo Hardoy:

"Por urbanización entiendo la concentración espontánea o planificada de la población en puntos del territorio con densidades comparativamente altas, para desempeñar esencialmente actividades de transformación o de servicios de acuerdo con una organización social compleja. La definición de esos puntos como centros urbanos ha cambiado con el tiempo.",33

\footnotetext{
${ }^{30}$ Marx desenvolve estes conceitos em MARX, Karl. Formações Econômicas Pré-capitalistas. $2^{\mathrm{a}}$ ed. Rio de Janeiro, Paz e Terra, 1977. Introdução de Eric Hobsbawm. Estes textos são conhecidos também como Formem.

${ }^{31}$ Embora seja de uso comum na área das ciências sócias, quem primeiro utilizou este termo na área de estudos urbanos foi SCHERER, Rebeca. Ver Notas sobre Planejamento e Método. Cadernos de Pesquisa do LAP 10. São Paulo, FAUUSP, nov. dez. 1995.

${ }^{32}$ REIS FILHO, Nestor Goulart. Op. cit.

33 HARDOY, Jorge E.; SCHAEDEL, Richard P. Las ciudades de América Latina y sus áreas de influencia a través de la historia. Buenos Aires, SIAP, 1975, p. 83.
} 
Enquanto, para Scherer, que enfatiza as questões de poder, o processo de urbanização é um...

“... processo social que se atualiza fisicamente em redes e núcleos urbanos. Esses constituem pólos de articulação multifuncional que respondem, assim como aquela, aos requisitos de um processo que tem sido, ao longo da História e em última instância, um processo de dominação."34

Já para Harvey, urbanização é...

“... um processo social que ocorre no espaço, no qual uma ampla gama de diferentes atores com objetivos e agendas bastante diversos interagem através de uma configuração específica de práticas espaciais interligadas.",35

Além de urbanização, é importante também definir o que entendemos por urbanismo. O Urbanismo é menos abrangente que a urbanização, que traz implícita toda a complexidade das relações entre a sociedade e o espaço. Já urbanismo é a "forma de organização do espaço com projeto". Este projeto pode ser feito por profissionais (arquitetos, engenheiros, etc.) ou por pessoas sem essa formação (autoconstrução, etc.), e ser objeto de diferentes graus de controle. "Não é a presença de um profissional que caracteriza o urbanismo, mas sim a presença de agentes que planejam realizar um investimento, implicando na apropriação, produção, uso e/ou transformação do espaço urbano". ${ }^{36}$

Não há um limite exato que marque a diferença entre a arquitetura e o urbanismo. Há associada em geral uma questão de escala: a arquitetura refere-se ao edifício e o urbanismo compreende, além dos edifícios em si, também outros elementos como por exemplo ruas e quadras. Um outro ponto de vista pode ser tratar a arquitetura como uma relação mais direta entre cliente e profissional, portanto com implicações mais restritas. No urbanismo as variáveis são mais complexas e envolvem um número maior de pessoas. Conseqüentemente a responsabilidade social é maior. ${ }^{37}$

\subsection{4 - Relação entre Sociedade e Espaço}

Uma outra questão que deve ser esclarecida é quanto à relação entre sociedade e espaço. Utilizamos um conceito de espaço que considera que este último não é apenas conseqüência das relações sociais, mas que há uma relação dialética entre ambos. Como diz Milton Santos:

"Consideramos o espaço como uma instância da sociedade, ao mesmo título que a instância econômica e a instância

\footnotetext{
${ }^{34}$ SCHERER, Rebeca. Sistematização Crítica do Conjunto dos Trabalhos. Tese de Livre Docência. São Paulo, FAUUSP, 1994, p. 56.

${ }^{35}$ HARVEY, David. Do gerenciamento ao empresariamento: a transformação da administração urbana no capitalismo tardio. São Paulo, Revista Espaço \& Debates, 1996, p. 51.

${ }^{36}$ MEDRANO, Ricardo Hernán. Op. cit. p. 11.

37 Idem, ibidem. p. 13.
} 
cultural-ideológica. Isso significa que, como instância, ele contém e é contido pelas demais instâncias, assim como cada uma delas o contém e é por ele contida... ...o espaço não pode ser apenas formado pelas coisas, os objetos geográficos, naturais e artificiais, cujo conjunto nos dá a Natureza. O espaço é tudo isso, mais a sociedade: cada fração da natureza abriga uma fração da sociedade atual." 38

$\mathrm{Na}$ maioria das vezes estuda-se o efeito do social no espacial e não o contrário, como aponta Flavio Villaça, que procura proceder nesta direção em um artigo chamado "Efeitos do espaço sobre o social na metrópole brasileira". Estuda o espaço através da teoria do valor. Neste caso, há um processo de segregação espacial. Seu objetivo é demonstrar que

“... através da segregação a classe dominante controla a produção e consumo do espaço urbano, sujeitando-o aos seus interesses. A segregação é um processo necessário para que haja esse controle."39

\subsection{5 - A Interdisciplinaridade}

$\mathrm{Na}$ medida em que estamos trabalhando apenas uma pequena parte da realidade, da qual pretendemos nos aproximar, devemos também colocar o conceito de interdisciplinaridade. Para Castells isto significa:

"... comunicación y establecimiento de relaciones entre los resultados obtenidos independientemente por cada disciplina con respecto a un mismo objeto real..." ${ }^{40}$

Para Milton Santos,

"O estudo das interações entre os diversos elementos do espaço é um dado fundamental da análise. Na medida em que função é ação, a interação supõe interdependência funcional entre os elementos. Através do estudo das interações, recuperamos a totalidade social, isto é, o espaço como um todo e, igualmente, a sociedade como um todo". ${ }^{41}$

\footnotetext{
38 SANTOS, Milton. Espaço e Método. $4^{\mathrm{a}}$ ed. São Paulo, Nobel, 1997, p. 1.

${ }^{39}$ VILLAÇA, Flávio. Efeitos do espaço sobre o social na metrópole brasileira. In: CEDESP. Metropolização e globalização: conhecendo a cidade de São Paulo. São Paulo, CEDESP, 1999, p. 221-236.

${ }^{40}$ CASTELLS, Manuel. Problemas de investigación en sociologia urbana. Buenos Aires, Siglo XXI, 1972. p. 70.

${ }^{41}$ SANTOS, Milton. Op. Cit, p. 7. Embora conceituemos o espaço de forma semelhante, evitamos o uso da palavra "função", já que a mesma pode remeter a visões positivistas.
} 
Já Harvey destaca também as questões de dominação:

"... deve ser primeiro reconhecido que todas as fronteiras disciplinares são elas próprias contra-revolucionárias. A divisão do conhecimento leva o corpo político a dividir e a dominar tanto quanto se concebe a aplicação do conhecimento. Isso, também, torna grande parte da comunidade acadêmica impotente, porque leva-nos a pensar que podemos entender a realidade somente através de uma síntese do que cada disciplina tem a dizer sobre seu segmento particular; e rapidamente sucumbimos ao que é uma tarefa tão claramente impossível. Estudos inter, multi e intra-disciplinares são potencialmente revolucionários, mas nunca realmente acontecem; os obstáculos contra eles são bastante grandes. A realidade tem que ser, por isso, abordada diretamente mais do que através de formulações das disciplinas acadêmicas. Devemos pensar em termos não disciplinares ou contra disciplinares se queremos pensar academicamente sobre todos nossos problemas. Formulações genuinamente revolucionárias não podem ter base disciplinar especifica; elas devem referir-se a todos os aspectos relevantes da realidade material". ${ }^{42}$

\subsection{6 - Uma Teoria da Urbanização}

Em resumo, o objetivo é buscar construir uma teoria global da urbanização, que segundo Reis Filho deverá estar voltada:

“... não para a conceituação da cidade, mas da urbanização, como um processo social suficientemente amplo para abarcar as mais diversas configurações, como os pequenos núcleos urbanos, as grandes aglomerações e os sistemas de núcleos, como as regiões metropolitanas e os campos urbanos e propiciar a análise tanto dos aspectos mais gerais dos problemas, como de suas características em quadros empíricos definidos."

\footnotetext{
42 HARVEY, David. A justiça social e a cidade. São Paulo, Hucitec, 1980, p. 128. Citado em SCHERER, Rebeca. Op. cit. p. 11.

${ }^{43}$ REIS FILHO, Nestor Goulart. Urbanização e Teoria. São Paulo, Edição do autor, 1967, p. 106.
} 


\section{3 - CONCLUSÕES E PROPOSTA}

Concluindo, buscamos com este trabalho:

\section{1}

Contribuir para o entendimento da relação entre sociedade e espaço. Ou seja, mostrar que o espaço não é apenas conseqüência direta dos fenômenos sociais, e principalmente econômicos (que é o discurso dominante neste momento), mas que há nesta relação tanto o social interferindo no espaço como o espaço interferindo no social.

Não é a visão usual em relação ao nosso período de estudo, já que o espaço produzido geralmente é considerado como sendo apenas uma conseqüência de uma nova divisão internacional do trabalho. Trazendo esta questão para o presente, verificamos que existe bastante difundida a idéia de que há atualmente uma nova divisão internacional do trabalho, uma "Era da Informação", que é o início de um novo ciclo após a Revolução Industrial. Neste caso também é comum que as mudanças na arquitetura sejam tratadas como conseqüência destas mudanças. Mas em geral o discurso refere-se a apenas algumas obras pontuais, muito divulgadas pelo mercado editorial.

Uma outra questão importante é que os fenômenos espaciais não necessariamente são simultâneos aos políticos ou econômicos; pelo contrário, têm sua própria dinâmica. Neste sentido, abordar o espaço por meio de um estudo histórico pode permitir identificar séries mais amplas, e com isto construir modelos teóricos mais precisos. Vamos procurar verificar estes mecanismos, em nosso período.

Quanto à relação entre história e projeto, como nosso objetivo como arquiteto pressupõe o trabalho de prever os resultados de nossas ações, ou seja, planejar, é importante conhecer o processo que levou às atuais configurações social e urbana.

Nesse mesmo sentido, é necessário também destacar que estamos estudando uma etapa na qual São Paulo e Buenos Aires passam por mudanças muito intensas. Um dos objetivos é compreender as respostas dadas pela sociedade, com ênfase no espaço, em momentos de transformações rápidas e intensas. $E$ conseqüentemente obter subsídios para a intervenção neste tipo de condições nos dias de hoje.

\section{2}

Vejamos agora como se posiciona esta pesquisa em relação às discussões teóricas até aqui apresentadas. Em primeiro lugar verificamos que os estudos sobre a urbanização na América Latina, portanto com ênfase na relação com 
a sociedade, deixaram de ter a partir dos anos 1970 o ímpeto de duas décadas antes, perdendo de vista a visão de conjunto do continente. Pesquisas estas que muito pouco trataram dos aspectos mais ligados à arquitetura e ao urbanismo.

Por outro lado, a produção sobre estes últimos aspectos, embora extensa e de qualidade, normalmente não aprofunda teoricamente a relação com a sociedade. Além disso, embora estudar todos os aspectos de ambas cidades seja tarefa que está longe do nosso alcance, vamos procurar ir além do habitual estudo das reformas nas áreas centrais e das áreas mais nobres, e confirmar que aquela abordagem é insuficiente para a construção de modelos teóricos mais precisos (que exige uma aproximação ao todo). Por último, não encontramos estudos comparativos de cidades onde esteja presente uma análise detalhada, a partir das categorias de análise da organização do espaço intra-urbano, das diferenças e semelhanças na arquitetura e no urbanismo.

Em conseqüência da ausência de estudos comparativos entre duas cidades latino-americanas, neste trabalho daremos ênfase, de todo o material que levantamos e analisamos, principalmente aos aspectos empíricos. Uma das razões refere-se à nossa formação. Acreditamos que é obrigação dos arquitetos assumir o papel de estudar com maior profundidade os aspectos físicos (em outras palavras, a "lógica do projeto") em face das possibilidades advindas de sua formação específica. ${ }^{44}$ Como neste trabalho vamos abordar apenas uma pequena parte de um extenso universo de possibilidades, este trabalho pode contribuir para outros na mesma área.

Para exemplificar as possibilidades advindas desta forma de procedimento, podemos citar dois trabalhos que, ao proceder a uma análise mais detalhada de projetos urbanísticos, permitiram questionar algumas idéias vigentes e consolidadas. Um foi realizado por Antonio Carlos Carpintero, a respeito de Brasília. ${ }^{45}$ Estudando mais detalhadamente os projetos do concurso, e mais particularmente a proposta vencedora de Lucio Costa, concluiu que Brasília não pode ser reduzida apenas a uma mera aplicação direta dos princípios do CIAM. Pelo contrário, seu urbanismo é mais complexo e envolve concomitantemente também outros princípios urbanos, como os da tradição da cidade linear e da cidade-jardim. Mais do que invalidar os trabalhos baseados naquela visão tradicional, esta perspectiva, que busca uma análise mais detalhada do urbanismo, permite enriquecê-los.

Um outro exemplo é um trabalho realizado por Gorelik e Silvestri. ${ }^{46}$ Eles questionam uma das interpretações tradicionais sobre Buenos Aires, de autoria de Scobie $^{47}$ sobre a construção do porto. Segundo este último autor, sua construção envolveu um conflito estrutural entre dois grupos: os situados ao sul da Praça de Maio (Huergo), e os situados ao norte (Madero). A forma de crescimento da cidade teria sido determinada pela vitória destes últimos. Entre as críticas de Gorelik e Silvestri há uma específica, que parte da constatação de que os dois projetos, quando observados

\footnotetext{
${ }^{44}$ A versão mais completa sobre o conceito de "lógica do projeto" foi apresentada por Nestor Goulart Reis na palestra "Algumas questões de método e alguns exemplos relevantes", no evento "A invenção da cidade na América Latina". Rio de Janeiro, Centro Cultural Banco do Brasil, 8 de maio de 2003.

${ }^{45}$ CARPINTERO, Antonio Carlos Cabral. Brasília: prática e teoria urbanística no Brasil, 1956-1998. Tese de Doutorado. São Paulo, 1998.

${ }^{46}$ GORELIK, Adrián ; SILVESTRI, Graciela. Imágenes al sur. Sobre algunas hipótesis de James Scobie para el desarrollo de Buenos Aires. In: Buenos Aires, Anales del Instituto de Arte Americano e Investigaciones Esteticas "Mario J. Buschiazzo" N² 27-28, 1989-1991, p. 93-104.

47 SCOBIE, James R. Buenos Aires. Del centro a los barrios. 1870-1910. Buenos Aires, Solar/Hachette, 1977.
} 
com atenção quantos aos seus aspectos espaciais, não pressupõem na realidade modelos antagônicos. A crítica é justamente o fato de que

“... en el texto de Scobie no se miran los proyectos, no se incorpora el análisis de su materialidad;..." ${ }^{48}$

para acrescentar

“... y esto es verdaderamente paradójico, teniendo en cuenta que análisis así construido tuvo un impacto determinante en disciplinas cuyo objeto es, sí, la materialidad de la ciudad."49

Este tipo de enfoque é imprescindível para que profissionais de outras áreas (historiadores, sociólogos, geógrafos, antropólogos, etc.) tenham os subsídios necessários, principalmente na escala da arquitetura e do urbanismo, para embasar as pesquisas nos seus respectivos campos de atuação. Estas, em contrapartida, revertem positivamente nas atividades dos arquitetos, já que tanto nas pesquisas quanto na atividade profissional devem lidar também com questões para as quais não têm o pleno domínio das ferramentas adequadas de análise, daí a necessidade desta interação.

\section{3}

Podemos elencar algumas possíveis contribuições desta pesquisa para a elaboração de modelos teóricos mais precisos sobre a urbanização, o urbanismo e arquitetura na América Latina:

Por um lado tentaremos mostrar que realizar a comparação de dois ou mais núcleos urbanos pode ser um instrumento útil para identificar regularidades nas diversas escalas, já que é possível observar quais fenômenos se repetem e quais não (ambos devem ser explicados). Conseqüentemente, é possível verificar a validade dos modelos teóricos desenvolvidos para cada cidade, o que pode permitir questioná-los e/ou aperfeiçoá-los. Além disso, procuramos com este trabalho apontar um possível caminho, decorrente da comparação de duas cidades, que permita ampliar o conhecimento produzido.

Também podemos contribuir para o estudo das redes urbanas brasileira e argentina, e para a latino-americana em geral. E ao mesmo tempo testar a hipótese de que para entender o processo de urbanização no período é fundamental a abordagem de múltiplos movimentos. Ou seja, contribuir para recuperar uma visão conjunta das especificidades e generalidades da América Latina.

\section{4}

Resumindo, nesta tese procuramos mostrar que para explicar a arquitetura e o urbanismo em ambas cidades é necessário entender uma articulação de movimentos que vão além das determinações geradas pela nova divisão internacional do trabalho. Estas, embora centrais, respondem pelas generalidades mas não

\footnotetext{
${ }^{48}$ Idem, ibidem. p. 96.

49 Idem, ibidem. p. 96.
} 
explicam as especificidades, o que exige uma abordagem que reconheça a existência de outras racionalidades, nas quais são atribuídos papéis específicos aos diferentes espaços e escalas.

\section{4 - COMENTÁRIOS SOBRE PROCEDIMENTOS}

Como em qualquer pesquisa, é muito maior a quantidade de material levantado do que aquilo que é apresentado. Fazer uma tese é a arte de selecionar e sintetizar, ou seja, de apresentar apenas o necessário para demonstrá-la. Como conseqüência, deixamos de lado uma grande quantidade de material, que esperamos poder utilizar em futuros trabalhos.

Por outro lado, abordar todos os aspectos da arquitetura e do urbanismo estaria fora de nosso alcance. Como nosso objetivo é verificar a validade dos modelos teóricos existentes, selecionamos alguns desses aspectos, que indicamos mais adiante, a partir dos quais faremos o confronto entre nosso material empírico e a teoria. $^{50}$

Assim, a parte principal da tese consiste em analisar a arquitetura e 0 urbanismo em ambos núcleos urbanos, encontrar as regularidades existentes, com as quais podemos identificar as determinações mais gerais e as locais. Isto implica analisar, por meio de categorias de análise da organização do espaço intra-urbano, as inúmeras diferenças e semelhanças encontradas. Como exemplo dessas categorias podemos citar: traçado, quadra, lote, implantação, partido, fachada, decoração, vias, cobertura, vãos, estrutura, infra-estrutura, etc.

Entretanto, certas regularidades ficam mais claras através de comparações complementares. Assim, para identificar as continuidades das explicações e construir séries mais precisas, utilizamos material empírico de outras cidades latino-americanas, como Montevidéu, Santiago do Chile, La Plata, Rio de Janeiro etc.

Com o mesmo objetivo, vamos nos valer também de algumas comparações que permitam elucidar algumas questões referentes à rede urbana internacional. Obviamente estudar a urbanização geral seria tarefa por demais extensa, da mesma forma que a abordagem apenas da Europa, que pelo fato de ser extremamente heterogênea, fatalmente nos conduziria a uma análise muito genérica. Além disso, como colocamos acima, o objetivo é apenas fazer comparações complementares. Assim, nosso recorte se restringirá à Espanha, que não figura usualmente como referência para a produção do espaço em São Paulo e Buenos Aires, mas que é o país que depois da Itália mais aportou imigrantes. Pelo fato de supostamente se inserir de forma diferente na divisão internacional do trabalho, intermediária entre países como Brasil e Argentina e os países mais desenvolvidos da Europa, é um interessante contraponto para nossa análise.

\footnotetext{
${ }^{50}$ Embora durante o trabalho tenhamos procurado dar peso equivalente a ambas cidades, na prática certamente o conhecimento sobre São Paulo deve estar mais completo, dada a facilidade de acesso às informações.
} 
É fundamental destacar também alguns aspectos referentes às fontes utilizadas nesta pesquisa. Fazemos uso principalmente daquelas que permitem uma análise direta do espaço, como fotografias, desenhos e mapas. Também é imprescindível a observação direta. É importante salientar que uma boa parte dos resultados obtidos neste trabalho são resultado da análise deste tipo de fonte. Isto pode ser comprovado pela maneira como são trabalhadas (não são meramente ilustrativas), como também pela quantidade de informações gráficas apresentadas. Uma das razões de usar prioritariamente estas fontes está diretamente associada à nossa formação de arquiteto e urbanista. De fato, esta área do conhecimento exige um contínuo treinamento, que irá permitir o desenvolvimento da capacidade de observação de aspectos visuais. Conseqüentemente possibilita a obtenção de numerosas informações na abordagem das fontes acima citadas. Em compensação, como poderá perceber o leitor, não temos pleno domínio das fontes primárias usuais de outros profissionais das ciências humanas.

As fotografias e os desenhos, ao serem comparados, permitem a construção de séries, o que por sua vez possibilita a identificação de regularidades. $O$ mesmo acontece com a cartografia, através da qual é possível apreender aspectos específicos como traçado, extensão da mancha urbana, infra-estrutura instalada e parcelamento do solo (com sua respectiva ocupação), além de referências geográficas como topografia, rios e córregos, etc. Estas fontes também permitem uma análise dimensional, o que é extremamente útil quando são comparadas duas cidades.

Por último, não podemos deixar de mencionar que esta pesquisa não foi desenvolvida isoladamente, mas no âmbito do LAP - Laboratório de Estudos da Urbanização, Arquitetura e Preservação, na Faculdade de Arquitetura e Urbanismo da Universidade de São Paulo. Esta circunstância implica na incorporação ao trabalho, durante seu desenvolvimento, de contribuições de outras linhas de pesquisa, assim como dos demais pesquisadores do grupo. Certamente este trabalho deve muito à possibilidade de termos podido fazer parte de um grupo de pesquisas com a competência e a qualidade das pessoas que formam o LAP. 
CAPÍTULO 2

CARACTERIZAÇÃO GERAL 


\section{$2.1-O M U N D O$}

O período que estudamos corresponde a uma etapa de enormes transformações em todo o mundo. A rapidez e intensidade deste processo não encontram precedentes na história da humanidade, nem na história da urbanização.

Este processo começa com a Revolução Industrial, que toma impulso principalmente a partir do século XVIII, particularmente na Inglaterra. No início as unidades de produção industrial estavam localizadas próximas às fontes naturais de energia, principalmente os rios. Com o desenvolvimento de outras fontes de energia, como o vapor, e com os novos meios de transporte, foi possível a instalação de indústrias em outros lugares. Em geral este processo gerou uma intensa migração do meio rural para o urbano, e uma tendência à concentração em algumas cidades. As formas assumidas por este processo, entretanto, variaram significativamente de país para país.

Pela primeira vez na história o mundo tornou-se global, no sentido de que diversos fenômenos passam a ter impacto sobre boa parte do planeta. Uma das principais características deste processo é a intensidade dos fluxos de pessoas e mercadorias, que são possíveis graças ao desenvolvimento dos meios de transporte. Em terra firme as ferrovias irão permitir que matérias-primas e produtos acabados sejam levados das fontes às fábricas, e daí aos consumidores. E permitem que as pessoas possam percorrer distâncias que até aquele momento exigiam um enorme tempo de deslocamento. A primeira linha ferroviária entre duas cidades foi construída em 1830 entre Liverpool e Manchester. Em pouco tempo foram implantados muitos quilômetros de trilhos. Alguns dados mostram a intensidade desse processo: em 1860 a rede européia tem quase $100.000 \mathrm{~km}$. Em 1910 serão em torno de um 1.100 .000 $\mathrm{km} .^{1}$

Trata-se de uma enorme mudança de velocidade, já que como observou argutamente Braudel, Napoleão ainda andava na mesma velocidade que Julio César.

O decréscimo dos custos das viagens de navio permitiu que milhões de pessoas migrassem de um continente a outro. Muitas destas viagens eram sazonais, como os milhares de trabalhadores que passavam uma temporada na Europa e a outra metade na América, trabalhando na agricultura. O próprio turismo já assumia características massivas: em 1879 mais de 200.000 estadunidenses atravessaram o atlântico para visitar a Suíça.

Um das facetas mais notáveis é que as maiores transformações se deram em pouco mais de uma geração: em 1750 a Inglaterra é exportadora de grãos e em 1880 é importadora. Segundo Hobsbawm:

"O que definia o século XIX era a mudança: mudanças em termos de e em função dos objetivos e das regiões dinâmicas do litoral do atlântico norte, que eram, à época, o núcleo do

\footnotetext{
${ }^{1} \mathrm{O}$ continente europeu recebeu inicialmente os maiores investimentos, mas a partir dos últimos anos do século XIX a rede ferroviária nos paises periféricos passa por um desenvolvimento mais intenso, de tal sorte que em 1915 a rede ferroviária na Argentina é equivalente à da Inglaterra.
} 
capitalismo mundial. Com algumas exceções marginais e cada vez menos importantes, todos os países, mesmo os até então mais isolados, estavam, ao menos perifericamente, presos pelos tentáculos dessa transformação mundial". ${ }^{2}$

Fenômenos importantes também ocorrem no intra-urbano. Até aquele momento a extensão da maioria das cidades permitia que fossem percorridas a pé ou a cavalo. Mas o surgimento de aglomerados com muitos milhares ou milhões de habitantes exigem que os deslocamentos sejam feitos através de novos meios, como os bondes. Em contrapartida, estes mesmos meios permitem a extensão das cidades, através da ocupação de áreas que somente são viáveis com a existência de um meio de transporte que permita deslocar a população que habita nas periferias para os setores onde haja disponibilidade de emprego e/ou comércio. Segundo Sica, a respeito das cidades nos paises industrializados:

"O fenômeno de formação da cidade industrial se caracteriza pelo decisivo predomínio da quantidade de edificação (residencial, comercial, produtiva), que, sob o impulso excepcional dos interesses capitalistas, abarca enormes extensões, assumindo configurações repetitivas, freqüentemente com um dinamismo devido, em parte, a processos de mecanização e de padronização do trabalho, do projeto e, parcialmente, da execução".

Enfim, este é um breve panorama no qual se inserem as transformações em São Paulo e Buenos Aires. Uma análise mais detalhada da rede urbana internacional está no capítulo 3, enquanto que alguns aspectos da arquitetura e do urbanismo nas diferentes escalas são analisados nos capítulos 4 e 5.

\section{2 - AS SOCIEDADES BRASILEIRA E ARGENTINA}

Para comparar as sociedades brasileira e argentina é necessário antes de mais nada marcar as diferenças na forma como ocorreu a transição entre as antigas colônias e os países independentes. No caso da Espanha, este processo foi extremamente conflituoso, travado em duas frentes: uma entre as forças locais e as tropas espanholas, resultando na sucessiva independência das diversas partes do continente. Por outro lado houve uma série de conflitos internos que levaram à subdivisão do antigo império em numerosos países. Embora em geral a independência e transformação em república de muitos destes países tenha ocorrido no início do século XIX, somente no final daquele século o processo estaria praticamente consolidado. No caso da Argentina, cuja unidade data de 1880, se deu com a subida ao poder do general Roca.

\footnotetext{
${ }^{2}$ HOBSBAWM, Eric J. A era dos Impérios. 1875-1914. $7^{\text {a }}$ ed. Rio de Janeiro, Paz e Terra, 1988, p. 46.

3 SICA, Paolo. Historia del Urbanismo. El siglo XIX. 2 vol. $2^{-a}$ ed. Madrid, Instituto de Estudios de Administración Local, 1981, p. 60.
} 
O caso brasileiro difere. Uma de suas facetas particulares deve-se ao fato de que o Brasil passa a ocupar uma posição central no Império português quando da vinda da Família Real, em 1808, fugindo das tropas de Napoleão. Isto evitou a desintegração do território. Este processo não foi, entretanto, pacífico. ${ }^{4}$ Ao contrário, principalmente nas primeiras três décadas do século XIX, existiram numerosos conflitos, tanto internos, separatistas, como entre grupos locais e a Coroa portuguesa. Como resultado, Dom João VI retorna a Portugal em 1821 e o Brasil torna-se oficialmente independente em 1822, com a coroação do príncipe regente Dom Pedro. Este abdica em 1831, e em 1840 é antecipada a maioridade de Dom Pedro II, que à época tinha 14 anos. O Brasil continuará sendo uma monarquia até a proclamação da República, em 1889.

Um dos aspectos no qual há marcadas diferenças refere-se à forma de organização nacional. Com a República, o Brasil se torna uma federação. Nesta, os estados têm significativa autonomia, configurando um sistema político baseado em três elementos: um são os coronéis, os chefes políticos do interior, que detém o poder em sua região. O segundo elemento são as oligarquias estaduais, que dependiam dessas forças. O terceiro elemento é o governo federal, que na prática era uma federação de oligarquias, já que era o resultado da somatória das oligarquias estaduais. $^{5}$

Este sistema, na prática, significava o fortalecimento dos municípios. Alguns dados deixam claro este processo em comparação com o período monárquico: em 1868/1869 o governo imperial recebeu $80,8 \%$ da renda pública, as províncias 16,7\% e os municípios 2,5\%. Em 1900 o governo central recebeu 59,9\%, os estados $21,5 \%$ e os municípios de $18,6 \% .{ }^{6}$ Por se tratar de um sistema federativo, existiam impostos quando produtos de um estado eram "exportados" para outro. Esta prática, embora tenha sido formalmente abolida em 1904, continuou sendo aplicada ainda por algum tempo, existindo registros ainda em 1942.

Essa federação não era formada por pesos iguais. Na prática São Paulo detinha um poder maior devido à enorme preponderância econômica do estado. Os outros estados mais importantes eram Rio Grande do Sul e Minas Gerais. Este último estado foi durante muito tempo o principal aliado de São Paulo no poder, com o qual compactuava a alternância na presidência. O governo central não tinha o monopólio do uso da força. Pelo contrário, cada estado podia ter sua própria milícia, e alguns destes detinham tal poder que não podiam ser ameaçados pelo poder central, principalmente São Paulo. Os coronéis continuaram mantendo um importante poder, particularmente nos estados menos desenvolvidos. É o caso, por exemplo, do coronel Horácio de Matos, da Bahia, que ainda em 1920 tinha o direito de conservar armas e munições, e a posse dos doze municípios que controlava. ${ }^{7}$

$\mathrm{Na}$ Argentina o processo foi o oposto. Após os últimos conflitos no final da década de 1870 entre forças políticas internas, e após a chamada conquista do deserto, que na prática significou a incorporação efetiva de grande parcela de território

\footnotetext{
${ }^{4}$ MOTA, Carlos Guilherme. Idéias de Brasil: formação e problemas (1817-1850). In: MOTA, Carlos Guilherme (org). Viagem incompleta. A experiência brasileira. Formação: histórias. São Paulo, SENAC São Paulo, 2000.

${ }^{5}$ FAUSTO, Boris. Brasil: estrutura social e política da $1^{a}$ República. In: BETHELL, Leslie (org). Historia da América Latina: de 1870 a 1930. Volume V. São Paulo, Edusp/Imprensa Oficial; Brasília, Fundação Alexandre de Gusmão, 2002.

${ }^{6}$ Idem, ibidem. p. 773.

7 Idem, ibidem. p. 774 .
} 
à Nação, principalmente ao sul dos pampas, sobe ao poder o general Roca, cuja primeira presidência se estende de 1880 até 1886. Ao contrário da situação existente até aquele momento, o governo central ganha muito mais poder. A cidade de Buenos Aires é federalizada, ou seja, passa a ser a capital da República Argentina, e La Plata, criada em 1882, se converte na capital da província de Buenos Aires. Entre algumas mudanças importantes, figuram o fortalecimento do exército nacional, a existência pela primeira vez de uma moeda única nacional, e a subordinação à jurisdição nacional do ensino primário e do registro civil, que antes eram atribuições da igreja. Com isso perderam poder os caudilhos do interior, que eram chefes políticos e militares locais, que em certo sentido equivaliam aos coronéis do Brasil.

Tanto as elites que assumiram o poder na Argentina em 1880 quanto as que subiram ao poder no Brasil em 1889 tinham como objetivo modernizar os respectivos países. Dada a grande disparidade regional que se estabelece nessa época, significou na prática a modernização principalmente das cidades mais importantes, Buenos Aires na Argentina (e em grau menor Rosário), e São Paulo e Rio de Janeiro no Brasil (além de Recife, Salvador e Porto Alegre). ${ }^{8}$ Em ambos casos, no Brasil e na Argentina, os imigrantes eram vistos como agentes de transformação e modernização da sociedade. E foram principalmente Buenos Aires e São Paulo as que receberam maior número de imigrantes europeus, cuja contribuição ia desde a simples mão-de-obra até pessoas qualificadas que trouxeram bagagem técnica e conhecimento empresarial. As elites locais também tinham como objetivo o "branqueamento" da população. No caso do Brasil, onde ainda existia uma numerosa população negra, os imigrantes europeus permitiriam inverter esse quadro e conseqüentemente almejar um desenvolvimento como o dos países europeus. Nessa época tinha bastante aceitação o "racismo científico", que procurava justificar cientificamente a superioridade da raça branca. O contínuo e intenso afluxo de imigrantes levou Euclides da Cunha, em "Os sertões", a proclamar a extinção das raças do interior do país:

"O jagunço destemeroso, o tabaréu ingênuo e o caipira simplório serão em breve tipos relegados às tradições evanescentes, ou extintas... ...destinadas a próximo desaparecimento ante as exigências crescentes da civilização e a concorrência material intensiva das correntes migratórias que começam a invadir profundamente a nossa terra. ${ }^{\prime 9}$

Na Argentina não foi diferente, embora as populações de origem africana e nativa tivessem muito menor peso do que no Brasil. Prevaleceu a contradição propagada por Sarmiento em "Facundo" entre "civilização" e "barbárie". ${ }^{10}$ Mas não podiam ser quaisquer europeus, eram preferidos aqueles vindos dos países mais desenvolvidos. Havia a crença de que era possível transformar uma terra inóspita e rude em um país civilizado, desde que nele fossem colocadas as pessoas certas. Neste sentido havia o exemplo dos Estados Unidos.

$\mathrm{Na}$ Argentina o processo de modernização foi anterior ao ocorrido no Brasil e apresenta características notáveis. Podemos citar alguns exemplos: no caso do analfabetismo, este era de $77,9 \%$ em 1869 , e pula para $35,2 \%$ em 1914 . Se levarmos

\footnotetext{
8 LEME, Maria Cristina da Silva (coord.). Urbanismo no Brasil 1895-1965. São Paulo, Studio Nobel/Fauusp/Fupam, 1999.

${ }^{9}$ CUNHA, Euclides. Os Sertões. São Paulo, Nova Cultural, 2002, p. 9.

${ }^{10}$ SARMIENTO, Domingo Faustino. Facundo: civilização e barbárie. Petrópolis, Vozes, 1996.
} 
em conta a distribuição regional, verificamos que em 1914 os índices de analfabetismo em alguns lugares já estavam em níveis relativamente baixos: na cidade de Buenos Aires este era de apenas $22,2 \%{ }^{11}$ Naquele mesmo ano três quartos das crianças de Buenos Aires freqüentavam a escola primária. Segundo Alejandro Bunge, depois da primeira guerra mundial a Argentina possuía em torno de $42 \%$ das estradas de ferro de toda a América Latina, os pampas argentinos eram a fonte de metade do comércio exterior do subcontinente, e eram gastos três quartos das despesas de educação de toda a América Latina. ${ }^{12}$ Gutman e Hardoy também destacam a forma pacífica como ocorreu esta modernização:

"El ascenso de las clases medias al poder y el surgimiento de la conciencia laboral en la clase trabajadora, se alcanzaron sin los grados de violencia que caracterizaron la historia de México y luego la de los países de América Central, Bolivia, Perú y Colombia. Que eso haya ocurrido en un período de crecimiento fenomenal de su población, es el acontecimiento central de Buenos Aires entre 1880 y 1950."13

Embora não tão espetacular, na transição do Império para a República no Brasil também houve um incremento significativo em diversos índices. $O$ analfabetismo passou de 85,2\% em 1890 para 75,6\% em $1920 .{ }^{14} \mathrm{Em} 1886$ existia um aluno na escola primária ou secundária para cada 75 brasileiros. Em 1907 este índice aumentou para 33. São Paulo em 1912 gastava sozinho em educação pública o mesmo montante que o Império como um todo no final da década de $1880 .{ }^{15}$ Entretanto, como na Argentina, estes benefícios não estavam distribuídos de forma homogênea, mas razoavelmente concentrados principalmente em São Paulo.

Em relação à organização partidária, podemos destacar no período a predominância de alguns partidos políticos. No Brasil o partido mais importante era o Partido Republicano Paulista (PRP), que representava os interesses das elites ligados ao café e possuía uma razoável organização. No país somente o Partido Republicano de Minas (PRM) e o Partido Republicano do Rio Grande do Sul (PRR) (a partir principalmente de 1910) é que terão algum papel de importância além do partido estadual paulista. Este por sua vez será o único partido da classe dirigente até 1926 quando é fundado o Partido Democrático (PD).

$\mathrm{Na}$ Argentina o primeiro partido de âmbito nacional será o Partido Autonomista Nacional (PAN), formado logo após a vitória de Roca nas eleições de 1880. Este partido será hegemônico até 1916 , com a vitória para a presidência de Yrigoyen, da Union Cívica Radical (UCR). Antes disso, em 1904, já havia sido eleito para a assembléia um socialista, Alfredo Palácios. A UCR foi formada no início da década de 1890, e ao menos em princípio representava as camadas médias, que com

\footnotetext{
${ }^{11}$ GALLO, Ezequiel. A Argentina: sociedade e política, 1880-1916. In: BETHELL, Leslie (org). Historia da América Latina: de 1870 a 1930. Volume V. São Paulo, Edusp/Imprensa Oficial; Brasília, Fundação Alexandre de Gusmão, 2002.

${ }^{12}$ Citado em: ROCK, David. A Argentina de 1914 a 1930. In: BETHELL, Leslie (org). Op. cit.

13 GUTMAN, Margarita; HARDOY, Jorge Enrique. Buenos Aires. Coleção Ciudades de Iberoamérica. Madrid, MAPFRE, 1992.

${ }^{14}$ No Brasil estão incluídos entre os analfabetos indivíduos de todas as idades (inclusive de 0 a 4 anos), enquanto que na Argentina são contados apenas os que têm mais de seis anos.

${ }^{15}$ LOVE, Joseph L. A República brasileira: federalismo e regionalismo (1889-1937). In: BETHELL, Leslie (org). Op. cit.
} 
isso conseguiram derrotar as oligarquias e abrir espaço para sua maior participação política na sociedade.

Embora as eleições para presidente fossem diretas, a porcentagem de eleitores em relação ao total da população era bastante pequena. O critério para que as pessoas pudessem votar diferiam em cada país. No Brasil, a partir da Constituição de 1891, passa a existir o direito de voto a todos os homens brasileiros alfabetizados maiores de 21 anos. Até aquele momento o sufrágio estava baseado em bens e renda. Mesmo assim em 1898 somente votaram 2,7\% da população brasileira, em 1910 foram $2,8 \%$, e em 1930 ainda eram apenas $5,7 \% .{ }^{16} \mathrm{O}$ voto era facultativo.

$\mathrm{Na}$ Argentina votavam todos os cidadãos do sexo masculino maiores de 18 anos, alfabetizados ou não. Ainda assim, considerando que nem as mulheres nem os estrangeiros podiam votar, e que o voto era facultativo até 1912, na prática o índice de participação da população era bastante pequeno.

Um dos episódios que mostram as enormes transformações ocorridas na Argentina no período e o grau de modernização atingido foram os movimentos de reforma universitária. Estes se iniciaram em 1904 na Universidade de Buenos Aires, quando os estudantes paralisaram a instituição exigindo que a gestão ficasse a cargo de professores e estudantes (e não de pessoas externas ligadas ao governo), que se reformassem as práticas de exames e que houvesse concursos para a admissão dos professores. Embora nem todas as reivindicações tenham sido atendidas, houve avanços importantes na área. Alguns anos mais tarde em Córdoba, mais precisamente em 1918, começou um grande movimento que se alastrou por todo o país, que ficou conhecido como "La Reforma", também com significativo impacto no sistema universitário argentino. ${ }^{17}$

Embora a sociedade Argentina apresentasse alguns sinais de modernidade, e apesar da pujança econômica (na época da primeira guerra mundial a renda per capta da Argentina era mais elevada do que a da maioria dos países europeus), ainda existiam características sociais que não condiziam com esses avanços. Como exemplo podemos citar o fato de que em 1914 não existia, na legislação social para a classe trabalhadora, salário mínimo, lei sobre jornada de oito ou dez horas (a lei de oito horas é de 1929), nem pensões ou previdência para aposentadoria. ${ }^{18}$

Apesar das expectativas, nenhum dos dois países pertence atualmente ao grupo dos mais desenvolvidos. Na Argentina a esperança começou a ser perdida após os anos 1930, depois de apontar, nas duas primeiras décadas do século XX, como um dos prováveis países mais desenvolvidos do mundo ocidental. O Brasil teve seu momento de euforia após os anos 1950, com a presidência de Juscelino Kubitschek e mais adiante durante o "milagre econômico" implantado pelo regime militar.

Ambos casos são paradigmáticos e o entendimento das limitações daqueles projetos sociais são imprescindíveis para a elaboração dos novos. Esta empresa envolve necessariamente uma ampla gama de áreas do conhecimento. Mas,

\footnotetext{
${ }^{16}$ FAUSTO, Boris. Op. cit.

17 ROMERO, José Luis. Latinoamérica: las ciudades y las ideas. $4^{\mathrm{a}}$ ed. Buenos Aires, Siglo XXI, 1986; TEDESCO, Juan Carlos. La universidad y su reforma. In: ROMERO, José Luis; ROMERO, Luis Alberto (org.). Buenos Aires. Historia de cuatro siglos. 2 v. Buenos Aires, Abril, 1983.

${ }^{18}$ ROCK, David. Op. cit.
} 
vale a pena deixar citada, como subsídio à reflexão, a distinção esclarecedora que Raymundo Faoro faz entre modernidade e modernização:

“... a modernidade compromete, no seu processo, toda a sociedade, ampliando o raio de expansão de todas as classes, revitalizando e removendo seus papéis sociais, enquanto que a modernização, pelo seu toque voluntário, se não voluntarista, chega à sociedade por meio de um grupo condutor, que, privilegiando-se, privilegia os setores dominantes. Na modernização não se segue o trilho da "lei natural" [do desenvolvimento], mas se procura moldar, sobre o país, pela ideologia ou pela coação, uma certa política de mudança."

\section{(..)}

"Na modernidade, a elite, o estamento, as classes - dizemos, para simplificar, as classes dirigentes - coordenam e organizam um movimento. Não o dirigem, conduzem ou promovem, como na modernização. A modernização, quer se chame ocidentalização, europeização, industrialização, revolução passiva, via prussiana, revolução do alto, revolução de dentro - ela é uma só, com um vulto histórico, com muitas máscaras, tantas quantas as das diferentes situações históricas". ${ }^{19}$

Não será demais também citar Alan Touraine, que igualmente nos ajuda a entender a modernidade, neste caso especificamente em relação às condições necessárias para o uso da razão:

"Não basta que estejam presentes as aplicações tecnológicas da ciência para que se fale de sociedade moderna. É preciso, além disso, que a atividade intelectual seja protegida das propagandas políticas ou das crenças religiosas, que a impersonalidade das leis proteja contra o nepotismo, o clientelismo e a corrupção, que as administrações públicas e privadas não sejam os instrumentos de um poder pessoal, que vida pública e vida privada sejam separadas, assim como devem ser as fortunas privadas do orçamento do Estado ou das empresas." ${ }^{20}$

Uma análise mesmo superficial de nossas histórias mostra que ambos países passaram por processos que apresentam muito mais características de modernização do que de modernidade. O que não significa que esta não seja possível. Trata-se de encontrar o caminho mais adequado.

\footnotetext{
19 FAORO, Raymundo. A questão nacional: a modernização. São Paulo, Revista Estudos Avançados 6(14), 1992, p. 8.

${ }^{20}$ TOURAINE, Alain. Crítica da Modernidade. $6^{\text {a }}$ ed. Petrópolis, Vozes, 1999, p. 18.
} 


\section{2 - ARQUITETURA E URBANISMO}

\subsection{1 - A Cidade Européia}

Talvez os aspectos mais evidentes das transformações que sofreram São Paulo e Buenos Aires estejam relacionados com a arquitetura e os espaços criados pelas elites, bem como pela adoção de costumes mais refinados, ao menos se comparados com os das elites de períodos anteriores.

No caso das residências, ocupavam lotes de grandes dimensões, o que permitia o afastamento dos limites destes, com uma arquitetura que procurava imitar modelos europeus. As famílias ricas procuravam contratar arquitetos estrangeiros ou que lá tivessem estudado, e as construções se caracterizavam também pelo uso intensivo de materiais importados. Em geral procuravam lugares altos, que eram mais saudáveis, como a avenida Paulista em São Paulo, e os bairros de Flores e Belgrano, em Buenos Aires. Analisaremos esta arquitetura com maiores detalhes no capítulo 5.

Passam a ser construídos também edifícios grandes e imponentes, que irão sediar tanto instituições públicas como privadas, configurando uma mudança de qualidade em relação ao aspecto destas cidades em épocas anteriores (figuras 1 e 2).

Com a dinamização da vida econômica, as regiões centrais passam a concentrar intensas atividades comerciais e financeiras. Nas figuras 3 e 4 podemos comprovar que também há semelhanças notáveis no aspecto destas áreas.

Também são reiteradamente citados os grandes planos de intervenção propostos para estas cidades, que na prática significaram apenas a reforma das áreas centrais. Como exemplo podemos citar o projeto para o Vale do Anhangabaú, Parque D. Pedro e Praça da Sé em São Paulo, e a abertura da Avenida de Mayo e remodelação da Praça de Mayo, em Buenos Aires. Veremos estes planos de forma mais detalhada no capítulo 4.

A intensa atividade social das camadas mais ricas é um dos aspectos que diferencia este período dos anteriores (figuras 5 e 6 ).

Em Buenos Aires uma das características é a proliferação de clubes, restaurantes e cafés exclusivos, onde se reuniam as pessoas mais importantes. Em um primeiro momento as oligarquias terratenentes, ligadas às atividades do campo, e os imigrantes enriquecidos não se misturam. Mas aos poucos existe um processo de integração que permite aos primeiros manter a hegemonia como elite, enquanto os segundos passam a ser aceitos como parte desse grupo fechado graças às fortunas amealhadas.

Nesse sentido, um dos eventos mais importantes foi a fundação do Jockey Club, sediado em um edifício muito refinado na rua Florida, inaugurado em $1897 .{ }^{21}$

\footnotetext{
${ }^{21}$ KORN, Francisco. La gente distinguida. In: ROMERO, José Luis; ROMERO, Luis Alberto (org.). Op. Cit.
} 


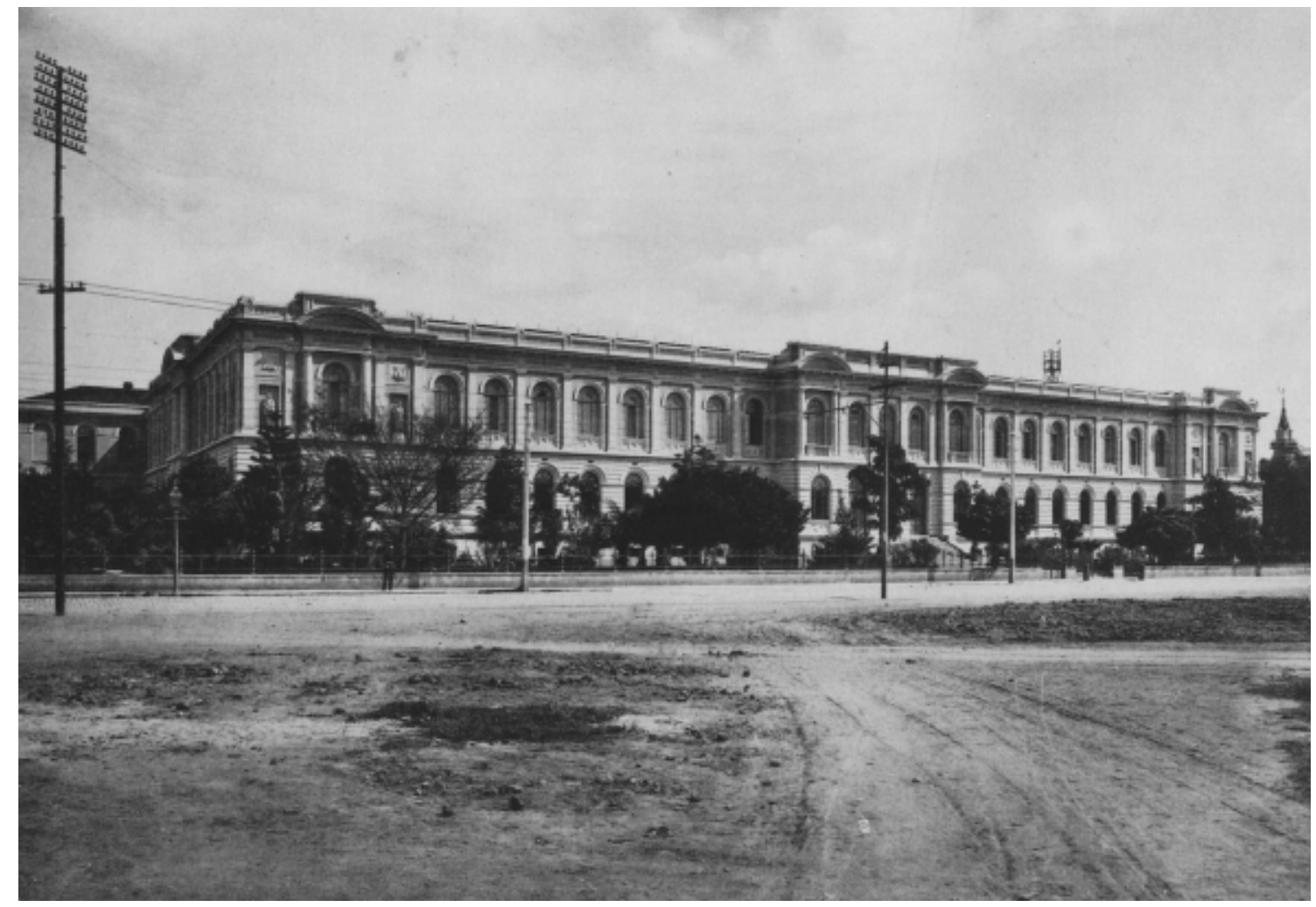

Figura 1 - A Escola Caetano de Campos foi a primeira grande obra após a Proclamação da República. O edifício foi inaugurado em 1894 e como a maioria das principais obras do período, é projeto do escritório de Ramos de Azevedo. Notar que a Praça da República é ainda um descampado.

Fonte: REIS FILHO, Nestor Goulart. Aspectos da História da Engenharia Civil em São Paulo 1860-1960. São Paulo, Kosmos, 1989.

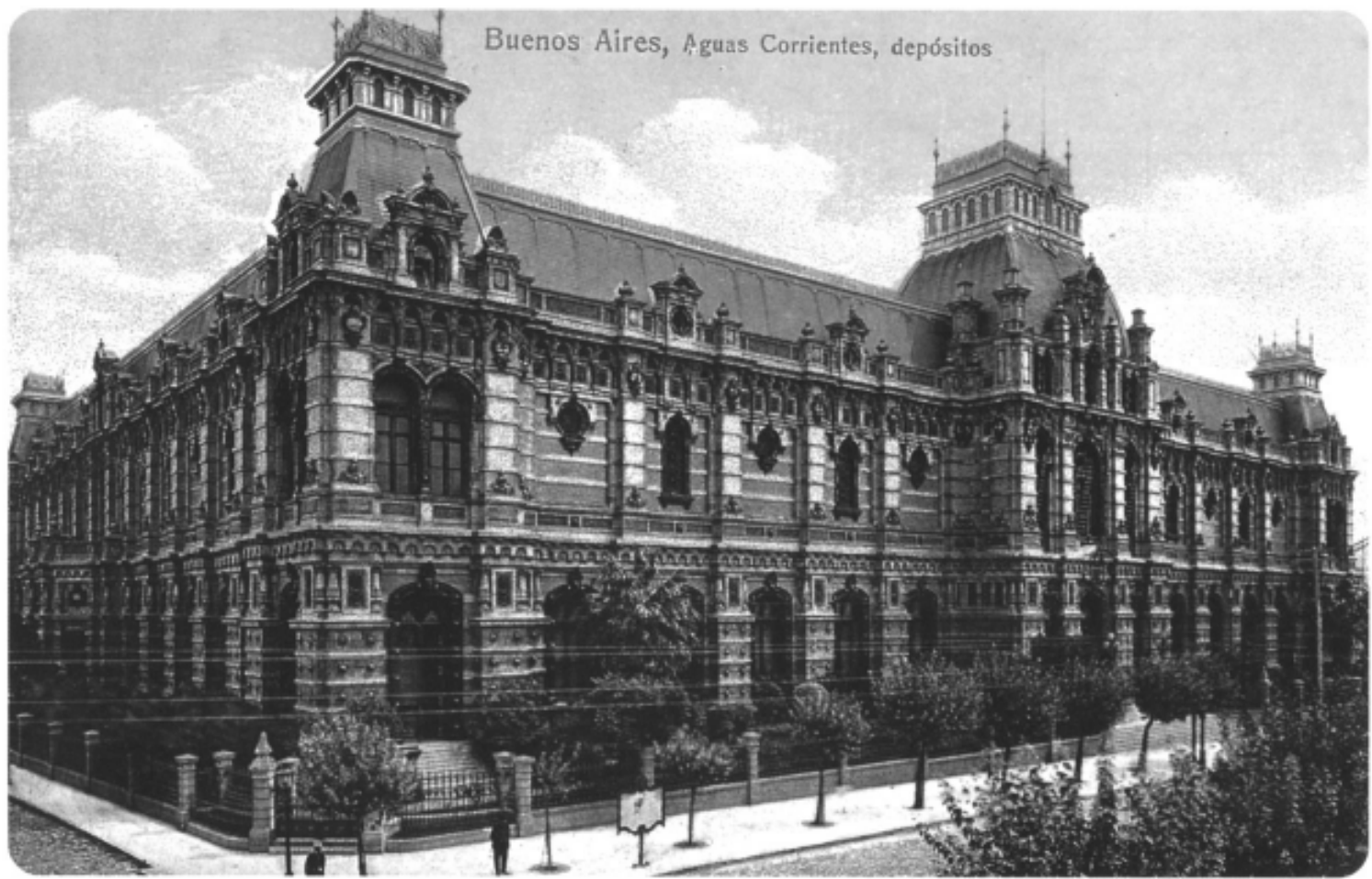

Figura 2- Palacio de las Aguas. Embora as fachadas sugiram um edifício normal trata-se na verdade de um enorme depósito de água. Fica na Avenida Córdoba e foi construído entre os anos 1887 e 1894, com utilização massiva de materiais importados.

Fonte: GUTIERREZ, Ramón (dir.). El Palacio de las Aguas. Buenos Aires, Aguas Argentinas, 1996. 

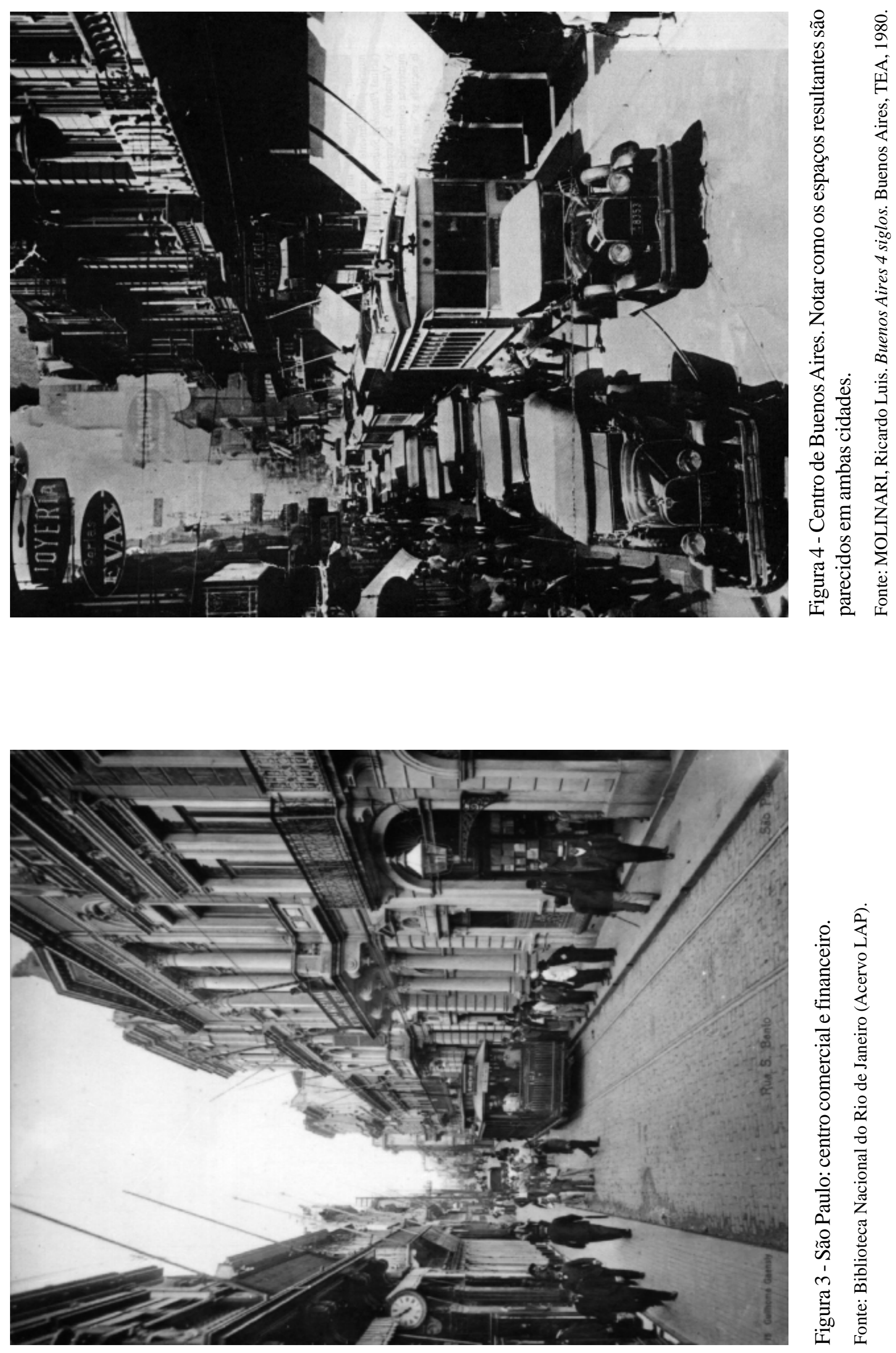

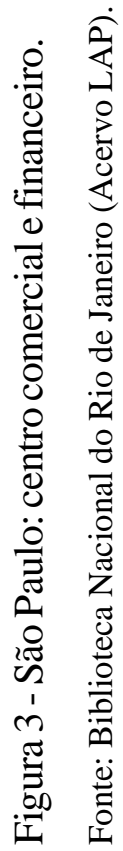



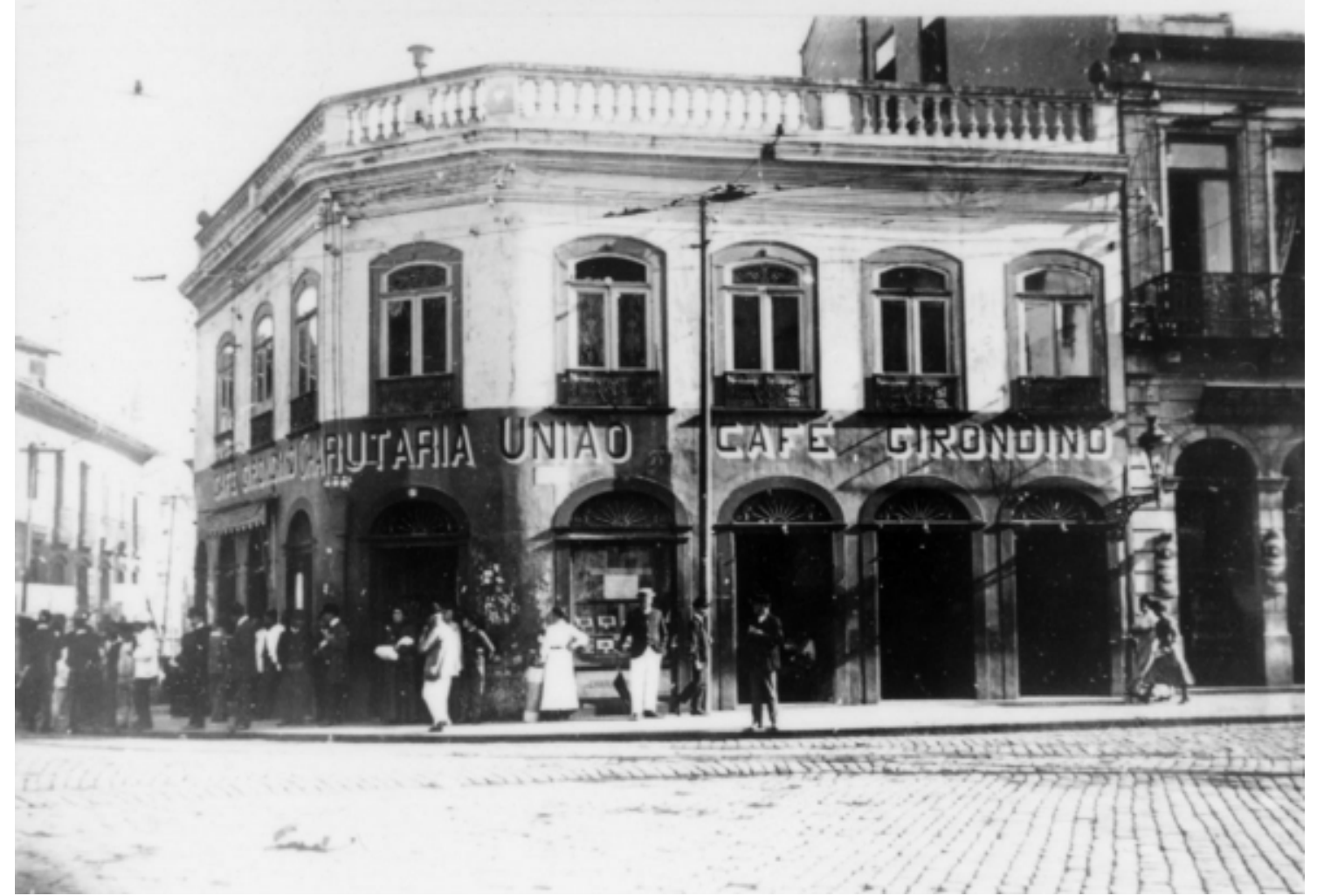

Figura 5 - Os cafés e confeitarias eram importantes pontos de reunião. Aqui vemos o café Girondino em 1910, quando ainda estava localizado na praça da Sé.

Fonte: Acervo LAP.

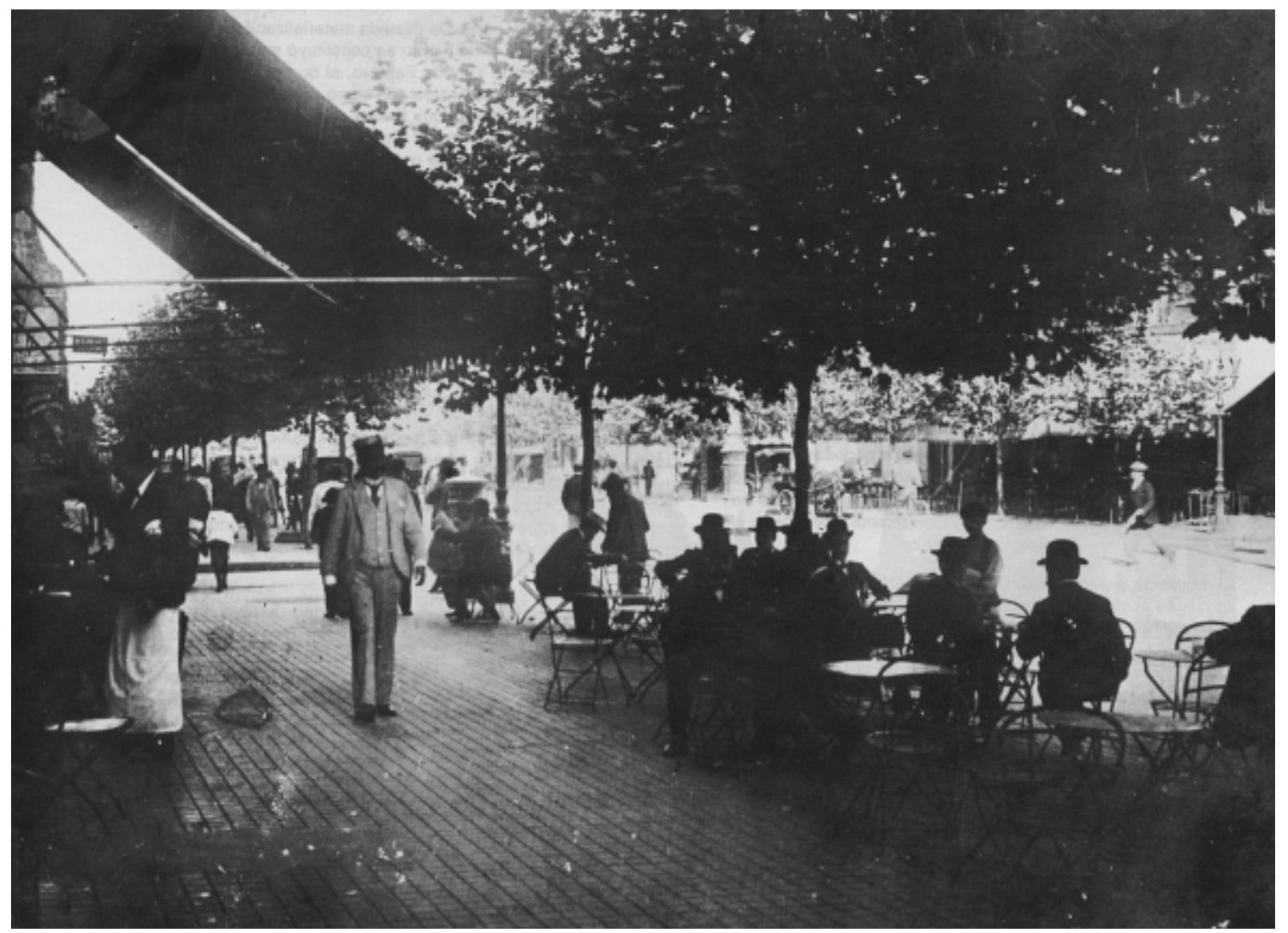

Figura 6 - A tradição francesa dos cafés encontrou terreno fértil em Buenos Aires, hábito que se mantém até os dias de hoje. Mas, como observou Ramón Gutierrez, ao contrário de Paris onde as mesas são colocadas na entrada para observar a avenida, aqui estas são posicionadas ao lado da via, deixando um espaço para a circulação dos pedestres.

Fonte: GUTIERREZ, Ramón. Buenos Aires. Evolución Histórica. Buenos Aires, Editorial Escala, 1990. 
Numerosos foram os teatros em Buenos Aires. Ainda no século XIX existiram algumas salas importantes como, por exemplo, o primeiro teatro Colón (inaugurado em 1857, que ficava onde atualmente está localizado o Banco de la Nación), o Ópera (1872), o Éden Argentino (1872), o Galdoni (1876), o Politeama (1879) e o Nacional (1882).

Mas sem dúvida o teatro definitivo será o novo Colón. Projetado por Francisco Tamburini, foi continuado por Victor Meano e finalizado em 1908 por Jules Dormal. Apesar do aspecto exterior um tanto despojado, trata-se de um projeto extremamente sofisticado e possui uma acústica que é considerada uma das melhores do mundo (figura 7).

Embora a cidade de Buenos Aires se caracterize pela predominância da quadricula, alguns bairros situados ao norte exibem características de desenho urbano cujo objetivo é torná-los diferenciados. Isto é feito com a introdução de alguns elementos exclusivos, tais como pequenas praças (Carlos Pellegrini e avenida Alvear), fontes (Guido e Anchorena, Arroyo e Esmeralda), ruas em declive ou curvas, como Arroyo, escadarias como Seaver ou ainda através de um desenho labiríntico, como no bairro de Palermo Chico. Eram bairros caros que impediam a aquisição por aqueles que não tinham dinheiro e esse distanciamento, como aponta Sebreli, criava um papel mítico-real de personagens de lenda. ${ }^{22}$

Este mundo se introjetava nas classes médias como padrão de desejo através de diversos meios, entre os quais revistas como "Caras e Caretas" (a partir de 1898) e "El Hogar" (desde 1903). Através destas as classes médias podiam sonhar em almejar pertencer à aristocracia (como também saber seu lugar na sociedade). Estas revistas somente irão perder força em fins dos anos 1930, quando o rádio e a televisão substituem aquela em seu papel mítico. Aí surgem revistas como Sintonía, Antena e Radiolandia. ${ }^{23}$

O lugar preferido para os passeios era nos parques de Palermo. Tratavase de um curioso "corso", realizado nas tardes das quintas-feiras e domingos. Assim funcionava:

“... cuatro filas de coches yendo y viniendo em um tramo de tres cuadras por la actual Avenida Sarmiento, intercambiando en cada vuelta la ubicación para que todos pudieran cruzarse inevitablemente con todos. La ceremonia tenía sus reglas fijas: en la primera se saludaban, en las siguintes fingían no verse $y$ en la última se despedían."24

Estes desfiles não eram exclusividade de Buenos Aires, mas eram praticados também em diversas cidades latino-americanas: nas Alamedas de Lima e de Santiago, no Paseo de la Reforma no México e no Prado de Montevidéu. ${ }^{25}$

\footnotetext{
22 SEBRELI, Juan José. Buenos Aires, vida cotidiana y alienación. $15^{\mathrm{a}}$ ed. Buenos Aires, Ediciones Siglo Veinte, 1990.

${ }^{23}$ Idem, ibidem.

24 Idem, ibidem. p. 45.

${ }^{25}$ ROMERO, José Luis. Latinoamérica: las ciudades y las ideas. $4^{\mathrm{a}}$ ed. Buenos Aires, Siglo XXI, 1986, p. 277.
} 


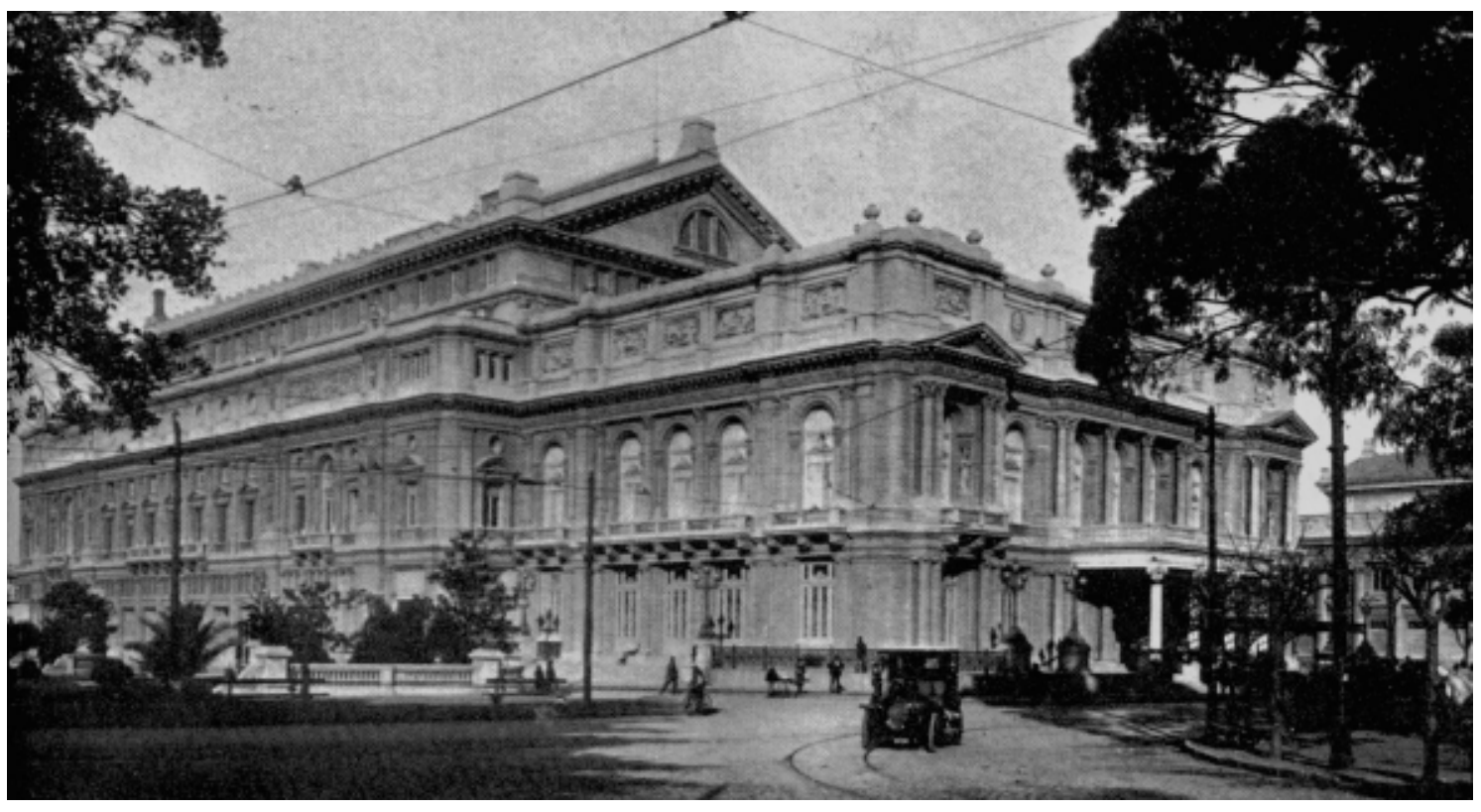

Figura 7 - Teatro Colón, em Buenos Aires.

Fonte: MOLINARI, Ricardo Luis. Buenos Aires 4 siglos. Buenos Aires, TEA, 1980.

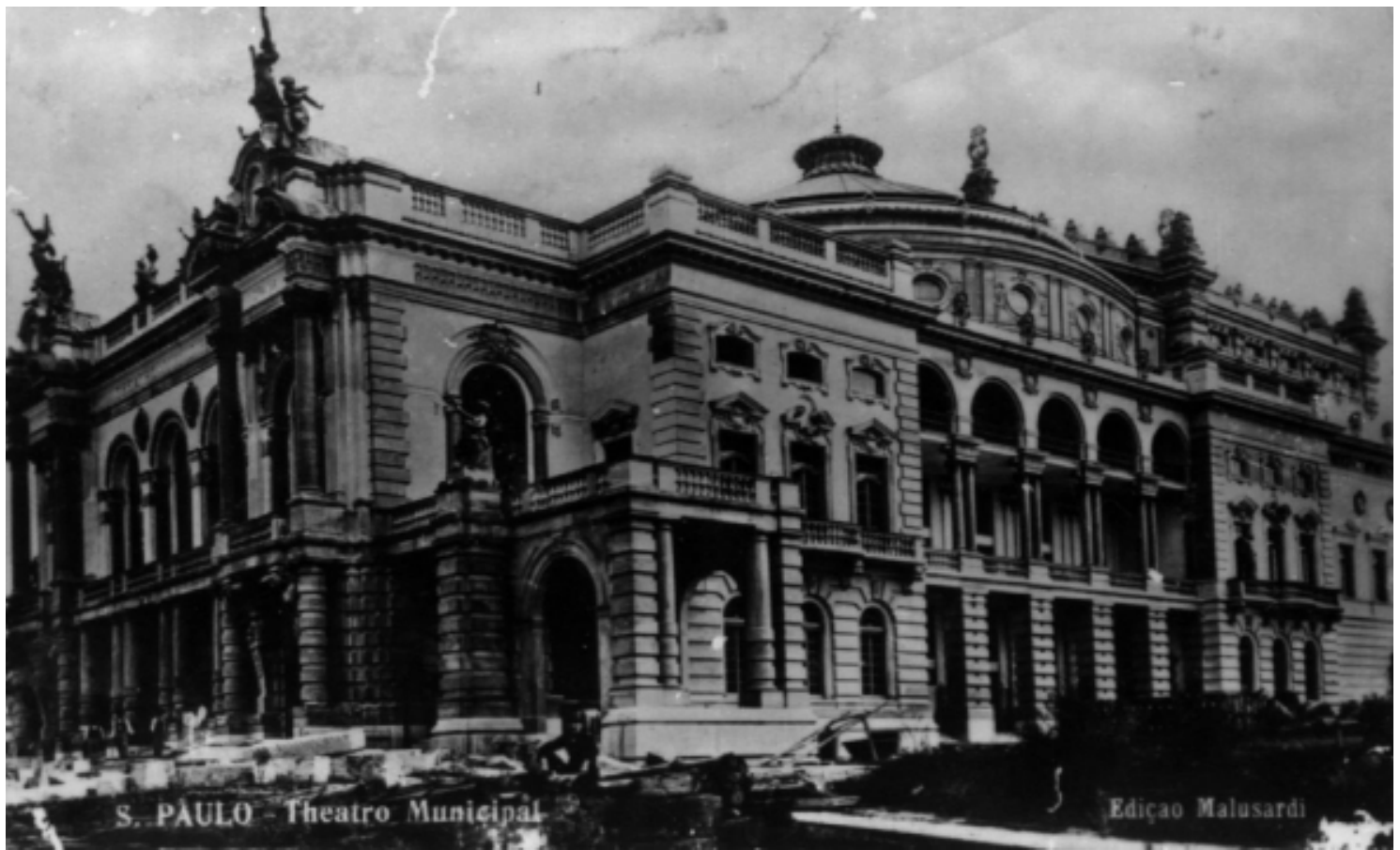

Figura 8 - Em São Paulo, as novas elites passam a frequentar lugares diferenciados, como o Teatro Municipal.

Fonte: Biblioteca Municipal Mário de Andrade (Acervo LAP). 
Em São Paulo as famílias mais ricas freqüentavam a área do "triângulo" central. As confeitarias de luxo estavam situadas principalmente no Largo do Rosário e na Rua Quinze de Novembro. Após a demolição da igreja do Rosário e as reformas efetuadas no local, terminadas por volta de 1904, este ponto passou a ser o "coração da cidade", que é a atual praça Antonio Prado. Nestas confeitarias reuniam-se os rapazes elegantes da cidade. Por ali também passavam todas as linhas de bonde. ${ }^{26}$

A livraria Garraux era um dos pontos de encontro da intelectualidade. Ficava na Rua Quinze de Novembro em frente à rua da Quitanda. Na porta da livraria reuniam-se os homens "de idade provecta", para apreciar as "belezas femininas que iam às compras". ${ }^{27}$

Nessa região também estavam instalados importantes hotéis, como o Grande Hotel, que era um dos principais edifícios da cidade. Fora fundado, ao que parece em 1878, pelo alemão Frederico Glette, tinha sua frente voltada para a Rua de São Bento e ocupava todo um quarteirão do beco da Lapa. Hospedou diversos visitantes ilustres, como o príncipe Enrique da Prússia, irmão de Guilherme II. Segundo diversos cronistas da época, era o melhor hotel do Brasil. Também ali ficou hospedada a famosa atriz Sara Bernhardt, que chegou a São Paulo vinda do Rio de Janeiro em um trem especial, no dia 27 de junho de 1886. Ocupou três aposentos do primeiro pavimento superior e estreou no dia 28, no teatro São José, o drama Fédora, de Victorian Sardou. ${ }^{28}$

São Paulo teve vários teatros, como o Teatro Minerva, o Provisório Paulistano, o Ginásio Paulistano e o das Variedades Paulistanas. Havia também o teatro São José, que se incendiou em 1898 e foi depois reconstruído. Também figuravam dois teatros improvisados em barracões de zinco - o Politeama e o Eldorado. Posteriormente foi edificado o Santana, o melhor até a inauguração do Teatro Municipal.

Este último foi projeto de Cláudio Rossi, executado pelo escritório Ramos de Azevedo, com participação de Domiziano Rossi. Sua construção foi iniciada em 1903 e a inauguração deu-se em setembro de 1911, com Tita Ruffo cantando em Hamlet (figura 8).

Família sofisticada que se prezasse costumava viajar à Europa, geralmente de março ou abril a setembro. As saídas do Porto de Santos eram um dos acontecimentos sociais mais importantes. Embarcavam em um trem especial da São Paulo Railway, na Estação da Luz, que os deixava ao lado do navio, graças a um desvio especial. O mesmo acontecia com as chegadas, em setembro ou outubro, que eram noticiadas nos jornais e que deixavam a sociedade alvoroçada, sempre ávida por novas modas vindas da Europa. ${ }^{29}$

Assim como em Buenos Aires, em São Paulo também existiu um processo de integração entre as antigas elites e os imigrantes recém enriquecidos. Alcântara Machado tem um conto chamado "A sociedade", que trata de um casamento entre 0 filho de Salvatore Melli, um italiano enriquecido, e a filha do conselheiro José

\footnotetext{
${ }^{26}$ BRUNO, Ernani da Silva. História e Tradições da Cidade de São Paulo. 3 Vol. $3^{\underline{a}}$ ed. São Paulo, Hucitec, 1984.

${ }^{27}$ AMERICANO, Jorge. São Paulo naquele tempo (1895-1915). São Paulo, Saraiva, 1957, p. 155.

${ }^{28}$ MARTINS, Antônio Egidio. São Paulo antigo (1554 a 1910). São Paulo, Conselho Estadual de Cultura, s.d., p. 311.

${ }^{29}$ AMERICANO, Jorge. Op. cit., p. 237.
} 
Bonifácio. O conto começa com a seguinte frase, dita pela esposa do conselheiro: "Filha minha não casa com filho de carcamano!" E termina com o casamento de Adriano e Teresa Rita. O desfecho é resultado de um acordo econômico entre o italiano que começou vendendo cebolas e batatas para a esposa do conselheiro e enriqueceu. Neste acerto, o conselheiro entra com sua posição social e o italiano com o dinheiro. ${ }^{30}$

\subsection{2 - A Cidade Inacabada}

Uma característica de ambas cidades é o fato de serem um permanente canteiro de obras. De fato, a velocidade das transformações implicou na substituição contínua de edificações bem como de abertura ou alargamento das vias. Com isso as cidades passam a ter um aspecto inacabado. Em 1886, um italiano, Dr. Lomônaco observava:

"São Paulo não apresenta ainda os aspectos de grande cidade, no sentido exato da palavra. Está sujeita, presentemente, a um regimen, a uma obra de continuas demolições e transformações, que a melhoram e embelezam de dia para dia e não pode concluir-se em breve lapso.

Uma cidade nova tende a tomar o lugar de outra antiga, e ao mesmo tempo, novos bairros se constroem, obedecendo a melhor planta e melhores canones de que os antigos, dilatando-se-Ihe diariamente a periferia... Daí provêm contrastes muito acentuados.

Ao lado dos belos palacetes, em condições de figurar em qualquer grande cidade, ainda se notam os casebres baixos e humildes, as casas de taipa construidas pelos primeiros colonos portugueses. Em confronto com algumas ruas, bem pavimentadas, com numerosos edifícios, outras já se apresentam, apenas delineadas e de edificação esparsa, cobertas de hervas rasteiras, ou de chão de terra, impraticaveis desde que chova.

Tal desequilibrio de construção e de diferenças de aspectos materiais observa-se tanto na parte velha como na nova. Não há bairro, pode-se dizer, do qual se afirme que tem definitivo aspecto. Assim só dentro de dez ou quinze anos terá São Paulo definitivo facies, conquistando o feitio de grande e bela cidade. ${ }^{, 31}$

\footnotetext{
${ }^{30}$ MACHADO, António de Alcântara. Brás, Bexiga e Barra Funda: notícias de São Paulo. Ed. Fac-similar. São Paulo, Imprensa Oficial do Estado/Arquivo do Estado, 1982, p. 69.

${ }^{31}$ Citado em MORSE, Richard M. Formação Histórica de São Paulo. São Paulo, Difusão Européia do Livro, 1970, p. 243.
} 
Esta situação aparentemente ainda permanecia em 1905, a julgar pela afirmação do escritor Souza Pinto, de que a cidade não estava ainda "de todo concluída". ${ }^{32}$

Essas constantes transformações em Buenos Aires não passaram desapercebidas a Borges, que no poema "Para uma calle del Oeste" escreveu: "calle que dolorosamente como uma herida te abres". ${ }^{33}$

Em relação a este tema, Liernur fez um interessante trabalho chamado "A cidade efêmera". ${ }^{34}$ Analisando uma grande coleção de fotografias antigas observou que as construções provisórias ou fora do padrão usualmente aceito como representativo de Buenos Aires no período têm muito maior significância do que usualmente lhe é dada. Mas não é apenas uma impressão, já que o mesmo fenômeno pode ser confirmado nos censos, onde está registrada uma grande quantidade de casas de chapa e madeira. Em resumo, conclui que pelo menos até a década de 1910, a idéia de Buenos Aires como uma cidade "acabada" é a construção de uma imagem, que não corresponde à realidade (figuras 9 a 16).

Em outras palavras, podemos dizer que os discursos procuravam vender a idéia teleológica de que aquelas reformas teriam como resultado final uma cidade terminada, sem levar em conta nem sua contínua construção e reconstrução, nem o fato de que a urbanização é um processo, o que pressupõe transformações permanentes.

\subsection{3 - Infra-estrutura}

Um dos processos mais significativos que tem curso neste período é o imenso investimento realizado em infra-estrutura: sistemas de águas e esgotos, gás e energia elétrica, bondes, ônibus e trens, etc. Estas cidades passam na época a contar com equipamentos comparáveis aos existentes nas cidades dos países mais desenvolvidos.

Em geral a data de introdução das principais inovações técnicas é aproximadamente a mesma em ambas cidades. Entretanto, devido às diferenças de tamanho e população, quantitativamente há diferenças.

Um exemplo são os transportes públicos. No século XIX os principais meios de transportes urbanos eram os movidos por animais. Podiam ser vários tipos de carruagens, particulares ou de aluguel, como também os bondes. Estes padeciam em São Paulo de uma dificuldade não existente em Buenos Aires, que são os desníveis topográficos. Era comum que em determinados lugares fossem atrelados mais animais para vencer as ladeiras, ainda assim com dificuldade para estes últimos.

\footnotetext{
${ }^{32}$ Citado em: BRUNO, Ernani da Silva. História e Tradições da Cidade de São Paulo. 3 Vol. $3^{\text {a }}$ ed. São Paulo, Hucitec, 1984, p. 913.

${ }^{33}$ Citado em: GRAU, Cristina. Borges y la arquitectura. Madrid, Cátedra, 1989, p. 20.

34 LIERNUR, Jorge F. e SILVESTRI, Graciela. El umbral de la metrópolis. Transformaciones técnicas y cultura en la modernización de Buenos Aires (1870-1930). Buenos Aires, Editorial Sudamericana, 1993.
} 


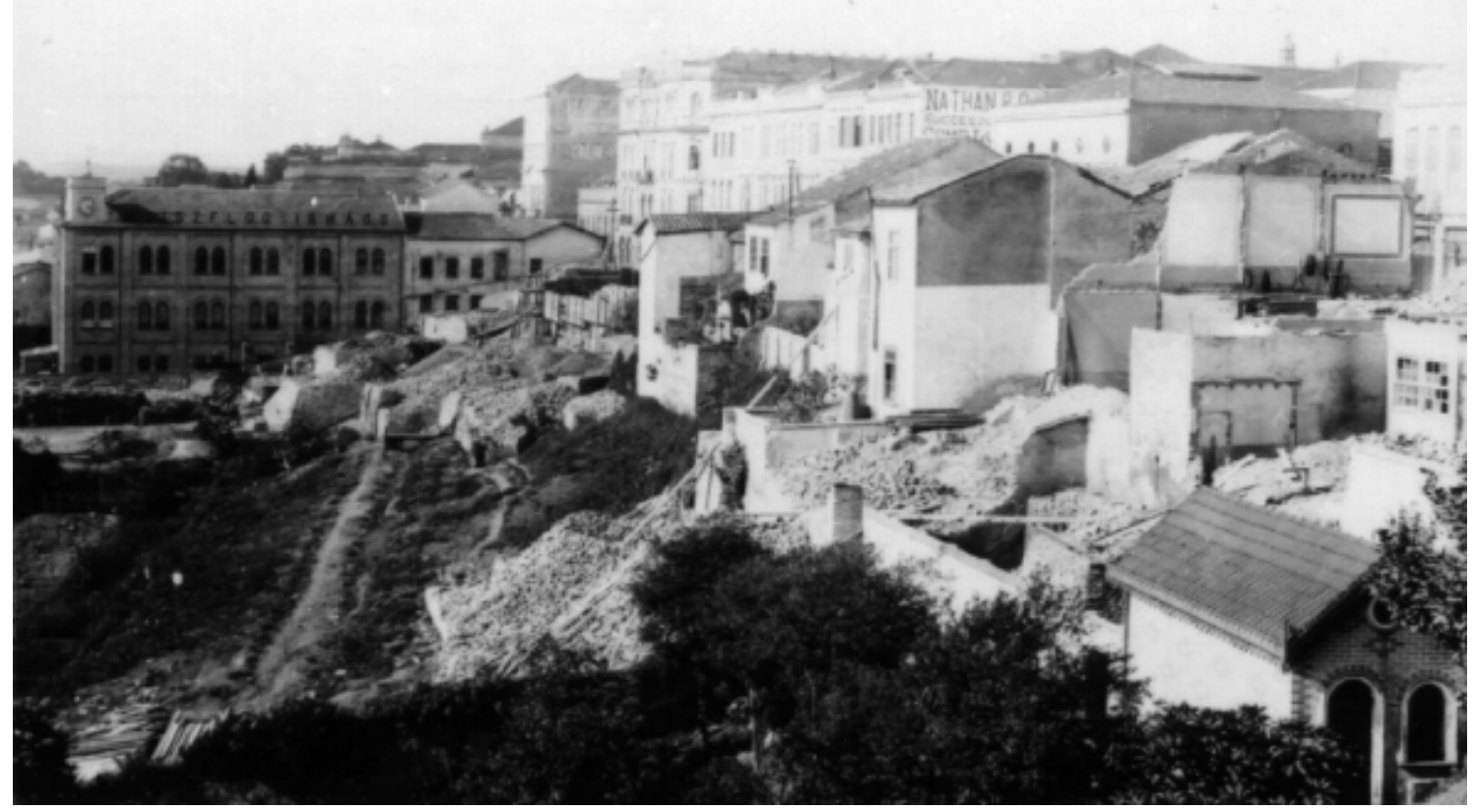

Figura 9 - O período é marcado pela sucessiva construção e reconstrução da cidade de São Paulo. Aqui vemos as obras no vale do Anhangabaú, realizadas na década de 1910.

Fonte: Biblioteca Municipal Mário de Andrade (Acervo LAP).

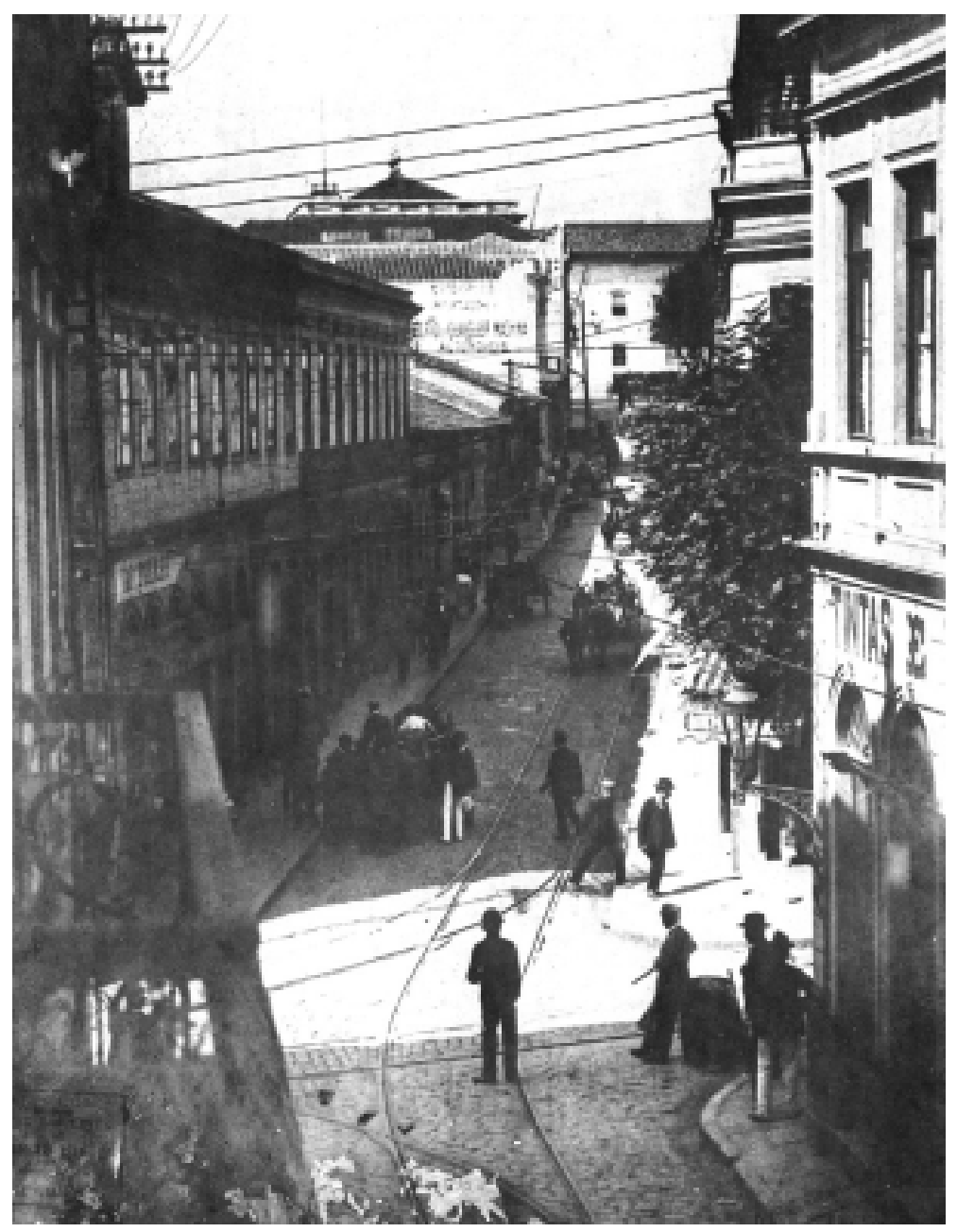

Figura 10 - Vista da rua Líbero Badaró, esquina com a rua São João. Ao fundo o Largo de São Bento. Foto de 1902, antes do alargamento da rua.

Fonte: ELETROPAULO. A Cidade da Ligth. 1899/1930. Departamento de Patrimônio Histórico/Eletropaulo, 1990. 


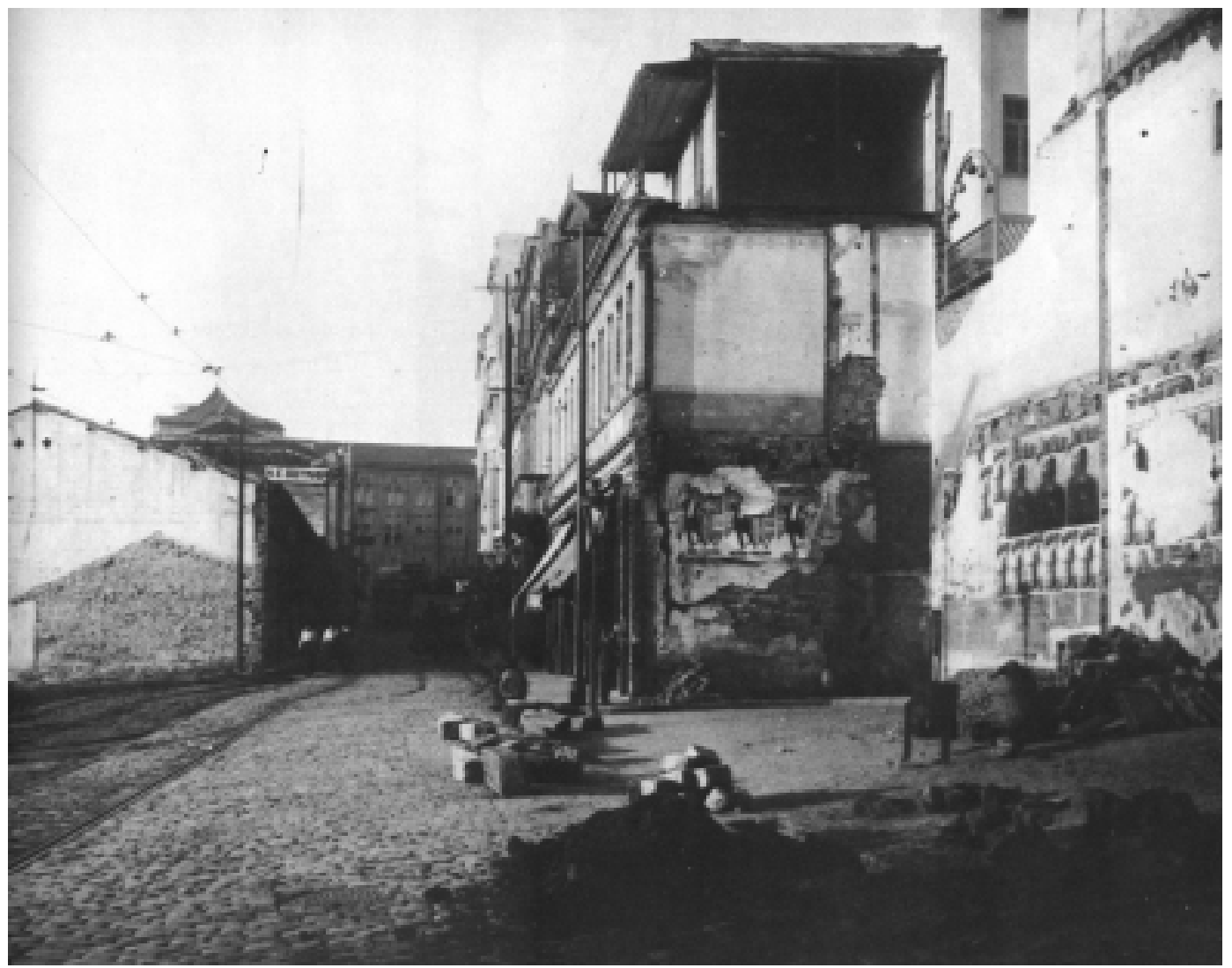

Figura 11 - Foto tomada na mesma direção da anterior. Podem ser observadas as demolições para alargamento da rua Líbero Badaró. Ao fundo, o Mosteiro de São Bento já reformado.

Fonte: ELETROPAULO. A Cidade da Ligth. 1899/1930. Departamento de Patrimônio Histórico/ Eletropaulo, 1990.

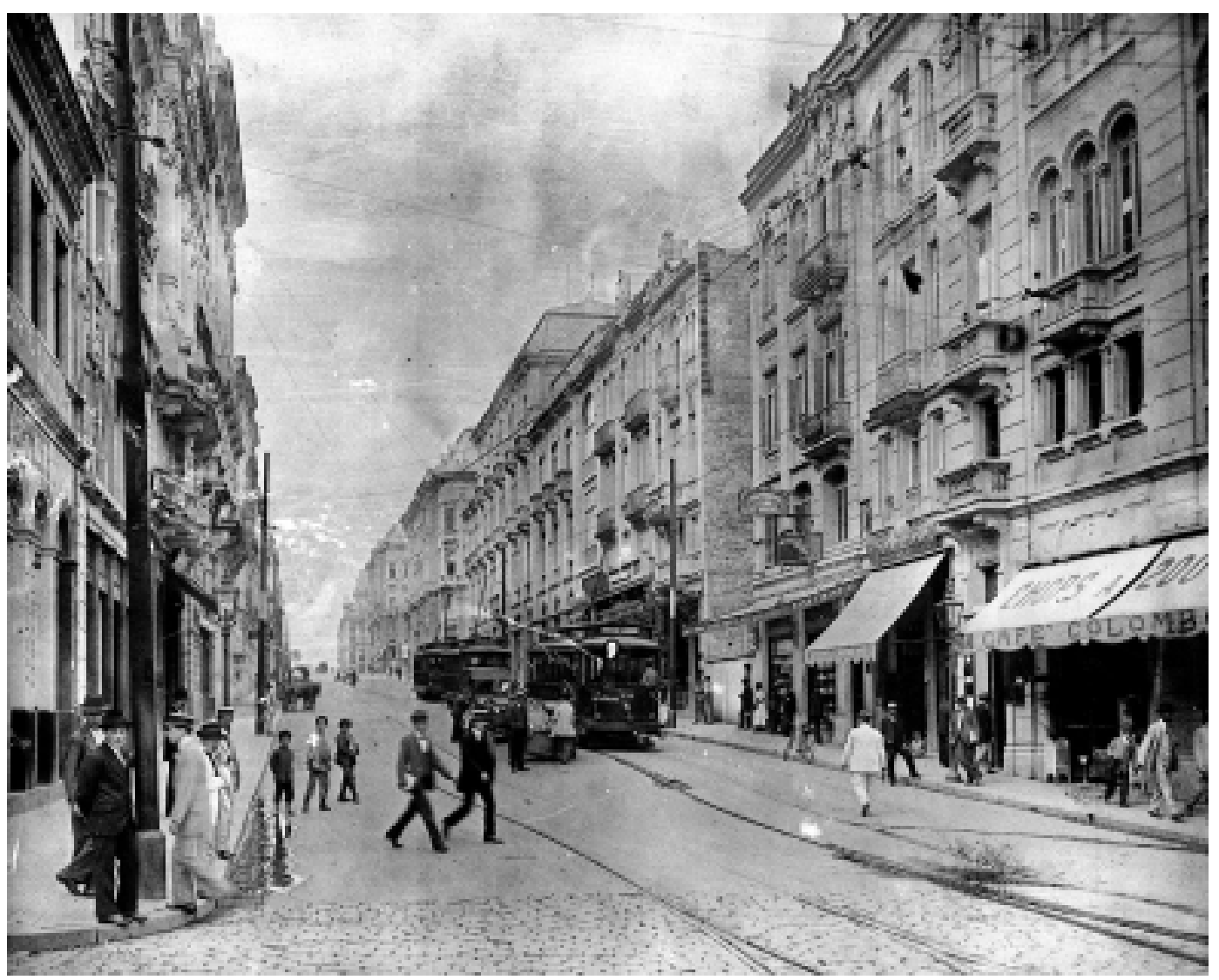

Figura 12 - Foto de 1916 da rua Líbero Badaró, já finalizada.

Fonte: ELETROPAULO. A Cidade da Ligth. 1899/1930. Departamento de Patrimônio Histórico/ Eletropaulo, 1990. 


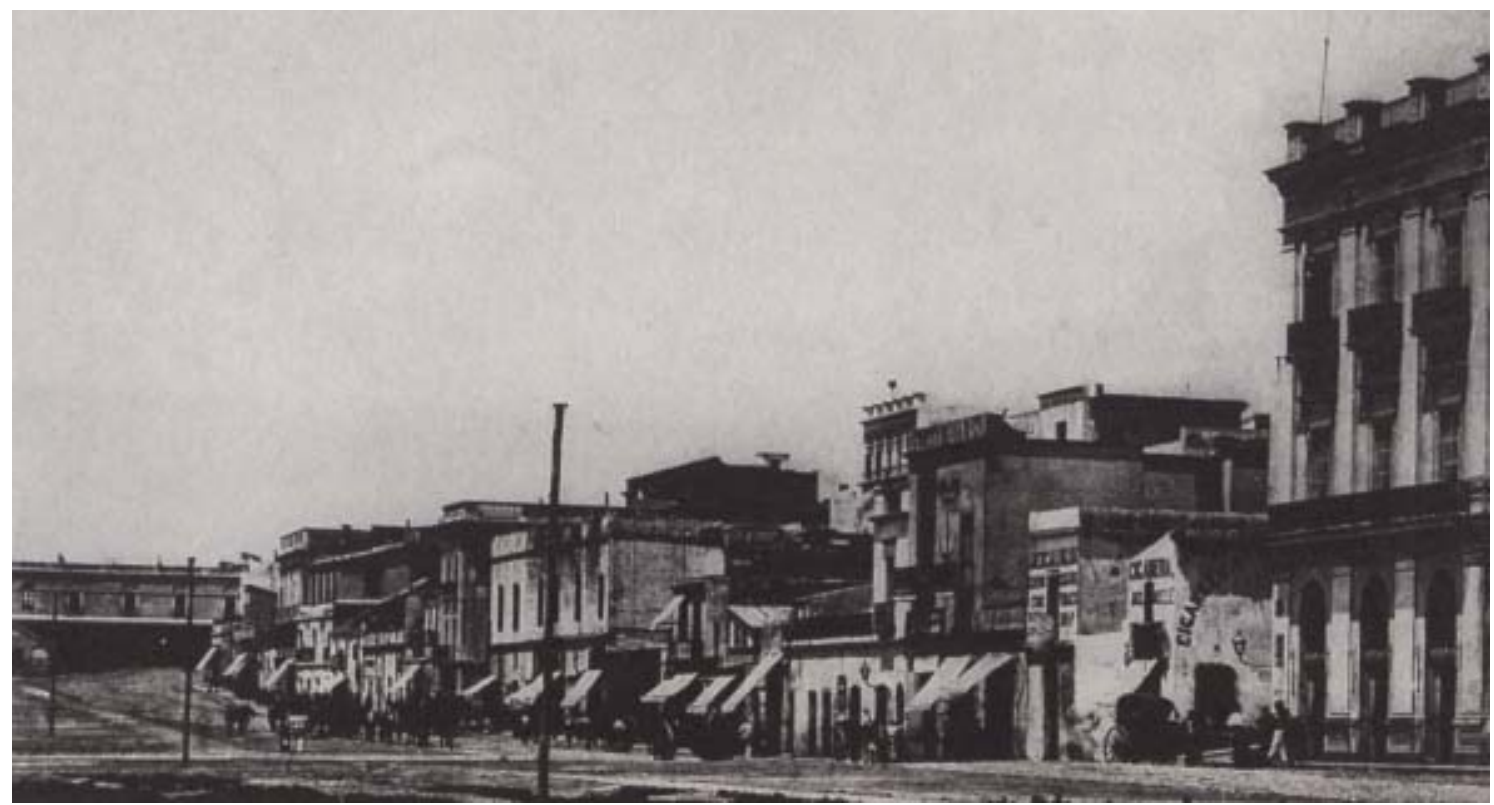

Figura 13 - Baixos do Paseo de Julio. Notar a precariedade das construções.

Fonte: GUTIERREZ, Ramón. La Plaza de Mayo. Buenos Aires, Fundación Banco de Boston, 1995.

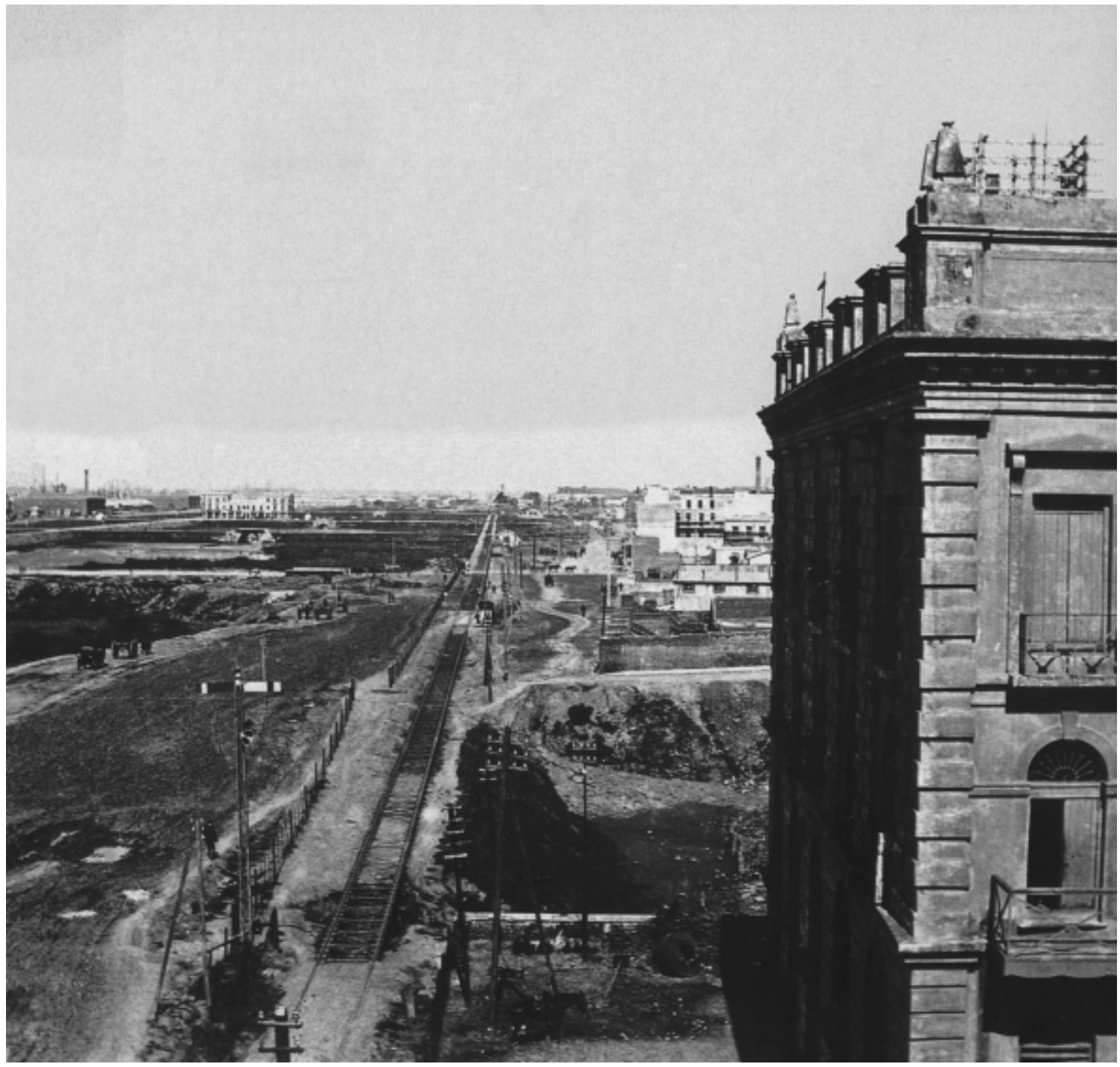

Figura 14 - Paseo Colón. Foto tirada em 1895, desde a Casa de Governo. Comparar com as fotos seguintes.

Fonte: GUTMAN, Margarita (ed.). Buenos Aires 1910: memoria del porvenir. Buenos Aires, Gobierno de la Ciudad de Buenos Aires/ Faculdade de Arquitetura, Design e Urbanismo da Universidade de Buenos Aires/ IIED-America Latina, 1999. 


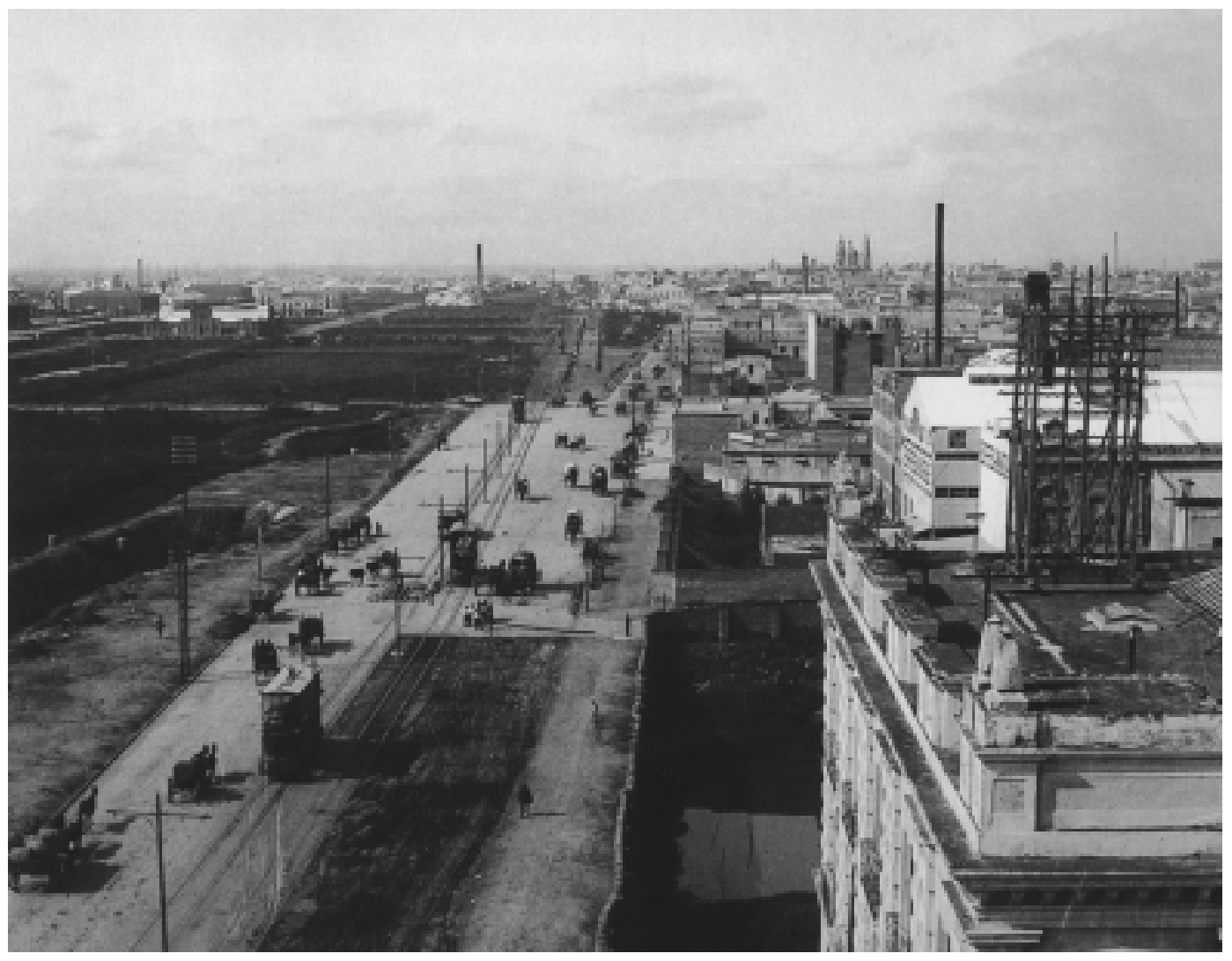

Figura 15 - Paseo Colón, 1900. Foto tirada do mesmo ponto da anterior, mostra o início da execução das obras de calçamento.

Fonte: GUTMAN, Margarita (ed.). Buenos Aires 1910: memoria del porvenir. Buenos Aires, Gobierno de la Ciudad de Buenos Aires/ Faculdade de Arquitetura, Design e Urbanismo da Universidade de Buenos Aires/ IIED-America Latina, 1999.

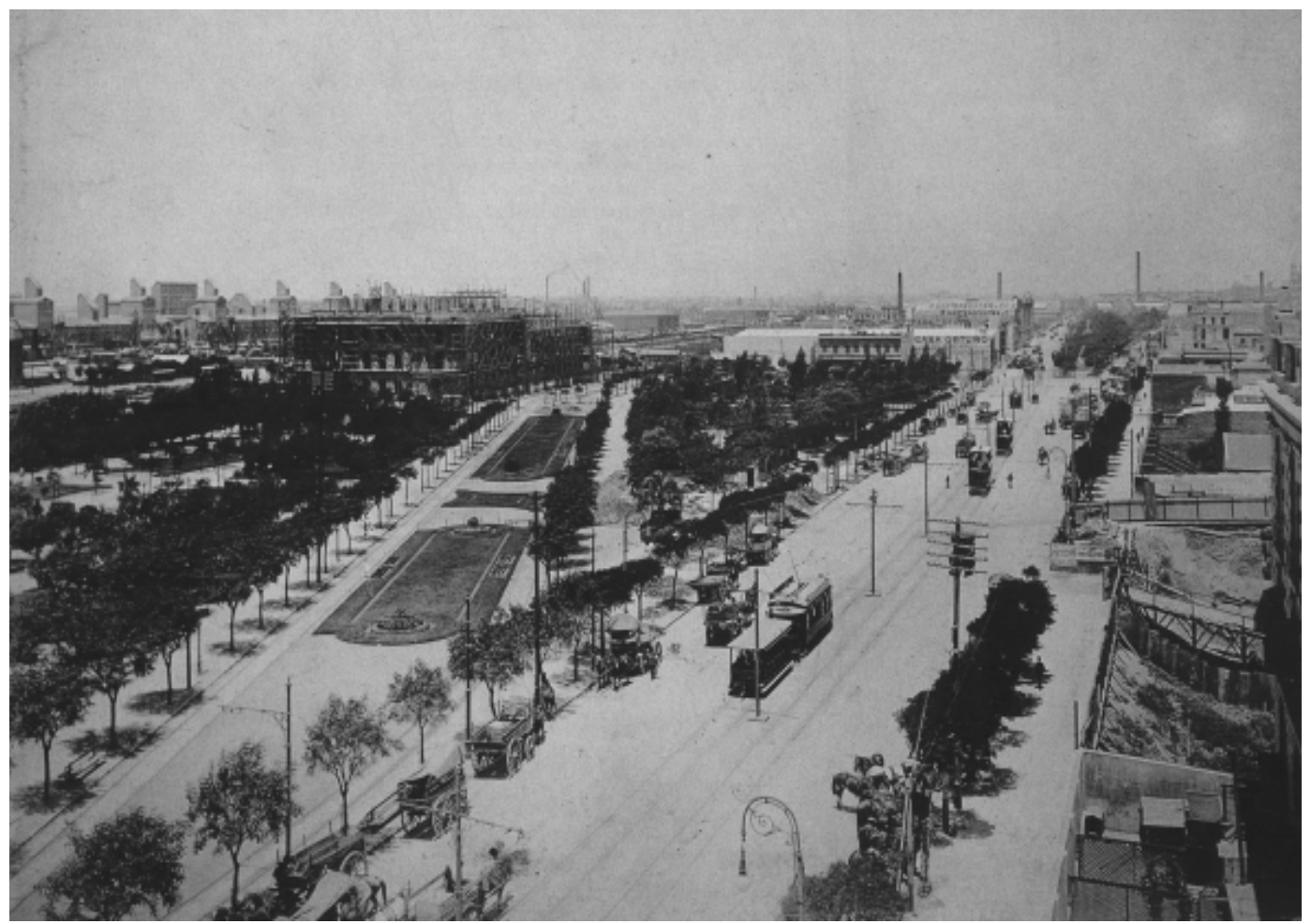

Figura 16 - Paseo Colón, 1912. Foto tomada da Casa de Governo. Notar as grandes transformações ocorridas no entorno.

Fonte: GUTMAN, Margarita (ed.). Buenos Aires 1910: memoria del porvenir. Buenos Aires, Gobierno de la Ciudad de Buenos Aires/ Faculdade de Arquitetura, Design e Urbanismo da Universidade de Buenos Aires/ IIED-America Latina, 1999. 
Em 1886 a cidade contava com aproximadamente $20 \mathrm{~km}$ de linhas. ${ }^{35} \mathrm{Em}$ Buenos Aires, em 1870, a rede tinha perto de $30 \mathrm{~km}$ de extensão. ${ }^{36}$

Em São Paulo, em 1890, os bondes transportaram pouco mais de 2.800.000 passageiros. Em 1892 foram mais de 10 milhões, e em 1894 mais de 17 milhões. ${ }^{37}$ Nos mesmos anos em Buenos Aires foram respectivamente 56.141.000, 67.161 .000 e $76.994 .000 .^{38}$

$\mathrm{Na}$ virada do século XIX para o XX as linhas de bondes começaram a ser eletrificadas, o que permitiu um funcionamento mais eficiente do sistema, principalmente em São Paulo onde, como já observamos, havia a dificuldade dos desníveis. O número de passageiros transportados indica a rápida expansão da rede.

Em São Paulo, em 1911 havia $180 \mathrm{Km}$ de linhas transportando 37.471 .293 passageiros. Em 1913 eram respectivamente $230 \mathrm{Km}$ e 56.537 .512 passageiros ${ }^{39} \mathrm{Em}$ Buenos Aires em 1910 havia $652 \mathrm{Km}$ de linhas e 323.791 .000 passageiros transportados. Em 1913 já eram 771 km de linhas com 411.494 .512 passageiros $^{40}$ (figuras 17 a 20).

Como era de se esperar, o sistema em Buenos Aires é bem maior naquele período. Não nos devemos esquecer também que já em 1913 esta cidade passa a contar com um sistema de metrô, que ligava a Praça de Mayo com a Praça Once (figuras 21 a 24).

Em São Paulo também foram importantes algumas obras de infra-estrutura que permitiam vencer os desníveis. É o caso do Viaduto do Chá, inaugurado em 1892, que possuía $240 \mathrm{~m}$ de comprimento (180 m em ferro e $60 \mathrm{~m}$ em aterro) e $14 \mathrm{~m}$ de largura. Para utilizá-lo era necessário pagar uma taxa de três vinténs (figura 25). Outro viaduto importante foi o de Santa Efigênia, que foi concluído em 1913, tendo sido todo fabricado na Bélgica. Possuía 225 m de extensão (figura 26).

As obras de saneamento também tiveram um impacto significativo nas cidades de então. Em parte foram necessárias devido às enormes deficiências sanitárias e ocorrência crônica de pestes e epidemias. Nesse sentido, Buenos Aires sofreu mais intensamente que São Paulo, principalmente no período de 1871 a 1876.

Em São Paulo a primeira iniciativa efetiva de implantar um sistema sanitário nasceu da criação da Companhia Cantareira, criada em 1877, que começou a funcionar em $1881 .{ }^{41}$ Antes a água estava disponível apenas em alguns chafarizes, que em geral não a forneciam em quantidade suficiente para toda a população. Não se deve esquecer que enquanto existiu escravidão, eram os escravos os encarregados de buscar tanto a água nos chafarizes como eliminar os esgotos das casas. Em 1878 começou a ser construído o reservatório da Consolação, para armazenar a água

\footnotetext{
35 STIEL, Waldemar Correa. História dos transportes coletivos em São Paulo. São Paulo, McGrawHill/Edusp, 1978.

${ }^{36}$ BUENOS AIRES (Cidade). Censo General de la Ciudad de Buenos Aires. 1909. Tomo III, p. 540.

37 BRUNO, Ernani da Silva. História e Tradições da Cidade de São Paulo. 3 Vol. $3^{\text {a }}$ ed. São Paulo, Hucitec, 1984, p. 1079.

38 SCOBIE, James R. Buenos Aires. Del centro a los barrios. 1870-1910. Buenos Aires, Solar/Hachette, 1977, p. 342.

${ }^{39}$ STIEL, Waldemar Correa. Op. Cit.

${ }^{40}$ BUENOS AIRES (Cidade). Op. cit.

${ }^{41} \mathrm{O}$ primeiro distrito com esgotos foi o bairro da Luz. O serviço foi entregue no dia $1^{\circ}$ de fevereiro de 1883, servindo um total de 71 prédios. MARTINS, Antônio Egídio. Op. cit. p. 293.
} 

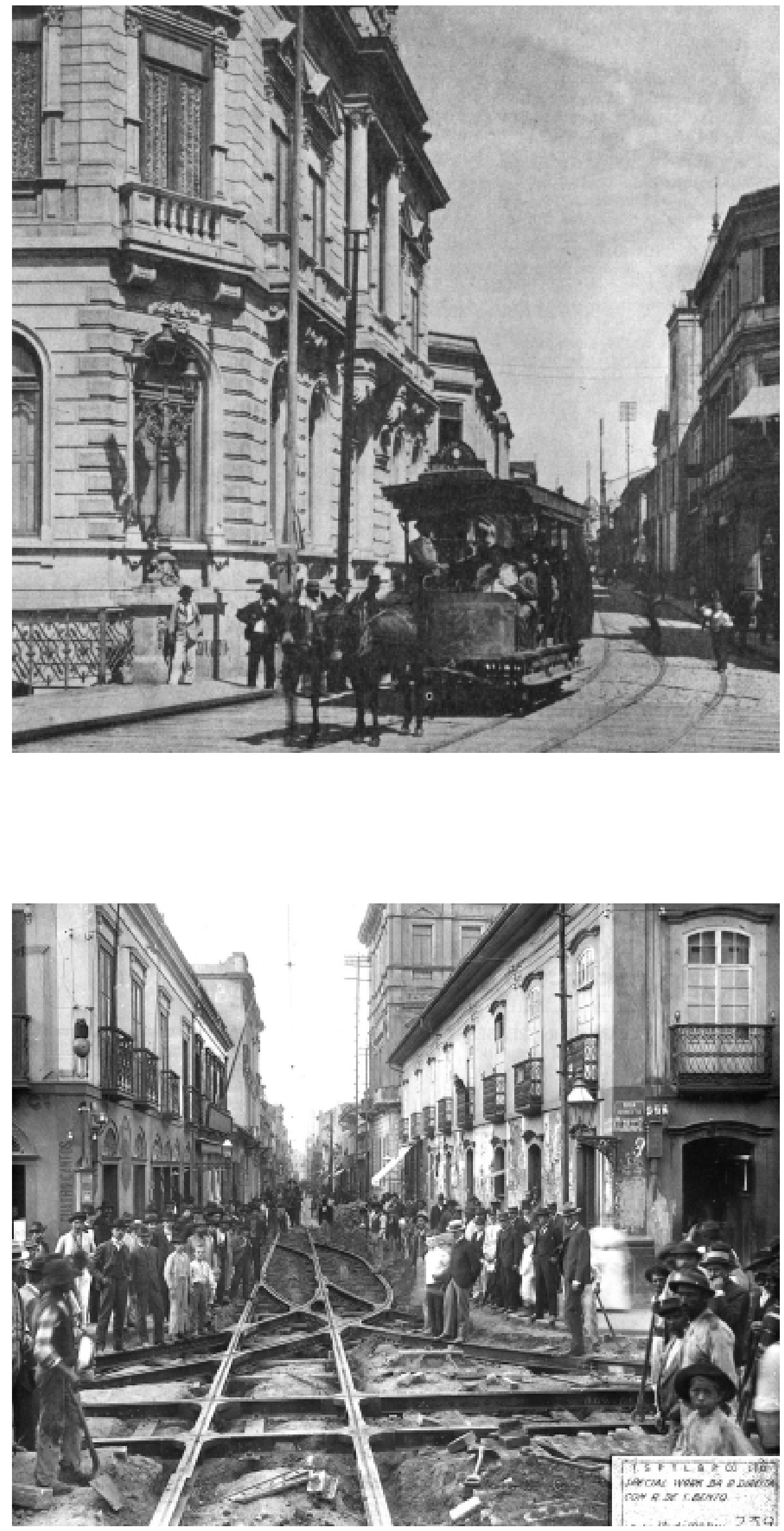

Figura 17 - Viaduto do Chá, em foto de 1894/96. Bonde a tração animal.

Fonte: STIEL, Waldemar Correa. História dos transportes coletivos em São Paulo. São Paulo, McGraw-Hill/Edusp, 1978.
Figura 18 - Rua São Bento, esquina com a rua Direita, 1902. Obras de instalação de trilhos.

Fonte: ELETROPAULO. A Cidade da Ligth. 1899/1930. Departamento de Patrimônio Histórico/Eletropaulo, 1990. 


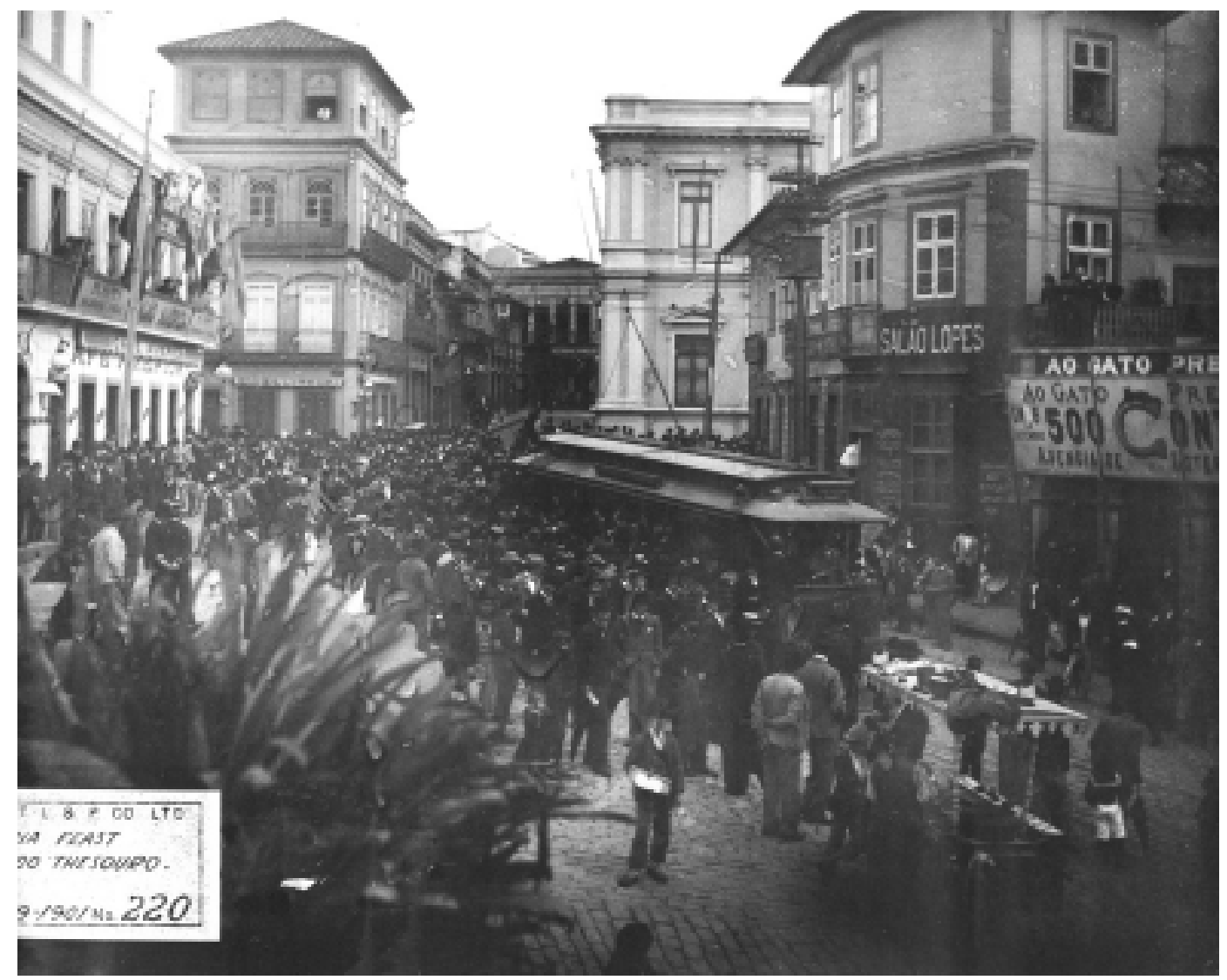

Figura 19 - Inauguração do bonde elétrico para a Penha, em 1901.

Fonte: ELETROPAULO. A Cidade da Ligth. 1899/1930. Departamento de Patrimônio Histórico/ Eletropaulo, 1990.

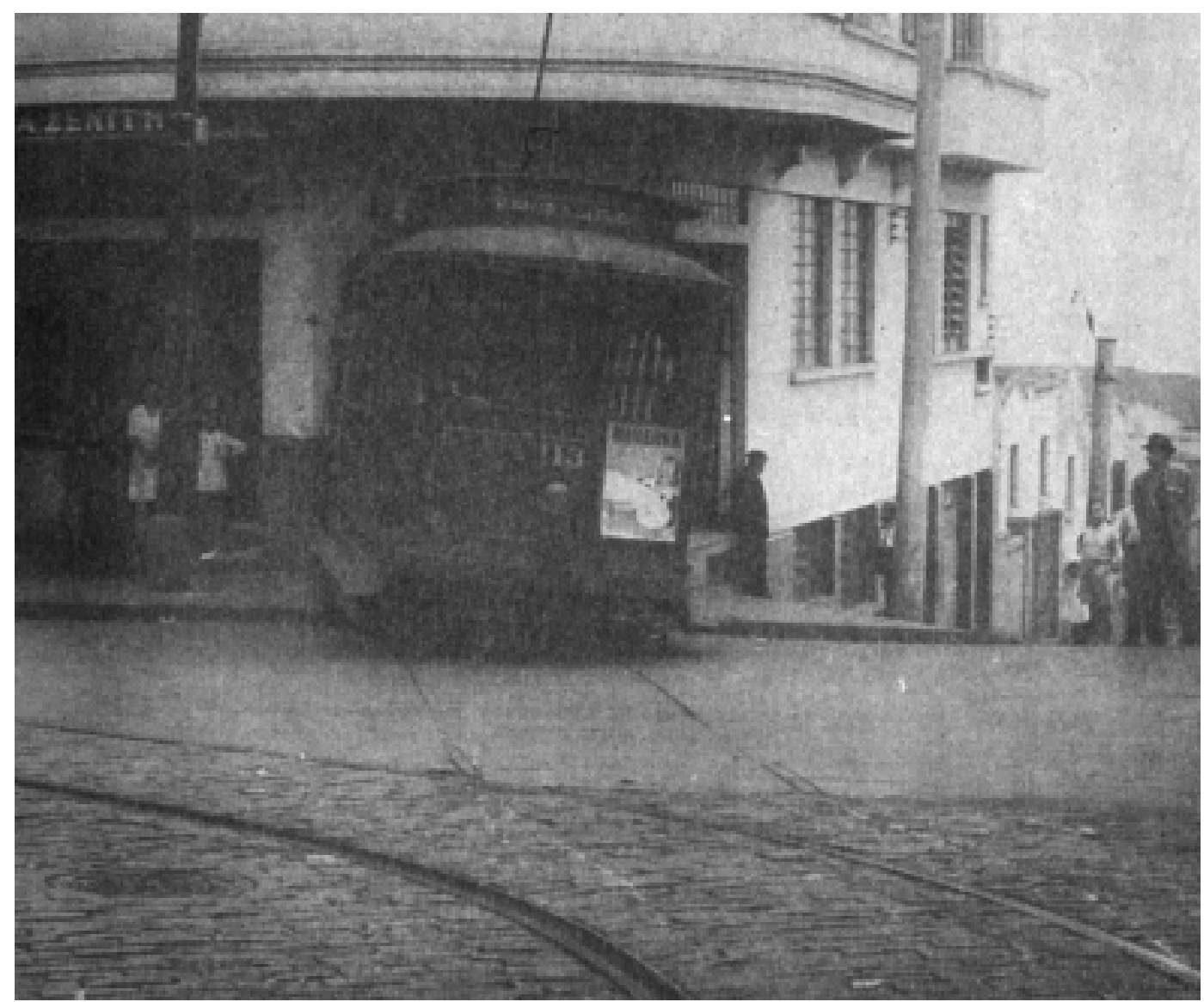

Figura 20 - Às vezes os bondes descarrilavam, como este, no Ipiranga.

Fonte: STIEL, Waldemar Correa. História dos transportes coletivos em São Paulo. São Paulo, McGrawHill/Edusp, 1978. 


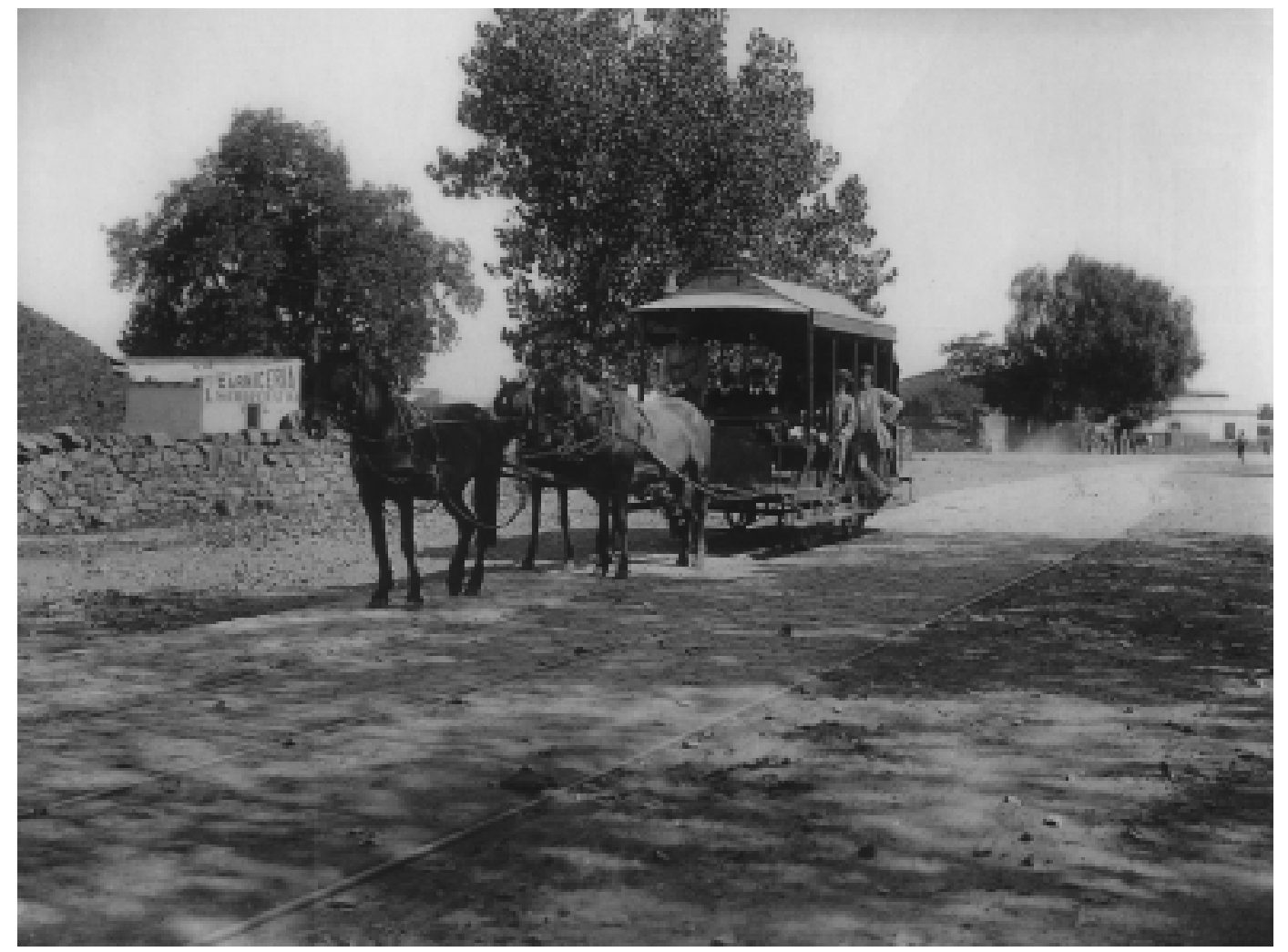

Figura 21 - Bonde a tração animal circulando por um bairro de Buenos Aires. Provavelmente um dos últimos existentes, já que a foto é de 1910.

Fonte: GUTMAN, Margarita (ed.). Buenos Aires 1910: memoria del porvenir. Buenos Aires, Gobierno de la Ciudad de Buenos Aires/ Faculdade de Arquitetura, Design e Urbanismo da Universidade de Buenos Aires/ IIED-America Latina, 1999.

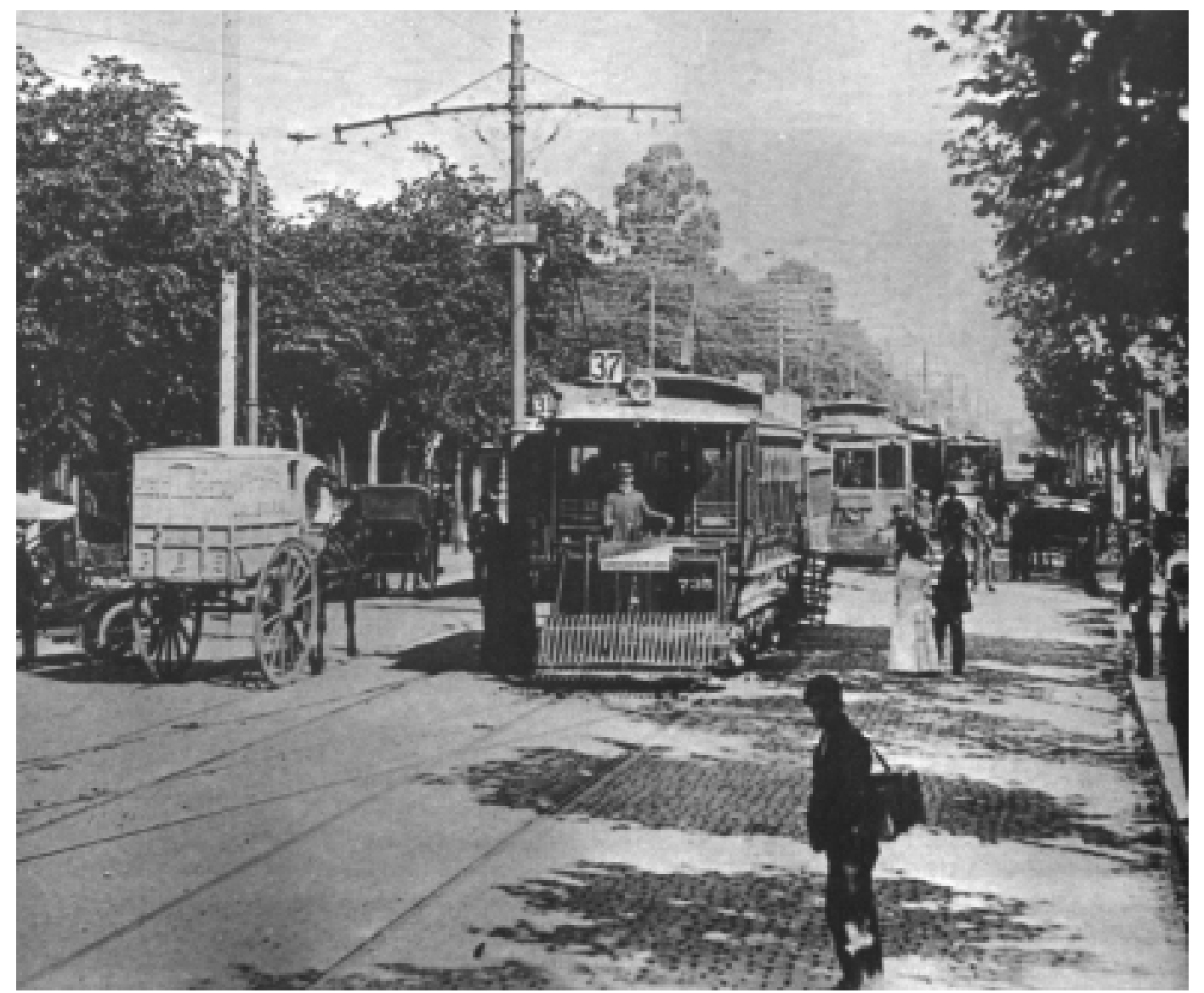

Figura 22 - Fila de bondes elétricos na avenida Santa Fé. A linha 37 ligava a praça de Mayo com o bairro de Belgrano.

Fonte: MOLINARI, Ricardo Luis. Buenos Aires 4 siglos. Buenos Aires, TEA, 1980. 


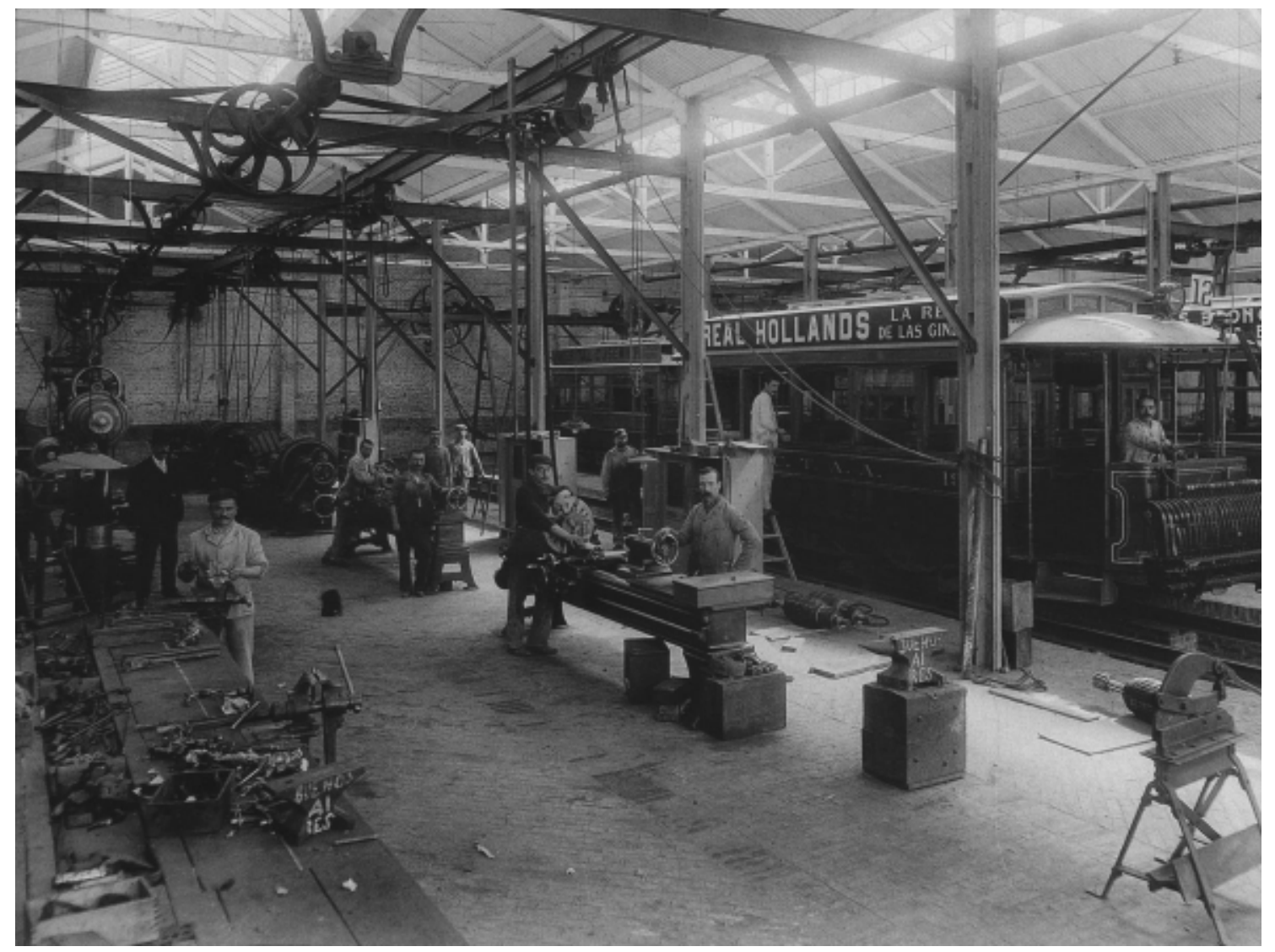

Figura 23 - Oficina de reparos de uma empresa de bondes, em 1900.

Fonte: GUTMAN, Margarita (ed.). Buenos Aires 1910: memoria del porvenir. Buenos Aires, Gobierno de la Ciudad de Buenos Aires/ Faculdade de Arquitetura, Design e Urbanismo da Universidade de Buenos Aires/ IIED-America Latina, 1999.

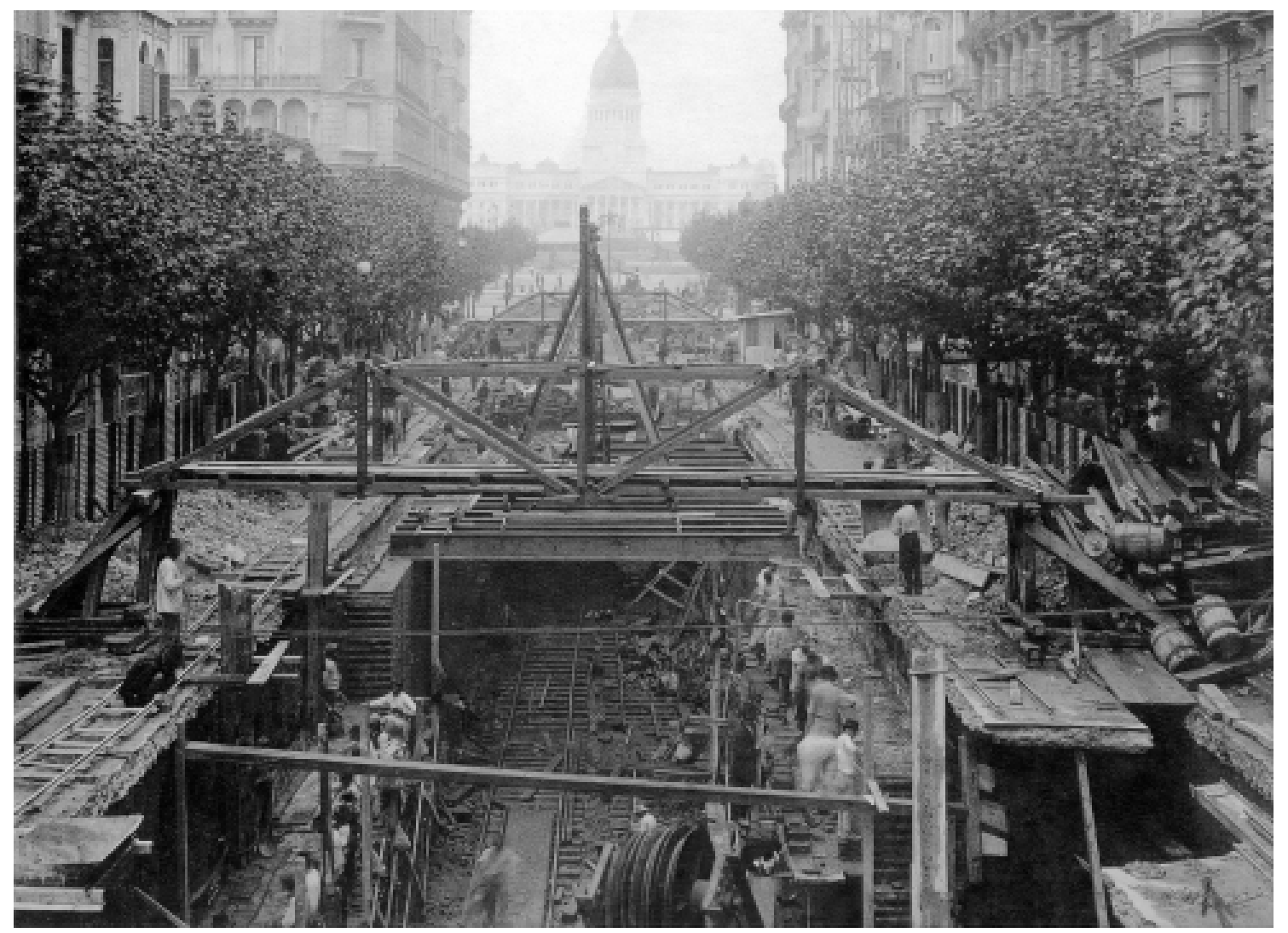

Figura 24 - Obras de construção da primeira linha de metrô em Buenos Aires, inaugurado em 1913. Foto de 1912.

Fonte: GUTMAN, Margarita (ed.). Buenos Aires 1910: memoria del porvenir. Buenos Aires, Gobierno de la Ciudad de Buenos Aires/ Faculdade de Arquitetura, Design e Urbanismo da Universidade de Buenos Aires/ IIED-America Latina, 1999. 


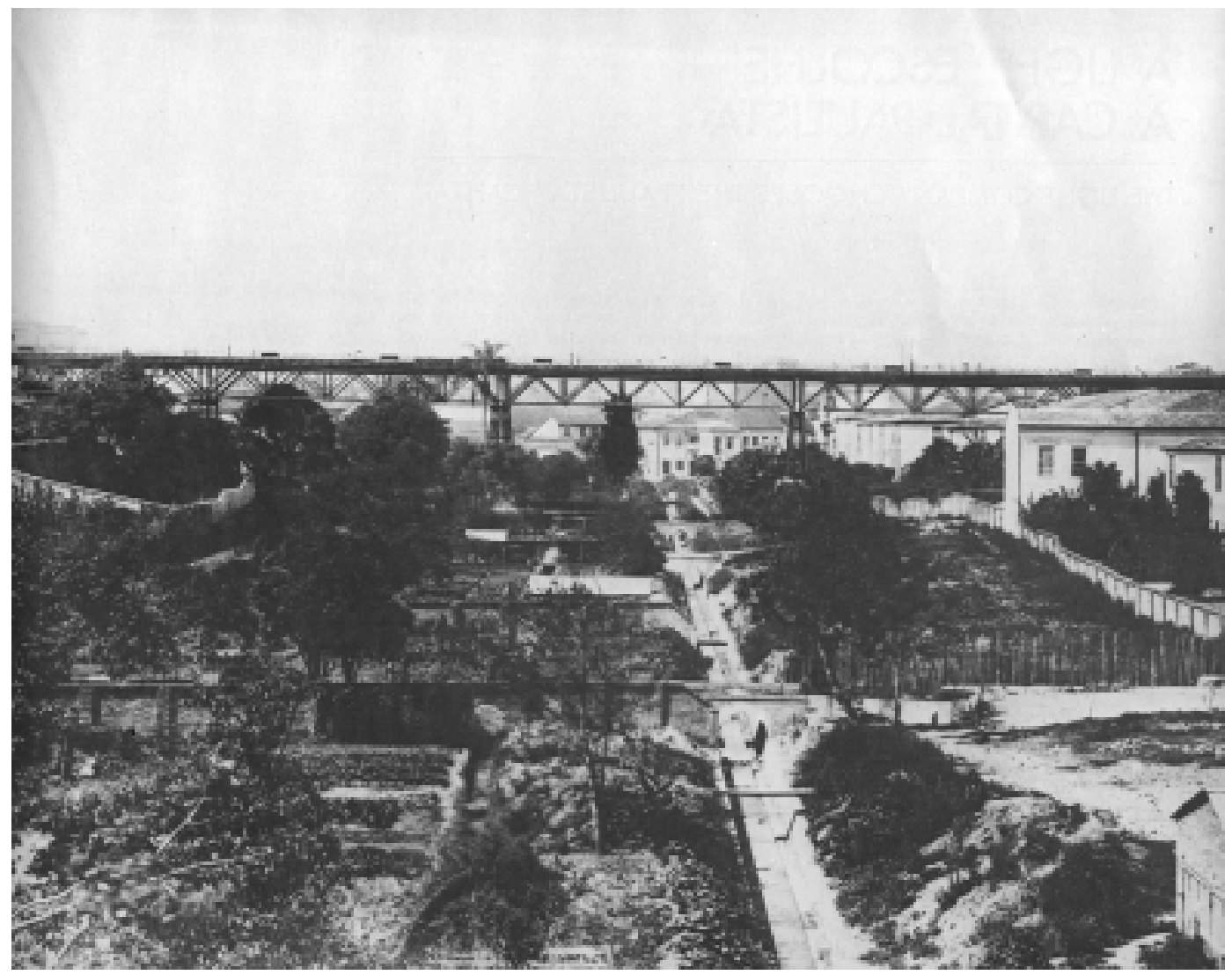

Figura 25 - Viaduto do Chá, em foto tirada por volta de 1905. Notar o aspecto rural que tinha o vale do Anhangabaú antes das reformas realizadas na década de 1910.

Fonte: ELETROPAULO. A Cidade da Ligth. 1899/1930. Departamento de Patrimônio Histórico/ Eletropaulo, 1990.

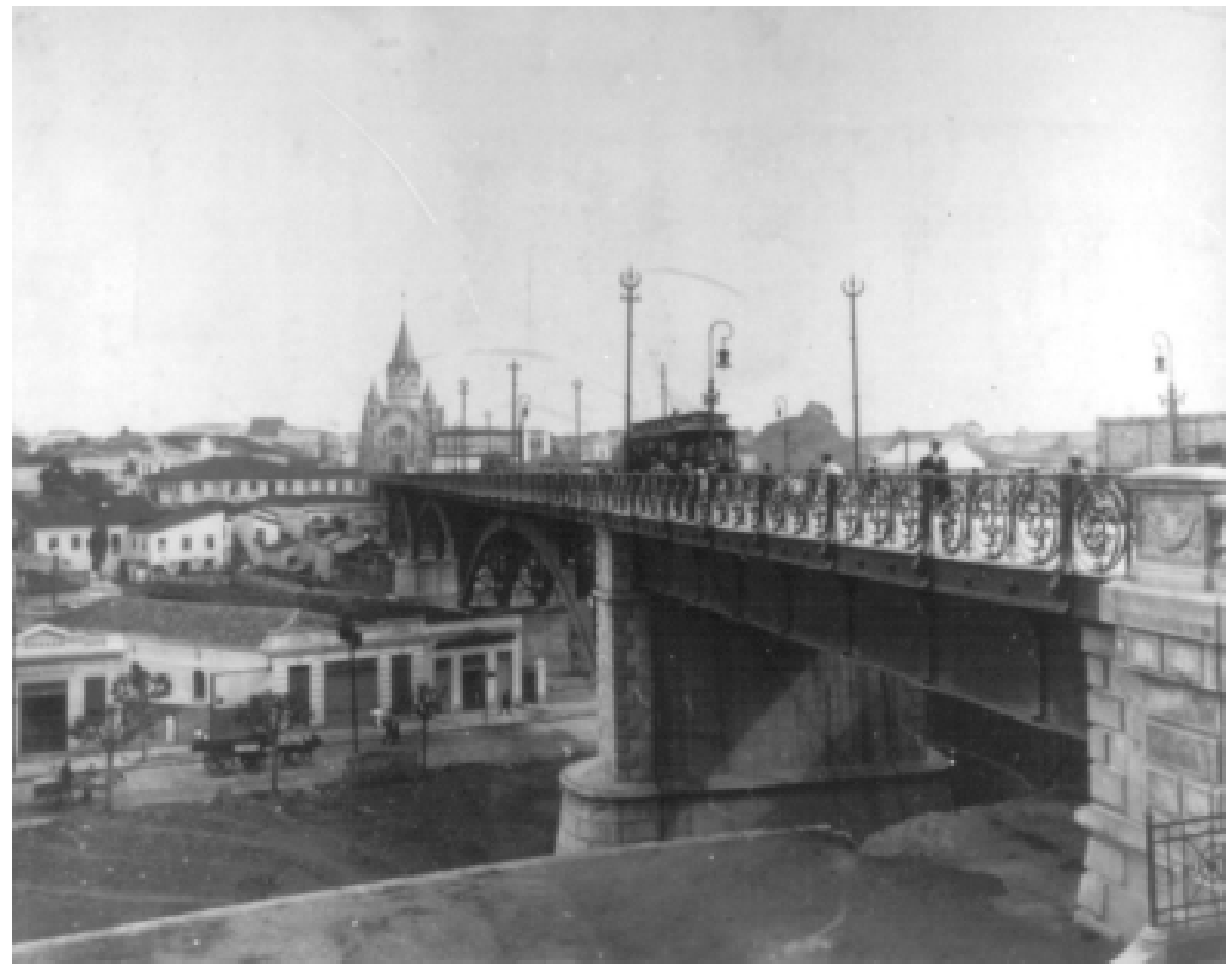

Figura 26 - Viaduto Santa Ifigênia. Ao fundo, a igreja de mesmo nome. Notar como sob o viaduto ainda existiam casas. Essa ocupação implicava em uma relação urbana distinta da existente hoje, já que o vão encontra-se atualmente desimpedido. 
extraída na Cantareira. Era possível assim abastecer alguns chafarizes, como os do Campo da Luz, dos largos de São Bento e dos Guaianases, Sete de abril (atual praça da República) e do Pelourinho. Apesar das obras realizadas houve graves crises de abastecimento, como as ocorridas nos anos 1903 e 1910.

Em Buenos Aires os projetos para criar um sistema de esgotos datam do início da segunda metade do século XIX. O primeiro foi inaugurado em 1868. Devido à epidemia de febre amarela que começou em 1871, foi assinado um contrato com o engenheiro inglês Bateman para ampliação da rede existente. As obras foram iniciadas em 1873 e depois de sucessivas ampliações foram finalizadas em 1915. Alguns dados mostram o alcance deste sistema: em 1895, 62\% da população já estava servida, e em 1922 este índice chegou a 97.5\% da população. ${ }^{42}$

Outra inovação importante foi a utilização da energia elétrica para a iluminação pública. Embora fossem usados até aquele momento outros meios como querosene ou gás (que ainda continuaram sendo utilizados por bastante tempo), a iluminação elétrica permitiu um ganho de qualidade que possibilitou à população passar a freqüentar lugares privados e públicos à noite.

É interessante notar que não há muita diferença nas datas de instalação de eletricidade no mundo, até porque era uma forma de energia que despertava inseguranças. Talvez por este motivo nem no Brasil nem na Argentina as primeiras cidades a contar com esta fonte foram as mais importantes. São Paulo foi a quinta no Brasil (depois de Campos, Rio Claro, Porto Alegre e Juiz de Fora), datando de 1889. O Rio de Janeiro só passou a ter energia elétrica em $1904 .{ }^{43}$ O mesmo ocorre na Argentina: embora em Buenos Aires, em 1882 tivessem sido feitos alguns ensaios para o uso de eletricidade, o primeiro projeto integral de iluminação somente acontecerá em 1895. Antes disso, La Plata (1883), Córdoba e Rosário já tinham redes de energia elétrica funcionando. ${ }^{44}$

Outra melhoria implantada no período foi a pavimentação das ruas, que através de pedras e outros materiais permitiam que veículos sobre rodas pudessem transitar, o que antes era quase impossível. Não vamos nos alongar neste item, mas é interessante notar que nem sempre existia apenas uma transposição de técnicas dos países mais desenvolvidos para os menos. Um exemplo é o desenvolvimento em Buenos Aires da pavimentação com madeira. Embora tenha sido abandonada com o tempo, o fato é que os europeus se impressionaram com os pisos feitos de "algarrobo", tendo importado esta madeira para realizar experiências em cidades como Paris e Londres. Em Roma as ruas que rodeavam o Panteão foram pavimentadas com esta madeira, cedida pela prefeitura de Buenos Aires. ${ }^{45}$

Por último não podemos deixar de citar as ferrovias, que se bem seguissem uma lógica regional, nem por isso deixaram de ter algum impacto no intraurbano. Por um lado, levaram ao abandono de alguns dos caminhos tradicionais e à conseqüente decadência dos assentamentos situados ao longo dos mesmos. Por outro lado, as estações foram um foco de atração de diversas atividades, como

\footnotetext{
${ }^{42}$ PESCUMA, Augusto. Las águas de Buenos Aires. Buenos Aires, Revista Encrucijadas UBA, março de 1997. Ano 3, N 5, p. 88-89.

43 GOMES, Francisco de Assis Magalhães. A Eletrificação no Brasil. São Paulo, Eletropaulo, outubro de 1986. Revista História \& Energia $N^{0}$ 2, p. 4.

${ }^{44}$ Ver o capítulo intitulado "El torbellino de la electrificación" em LIERNUR, Jorge F. e SILVESTRI, Graciela. Op. cit.

${ }^{45}$ BUENOS AIRES (Cidade). Op. cit. p. 536.
} 
comércio e armazéns. Em São Paulo a primeira foi a São Paulo Railway, que ligava Santos a Jundiaí, inaugurada em 1867. Na Argentina, a primeira ferrovia, a F. C. Oeste, ligava a estação Parque com a localidade de Floresta, inicialmente com um percurso de apenas $10 \mathrm{~km}$.

Algumas destas estações (muitas ainda existentes) possuíam aspecto monumental e eram de vastas proporções. Estas características as tornavam importante ponto de referência nas cidades onde foram construídas. Possuíam grandes estruturas metálicas, importadas em geral da Inglaterra, e existiram por toda a América Latina. Podemos citar, por exemplo, as estações San Francisco, em Assunção (1859-64), a General Artigas, em Montevidéu (1897), as estações Central (1897) e Mapocho (1913) em Santiago do Chile e a estação Central de La Habana (1912). ${ }^{46}$

Em São Paulo a mais importante é a estação da Luz, construída entre 1895 e 1901 (figura 27). Outra estação importante é a da linha Sorocabana, a Julio Prestes. ${ }^{47}$ Foi inaugurada em 1930, na época ainda incompleta (figura 28).

Em Buenos Aires também foram construídas estações importantes, como a Terminal Constitución, inaugurada inicialmente em 1885. Esta estação sofreu posteriormente diversas reformas de grande porte até 1912, e mais adiante a partir de 1929, quando foram iniciadas novas ampliações que nunca foram efetivamente terminadas (figura 29). A estação Once é outra importante, tendo funcionado como terminal da The Buenos Aires Western Railway Co. Ltd. O primeiro edifício foi inaugurado em 1896, mas sofreu diversas alterações até por volta de 1907. Por último citamos aquela que é considerada a mais importante, a Terminal Retiro, do antigo $\mathrm{F}$. C. Central Argentino. Sua construção foi iniciada em 1909 e a inauguração realizada em 1915 (figura 30).

\subsection{4 - Indústrias}

A preponderância da agricultura no período não impediu que desde cedo se iniciasse uma incipiente atividade industrial. Uma parte desta era realizada em pequenas oficinas, geralmente localizadas em áreas já consolidadas das cidades. ${ }^{48}$ Era comum que o aspecto exterior tivesse o mesmo padrão que a arquitetura residencial e comercial, embora internamente as atividades fossem diferentes (figuras 31 e 32).

Algumas dessas pequenas indústrias, que começaram como empreendimentos familiares, experimentaram um crescimento de tal intensidade que houve a necessidade de constantes mudanças devido às exigências de expansão das instalações.

\footnotetext{
46 TARTARINI, Jorge D. Arquitectura Ferroviária. Buenos Aires, Ediciones Colihue, 2001.

${ }^{47}$ Onde atualmente funciona a Sala São Paulo, sede da Sinfônica do Estado.

48 Francisco Liernur e Graciela Silvestri levantam a hipótese de que talvez a adoção da tensão de 220 volts em Buenos Aires e de 110 volts nos Estados Unidos possa estar ligada à existência em Buenos Aires de inúmeros estabelecimentos pequenos espalhados pela cidade, o que permitiria seu funcionamento com esta tensão, que exige menos corrente. Entretanto, em São Paulo a tensão é de 127 volts, o que por este modelo implicaria uma configuração industrial diferente da existente em Buenos Aires. Um estudo mais aprofundado sobre a indústria em ambas cidade poderia permitir comprovar ou não esta hipótese. In: LIERNUR, Jorge F. e SILVESTRI, Graciela. Op. Cit.
} 


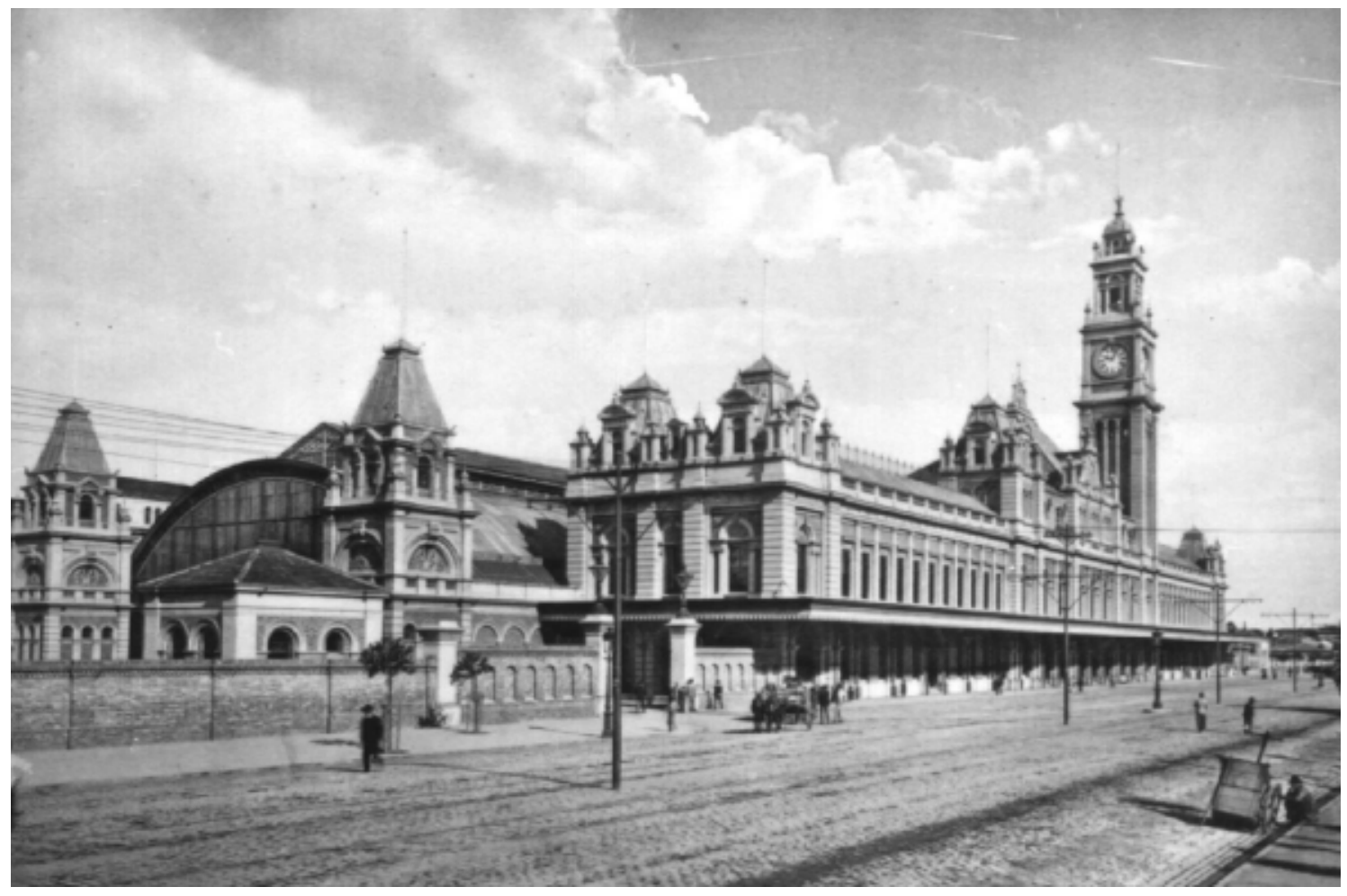

Figura 27 - As estações ferroviárias constituem grandes edifícios e são referência na paisagem urbana. Estação da Luz, em São Paulo.

Fonte: Biblioteca Nacional do Rio de Janeiro (Acervo LAP).

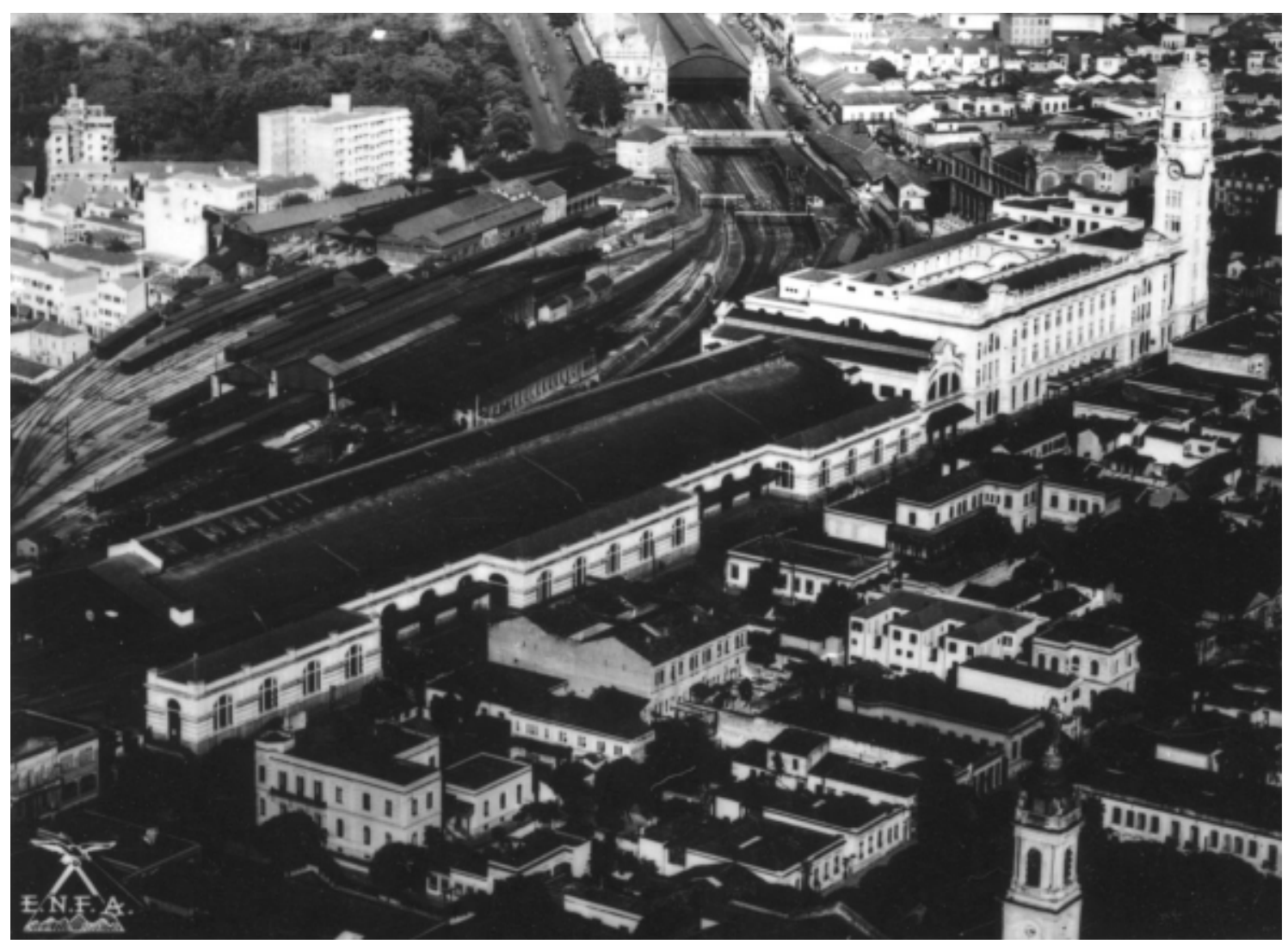

Figura 28 - Conjunto de edificações da estação Julio Prestes, da estrada de ferro Sorocabana, quando todo o edifício ainda funcionava como estação de trens. Ao fundo, a estação da Luz.

Fonte: Acervo LAP. 


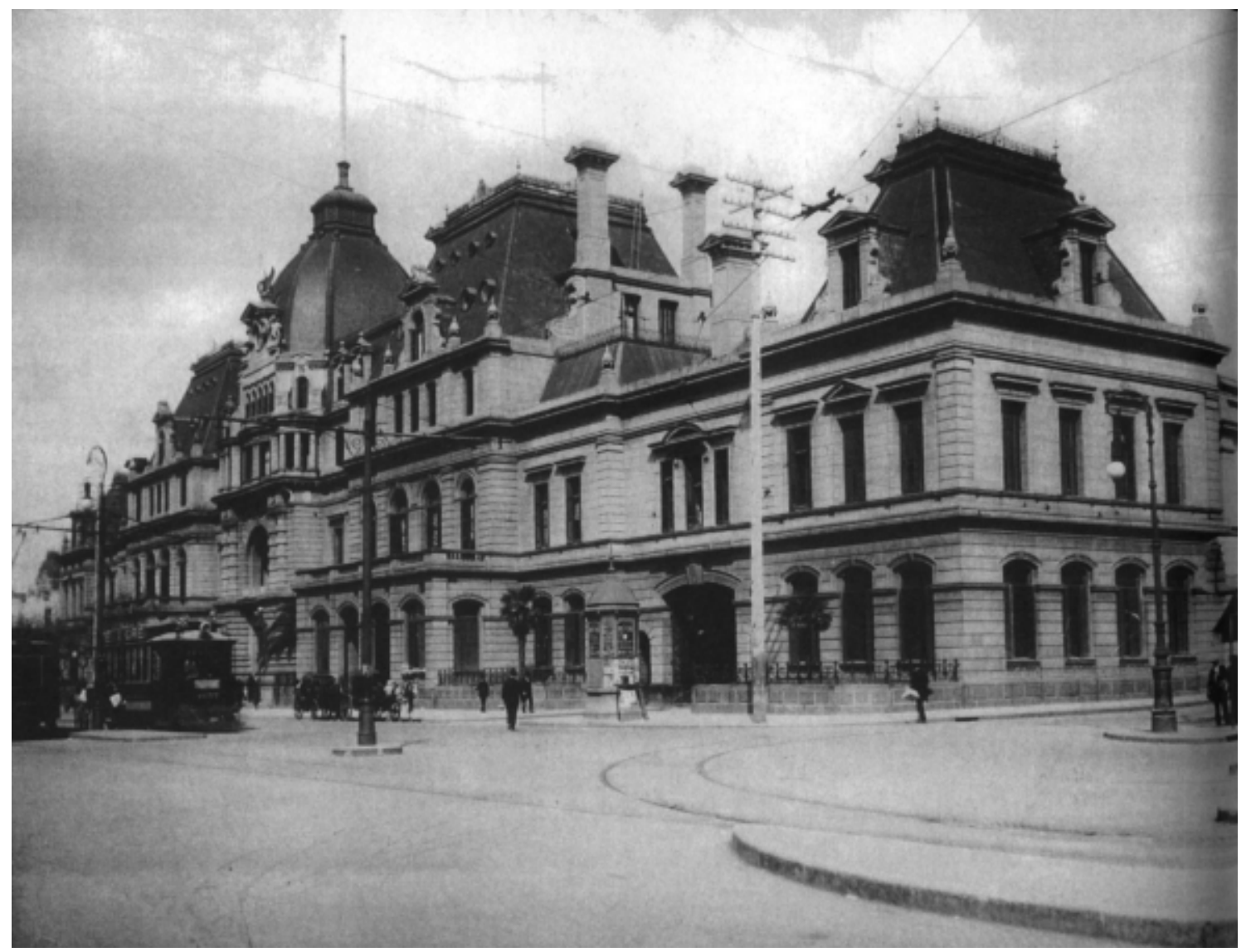

Figura 29 - Estação Constitución após as reformas realizadas na primeira década do século XX. Fonte: TARTARINI, Jorge D. Arquitectura Ferroviária. Buenos Aires, Ediciones Colihue, 2001.

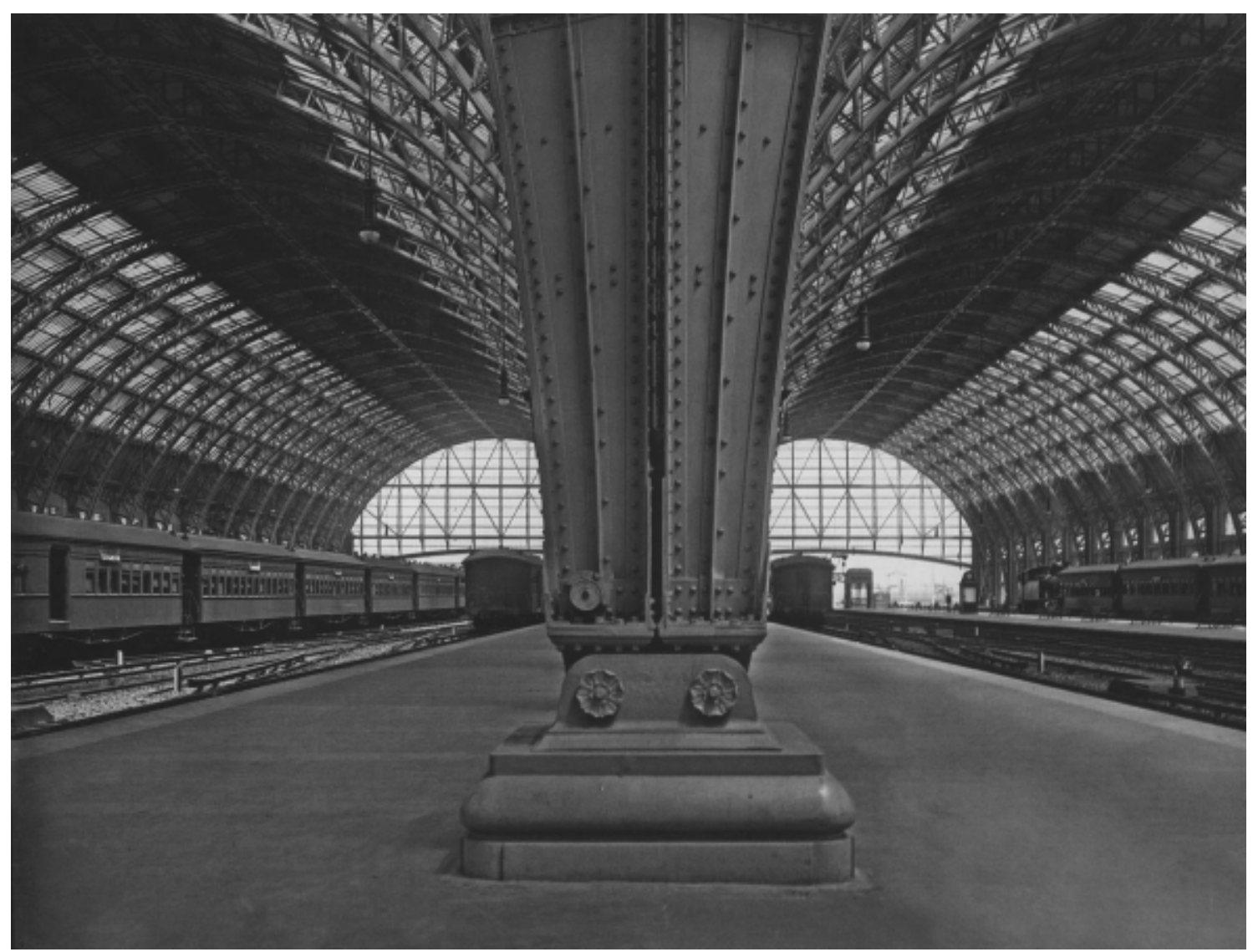

Figura 30 - Vista das plataformas e da estrutura metálica da Terminal Retiro, em 1915.

Fonte: TARTARINI, Jorge D. Arquitectura Ferroviária. Buenos Aires, Ediciones Colihue, 2001. 


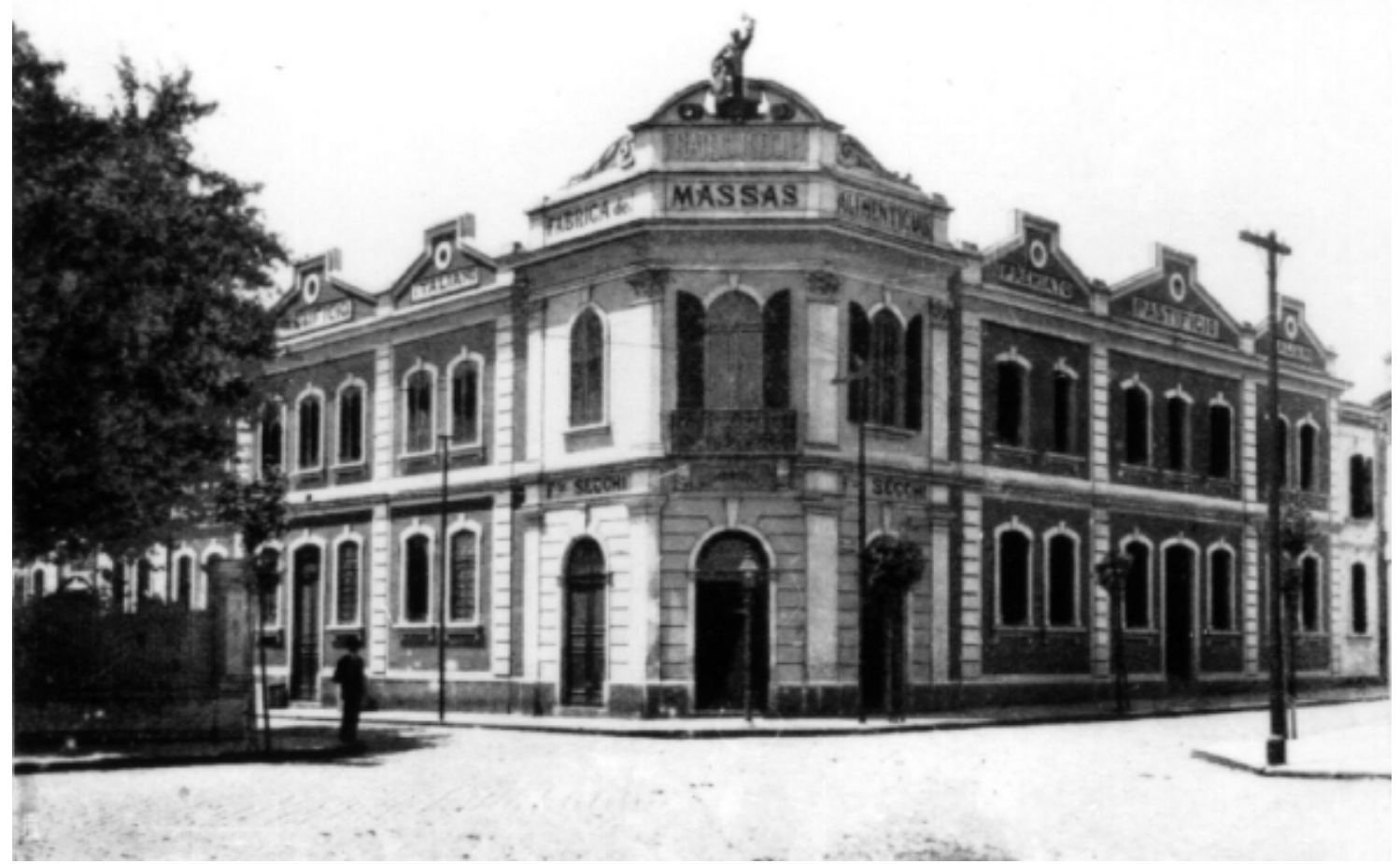

Figura 31 - Existiam indústrias em regiões ocupadas, como esta fábrica de massas em São Paulo.

Fonte: Biblioteca Municipal Mário de Andrade (Acervo LAP).

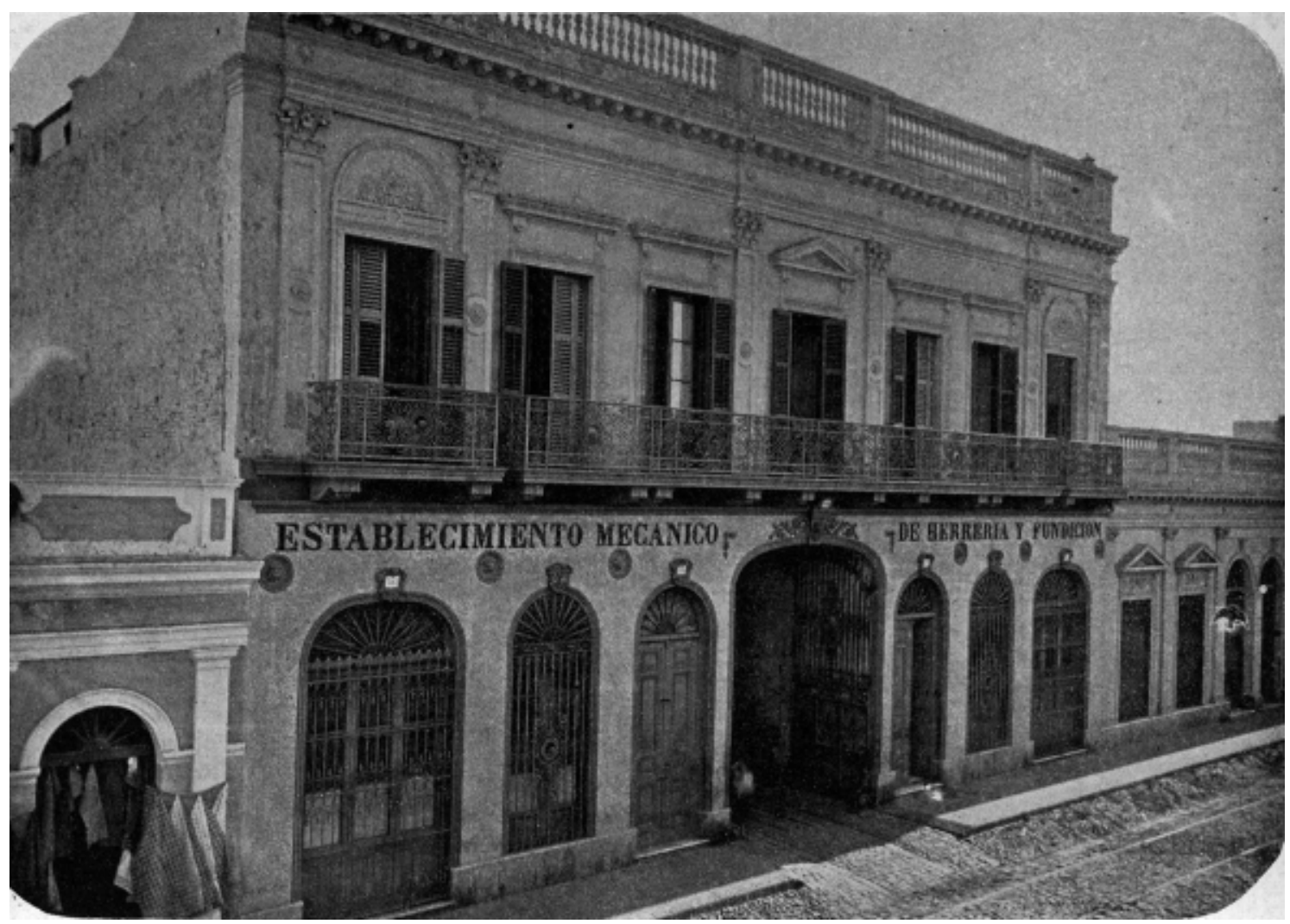

Figura 32 - É o caso também desta oficina mecânica em Buenos Aires. Em ambos os casos as fachadas escondiam o caráter industrial, assemelhando-se a residências ou estabelecimentos comerciais.

Fonte: COMITATO DELLA CAMERA ITALIANA DI COMMERCIO ED ARTI. Gli italiani nella Repubblica Argentina. Buenos Aires, Compañia Sud-Americana de Billetes de Banco, 1898 
Como exemplo podemos citar em Buenos Aires a indústria Bagley: situada em 1864 na rua Maipú $\mathrm{N}^{0}$ 200, depois de três mudanças instalou-se definitivamente na rua Montes de Oca, em 1892. Outro caso é Canale, que começou como uma pequena padaria em 1875, em Cochabamba e Defensa, e que em 1910 se transferiu para a rua Martin Garcia, já transformada em uma indústria de grandes proporções. Podemos citar também a cervejaria Bieckert, que se instalou em 1860 em frente à igreja de Balvanera. Depois de alguns anos em Salta $\mathrm{N}^{\circ} 12$, a empresa mudou-se para Juncal e Esmeralda. Em 1908 instalou-se definitivamente na área sul da cidade de Buenos Aires (em Llavallol). ${ }^{49}$

Em São Paulo o caso mais importante é o das indústrias Matarazzo. Francisco Matarazzo era proprietário de um empório em Sorocaba, em 1882. Começou importando banha e farinha de trigo. Em 1890 transferiu-se para São Paulo onde, em 1900 inaugurou no Brás seu próprio moinho de trigo, e em 1904 a tecelagem Mariângela. Em 1912 trabalhavam no moinho 500 operários e na Mariângela 2 mil. ${ }^{50}$

Porém, no início da industrialização, mesmo as maiores fábricas ainda localizavam-se em áreas centrais. Um destes locais em São Paulo era na continuação da rua São Bento, como é o caso da Companhia Industrial, Iocalizada em um beco da rua Florêncio de Abreu. ${ }^{51}$ Entretanto, à medida que a cidade crescia, estas foram deslocadas para bairros que iriam assumir características próprias, pela presença das fábricas e por serem lugar de residência dos operários.

Muitas das grandes fábricas em São Paulo surgiram antes do início das grandes imigrações, a partir de 1860, por iniciativa de famílias locais ligadas ao café e ao comércio, principalmente no ramo têxtil. Entre estas podemos citar os Silva Prado, Aguiar de Barros, Penteado, Lacerda Franco, Rodovalho, Pacheco Jordão, Souza Queiroz e Souza Aranha. A esses se juntaram mais adiante os imigrantes que enriqueceram, como o já citado Matarazzo, além de Crespi, Scarpa e Siciliano. As principais indústrias pioneiras foram a já citada Companhia Industrial (1874), a fábrica Anhaia, a Companhia Antarctica Paulista (1885), a cervejaria Bavária, (1890), a vidraçaria Santa Marina (1896) e a fábrica Santana (1890). ${ }^{52}$

Estes grandes empreendimentos localizavam-se em geral em áreas de cotas de nível mais baixas, onde os terrenos eram mais baratos. Também procuravam as cercanias das estradas de ferro, das quais dependiam tanto para importação de insumos como para escoamento da produção. Em São Paulo estavam localizadas em bairros como Brás, Mooca, Bom Retiro, Belenzinho, Vila Prudente, Cambuci, Ipiranga, Pari, Luz, Barra Funda, Água Branca e Lapa (figuras 33 e 34).

Em Buenos Aires as indústrias também se instalaram em regiões baixas, portanto mais baratas, preferencialmente na região sul da cidade, nos bairros de Barracas e Avellaneda (figuras 35 a 37). Entre estas, podemos reconhecer algumas que tiveram ou ainda têm grande importância, como por exemplo Noel, Alpargatas, Bagley, Canale, Terrabusi, etc. Nestes bairros era possível aproveitar as vantagens

\footnotetext{
${ }^{49}$ SCHVARZER, Jorge. La implantación industrial. In: ROMERO, José Luis; ROMERO, Luis Alberto (org.). Buenos Aires. Historia de cuatro siglos. 2 v. Buenos Aires, Abril, 1983.

${ }^{50}$ REIS FILHO, Nestor Goulart. São Paulo e outras cidades: produção social e degradação dos espaços urbanos. São Paulo, Hucitec, 1994.

${ }^{51}$ BRUNO, Ernani da Silva. Op. cit.

${ }^{52}$ REIS FILHO, Nestor Goulart. Op. cit.
} 


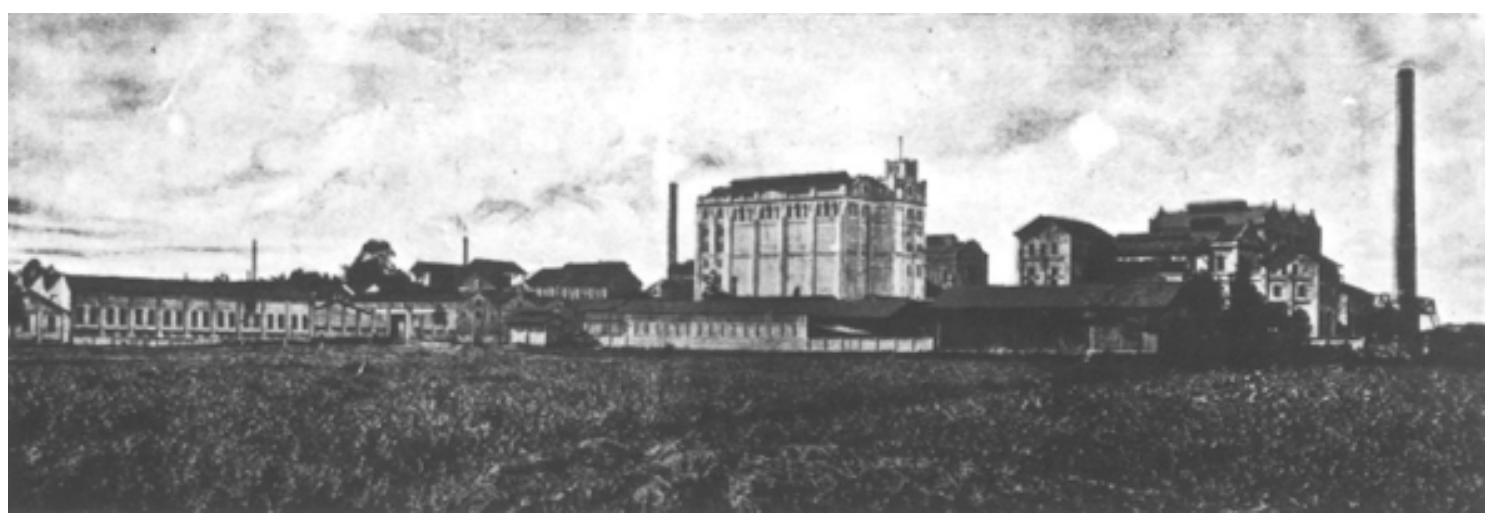

Figura 33 - As grandes indústrias em São Paulo em geral estavam localizadas no entorno da cidade, em áreas baixas.

Fonte: Biblioteca Municipal Mário de Andrade (Acervo LAP).

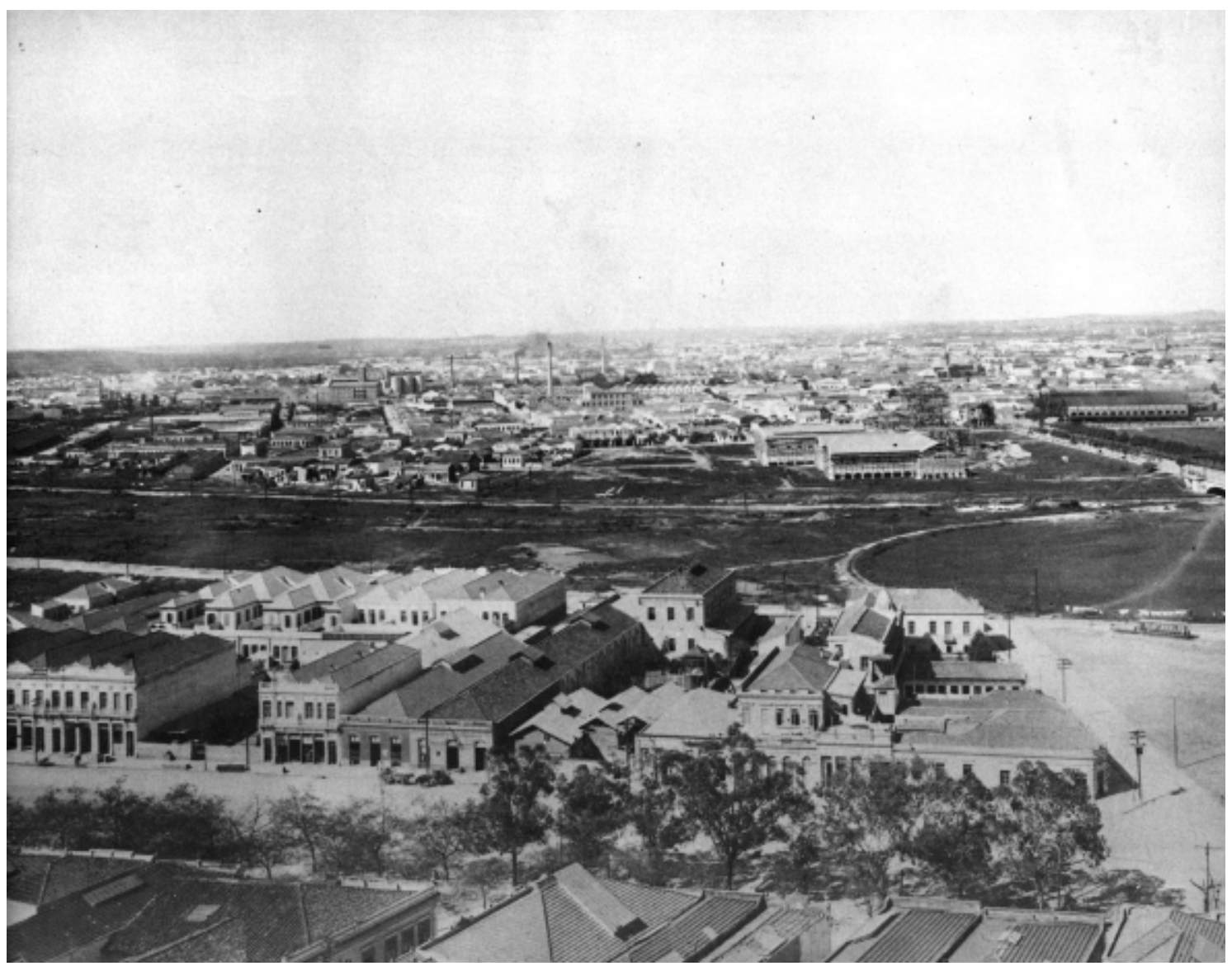

Figura 34 - Esta fotografia foi tirada da torre do Mosteiro de São Bento, em direção ao bairro de Brás. A área não ocupada é a várzea do Carmo. Ao fundo é possível observar diversas chaminés de fábricas (1913).

Fonte: ELETROPAULO. A Cidade da Ligth. 1899/1930. Departamento de Patrimônio Histórico/Eletropaulo, 1990. 


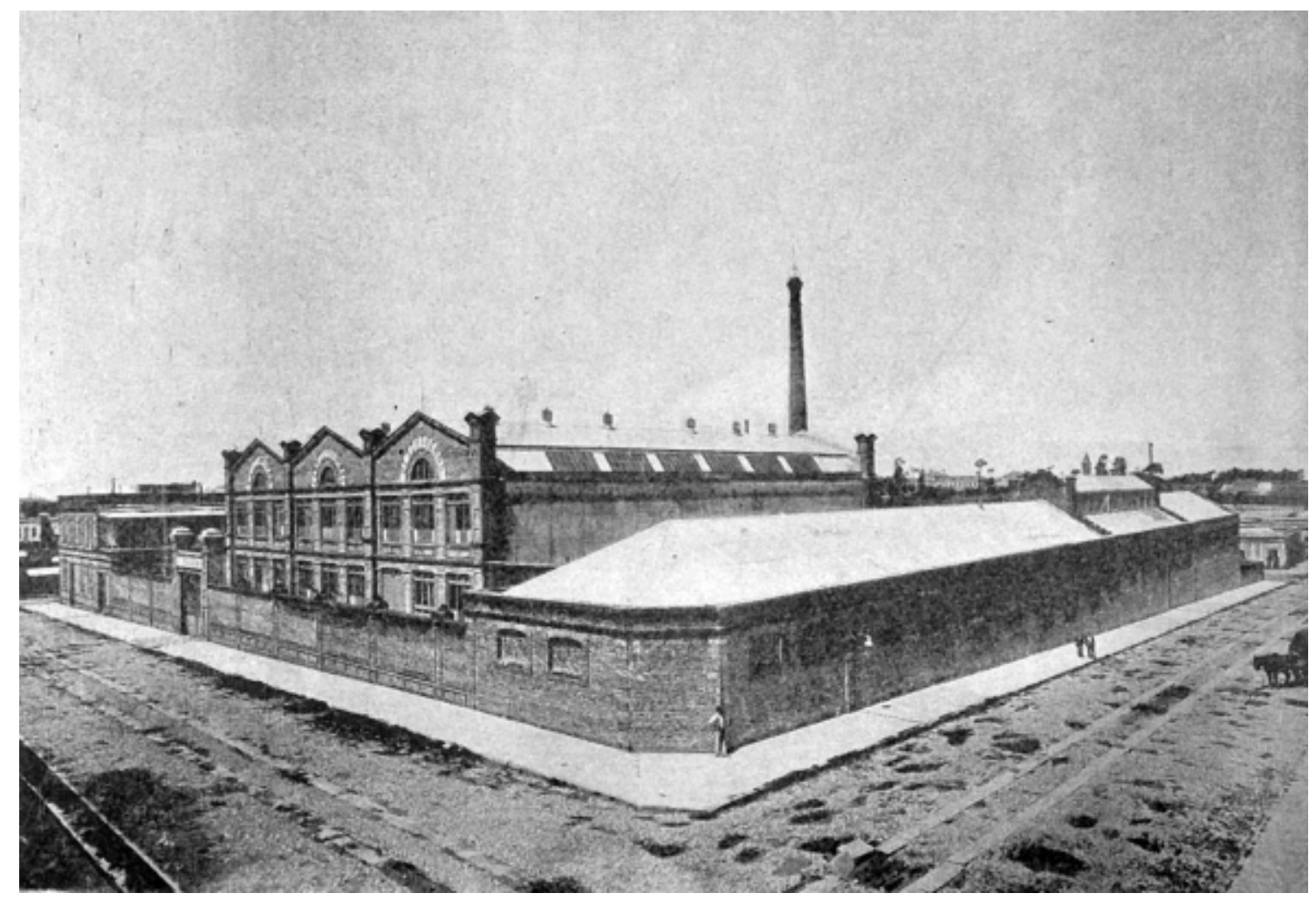

Figura 35 -Como em São Paulo, também em Buenos Aires as grandes fábricas estavam localizadas no entorno da cidade, principalmente na região sul. Esta fábrica de chapéus, de propriedade de Gaetano Dellachá, foi fundada em 1886, e estava localizada na rua Uspallata 1116.

Fonte: COMITATO DELLA CAMERA ITALIANA DI COMMERCIO ED ARTI. Gli italiani nella Repubblica Argentina. Buenos Aires, Compañia Sud-Americana de Billetes de Banco, 1898

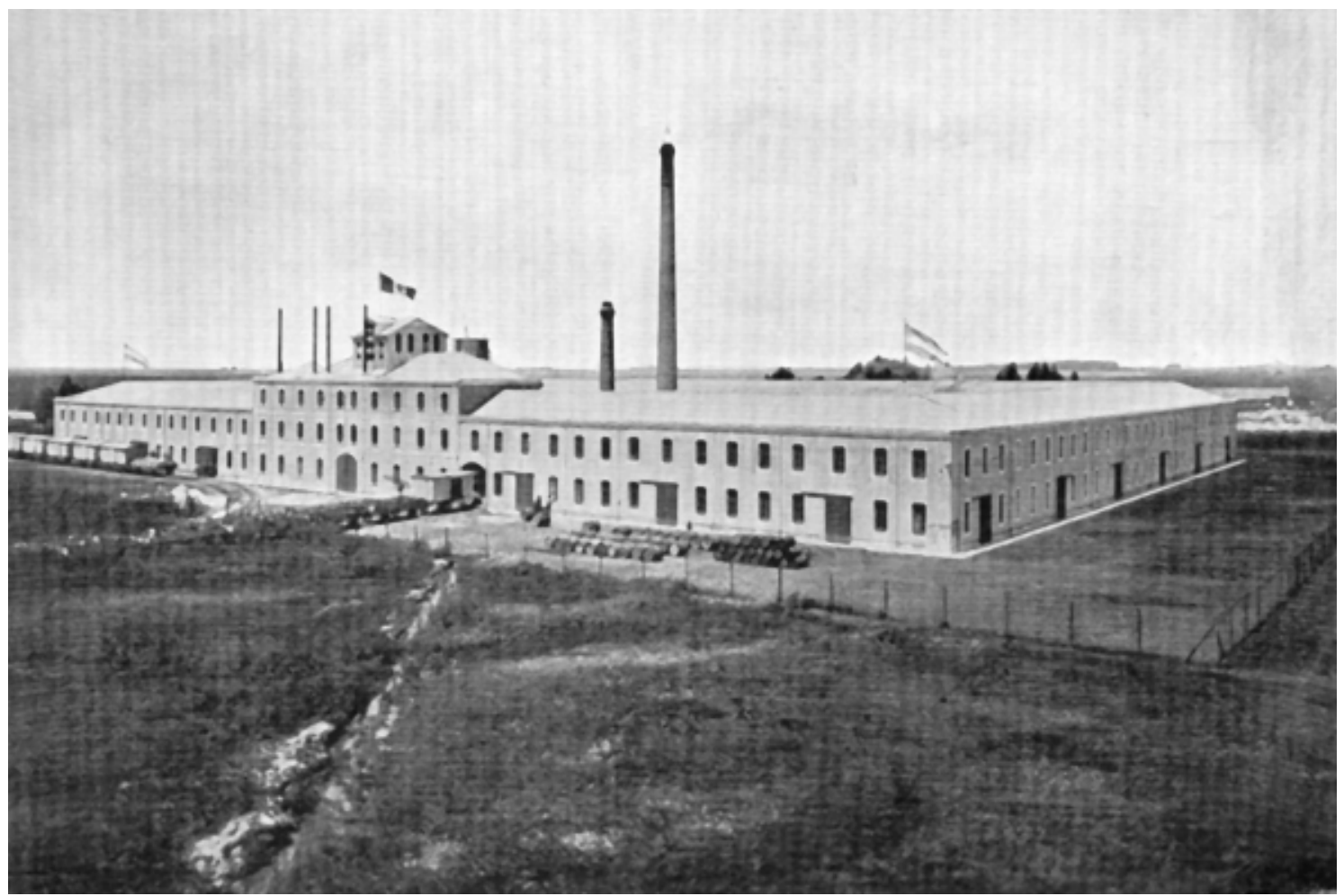

Figura 36 - Estabelecimento industrial de P. Griffero e Figlio, fundada em 1892. Localizada em Villa Elisa, produzia destilados. O terreno tinha 3.500 ha de área, e a fábrica media 145 metros de lado.

Fonte: COMITATO DELLA CAMERA ITALIANA DI COMMERCIO ED ARTI. Gli italiani nella Repubblica Argentina. Buenos Aires, Compañia Sud-Americana de Billetes de Banco, 1898 


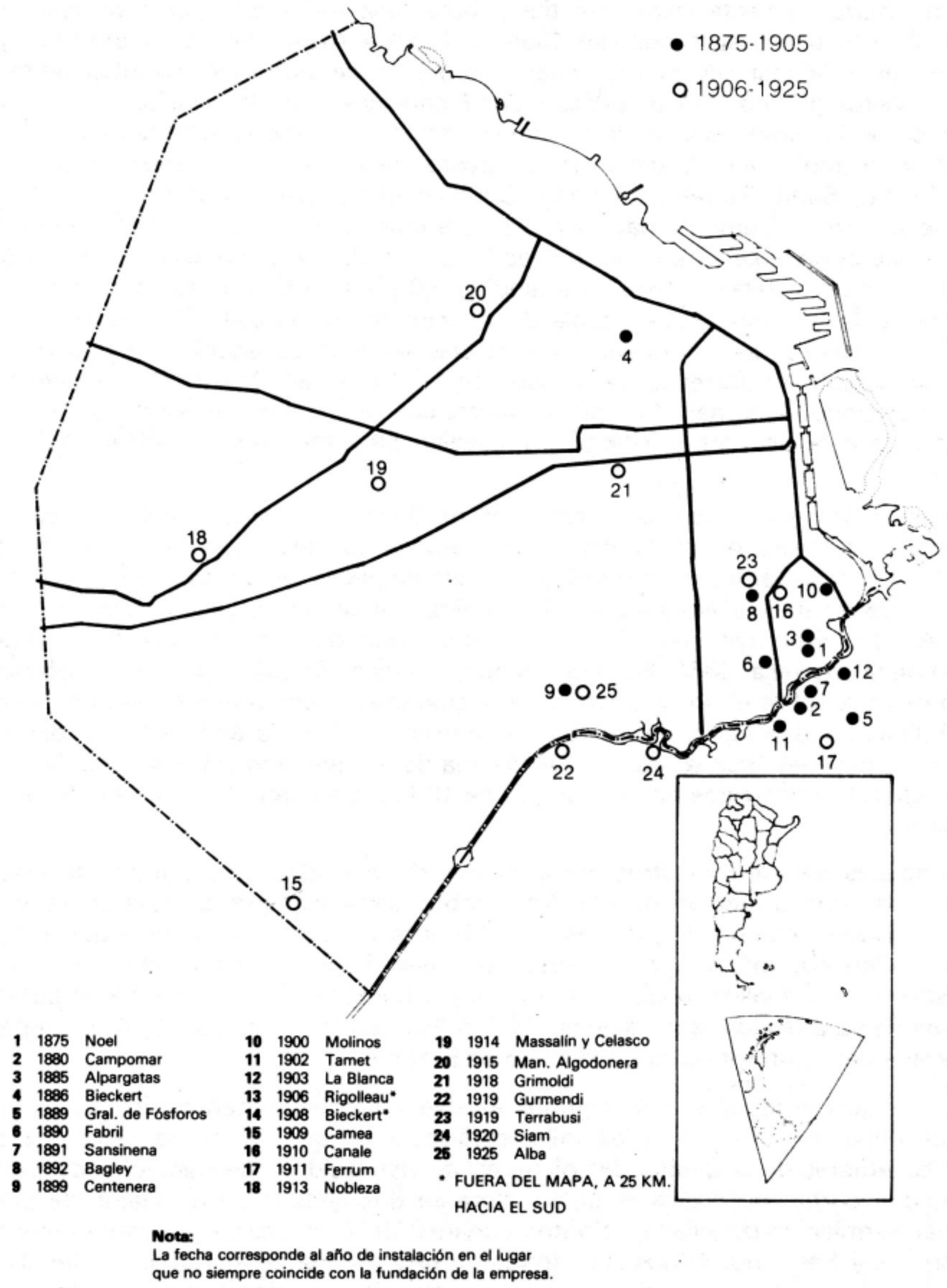

Figura 37 - Implantação industrial em Buenos Aires, 1875-1925. Notar a grande concentração de indústrias na região sul da cidade.

Fonte: ROMERO, José Luis; ROMERO, Luis Alberto (org.). 2 v. Buenos Aires. Historia de cuatro siglos. Buenos Aires, Abril, 1983. 
do rio Riachuelo e da estrada de ferro Roca. Os principais ramos eram os de frigoríficos, metalúrgicas, estaleiros e alimentos.

Por último é importante assinalar que as grandes instalações fabris, embora situadas nos arredores das cidades, ainda assim guardavam uma distância não muito grande da área central. O fenômeno da localização industrial regional somente ocorrerá algumas décadas depois: em São Paulo na direção das principais rodovias, Dutra, Anhangüera e Castelo Branco, em Buenos Aires em torno da avenida General Paz; depois de 1960, na direção norte. ${ }^{53}$

\subsection{5 - Habitação Precária}

Um dos fenômenos mais importantes nas cidades latino-americanas naquele período foi o surgimento de uma grande camada de classe média. ${ }^{54}$ Esta tinha alguma possibilidade de poupança, ainda que bem pequena, mas suficiente para permitir o acesso à compra de terrenos em loteamentos distantes, que começam a ser ocupados em quantidade, à medida que existem financiamentos e é ampliada a rede de transportes. Nos capítulos 7 e 8 analisaremos com mais detalhes este fenômeno.

Também é característica do período a existência de um grande contingente de habitantes marginalizados, muitos dos quais irão morar nas áreas centrais em cortiços ou conventillos. Via de regra as condições de vida nestes eram precárias e houve poucas iniciativas do Estado no sentido de resolver o problema (figuras 38 a 41). Os maiores beneficiados certamente eram os donos dos edifícios, muitos dos quais pertencentes às elites locais.

Em ambas cidades os cortiços podiam ser grandes casas que haviam pertencido a famílias ricas, que se mudaram, as quais eram subdivididas de forma a maximizar a quantidade que moradores. Também existiam cortiços instalados em edifícios projetados especificamente para esse fim. Em Buenos Aires, em 1880, 15\% dos conventillos eram de nova construção. Nesta mesma cidade as condições de vida foram piorando com o tempo: em 1883 havia 1.900 conventillos com 64.000 habitantes, o que dá uma média de 2.5 por quarto. Em 1892 nos 2.200 conventillos habitava uma população de 121.000 pessoas, o que dá uma média de 4 por quarto. Ainda em 1904 existia apenas um chuveiro para cada 60 pessoas como média. ${ }^{55}$

Não é diferente o caso de São Paulo. Em torno do centro surgiram cortiços, que abrigaram imigrantes e outros habitantes pobres da cidade. Um dos principais bairros onde este fenômeno ocorreu foi o de Santa Efigênia, o que inclusive motivou a prefeitura a realizar um inquérito para verificar as condições de habitabilidade, que resultou no famoso Relatório da Comissão de Exame e Inspecção das Habitações Operárias e Cortiços no Districto de Santa Ephigênia. ${ }^{56}$ Neste relatório

\footnotetext{
${ }^{53}$ Em 1941 as indústrias ainda estão fortemente concentradas ao sul e próximas da área central: os estabelecimentos situados na Capital Federal empregavam 300.000 operários, e no Grande Buenos Aires 110.000. Destes últimos mais da metade trabalhava em Avellaneda, Valentim Alsina e Lanús, ou seja, ao sul da Capital Federal. SCHVARZER, Jorge. Op. cit.

${ }^{54}$ ROMERO, José Luis. Latinoamérica: las ciudades y las ideas. $4^{\mathrm{a}}$ ed. Buenos Aires, Siglo XXI, 1986.

${ }^{55}$ GUTIERREZ, Ramón. Buenos Aires. Evolución Histórica. Buenos Aires, Editorial Escala, 1990.

${ }^{56}$ MOTTA, Cesário et alli. Relatório da Comissão de Exame e Inspecção das Habitações Operárias e Cortiços no Districto de Santa Ephigênia. São Paulo, Tipographia Vanordem \& Comp., 28 de março de 1894. Citado em: BONDUKI, Nabil Georges. Origens da habitação social no Brasil. São Paulo, Estação Liberdade/Fapesp, 1998.
} 


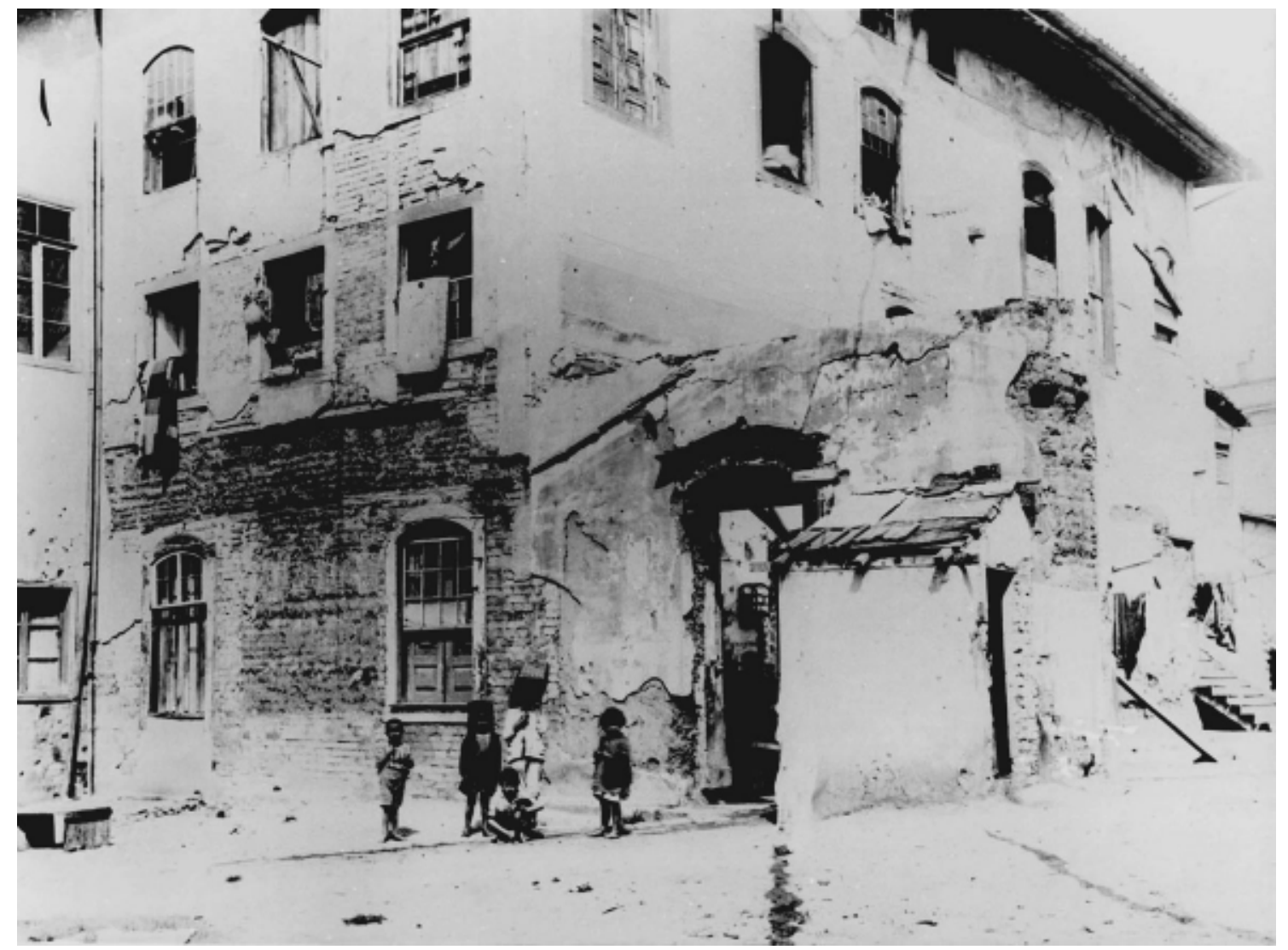

Figura 38 - Casarão transformado em cortiço, no bairro de Santa Ifigênia.

Fonte: REIS FILHO, Nestor Goulart. Cadernos do LAP 2. Habitação popular no Brasil: 1880-1920. São Paulo, FAUUSP, 1994.

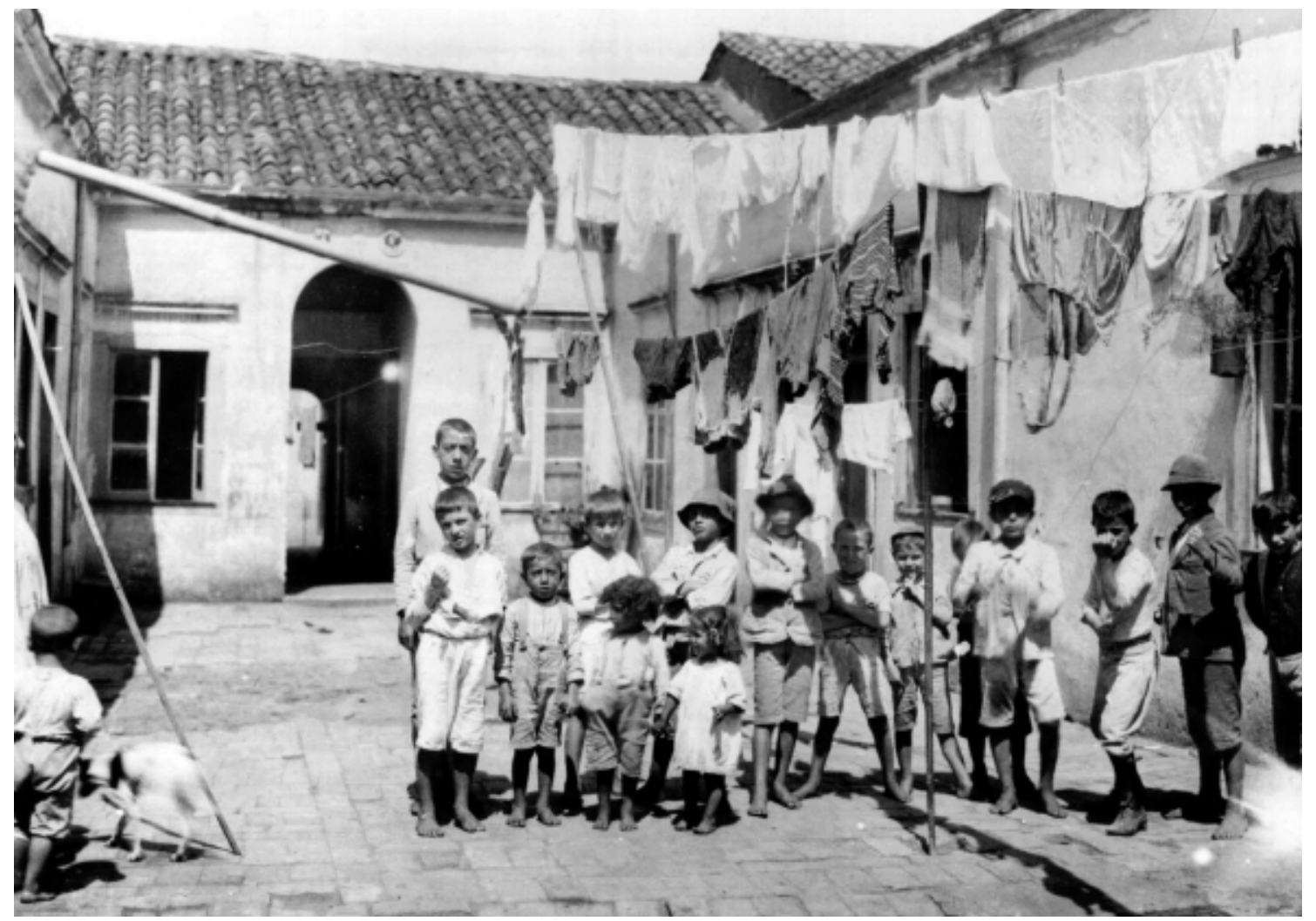

Figura 39 - Pátio de um cortiço na rua Conselheiro Ramalho, em São Paulo.

Fonte: REIS FILHO, Nestor Goulart. Cadernos do LAP 2. Habitação popular no Brasil: 1880-1920. São Paulo, FAUUSP, 1994. 


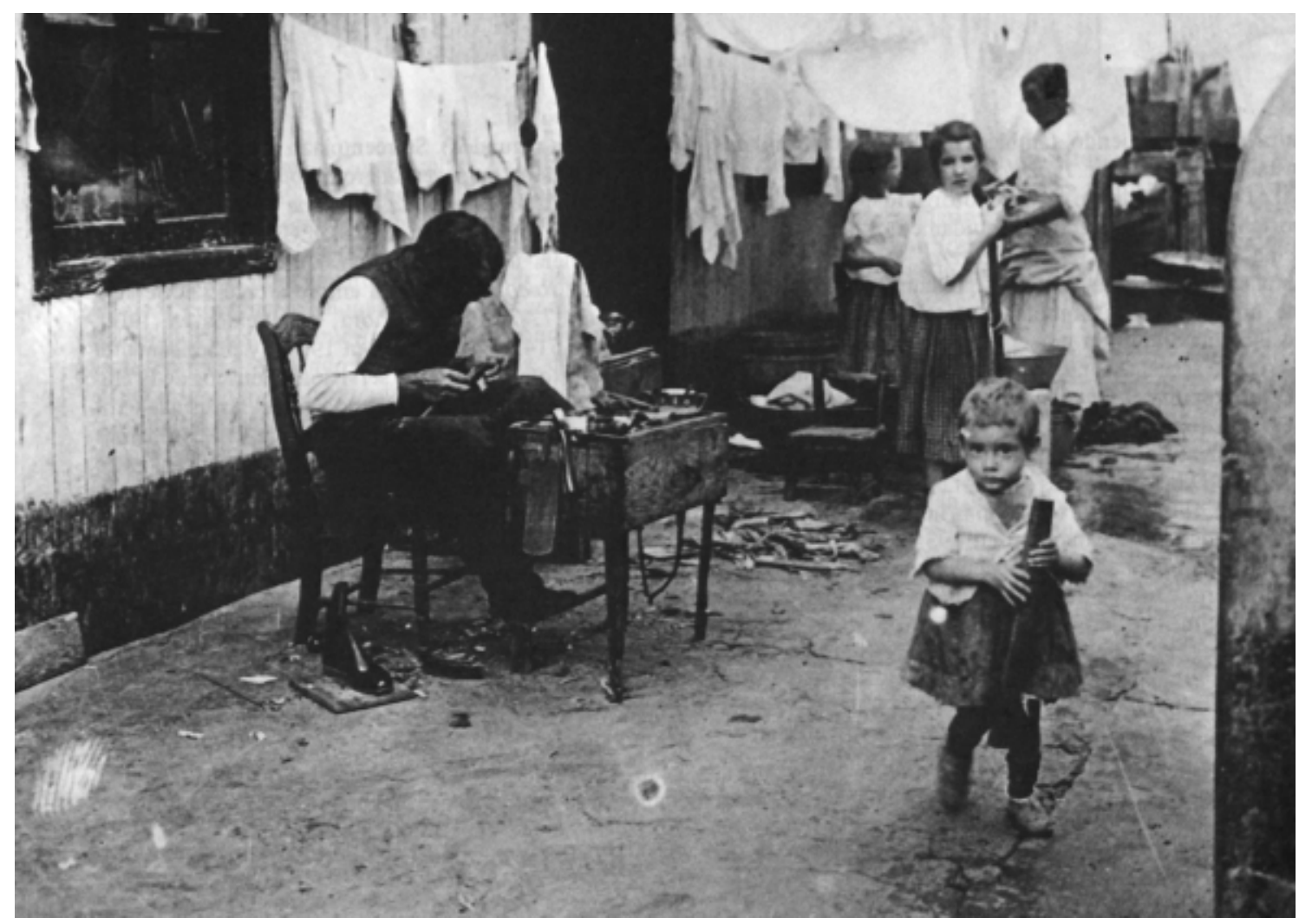

Figura 40 - Interior de um conventillo portenho em 1910.

Fonte: MOLINARI, Ricardo Luis. Buenos Aires 4 siglos. Buenos Aires, TEA, 1980.

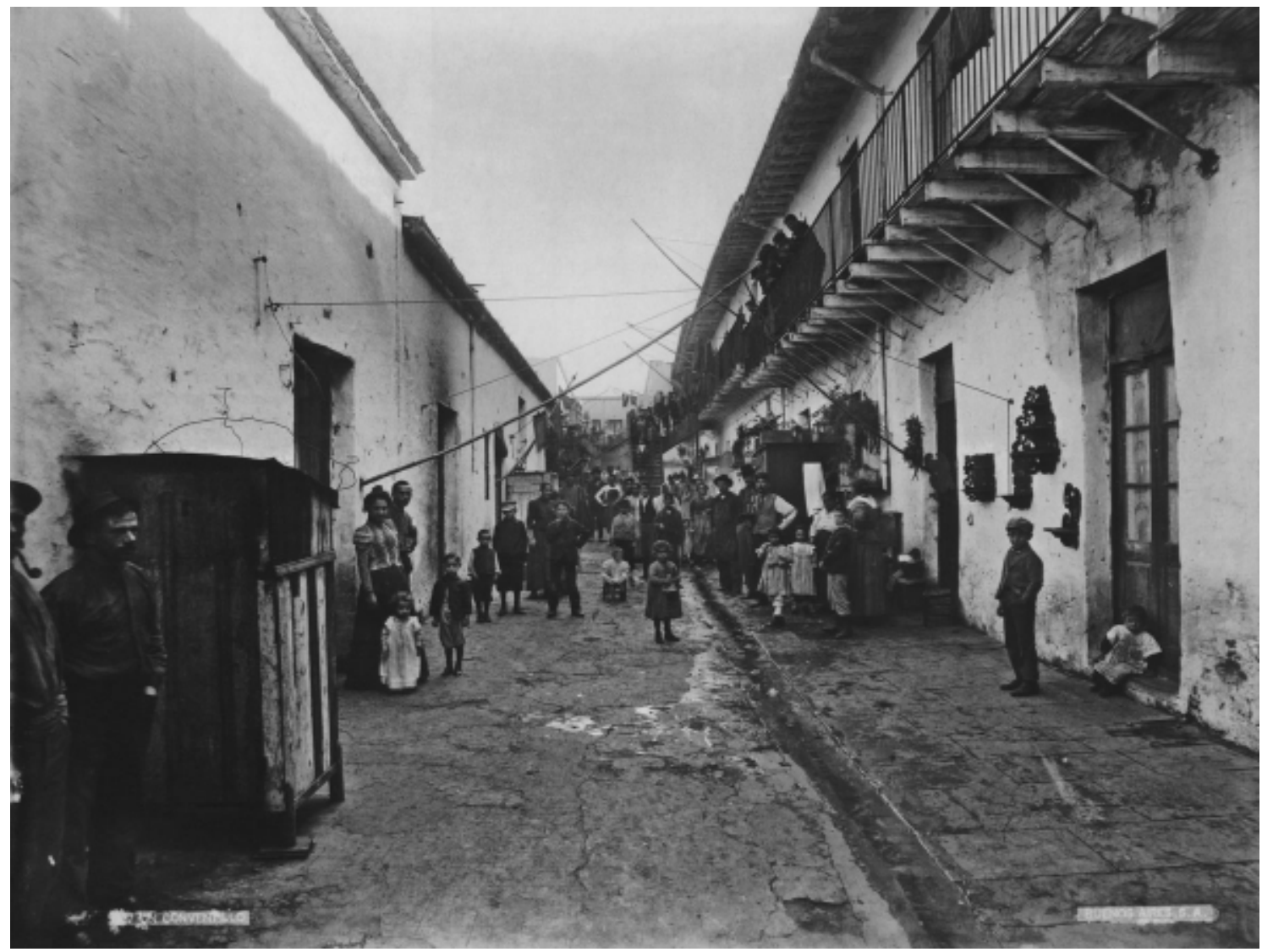

Figura 41 - Pátio de um conventillo em Buenos Aires, por volta de 1900-1905.

Fonte: GUTMAN, Margarita (ed.). Buenos Aires 1910: memoria del porvenir. Buenos Aires, Gobierno de la Ciudad de Buenos Aires/ Faculdade de Arquitetura, Design e Urbanismo da Universidade de Buenos Aires/ IIED-America Latina, 1999. 
verificou-se na área um grande aumento de população, que passou de 14.025 habitantes em 1890 para 42.715 em 1893. Boa parte dessa população se alojou em cortiços ou outras construções precárias, como alojamentos situados nos fundos de vendas ou depósitos. O mesmo relatório indica que havia 60 cortiços com população de 1320 habitantes. ${ }^{57}$

\footnotetext{
${ }^{57}$ Idem, ibidem. p. 23.
} 
CAPÍTULO 3

\section{A REDE URBANA REGIONAL E INTERNACIONAL}




\section{$3.1-$ INTRODUÇÃO}

Nosso método de análise pressupõe sempre operar com mudanças de escala, ou seja, significa que, definido um determinado recorte, é necessário verificar as continuidades dos modelos teóricos. Dito em outras palavras, não basta definir um recorte escalar e estudar apenas o que acontece naquela determinada escala, é necessário também identificar as relações existentes entre a escala de estudo e as demais, desde a local até a internacional. Somente desta forma conseguimos identificar as diferentes determinações existentes, obtendo conseqüentemente modelos teóricos mais precisos e gerais.

Nesta etapa do trabalho vamos analisar a relação existente entre a escala que nós estamos estudando, que é a escala da cidade, com as redes urbanas latinoamericana e européia.

Em primeiro lugar utilizaremos diversos dados, tais como índices demográficos e taxas de urbanização, com o objetivo de caracterizar alguns aspectos gerais do processo de urbanização no período.

$\mathrm{Na}$ seqüência analisaremos alguns dados referente às migrações, que foram, no período que estudamos, um dos fatores de maior impacto sobre o processo de urbanização em São Paulo e Buenos Aires.

Por último, analisaremos a rede urbana latino-americana, visando caracterizar a forma de organização da rede de núcleos urbanos no continente e no território nacional.

\section{2 - A REDE URBANA GERAL}

O primeiro aspecto que vamos estudar com o objetivo de iniciar uma comparação entre ambas as redes urbanas são os dados populacionais. Podemos observar nas tabelas seguintes que, embora o Brasil tenha uma área geográfica da mesma ordem de grandeza que a da Europa, sua população em 1900 é inferior à registrada na Idade Média naquele continente. A população da América Latina, nesse mesmo ano, corresponde aproximadamente à população da Europa no século XIV. E a população brasileira de hoje é próxima à da Europa de dois séculos atrás. 


\section{EVOLUÇÃO DA POPULAÇÃO DA EUROPA (SEM RÚSSIA) ${ }^{1}$}

\begin{tabular}{|c||c||c|}
\hline \hline \multicolumn{1}{|c||}{ Datas } & População (milhões) & Margem de erro (\%) \\
\hline 200 & 48 & 35 \\
\hline 500 & 36 & 30 \\
\hline 800 & 32 & 30 \\
\hline 1000 & 39 & 20 \\
\hline 1300 & 75 & 20 \\
\hline 1340 & 79 & 20 \\
\hline 1400 & 56 & 20 \\
\hline 1500 & 76 & 10 \\
\hline 1600 & 95 & 8 \\
\hline 1700 & 102 & 8 \\
\hline 1750 & 120 & 7 \\
\hline 1800 & 154 & 4 \\
\hline 1850 & 203 & 3 \\
\hline 1913 & 320 & 2 \\
\hline 1980 & 456 & 1 \\
\hline
\end{tabular}

\begin{tabular}{|c|c|c|c|c|c|c|c|}
\hline \multicolumn{7}{|c||}{ POPULAÇÃO NA AMÉRICA LATINA ${ }^{2}$} \\
\hline \hline \hline 1570 & 1650 & 1750 & 1800 & 1825 & 1850 & 1900 & 1950 \\
\hline \hline 10,2 & 11,4 & 11,1 & 18,9 & 23,1 & 33,0 & 63,0 & 160,0 \\
\hline
\end{tabular}

\begin{tabular}{|c|c|c|c|c|c|c|c|}
\hline \multicolumn{7}{|c|}{ POPULAÇÃO NO BRASIL } \\
\hline 1576 & 1660 & 1766 & 1800 & 1825 & 1850 & 1900 & 1950 \\
\hline \hline \hline 0,02 & 0,2 & 1,5 & 3,5 & 5,0 & 8,0 & 17,4 & 51,9 \\
\hline \hline
\end{tabular}

\footnotetext{
${ }^{1}$ Fonte: BAIROCH, Paul. De Jericó a México. Historia de la urbanización. México, Trillas, 1990.

2 Fonte: PEREIRA, Luiz. Urbanização "sociopática" e tensões sociais na América Latina. In: ALMEIDA, Fernando Lopes (org.). A Questão Urbana na América Latina. Rio de Janeiro, Forense-Universitária, 1978.

${ }^{3}$ Fonte: IBGE.
} 
Estes dados ${ }^{4}$ indicam que há uma enorme diferença populacional entre ambos continentes na época que estudamos. Conseqüentemente o território europeu era bem mais denso que o brasileiro e latino-americano. Isto pressupõe, em princípio, relações urbano-rurais diferentes, já que é necessário alimentar toda essa população. Neste aspecto, há vários séculos a Europa vem enfrentando o desafio de produzir alimentos para uma grande população.

Consideramos a população como sendo urbana quando não depende de si própria para produzir seus alimentos, que são o resultado do excedente produzido por uma população rural. Este critério, entretanto, é difícil de traduzir em dados objetivos. Outro problema é que cada país tem um critério diferente para definir a taxa de urbanização, o que dificulta muito a comparação de dados. Assim, os que apresentamos na continuação são aqueles cujos critérios são iguais, sendo que a população urbana corresponde às pessoas que vivem em cidades com mais de um determinado número de habitantes. ${ }^{5}$ Este número estará especificado em cada tabela. Nos quadros a seguir temos as taxas de urbanização na América Latina e Europa, de 1750 a 1920:

\begin{tabular}{|c|c|c|c|c|c|}
\hline \multicolumn{6}{|c|}{ TAXAS DE URBANIZAÇÃO NA AMÉRICA LATINA - 1750/19206 } \\
\hline \multirow[b]{2}{*}{ Taxa de urbanização } & 1750 & 1800 & 1850 & 1900 & 1920 \\
\hline & 13,0 & 14,5 & 13,0 & 20,3 & 25,5 \\
\hline
\end{tabular}

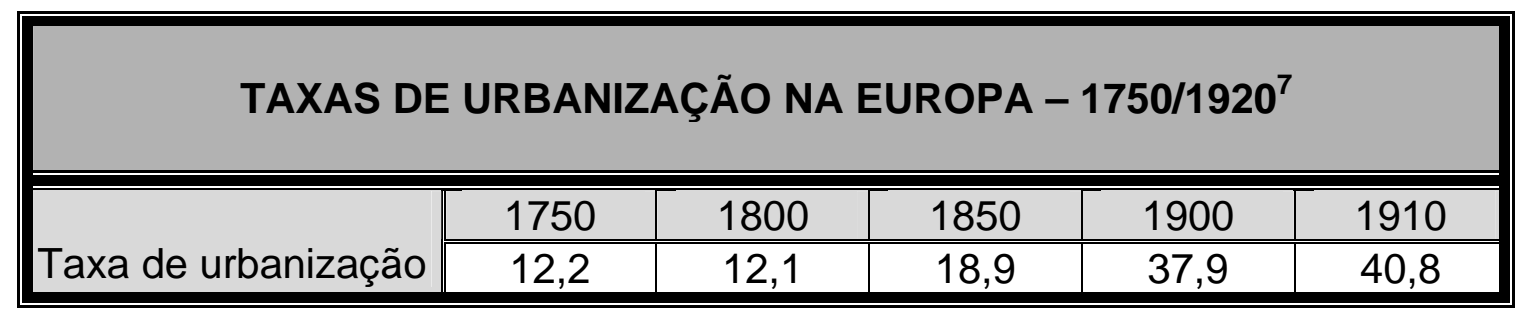

Como vemos, até 1800 as taxas eram próximas. A partir daí na Europa há um crescimento da população urbana, fenômeno que irá ocorrer algum tempo depois na América Latina. No quadro a seguir verificamos que as taxas de urbanização variavam significativamente de um país para outro, em alguns casos com índices menores que a média latino-americana. Esta heterogeneidade mostra que social e espacialmente o continente europeu era extremamente variado, o que evidencia a

\footnotetext{
${ }^{4}$ Estes dados são estimativas, que os próprios autores assumem como sujeitos a erros. Entretanto, servem aos nossos propósitos já que os utilizamos nesta etapa apenas para caracterizar em grandes linhas os fenômenos de urbanização.

5 Temos porém para a Europa alguns dados sobre a população que dependia das atividades agrícolas: Inglaterra: 75\% em 1688. França, em 1700, 80/85\%. Inglaterra, 26\% em 1841. Bélgica 51\% em 1846; França em 1856, 54\%. Dinamarca em 1850, 60\%. Itália, 64\% em 1871; Suécia, 67\% em 1860; Áustria, $68 \%$ em 1869; Espanha, 72\% em 1860. Vésperas da primeira Guerra: 41\% na França, 37\% na Alemanha, $9 \%$ no Reino Unido, $54 \%$ na Itália, mais de $60 \%$ na Rússia. BACCI, Massimo Livi. Historia de la Población Europea. Barcelona, Crítica, 1999.

${ }_{7}^{6}$ BAIROCH, Paul. Op. cit. Criterio: maior de 5.000 habitantes.

${ }^{7}$ Idem.
} 
necessidade de relativizar a utilização de fenômenos econômicos macro, para explicar os fenômenos espaciais.

\begin{tabular}{|c|c|c|c|}
\hline \multicolumn{4}{|c|}{ TAXA DE URBANIZAÇÃO EM ALGUNS PAÍSES EUROPÉUS ${ }^{8}$} \\
\hline & 1800 & 1850 & 1910 \\
\hline Alemanha & 9 & 15 & 49 \\
\hline Inglaterra & 23 & 45 & 75 \\
\hline Bélgica & 18 & 34 & 57 \\
\hline Espanha & 13 & 18 & 38 \\
\hline França & 12 & 19 & 38 \\
\hline Itália & 17 & 20 & 40 \\
\hline Países Baixos & 37 & 39 & 53 \\
\hline Portugal & 16 & 16 & 16 \\
\hline Suécia & 7 & 7 & 23 \\
\hline Suíça & 6 & 12 & 33 \\
\hline
\end{tabular}

Há poucos dados disponíveis sobre a taxa de urbanização na América Latina com os mesmos critérios (aglomerações com mais de 5.000 habitantes). No caso da Argentina, temos os seguintes índices: em 1869, taxa de 22,0\%. Em 1895, 31,8\%. E em 1914, 45,2\%. São números comparáveis aos de muitos dos países considerados como os mais desenvolvidos na época. No caso do Brasil, temos a taxa de urbanização a partir do critério de núcleos com mais de 10.000 habitantes: esta era em 1890 de 11,0\%, enquanto na Argentina em 1895 era de 26,8\%. Ou seja, na Argentina a população urbana era maior naquela época. ${ }^{9}$

Verificamos portanto que os fenômenos urbanos apresentam grande heterogeneidade, tanto na Europa como na América Latina, o que mostra que é necessário cuidado com as generalizações. Além disso, vimos que ao menos nos aspectos anteriores, nem sempre há uma distância tão grande entre ambos continentes, como fazem supor as interpretações baseadas apenas em fatores econômicos.

Para que isto fique mais claro, vamos comparar alguns índices que reflitam a qualidade de vida dos habitantes urbanos. Vejamos inicialmente os indicadores de mortalidade:

\footnotetext{
${ }^{8}$ BAIROCH, Paul. Op. cit. Criterio: maior de 5.000 habitantes.

9 Dados obtidos de SCOBIE, James R. El crecimiento de las ciudades latinoamericanas, 1870-1930. In: BETHELL, Leslie (ed.). Historia de América Latina. Vol. 7: América Latina: Economía y Sociedad, 18701930. Barcelona, Crítica, 2000.
} 


\begin{tabular}{|c|c|c|c|c|c|}
\hline \multicolumn{6}{|c|}{$\begin{array}{l}\text { MORTALIDADE EM ALGUNS PAÍSES EUROPÉUS } \\
\text { 1800-1913 (TAXAS POR } 1000 \text { HABITANTES) }\end{array}$} \\
\hline Países & 1800 & 1850 & 1870 & 1900 & 1913 \\
\hline \multicolumn{6}{|c|}{ Mortalidade } \\
\hline Suécia & 24,4 & 21,7 & 18,3 & 15,5 & 13,7 \\
\hline Inglaterra & 27,1 & 22,5 & 22,0 & 16,1 & 13,8 \\
\hline Alemanha & 25,8 & 27,1 & 27,8 & 19,5 & 15,0 \\
\hline Rusia & - & 36,5 & 37,1 & 31,0 & 27,4 \\
\hline França & 30,1 & 23,8 & 24,9 & 19,6 & 17,7 \\
\hline Áustria & 26,7 & 32,0 & 32,6 & 24,3 & 20,3 \\
\hline Itália & - & 29,9 & 30,4 & 22,0 & 18,7 \\
\hline
\end{tabular}

\begin{tabular}{|c|c|}
\hline \multicolumn{2}{|c|}{$\begin{array}{l}\text { MORTALIDADE EM ALGUMAS CIDADES } \\
\text { DO MUNDO EM } 1913 \\
\text { (TAXAS POR } 1000 \text { HABITANTES) }^{11}\end{array}$} \\
\hline Cidade & Índice \\
\hline Londres & 14,03 \\
\hline Munique & 14,62 \\
\hline Berlim & 13,67 \\
\hline Copenhague & 13,68 \\
\hline Moscou & 25,03 \\
\hline Paris & 15,92 \\
\hline Bruxelas & 12,20 \\
\hline Amsterdã & 11,63 \\
\hline Viena & 15,46 \\
\hline Nova York & 13,99 \\
\hline Chicago & 15,32 \\
\hline Nova Orleans & 19,00 \\
\hline
\end{tabular}

\footnotetext{
${ }^{10}$ Fonte: BACCI, Massimo Livi. Historia de la Población Europea. Barcelona, Crítica, 1999.

${ }^{11}$ Fonte: Annuario Demographico. Estado de São Paulo. Secção de Estatística Demographo-Sanitaria. 1914.
} 


\begin{tabular}{|c|c|}
\hline \multicolumn{2}{|c|}{} \\
ÍNDICE DE MORTALIDADE \\
Buenos Aires ${ }^{12}$
\end{tabular}

\begin{tabular}{|c|c|}
\hline \multicolumn{2}{|c|}{ ÍNDICE DE MORTALIDADE } \\
São Paulo \\
\hline \multicolumn{1}{|c|}{} \\
\hline \hline Ano & Índice (\%) \\
\hline \hline 1894 & 28,1 \\
\hline 1895 & 30,5 \\
\hline 1905 & 17,0 \\
\hline 1910 & 19,9 \\
\hline 1915 & 15,2 \\
\hline 1923 & 16,6 \\
\hline
\end{tabular}

Destes dados podemos auferir algumas conclusões: a primeira é que somente a partir da segunda metade do século XIX é que estes índices começam efetivamente a diminuir na Europa. A segunda conclusão é que embora estes índices comecem a cair em Buenos Aires um pouco antes do que em São Paulo, por volta de 1913, não apenas são muitos próximos entre si, como equivalentes ao de muitas das cidades acima listadas, em muito casos inclusive superiores.

O mesmo pode ser observado no quadro abaixo, sobre a esperança de vida na Europa. Assim como nos exemplos anteriores, pode ser observada uma rápida melhora qualitativa, que depende de país para país, mas em todos os casos crescente, com alto gradiente.

Não deixa de surpreender o quanto melhoraram as condições de vida, em especial no século XX, já que as condições de sobrevivência eram difíceis para todos, sem muita distinção. Na Inglaterra, por exemplo, a esperança de vida entre os nobres oscila entre um mínimo de 32 anos no período 1650-1675, e um máximo de 38,1 anos em 1725-1600. No caso da população, oscila entre um mínimo de 32 anos em 1650-

\footnotetext{
${ }^{12}$ BOURDÉ, Guy. Buenos Aires: Urbanización e Inmigración. Buenos Aires, Ed. Huemul, 1977.

${ }^{13}$ EMPLASA. Memória Urbana. A Grande São Paulo até 1940. São Paulo, Emplasa / Arquivo do Estado / Imprensa Oficial, 2001.
} 
1675 e um máximo de 38 entre 1575 e $1600 .{ }^{14}$ Como podemos observar, além de baixa, a esperança de vida era muito próxima, dependendo pouco da condição social. Irlanda, Finlândia e Rússia, em fins do século XIX, tinham índices de expectativa de vida em torno de 32 anos.

anos ou mais.

Hoje a maioria destes países tem expectativas de vida superiores aos 70

\begin{tabular}{|c|c|c|c|c|c|c|}
\hline \multicolumn{7}{|c|}{$\begin{array}{l}\text { ESPERANÇA DE VIDA AO NASCER EM ALGUNS PAÍSES EUROPEUS } \\
1750-1915^{15}\end{array}$} \\
\hline Países & $1750-1759$ & $1800-1909$ & $1850-1859$ & 1880 & 1900 & 1910 \\
\hline Suécia & 37,3 & 36,5 & 43,3 & 448,5 & $\overline{54,0}$ & $\overline{57,9}$ \\
\hline Inglaterra & 36,9 & 37,3 & 40,0 & 43,3 & 48,2 & 53,4 \\
\hline Holanda & - & 32,2 & 36,8 & 41,7 & 49,9 & 54,1 \\
\hline Alemanha & - & - & - & 37,9 & 44,4 & 49,0 \\
\hline Rusia & 24,2 & - & 24,4 & 27,7 & 32,4 & - \\
\hline França & 27,9 & 33,9 & 39,8 & 42,1 & 47,4 & 50,5 \\
\hline Itália & 32 & 30 & 32 & 35,4 & 42,8 & 47,0 \\
\hline Espanha & - & 28,0 & 29,8 & 31,0 & 34,8 & 42,3 \\
\hline
\end{tabular}

Infelizmente não possuímos dados confiáveis sobre a expectativa de vida no Brasil e na Argentina naquele período, para comparação. Mas é possível fazer um paralelo entre as taxas de mortalidade infantil. Não temos dados completos, mas via de regra são igualmente válidas as conclusões anteriores.

\begin{tabular}{|c|c|c|c|c|c|}
\hline \multicolumn{7}{|c||}{ TAXAS DE MORTALIDADE INFANTIL EM SÃO PAULO ${ }^{16}$} \\
\hline \hline 1909 & 1910 & 1911 & 1912 & 1913 & 1914 \\
\hline 167 & 161 & 188 & 199 & 192 & 172 \\
\hline
\end{tabular}

\begin{tabular}{|c|c|c|}
\hline \multicolumn{3}{|c|}{ TAXAS DE MORTALIDADE INFANTIL EM BUENOS AIRES ${ }^{17}$} \\
\hline \hline $1890-1899$ & $1900-1909$ & $1911-1914$ \\
\hline 142 & 99 & 92 \\
\hline
\end{tabular}

\footnotetext{
${ }^{14}$ BACCI, Massimo Livi. Op. cit., p. 62.

${ }^{15}$ Fonte: BACCI, Massimo Livi. Op. cit.

${ }_{16}^{16}$ Fonte: Annuario Demographico. Op. cit.

${ }^{17}$ BAIROCH, Paul. Op. cit.
} 


\begin{tabular}{|c|c|c|c|c|c|}
\hline \multicolumn{6}{|c|}{$\begin{array}{l}\text { TAXAS DE MORTALIDADE INFANTIL EM ALGUMAS } \\
\text { CIDADES EUROPEIAS }{ }^{18}\end{array}$} \\
\hline Paises & $1880-84$ & $1890-94$ & $1900-04$ & $1911-13$ & $1924-26$ \\
\hline Berlim & 291 & 243 & 208 & 151 & 90 \\
\hline Londres & 152 & 155 & 144 & 109 & 67 \\
\hline Viena & 189 & 216 & 179 & 157 & 103 \\
\hline Bruxelas & -- & 194 & 174 & 177 & 129 \\
\hline Copenhague & 220 & 184 & 160 & 101 & 75 \\
\hline Nápoles & 246 & 206 & 154 & 99 & 124 \\
\hline Turim & 151 & 139 & 152 & 136 & 90 \\
\hline Paris & 172 & 138 & 111 & 109 & 91 \\
\hline
\end{tabular}

Estes dados demográficos são o reflexo tardio de uma grande transformação que ocorre na Europa entre meados do século XIX e início do XX. Como afirma Bacci:

"La Europa de 1914 representa, en el ciclo contemporâneo que se está acabando, el momento en que las diferencias y la variabilidad de los fenómenos es máxima, y en que poblaciones con paradigmas de comportamiento proprios del antiguo régimen conviven con poblaciones que están concluyendo su transición demográfica." ${ }^{19}$

Não vamos entrar em muitos detalhes quanto às questões de demografia que são complexas e fogem ao nosso campo de estudo. O que nos interessa é o fenômeno: por um lado temos a Revolução Industrial, muito estudada, quando a utilização de máquinas e novos meios de energia é acompanhada de grandes mudanças sociais e espaciais. Mas acompanha também este processo, na Europa, um fenômeno menos citado, que é o da Revolução Agrícola, cujo desenvolvimento é menos intenso que o da Revolução Industrial, mas existe. Estima-se que a produtividade laboral rural aumentasse a partir de 1800 em $1 \%$ anualmente. ${ }^{20}$

Isto significa que antes da revolução agrícola a produção de um trabalhador apenas excedia o necessário para atender a demanda de trabalhadores de outros setores e resistir às flutuações naturais da colheita. Esta dependência no limite dos fenômenos naturais provocava grandes crises de subsistência. Como exemplo podemos citar a Irlanda, onde nos anos 1845-46 um fungo na batata, que era o principal alimento, provocou grande mortalidade e emigração. O impacto foi tão intenso, que em 1910 a Irlanda ainda tinha apenas a metade da população de antes da crise.

\footnotetext{
18 Idem.

${ }^{19}$ BACCl, Massimo Livi. Op. cit., p. 136.

${ }^{20}$ Idem.
} 
As causas do aumento da produtividade são várias: diminuição do tempo de repouso das terras, recuperação e saneamento de novas terras, adoção de novos cultivos e melhoria dos utensílios, seleção de sementes e animais, e introdução e difusão de novas máquinas.

A melhoria geral das condições de vida provoca uma diminuição dos índices de mortalidade, tanto no meio rural como no urbano, e conseqüentemente um aumento na população. ${ }^{21}$ Algum tempo depois irá diminuir também a taxa de natalidade. No meio rural, por exemplo, na Dinamarca entre 1850 e 1880 a população agrícola aumentou 46\%, e na Suécia, entre 1860 e 1890 aumentou 66\%. Por outro lado, a área cultivável teria aumentado, entre 1860 e 1910, apenas de 140 a 147 milhões de hectares, segundo Grigg. ${ }^{22}$

Há portanto um excedente populacional que é em parte absorvido pelo trabalho urbano, enquanto outra parte emigra para a América e outras regiões. Uma significativa parte do crescimento populacional no Brasil e na Argentina no período deve-se a este excedente. ${ }^{23}$

Por outro lado, se faltavam terras na Europa, estas existiam em abundância na América. No caso, a superfície cultivada aumentou entre 1860 e 1910 de 66 milhões para 174 milhões de hectares. Na Argentina em 1872 havia 73.096 hectares de trigo plantados. Em 1888 já são 815.438, em 1895 2.049.683, para chegar a 1916 com 6.511.000 hectares. Em 44 anos, a superfície plantada aumenta 89 vezes. ${ }^{24}$ Também a produtividade agrícola passa a ser maior na América. Em 1840, a produtividade agrícola nos Estados Unidos era 20\% superior à do Reino Unido, que por sua vez era 100\% maior que a do resto da Europa. Em 1910, os Estados Unidos têm níveis perto de $80 \%$ maiores que os do Reino Unido. ${ }^{25}$

\footnotetext{
${ }^{21}$ A rigor, no início da industrialização, os índices de mortalidade eram maiores nas cidades do que no campo. Isto somente se reverteu quando houve uma reacomodação às novas condições depois de períodos de intenso incremento populacional urbano.

22 BACCl, Massimo Livi. Op. cit.

${ }^{23}$ Nosso recorte limita-se à identificação da relação entre a rede urbana européia e a latino-americana. Mas em geral esquece-se que enquanto uma parte da população veio para a América, onde houve uma extensão da área cultivável, outra parte se dirigiu além dos Urais (cerca de 5,3 milhões de pessoas entre 1850 e 1937). Ao que saibamos, o estudo comparativo do processo de urbanização nestas duas regiões ainda não foi realizado.

${ }^{24}$ BARSKY, Osvaldo; GELMAN, Jorge. Historia del Agro Argentino. Desde la Conquista hasta fines del siglo XX. Buenos Aires, Grijalbo, 2001.

${ }^{25}$ BAIROCH, Paul. Op. cit.
} 


\section{3-MIGRAÇÕES}

Uma das características mais marcantes do período que estudamos é o intenso processo migratório, já que mais de 53 milhões de pessoas cruzaram o Atlântico entre 1846 e 1932. Nas tabelas abaixo temos os números das emigrações da Europa (inclui outros destinos além da América), e de imigração, por países: ${ }^{26}$

\begin{tabular}{|l|c|c|}
\hline \multicolumn{3}{|c|}{ IMIGRAÇÃO NA AMÉRICA: 1821 A 1932 } \\
(EM MILHARES) \\
\hline \hline \multicolumn{1}{|c|}{ País } & Período & Total \\
\hline \hline Argentina & $1856-1932$ & 6.405 \\
\hline Brasil & $1821-1932$ & 4.431 \\
\hline Canadá & $1821-1932$ & 5.206 \\
\hline Cuba & $1901-1932$ & 857 \\
\hline México & $1911-1932$ & 226 \\
\hline Paraguai & $1881-1931$ & 26 \\
\hline Estados Unidos & $1821-1932$ & 34.244 \\
\hline Uruguai & $1836-1932$ & 713 \\
\hline Total & & 53.826 \\
\hline
\end{tabular}

\footnotetext{
${ }^{26}$ Novamente os especialistas em migrações alertam para a pouca confiabilidade dos dados existentes. Por exemplo, para o caso da Espanha, as estatísticas de saída de emigrantes para todos os destinos são equivalentes às estatísticas de entrada de apenas um país, a Argentina. GARRABOU, Ramón (ed.). La crisis agrária de fines del siglo XIX. Barcelona, Crítica, 1988.

${ }^{27}$ Fonte: CARR-SAUNDERS, M. Op. cit.
} 


\begin{tabular}{|c|c|c|}
\hline \multicolumn{3}{|c|}{$\begin{array}{c}\text { EMIGRAÇÃO DA EUROPA: } 1846 \text { A } 1932 \\
\text { (EM MILHARES) }^{28}\end{array}$} \\
\hline País & Período & Total \\
\hline Áustria - Hungria & 1846-1932 & 5.196 \\
\hline Bélgica & $1846-1932$ & 193 \\
\hline Ilhas Britânicas & 1846-1932 & 18.020 \\
\hline Dinamarca & $1846-1932$ & 387 \\
\hline Finlândia & 1871-1932 & 371 \\
\hline França & 1846-1932 & 519 \\
\hline Alemanha & 1846-1932 & 4.889 \\
\hline Itália & 1846-1932 & 10.092 \\
\hline Malta & 1911-1932 & 63 \\
\hline Holanda & $1846-1932$ & 224 \\
\hline Noruega & 1846-1932 & 854 \\
\hline Polônia & 1920-1932 & 642 \\
\hline Portugal & $1846-1932$ & 1.805 \\
\hline Rusia & 1846-1924 & 2.253 \\
\hline Espanha & 1846-1932 & 4.653 \\
\hline Suécia & $1846-1932$ & 1.203 \\
\hline Suíça & $1846-1932$ & 332 \\
\hline Total & & 51.696 \\
\hline
\end{tabular}

\footnotetext{
${ }^{28}$ Fonte: CARR-SAUNDERS, M. Op. cit.
} 

períodos $^{29}$.

No gráfico seguinte, temos os totais de emigração da Europa por

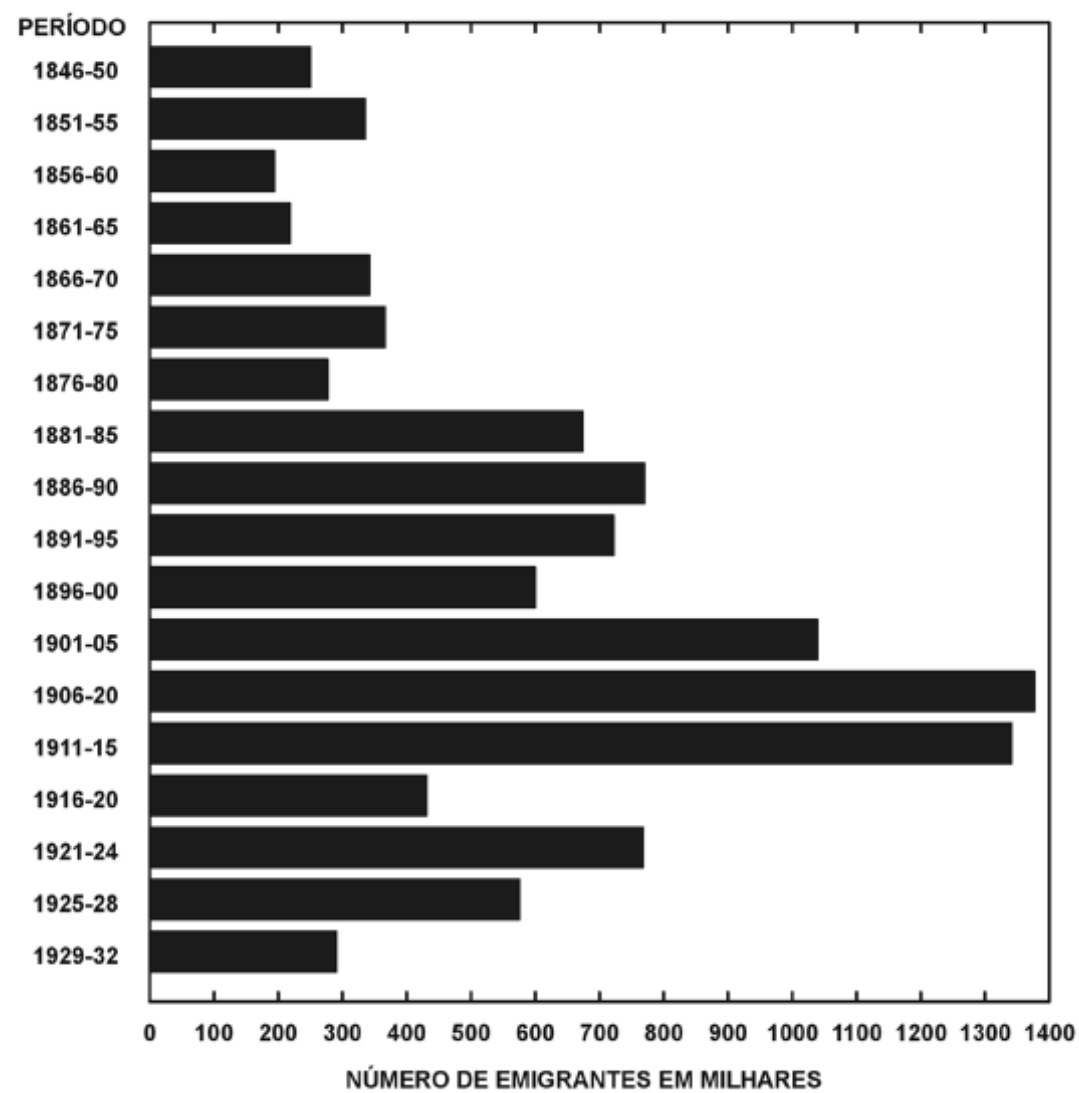

Assim como no caso dos índices de natalidade e mortalidade, o fenômeno das migrações também muda enormemente de um país a outro, o que exige cuidado com as generalizações. Entretanto, estes números mostram a intensidade do processo, de sorte que houve países como a Itália, por exemplo, onde em alguns anos foram maiores as emigrações do que o crescimento natural (1905 a 1907 e 1913) ${ }^{30}$

Em geral, na Europa existe uma grande tradição de estudo das cidades, em detrimento das abordagens sobre a área rural, que como vimos são de vital importância para entender a urbanização entre nós. Por este motivo, recorrer aos historiadores agrários pode ser útil. Um destes é De Vries, que estuda o espaço europeu entre 1500 e 1800. Em um trabalho publicado em 1984, mostra que no período pré-industrial já existia um complexo sistema urbano, constituído não apenas pelas cidades mais importantes (em geral, bastante estudadas), como também por uma extensa rede de pequenos núcleos urbanos. ${ }^{31}$

\footnotetext{
${ }^{29}$ Fonte: CARR-SAUNDERS, M. Op. cit.

${ }^{30}$ As migrações neste período não se limitaram apenas aos europeus. Temos o caso dos chineses, por exemplo, que foram levados em número de 125 mil para Cuba entre 1848 e 1874. Para o Perú, totalizando perto de 90 mil antes de 1874; e 18 mil foram levados para a Guiana e Índias Ocidentais britânicas. KLEIN, Herbert S. Migração internacional na história das Américas. In: FAUSTO, Boris (org). Fazer a América. $2^{\mathrm{a}}$ ed. São Paulo, Edusp, 2000.

${ }^{31}$ VRIES, J. de. La Urbanización de Europa 1500-1800. Barcelona, Crítica, 1987.
} 
No caso particular da Espanha, um dos primeiros intentos de estudar a crise agrária do século XIX é relativamente recente, de $1986 .^{32}$

Um dos artigos trata especificamente das causas da emigração da Espanha. ${ }^{33}$ Neste, o autor mostra que os motivos são os mais diversos, variando de região para região, como mostrado no quadro abaixo. Entretanto, mesmo havendo diferenças, de forma geral foram as províncias do sul e noroeste as que mais contribuíram com emigrantes.

Comparada com a italiana, que também foi intensa, a emigração espanhola é mais tardia, com maior incremento particularmente nos anos 1904-1913. No gráfico após a tabela temos os totais para Brasil e Argentina. ${ }^{34}$

\begin{tabular}{|c|c|}
\hline \multicolumn{2}{|c|}{ ESPANHA: CAUSAS DA EMIGRAÇÃO ${ }^{35}$} \\
\hline Causas & Províncias \\
\hline Decadência ou esgotamento de minas & Almería, Jaén, Murcia, Huelva, \\
\hline Paralisação da indústria do ferro & Guipúzcoa, Vizcaya \\
\hline $\begin{array}{lllll}\text { Diminuição ou perda } & \text { total do esparto } \\
\text { (concorrência do argelino) } & & & \\
\end{array}$ & Almería, Murcia, Albacete \\
\hline Decadência industrial da indústria de tecidos & Logroño, Palencia \\
\hline Decadência industrial farinheira & Santander, Palencia \\
\hline $\begin{array}{l}\text { Dificuldades na exportação } \\
\text { (Tratado de 1892, preços dos câmbios) }\end{array}$ & $\begin{array}{l}\text { Orense, Extremadura: gado } \\
\text { Castellón: laranja } \\
\text { Cádiz, Tarragona: vinhos }\end{array}$ \\
\hline Ruína da produção vitícola & Orense \\
\hline Depreciação da Cochonilha-do-carmin & Canarias \\
\hline
\end{tabular}

\footnotetext{
${ }^{32}$ Dessa data é o I Seminari Internacional d'Història, realizado em Girona, reunindo pesquisadores de diversas instituições espanholas, e de outros países (França, Itália, Portugal e Grã-Bretanha). O objetivo era trocar conhecimentos sobre este fenômeno nas diversas regiões, e suas conseqüências. In: GARRABOU, Ramón (ed.). Op. cit.

${ }^{33}$ ROBLEDO, Ricardo. Crisis agrária y éxodo rural: emigración española a ultramar, 1880-1920. In: GARRABOU, Ramón (ed.). Op. cit.

${ }^{34}$ Para Argentina: SILBERSTEIN, Carina Frid de. A imigração espanhola na Argentina (1880-1930). Para Brasil: MARTÍNEZ, Elda Evangelina González. O Brasil como país de destino para os migrantes espanhóis. In: FAUSTO, Boris (org). Op. cit.

${ }^{35}$ Fonte: ROBLEDO, Ricardo. Op. cit.
} 


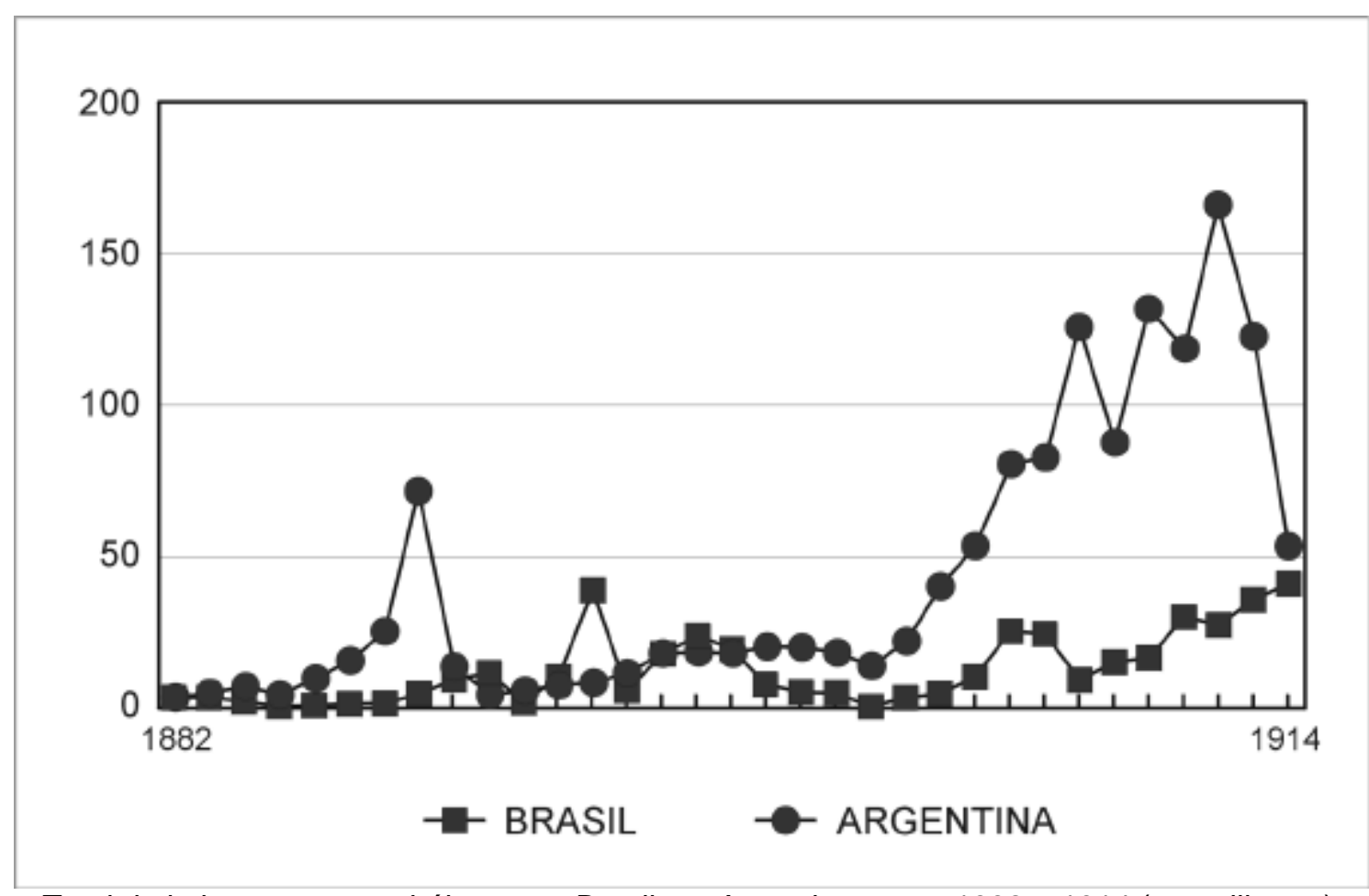

Total de imigrantes espanhóis para o Brasil e a Argentina, entre 1882 e 1914 (em milhares)

Não se pode também esquecer a diminuição dos custos de transporte, o que possibilitou a emigração de muitas pessoas. Entretanto, não necessariamente as regiões mais pobres são as que mais contribuíram para as migrações, já que muitas vezes o custo de transporte era proibitivo, tal o grau de penúria em algumas localidades.

Também foram importantes as migrações temporárias, pois havia pessoas que trabalhavam um determinado tempo e depois voltavam. Entre 1880 y 1930, dos dois milhões de espanhóis que foram para a Argentina, apenas $60 \%$ ficaram $(1,2$ milhões).

Não faltam fatos curiosos, como de um povoado castelhano que em carta enviada ao presidente argentino em 1905, se oferece para emigrar em massa para aquele país. Outro dado curioso, mas não desprezível em certos anos, é a deserção de pessoas convocadas para o serviço militar. Havia a possibilidade de pagar para não prestar serviço, mas era muito mais caro do que emigrar. Em tempos da campanha na África, houve anos em que perto de $20 \%$ dos alistados correspondia a desertores.

Os dados que aqui apresentamos mostram que também no caso das migrações as variações são significativas. Por um lado há grandes diferenças entre os diversos países europeus quanto aos contingentes de imigrantes. E por outro, no caso específico de um país, a Espanha, verificamos que as causas das emigrações também são muito variadas. Novamente comprovamos que as generalizações devem ser feitas com critério. 
Muito pouco ainda foi estudado sobre o fenômeno da imigração para a América, tanto que Bacci, ao abordar esta questão, faz a seguinte afirmação:

"¿Qué habría sido de Europa sin América, y qué habría sido de América sin Europa? Que quede bien claro que es una pregunta que un estudioso no debería plantearse nunca..."36

Boris Fausto, na introdução do livro referente ao seminário "Fazer a América", realizado no Memorial da América Latina em 1993, chama a atenção para o fato de praticamente não terem sido realizados até aquela data estudos comparados entre países latino-americanos sobre imigração. ${ }^{37}$

Ou seja, repete-se nesta área o mesmo fenômeno observado na área de estudos urbanos, que é a ênfase na relação entre os continentes europeu e latinoamericano em detrimento das relações internas a cada continente. Além disso, enfatiza-se principalmente o impacto deste fenômeno na América Latina, e não o contrário, seu impacto na Europa. Entretanto, certamente a história das cidades européias teria sido muito diferente se estas milhões de pessoas não tivessem migrado.

\section{4 - A REDE URBANA LATINO-AMERICANA}

Vejamos agora como se reflete este processo geral de urbanização na escala da rede regional latino-americana. Em geral o período em questão significou o crescimento da importância dos principais núcleos urbanos de cada país, localizados junto à costa, e contando com instalações portuárias.

Este fenômeno se caracteriza pela formação de um sistema de transportes cujos fluxos assumem a forma de uma "árvore", com foco nas principais cidades. Isto pode ser observado claramente nas figuras 42 e 43 referentes ao transporte ferroviário. No primeiro caso, o Estado de São Paulo, as linhas convergem para São Paulo, que por sua vez está ligada ao seu porto, a cidade de Santos. Na prática, neste sentido, ambas cidades formam um único sistema urbano, separadas apenas por um obstáculo físico, a serra do Mar.

$\mathrm{Na}$ figura 43 vemos a organização da rede ferroviária na Argentina. Podemos observar que predominam as linhas convergentes em Buenos Aires, embora pólos, como Rosário, também sejam fator de atração. Também podemos notar que na Argentina um único sistema possuía abrangência nacional, enquanto no Brasil, embora a maior parte da rede estivesse em São Paulo, havia linhas em outros estados que não possuíam qualquer interligação entre si. A exceção é o eixo São Paulo-Rio de Janeiro, como pode ser observado na figura $42 .{ }^{38}$

\footnotetext{
${ }^{36}$ BACCI, Massimo Livi. Op. cit.

${ }^{37}$ FAUSTO, Boris (org). Op. cit.

${ }^{38}$ No Brasil isto somente começa a ser superado nos anos 1950, com a construção de rodovias que integravam o interior do país.
} 


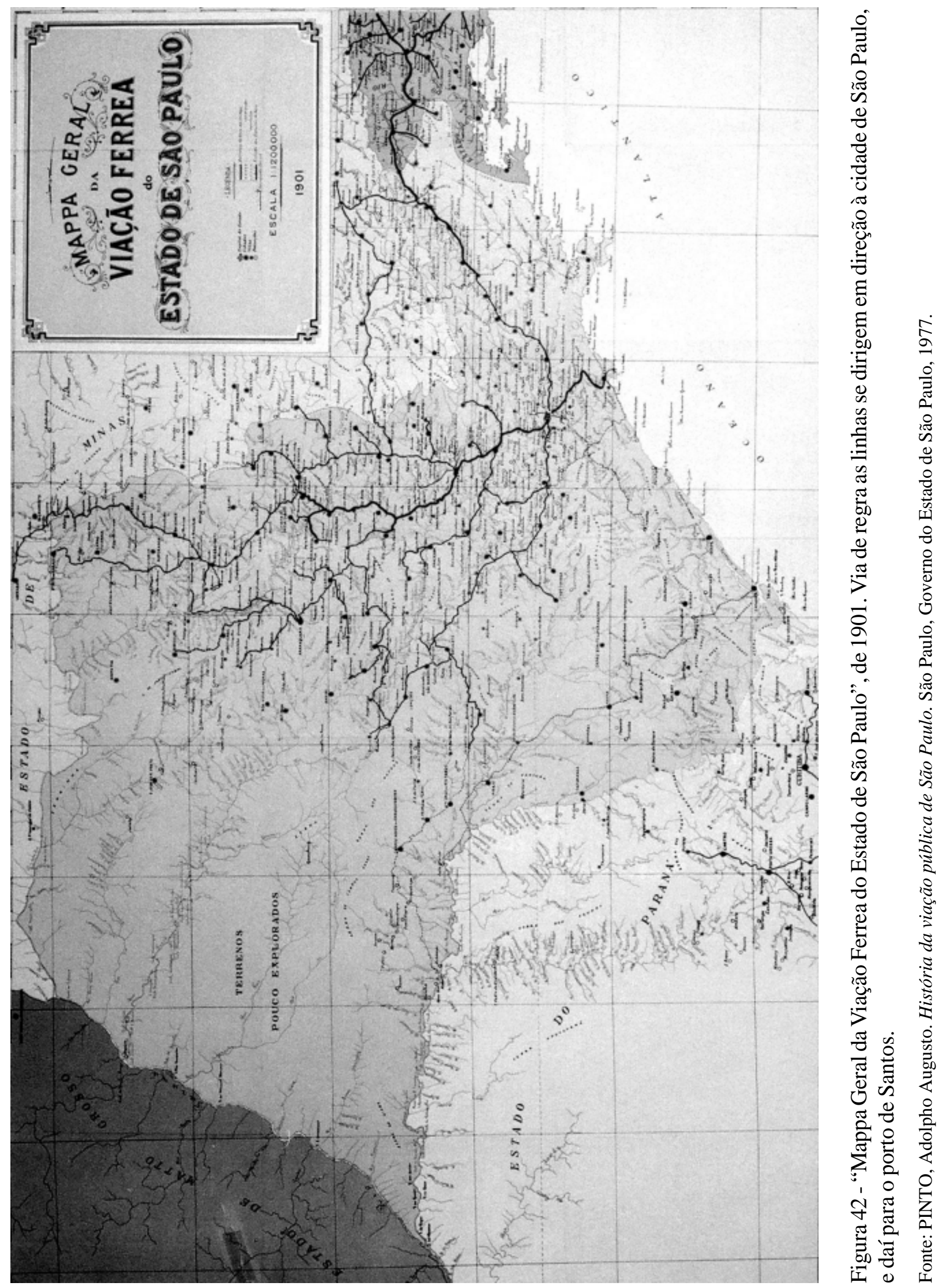




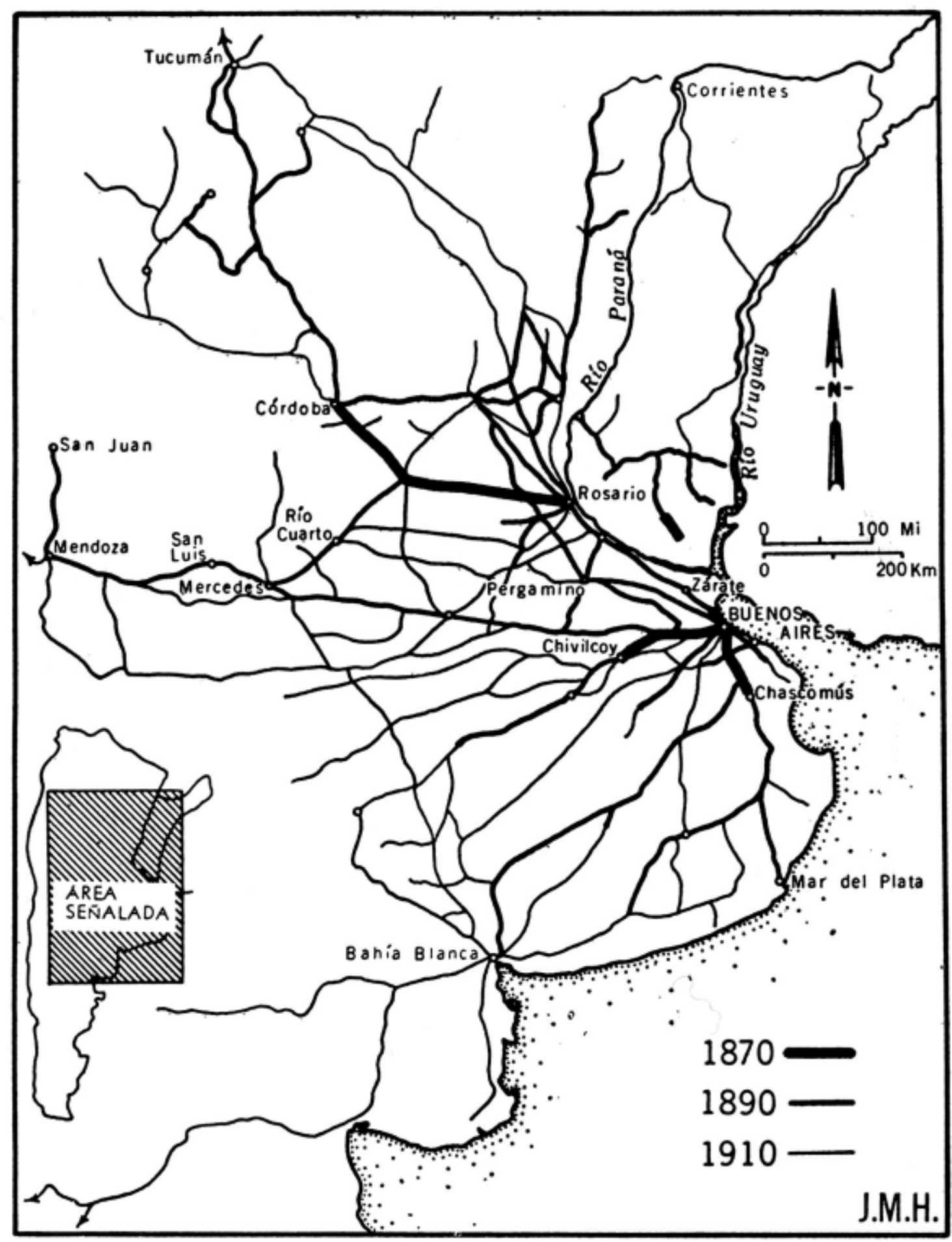

Figura 43 - Mapa da rede ferroviária na Argentina entre 1870 e 1910. Notar que embora Buenos Aires seja o principal destino das linhas, Rosário também se caracteriza como um importante pólo .

Fonte: SCOBIE, James R. Buenos Aires. Del centro a los barrios. 1870-1910. Buenos Aires, Solar/Hachette, 1977. 
Outra característica importante é o aumento da taxa de urbanização. Significou, na maioria dos casos, que a principal cidade em população passa a ter maior preponderância. Isto pode ser observado no quadro a seguir, onde são comparados dados das décadas de 1870 e de 1930. Duas exceções importantes são justamente São Paulo e Buenos Aires. No primeiro caso, pelo fato de não coincidirem a cidade mais importante da primeira metade do século XIX (Rio de Janeiro) com a que deverá experimentar um maior desenvolvimento no período que estudamos, no caso São Paulo. Na Argentina, pelas possibilidades de navegação pelo rio Paraná, Rosário também passa a ter um importante porto, daí seu desenvolvimento. O mesmo ocorre com Bahia Blanca. Apesar disto, a relação entre ambas cidades é significativa: 4,5 .

$\mathrm{Na}$ tabela da próxima página verificamos que, via de regra, o índice de urbanização é crescente, variando de país para país, sendo os mais urbanizados, da tabela, Argentina, Chile e Cuba.

\begin{tabular}{|c|c|c|c|}
\hline \multicolumn{4}{|c|}{$\begin{array}{l}\text { POPULAÇÃO: FATOR DE PROPORÇÃO ENTRE AS PRIMEIRAS E } \\
\text { SEGUNDAS CIDADES DOS PRINCIPAIS PAIISES LATINO- } \\
\text { AMERICANOS }\end{array}$} \\
\hline Pais & Cidades primeira e segunda & Data & Diferença (\%) \\
\hline \multicolumn{4}{|l|}{ Século XIX } \\
\hline Argentina & Buenos Aires /Córdoba & 1869 & 6,4 \\
\hline Brasil & Rio de Janeiro/Salvador & 1872 & 2,1 \\
\hline Chile & Santiago /Valparaiso & 1875 & 1,5 \\
\hline Colômbia & Bogotá /Medellín & 1870 & 1,4 \\
\hline Cuba & La Habana /Santiago & $1875 / 79$ & 5,1 \\
\hline México & $\begin{array}{l}\text { Cidade do México } \\
\text { /Guadalajara }\end{array}$ & 1877 & 3,5 \\
\hline Peru & Lima /Arequipa & 1876 & 3,4 \\
\hline \multicolumn{4}{|l|}{ Século XX } \\
\hline Argentina & Buenos Aires /Rosário & $1930 / 32$ & 4,5 \\
\hline Brasil & Rio de Janeiro/São Paulo & 1940 & 1,2 \\
\hline Chile & Santiago /Valparaiso & 1930 & 3,6 \\
\hline Colômbia & Bogotá /Medellín & 1938 & 2,0 \\
\hline Cuba & La Habana /Santiago & 1931 & 6,4 \\
\hline México & $\begin{array}{l}\text { Cidade do México } \\
\text { /Guadalajara }\end{array}$ & 1930 & 5,8 \\
\hline Peru & Lima /Arequipa & $1931 / 33$ & 4,1 \\
\hline
\end{tabular}

${ }^{39}$ SCOBIE, James R. El crecimiento de las ciudades latinoamericanas, 1870-1930. In: BETHELL, Leslie (ed.). Historia de América Latina. Vol. 7: América Latina: Economía y Sociedad, 1870-1930. Barcelona, Crítica, 2000. 


\begin{tabular}{|c|c|}
\hline \multicolumn{2}{|c|}{$\begin{array}{l}\text { POPULAÇÃO DE CENTROS URBANOS } \\
\text { (porcentagem da população total) }^{40}\end{array}$} \\
\hline Pais & $\begin{array}{c}\text { Centros com mais de } \\
20.000 \text { habitantes }\end{array}$ \\
\hline \multicolumn{2}{|l|}{ Argentina } \\
\hline 1869 & 13,8 \\
\hline 1895 & 24,2 \\
\hline 1914 & 33,5 \\
\hline \multicolumn{2}{|l|}{ Brasil } \\
\hline 1872 & 8,5 \\
\hline 1890 & 8,6 \\
\hline 1940 & 15,3 \\
\hline \multicolumn{2}{|l|}{ Chile } \\
\hline 1875 & 11,0 \\
\hline 1895 & 19,0 \\
\hline 1930 & 32,4 \\
\hline \multicolumn{2}{|l|}{ Colômbia } \\
\hline 1870 & 2,4 \\
\hline 1905 & 7,7 \\
\hline 1928 & 8,7 \\
\hline \multicolumn{2}{|l|}{ Cuba } \\
\hline 1877 & 20,6 \\
\hline 1899 & 25,0 \\
\hline 1931 & 20,1 \\
\hline \multicolumn{2}{|l|}{ México } \\
\hline 1900 & 9,3 \\
\hline 1930 & 15,6 \\
\hline \multicolumn{2}{|l|}{ Perú } \\
\hline 1876 & 5,9 \\
\hline 1940 & 14,6 \\
\hline \multicolumn{2}{|l|}{ Venezuela } \\
\hline 1873 & 7,3 \\
\hline 1891 & 8,5 \\
\hline 1926 & 17,0 \\
\hline
\end{tabular}

Entretanto, como mostrado no quadro abaixo, vemos que em todos os casos aumenta a porcentagem da população das capitais em relação ao total do país. São Paulo em 1872 tinha 0,31\% da população brasileira, em 1920 1,89\%, e em 1940

${ }^{40}$ SCOBIE, James R. El crecimiento de las ciudades latinoamericanas, 1870-1930. In: BETHELL, Leslie (ed.). Historia de América Latina. Vol. 7: América Latina: Economía y Sociedad, 1870-1930. Barcelona, Crítica, 2000. Neste caso estamos usando o critério de núcleos urbanos com mais de 20.000 habitantes, já que não há dados disponíveis com o critério de 5.000 habitantes, o que nos impede de comparar estes dados com os da rede urbana européia. 
$3,22 \%$. Atualmente é de aproximadamente $10 \%$ da população total do país. Buenos Aires continuará aumentando sua preponderância nas décadas seguintes, até chegar a 34,72\% em 1991 (grande Buenos Aires).

Esta enorme concentração é enfatizada por Alejandro Bunge, que no clássico "Una nueva Argentina", de 1940, coloca que:

"un tercio del território de la República, abarcado dentro de un arco de círculo de $780 \mathrm{Km}$ de radio con centro en la Capital, comprendía ocho décimos de la población y nueve décimos de la capacidad económica." ${ }^{41}$

\begin{tabular}{|c|c|c|c|}
\hline \multicolumn{4}{|c|}{$\begin{array}{l}\text { PORCENTAGEM DA POPULAÇÃO NACIONAL } \\
\text { LOCALIZADA NA CAPITAL }-1870-1930^{42}\end{array}$} \\
\hline \multirow[t]{2}{*}{ País } & \multirow[t]{2}{*}{ Capital } & \multicolumn{2}{|c|}{ Porcentagem do total naciona } \\
\hline & & 1870 & 1930 \\
\hline Argentina & Buenos Aires & 10,8 & 18,3 \\
\hline Bolivia & La Paz & 3,5 & 8,2 \\
\hline Brasil & Rio de Janeiro & 2,7 & 5,0 \\
\hline Colombia & Bogotá & 1,4 & 3,8 \\
\hline Costa Rica & San José & 5,5 & 10,8 \\
\hline Cuba & La Habana & 15,2 & 16,5 \\
\hline Chile & Santiago & 7,2 & 16,2 \\
\hline Equador & Quito & 7,1 & 8,2 \\
\hline Guatemala & Guatemala & 4,6 & 6,0 \\
\hline México & Cidade do México & 2,4 & 6,3 \\
\hline Paraguai & Assunção & 7,6 & 11,0 \\
\hline Peru & Lima & 3,7 & 4,8 \\
\hline Uruguai & Montevidéu & 25,0 & 33,0 \\
\hline Venezuela & Caracas & 2,8 & 6,0 \\
\hline
\end{tabular}

Uma das tentativas realizadas para a ocupação de áreas no interior é a fundação de colônias agrícolas. Na Argentina as primeiras tentativas nesse sentido são de 1853, na província de Corrientes, sem sucesso. Mas aos poucos, e praticamente só por iniciativa do capital privado, é assentada alguma população em colônias agrícolas, em geral de origem européia, nas províncias de Santa Fé e no eixo Rosario-Córdoba. As empresas ligadas ao setor ferroviário também tiveram importante participação, já que estas conseguiam a concessão das faixas de terras por onde passavam as linhas. Nessas áreas construíam colônias, e, devido à valorização

\footnotetext{
41 BUNGE, Alejandro. Una nueva Argentina. Buenos Aires, Ed. Guillermo Kraft, 1940. Citado em: HARDOY, Jorge Enrique; LANGDON, Maria E. El pensamiento regional en Argentina y Chile entre 1850 y 1930. México, Revista Interamericana de Planificación, Vol. XIV, Nº 55/56, setembro/ dezembro, 1980.

42 SCOBIE, James R. El crecimiento de las ciudades latinoamericanas, 1870-1930. In: BETHELL, Leslie (ed.). Historia de América Latina. Vol. 7: América Latina: Economía y Sociedad, 1870-1930. Barcelona, Crítica, 2000.
} 
provocada pela infraestrutura instalada, obtinham grandes lucros com sua venda. A ocupação destas terras foi, de fato, um grande negócio. ${ }^{43}$

Não é muito diferente o caso do Brasil, particularmente no interior do estado de São Paulo. Este processo, bem estudado por Monbeig ${ }^{44}$, mostra como também há a ocupação, o uso agrícola e a implantação de colônias. Muitos destes empreendimentos eram privados, vários de capital estrangeiro, mas a partir da crise de 1896 também o governo do estado de São Paulo incentiva a criação de colônias nas regiões onde já existia uma produção cafeeira. ${ }^{45}$

São também importantes no período a construção das ferrovias e das estradas. Da mesma forma, foram grandes os lucros obtidos com a compra e venda dessas terras. ${ }^{46}$ Esse processo continuou, já em tempos mais recentes, no Paraná, onde uma grande empresa privada promoveu a ocupação de parte desse estado.

Quanto ao desenho dessas colônias, vemos na figura 44 um modelo de assentamento no estado de São Paulo. Na Argentina, este desenho irá depender de diversos fatores, inclusive da origem dos imigrantes. Mas em geral as disposições constantes na Lei de Colonização de 1857 e a pouca originalidade dos técnicos dos Departamentos de Topografia levam a um traçado ortogonal, como o da figura $45 .{ }^{47}$

Na Argentina, apesar das leis destinadas ao incentivo à imigração, como a lei 817 de 1876 (também conhecida como lei Avellaneda), através da qual foram criadas oficinas nas províncias e um hotel de imigrantes junto ao porto de Buenos Aires, o número de colônias fundadas não foi expressivo. Em Santa Fé, por exemplo, entre 1860 e 1869 foram fundadas 16 colônias. Entre 1870 e 1879 foram 48. E entre 1880 e 1889 este número subiu a $160 .^{48}$

$\mathrm{Na}$ prática, entretanto, a realidade é que quando os imigrantes chegaram, a grande maioria das terras já tinha dono. Quando o governo argentino decidiu atuar, em 1903 prescrevendo o latifúndio, já era tarde: as melhores terras já haviam sido subdivididas. A lei Avellaneda, apesar de procurar incentivar a colonização, também autorizava (artigo 104) grandes concessões a sociedades e empresas capitalistas, encarregadas das iniciativas de povoamento, o que poucas vezes ocorreu, e permitiu uma desenfreada especulação. Entre 1876 e 1903 afirma-se que 1800 pessoas passaram a ser proprietárias de 40 milhões de hectares. ${ }^{49}$

"Cuando se inició el proceso de expansión, la oligarquía lo condujo de modo tal que las bases de su hegemonía - la posesión de la tierra - no se vieron alteradas; la expansión se realizó al ritmo de la progresiva conquista y ocupación de nuevos territorios, que fueron entregados por el Estado a

\footnotetext{
43 ORTIZ, Ricardo M. História Económica de la Argentina. $4^{\underline{a}}$ ed. Buenos Aires, Plus Ultra, 1974.

${ }_{44}^{4}$ MONBEIG, Pierre. Pioneiros e fazendeiros de São Paulo. São Paulo, Hucitec/Polis, 1984.

45 GADELHA, Maria Regina D'Aquino Fonseca. Os núcleos coloniais e o processo de acumulação cafeeira (1850 - 1920): contribuição ao estudo da colonização em São Paulo. Tese de doutorado. São Paulo, FFLCH, 1982.

46 REIS FILHO, Nestor Goulart. Memória do transporte rodoviário. Desenvolvimento das atividades rodoviárias de São Paulo. São Paulo, CPA, s.d.

${ }^{47}$ GUTIERREZ, Ramón. Arquitectura y Urbanismo en Iberoamérica. Madrid, Cátedra, 1983.

${ }^{48}$ CARRASCO, Gabriel. La colonización agrícola en la provincia de Santa Fé. Santa Fe, 1893. Citado em: HARDOY, Jorge Enrique; LANGDON, Maria E. Op. Cit.

49 CHEVALIER, Françoise. América Latina. De la Independencia a nuestros días. México, Fondo de Cultura Económica, 1999.
} 


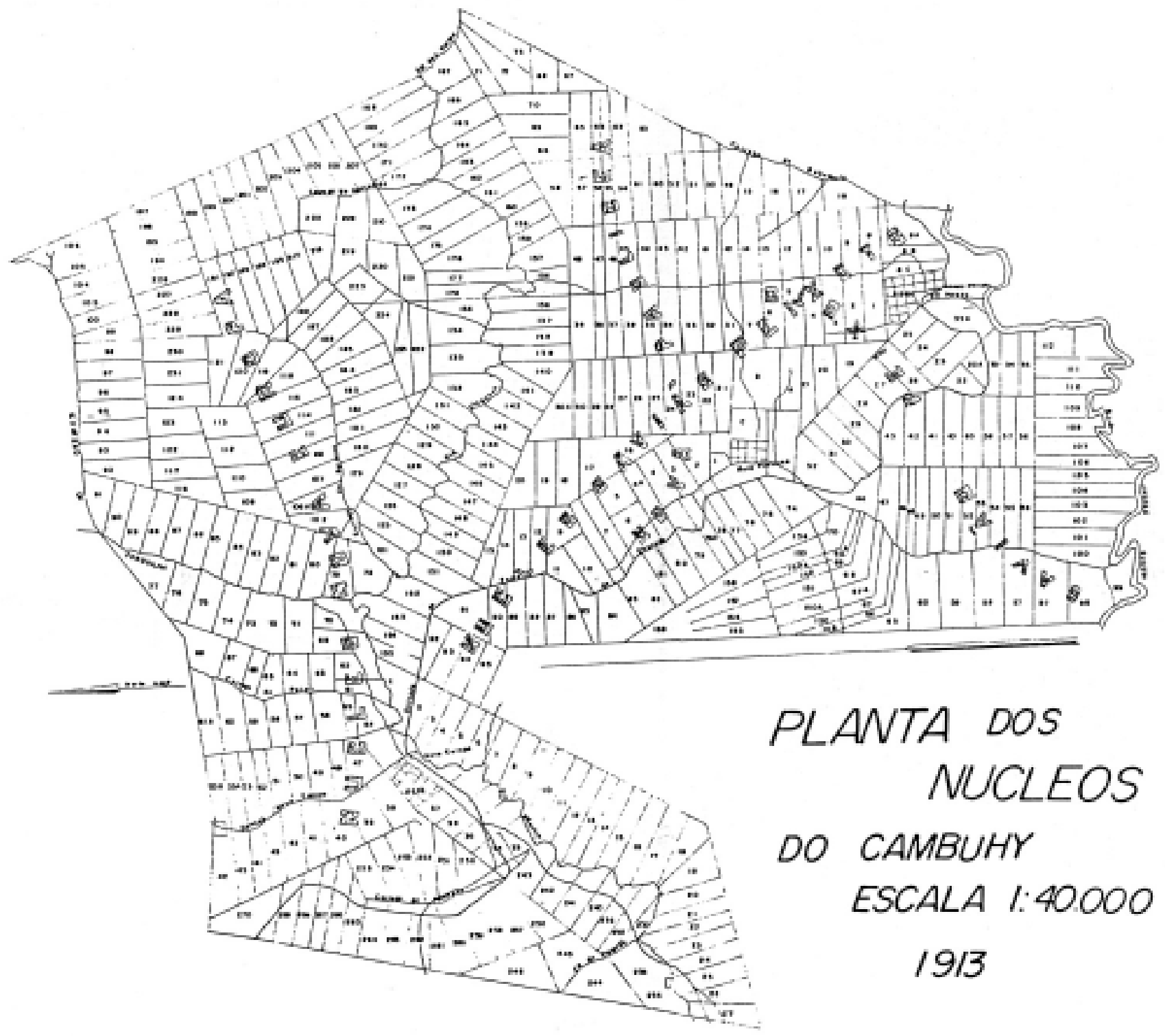

Figura 44 - Colônia do Cambuhy, na região de Araraquara, Matão e Ibitinga. O núcleo Nova Europa é de 1907.

Fonte: GADELHA, Maria Regina D’Aquino Fonseca. Tese de doutorado. Os núcleos coloniais e o processo de acumulação cafeeira (1850 - 1920): contribuição ao estudo da colonização em São Paulo. São Paulo, FFLCH, 1982. 


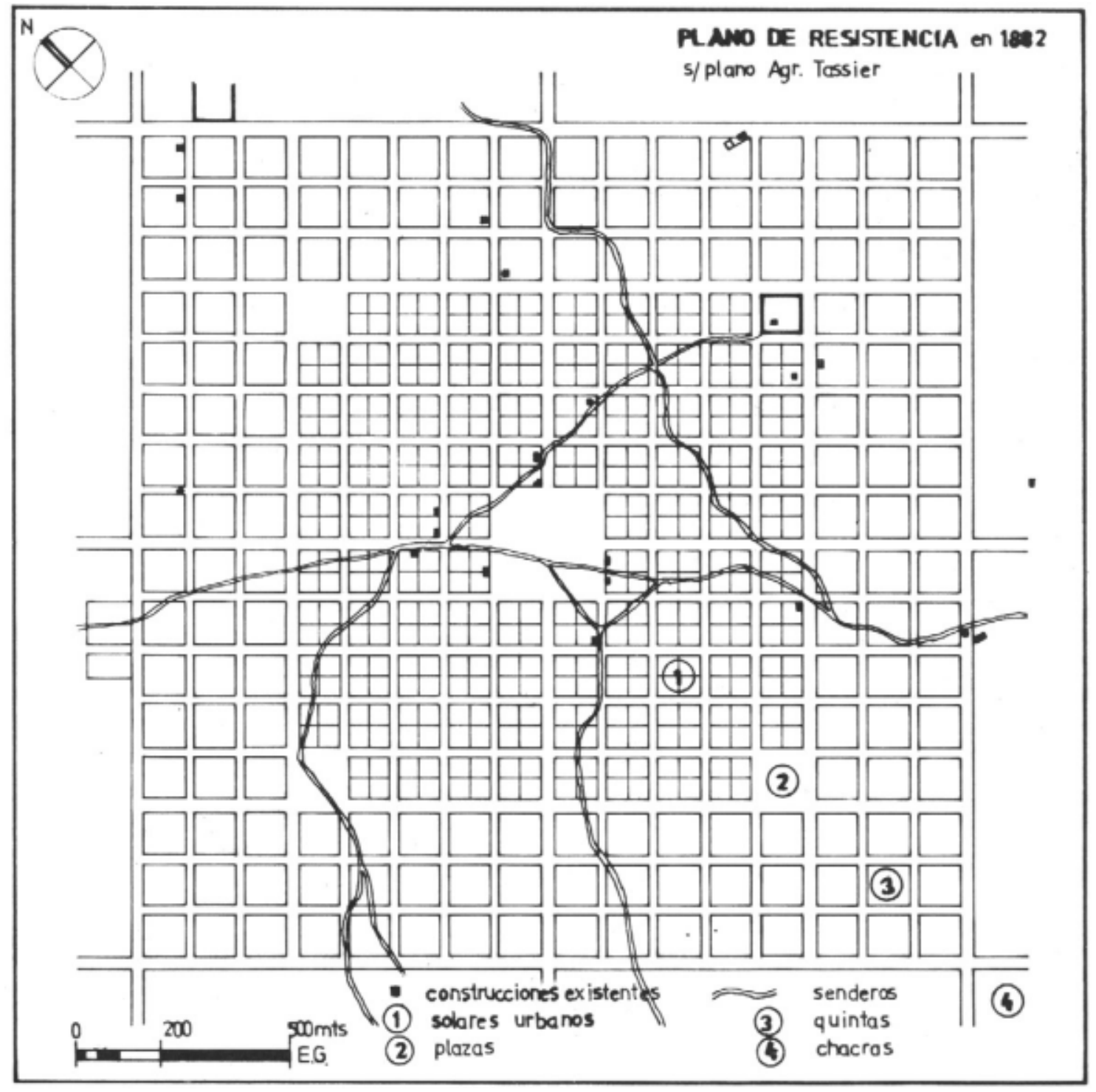

Figura 45 - Colônia em Resistencia, província do Chaco, Argentina.

Fonte: GUTIERREZ, Ramón. Arquitectura y Urbanismo en Iberoamérica. Madrid, Cátedra, 1983. 
precios muy bajos, a los que ya entonces eran grandes propietarios. El mismo carácter militar de la ocupación evitó que pequeños colonos se apropiaran de ella, como hubiera ocurrido en el caso de una frontera abierta, creando una amplia clase de pequeños y medianos propietarios."

Não é diferente o caso do Brasil. A partir de 1822 é suspenso o antigo regime de concessão de terras, o das sesmarias, sem a instauração de outro regime até a lei de Terras, promulgada em 1850 e regulamentada em 1854. Nesse espaço de tempo as terras foram simplesmente ocupadas, origem de muitos dos conflitos sobre a posse de terras até hoje. A partir da Lei de Terras, a apropriação se faz pela compra e venda, e não mais pela concessão do Estado. Passa a ter valor de mercadoria. Na prática significou a concentração de terras em poucas mãos, processo que se deu principalmente no período compreendido entre 1822 e 1850, quando as terras foram ocupadas principalmente por aqueles que já as possuíam e tinham melhores condições de fazê-lo. Somente em 1917 será aprovado o Código Civil, após décadas de indefinição legal que levaram à complexa situação atual da questão de terras no Brasil

Resumindo, do ponto de vista da ocupação regional, há um processo de concentração populacional em cidades situadas no litoral, que em geral passam a ser muito maiores que as demais cidades do país. Estão equipadas com infra-estrutura portuária, e é para estes portos que as linhas de transporte convergem. No interior, são realizadas tentativas de implantação de colônias, mas a maioria da população imigrante acaba por se instalar nas grandes cidades, inclusive porque antes de sua chegada a maior parte das terras já havia sido comprada por alguns poucos proprietários.

\section{$3.5-$ CONCLUSÕES}

É possível tirar algumas conclusões a partir do estudo da relação entre a rede urbana européia e a latino-americana.

Do ponto de vista populacional, vimos que há uma enorme diferença quantitativa entre ambos continentes. Isto significa que na Europa daquela época deveria existir uma organização social, relacionada a uma rede urbana relativamente densa, de tal forma que fosse possível garantir alimento a todos ou pelo menos a uma boa parte da população. Este alimento provinha dos próprios campos europeus, como também, já desde os tempos coloniais, da própria América.

Esta relação assimétrica está refletida no espaço regional latinoamericano. Os dados mostram a construção de uma rede de transportes convergindo para as cidades-porto, as quais servirão de ponto de apoio a um sistema que funcionava em mão dupla: em uma direção, matérias-primas e na outra, manufaturas. Além disso, estas cidades passam a ter uma enorme preponderância sobre os demais núcleos urbanos da rede regional.

Outra relação importante entre ambos continentes são as migrações. Estas tiveram um papel importante tanto na formação urbana da América Latina, pela 
quantidade de pessoas que para cá vieram, e que contribuíram significativamente para o crescimento das cidades, como na Europa, porque aliviaram o sistema urbano europeu. Como já dissemos anteriormente se estes milhões de pessoas não tivessem migrado a história das cidades na Europa teria sido muito diferente, tanto em termos quantitativos como também devido ao fato de que enquanto alguns países são a origem de grandes contingentes de imigrantes, outros pouco aportaram, e provavelmente seriam o destino daqueles.

Porém, também é importante assinalar que, embora significativo em ambos continentes (afinal foram mais de 53 milhões de pessoas entre 1846 e 1932), esse impacto é desigual, devido ao fato da população na Europa ser muito maior do que a da América Latina.

Entretanto, se olhado este processo do ponto de vista das condições de vida nas cidades européias, verificamos que além de variarem muito de um ponto para outro, não são particularmente diferentes das condições existentes em São Paulo e Buenos Aires, nas últimas décadas do século XIX e início do XX. Pelo contrário, algumas vezes, as condições aqui são melhores. Isto se deve a que o período que estudamos, na Europa, ainda é um período de transformações que somente se consolidará a partir da década de 1910. Na prática, não é possível generalizar o urbanismo europeu em seus diferentes aspectos, já que é extremamente variado.

Isto evidencia que o processo de consolidação das cidades européias não é necessariamente coincidente com o processo econômico, referente à nova divisão internacional do trabalho. Na prática, este último raciocínio tem uma característica linear e dicotômica que permite, em princípio, explicar os fenômenos macro. Não é suficiente, entretanto, para explicar diversos aspectos da urbanização em um período de mudanças muito intensas e rápidas, o que significa que o estudo da arquitetura e do urbanismo exige uma abordagem que leve em conta outros determinantes. Não se deve esquecer também de considerar as especificidades, ou seja, as particularidades que distinguem uma sociedade da outra. 
CAPÍTULO 4

INTERVENÇÕES NAS

ÁREAS CENTRAIS 


\section{$4.1-$ INTRODUÇÃO}

Uma das principais características do período que estudamos é a proposta e realização (em geral parcial) de planos de transformação de cidades latinoamericanas, a exemplo do processo de reformas que se havia iniciado anteriormente em cidades européias. Estes planos podem abranger toda a aglomeração urbana (um ou mais municípios) ou podem ser parciais, restritos a apenas uma parte da cidade, geralmente a área central.

Trata-se de um tema bastante estudado na bibliografia existente, inclusive pela disponibilidade de um amplo material, resultado da grande divulgação que estes projetos tiveram. Por este motivo, neste capítulo daremos ênfase principalmente à análise comparada destes projetos, sem entrar em muitos detalhes sobre as intervenções realizadas em São Paulo e Buenos Aires, sobre as quais já existe uma ampla bibliografia. ${ }^{1} \mathrm{O}$ objetivo principal é verificar a validade de alguns conceitos teóricos que vimos utilizando. ${ }^{2}$

\section{2 - EM SÃO PAULO}

Há notícias de que, já em 1863, o vereador João Mendes de Almeida apresenta à Câmara uma indicação visando a criação de uma comissão para

\footnotetext{
${ }^{1}$ Por exemplo, sobre São Paulo: ANDRADE, Carlos Roberto Monteiro. A peste e o plano: o urbanismo sanitarista do engenheiro Saturnino de Brito. Dissertação de Mestrado. 2v. São Paulo, FAUUSP, 1992; CAMPOS, Candido Malta. Os rumos da cidade. Urbanismo e modernização em São Paulo. São Paulo, Senac, 2002. LEME, Maria Cristina da Silva. Revisão do Plano de Avenidas: um Estudo de Planejamento Urbano, 1930. Tese de Doutoramento São Paulo, Fauusp, 1990; OSELLO, Marco Antonio. Planejamento urbano em São Paulo (1899-1961): introdução ao estudo dos plano e realizações. Dissertação de Mestrado. São Paulo, EAESP/FGV, 1983; OTTONI, Dácio Araújo Benedicto. São Paulo Rio de Janeiro. Séculos XIX-XX. Aspectos da formação dos seus espaços centrais. Tese de Doutoramento. São Paulo, FAU/USP, 1972; MEYER, Regina Maria Prosperi. Metrópole e urbanismo: São Paulo anos 50. Tese de Doutoramento. São Paulo, Fauusp, 1991; REIS FILHO, Nestor Goulart. Algumas experiências urbanísticas no início da República: 1890-1920. Cadernos do LAP 1. São Paulo, Fauusp, 1994; SEGAWA, Hugo. Prelúdio da Metrópole. Arquitetura e urbanismo em São Paulo na passagem do século XIX ao XX. São Paulo, Ateliê Editorial, 2000; SIMÕES JUNIOR, José Geraldo. O Setor de Obras Públicas e as Origens do Urbanismo na Cidade de São Paulo. Dissertação de Mestrado. São Paulo, Fundação Getúlio Vargas, 1990; TOLEDO, Benedito Lima de. Prestes Maia e as origens do urbanismo moderno em São Paulo. São Paulo, Empresa das Artes, 1996; Sobre Buenos Aires: GUTIERREZ, Ramón. Buenos Aires. Evolución Histórica. Buenos Aires. Editorial Escala, 1990; GUTMAN, Margarita; HARDOY, Jorge Enrique. Buenos Aires. Coleção Ciudades de Iberoamérica. Madrid, MAPFRE, 1992; GUTMAN, Margarita (ed.). Buenos Aires 1910: memoria del porvenir. Buenos Aires, Gobierno de la Ciudad de Buenos Aires/ Faculdade de Arquitetura, Design e Urbanismo da Universidade de Buenos Aires/ IIED-America Latina, 1999; ROMERO, José Luis; ROMERO, Luis Alberto (org.). Buenos Aires. Historia de cuatro siglos. 2 v. Buenos Aires, Abril, 1983; SCOBIE, James R. Buenos Aires. Del centro a los barrios. 1870-1910. Buenos Aires, Solar/Hachette, 1977; TARANTINI, Jorge. El plan Bouvard para Buenos Aires (1907-1911). Algunos antecedentes. Buenos Aires, Anales del IAAIE "Mario J. Buschiazzo" № 27-28, 1889-1991; VAZQUEZ RIAL, Horácio (org.). Buenos Aires 1880-1930. La capital de un império imaginário. Madrid, Alianza, 1996. ${ }^{2}$ Este capítulo está baseado parcialmente em trabalho nosso anterior: MEDRANO, Ricardo Hernán. Arquitetura e urbanismo em São Paulo e Buenos Aires na virada do século XIX: algumas considerações preliminares. In: MACHADO, Denise Pinheiro (org.). Anais do IV Seminário de História da Cidade e do Urbanismo. Rio de Janeiro, UFRJ/Prourb, 1996.
} 
organizar um "Plano Geral de Melhoramentos", com o objetivo principalmente de enfrentar os problemas causados pelas inundações do Tamanduateí, e também para melhoria de algumas vias, cujo péssimo calçamento impedia a circulação de um incipiente trânsito. Embora sem resultados práticos, trata-se de uma das primeiras tentativas de abordar dois pontos que serão recorrentes em diversas propostas posteriores: a questão do Tamanduateí e a melhoria da rede viária.

Durante a gestão de João Theodoro Xavier de Matos (1872-1875) foram realizadas diversas obras nesse sentido, incluindo já algumas na outra margem do Anhangabaú, do lado oposto do "triângulo", nome pelo qual é conhecido o núcleo urbano da época colonial. ${ }^{3}$

Também na gestão de João Alfredo Correa de Oliveira são realizadas algumas obras, e é interessante notar como já em 1886 é proposta uma via circular em torno do centro, fazendo a ligação Ipiranga-Brás-Luz-Ponte Grande.

Em 1897, o intendente de obras Pedro Augusto Gomes Cardim elaborou uma "Planta Geral da Cidade", que contêm, além do sistema viário já existente, algumas propostas entre as quais a realização de uma avenida circular. Esta visava integrar os bairros mais distantes, como Campos Elíseos, Paraíso e avenida Paulista, às estações ferroviárias, sem necessidade de passar pelo centro. O percurso previsto era: avenida Angélica-avenida Paulista-rua do Paraíso-estrada do Vergueiro (figura 46).

No início do século $X X$ são iniciadas as obras de reforma do centro, na gestão de Antonio Prado, com a demolição da igreja do Rosário, em 1903, e no ano seguinte com a abertura da atual praça Antonio Prado.

Com a ocupação da margem esquerda do Anhangabaú e com a construção do Teatro Municipal (1903-1911) há a necessidade de se realizar obras visando melhorar o aspecto do vale, já que este local era ocupado até aquele momento por plantações e percorrido por um infecto ribeirão. Era necessário, portanto, transpô-lo e também "embelezá-lo".

Surge assim, em 1906, uma proposta do vereador Augusto da Silva Telles, a qual previa basicamente melhorias na rua Anhangabaú, e o controle das fachadas, procurando evitar que as construções dessem as costas para o vale.

Esta idéia inicial será melhor desenvolvida pela Diretoria de Obras Municipais, que apresenta um plano em 1910, no final da gestão de Antonio da Silva Prado, plano conhecido pelo nome de Freire-Guilhem. Este projeto previa intervenções em vários pontos da cidade, mas a principal preocupação refere-se ao vale (figura 47). A polêmica se estabelece ao proporem os autores a demolição de todo o lado ímpar da rua Líbero Badaró, para a construção de jardins em sua encosta, formando um parque nesse trecho do vale, já que a outra margem, junto ao teatro Municipal, já contava com esse tipo de tratamento. ${ }^{4}$

\footnotetext{
${ }^{3}$ Sobre este período ver: FRANCO, Herta. Modernização e melhoramentos urbanos em São Paulo: a gestão do presidente de província João Theodoro (1872-1875). Tese de Doutorado. São Paulo, FAUUSP, 2002.

${ }^{4}$ SIMÕES JUNIOR, José Geraldo. Anhangabaú - História e Urbanismo. Tese de Doutorado. São Paulo, FAUUSP, 1995.
} 


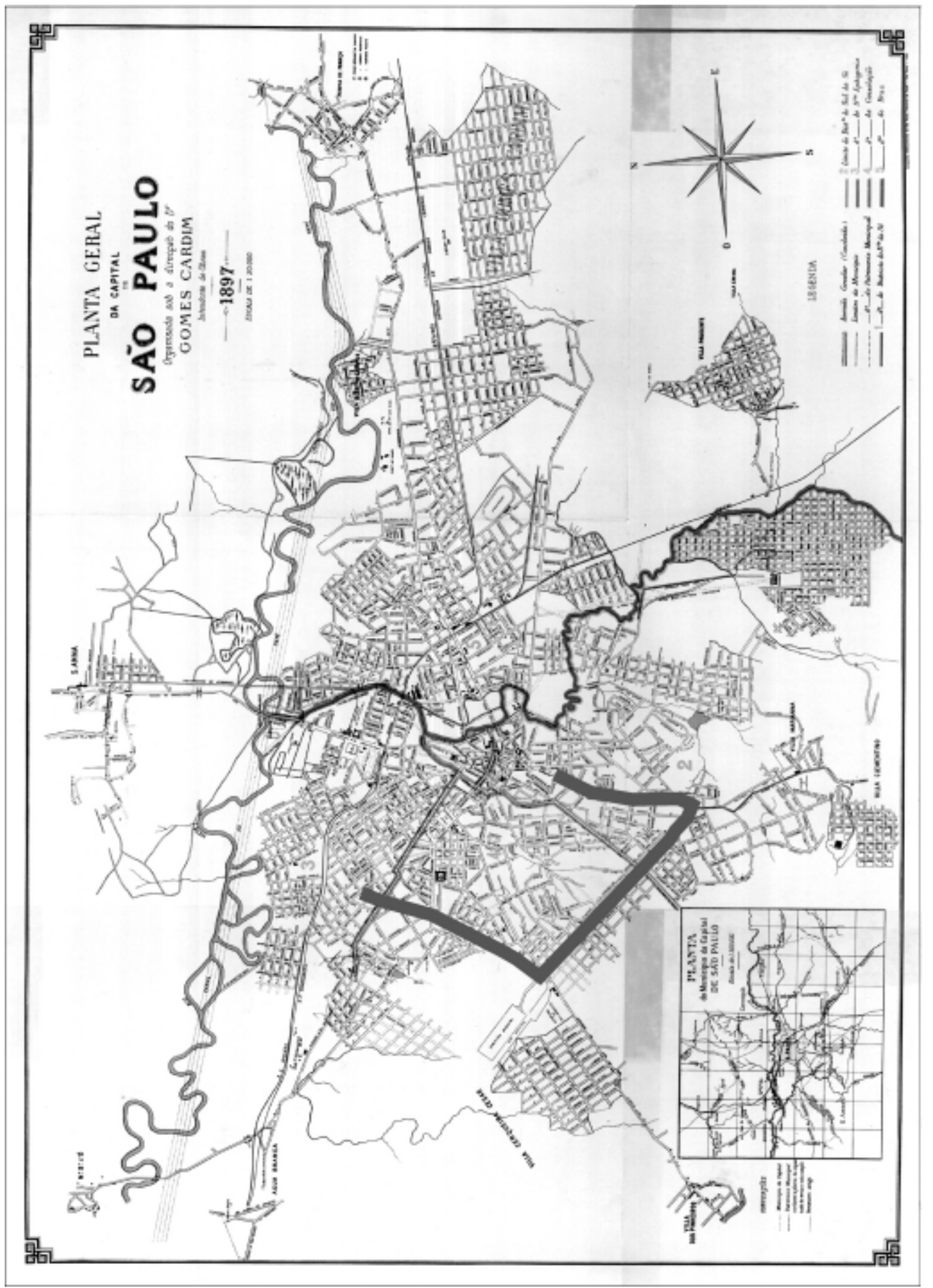

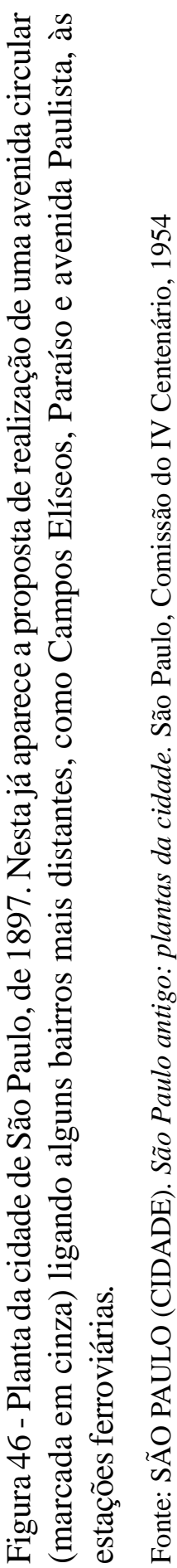




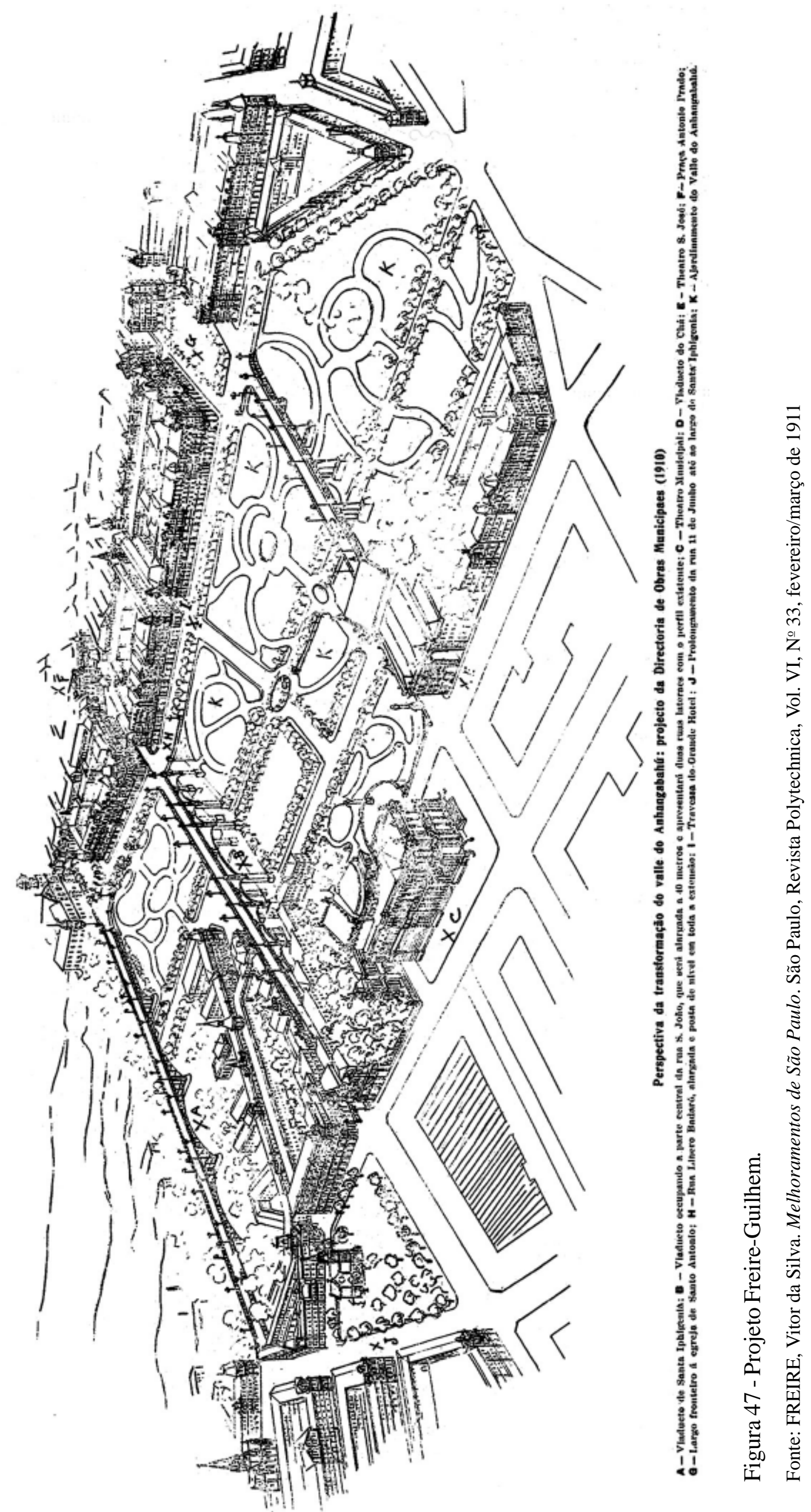


Ao mesmo tempo, o executivo estadual apresenta um outro projeto, de autoria de Samuel das Neves, que aparentemente defendia os interesses do sr. Conde de Prates, proprietário da maioria dos terrenos desapropriados, e que prevê construções em toda essa margem.

Para resolver o impasse, são contratados os serviços do arquiteto francês Bouvard, que estava de passagem pelo Brasil após realizar um projeto para Buenos Aires. Este realiza uma proposta conciliatória, prevendo tanto jardins como dois grandes blocos, projetados por Samuel das Neves, que foi executada quase que integralmente na gestão de Raymundo Duprat (1911-1914). Além do Anhangabaú, fez ainda alguns outros projetos, como um parque na várzea do Tamanduateí (atual parque D. Pedro II) e a remodelação da praça da Sé (figura 48).

Nos anos seguintes seriam executadas várias das propostas contidas no plano da Diretoria de Obras (figura 49). ${ }^{5}$

Nessa mesma época (1910), surge um projeto para construir três "largas e extensas avenidas", de autoria de Alexandre de Albuquerque, na qual uma série de capitalistas (entre os quais Ramos de Azevedo) se propõem construir tais avenidas, pedindo em contrapartida garantias de juros e direitos de desapropriação. Estas três grandes avenidas se cruzariam em uma grande praça, onde futuramente seria erigido um "magestoso monumento allusivo à cidade de S. Paulo" (figura 50). A inspiração nas reformas efetuadas em Paris é evidente.

Em 1924, Ulhôa Cintra propõe um "perímetro de irradiação", nos moldes do "ring" de Viena. Consistia na conexão de diversas vias, formando um anel em volta do centro, com o objetivo de resolver o problema de circulação nessa região (figura 51).

Este conceito será logo depois retomado por Prestes Maia, em seu "Plano de Avenidas", apresentado em 1930. Este projeto, de grande abrangência, consistia na realização de inúmeras obras visando uma ampla estruturação do sistema viário, para adequá-lo ao crescente trânsito. Previa, de forma simplificada, três grandes anéis articulados com algumas avenidas radiais principais, e uma série de outras vias organizadas hierarquicamente em função do fluxo. Este plano era abrangente a ponto de incluir o rio Tietê e as estações ferroviárias. Este projeto, que teve uma parte executada nos anos seguintes, ainda hoje é a base do sistema de circulação da área central.

Como é possível observar, as propostas de ligações circulares são um tema muito frequente em São Paulo. Podemos citar mais alguns exemplos, como a proposta de uma ligação ferroviária circular, realizada em 1898 por Benedito Galvão de Moura Lacerda. Ou ainda o projeto da "Metropolitana", de Felipe Gonçalves (1906), que propunha um transporte ferroviário alternativo ao dos bondes da Light, já que seria bem mais barato. Seu traçado era circular, e previa inclusive um pequeno trecho subterrâneo.

\footnotetext{
${ }^{5}$ Como o alargamento da Rua São João, transformada em avenida, em continuação à Praça Antonio Prado; o alargamento da Rua Líbero Badaró, em uma das faces do Vale do Anhangabaú; o prolongamento da Rua Boa Vista até o Páteo do Colégio, com a construção de um viaduto, mais tarde denominado Boa Vista; a abertura da atual Praça do Patriarca e o prolongamento da Avenida Brigadeiro Luís Antonio, em direção à Rua José Bonifácio (atual Rua Senador Paulo Egidio) e à Rua Direita (trecho jamais executado). REIS FILHO, Nestor Goulart. Op. Cit., p. 43.
} 

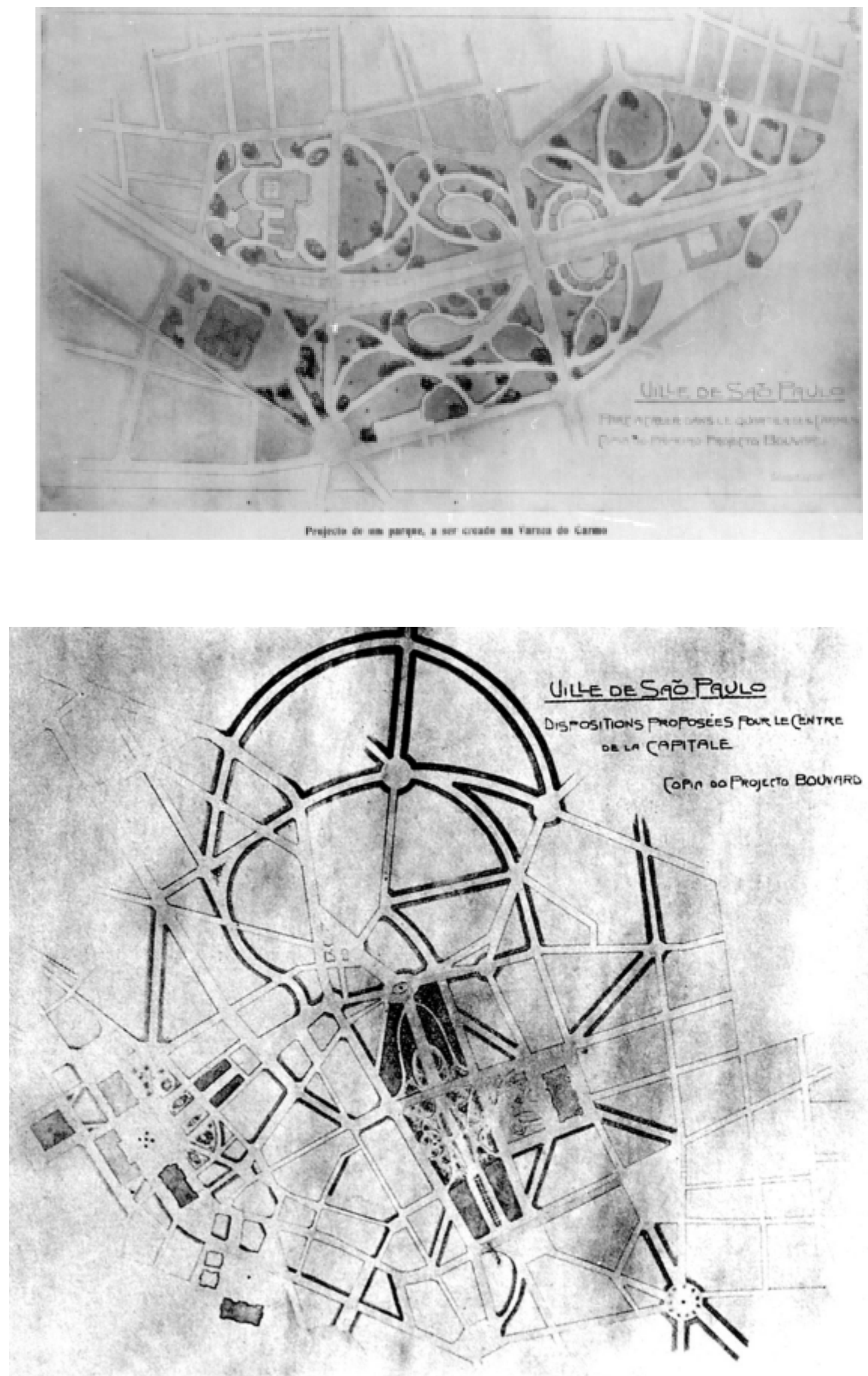

Figura 48 - Propostas de Bouvard para São Paulo. Várzea do Tamanduateí e área central.

Fonte: REIS FILHO, Nestor Goulart. Cadernos do LAP 1. Algumas experiências urbanísticas no início da República: 1890-1920. São Paulo, FAUUSP, 1994. 

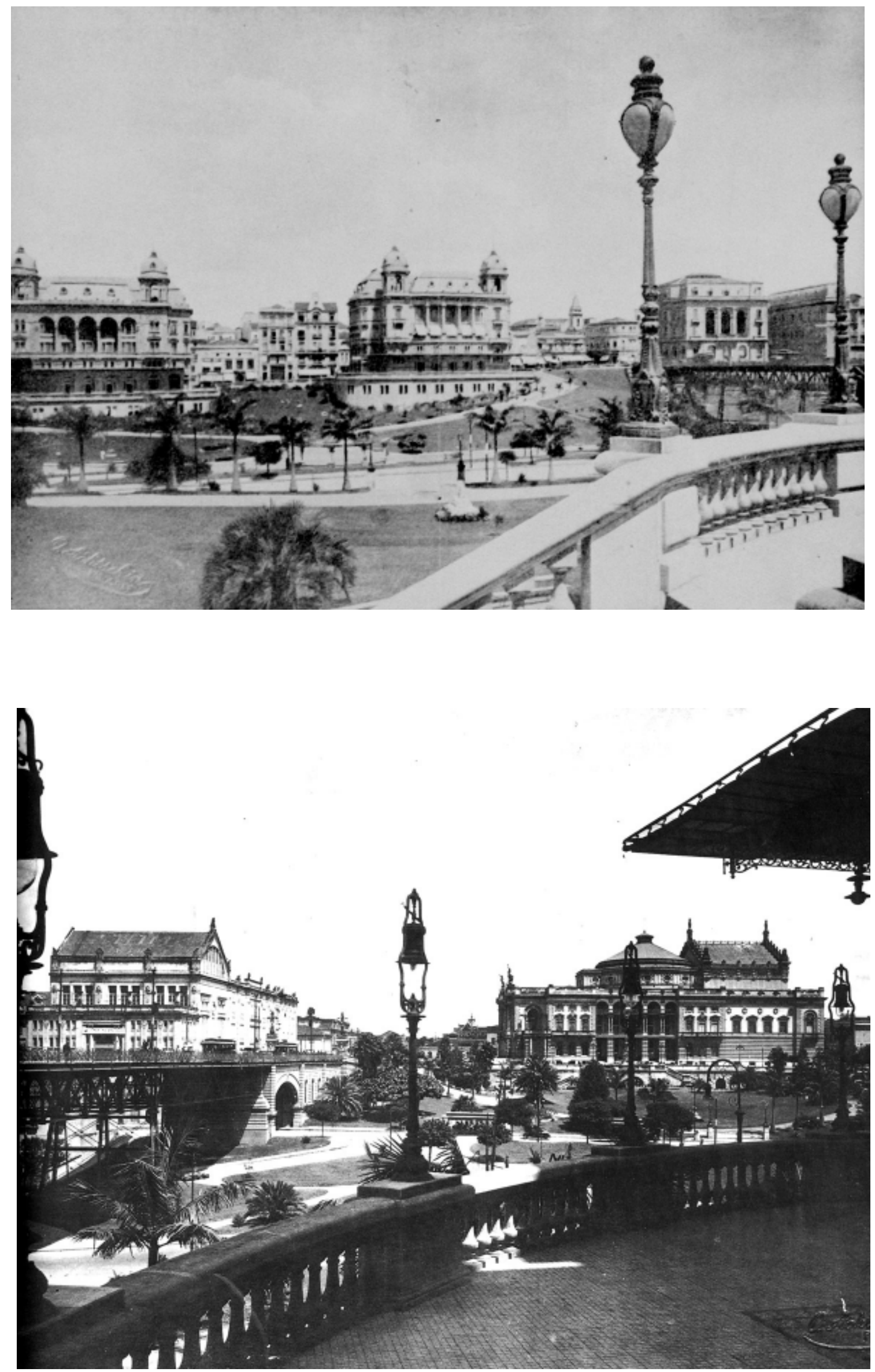

Figura 49 - O vale do Anhangabaú depois de finalizado.

Fontes: (1) Acervo LAP (2) ELETROPAULO. A Cidade da Ligth. 1899/1930. Departamento de Patrimônio Histórico/Eletropaulo, 1990 


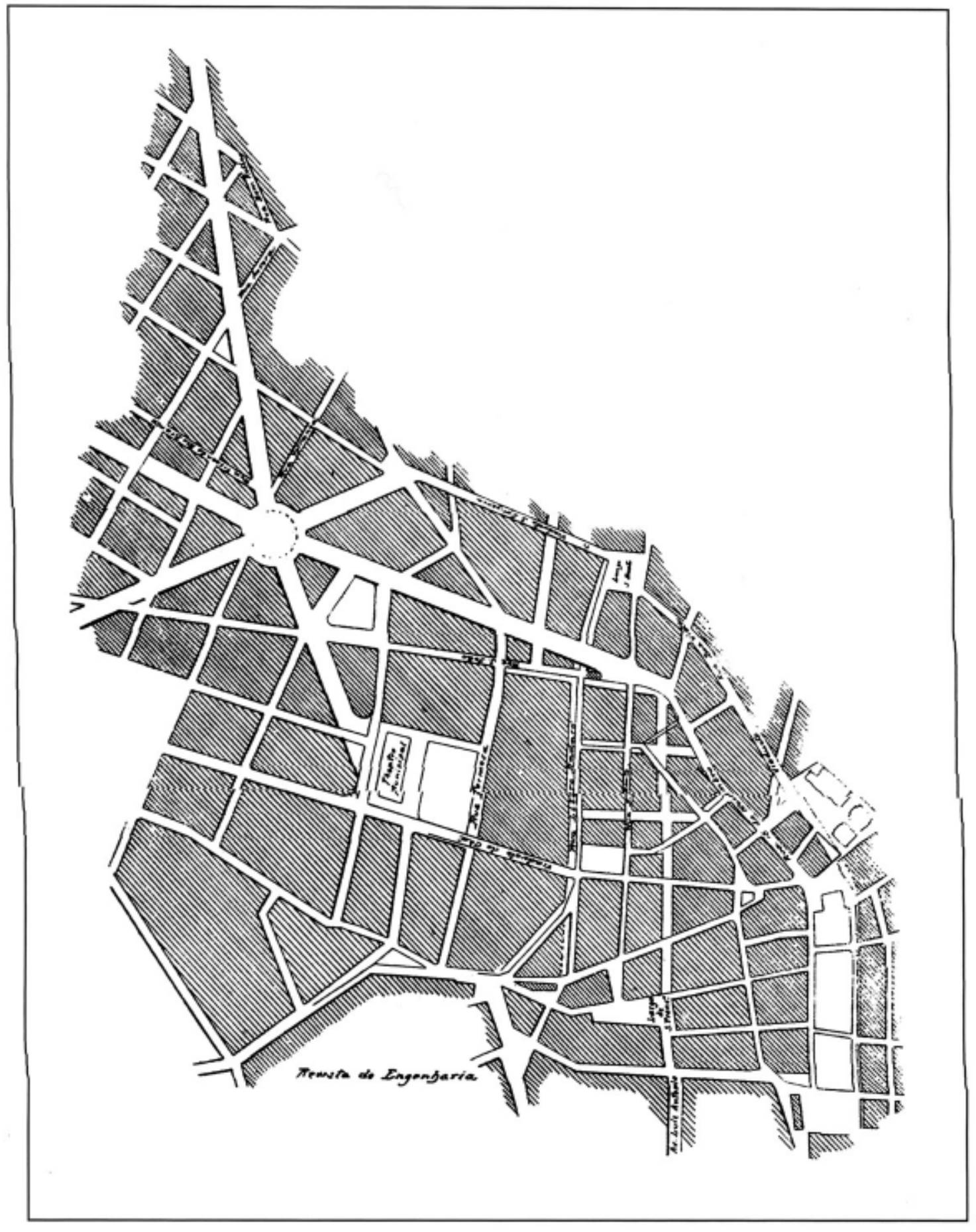

Figura 50 - Proposta de Alexandre de Albuquerque.

Fonte: REVISTA DE ENGENHARIA. Os Melhoramentos de São Paulo. São Paulo, Revista de Engenharia, Vol. 1, № 2, 10 de julho de 1911 


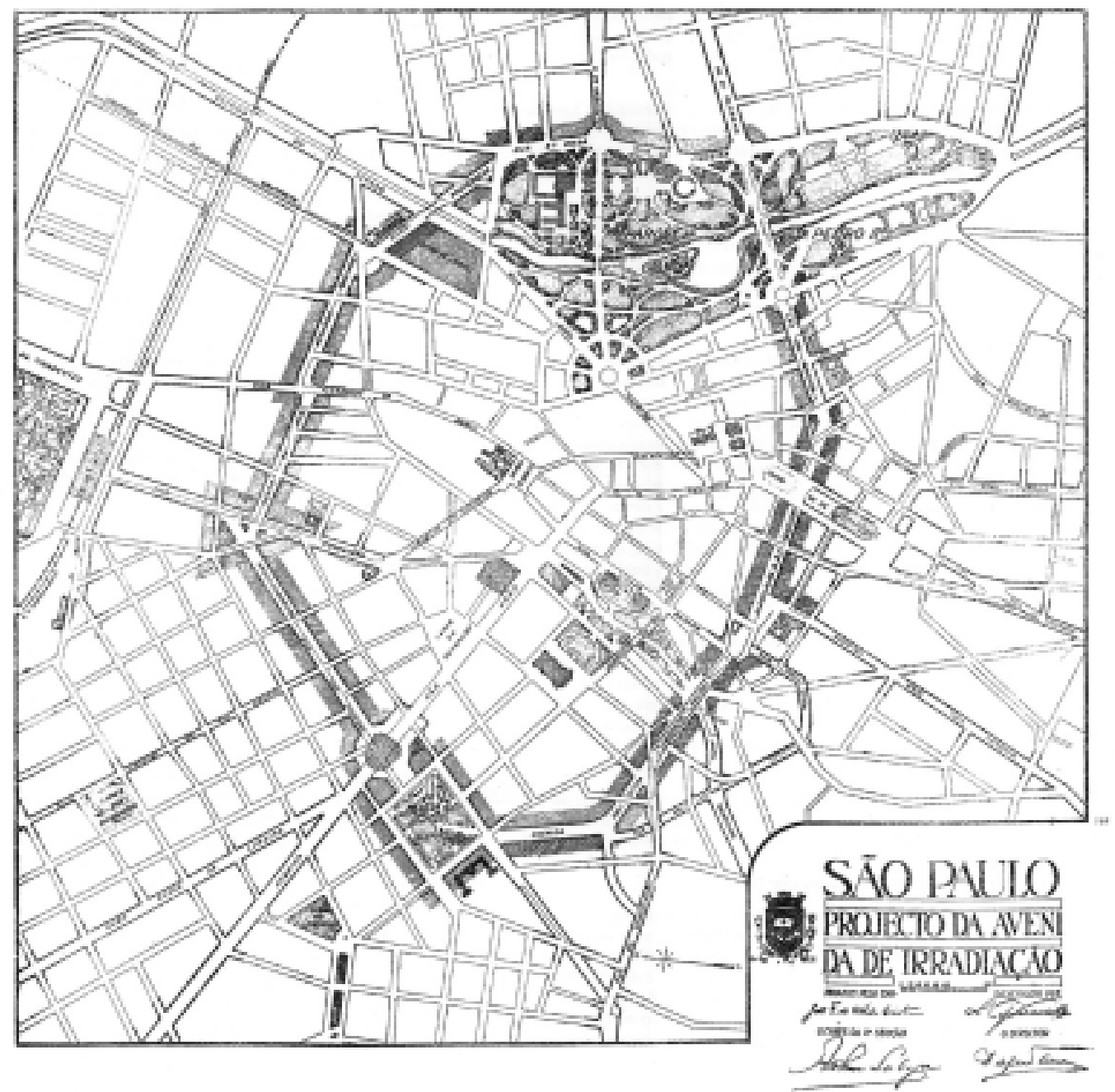

Figura 51 - Proposta de Ulhôa Cintra para criaçao de um perímetro de irradiação em torno da área central, apresentado em 1924.

Fonte: MAIA, Francisco Prestes; CINTRA, João Florense de Ulhôa. Os grandes melhoramentos de São Paulo. Boletim do Instituto de Engenharia. São Paulo, № 29, julho a outubro de 1925. Pág. 192.

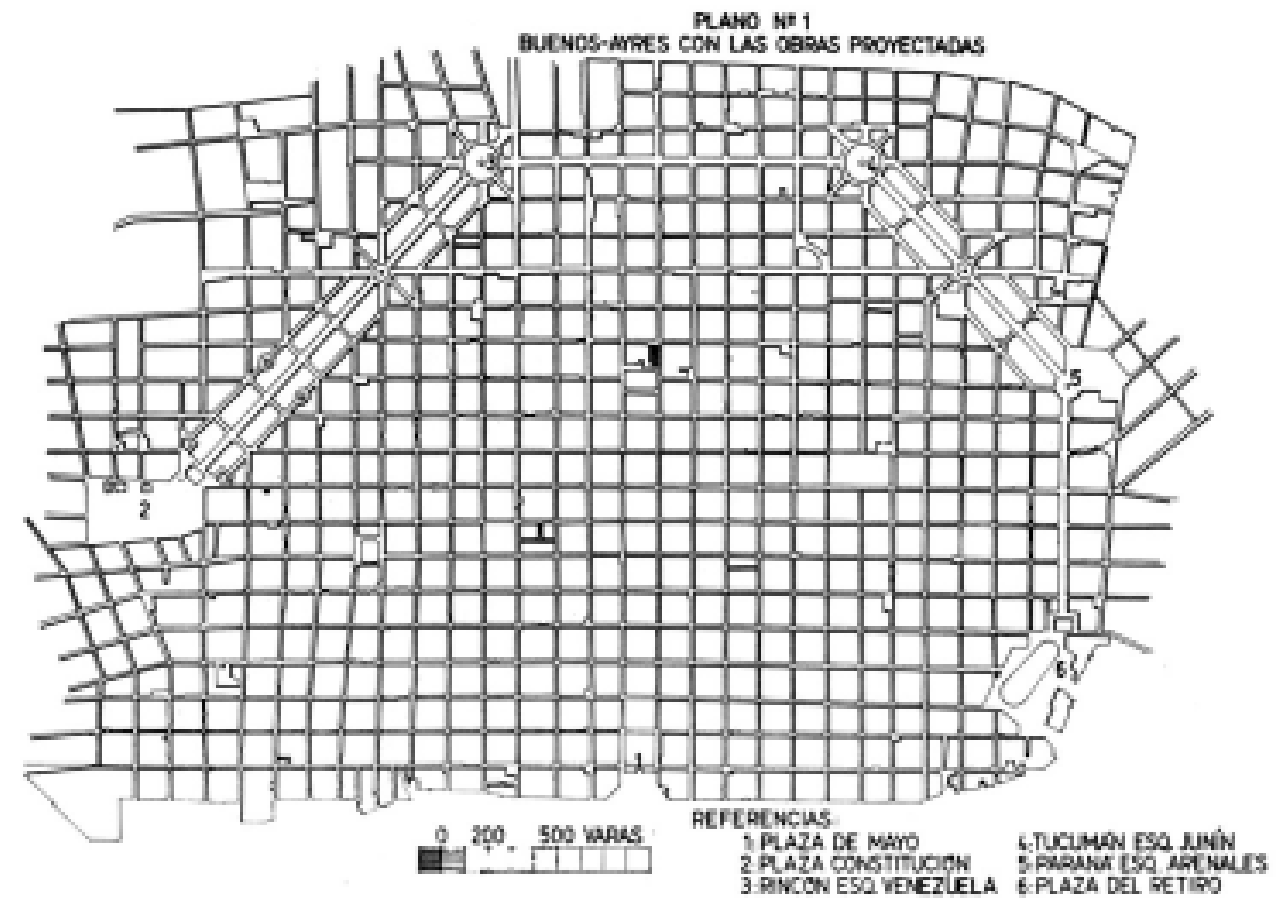

Figura 52 - Plano para Buenos Aires de Felipe Senillosa, apresentado em 1875. Pode-se notar os dois “sistemas de diagonais” propostos, saindo de Retiro e Constitución.

Fonte: PAULA, Alberto S. J. de. Una modificación del diseño urbano porteño proyectada en 1875. Buenos Aires, Anales del IAAIE “Mário J. Buschiazzo” №19, 1966. P. 71-77. 


\section{3 - EM BUENOS AIRES}

No caso de Buenos Aires, temos já em 1827 uma proposta de um avenida de contorno e mais sete avenidas de conexão com a pampa, feita por Rivadavia.

Em 1869, José M. Lagos apresenta uma proposta que consta também de uma avenida de contorno, duas avenidas de 139 metros de largura, nas direções norte-sul e leste-oeste, cruzando-se em uma grande praça circular, e 4 diagonais de 30 metros de largura.

Carlo Carranza e Daniel Solier apresentam em 1872 uma proposta de construção de uma avenida de 40 metros de largura, entre a Plaza de Mayo e o limite oeste do antigo município (ou seja, posicionada aproximadamente na mesma linha da atual avenida de Mayo), além de avenidas ligando alguns pontos da então cidade com povoações próximas (Belgrano, Flores, Barracas).

Em 1875 é apresentada a proposta de Felipe Senillosa, que previa uma avenida poligonal, formada por duas diagonais unidas por uma avenida na direção norte-sul, coincidente com a quadrícula existente. Na figura 52 podemos observar que há dois "sistemas de diagonais", já que em ambos os lados das duas principais (com 32 varas de largura e passeios de 7 varas) há avenidas de 18 varas de largura.

Provavelmente o projeto mais importante na época foi o proposto durante a intendência do Dr. Crespo, que foi publicado como plano oficial do município em 1887.

Mas algumas das grandes intervenções realmente executadas em Buenos Aires se darão durante a administração de Torquato de Alvear, em cuja gestão (18801887) saíram os projetos de remodelação da Plaza de Mayo (1884)(figura 53), a avenida de Mayo (1889-1894)(figura 54), e o traçado dos parques de Palermo e Recoleta.

As propostas para novas reformas continuaram sendo frequentemente apresentadas, ${ }^{6}$ e consequentemente as discussões em torno destas, até que em 1907, o intendente Carlos de Alvear decide contratar Bouvard para realizar um plano para a cidade. Este, após uma breve visita à cidade, retorna à França, de onde volta em 1909 para apresentar o projeto final, que consiste na construção de 32 avenidas e mais de 100 rond-points, parques e praças, seguindo, em teoria, os passos de Haussmann (figura 55).

Um dos principais opositores ao projeto de Bouvard é Jaeschke, que em 1898 forma a Comisión Pro-avenidas Diagonales. Em diversos artigos, reunidos em 1912 em sua obra "Las Avenidas", critica a abertura de avenidas paralelas à quadrícula e propõe a realização de inúmeras diagonais, buscando inspiração também nas idéias de Camillo Sitte.

\footnotetext{
${ }^{6}$ Entre outras a proposta de uma avenida Norte-Sul do Dr. Eugenio Badaró (1905); a do engenheiro Enrique Chardounie (1906); o de Varela; o de Ocantos-Bemberg-Coelho; o de Justo; o de Desplasts; o de Láinez; etc.
} 


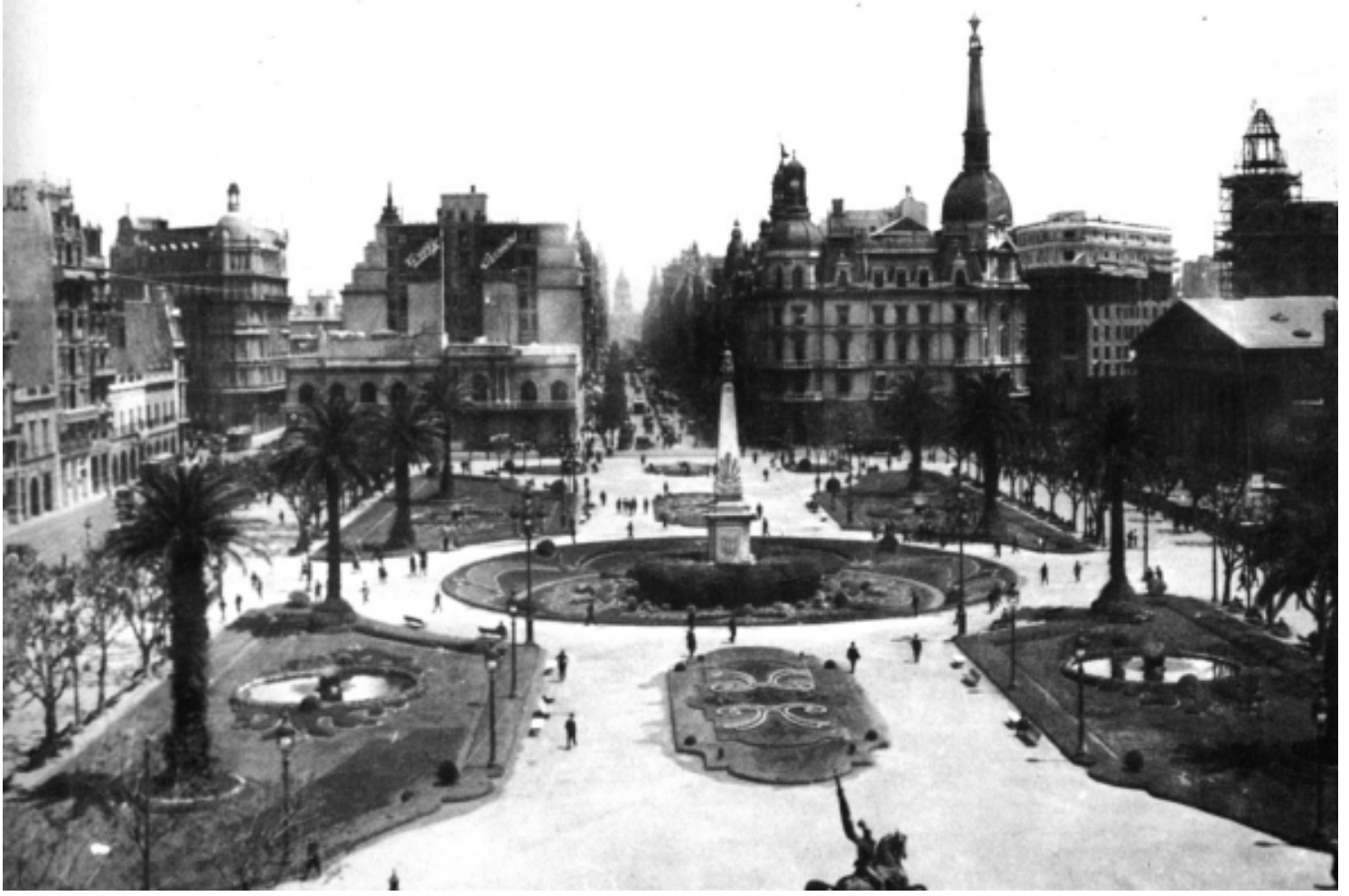

Figura 53 - Praça de Mayo

Fonte: GUTIERREZ, Ramón. Buenos Aires. Evolución Histórica. Buenos Aires, Editorial Escala, 1990

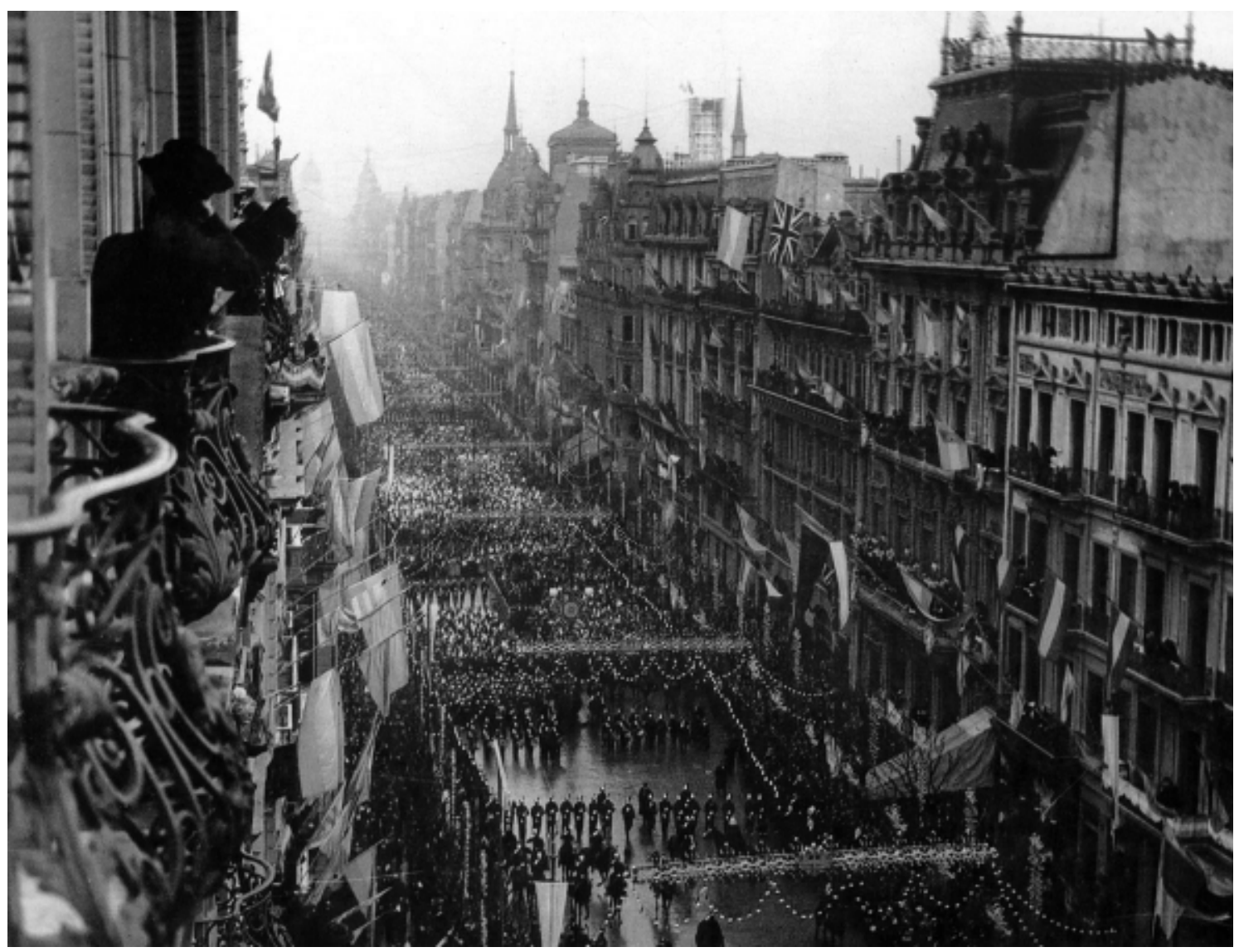

Figura 54 - Avenida de Mayo, nas comemorações do Centenário, em 1910

Fonte: GUTMAN, Margarita (ed.). Buenos Aires 1910: memoria del porvenir. Buenos Aires, Gobierno de la Ciudad de Buenos Aires/ Faculdade de Arquitetura, Design e Urbanismo da Universidade de Buenos Aires/ IIED-America Latina, 1999 


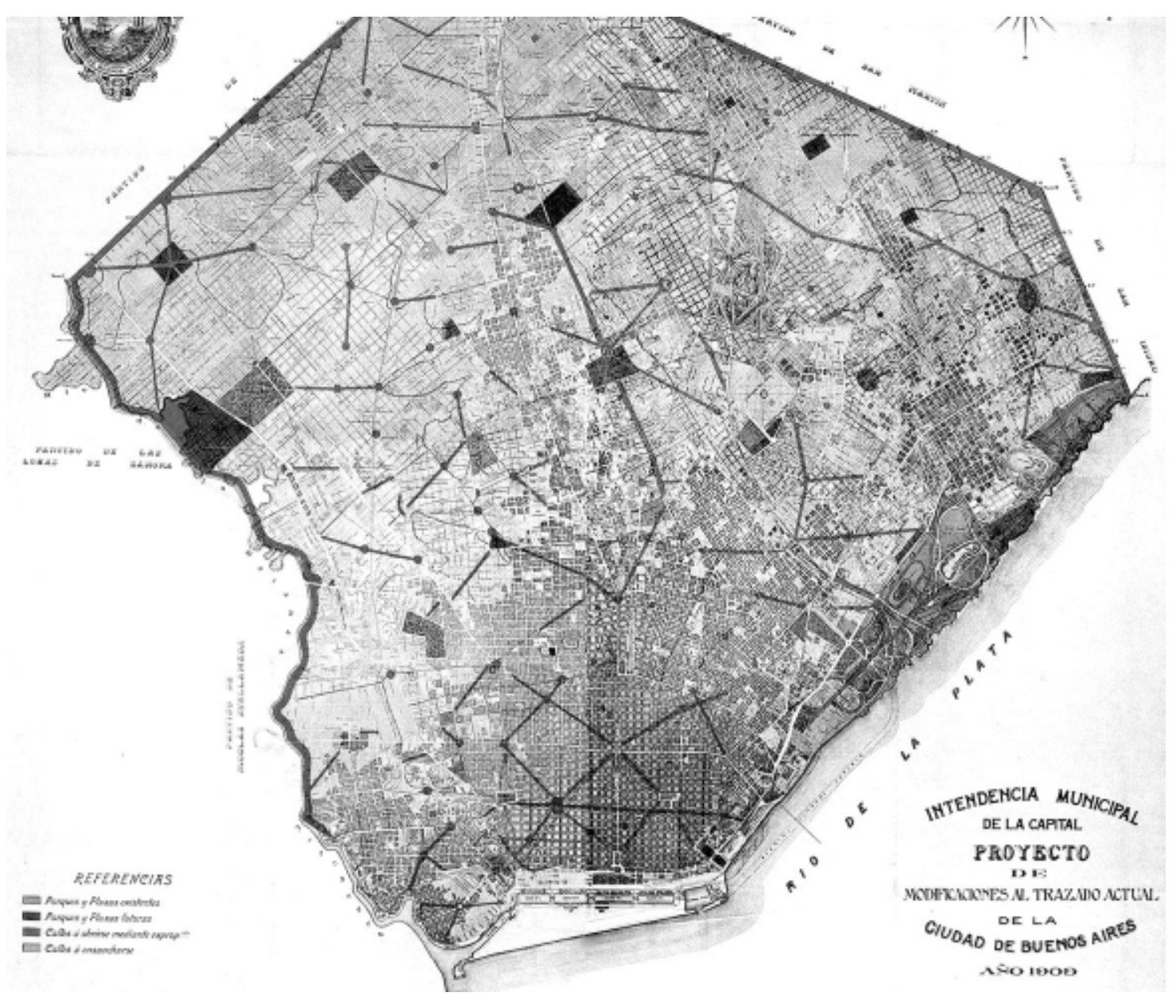

Figura 55 - Plano de Buenos Aires, com as intervenções propostas no projeto de Bouvard

Fonte: GUTMAN, Margarita (ed.). Buenos Aires 1910: memoria del porvenir. Buenos Aires, Gobierno de la Ciudad de Buenos Aires/ Faculdade de Arquitetura, Design e Urbanismo da Universidade de Buenos Aires/ IIED-America Latina, 1999 
A este propósito, houve em Buenos Aires uma polarização entre os partidários das avenidas paralelas ao traçado existente (como o projeto da avenida Norte-sul do dr. Eugenio Badaro, de 1905), e os partidários das diagonais, como Jaeschke e Chanourdie.

Dessas discussões resultou a aprovação, em 1912, da construção das diagonais Norte e Sul (a primeira terminada em 1940, e a segunda inacabada), e da avenida Norte-sul, esta somente iniciada em 1936 e finalizada na década de 1980 (atual 9 de Julio) (figuras 56 e 57)

\section{4 - EM OUTRAS CIDADES LATINO- AMERICANAS}

Este tipo de intervenção não ocorreu somente em São Paulo e Buenos Aires, mas também foi recorrente em numerosas outras cidades latino-americanas, como veremos a seguir.

No caso de Santiago do Chile, as primeiras propostas para modificar a estrutura interna da cidade foram realizadas durante a gestão do intendente Benjamín Vicuña Mackenna, no período de 1872 a 1875. O plano previa entre outros a construção de uma via de contorno da cidade, pavimentação e abertura de novas ruas e avenidas, e criação e arborização de praças e parques. Neste aspecto destaca-se o passeio Santa Lucía, situado no centro da cidade.

Estas transformações foram as mais importantes efetivamente realizadas em Santiago até perto dos anos 1930, embora não tenham faltado nesse período outras propostas, em especial as realizadas em 1894, 1912, 1913 e 1915. Nestas propostas são reiteradas várias idéias básicas de planos propostos e/ou executados em vários países latino-americanos, como as diagonais, a ampliação de vias, a abertura de largas avenidas na região central e a construção de avenidas de contorno (figura 58). Deve-se notar, entretanto, que as primeiras diagonais somente serão construídas a partir da década de 1950, e o anel de contorno em $1960 .^{7}$

Não é diferente o caso de Montevidéu. Em 1887 é apresentado o projeto do arquiteto Norberto Maillart, que consistia, entre outros elementos, em uma avenida de pelo menos 25 metros de largura saindo de frente do palácio, e abertura de uma diagonal de pelo menos 25 metros de largura partindo do ângulo nordeste da praça do antigo cemitério inglês. Ambas deveriam ter calçadas de pelo menos 6 metros de largura. Este projeto teve poucas partes executadas.

Em 1889 é encomendado a Edouard André (que havia trabalhado com Haussmann em Paris) um "Plan de Embellecimiento y Ensanche de Montevideo", o qual foi entregue em 1891. No projeto o autor estabelece um sistema de espaços públicos verdes, formado por praças e parques unidos por boulevares arborizados que ligavam importantes edifícios públicos. Embora nem todo o plano tenha sido

\footnotetext{
${ }^{7}$ GROSS, Patrício. Los planes de transformación de Santiago entre finales del siglo XIX y princípios del siglo XX. In: CEDEX. La Ciudad Iberoamericana. Madrid, MOPU, 1987, p. 351- 362.
} 


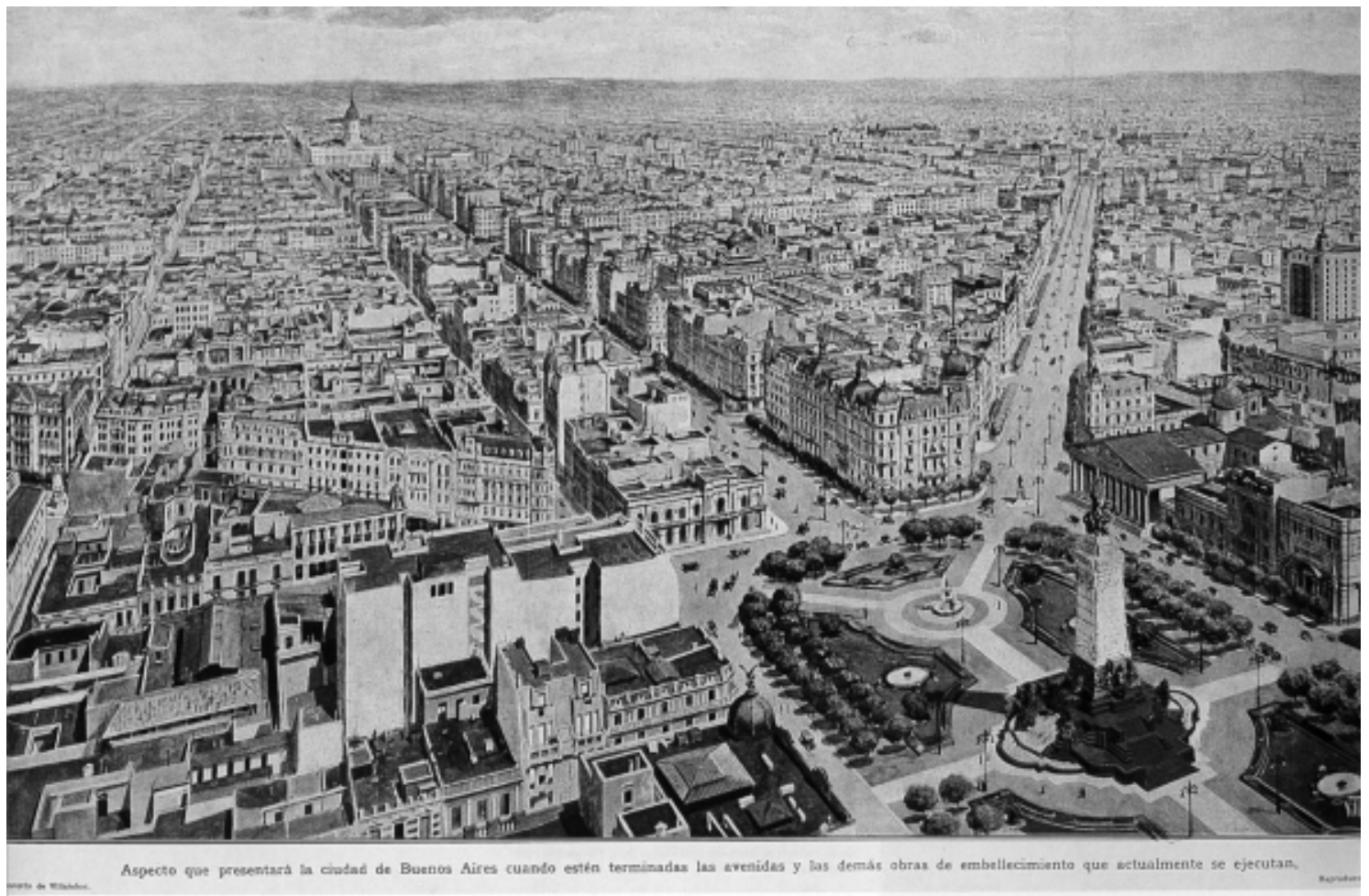

Figura 56 - Aquarela de Villalobos, de 1913, procurando retratar como ficaria a cidade de Buenos Aires depois de terminadas as obras de embelezamento em execução.

Fonte: GUTMAN, Margarita (ed.). Buenos Aires 1910: memoria del porvenir. Buenos Aires, Gobierno de la Ciudad de Buenos Aires/ Faculdade de Arquitetura, Design e Urbanismo da Universidade de Buenos Aires/ IIED-America Latina, 1999

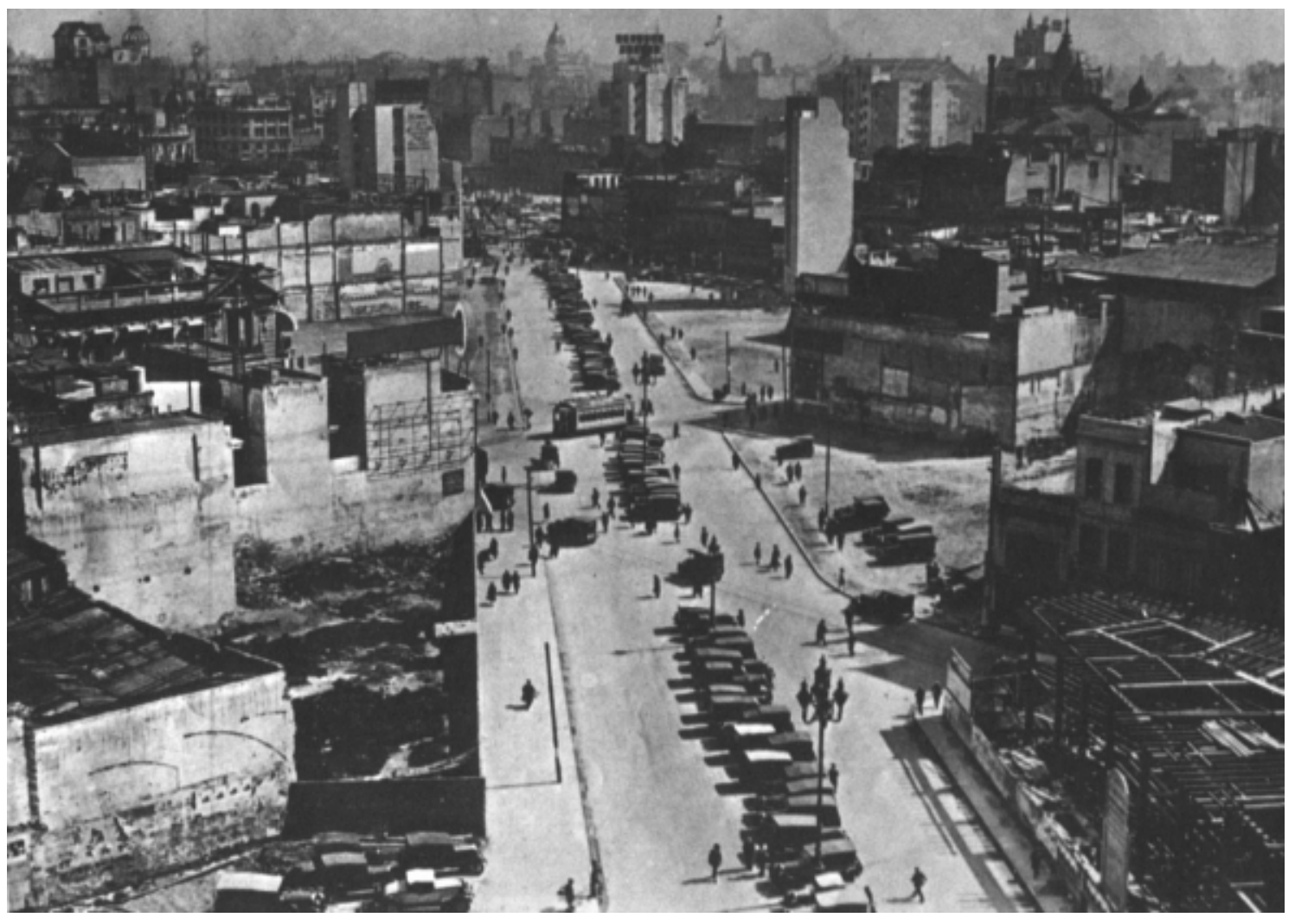

Figura 57 - Demolições realizadas para a abertura da diagonal Roque Saenz Peña (norte). Foto de 1931.

Fonte: MOLINARI, Ricardo Luis. Buenos Aires 4 siglos. Buenos Aires, TEA, 1980. 


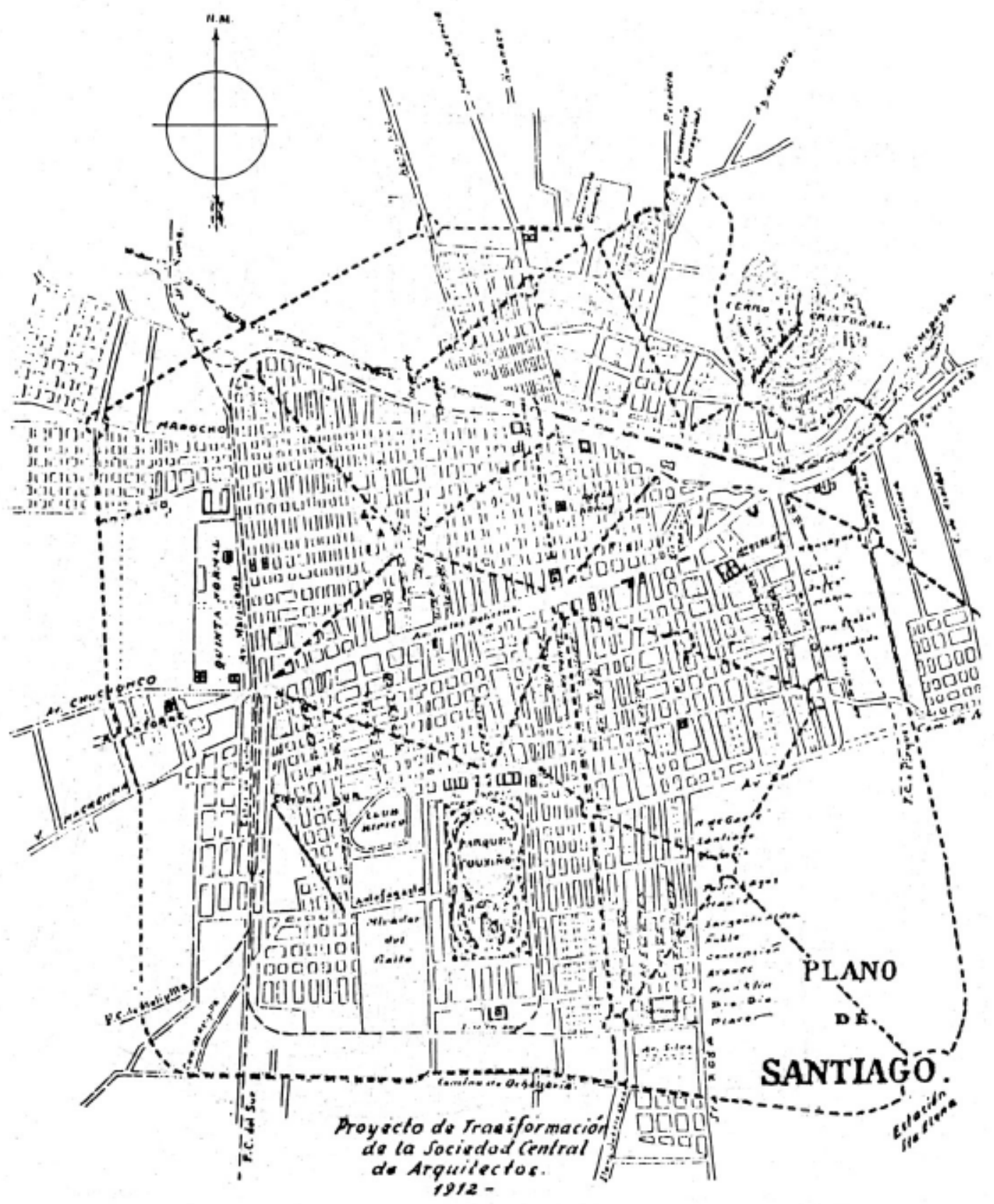

Figura 58 - Plano para Santiago do Chile, proposto pela Sociedad Central de Arquitectos, em 1912.

Fonte: GROSS, Patrício. Los planes de transformación de Santiago entre finales del siglo XIX y princípios del siglo XX. In: CEDEX. La Ciudad Iberoamericana. Madrid, MOPU, 1987. P. 351-362. 
executado, o foram o sistema de espaços verdes, a ampliação do Parque El Prado e a localização do Parque Battle, além de algumas obras menores.

Em 1911 é realizado um concurso internacional de projetos para o traçado geral de avenidas e localização de edifícios públicos em Montevidéu. São convidados diversos profissionais nacionais e estrangeiros (entre os quais Bouvard). Os jurados concedem três prêmios, sendo que o primeiro lugar coube ao arquiteto Augusto Guidini (figura 59). Em geral os três projetos vencedores priorizam o traçado de avenidas e parques. Nenhum deles teve aplicação prática, mas formou a base do plano regulador da cidade de Montevidéu, aprovado em 1912, o qual foi realizado por uma equipe que incluía dois dos três vencedores (Guidini e Baroffio). ${ }^{8}$

Este tipo de propostas não surge apenas nas cidades capitais. Podemos citar, por exemplo, a cidade de Rosário, na Argentina. Vários projetos apresentados também previam largas avenidas e o rompimento da quadricula através de diagonais. É o caso, por exemplo, do "Plano de Embellecimiento de la Ciudad de Rosario", apresentado em 1910 por Bouvard, e que reitera os elementos característicos de seus trabalhos em Paris e em outras cidades.

Também é muito interessante o projeto de uma "Avenida Central" proposta por J. Daniel Infante, no mesmo ano de 1910. A idéia era realizar a abertura de uma grande avenida e construção dos edifícios lindeiros. Com isso a cidade poderia contar com um grande âmbito onde se levantasse uma "edificação moderna, cômoda e artística". Este projeto dividia o centro em duas partes, e a intenção era executá-lo com capitais privados. Talvez a característica que mais chama a atenção neste projeto seja o fato de que estava previsto que os edifícios residenciais destinassem os dois últimos andares das frentes interiores para apartamentos "modestos". Assim os mais pobres entrariam em contato com os mais ricos cotidianamente e ambos poderiam entender melhor as carências e problemas uns dos outros:

"Los primeros tendrían oportunidad de tomar conciencia de 'los muchos sinsabores que amargan la vida' de los segundos, mientras que estos estarán em condiciones de conocer las necesidades que sufren los primeros, que a distancia pudieran considerar suficientemente retribuídos." ${ }^{\prime 9}$

Isto em certo sentido antecipa as idéias vigentes em certas linhas do urbanismo moderno que acreditavam ser possível que em um mesmo edifício pudessem coabitar sem conflitos diferentes classes sociais.

No Brasil as reformas mais significativas foram realizadas em São Paulo e Rio de Janeiro. Nesta última cidade o período mais profícuo de realizações se deu na intendência de Pereira Passos (1902/1906), durante a presidência de Rodrigues Alves. Não é demais lembrar que naquele então o Rio de Janeiro era a capital da República tornando-se, portanto, foco privilegiado das intervenções de caráter simbólico.

\footnotetext{
${ }^{8}$ CARMONA, Liliana; GÓMEZ, Maria Julia. Montevideo. Proceso Planificador y Crecimientos. Montevidéu, Facultad de Arquitectura de la Univesidad de la República, 1999.

9 BRAGOS, Oscar. Ciudades, sueños, planes. La emergencia del urbanismo en la Argentina y los primeros planes para la ciudad de Rosario. In: MACHADO, Denise Pinheiro (org.). Anais do IV Seminário de História da Cidade e do Urbanismo. Rio de Janeiro, UFRJ/Prourb, 1996, p. 110.
} 


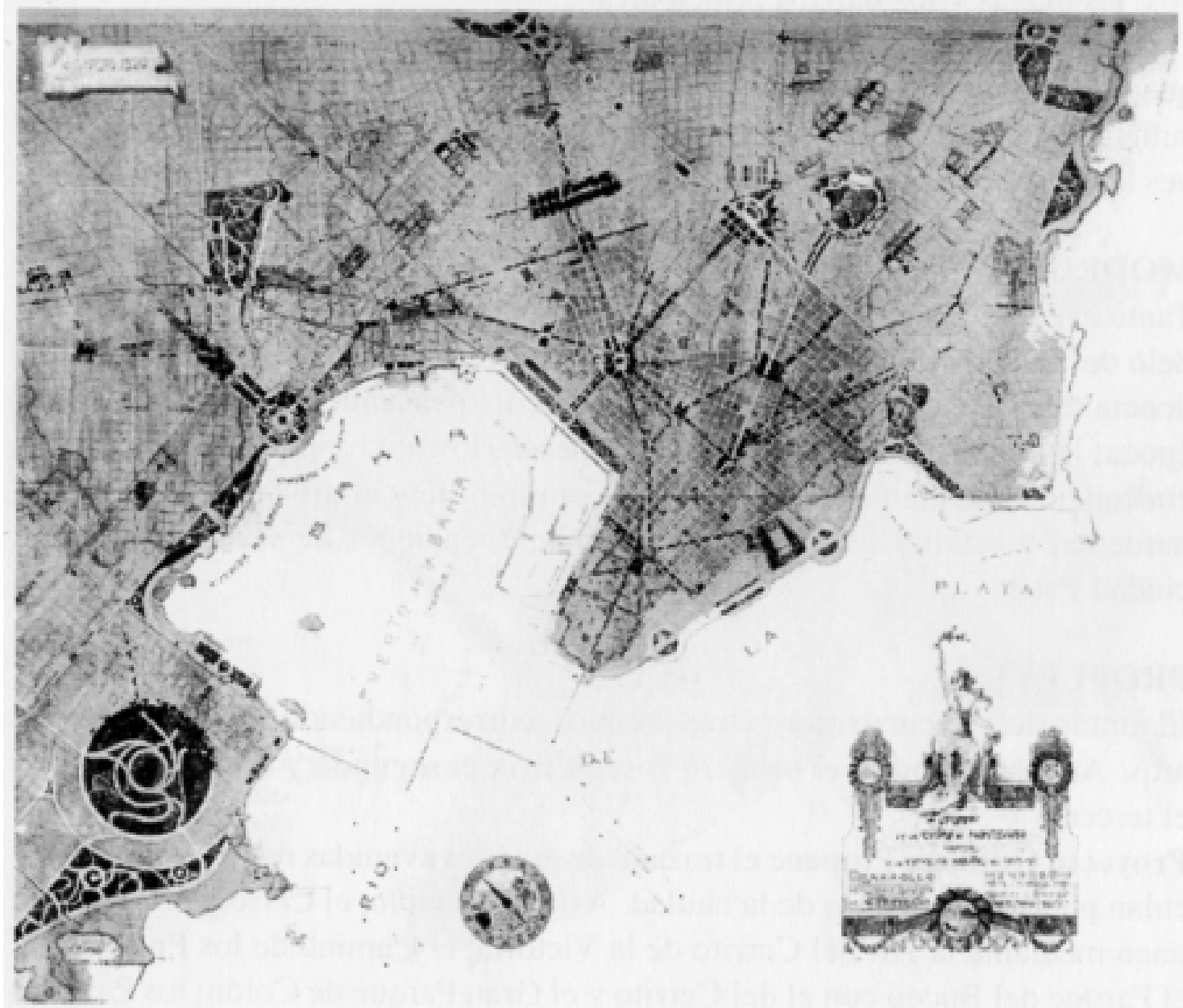

Figura 59 - Proposta de Augusto Guidini para Montevidéu, vencedor do concurso de projetos de traçado e edifícios públicos (1912).

Fonte: CARMONA, Liliana; GÓMEZ, Maria Julia. Montevideo. Proceso Planificador y Crecimientos. Montevidéu, Facultad de Arquitectura de la Univesidad de la República, 1999.

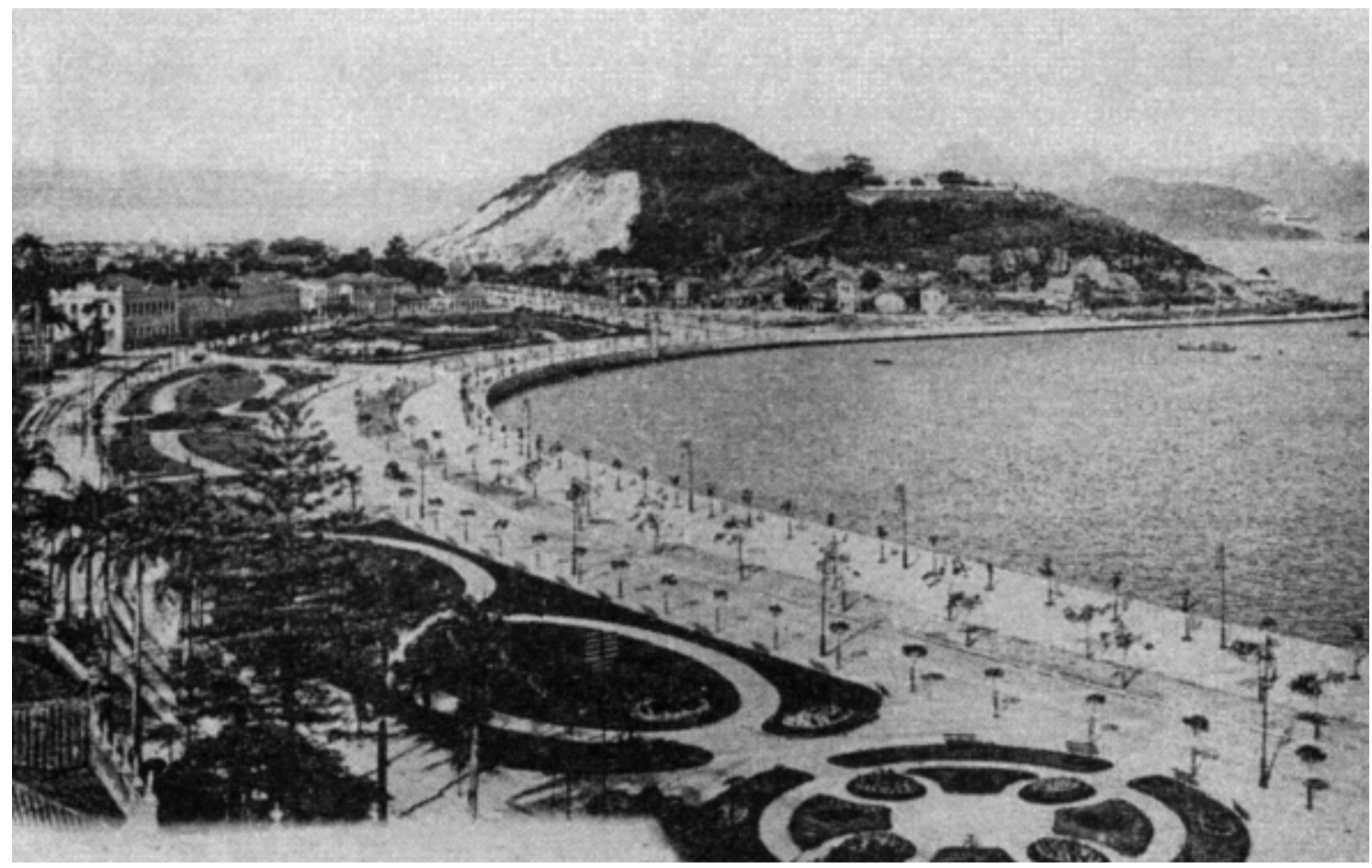

Figura 60 - Avenida Beira-Mar (Botafogo), no Rio de Janeiro. Este projeto faz parte do plano Pereira Passos.

Fonte: Acervo Nestor Goulart Reis 
O plano de Pereira Passos era de "Embelezamento e Saneamento da Cidade", e é uma reformulação de um antigo "Plano de Melhoramentos" elaborado pela Comissão de Melhoramentos em 1875, da qual fazia parte o próprio Pereira Passos. ${ }^{10}$

As principais reformas são de remodelação do porto, e abertura das avenidas Francisco Bicalho, Rodrigues Alves e Central. Também são abertas diversas vias de comunicação do centro com as zonas sul e norte, como as avenidas BeiraMar, Mem de Sá e Sete de Setembro, além de diversas obras de saneamento e abertura de praças e largos, como as praças da República, Quinze de novembro, Carioca e Tiradentes (figura 60).

Um dado que mostra a escala destas intervenções é que para sua realização o governo emprestou da Inglaterra quantia equivalente à metade da receita da União. ${ }^{11}$

Interessa-nos particularmente o caso da avenida Central (atual Rio Branco), pelas semelhanças que guarda com a avenida de Mayo, em Buenos Aires. Esta semelhança não é casual, já que esta foi utilizada como referência para aquela, que foi construída com três metros a mais de largura. ${ }^{12}$ É notável como, vistas a partir de certos ângulos, o aspecto destas avenidas é parecido (figuras 61 e 62).

Há antecedentes para a avenida Central, já que em 1884 o arquiteto italiano Giuseppe Fogliani havia proposto uma avenida cortando o centro com $1.130 \mathrm{~m}$ de extensão e $25 \mathrm{~m}$ de largura. Portanto contemporânea à avenida de Mayo, que foi projetada em 1885, iniciada em 1889 e finalizada em 1894.

No entanto, se atentarmos com maiores detalhes aos aspectos da arquitetura e do urbanismo, percebemos que o entorno da avenida Central é um espaço bastante diferente do existente em Buenos Aires: há quantidade de ruas muito estreitas, do período colonial, cuja arquitetura guarda poucas semelhanças. Além disso, a avenida de Mayo liga dois pontos significativos, que são a casa de Governo e o Congresso, e a altura dos edifícios em Buenos Aires é maior. Ou seja, embora supostamente inspiradas em modelos semelhantes, à Paris haussmanniana, são na verdade intervenções cenográficas limitadas às próprias avenidas, e o entorno é desconsiderado. ${ }^{13} \mathrm{Na}$ figura 64 podemos perceber claramente que os edifícios localizados atrás daqueles que compõem a avenida de Mayo são de baixa altura, não existindo qualquer continuidade no gabarito. Isto somente mudará com o passar do tempo. No caso da avenida Central, a figura 63 mostra a magnitude das demolições que foram realizadas para a abertura da avenida. Entretanto, como os edifícios construídos na avenida (figura 61) não são muito mais altos que os existentes (figura 63), este efeito não é tão marcante como em Buenos Aires.

\footnotetext{
${ }^{10}$ A respeito das intervenções urbanas realizadas no Brasil que serão citadas na seqüência, estamos nos baseando, exceto quando indicado, em LEME, Maria Cristina da Silva (coord.). Urbanismo no Brasil 18951965. São Paulo, Studio Nobel/FAUUSP/Fupam, 1999.

11 Idem, ibidem. p. 35.

12 REIS FILHO, Nestor Goulart. Op. cit.

${ }^{13}$ Para o Rio de Janeiro ver: FERREZ, Marc. O Álbum da Avenida Central. Rio de Janeiro, João Fortes Eng./Ex Libris, 1982. Para Buenos Aires: ASENCIO, Miguel et alli. La Avenida de Mayo. Buenos Aires, Ayuntamiento de Madrid/Municipalidad de la Ciudad de Buenos Aires/Manrique Zago ed./Eudeba, 1988; SOLSONA, Justo et alli. La Avenida de Mayo. Un proyecto inconcluso. Buenos Aires, FADU-UBA, 1990.
} 


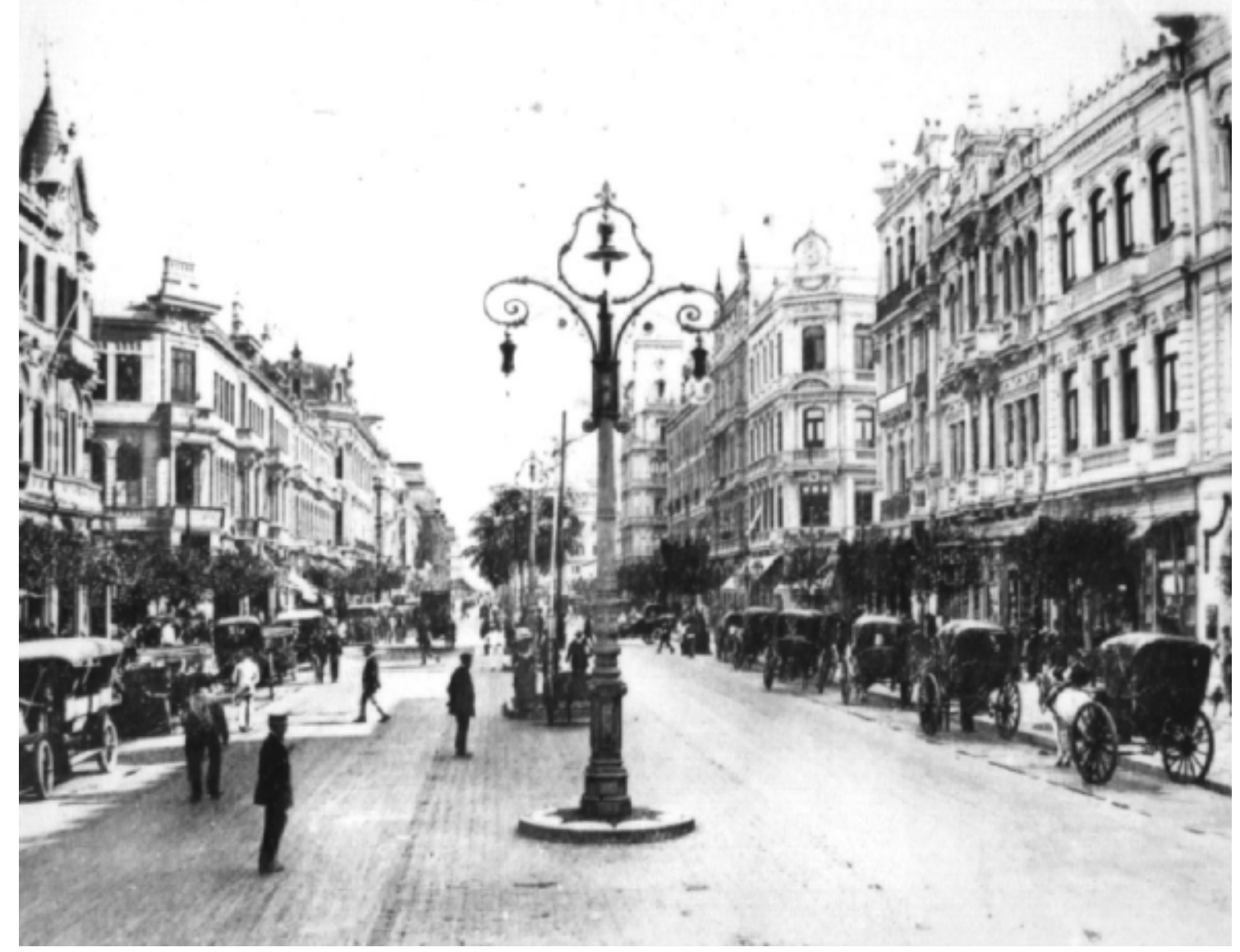

Figura 61 - Avenida Central (atual Rio Branco) no Rio de Janeiro. Foi construída em menos de dois anos (1904-5), cortando o antigo tecido colonial.

Fonte: EULÁLIO, Joaquim. Impressões do Brazil no século vinte: sua história, seu povo, commercio, indústrias e recursos. Londres, Lloyd's \& Walter Britain Publishing Company Ltd., 1913.

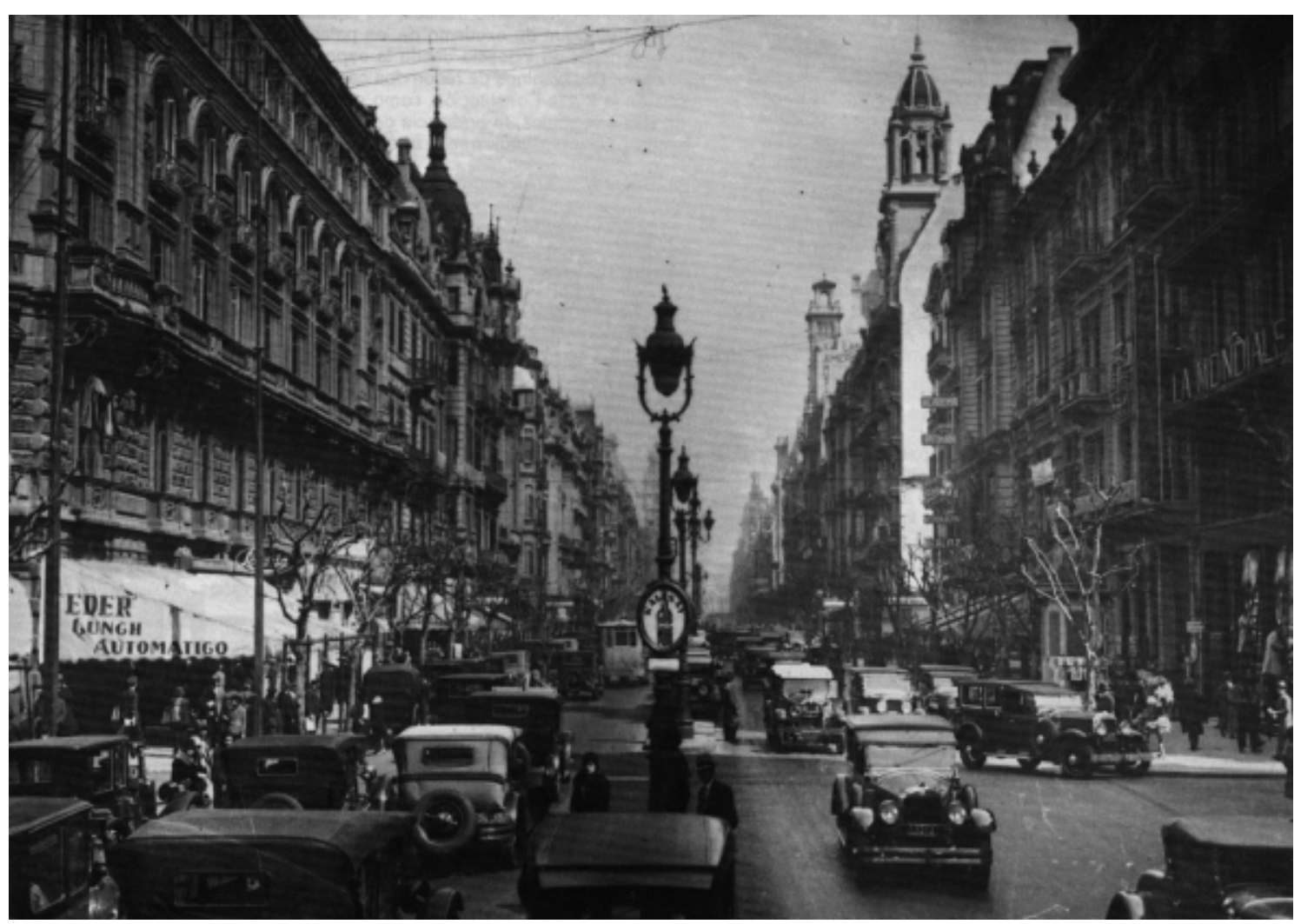

Figura 62 - A avenida de Mayo, em Buenos Aires, foi inaugurada em 1894. Exceto por alguns detalhes, é notável a semelhança em ambos os casos dos cenários criados.

Fonte: GUTIERREZ, Ramón. Buenos Aires. Evolución Histórica. Buenos Aires, Escala, 1990. 


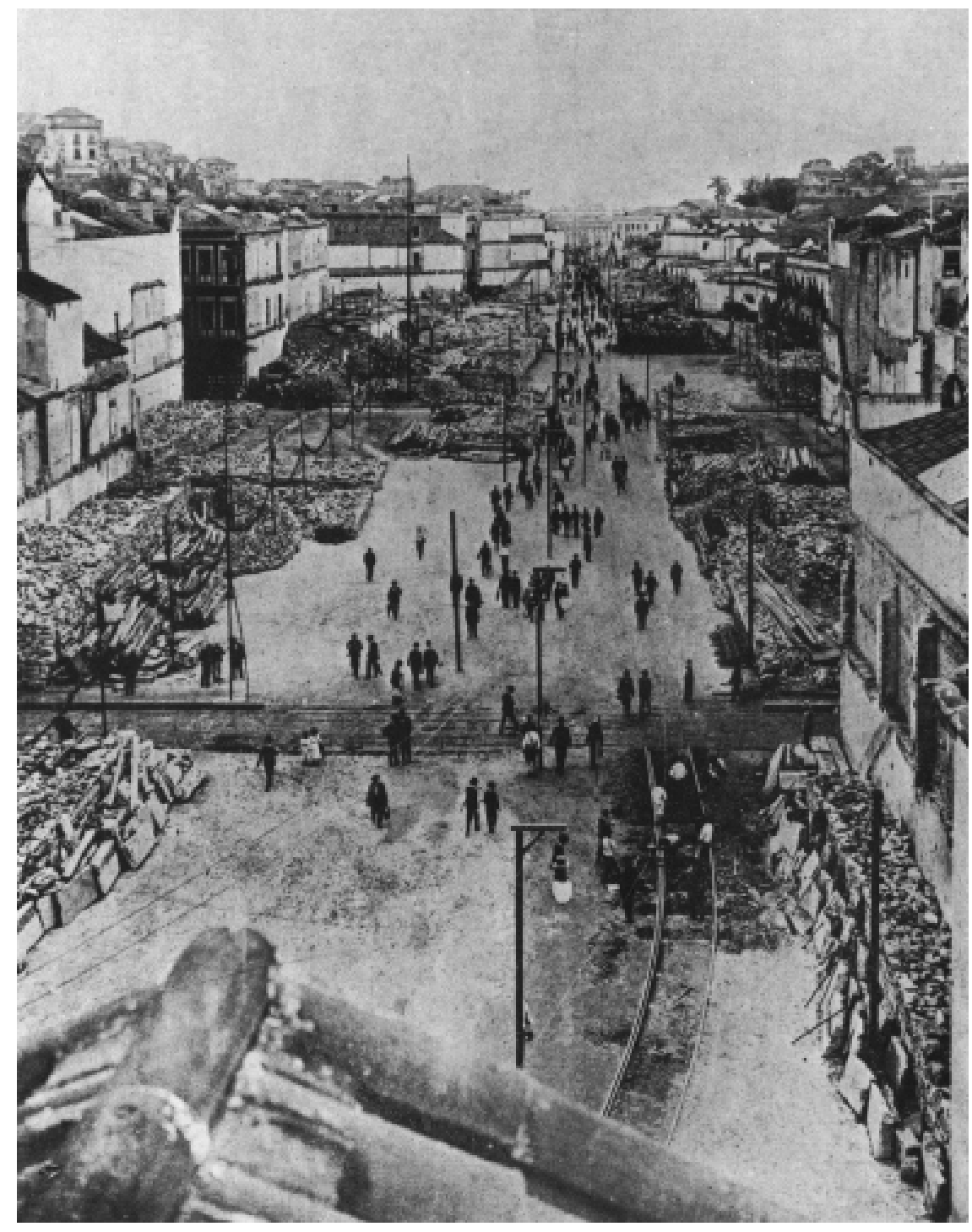

Figura 63 - Foto tirada em 1904, mostrando as demolições realizadas para a abertura da avenida Central. Fonte: FERREZ, Marc. O Álbum da Avenida Central. Rio de Janeiro, João Fortes Eng./Ex Libris, 1982.

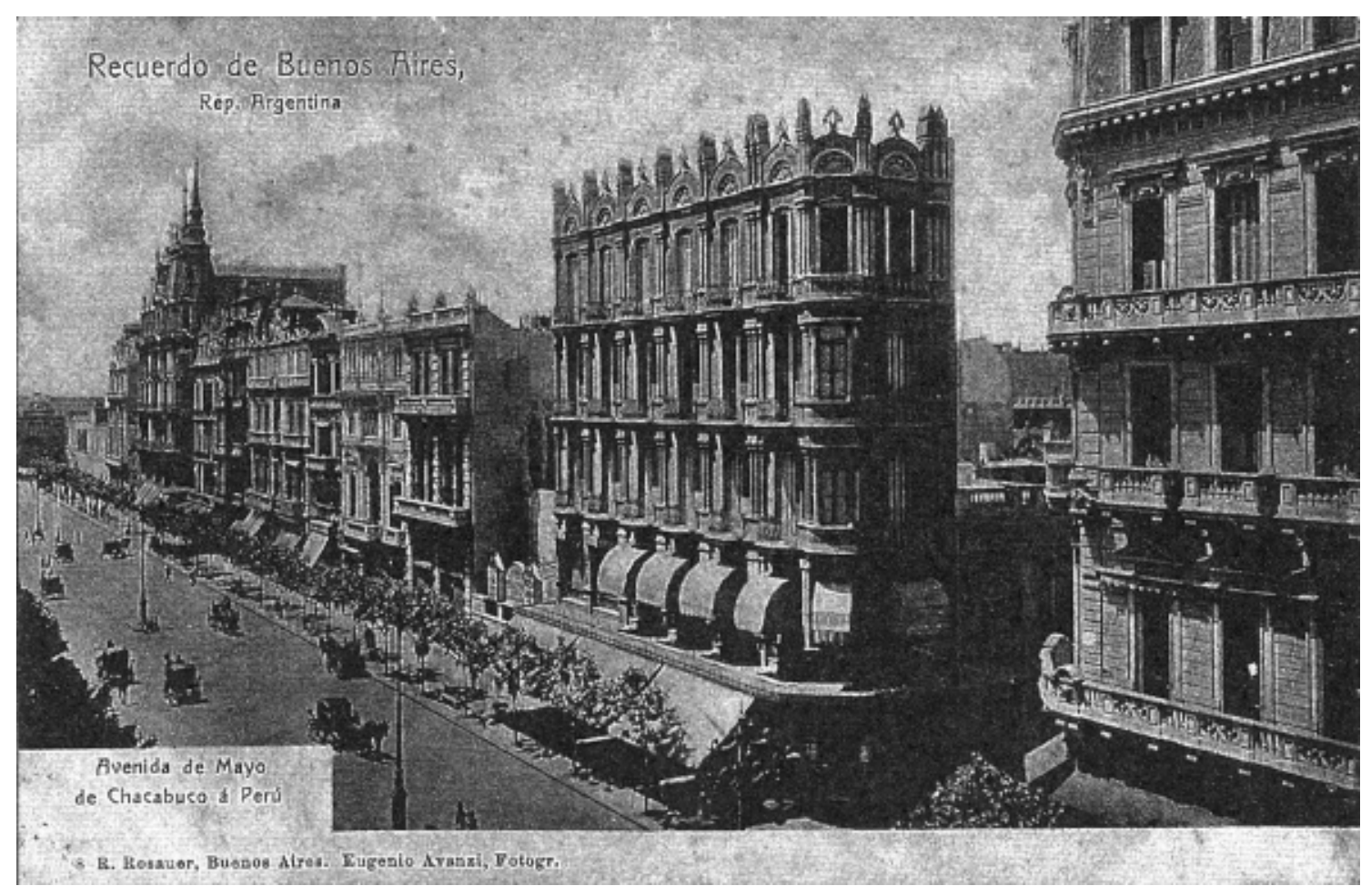

Figura 64 - Nesta foto da Avenida de Mayo percebe-se claramente que os edifícios lindeiros à avenida são mais altos que o entorno, caracterizando uma intervenção que guarda pouca relação com o entorno, e cria um cenário com ares europeus.

Fonte: GUTIERREZ, Ramón. Buenos Aires. Evolución Histórica. Buenos Aires, Editorial Escala, 1990. 
Voltando aos planos para o Rio de Janeiro, anos mais tarde, no período 1927/1930, é proposto o plano Agache. Consiste em um plano geral para a cidade utilizando elementos característicos do urbanismo francês, como grandes avenidas arborizadas e áreas com jardins. Na zona sul, destinada à população de mais alta renda, seriam criados bairros-jardins. As questões de saneamento mereceram significativo destaque, configurando uma terça parte do plano. Embora quase nada deste plano tenha sido executado, algumas das idéias nele constantes influenciaram em intervenções posteriores na área central. Na figura 65 podemos ver o aspecto que o plano previa para a cidade, onde é possível perceber o caráter de monumentalidade que se lhe procurava auferir.

Outras cidades brasileiras também tiveram planos deste tipo. É o caso do Plano Geral de Melhoramentos da cidade de Porto Alegre, proposto por Moreira Maciel em 1914 (figura 66). Como outros planos, consistia em enfrentar três problemas: circulação, embelezamento e saneamento. Em suas palavras a intenção era "nos cingirmos ao que era praticável, esperando porém que o projeto actual possa satisfazer em muitos pontos as necessidades crescentes de trânsito, belleza e hygiene da Capital"14

No Recife foram realizadas obras entre 1909 e 1914 para reforma do bairro portuário, chamado bairro do Recife, consistente na demolição do antigo tecido colonial e a construção de duas amplas avenidas radiais convergindo para o porto. Também foi importante o plano de saneamento do Recife realizado por Saturnino de Brito entre 1909 e 1915.

Em Salvador é apresentado em 1910 um "Plano Geral de Melhoramentos em Parte da Cidade do Salvador", elaborado por Jeronymo Teixeira de Alencar Lima, que previa a abertura e alargamento de diversas ruas da cidade alta de Salvador, com o objetivo de desafogar o distrito da Sé. (figuras 67)

\section{5 - AS REFERÊNCIAS REGIONAIS}

É interessante notar também que a utilização de referências não se limita apenas às cidades européias e estadunidenses, existindo espaço também para citações regionais. Estas podem ser encontradas, por exemplo, em diversos textos sobre a cidade de São Paulo, onde os autores diversas vezes reiteram experiências realizadas na América do sul, particularmente Buenos Aires. ${ }^{15}$

Das críticas realizadas, muitas se referem ao traçado em forma de xadrez da cidade argentina, considerado monótono e pouco eficiente do ponto de vista da circulação. Este aspecto é recorrente em textos escritos principalmente por Vitor da Silva Freire, que enfatiza a necessidade de não incorrer no erro de adotar o desenho

\footnotetext{
${ }^{14}$ LEME, Maria Cristina da Silva (coord.). Op. Cit., p. 92.

${ }^{15}$ Como não pudemos realizar uma consulta mais sistemática a fontes primárias em Buenos Aires, não localizamos referências à cidade de São Paulo. Entretanto certamente devem existir, já que principalmente a partir do início do século XX há uma disputa entre ambas cidades e países pela hegemonia na América do Sul.
} 


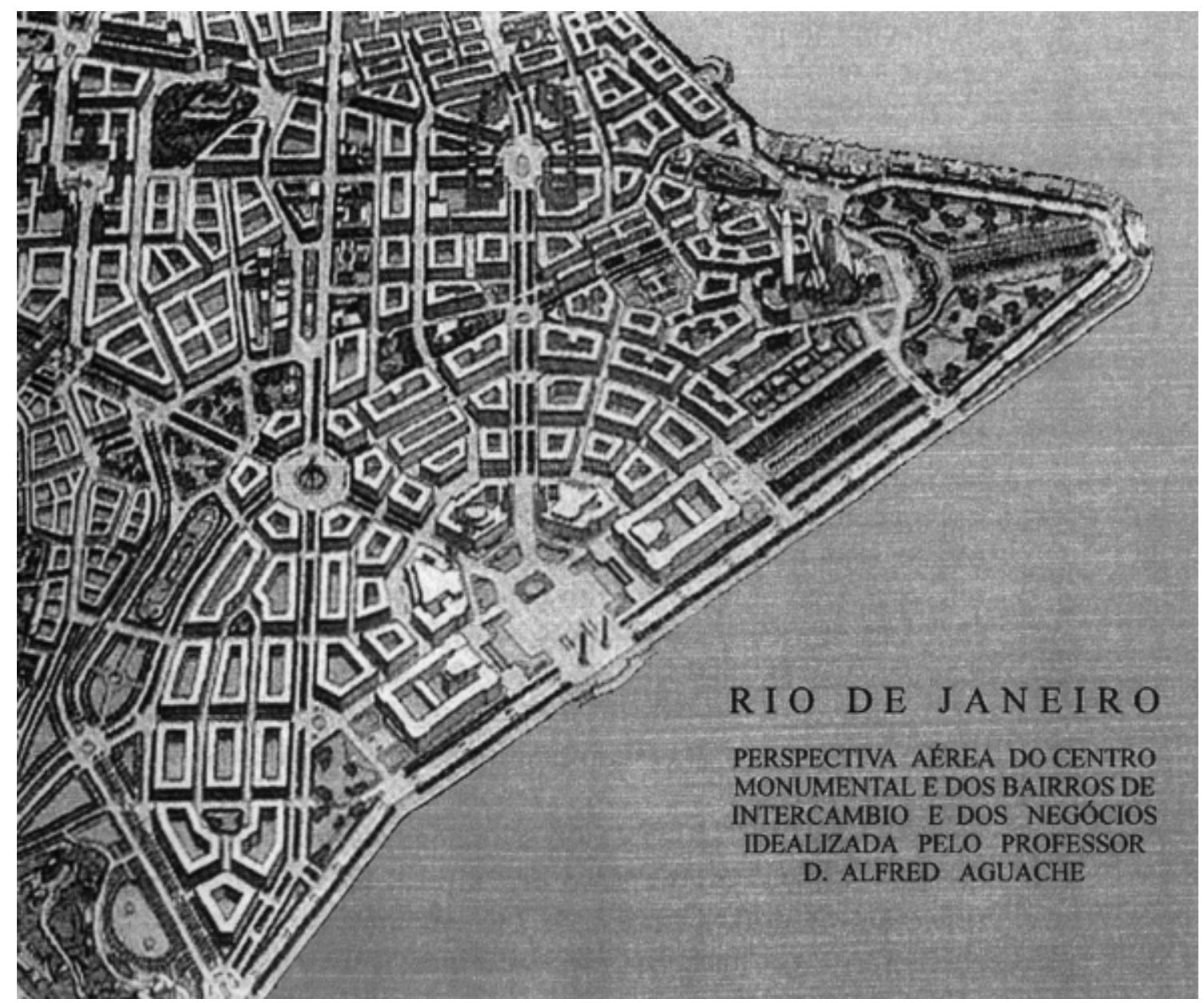

Figura 65 - Plano Agache para o Rio de Janeiro (1930).

Fonte: LEME, Maria Cristina da Silva (coord.). Urbanismo no Brasil 1895-1965. São Paulo, Studio Nobel/ FAUUSP/Fupam, 1999.

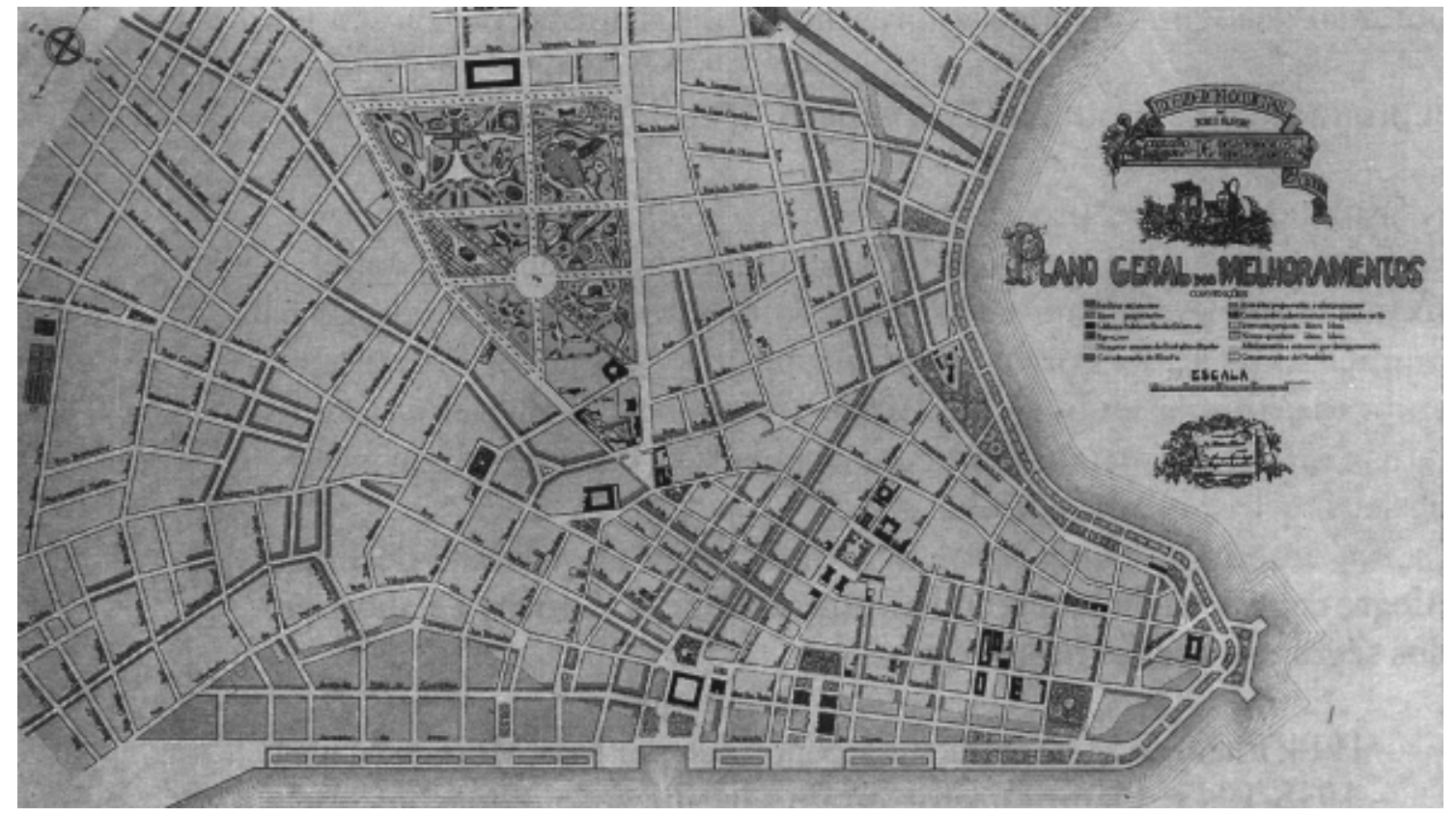

Figura 66 - Plano Geral de Melhoramentos para Porto Alegre, de Moreira Maciel (1914).

Fonte: LEME, Maria Cristina da Silva (coord.). Urbanismo no Brasil 1895-1965. São Paulo, Studio Nobel/ FAUUSP/Fupam, 1999. 


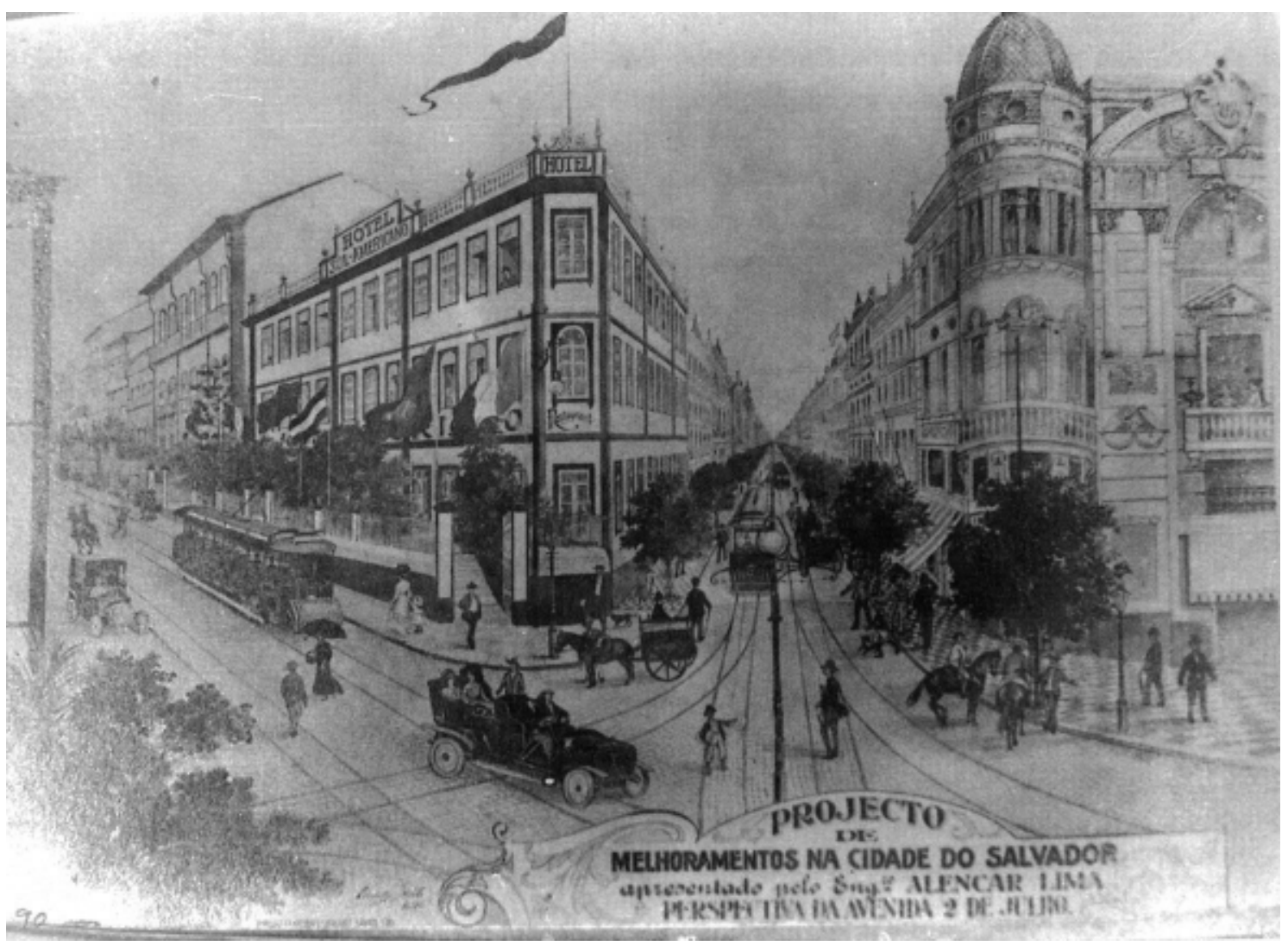

Figura 67 - "Projeto de Melhoramentos na Cidade de Salvador”, apresentado pelo eng. J. T. de Alencar Lima (1910).

Fonte: LEME, Maria Cristina da Silva (coord.). Urbanismo no Brasil 1895-1965. São Paulo, Studio Nobel/ FAUUSP/Fupam, 1999. 
em quadricula, como aconteceu em Belo Horizonte, já que o traçado existente em São Paulo é superior e deve ser continuado.

Por outro lado, este mesmo autor diversas vezes faz elogios a procedimentos realizados em Buenos Aires, referentes principalmente a transportes e desapropriações, destacando a necessidade de serem adotados em São Paulo. Citemos um exemplo:

\begin{abstract}
"Não é possível assistir ao espetaculo que nos offereceram então os nossos vizinhos, attentar no modo acertado, intelligente, esclarecido e pratico como souberam encarar o problema dos melhoramentos da sua capital, definil-o com precisão, resolvel-o conciliando os varios pontos de vista a satisfazer, traçar um programma methodico e começar a respectiva execução, sem ter de confessar a enorme vantagem que nos levam sob esse aspecto, entre todos os que traduzem o grau de adiantamento de um povo. Tudo isso foi feito com mão firme, com pessoal competente; não houve a registrar caprichos ou puerilidades. Não se teria passado melhor em qualquer dos paizes mais adiantados do mundo." ${ }^{\text {"6 }}$
\end{abstract}

Certamente estes elogios faziam parte de uma estratégia de, ao tocar em um ponto sensível como a disputa pela hegemonia sul-americana, tornar mais convincentes seus argumentos. Referências podem ainda ser encontradas em diversos outros textos. ${ }^{17}$

Também Prestes Maia cita a cidade de Buenos Aires. É o caso do Plano de Avenidas, de $1930 .{ }^{18}$ Nesta obra, em geral a análise dos diversos temas tratados se inicia com a descrição de experiências realizadas em outros países, incluindo a Argentina. Entretanto, há uma clara hierarquia quanto à importância que estas possuem para a justificativa da proposta realizada por Prestes Maia. Embora reiteradamente citada, a cidade de Buenos Aires merece sempre menos espaço que os países europeus e os EUA.

Nesta obra, as principais citações a respeito da cidade portenha referemse a desapropriações (página 20), largura das avenidas (página 62), valorização da topografia natural (página 128) e principalmente sistemas de transporte (páginas 204 e 255). Assim como Vitor da Silva Freire, também critica o traçado em quadrícula. Baseado nas idéias vigentes na Europa no momento, afirma que o sistema radiocêntrico é o mais adequado à circulação, e ao analisar a cidade de São Paulo

\footnotetext{
${ }^{16}$ FREIRE, Vitor da Silva. Melhoramentos de São Paulo. São Paulo, Revista Polytechnica N 33 , fev-mar 1911, p. 144.

${ }^{17}$ Por exemplo: FREIRE, Vitor da Silva. A planta de Bello Horisonte. São Paulo, Revista Polytechnica $\mathrm{N}^{\circ}$ 52, 1916, p. 166-168, 171-172. FREIRE, Vitor da Silva. A cidade salubre. São Paulo, Revista Polytechnica $\mathrm{N}^{0}$ 48, out-nov 1914, p. 352. FREIRE, Vitor da Silva. Melhoramentos de São Paulo. São Paulo, Revista Polytechnica $\mathrm{N}^{0}$ 33, fev-mar 1911, p. 93, 99, 111, 124, 134, 135, 138-141, 143-145. Estampas 1, 16 a 19.

18 MAIA, Francisco Prestes. Estudo de um Plano de Avenidas para a Cidade de São Paulo. São Paulo, Melhoramentos, 1930.
} 
chega à conclusão de que esta cresceu "naturalmente" assim, portanto é a forma mais adequada para sua proposta ${ }^{19}$.

Mas não apenas em São Paulo encontramos estas referências. Por exemplo, no plano proposto para Belém (PA) durante a gestão do intendente Lemos, Buenos Aires aparece como um dos modelos a seguir. ${ }^{20}$ Também em Santiago do Chile, em uma das propostas apresentadas no início do século $X X$, são citadas diversas outras cidades sul-americanas:

"Rio de Janeiro y Guayaquil son maravillas en su género, Barcelona y Buenos Aires tienen planos de extensión que son modelos dignos de estudiarse ..."21

\section{6 - O PROBLEMA DAS REFERÊNCIAS E INFLUENNCIAS}

Uma das constatações que é possível se fazer a partir dos exemplos anteriormente citados é que há uma constante repetição de projetos inspirados em alguns modelos em particular, especialmente nas idéias e realizações de Haussmann e Camillo Sitte, em muitos casos explicitadas pelos próprios autores. É interessante verificar também como certos elementos são sistematicamente reiterados, como por exemplo o caso dos anéis em torno do centro, em São Paulo. Quase todos os exemplos aqui colocados propõem este tipo de ligação.

Esses diversos projetos não são, porém, uma mera transposição direta de Haussmann ou Sitte, e nem mesmo admitem influências de apenas um. É freqüente o uso de várias referências ao mesmo tempo. O Plano de Avenidas, de Prestes Maia, por exemplo, propõe um terceiro anel inspirado nas "parkways" do urbanismo norteamericano, ao passo que outras idéias suas são de clara inspiração em Haussmann ${ }^{22}$. Vitor da Silva Freire, em vários de seus textos, faz referência às idéias de Camillo Sitte, enfatizando a importância do uso destes conceitos, ou seja, da cidade como obra de arte. Já o projeto de Alexandre de Albuquerque traz o conceito usado em

\footnotetext{
${ }^{19}$ Afirma Prestes Maia: "Em regra é o systema radial o mais conveniente e é justamente o que possúe São Paulo. Cabe-nos tornal-o melhor e completal-o, aproveitando quando possível as linhas mestras existentes". MAIA, Francisco Prestes. Op. Cit., p. 82.

${ }^{20}$ Consta no Relatório apresentado ao Conselho Municipal de Belém na sessão de 15 de novembro de 1902, pelo intendente Antônio de Lemos: "Li há poucos mezes que a municipalidade de Buenos Aires, sempre empenhada em desenvolver o gosto da construção urbana em aquela Formosa e adelantada capital, instituída prêmios para os architectos que fizessem as melhores e mais bonitas fachadas, em prasos determinados. Também aos proprietários dos referidos prédios foram concedidos favores, como a isenção dos impostos municipaes, quanto aos citados immóveis, por um determinado número de annos.

Estas medidas traduzem um esforço efficaz em pról do embellezamento urbano e eu julgar-me-ia em grave falta, se deixasse de apontal-as á patriótica previdencia do Conselho Municipal, pelo que possam valer ser adaptadas ao meio paraense, tão carente de prédios bonitos, elegantes, comodos e saudáveis". Município de Belém, p. 166. Devo a Yara Reis a indicação desta fonte.

${ }^{21}$ VALDÉS, Ismael Valdés. La transformación de Santiago. Santiago, Imprenta y Litografía Barcelona, 1917. Citado em: GROSS, Patrício. Los planes de transformación de Santiago entre finales del siglo XIX y princípios del siglo XX. In: CEDEX. La Ciudad Iberoamericana. Madrid, MOPU, 1987, p. 352.

${ }^{22}$ Por exemplo, no Plano de Avenidas de1930, a praça da Estrella, perto da Sé, a ponte da Cantareira ou a proposta para o viaduto do Chá.
} 
Paris de grandes eixos cruzando-se em uma grande praça circular, e uso de monumentos para composição das perspectivas.

Não é diferente o caso de Buenos Aires. As diversas propostas contêm alguns elementos sempre recorrentes, que são as diagonais, uma avenida de contorno nos limites do município (que hoje corresponde à avenida Gral. Paz), uma avenida norte-sul (que hoje é a 9 de julho), e a construção de uma ampla avenida central, partindo da casa de governo, na direção oeste (atual avenida de Mayo).

Tanto em São Paulo como em Buenos Aires as polêmicas em torno das diversas propostas geraram inúmeros debates, nas câmaras e nos jornais, opondo diversos grupos, cada qual com sua particular forma de encarar a questão, como é o caso do Anhangabaú, em São Paulo. Em Buenos Aires havia os defensores das diagonais, que quebrariam o sistema "arcaico" do "xadrez", e os defensores de uma ligação norte-sul (portanto mantendo as linhas do traçado colonial). Ou seja, os argumentos usados por uns e outros não eram muito diferentes entre si, e se em determinado momento um grupo defendia determinada proposta, não raro depois mudava de opinião. ${ }^{23}$

Não há dúvidas quanto à importância de se estudar a influência de obras ou idéias européias como referência para projetos aqui propostos ou realizados, dado que estão claramente refletidos no espaço produzido, ou seja, na arquitetura e no urbanismo. Hardoy foi um dos autores que abordou a questão, particularmente em um artigo intitulado "Teorias y practicas urbanísticas en Europa entre 1850 y 1930 . Su traslado a América Latina". ${ }^{24}$ Mostra a importância que este fenômeno assumiu no período em questão, fazendo uso para comprovar esta afirmação de uma grande quantidade de exemplos.

Recentemente foi lançado um livro, organizado por Heliana Salgueiro, com o objetivo de "tratar das modalidades de transferência do modelo" haussmanniano. ${ }^{25}$ No caso do Brasil o artigo assinado pela organizadora é sobre Belo Horizonte. O objetivo é compreender este processo, a partir do seguinte procedimento:

"Das representações aos funcionamentos, a inserção das imagens ideais na realidade física de uma cidade (a aplicação das utopias em circunstâncias efetivas) supõe discrepâncias e descontinuidades. Discrepâncias que resultam em transformações, elas próprias dependentes das remanescências estruturais da cultura receptora, assim como de seus ritmos específicos. Descontinuidades cujos mecanismos pertencem, de maneira implícita, à história de cada cidade e às modalidades de apropriação de modelos tidos como exemplares". ${ }^{26}$

Entretanto, podemos perceber as dificuldades e as limitações existentes ao tentar explicar estes projetos a partir dos argumentos usados pelos diversos autores,

\footnotetext{
23 Jorge Tartarini desenvolve estas idéias em: TARANTINI, Jorge. La polemica Bouvard-Jaeschke (Buenos Aires 1907-1911). Resistencia, DANA № 30, 1991.

24 HARDOY, Jorge Enrique. Teorias y practicas urbanísticas en Europa entre 1850 y 1930. Su traslado a América Latina. Resistencia, DANA N ${ }^{\text {os }} 37 / 38,1995$, p. 12-30.

${ }^{25}$ SALGUEIRO, Heliana Angotti (org.). Cidades Capitais do Século XIX. São Paulo, Edusp, 2001.

${ }^{26}$ Idem, ibidem. p. 167.
} 
no referente às influências e referências usadas, já que se bem esclarecem aspectos resultantes do espaço, não ficam claras as reais motivações dos diversos agentes envolvidos, já que como vimos grupos opostos utilizavam não raras vezes os mesmos referenciais. ${ }^{27}$

Para tentar superar esta dificuldade é necessário ir além da dicotomia Europa-América, e aprofundar o estudo destas relações em outras escalas. Antes, porém, devemos fazer algumas reflexões.

Vejamos, em primeiro lugar, como situar um plano dentro desse contexto social mais geral. Nós não estamos falando de ações individuais cujos reflexos no espaço urbano são de pequena ordem. Nós estamos falando sim, de propostas com grande impacto no espaço urbano, realizadas por grupos de pessoas, com objetivos em comum (naquele momento e naquela situação). Ou seja, nós temos grupos sociais, com projetos próprios, os quais agem em função de seus interesses. Uma das partes destes projetos refere-se ao espaço, que é onde entram as diversas propostas vistas. Temos ainda uma organização institucional, a qual é estruturada em função da forma de organização daquela sociedade, que, ou se propõe a realizar alguns desses projetos, ou quando a iniciativa é de particulares, em geral é quem vai garantir a base econômica para sua realização.

Portanto, quando falamos em um plano, estamos nos referindo a um projeto com impacto significativo sobre a cidade existente, proposto por grupos sociais com articulação política suficiente para garantir sua viabilidade.

Nós trabalhamos com o conceito de que a sociedade não é homogênea, há portanto, o domínio de uns sobre os outros. Os grupos existentes procuram ampliar seu poder, ao mesmo tempo que devem procurar manter o que já têm. Quando um plano destes é proposto, estes grupos estão, na verdade, realizando um investimento, ou seja, propondo uma forma de produção e uso do espaço urbano, que é parte de um projeto mais global de dominação. Ao realizar um loteamento, investem dinheiro para obter lucros com a valorização que estas operações proporcionam. É o caso também das grandes demolições para a construção de avenidas, e assim por diante. ${ }^{28}$

A produção de um espaço para as sociedades que estamos tratando também é parte de um projeto. Isto é facilmente verificável em ambas cidades: as grandes reformas, que em ambos os casos alcançam apenas a região central, além de grandes lucros, criam também um cenário europeu para estes mesmos grupos, no momento em que as classes populares abandonam os cortiços da região central (mais

\footnotetext{
27 Isto é freqüente quando há intervenções que causam polêmicas, em especial quando há grandes interesses envolvidos. Donatella Calabi, por exemplo, cita o caso do projeto de uma galeria comercial na Via Rizzoli, em Bolonha, onde o modelo francês era utilizado para sustentar teses opostas. CALABI, Donatella. O Papel de Paris na Urbanística Italiana do Século XIX: O Mito da Modernização. In: SALGUEIRO, Heliana Angotti (org.). Op. Cit., p. 121.

${ }^{28}$ Para que isto fique mais claro, vamos exemplificar como estas relações se configuram no espaço. Tomemos como exemplo uma favela, na qual é realizado um projeto de habitação popular, construindo-se uma série de casas, todas iguais. Como há diferenças sociais entre os moradores, em muito pouco tempo as pessoas começam a investir uma quantidade significativa de seus ganhos nas fachadas, para marcar sua posição social. Ou seja, investem em aparência. É possível perceber também que outros moradores, quando têm possibilidade, repetem alguns dos elementos do repertório usado pelos que têm mais recursos. Portanto, as diferenças formais na arquitetura refletem as diferenças existentes naquele grupo social. Ver MEDRANO, Ricardo Hernán. Resumos das aulas do Prof. Nestor Goulart Reis Filho na disciplina AUH 237 Urbanização e Urbanismo no Brasil I. Cadernos de Pesquisa do LAP 19. São Paulo, FAUUSP, 1997.
} 
valorizada), para ocupar loteamentos na periferia (facilitada pela expansão do sistema de transportes). Agora o centro passa a representar o espaço dos grupos dominantes. Também os novos locais de residência das classes abastadas possuem formas de implantação diferenciadas, com grandes lotes ocupadas por palacetes, nos mais variados estilos, como em Campos Elíseos, Higienópolis e avenida Paulista, em São Paulo, ou nos bairros da região norte, no caso de Buenos Aires. Ou como nos bairros com traçado mais sofisticado, como o Jardim América. Neste caso, a arquitetura e o urbanismo são também um investimento em valores, necessários igualmente para a manutenção do poder.

Nós entendemos que o espaço é sempre socialmente produzido. Isto exige, portanto, que se verifique qual o espaço produzido em suas diferentes escalas, como resultado da organização da sociedade em seus diferentes níveis.

Assim, em uma escala local, podemos reconhecer estas relações nos aspectos acima apontados, quanto às residências dos mais ricos. Muitos destes, por terem ascendido recentemente, tem maior necessidade de mostrar sua nova condição através da ostentação. Mas também a arquitetura oficial, articulada com esse urbanismo, expressa a importância das novas instituições republicanas, cuja arquitetura assume formas que remetem às sociedades onde esse sistema político está mais consolidado (França, Estados Unidos, etc.). A importância das instituições financeiras se verifica nos imponentes edifícios localizados na região central, cuja arquitetura procura passar uma imagem de solidez. Toda essa arquitetura deve também se opor à colonial, marcando a divisão entre dois períodos diferentes. Isto é facilmente observável tanto em São Paulo como em Buenos Aires.

Passemos agora para uma escala maior. Com essas intervenções, criam estes países uma imagem de modernidade, o que lhes permite atrair a confiança dos investidores internacionais, e portanto capitais, assim como as massas de imigrantes constantemente expulsas das áreas rurais (em geral) européias pelo processo de urbanização, e que são disputadas por países como Estados Unidos, Canadá, Austrália e outros, além de Brasil e Argentina.

Ao mesmo tempo, todo esse enorme dinamismo na atividade da construção, o rápido equipamento dessas cidades, e a exploração dos serviços instalados, também são fonte de grandes lucros, assim como o financiamento das obras. Estes são canalizados em geral para os investidores estrangeiros, e em menor medida para os locais, dentro de uma articulação de interesses entre as instâncias local e internacional.

Podemos considerar ainda que os modelos adotados na arquitetura e no urbanismo são também um reflexo das relações de dominação na escala internacional. Prova disto é a utilização de referenciais europeus (em sua maioria), mostra de um domínio econômico que é também um domínio cultural. Na escala local, estes modelos servem para criar uma identificação, ao olhos das classes mais pobres, entre as classes mais abastadas e os países mais ricos. Em contrapartida, são criadas condições para o surgimento de movimentos de oposição, através de projetos que questionam esses modelos adotados de forma acrítica, e que vão contribuir para o desenvolvimento de algumas correntes de arquitetura importantes, principalmente no modernismo.

Nessa escala, uma das diferenças existentes é que Buenos Aires concentra ao mesmo tempo tanto o dinamismo econômico quanto os valores 
simbólicos da Argentina. No Brasil, ao contrário, desloca-se para São Paulo o eixo do sistema econômico, enquanto as instituições nacionais permanecem no Rio de Janeiro, o que vai perdurar até a década de 60, quando são transferidas para Brasília. Por esta razão, é possível encontrar diversos paralelos entre Buenos Aires e o Rio de Janeiro, já que esta cidade é em grande medida responsável, aos olhos internacionais, pela imagem do Brasil como país moderno.

Apesar das intervenções realizadas no Rio de Janeiro, os grandes investimentos serão efetivamente realizados no estado de São Paulo, com a implantação inicialmente das ferrovias, e com a construção de uma grande infraestrutura (saneamento, energia, etc.) e a partir dos anos $20 \mathrm{com}$ o desenvolvimento das rodovias ${ }^{29}$.

Vejamos agora como ocorreu este processo na Espanha, lembrando que seu estudo tem o objetivo de verificar em que medida há continuidades e rupturas na arquitetura e no urbanismo, quando comparamos as realizações na Europa e na América.

Naquele país, uma das características marcantes do urbanismo são os "ensanches", sendo provavelmente o mais conhecido o projetado para Barcelona por Ildefonso Cerdá. As cidades espanholas, via de regra, mantinham as áreas urbanizadas dentro dos limites das antigas muralhas, mesmo quando estas já haviam sido derrubadas. Assim, o crescimento da população foi em geral absorvido pelos núcleos históricos já existentes, de origem medieval. Ou seja, aumentou a população, mas a área ocupada manteve-se a mesma. Isto acarretava problemas diversos, particularmente os referentes às condições de salubridade.

Para resolver isto foram idealizados os "ensanches", que são expansões planejadas, no sentido de que o traçado e algumas regras de edificação eram previamente definidos, condicionando a futura expansão das cidades. Trata-se de uma criação original do urbanismo espanhol, cujos antecedentes podem também ser encontrados no urbanismo colonial hispano-americano, citado explicitamente por Cerdá. Muitas das cidades espanholas terão projetos deste tipo, algumas bem cedo, como Nueva Población del Puerto de Tarragona (início em 1815) e Nueva Población de Vigo (1837). No caso de Barcelona, suas muralhas são derrubadas em 1854, e em 1859 Cerdá apresenta seu projeto. Na prática, estes projetos de expansões eram destinados principalmente às camadas médias e altas da população.

Embora seja um instrumento que tenha se generalizado, sua aplicação em geral foi precedida por polêmica. Em Madri, por exemplo, as duas principais posições eram a dos partidários da reforma da cidade existente e a dos que defendiam a criação de "ensanches". Depois de muitas discussões, em 1860 é aprovado o projeto de Carlos $\mathrm{M}^{\mathrm{a}}$ de Castro, prevendo a futura expansão da cidade.

Para regulamentar estas expansões, em 1864 foi promulgada a "Ley de Ensanche de Poblaciones", posteriormente modificada em 1876 e 1892. Outros projetos de expansão no século XIX são os de San Sebastián (1864), Gijón (1867), Alicante (1874), Vigo (1878), Valência (1886), León (1897), etc.

\footnotetext{
${ }^{29}$ A esse respeito ver: REIS FILHO, Nestor Goulart. Memória do transporte rodoviário. Desenvolvimento das atividades rodoviárias de São Paulo. São Paulo, CPA, s.d.
} 
Embora muitos desses "ensanches" tenham sido concebidos do século XIX, na prática a maioria somente será ocupado após o início do século XX, inclusive porque muitos proprietários guardavam uma parte como reserva para valorização. Entretanto, muitos projetos são efetivamente do século XX, como é o caso de Cádiz (1905), La Coruña (1910), Pamplona (1920), Valência (1924) e Logroño (1935). É interessante notar que embora tenham sido formuladas muitas críticas aos "ensanches", principalmente por sua incapacidade de atender à demanda de moradias modestas e impedir a formação de subúrbios periféricos, sua prática persistiu por toda a primeira metade do século $\mathrm{XX}$.

Assim como no caso das cidades hispano-americanas, os "ensanches" podem ser interpretados como uma forma de expansão ilimitada da cidade, através da repetição dos mesmos elementos. Entretanto, como assinala Fernando de Terán, ${ }^{30}$ os "ensanches" na prática possuem um conceito unitário, como "peça predefinida inclusive no tamanho e na extensão". Particularmente no caso de Madrid havia um passeio de contorno e um fosso exterior que limitavam sua expansão.

Isto diferencia o projeto realizado em Barcelona dos propostos para as demais cidades espanholas, embora à primeira vista pareçam semelhantes. Uma das diferenças é que Cerdá efetivamente trabalhou sobre o conceito de espaço ilimitado, e seu plano possui dimensões bem maiores do que outras intervenções. Outra diferença é que os ensanches geralmente eram concebidos como expansões da cidade existente. Em Barcelona, ao contrário, trata-se do projeto de uma nova cidade, onde a existente passa a ser uma peça daquela.

Além dos "ensanches" e dos bairros periféricos, houve grande atividade na reforma interior, ou seja, na cidade existente. Inclusive porque no início do século XX a maioria da população ainda habitava no interior dos velhos centros históricos. Nesse processo houve um intenso processo de alinhamento de ruas e formação de espaços livres, que alteraram significativamente a cidade antiga.

A partir da década de 1920 começaram a ser construídas as chamadas "Grandes Vías", embora existam alguns exemplos precedentes nas cidades de Granada, Barcelona e Madrid. Trata-se da abertura de grandes avenidas no interior da cidade antiga. Podemos citar como exemplo as realizadas em Bilbao (1923), Zaragoza (1925), Murcia (1926) e Valência (1928) (figuras 68, 69, 70 e 71). No caso de Barcelona, o próprio Cerdá havia previsto três grandes vias cortando a cidade antiga, das quais somente uma, a atual via Layetana seria efetivamente realizada a partir de 1908.

Em Madrid, a Gran Vía foi iniciada em 1910 e terminada em 1932, e realizada em partes que foram concluídas em 1917 e em 1921. É interessante observar na figura 72 que, a exemplo da avenida central, no Rio de Janeiro, e da avenida de Mayo, em Buenos Aires, trata-se de uma intervenção que corta linearmente o tecido pré-existente de origem medieval, e que também conforma um cenário, já que os edifícios situados na avenida são bem mais altos que os do entorno.

\footnotetext{
${ }^{30}$ TERÁN, Fernando de. Historia del urbanismo en España. Siglos XIX y XX. Madri, Cátedra, 1999.
} 


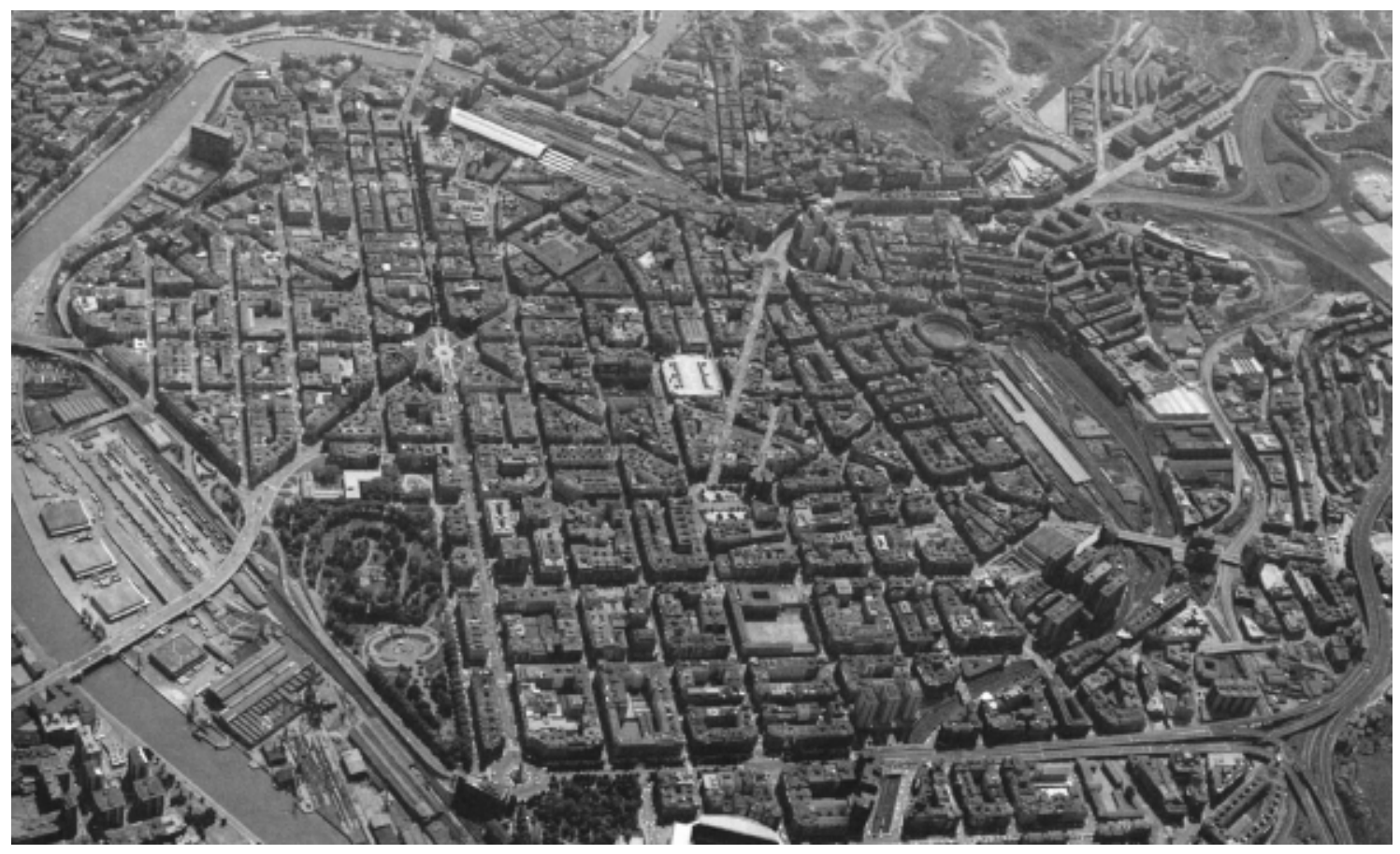

Figura 68 - Vista aérea da cidade de Bilbao, onde se pode observar o "ensanche”.

Fonte: GUÀRDIA, Manuel; MONCLÚS, Francisco Javier; OYÓN, José Luis (dir.). Atlas Histórico de Ciudades Europeas. Vol. I: Península Ibérica. Barcelona, CCCB/Salvat, 1994.

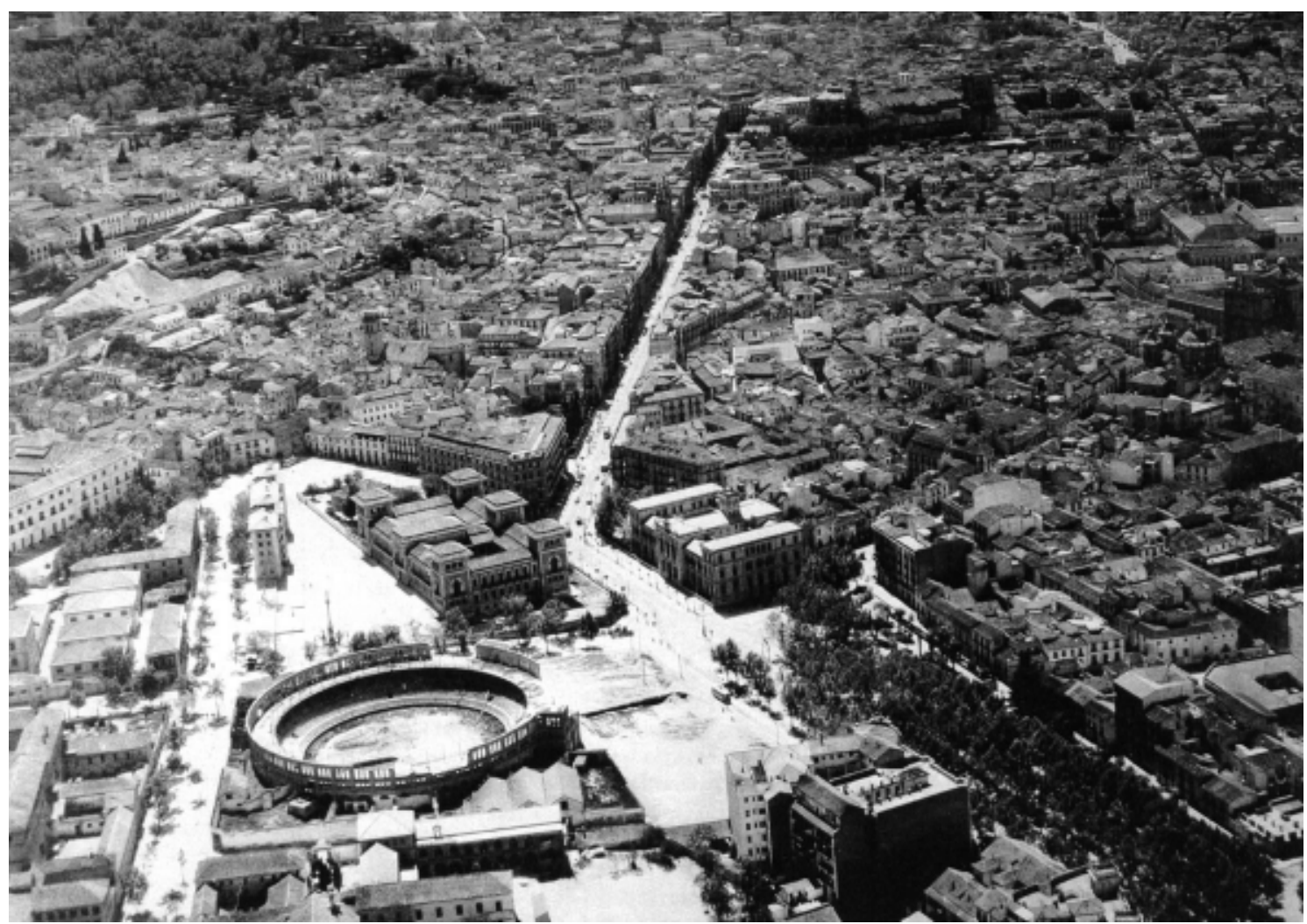

Figura 69 - Granada: Gran Vía de Colón.

Fonte: GUÀRDIA, Manuel; MONCLÚS, Francisco Javier; OYÓN, José Luis (dir.). Atlas Histórico de Ciudades Europeas. Vol. I: Península Ibérica. Barcelona, CCCB/Salvat, 1994. 


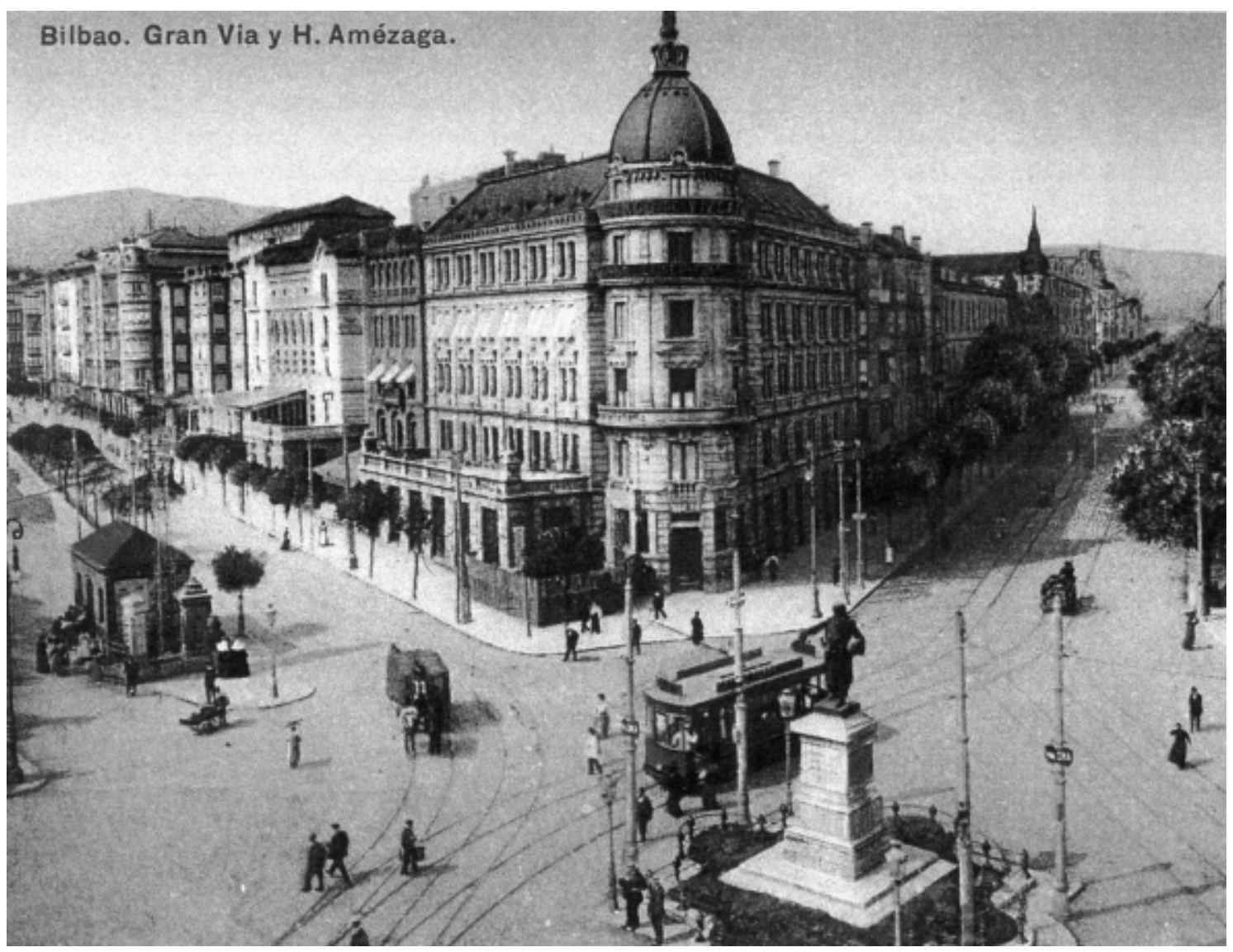

Figura 70 - Praça Circular e Gran Vía de Bilbao.

Fonte: GUÀRDIA, Manuel; MONCLÚS, Francisco Javier; OYÓN, José Luis (dir.). Atlas Histórico de Ciudades Europeas. Vol. I: Península Ibérica. Barcelona, CCCB/Salvat, 1994.

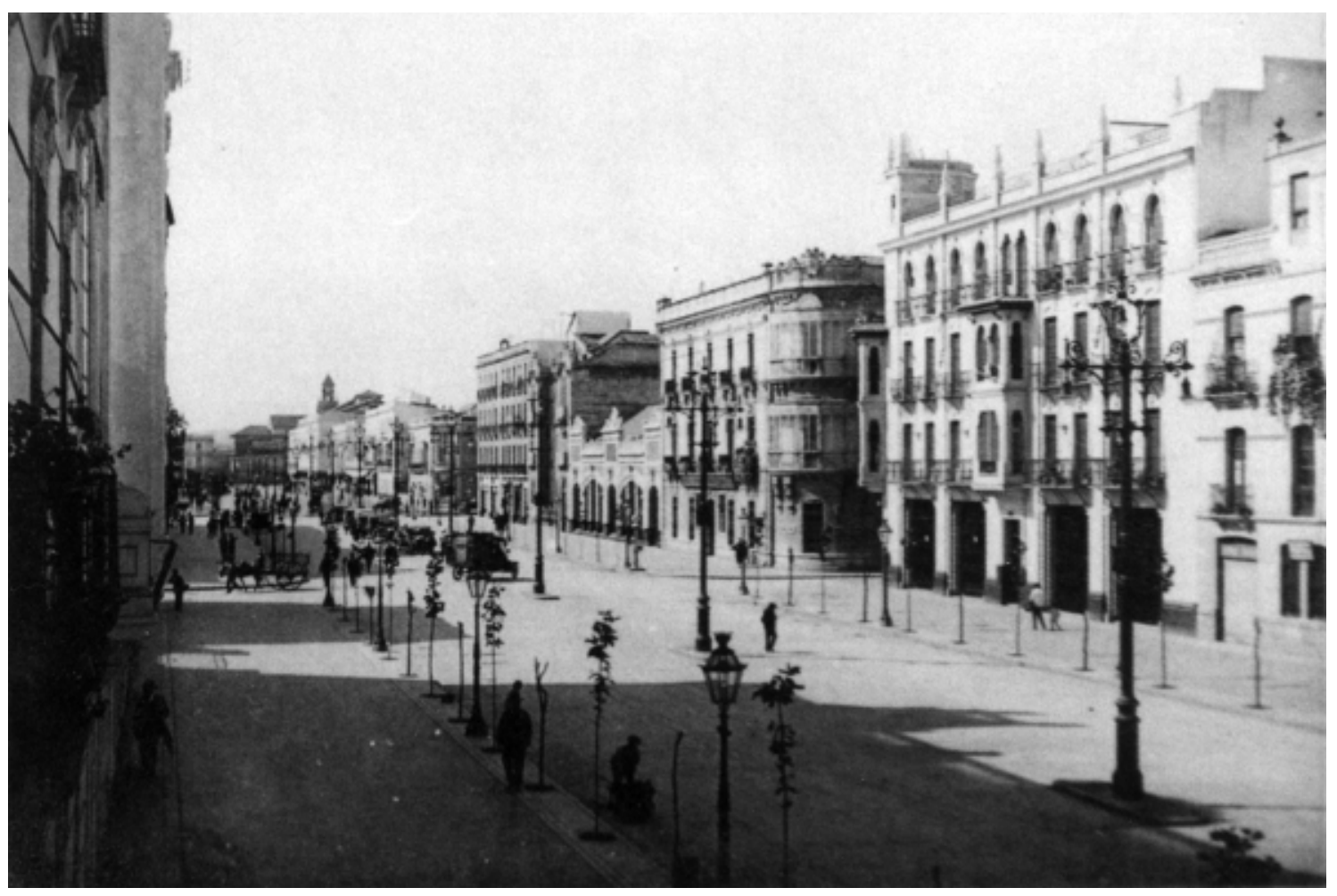

Figura 71 - “Paseo de Gran Capitán”, na região central de Córdoba.

Fonte: GARCIA VERDUGO, Francisco R.; MARTÍNEZ LOPEZ, Cristina. Cartografia y fotografia de un siglo de urbanismo en Cordoba. Córdoba, Ayuntamiento de Córdoba, 1994. 


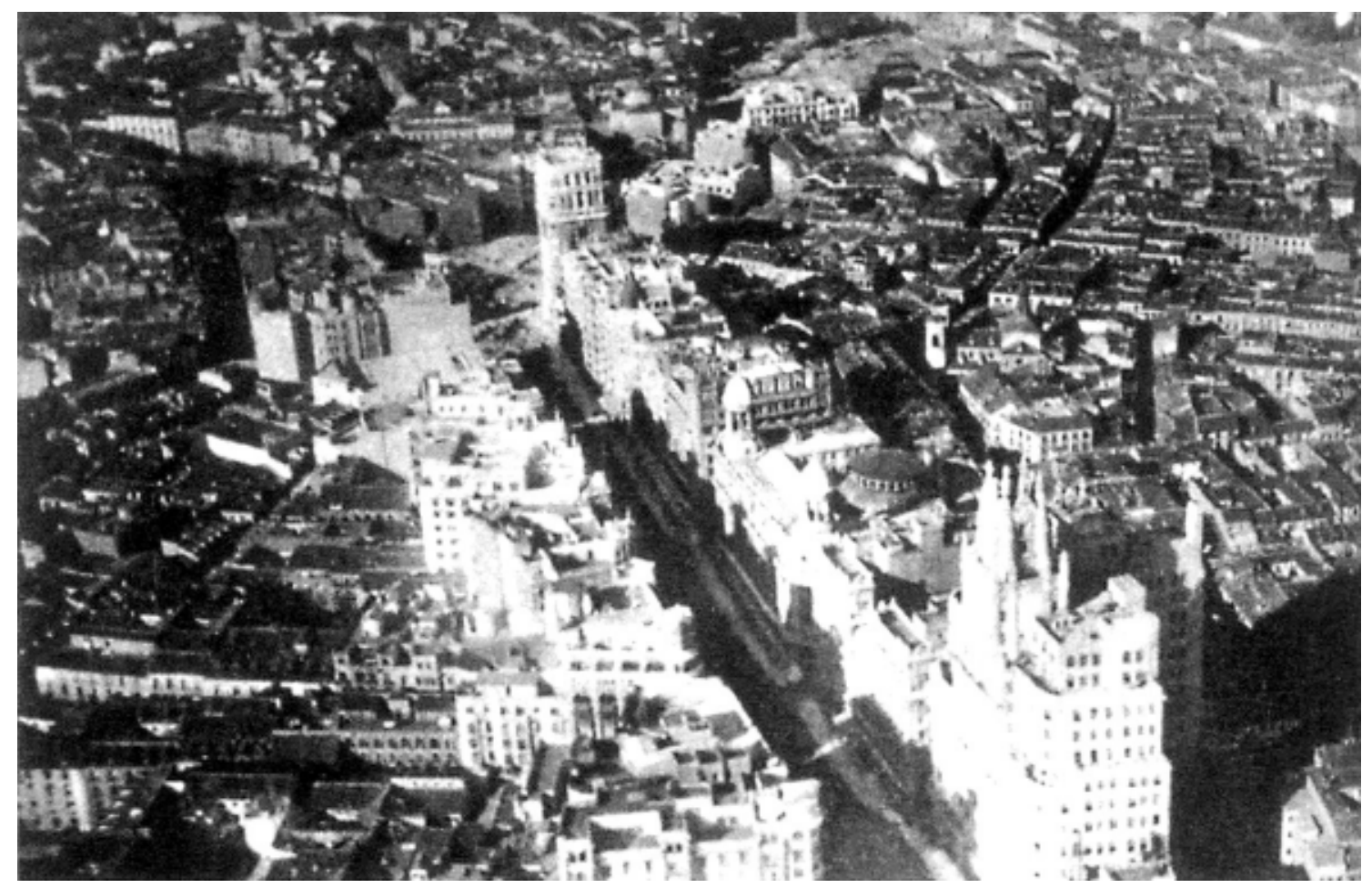

Figura 72 - Primeiro trecho da Gran Vía de Madrid, em 1931. Comparando com as figuras 61 a 64, podemos comprovar que trata-se de intervenções que guardam similitude, particularmente quanto à relação com o entorno e à criação de um espaço cenográfico.

Fonte: TERÁN, Fernando de. Historia del urbanismo en España. Siglos XIX y XX. Madri, Cátedra, 1999.
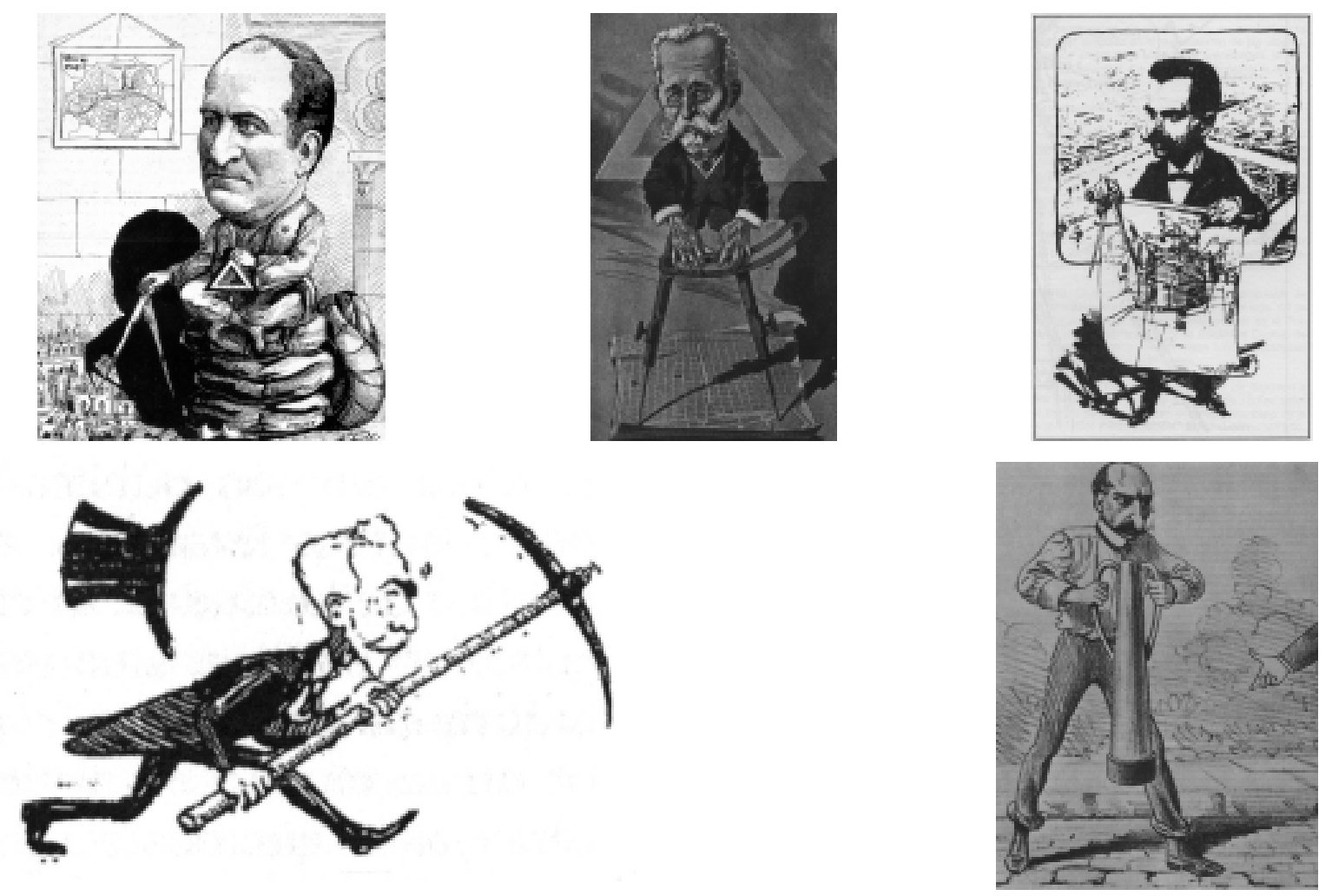

Figura 73 - Haussmann e seus homônimos. Na parte superior as representações nas quais os personagens usam compassos: O verdadeiro Haussmann (à esquerda), Bouvard (ao meio) e Carlos Carvajal Miranda (à direita), que fez diversas propostas em Santiago do Chile. Na parte inferior: o prefeito Pereira Passos (à esquerda) e o intendente Alvear.

Fontes: CARS, Jean; PINON, Pierre. Paris-Haussmann: le pari d'Haussmann. Paris, Picard, 1991; GUTMAN, Margarita (ed.). Buenos Aires 1910: memoria del porvenir. Buenos Aires, Gobierno de la Ciudad de Buenos Aires/ Faculdade de Arquitetura, Design e Urbanismo da Universidade de Buenos Aires/ IIED-America Latina, 1999;MOLINARI, Ricardo Luis. Buenos Aires 4 Siglos. $1^{\text {a }}$ reimp. Buenos Aires, TEA, 1980; DEL BRENNA, Giovanna Rosso. O Rio de Janeiro de Pereira Passos: uma cidade em questão. Rio de Janeiro, Index, 1985; SALAS, Jonás Figueroa. La ciudad lineal en Chile (1910-1930). Resistencia, DANA Nºs 37/38, 1995. p.64-70. 


\section{$4.7-$ CONCLUSÕES}

Vejamos inicialmente a questão das grandes avenidas, que foram comuns naquele período. Observando o espaço resultante, podemos perceber claramente que a principal intenção é a construção de um espaço cenográfico. Em primeiro lugar pela pouca relação com o entorno no qual foram inseridas, o que supostamente é uma prerrogativa da prática urbana. E em segundo pela ênfase nas questões de ornamento e estilo das fachadas, que buscavam reproduzir modelos europeus, caracterizando dessa forma um espaço de representação. Nesse sentido, não há uma diferença significativa entre as avenidas de Maio, Central e Gran Vía de Madri, como pudemos ver nas figuras 63, 64 e 72, como tampouco provavelmente haveria com o espaço resultante do projeto Alexandre de Albuquerque em São Paulo.

Por outro lado, foram utilizadas como referências formais os mesmos modelos, essencialmente os espaços resultantes das reformas realizadas em Paris na gestão de Haussmann, não apenas em São Paulo e Buenos Aires, mas também, como vimos, em outras cidades latino-americanas e européias. Assim, o estudo destas intervenções tem importância para se conhecer uma parte dos processos de produção do espaço, principalmente aqueles mais gerais ligados às questões de valor, portanto de poder e dominação. Entretanto, pelo fato de serem intervenções realizadas sem levar em consideração o tecido do entorno, e também pelo fato de apresentarem características formais muito próximas, são extremamente limitadas como meio de aproximação às especificidades dos processos sociais e espaciais locais.

Segundo Hardoy:

"La influencia directa de las ideas de Haussmann fue, por lo general, muy parcial y limitada a soluciones y proyectos puntuales en las ciudades que a fines del siglo pasado [século $X I X]$ y principios de éste [século $X X]$ recibieron una fuerte influencia cultural francesa." ${ }^{\text {"31 }}$

Este autor já destacava as limitações das intervenções baseadas naquele modelo, embora as associe à influência cultural francesa, o que é discutível. Estudos mais recentes também têm mostrado que na escala local podem existir significativas diferenças.

É o caso em Buenos Aires de tese proposta por Gorelik. Sabe-se que Bouvard, após uma breve estadia na cidade apresentou em 1907 um plano para a cidade, o qual foi reformulado e novamente apresentado em 1909. Este autor critica a forma como este foi visto já que habitualmente somente se analisam as propostas para a área central, sem que se tenha atentado para as propostas feitas para os subúrbios. Assim, os contemporâneos o teriam discutido como mais uma proposta de diagonais, e os historiadores o teriam sempre catalogado como "un plano que pretendía imponer un modelo haussmanniano inapropiado (por utópico o colonialista), $o$, en el mejor de los casos, como uma iniciativa que simplemente arbitró entre las propuestas locales en danza para el centro de la ciudad". ${ }^{32}$

\footnotetext{
${ }^{31}$ HARDOY, Jorge Enrique. Op. Cit., p. 19.

32 GORELIK, Adrián. La grilla y el parque. Espacio público y cultura urbana en Buenos Aires, 1887-1936. Buenos Aires, Universidad Nacional de Quilmes, 1998. p. 254.
} 
$\mathrm{Na}$ prática este plano teria sido dirigido por Carlos María Morales, que após vinte anos dirigindo a Comissão de obras públicas da municipalidade, era um dos que mais conheciam a cidade. ${ }^{33}$ Desta forma, pela precisão e extremo realismo com que são apresentadas as propostas para os subúrbios, trata-se da aceitação de um plano elaborado pela municipalidade em 1898-1904, no qual já está previamente definido todo o sistema viário e um sistema de parques. Este plano, mesmo que na época a grelha proposta abrangesse uma considerável área de território municipal ainda não ocupado, na prática foi obedecido quase sem modificações nas décadas seguintes.

No caso de São Paulo, particularmente na questão do Anhangabaú, Bouvard foi efetivamente um árbitro (embora tenha realizado algumas outras propostas), já que as partes mais importantes do projeto devem-se à Diretoria de Obras Municipais. Entretanto, sua estadia em São Paulo tinha também outros interesses, ligados à compra de terrenos e realização de empreendimentos imobiliários, junto à Companhia City. E, ao contrário de Buenos Aires, em São Paulo não houve um plano com a pré-definição do traçado viário.

Dessa forma, tanto em uma como em outra cidade, a presença de Bouvard teve muito mais peso no sentido da legitimação dos projetos sociais locais, ou seja, do uso de seu nome como garantia de qualidade e procedência, do que propriamente pelos projetos urbanos por ele realizados. Por outro lado, há indícios que os projetos realizados pelos órgãos públicos locais apresentam significativas diferenças.

Para Gorelik, a "influência" de Haussmann:

"mucho más que uma 'moda', mucho más que la aplicación 'parcial' o 'equivocada' de un sistema de reforma urbana, el haussmannismo en Latinoamérica fue una construcción de figuras semejantes de intendentes-administradores-dueños, los 'Lord mayores' de los que Haussmann fundó los tics principales y que han permanecido, casi podría decirse hasta nuestros días, como ideal de gobernante para la ciudad."34 (figura 73).

Concluindo, o estudo dos grandes planos permite relativizar duas questões: a primeira é que as diferenças observadas no processo de proposta e execução destes projetos mostram que, apesar de ambos países estarem inseridos de forma semelhante na divisão do trabalho (como produtores de matérias-primas), o espaço resultante apresenta características próprias em cada cidade, o que sugere que o grau de determinação da instância econômica não é total, havendo lugar para a execução de projetos próprios, determinados pela sociedade local. Trata-se de uma hipótese que pode ser confirmada através de novos estudos sobre estas e outras cidades latino-americanas.

Em segundo lugar, embora a análise das questões formais seja importante, assim como o estudo dos processos de transferência e re-interpretação

\footnotetext{
33 Jaeschke, um dos opositores de Bouvard, já havia dito que considerava que o projeto parecia ter sido feito em uma mesa de hotel, e que Bouvard somente teria assinado um projeto elaborado por representantes locais. Citado in: TARANTINI, Jorge. Op. cit.

${ }^{34}$ GORELIK, Adrián. La grilla y el parque. Espacio público y cultura urbana en Buenos Aires, 1887-1936. Buenos Aires, Universidad Nacional de Quilmes, 1998, p. 123.
} 
cultural, neste caso particular não podem deixar de ser consideradas como fundamentais, para interpretação do fenômeno urbano, as questões de valor, entendido este como caracterização de desigualdades. Somente através deste conceito é possível entender como as questões de estilo e a contratação de profissionais são utilizados como instrumento de legitimação dos projetos elaborados pelos diferentes agentes envolvidos. 
CAPÍTULO 5

HABITAÇÃO DAS ELITES 


\section{1 - SÃO PAULO}

No que se refere às residências das famílias mais abastadas, as mudanças começam a ocorrer progressivamente durante a segunda metade do século XIX, concomitantemente às transformações pelas quais passa a cidade de São Paulo. Enquanto esta era uma cidade de pequenas dimensões, muitas das principais famílias viviam na área central, na região do chamado "triângulo", formado pelas ruas Direita, São Bento e 15 de novembro. Seguindo a legislação da época, as fachadas destas casas deveriam ser alinhadas com a rua, e raramente possuíam algum recuo lateral. Algumas reuniam no andar térreo funções comerciais (depósitos, armazéns, escritórios, oficinas, etc.), ficando no andar superior a residência propriamente dita. No caso dos mais ricos, e que assim procuravam se caracterizar, ocupavam construções com a única função de moradia. O que distinguia uma residência das outras eram as dimensões, número de andares e detalhes decorativos (figura 74). ${ }^{1}$

Entretanto, algumas famílias de posses também viviam em chácaras nos arredores da cidade. Caracterizavam-se como unidades com alto grau de autoabastecimento: possuíam hortas e criação de pequenos animais, e algumas contavam com nascentes de água, permitindo uma razoável independência do incipiente comércio da cidade de então (figuras 75 e 76). A este respeito, é importante assinalar que mesmo aquelas famílias que ocupavam casarões na área central usualmente possuíam chácaras ou sítios cuja produção permitia abastecê-las. Esta situação começará a se reverter com o início do fornecimento de água pela Companhia Cantareira, em 1881.

Uma questão importante que deve ser sinalizada e que diferencia as sociedades paulistana e portenha refere-se à presença dos escravos. Embora na Argentina também tivessem existido, desempenhando funções na vida doméstica, no Brasil seu papel foi mais significativo, a ponto da arquitetura no período colonial e ao longo de quase todo o século XIX depender fortemente de sua presença, tornando-a em parte obsoleta quando a escravidão deixa de existir. Era o escravo que buscava água, quem retirava o esgoto, quem transportava a carga de um andar para outro, quem abanava o dono. Era muito comum no período colonial, principalmente nas cidades que foram mais importantes neste período, como Salvador, que a cozinha ficasse no último andar, e o estar nos inferiores. Desta forma, os donos não precisavam vencer maiores desníveis, enquanto o enorme esforço de transportar cargas até o último andar era feito pelos escravos (figura 77).

Com o início do processo de rápido crescimento da cidade, a área central sofre um processo de adensamento e deterioração. Áreas que haviam sido nobres, como Santa Ifigênia, Bela Vista, Santa Cecília, Vila Buarque e Consolação entram em decadência. Conseqüentemente, algumas famílias começam a construir palacetes em novas áreas, normalmente em loteamentos realizados através do parcelamento das

\footnotetext{
${ }^{1}$ LEMOS, Carlos Alberto Cerqueira. Alvenaria Burguesa: breve história da arquitetura residencial de tijolos em São Paulo a partir do ciclo econômico liderado pelo café. $2^{\underline{a}}$ ed. São Paulo, Nobel, 1989; HOMEM, Maria Cecília Naclério. O palacete paulistano e outras formas urbanas de morar da elite cafeeira 1867-1918. São Paulo, Martins Fontes, 1996; REIS FILHO, Nestor Goulart. Quadro da Arquitetura no Brasil. 5 ${ }^{\mathrm{a}}$ ed. São Paulo, Perspectiva, 1983. TOLEDO, Benedito Lima de. Prestes Maia e as origens do urbanismo moderno em São Paulo. São Paulo, Empresa das Artes, 1996.
} 


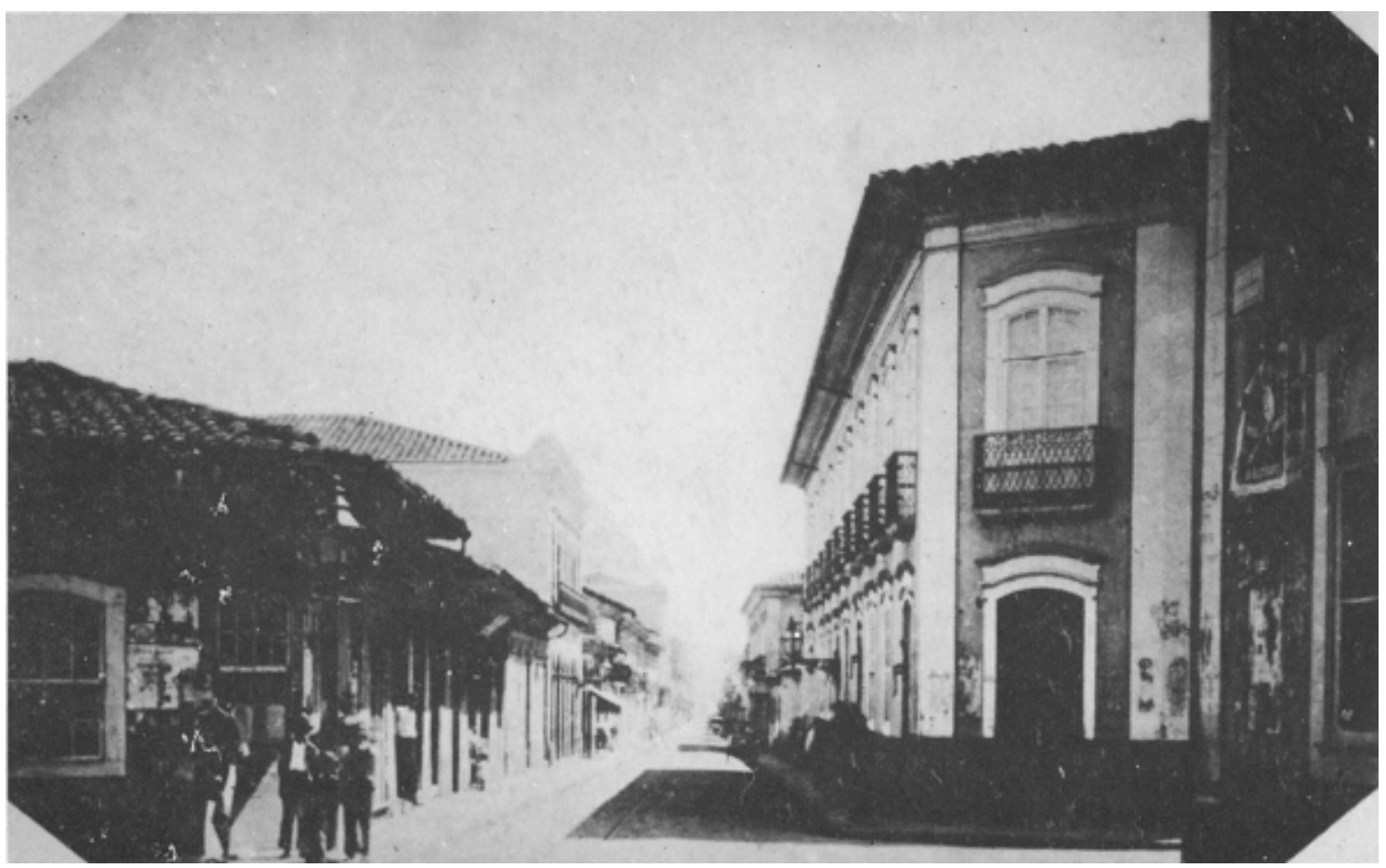

Figura 74 - Rua de São Bento, 1887. Foto de Militão Augusto de Azevedo. À direita vemos o sobrado que pertenceu ao Brigadeiro Luis Antônio de Souza.

Fonte: HOMEM, Maria Cecília Naclério. O palacete paulistano e outras formas urbanas de morar da elite cafeeira 1867-1918. São Paulo, Martins Fontes, 1996

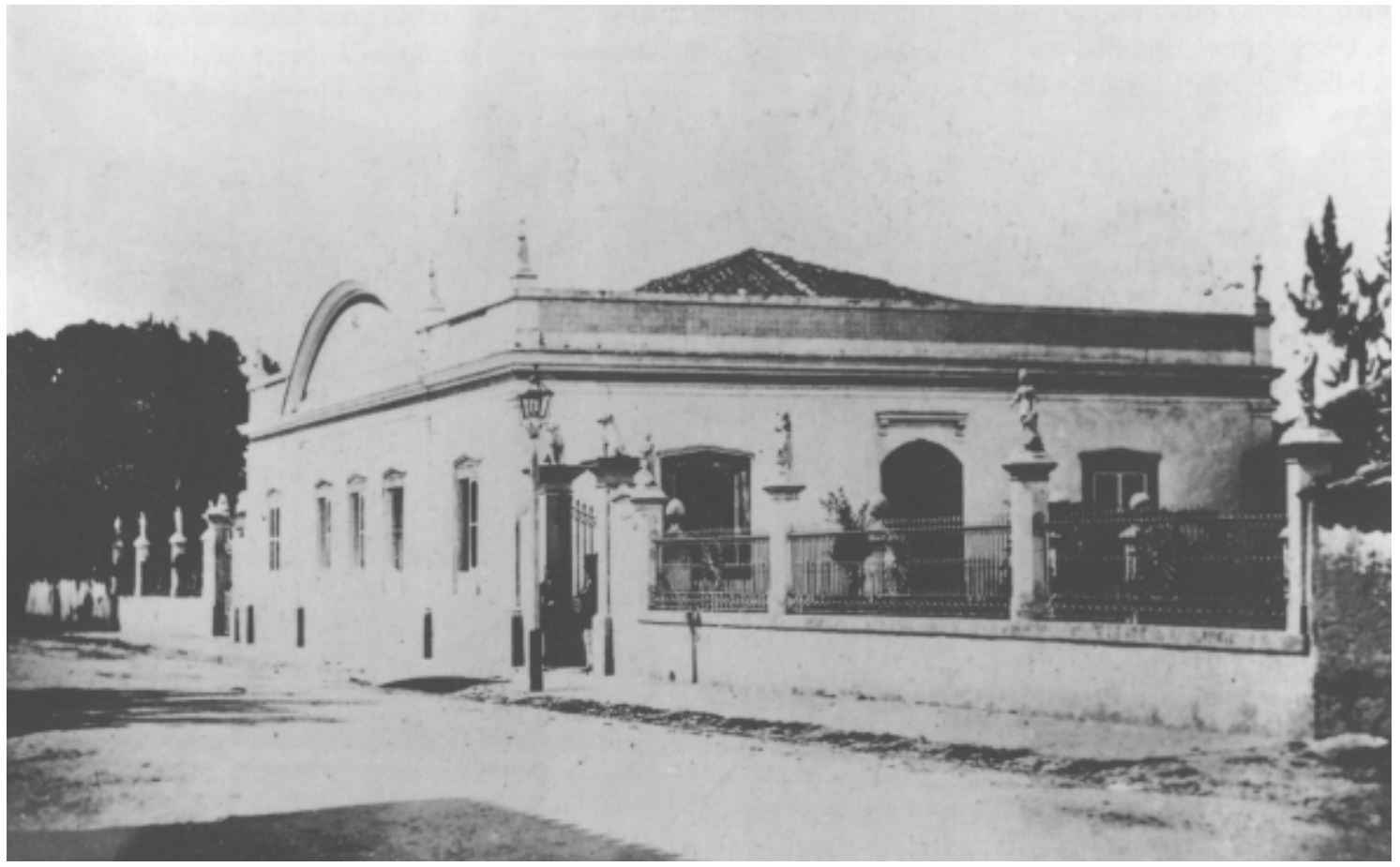

Figura 75 - Casa que pertenceu à família Gavião, localizada na rua Alegre. Foto de Militão Augusto de Azevedo, de 1862.

Fonte: HOMEM, Maria Cecília Naclério. O palacete paulistano e outras formas urbanas de morar da elite cafeeira 1867-1918. São Paulo, Martins Fontes, 1996 


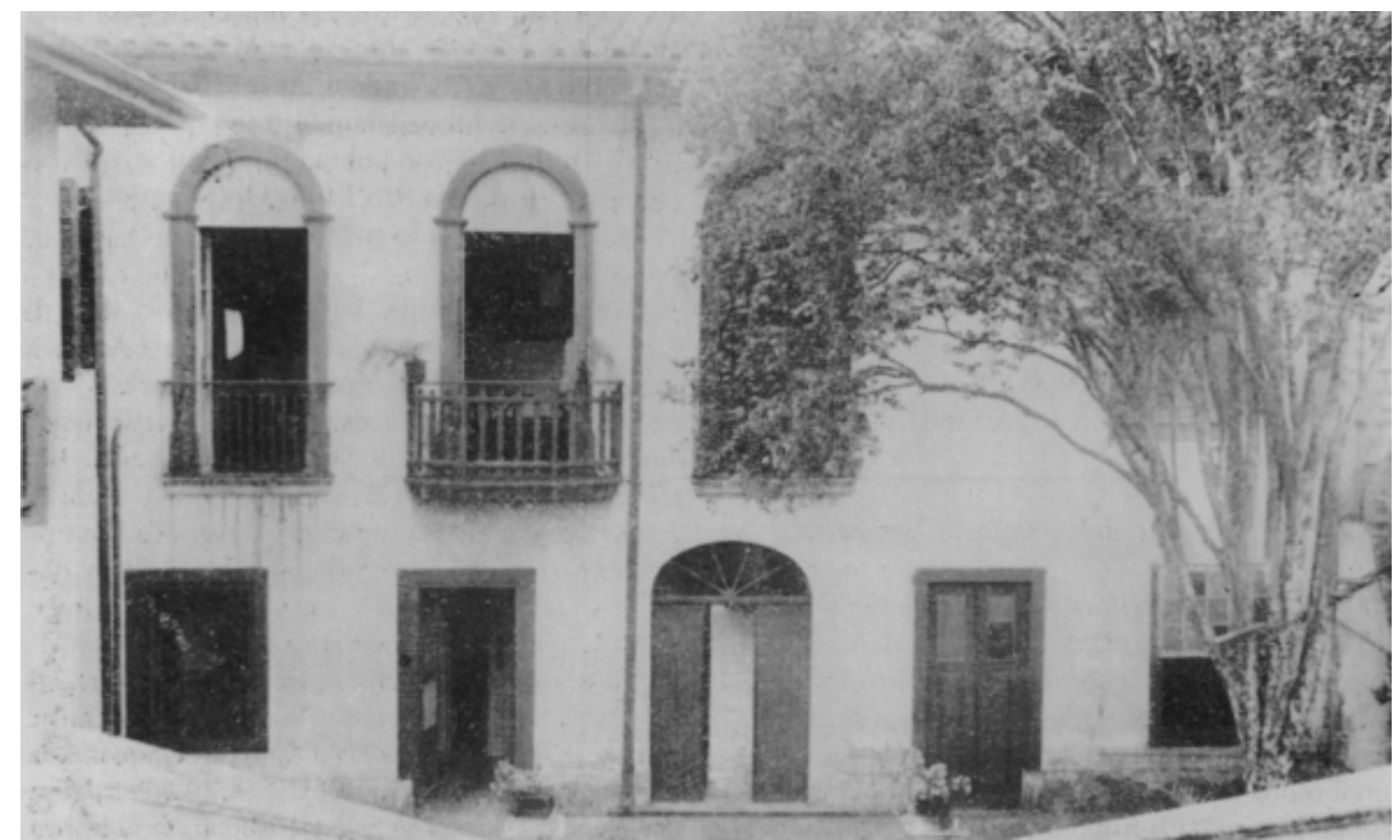

Figura 76 - Fundos da casa da chácara onde morou D. Veridiana Prado antes de se mudar para a Vila Maria.

Fonte: HOMEM, Maria Cecília Naclério. O palacete paulistano e outras formas urbanas de morar da elite cafeeira 1867-1918. São Paulo, Martins Fontes, 1996

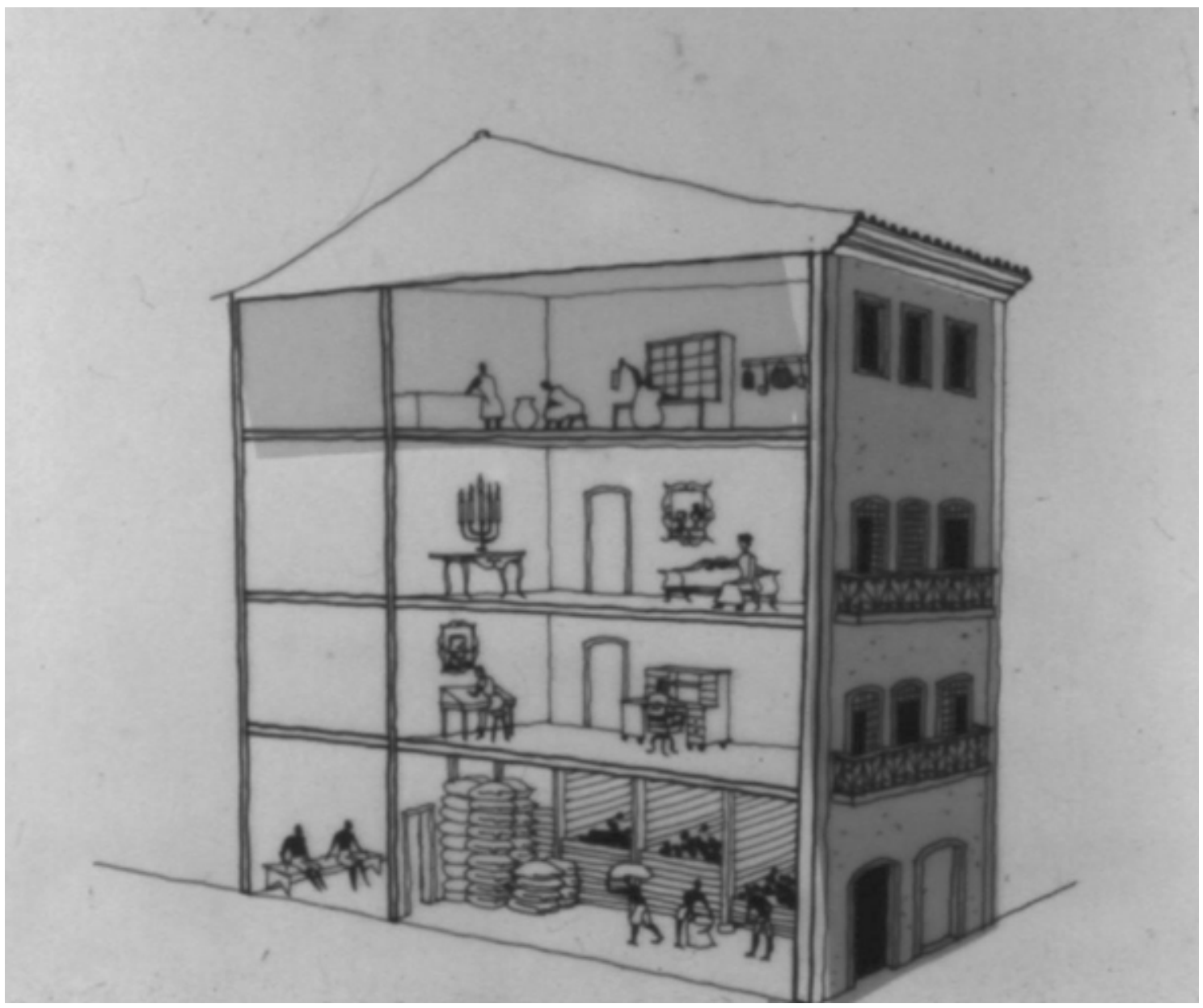

Figura 77 - Corte mostrando a organização de um sobrado no período colonial. Nos andares intermediários ficavam as áreas ocupadas pelos donos, e no superior a cozinha. Para que este sistema fosse viável, era necessária a presença de mão-de-obra escrava. 
chácaras que existiam em volta da cidade. Preferencialmente em lugares mais altos, que eram mais salubres. Isto, entretanto, nem sempre será a regra, já que como observa Villaça ${ }^{2}$, parte dos Jardins (a partir dos anos 1920) foi construída em áreas alagadiças.

O primeiro grande empreendimento imobiliário é o bairro de Campos Elíseos (1879), já localizado na "cidade nova", um loteamento com traçado que tende à ortogonalidade, onde se instalam alguns indivíduos de maiores posses. O auge deste bairro ocorre por volta de 1910, entrando em decadência em torno de 1930.

O bairro de Campos Elíseos não era exclusivamente residencial, assim como não era homogêneo o tamanho dos lotes, que variavam de pequenos lotes a grandes terrenos. O mesmo acontecia no bairro do Chá, e na Vila Buarque, outros loteamentos contemporâneos. Mas já aparecem os primeiros exemplares de residências com jardins na frente. Outra característica deste bairro é que nele é instalada uma infra-estrutura pouco usual até então: bondes elétricos, água encanada, esgotos, iluminação pública, gás domiciliar, arborização e ruas pavimentadas.

Pouco tempo depois surgem bairros onde a legislação é mais restritiva, obrigando à presença de recuos laterais e frontais. É o caso de Higienópolis e avenida Paulista, onde as leis na prática restringem empreendimentos de padrões baixo e médio. Ali surgirão grandes residências, construídas com padrões estéticos e técnicos mais refinados e sofisticados que os até então conhecidos.

Uma das transformações registradas refere-se ao programa adotado, notando-se uma maior especialização das funções, como é o caso das áreas de estar, subdivididas em numerosos ambientes como sala de recepções, sala de visitas, sala de música, sala de estar, sala da senhora, sala de jogo, bilhar, fumoir, sala de estudos, biblioteca, gabinete, jardim de inverno, etc. Criados europeus substituem parte das funções que eram desempenhadas pelos escravos, e professores também europeus passam a ministrar aulas de música, canto e outras artes, além de em muitos casos se ocuparem da educação dos filhos dos donos. Surge a governanta, e caracterizando o modelo europeu a ser seguido, falava-se cotidianamente em francês, como apontaram diversos viajantes. ${ }^{3}$

Mas estas casas não servem apenas para moradia. Numerosas atividades culturais ali acontecem, como exposições de arte, recitais de música e conferências, além de serem palco de importantes reuniões políticas. A recepção de visitas, as quais são convidadas com dia e hora marcadas, passa a ser um sinal de distinção.

O primeiro palacete em São Paulo teria sido o do barão de Piracicaba II, situado na rua brigadeiro Tobias, finalizado em 1877. ${ }^{4}$ Tinha 68 cômodos (34 dormitórios), 94 portas e 86 janelas (figura 78). Logo depois seria construído o palacete de D. Veridiana Valéria da Silva Prado, inaugurado em 1884, e que seria por muitos anos um dos mais importantes da cidade (figura 79).

Mas a maioria dos grandes palacetes surge nos últimos anos do século XIX e início do XX. Podemos citar entre outros a chácara do Carvalho (1893), a casa de dona Angélica de Barros (1890, baseada no Charlottenburg, de Berlim), o palacete

\footnotetext{
${ }^{2}$ VILLAÇA, Flávio. Espaço intra-urbano no Brasil. São Paulo, Studio Nobel/Fapesp/Lincoln Institute, 1998.

${ }^{3}$ HOMEM, Maria Cecília Naclério. Op. cit.

${ }^{4}$ Idem, ibidem.
} 


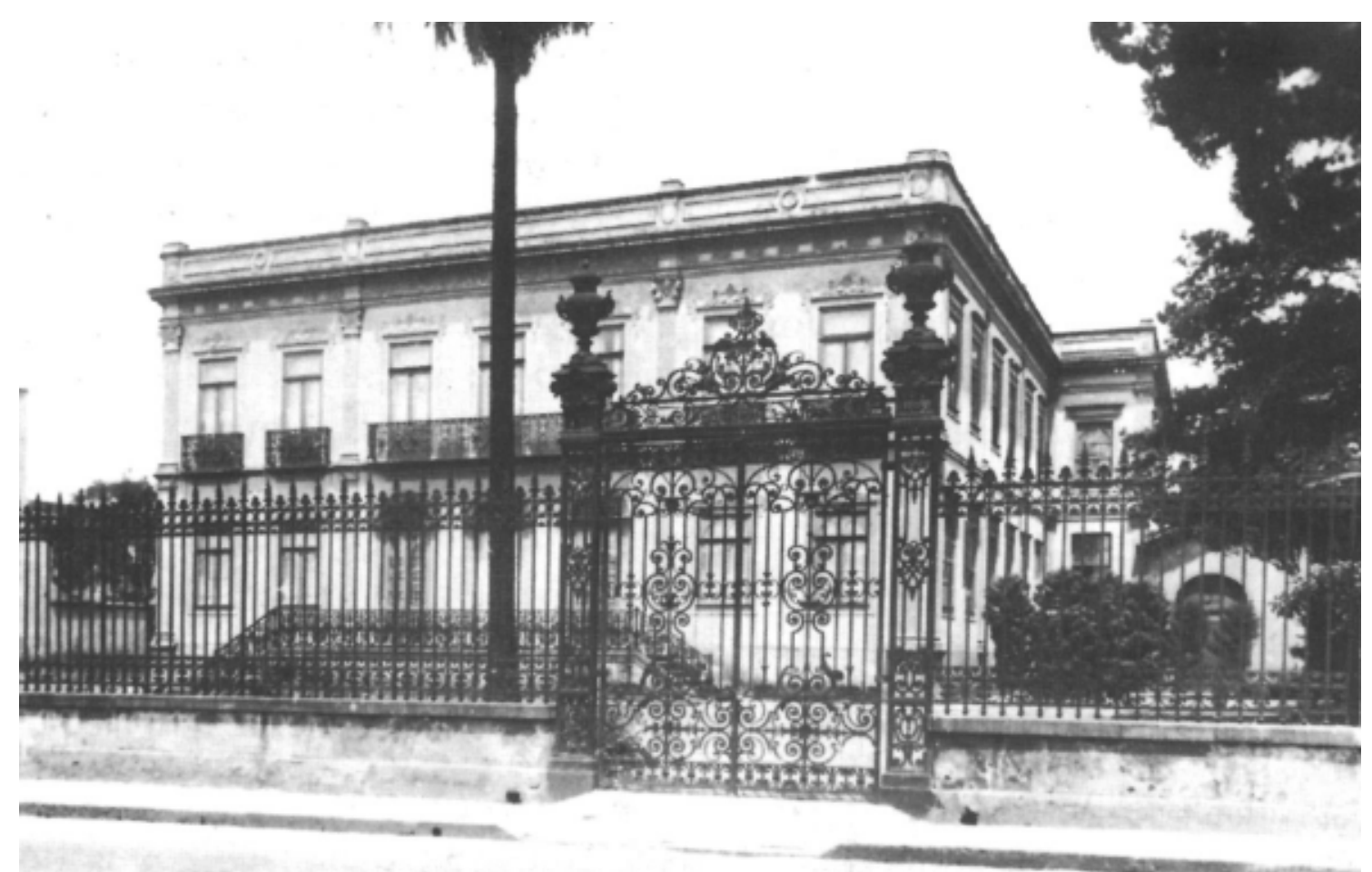

Figura 78 - Sobrado que pertenceu ao Barão de Piracicaba II.

Fonte: HOMEM, Maria Cecília Naclério. O palacete paulistano e outras formas urbanas de morar da elite cafeeira 1867-1918. São Paulo, Martins Fontes, 1996

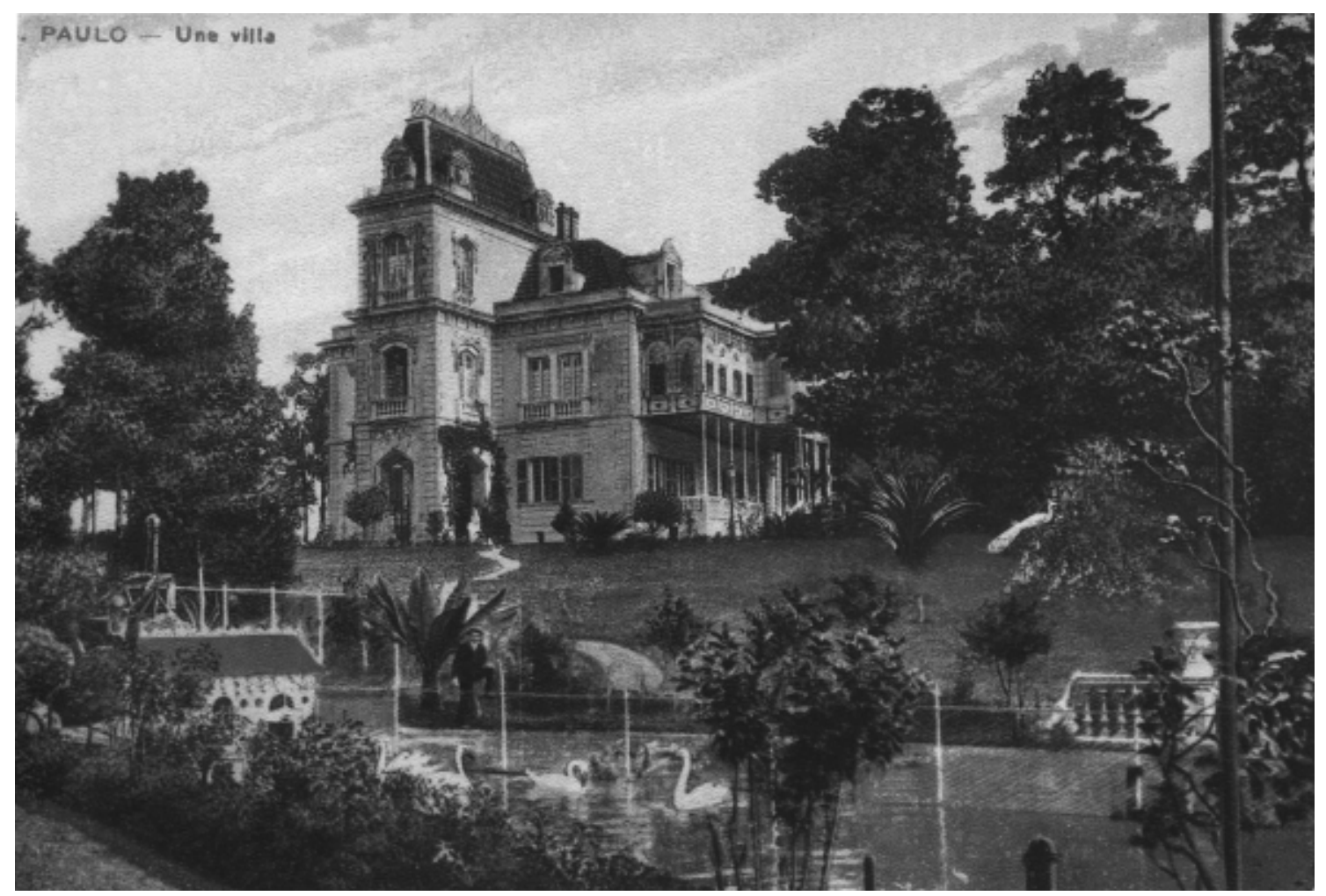

Figura 79 - Vila Maria. Palacete onde morou D. Veridiana Prado, localizado no bairro de Higienópolis.

Fonte: TOLEDO, Benedito Lima de. Prestes Maia e as origens do urbanismo moderno em São Paulo. São Paulo, Empresa das Artes, 1996 
Chaves (1899) ${ }^{5}$, o palacete de Ramos de Azevedo (1891), a casa de D. Olívia Guedes Penteado (1898). No século XX destacam-se construções como a Vila Penteado (1902) e a Vila Horácio Sabino (1903). Embora apresentassem diferenças, todos estes palacetes possuíam em comum a adoção de estilos europeus, utilizados como elementos simbólicos de distinção (figuras 80 a 86).

O arquiteto mais solicitado era Ramos de Azevedo, cujo escritório produziu uma enorme quantidade de residências, bem como boa parte dos principais edifícios públicos de então. Sem maiores ousadias, sua arquitetura adotava um repertório eclético, que respondia aos anseios dos clientes. Não se deve deixar de mencionar também seu espírito empresarial, cujas atividades iam desde o controle da importação e compra de materiais, até a formação de mão-de-obra. Foi o principal impulsionador do Liceu de Artes e Ofícios. ${ }^{6}$

A Vila Penteado (1904), onde atualmente funciona o curso de pósgraduação da FAUUSP, é projeto do arquiteto sueco Carlos Ekman. Sua arquitetura se baseava numa variante vienense do Art Nouveau, o estilo Sezession. Uma outra obra sua importante é a Fundação Álvares Penteado (1911), localizada no largo de São Francisco.

Outro grande expoente do período foi o arquiteto Victor Dubugras. Sua obra mostra, além de um grande refinamento, uma contínua procura de novos caminhos, já prenunciando o modernismo. Pela complexidade e originalidade, talvez possa ser apontado como o principal arquiteto da sua época, o que fica claramente evidenciado naquela que é considerada sua principal obra, a estação ferroviária de Mayrink (1906). ${ }^{7}$ Entre outros exemplos de sua obra nos primeiros anos do século XX podemos citar a Vila Uchoa (1902), a residência para Numa de Oliveira (1903) e a Vila Horácio Sabino (1903), situada onde hoje está localizado o Conjunto Nacional, na avenida Paulista (figura 86).

É interessante também notar que havia palacetes distribuídos em todo o entorno do antigo núcleo da cidade, exceto região leste (onde se localizavam os bairros operários). O palacete de Ramos de Azevedo, por exemplo, ficava na Liberdade. Isto caracteriza uma das diferenças com Buenos Aires, como veremos mais adiante. Na figura 87 vemos a distribuição dos palacetes em São Paulo.

\section{2 - BUENOS AIRES}

Em Buenos Aires, durante o período colonial e boa parte do século XIX, as elites habitavam no entorno da Plaza de Mayo. Estas famílias, chamadas "paquetas", residiam nos atuais bairros de San Telmo e Monserrat, localizados ao sul da praça. As áreas mais nobres situavam-se ao redor das igrejas de Santo Domingo, San Francisco

\footnotetext{
${ }^{5}$ REIS FILHO, Nestor Goulart. Campos Elíseos. A casa e o bairro. A tecnologia da construção civil em 1900. São Paulo, Secretaria da Ciência, Tecnologia e Desenvolvimento Econômico, s.d.

${ }^{6}$ LEMOS, Carlos A. C. Ramos de Azevedo e seu escritório. São Paulo, Pini, 1993.

7 REIS, Nestor Goulart. Racionalismo e Proto-Modernismo na obra de Victor Dubugras. São Paulo, FBSP, 1997.
} 


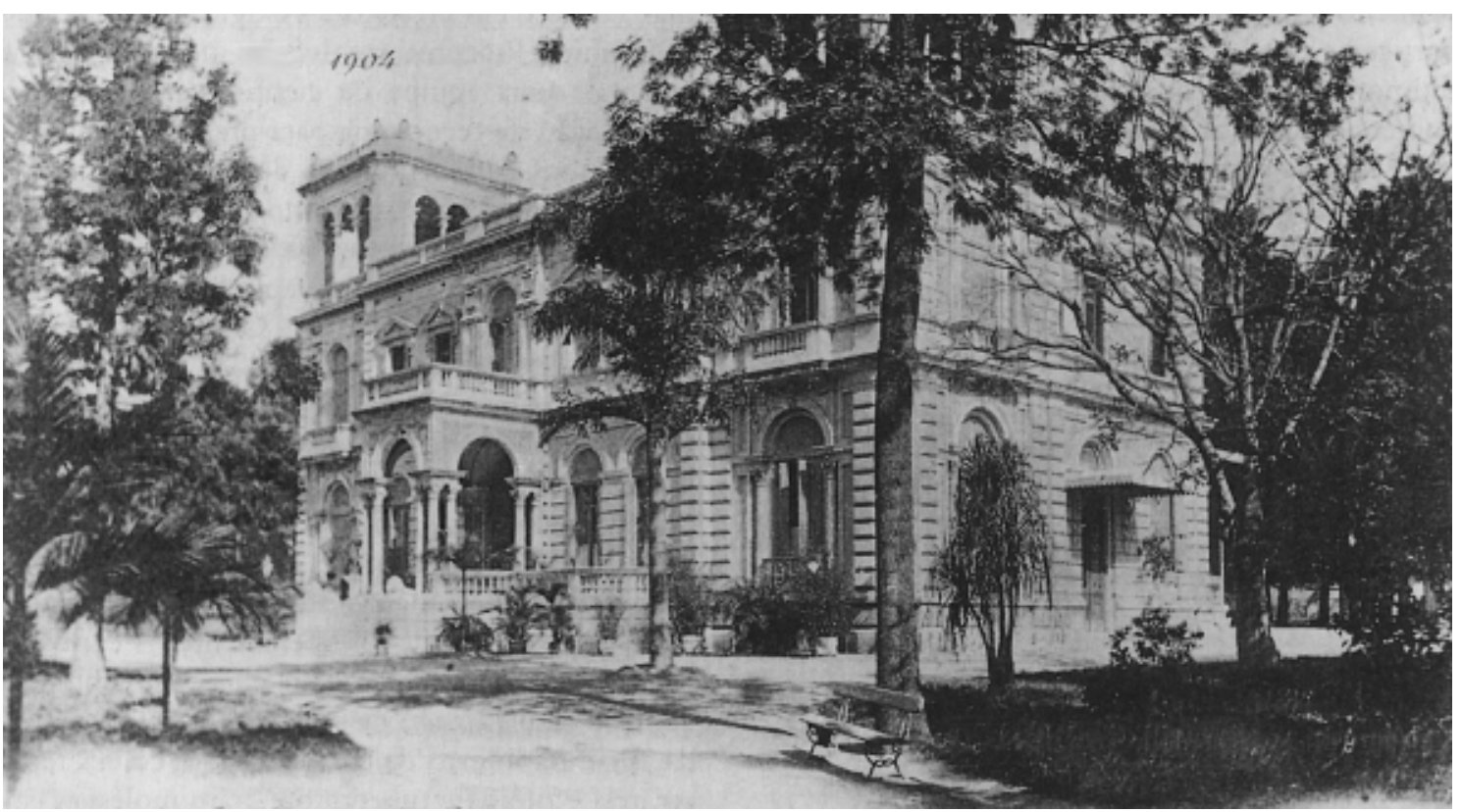

Figura 80 - Chácara do Carvalho

Fonte: HOMEM, Maria Cecília Naclério. O palacete paulistano e outras formas urbanas de morar da elite cafeeira 1867-1918. São Paulo, Martins Fontes, 1996

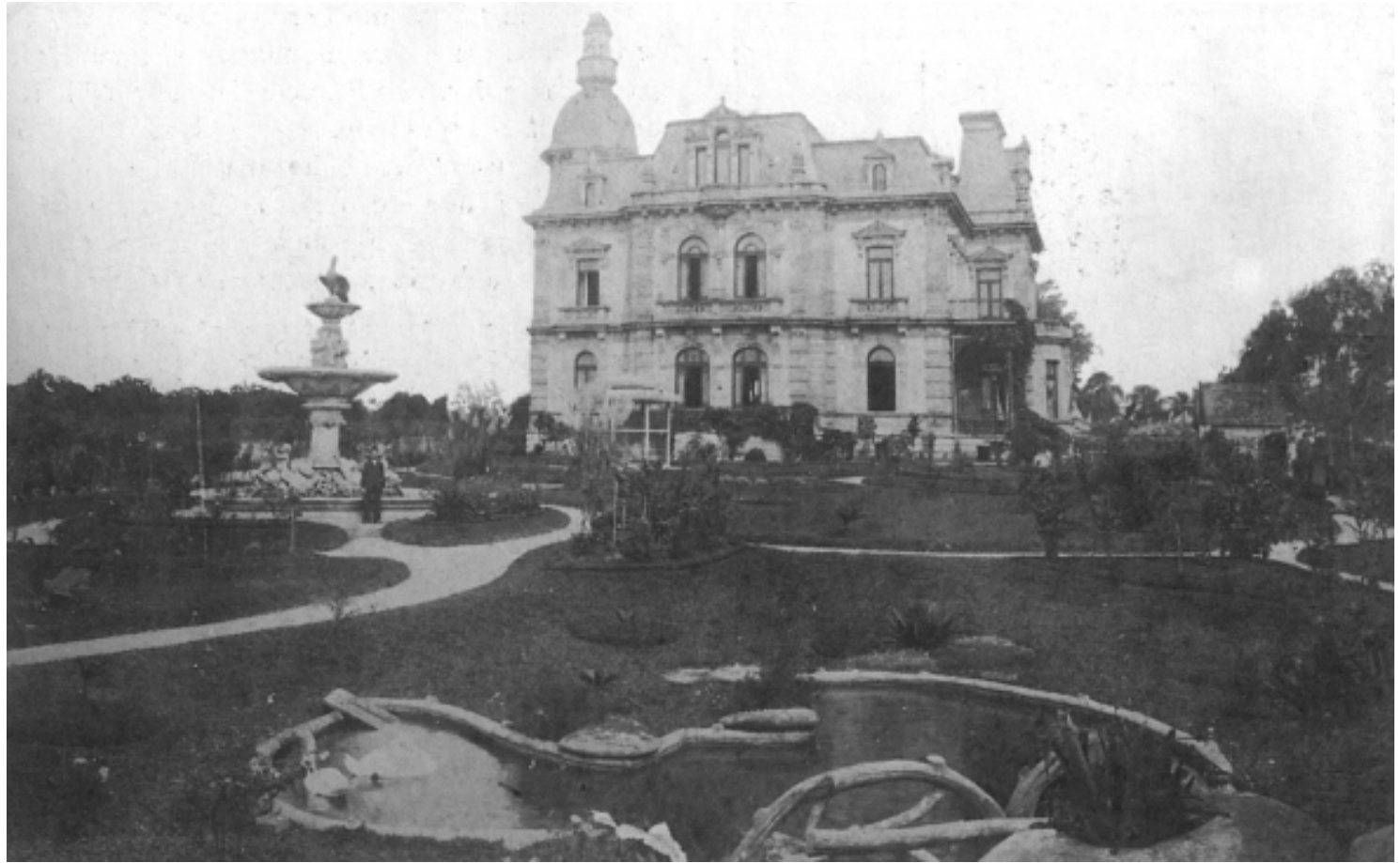

Figura 81 - Palacete de D. Maria Angélica Aguiar de Barros.

Fonte: HOMEM, Maria Cecília Naclério. O palacete paulistano e outras formas urbanas de morar da elite cafeeira 1867-1918. São Paulo, Martins Fontes, 1996 


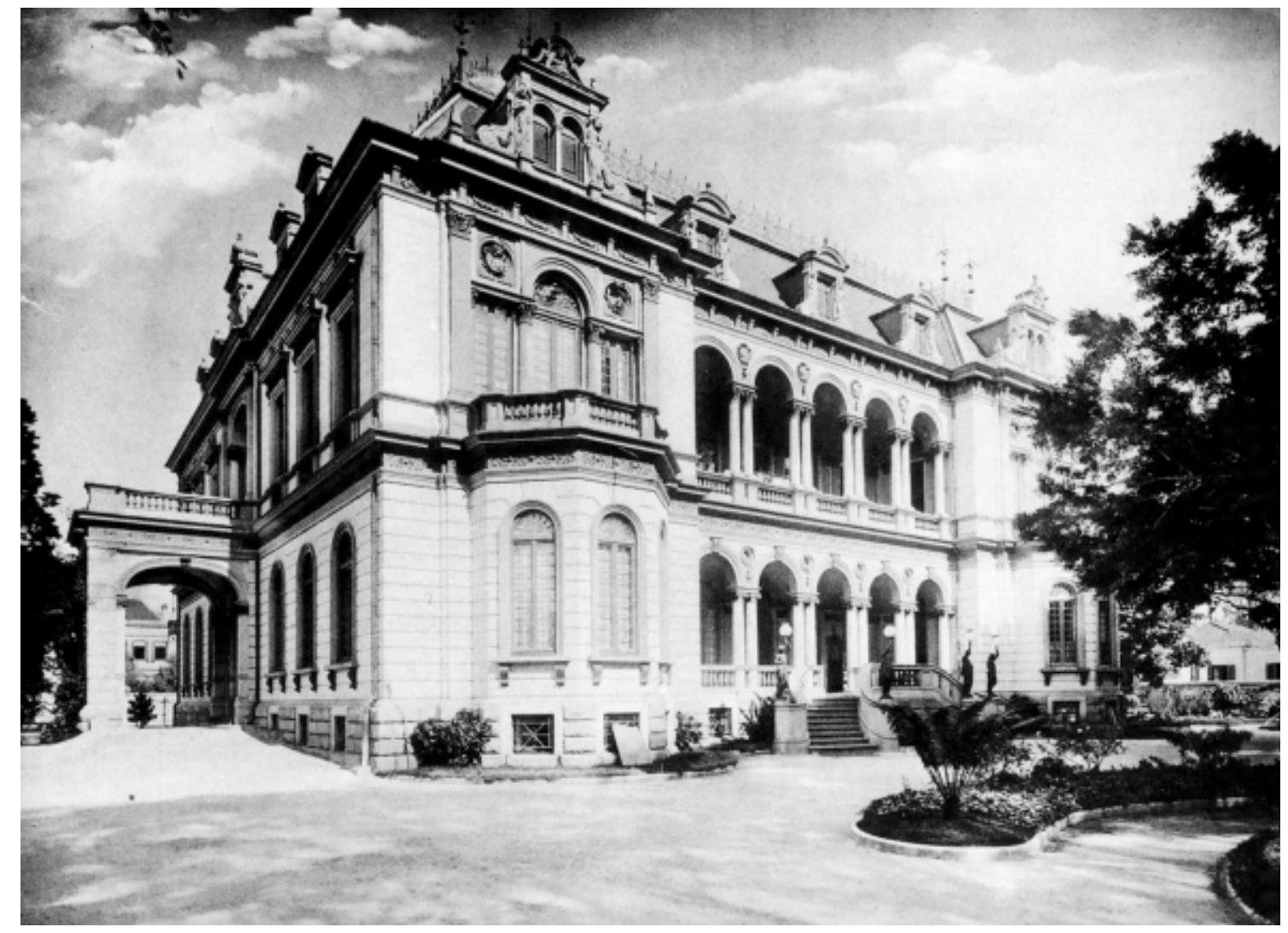

Figura 82 - Palacete Elias Chaves. A partir de 1915 passou a servir como residência oficial dos presidentes do Estado.

Fonte: REIS FILHO, Nestor Goulart. Campos Elíseos. A casa e o bairro. A tecnologia da construção civil em 1900. São Paulo, Secretaria da Ciência, Tecnologia e Desenvolvimento Econômico, s.d.

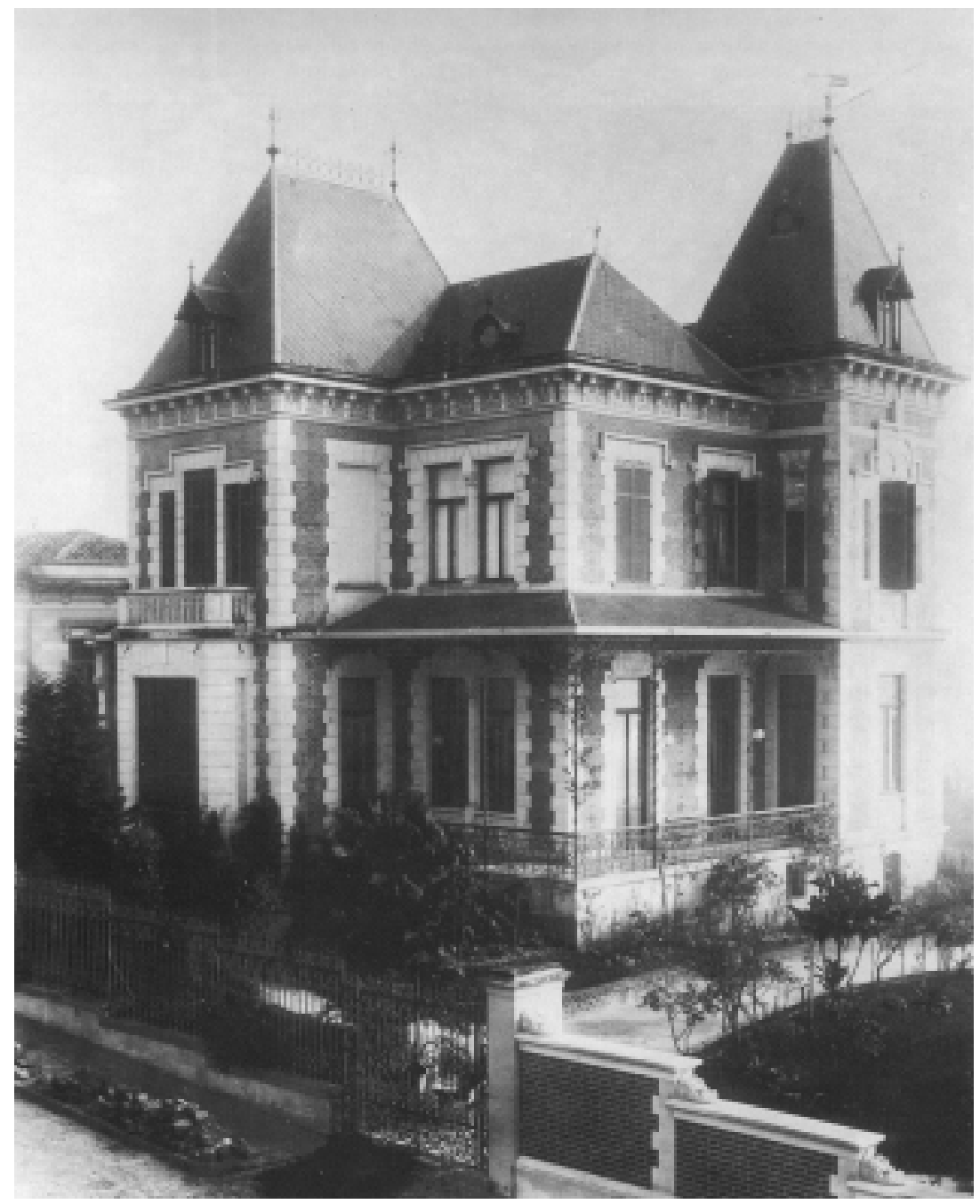

Figura 83 - Residência que pertenceu a Ramos de Azevedo, localizada no bairro da Liberdade.

Fonte: LEMOS, Carlos A. C. Ramos de Azevedo e seu escritório. São Paulo, Pini, 1993 


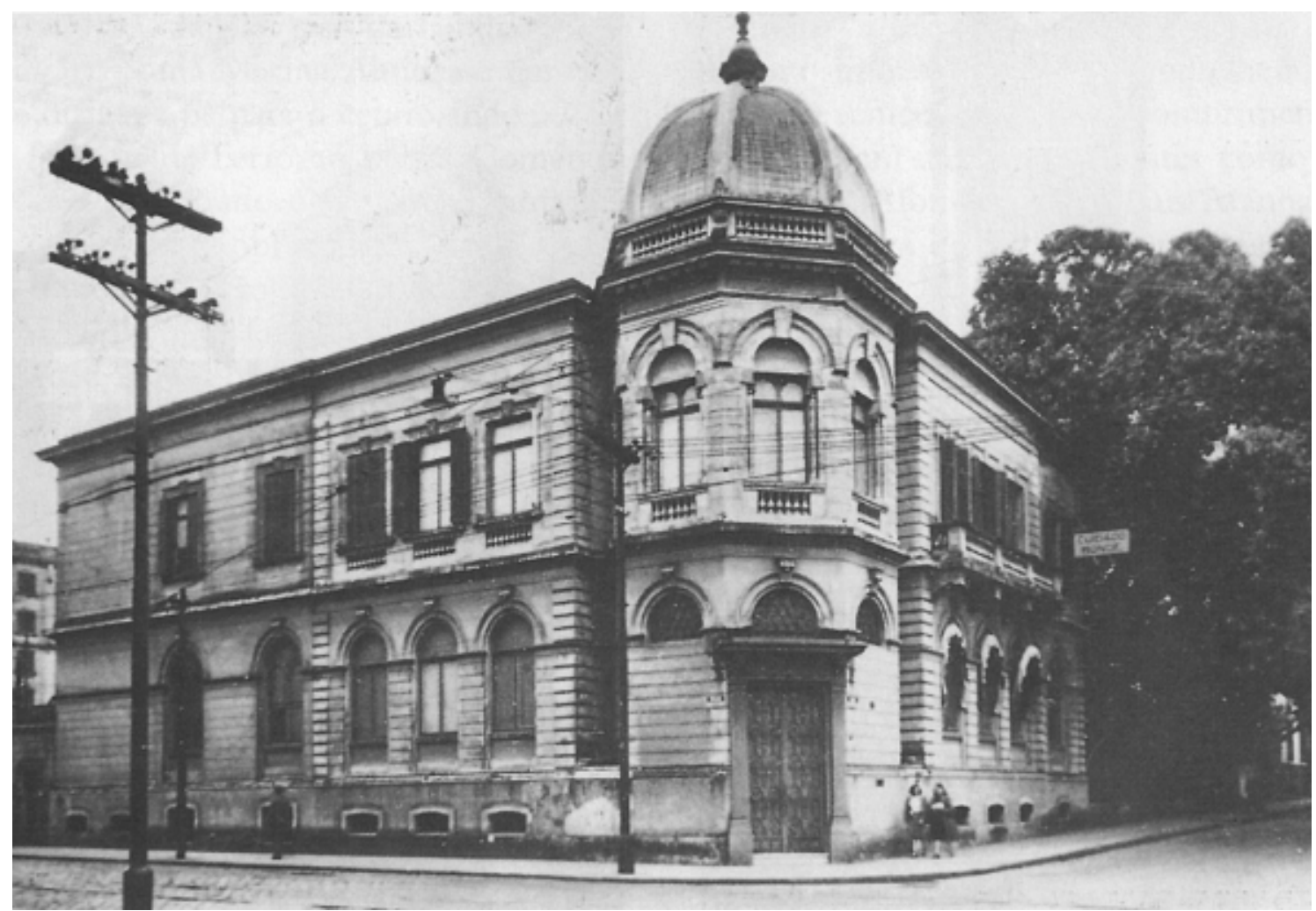

Figura 84 - Palacete de D. Olivia Guedes Penteado.

Fonte: HOMEM, Maria Cecília Naclério. O palacete paulistano e outras formas urbanas de morar da elite cafeeira 1867-1918. São Paulo, Martins Fontes, 1996

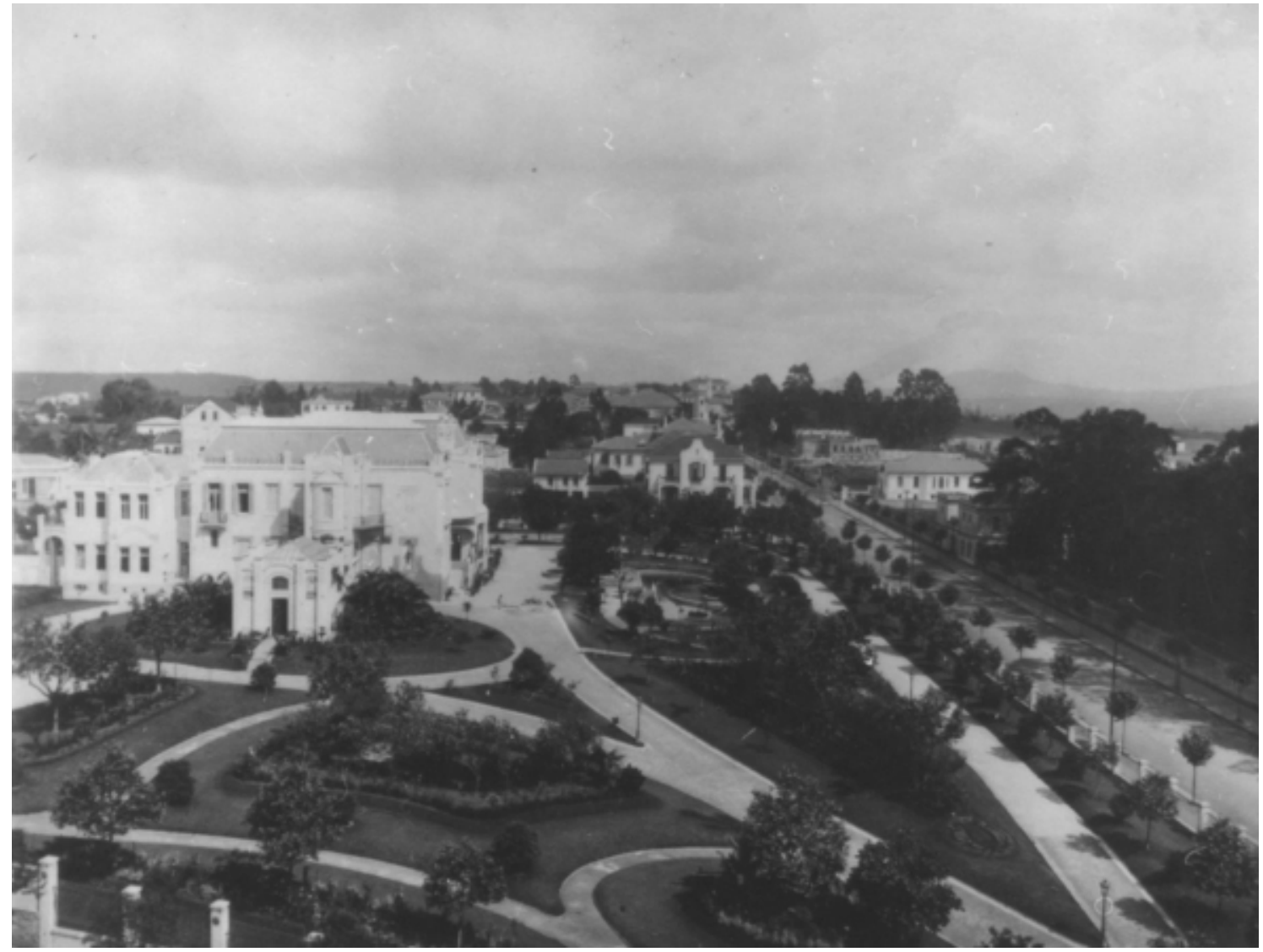

Figura 85 - Vila Penteado. Notar os grandes jardins, e a entrada, que era pela avenida Higienópolis. Atualmente ingressa-se pelos fundos, e a maior parte do terreno foi parcelado e vendido para a construção de prédios.

Fonte: Acervo LAP 


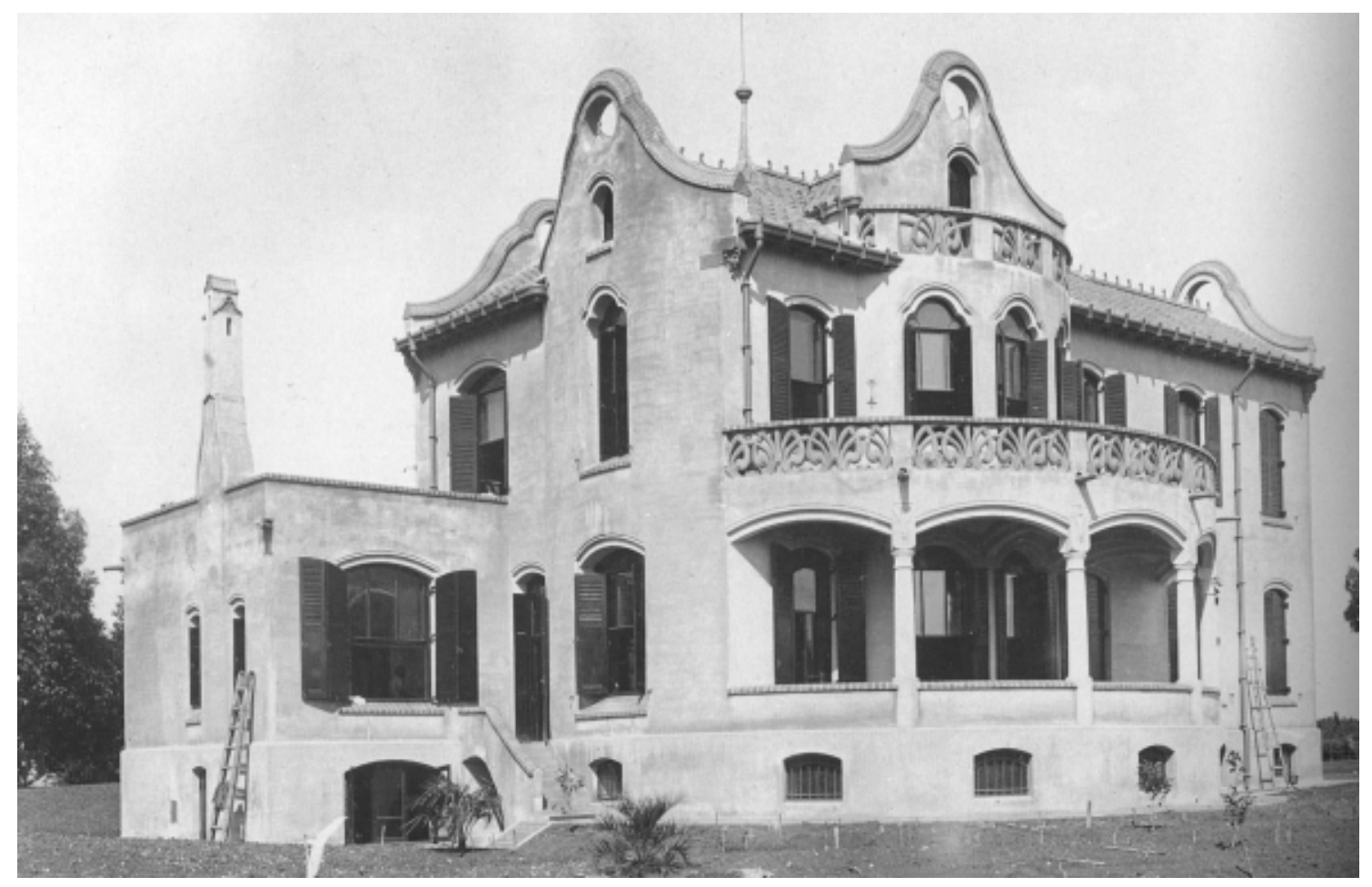

Figura $86 \quad-$ Residência de Horácio Sabino, projeto de Victor Dubugras.

Fonte: REIS, Nestor Goulart. Racionalismo e Proto-Modernismo na obra de Victor Dubugras. São Paulo, FBSP, 1997.

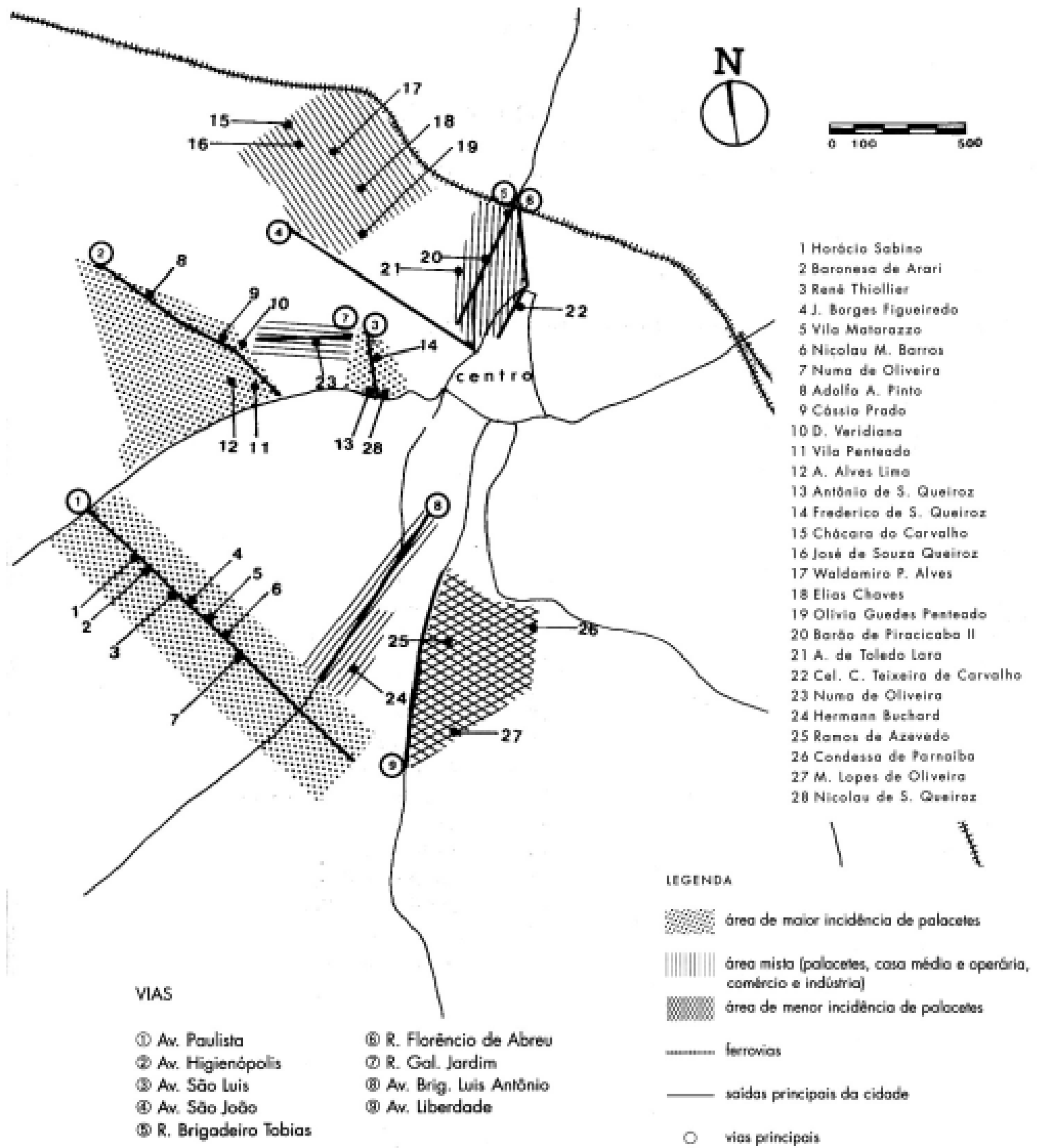

Figura $87 \quad-$ "Incidência e Localização dos Palacetes em S. Paulo”.

Fonte: HOMEM, Maria Cecília Naclério. $O$ palacete paulistano $e$ outras formas urbanas de morar da elite cafeeira 1867-1918. São Paulo, Martins Fontes, 1996 
e San Ignácio. Em meados do século XIX estas elites passam também a habitar o outro lado da praça, em torno da paróquia da Merced. ${ }^{8}$

A partir da década de 1870 aproximadamente, estas famílias começam a se mudar para novos bairros situados ao norte, ao mesmo tempo em que se inicia 0 grande crescimento da cidade (figura 88). Esta direção de crescimento é motivo de polêmicas entre os estudiosos. Mas um dos fatores que teriam definido a direção norte para os bairros nobres é a presença da casa e dos parques que haviam pertencido a Rosas, situados em Palermo. ${ }^{9}$ Outro fator teriam sido as epidemias, principalmente as do período 1871 a 1876, que fizeram com que estas famílias abandonassem suas casas nas áreas centrais e procurassem lugares mais salubres.

Scobie atribui esta diferenciação à opção por um dos projetos para a construção do porto, o de Madero, em detrimento do outro, de Huergo ${ }^{10}$ Este último apoiado por grupos nacionais situados ao sul da cidade, e o primeiro financiado por grupos estrangeiros, representando os grupos sociais localizados na região norte. A vitória do projeto Madero é que teria definido esta forma de crescimento para o norte. Esta hipótese foi criticada por Gorelik e Silvestri, que argumentam que os projetos para o porto não são excludentes, e que o desenlace da decisão é analisado a partir de uma configuração social referente a um período anterior. ${ }^{11}$

Trata-se de um processo gradual que começa com a construção de residências opulentas na Av. Quintana. Mais tarde abrem-se as avenidas Alvear e Libertador, que são progressivamente ocupadas. Ao mesmo tempo são trasladados as fábricas e o matadouro desta para outras partes da cidade, e a região recebe benefícios como água encanada, esgotos e transporte.

Assim como no caso de São Paulo, no lugar onde futuramente seriam erguidos os palacetes existiam casas em chácaras ou sítios, habitadas por famílias poderosas, muitas das quais de origem inglesa, que procuravam reproduzir o hábito de viver em maior contato com a natureza que traziam de seus países de origem. Similarmente, nos arredores era possível fugir das restrições edilícias vigentes na área central.

A partir principalmente do início do século XX surgem novas modalidades de residências para as camadas mais abastadas. Alicia Novick as divide em três tipos: as residências suburbanas, os grandes hotéis e os hotéis urbanos. ${ }^{12}$ As primeiras são residências situadas no meio de grandes parques, manifestando um desejo de isolamento em relação à cidade. Como exemplo podemos citar a casa de Alberto

\footnotetext{
${ }^{8}$ GUTIERREZ, Ramón. Buenos Aires. Evolución Histórica. Buenos Aires, Editorial Escala, 1990; NOVICK, Alicia. La traza de las grandes residências en la Recoleta, Buenos Aires (1880-1920). In: Buenos Aires, Anales del Instituto de Arte Americano e Investigaciones Esteticas "Mario J. Buschiazzo" N 26, 1988, p. 63-69; PETRINA, Alberto. Buenos Aires. Guia de Arquitectura. Buenos Aires, Municipalidad de la ciudad de Buenos Aires; Sevilha, Consejería de Obras Públicas y Transportes, 1994; SCOBIE, James R. Buenos Aires. Del centro a los barrios. 1870-1910. Buenos Aires, Solar/Hachette, 1977; SEBRELI, Juan José. Buenos Aires, vida cotidiana y alienación. . 15 a ed. Buenos Aires, Siglo Veinte, 1990; WAISMAN, Marina (coord.). Documentos para una historia de la arquitectura argentina. Buenos Aires, Ediciones Summa, 1988.

${ }^{9}$ NOVICK, Alicia. Op. Cit.

${ }^{10}$ Esta é a tese de SCOBIE, James. Op. cit.

${ }^{11}$ GORELIK, Adrián; SILVESTRI, Graciela. Imágenes al sur. Sobre algunas hipótesis de James Scobie para el desarrollo de Buenos Aires. In: Buenos Aires, Anales del Instituto de Arte Americano e Investigaciones Esteticas "Mario J. Buschiazzo" N² 27-28, 1989-1991, p. 93-104.

12 NOVICK, Alicia. Op. Cit.
} 
- Casas de la primera generación.

Casas de la primeia y la
segunda generaciones.

4 Casas de la se'gunda generación.

a Casas de la segunda y la

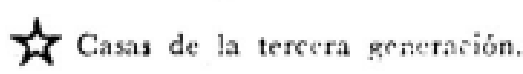

88 cas.us de ta cuarta genera ión.

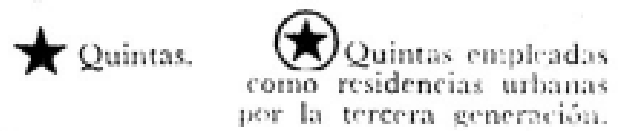

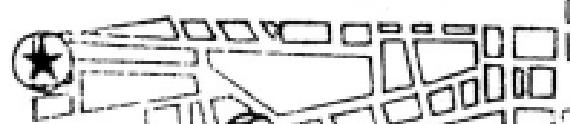

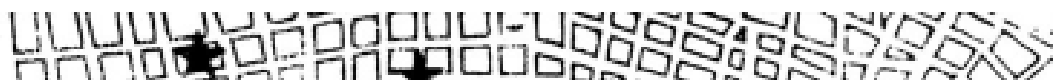

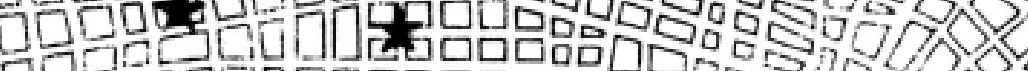

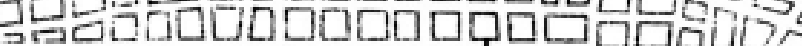

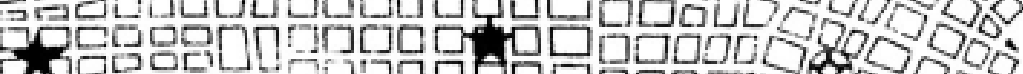

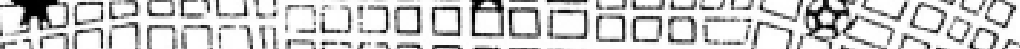

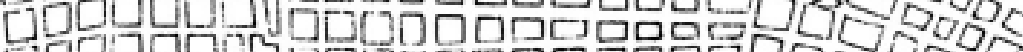

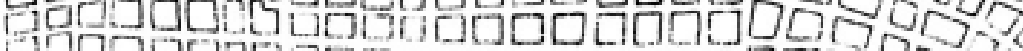

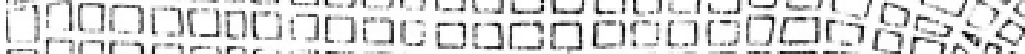
gagacan

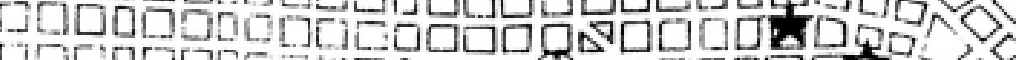
1 1.

G.JuEG

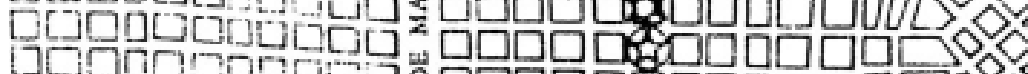

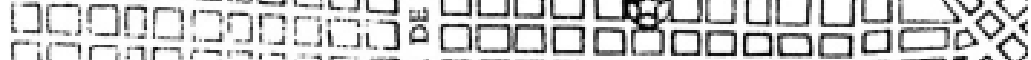

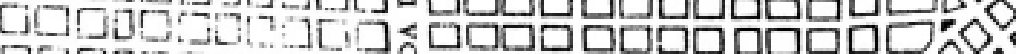

Depor juz AVENIDA 9 DE JULO

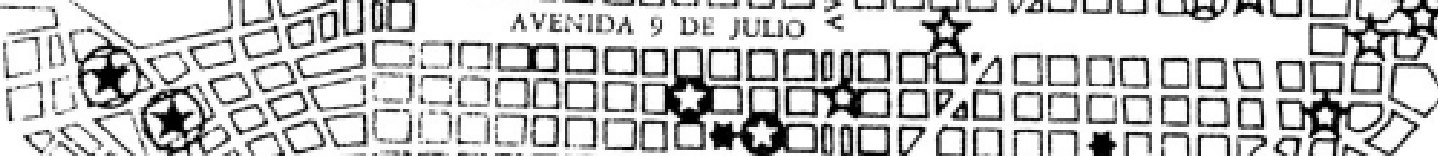
व 맨ㄷㄴ SS s

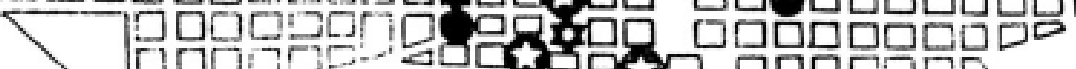

1:20000

ALEM

Figura 88 - Localização de algumas casas e sítios de 18 famílias de Buenos Aires através de três gerações.

Fonte: BALMORI, Diana; STUART, F.; WORTMAN, Miles. Las alianzas de familias y la formación del país en América Latina. México, Fondo de Cultura Econômica, 1990.

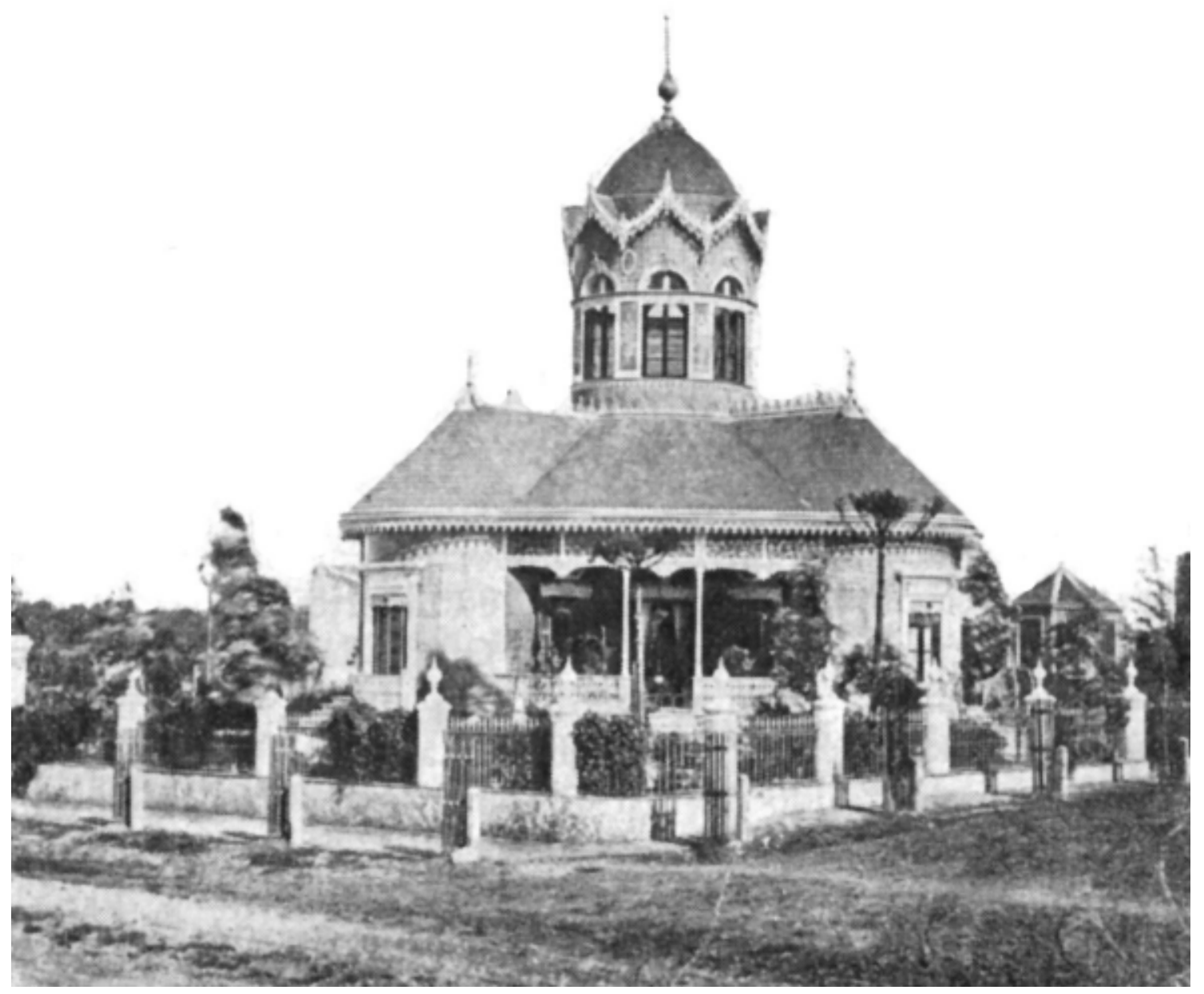

Figura 89 - Casa de verão da familia Rodriguez, localizada em Almagro.

Fonte: SCOBIE, James R. Buenos Aires. Del centro a los barrios. 1870-1910. Buenos Aires, Solar/Hachette, 1977. 
Williams em Belgrano, encomendada a Christophersen. ${ }^{13} \mathrm{Em}$ certas regiões do entorno, como Flores, Belgrano e Villa Devoto, podiam ser encontradas casas pertencentes a famílias ricas, que as utilizavam para veraneio. Por exemplo, o Palácio Antonio Devoto. Estes lugares eram apropriados por serem altos, portanto mais salubres nos quentes verões portenhos. Eram núcleos afastados da área central, mas que já na primeira década do século XX estavam incorporados à mancha urbana da cidade de Buenos Aires (figuras 89 e 90).

Os grandes hotéis ${ }^{14}$ estão localizados em áreas mais cêntricas, em geral em lugares de prestígio como praças e avenidas, e possuem um sofisticado aspecto exterior, que manifesta ao público um sinal de poder e riqueza do proprietário. Normalmente entre a fachada e a rua existiam jardins e entradas para carros, o que não impedia a visualização do edifício como acontecia com as residências suburbanas. São exemplos as atuais embaixadas do Brasil (antes Palácio Pereda. 1919-36) e França (antes Palácio Ortiz Basualdo. 1913), a Nunciatura (antes Palácio Fernandes Anchorena. 1919), o Círculo Militar (antigo Palácio Paz. 1912), a Chancelaria (antigo Palácio Anchorena, sobre a praça Martin. 1909) e o Palácio Errazuris (1920).(figuras 91 a 96).

Os hotéis urbanos se inserem de forma mais tradicional no tecido urbano. Quase sempre obedecem ao alinhamento da rua e demais edifícios do entorno e seu programa se desenvolve em três ou quatro níveis. Nos fundos do lote possuem jardins. Vistos da rua, podem ser confundidos com os edifícios de renda ou com o chamado petit-hôtel. O Petit-hôtel ocupa um lote mais estreito e é um desenvolvimento na vertical da antiga casa de pátios, cuja organização era horizontal (figura 97). Os edifícios de renda possuíam unidades independentes, garantindo ao proprietário o lucro dos aluguéis. Este sistema persistiu até 1947 (figuras 98 e 99). ${ }^{15}$

É importante assinalar que a qualidade de muitas destas obras deve-se à participação de excelentes arquitetos, entre os quais podemos citar Alejandro Christophersen, René Sergent (que por sinal nunca pisou em solo argentino), Lanús e Hary, Jules Dormal, Francisco Tamburini, Victor Meano, Carlos Altgelt e Norberto Maillart. ${ }^{16}$

\section{3 - COMPARAÇÃO}

Comparando as tipologias destinadas às camadas mais abastadas em ambas cidades, percebemos que em São Paulo predominavam os palacetes implantados em grandes lotes, muitos dos quais ocupavam um quarteirão ou mais, formando verdadeiros parques, localizados no entorno da cidade. Em Buenos Aires, além destes, existiam também as grandes residências localizadas em áreas mais centrais, com um tipo de relação mais direta com o espaço público, seja pela

\footnotetext{
${ }^{13}$ Idem, ibidem.

${ }^{14}$ Apesar da designação "hotel", tanto os grandes hotéis como os hotéis urbanos são apenas residências particulares, semelhante a determinadas tipologias na França, como Palau e Maison, que recebiam a mesma designação.

${ }^{15}$ Quando, segundo Novick, quando passa a existir o sistema legal de propriedade horizontal. NOVICK, Alicia. Op. Cit.

${ }^{16}$ GUTIERREZ, Ramón. Op. Cit.
} 


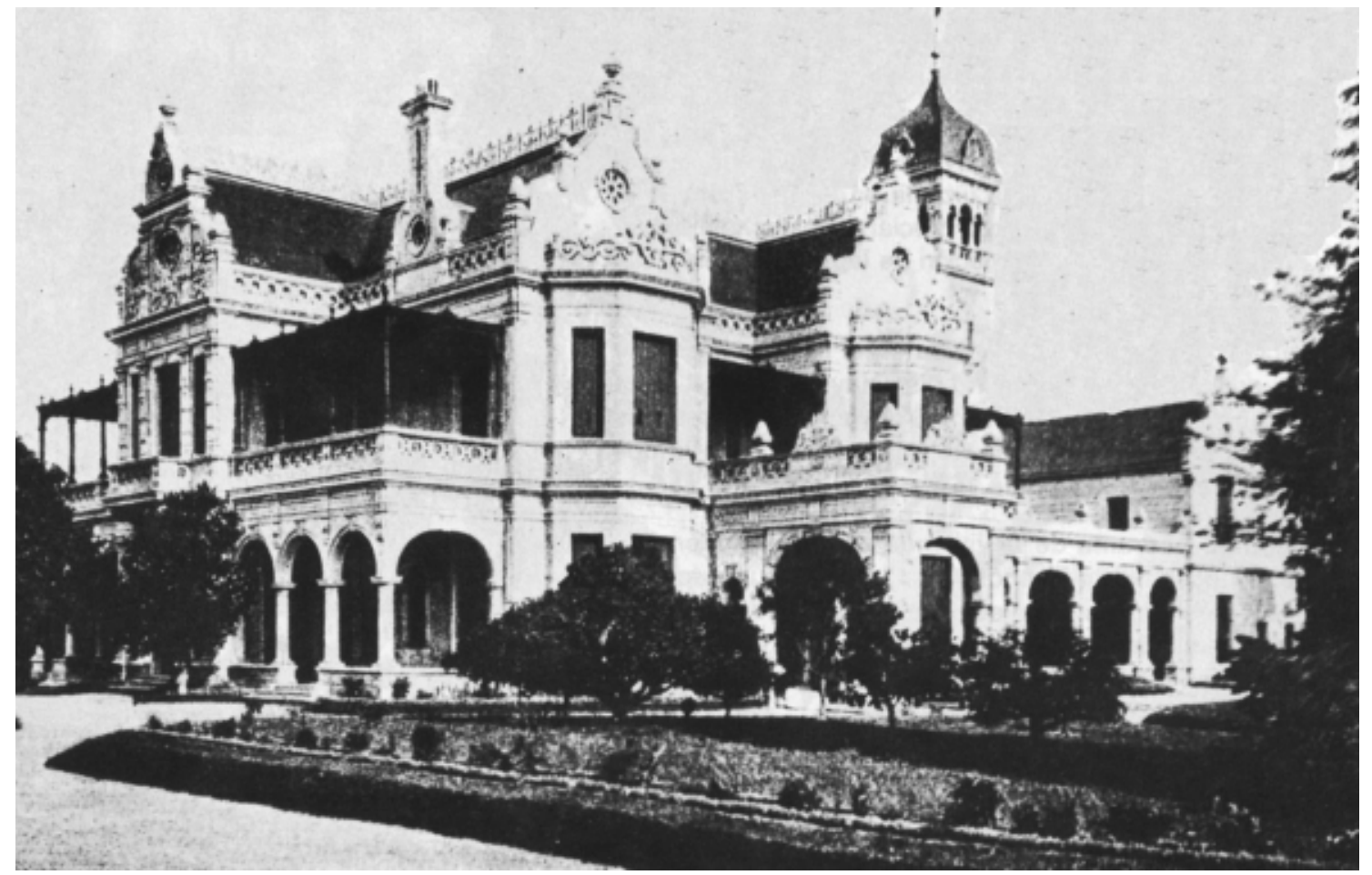

Figura 90 - Casa de verão no sítio Santa Felicitas, localizada em Barracas (sul da cidade de Buenos Aires), em fins do século XIX.

Fonte: GUTIERREZ, Ramón. Buenos Aires. Evolución Histórica. Buenos Aires, Editorial Escala, 1990.

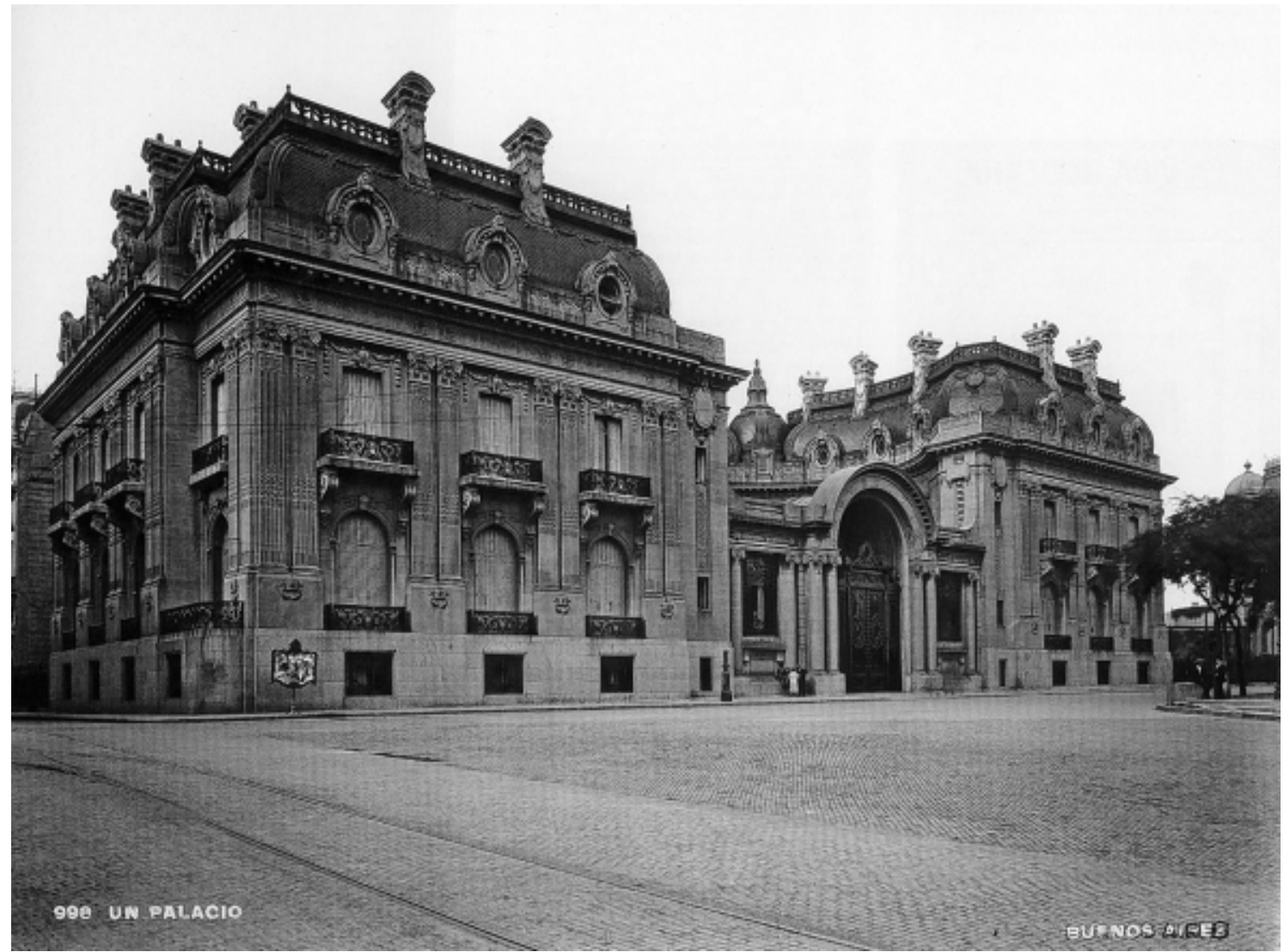

Figura 91 - Palacio da familia Anchorena, atual Chancelaria. Está localizada na praça San Martin.

Fonte: GUTMAN, Margarita (ed.). Buenos Aires 1910: memoria del porvenir. Buenos Aires, Gobierno de la Ciudad de Buenos Aires/ Faculdade de Arquitetura, Design e Urbanismo da Universidade de Buenos Aires/ IIED-America Latina, 1999. 


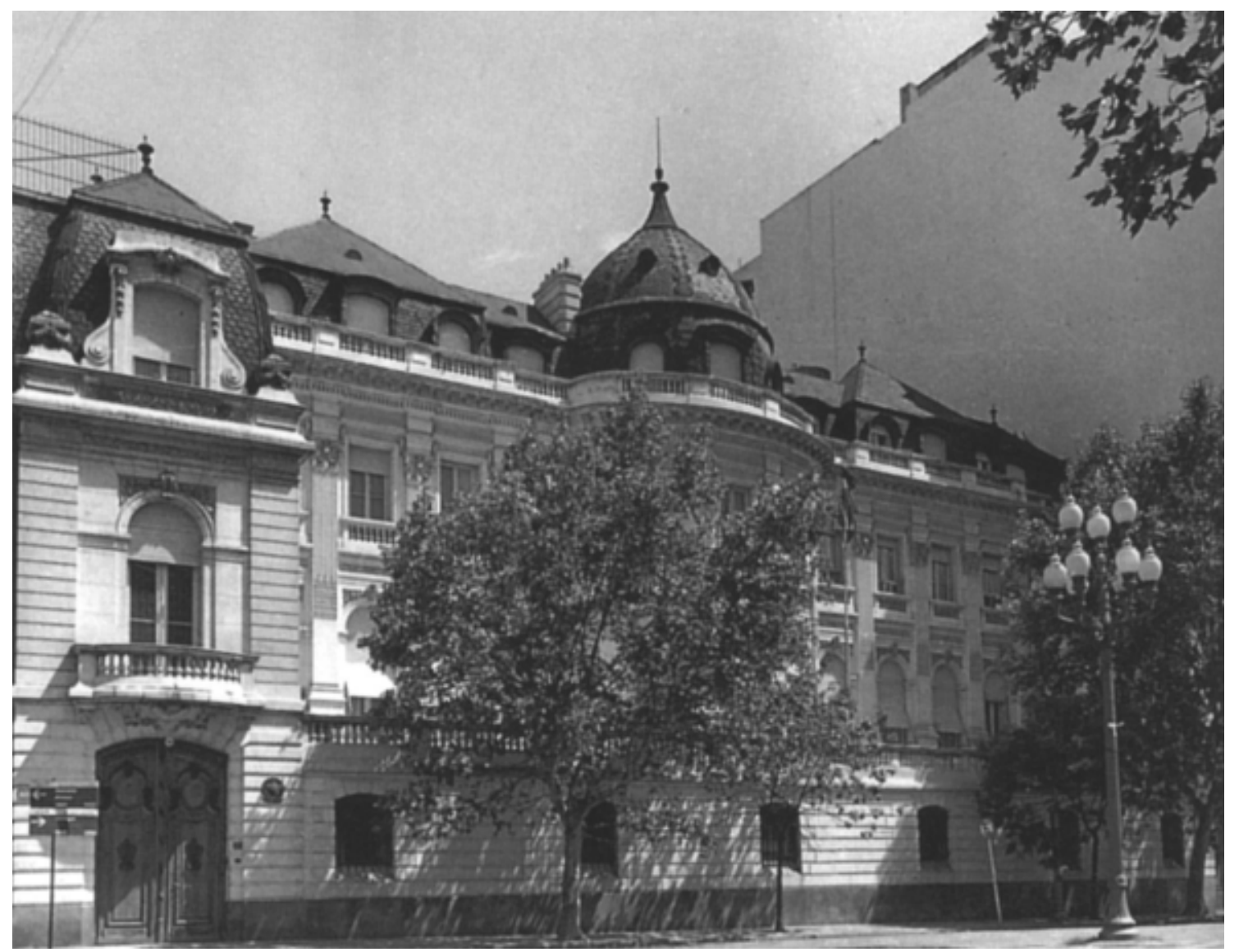

Figura 92 - Palacio Pereda, projeto de Louis Martín e Julio Dormal.

Fonte: PETRINA, Alberto. Buenos Aires. Guia de Arquitectura. Buenos Aires, Municipalidad de la ciudad de Buenos Aires; Sevilha, Consejería de Obras Públicas y Transportes, 1994.

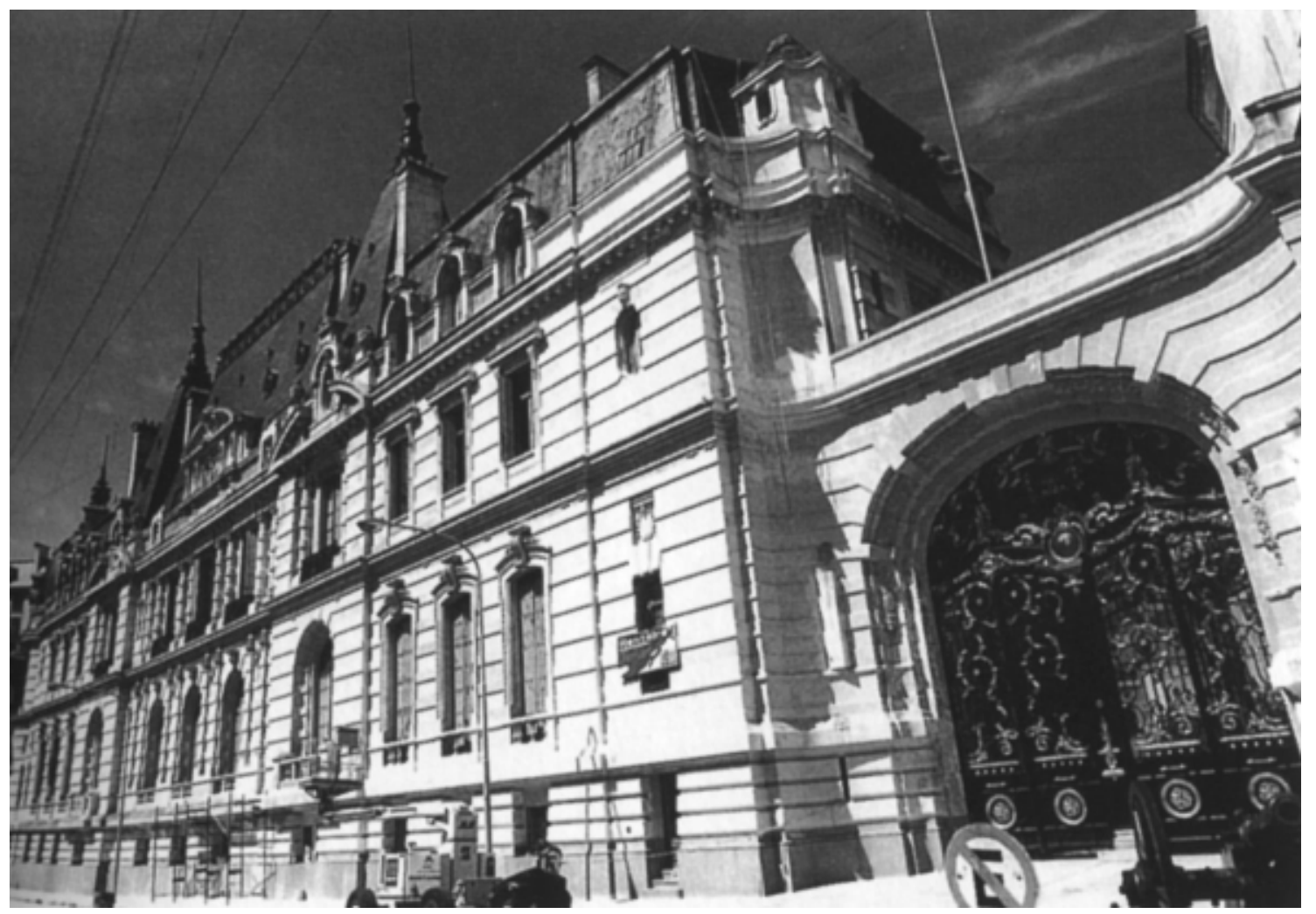

Figura 93 - Palacio Paz, sobre a praça San Martin. Atulamente alí funciona o Circulo Militar.

Fonte: PETRINA, Alberto. Buenos Aires. Guia de Arquitectura. Buenos Aires, Municipalidad de la ciudad de Buenos Aires; Sevilha, Consejería de Obras Públicas y Transportes, 1994. 


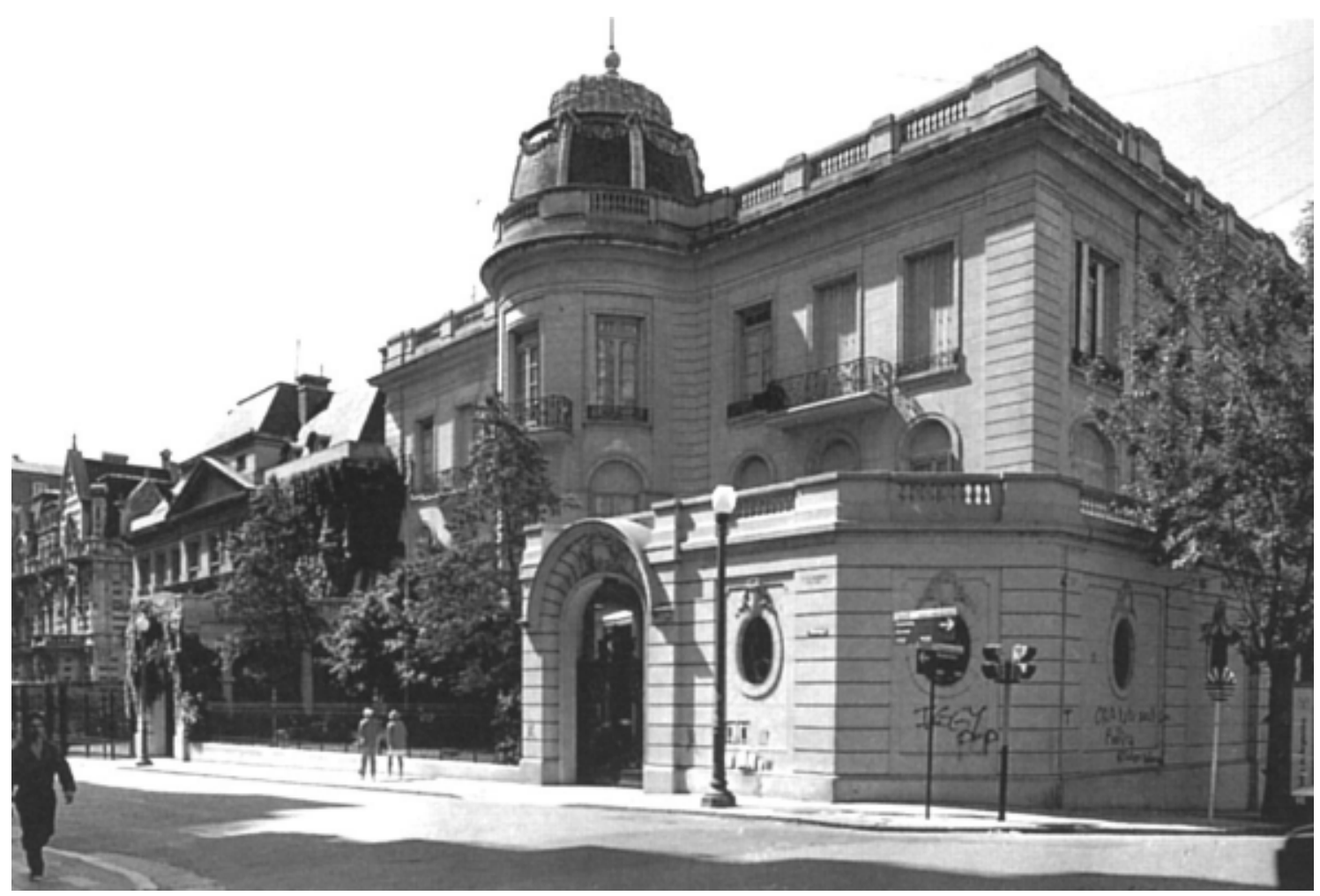

Figura 94 - Palacio Fernández de Anchorena, atual Nunciatura Apostólica. Projeto de Eduardo Le Monnier.

Fonte: PETRINA, Alberto. Buenos Aires. Guia de Arquitectura. Buenos Aires, Municipalidad de la ciudad de Buenos Aires; Sevilha, Consejería de Obras Públicas y Transportes, 1994.

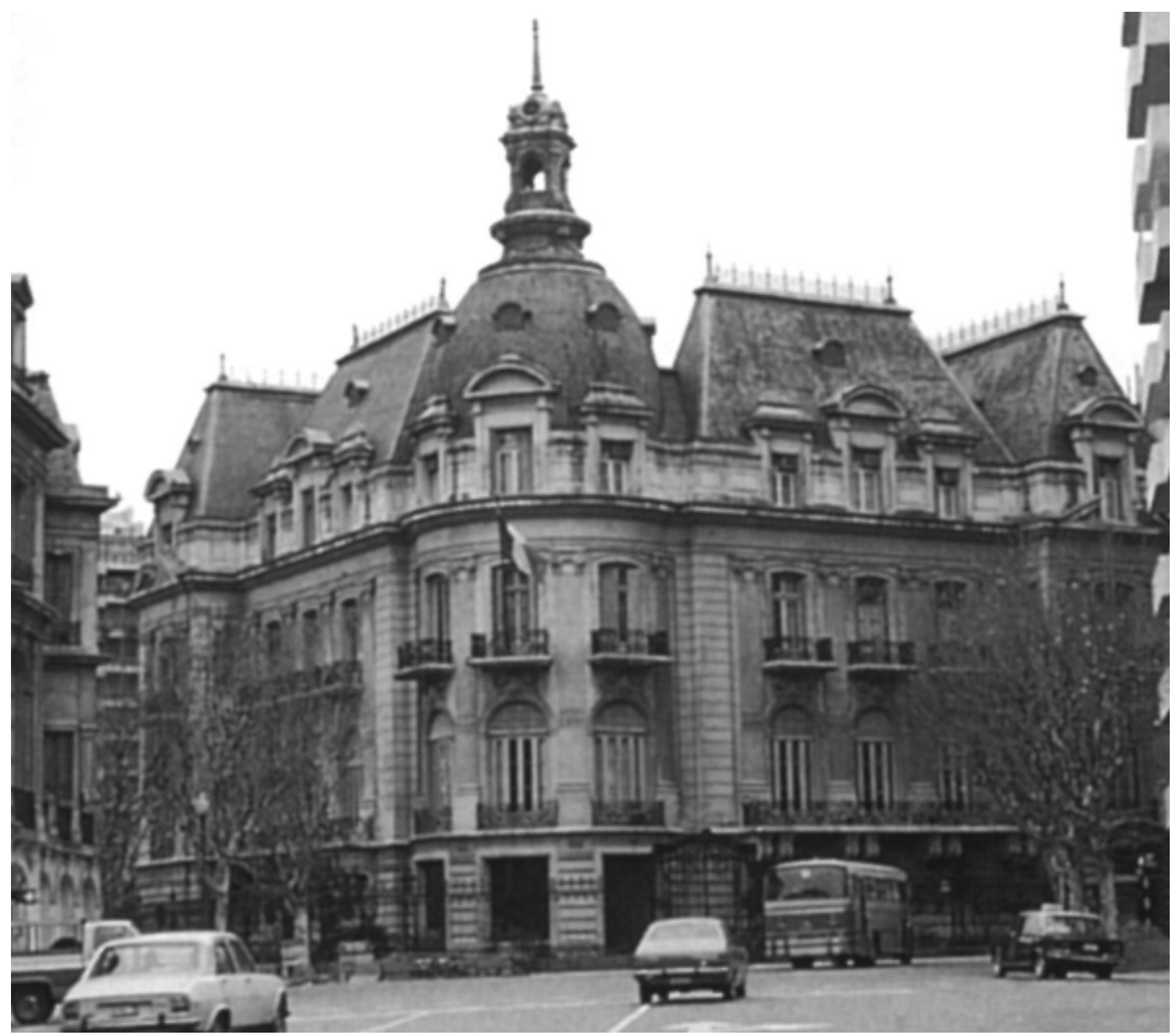

Figura 95 - Palacio Ortiz Basualdo, atual embaixada da França.

Fonte: PETRINA, Alberto. Buenos Aires. Guia de Arquitectura. Buenos Aires, Municipalidad de la ciudad de Buenos Aires; Sevilha, Consejería de Obras Públicas y Transportes, 1994. 


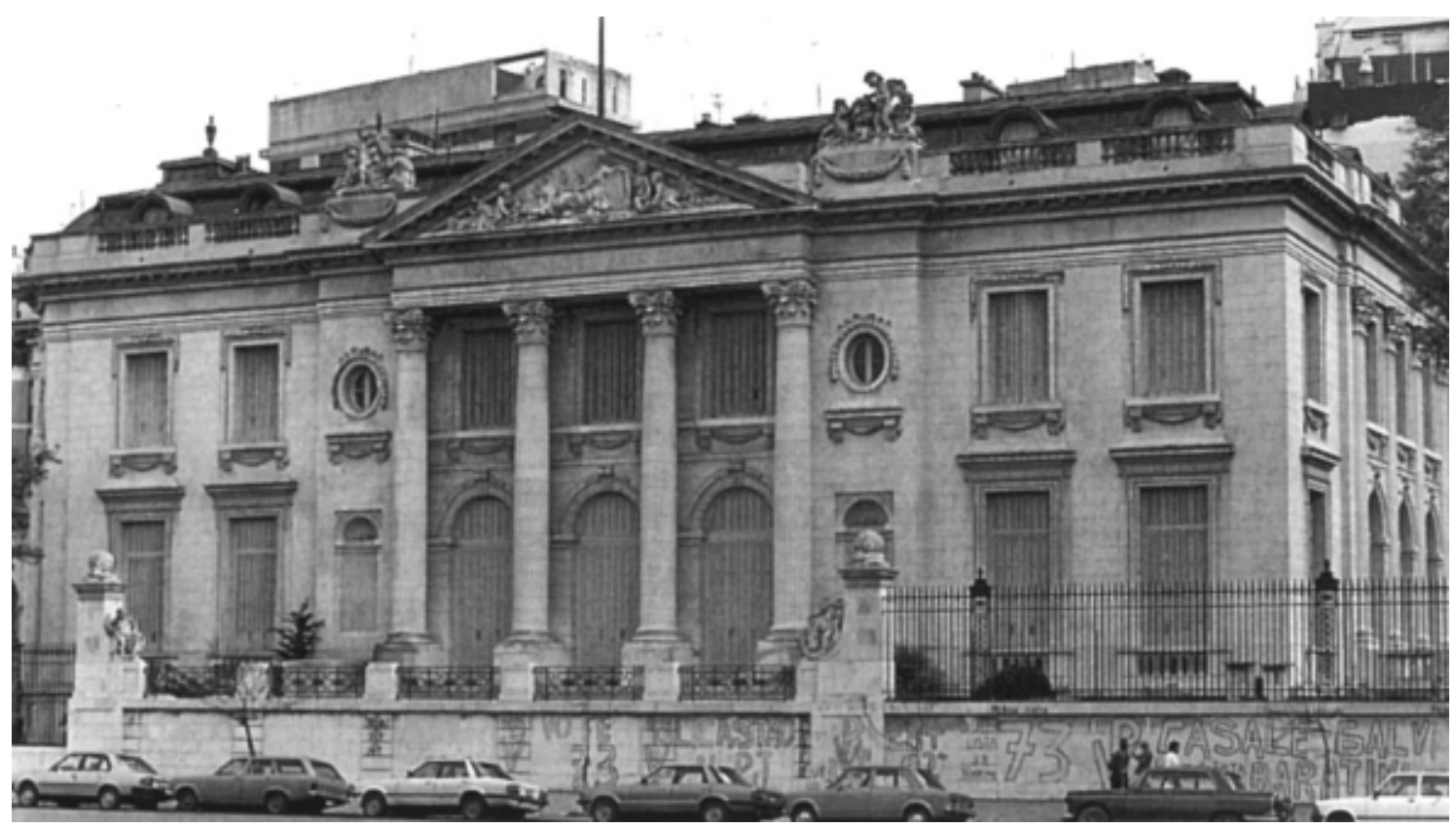

Figura 96 - Antigo Palacio Errázuris. Atualmente sede do Museu Nacional de Arte Decorativo e Arte Oriental.

Fonte: PETRINA, Alberto. Buenos Aires. Guia de Arquitectura. Buenos Aires, Municipalidad de la ciudad de Buenos Aires; Sevilha, Consejería de Obras Públicas y Transportes, 1994.

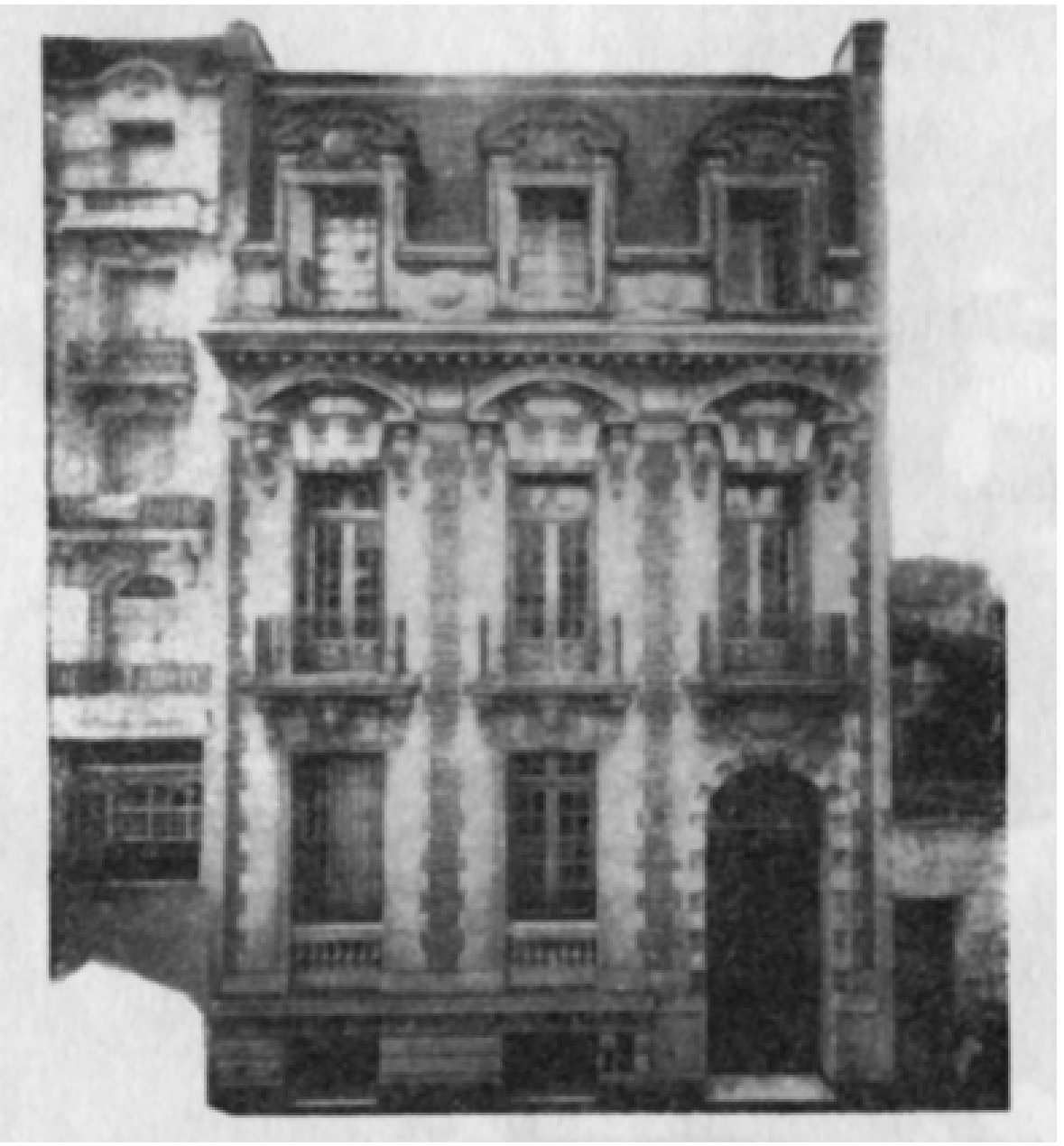

Figura 97 - Petit Hôtel, projeto de A l e j a n d r o Christophersen.

Fonte: WAISMAN, Marina (coord.). Documentos para una historia de la arquitectura argentina. Buenos Aires, Ediciones Summa, 1988. 


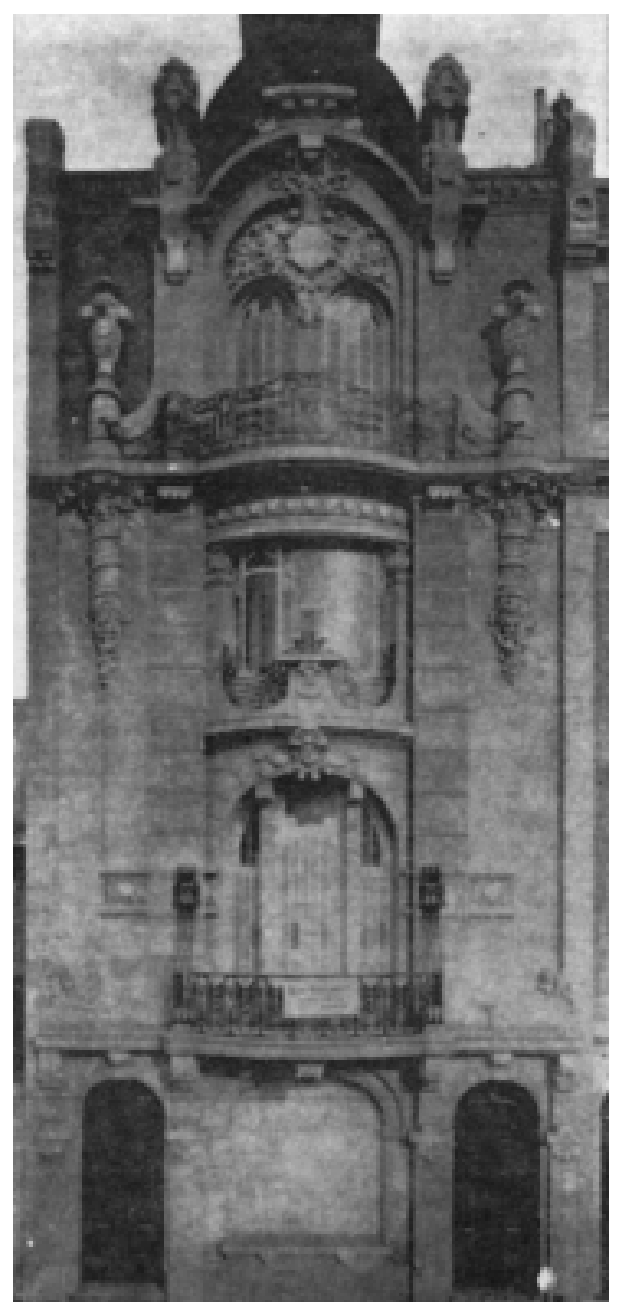

Figura 98 - Casa de renda, localizada na avenida de Mayo 916. Também projeto de Alejandro Christophersen.

Fonte: WAISMAN, Marina (coord.). Documentos para una historia de la arquitectura argentina. Buenos Aires, Ediciones Summa, 1988.

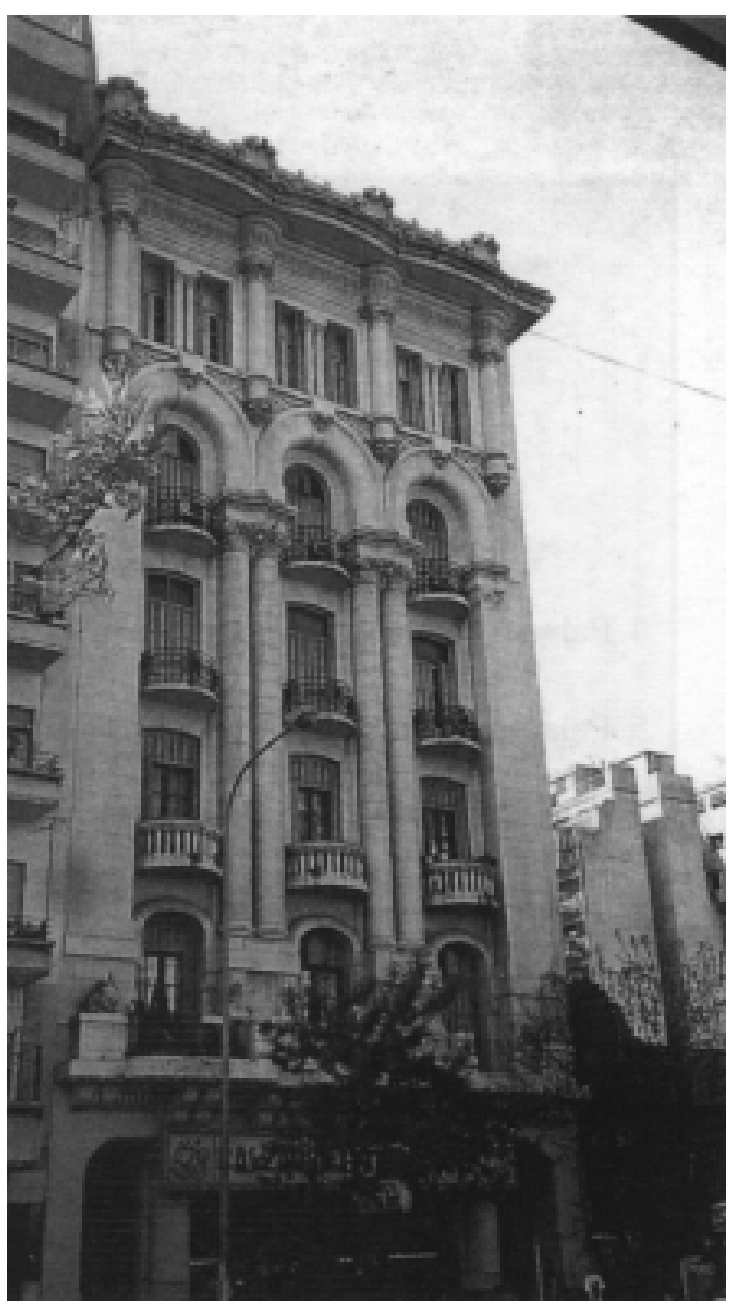

Figura 99 - Casa de renda, de autoria de Mario Palanti. Av. Rivadavia 2625.

Fonte: ALIATA, Fernando. Cuadernos de Historia 8. La cantera de la historia. Mario Palanti y la construcción de una poética ecléctica en Argentina. Buenos Aires, IAAIE "Mario J. Buschiazzo”, junho de 1997. 
importância e visualização da fachada, como pela ausência de recuos, que quando existiam eram modestos.

Não é fácil encontrar uma explicação para esta diferença, já que estas camadas sociais tinham em ambas cidades o mesmo propósito, qual seja o de manifestar através da arquitetura sua posição privilegiada na sociedade. Mas evidencia que situações sociais semelhantes não necessariamente conduzem as soluções arquitetônicas iguais. Isto permite inclusive relativizar a tradicional explicação para Buenos Aires a respeito da mudança para o norte devido à epidemia de febre amarela. Em São Paulo, mesmo sem a ocorrência de epidemias tão intensas, também se verifica o fenômeno da migração das famílias mais ricas do centro para outras áreas. Isto indica que mesmo sem a febre amarela, é muito provável que em Buenos Aires esta migração tivesse ocorrido da mesma forma.

Por outro lado, coincidem a linguagem adotada, que se bem variava quanto aos estilos utilizados, era essencialmente resultado de cópias de modelos europeus. Utilizava-se o que era moda na Europa, procurando legitimar uma identidade entre as elites locais e as do velho continente. Isto criava uma situação no mínimo curiosa, principalmente no caso das antigas famílias locais, já que os receptores destes significados eram em sua maioria genuinamente europeus, embora pobres.

Certamente uma análise mais aprofundada de outros aspectos referentes ao projeto, como programa e partido adotado, ou ainda a respeito de usos e funções das residências, deve ser capaz de apontar outras diferenças. Entretanto, do ponto de vista desta tese, é importante assinalar que esta arquitetura tem implícita uma profunda carga simbólica, baseada na imitação de modelos, enquanto que os aspectos técnicos guardam pouca relação com as efetivas condições locais, já que nestes casos técnicas, mão-de-obra e materiais eram quase todos importados. ${ }^{17}$

Em outras palavras, é uma arquitetura "transplantada" da Europa para a América, o que limita a capacidade explicativa decorrente da análise destas residências principalmente às questões de valor. Mais adiante, ao analisar a arquitetura associada às camadas médias, verificaremos que como a relação entre espaço e sociedade é bastante distinta, é possível formular outras explicações para o processo de urbanização no período.

\footnotetext{
17 Somente mais tarde passará a existir conhecimento e produção de componentes que irá diminuir essa dependência. Além disso, principalmente a partir dos anos 1920, também surgirão alguns movimentos, como o neocolonial e algumas vertentes do modernismo, que buscarão uma oposição ao que era estrangeiro, materializada através da utilização de elementos "locais" na arquitetura.
} 
CAPÍTULO 6

\section{PRODUÇÃO DO ESPAÇO PÚBLICO: OS PARQUES}




\section{$6.1-$ ANTECEDENTES}

Durante o período colonial não era usual a presença de árvores e outros espécimes vegetais nas cidades. Era o caso, em Buenos Aires, da Praça Maior, característica do urbanismo hispano-americano. Era essencialmente um espaço cívico, em torno do qual estavam localizados os principais edifícios e onde residiam os vizinhos mais importantes. Ali também era realizado um intenso comércio, conferindo à praça características de mercado.

O primeiro passeio público de fato na cidade é a chamada "Alameda", de 1757, que ficava na beira do Rio da Prata. Era o único espaço de passeio da cidade naquele então. Ainda em 1836 era freqüentado pela sociedade de Buenos Aires. Tornou-se ponto de reunião de nacionais e estrangeiros que o percorriam a pé, em carruagem ou a cavalo. Segundo D'Orbigny podia ser comparado em variedade, movimento e encanto com os Corsos de Roma e de Nápoles, com o Hyde Park de Londres, ou com os Campos Elíseos, de Paris. ${ }^{1}$

Outras praças que funcionavam como mercados eram as atuais praças Dorrego, Lorea, Miserere e Constitución.

As praças começam a assumir novas características ao mesmo tempo que surgem os edifícios destinados exclusivamente para mercados, o que ocorre na segunda metade do século XIX. A partir desse momento, estas praças começam a ganhar vegetação e um tratamento paisagístico mais apurado, passando a ser utilizadas para espairecimento, passeio e recreação.

Não é diferente o caso do Brasil. Em geral no período colonial as áreas livres eram os largos, não existindo praças como as conhecemos hoje. Mesmo os edifícios públicos em geral careciam de plantas e árvores.

Isto começou a mudar a partir da segunda metade do século XIX quando, aos poucos, o espaço público começa a ganhar um novo tratamento. Podemos encontrar na ladeira de São Bento, em Salvador, um exemplo interessante da transição entre as casas coloniais, que definiam as ruas com suas fachadas, e a incorporação de jardins. Isto pode ser observado na figura 100, quando no final do século XIX aos poucos os moradores das casas irão apropriar-se do espaço público com a construção de jardins na frente. ${ }^{2}$

Em São Paulo, como podemos observar na figura 101 que corresponde a um mapa de São Paulo de 1841, os principais edifícios são representados sem vegetação. ${ }^{3}$ Notar também que a única área verde é o Jardim da Luz, bastante afastado naquela época da área ocupada.

\footnotetext{
${ }^{1}$ Censo General de la Ciudad de Buenos Aires. 1909. Tomo III, p. 556.

${ }^{2}$ REIS, Nestor Goulart. Notas sobre História da Arquitetura e aparência das vilas e cidades. Cadernos de Pesquisa do LAP 20. São Paulo, FAUUSP, julho-agosto de 1997.

${ }^{3}$ Planta da Imperial Cidade de S. Paulo (1841). SÃO PAULO (CIDADE). São Paulo antigo: plantas da cidade. São Paulo, Comissão do IV Centenário, 1954.
} 

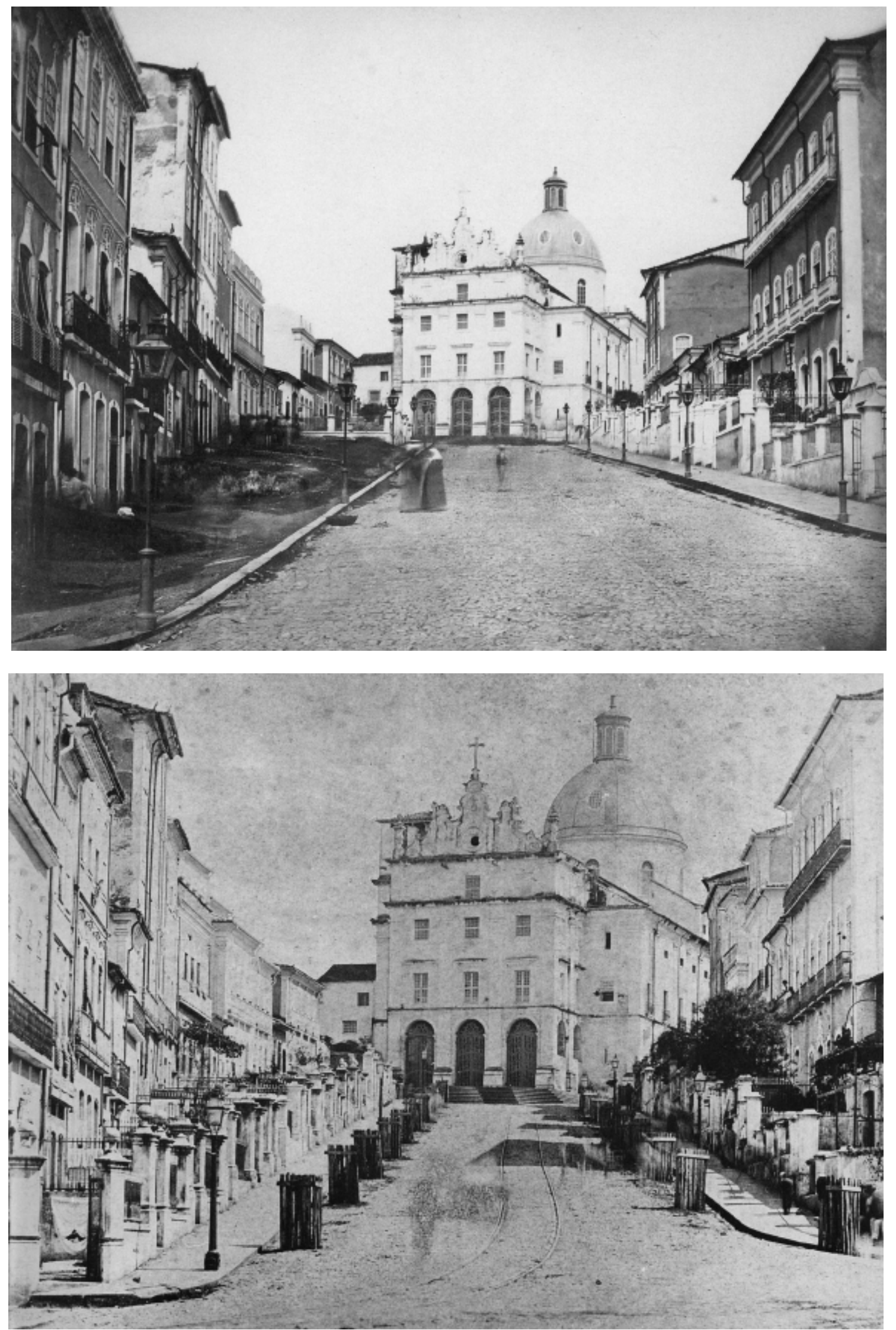

Figura 100 - Ladeira São Bento, em Salvador. Na foto superior, de 1860, vemos que em apenas um dos lados da rua há jardins. Já na foto inferior, de 1880, ambas as frentes possuem jardins, apropriados do espaço público.

Fonte: FERREZ, Gilberto. Bahia. Velhas fotografias 1858/1900. Rio de Janeiro, Kosmos Ed.; Salvador, Banco da Bahia Investimentos, 1989. A foto superior é de Benjamin R. Mulock. A inferior é de Guilherme Gaensly. 


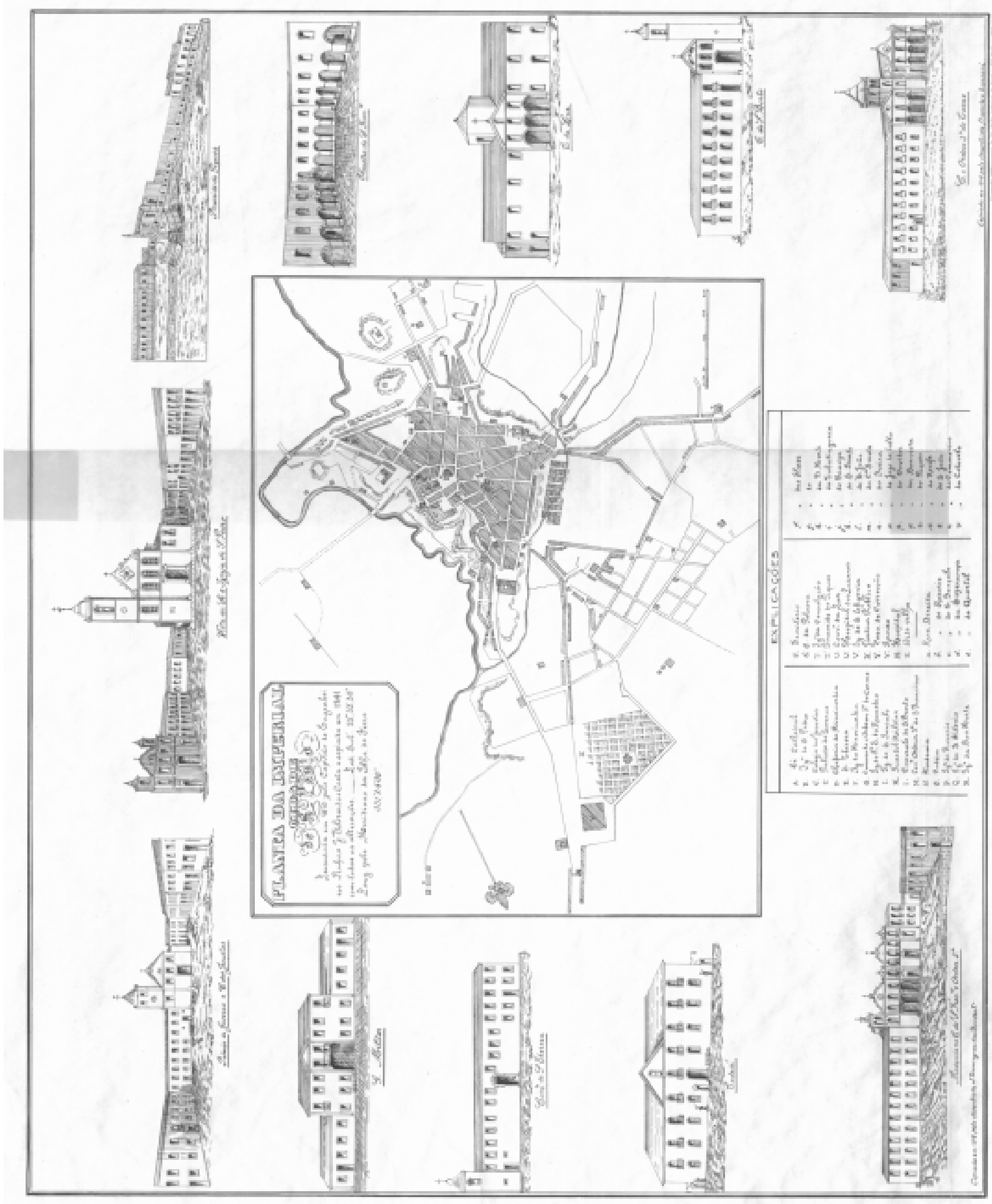

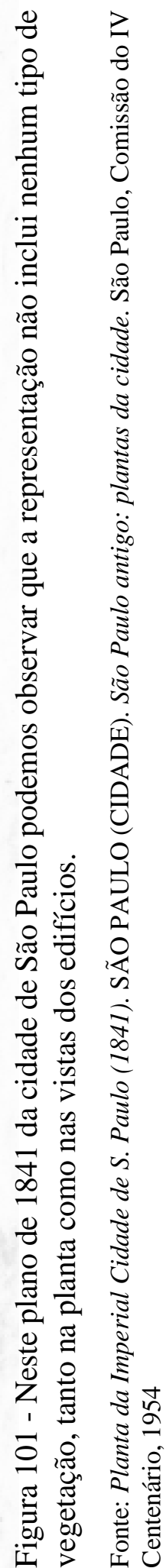


Mas o processo havia se iniciado: em fins do ano 1871, já estavam arborizados os largos de São Francisco, São Gonçalo, Misericórdia, Paissandu, Carmo, São Bento e se programava a arborização do largo da Glória. ${ }^{4}$

Na figura 102 temos um mapa de $1877,{ }^{5}$ onde podemos notar que a representação já inclui árvores em alguns lugares, como o Jardim da Luz, o largo 7 de abril, ${ }^{6}$ largo do Paysandú, largo dos Guayanazes ${ }^{7}$, região do largo do Palácio e caminhos que cruzam a várzea do Carmo.

Também está marcada a llha dos Amores, criada durante o governo do Dr. João Theodoro Xavier (1873/1874), aproveitando-se uma bifurcação do rio Tamanduateí. Para tal fim foi necessário sanear os terrenos próximos à rua 25 de março. Nela havia jardins com esculturas e até um banho público. Mais tarde a ilha foi destruída (já estava praticamente extinta quando passou para a esfera municipal em 1893), erguendo-se o mercado de peixes e verduras, derrubado posteriormente para a construção do Parque D. Pedro II.

Ainda no final do século XIX serão reformados o jardim da Praça João Mendes (1879), o jardim do Pátio do Colégio (1886) e o jardim do Largo de São Bento (1887).

Não podemos deixar de considerar, porém, que até avançado o século XIX ambas cidades tinham pequenas dimensões, e embora fossem raros os espaços verdes projetados, a população interagia cotidianamente com a vegetação nativa que ainda existia no interior e no entorno da cidade, principalmente em São Paulo. Isto começa a ser mais difícil com o aumento da população e da área física da cidade. Tampouco existiam os problemas sanitários que iriam justificar pouco tempo depois a criação de áreas verdes para a "higienização" da cidade.

\section{2 - DOIS PARQUES}

É interessante notar que, embora a idéia de construir áreas verdes em São Paulo e Buenos Aires tenha maior ênfase no final do século XIX, quando começam a existir problemas de higiene e também se iniciam as chamadas reformas de modernização, algumas das principais áreas são anteriores, como o Jardim da Luz, em São Paulo (figura 103), e o Parque Tres de Febrero (região de Palermo), em Buenos Aires (figuras 104 e 105).

O Parque da Luz teve sua origem na Ordem Régia de 19 de novembro de 1798, que previa a criação de um horto botânico, sendo aberto ao público, entretanto,

\footnotetext{
4 BARTALINI, Vladimir. Parques públicos municipais de São Paulo. Tese de doutorado. São Paulo, FAUUSP, 1999, p. 25.

${ }^{5}$ Mappa da Capital da Pia. de S. Paulo (1877). SÃO PAULO (CIDADE). São Paulo antigo: plantas da cidade. São Paulo, Comissão do IV Centenário, 1954.

${ }_{7}^{6}$ Atual praça da República.

7 Atual praça Princesa Isabel. Conhecido até 1885 como Campo Redondo, foi ajardinado e gradeado em 1897.
} 


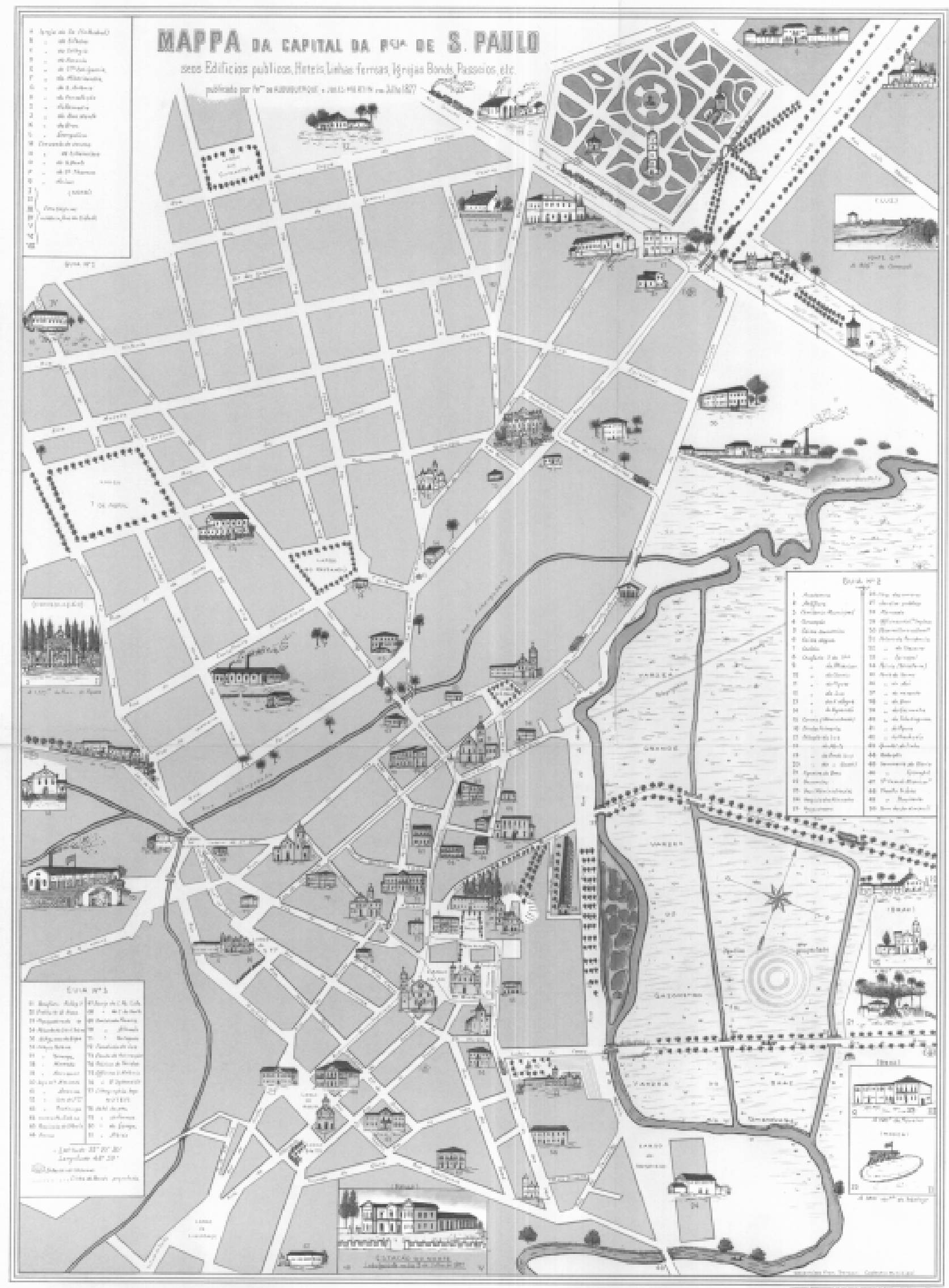

Figura 102 - Em 1877 é possível perceber que alguns espaços já recebem um tratamento que inclui espécies vegetais. Notar na parte inferior, à direita, a Ilha dos Amores.

Fonte: Mappa da Capital da Pia. de S. Paulo (1877). SÃO PAULO (CIDADE). São Paulo antigo: plantas da cidade. São Paulo, Comissão do IV Centenário, 1954 


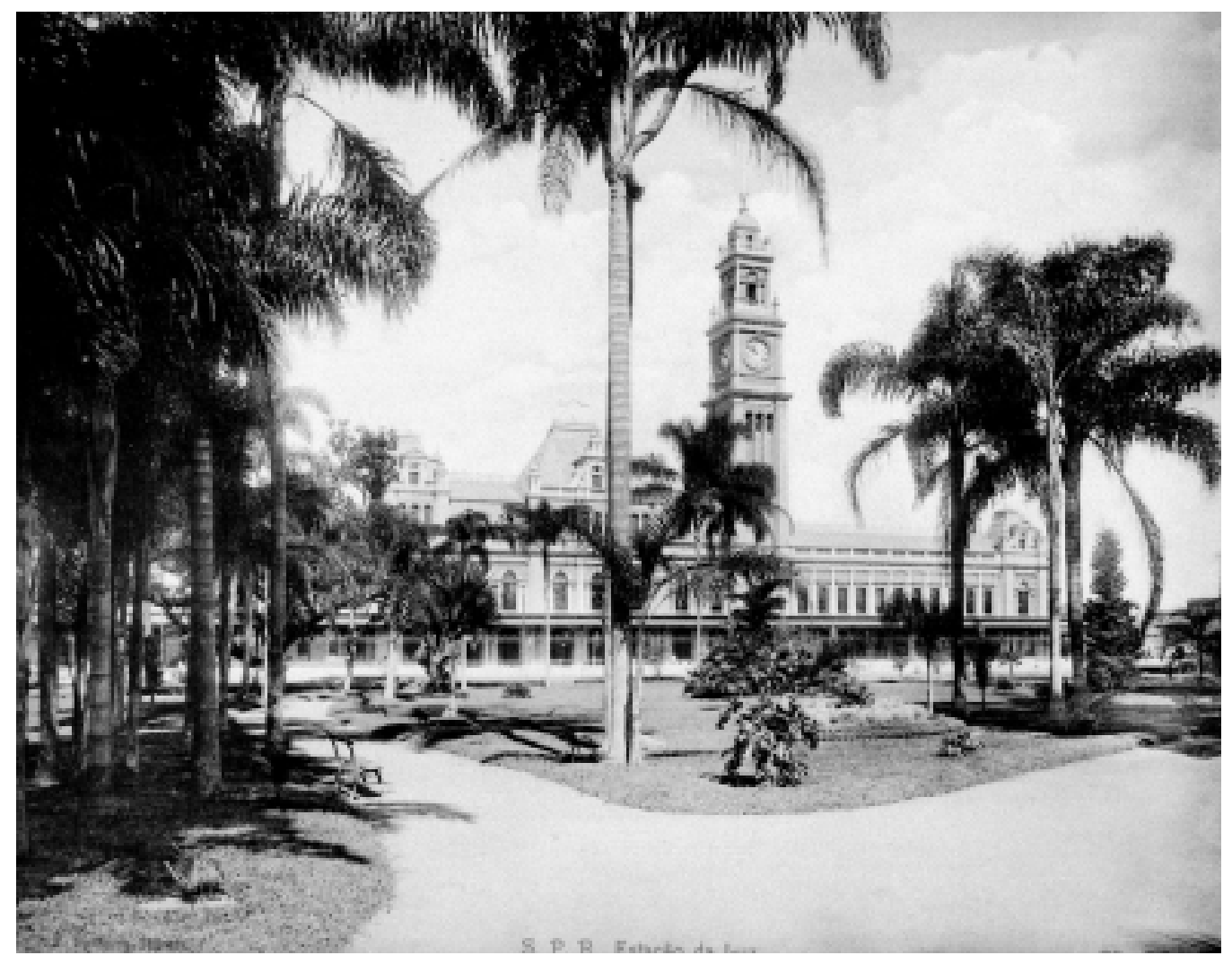

Figura 103 - O Parque da Luz foi a primeira área verde da cidade, e desde o início do século XIX passa a ser utilizada pela população.

Fonte: Acervo LAP

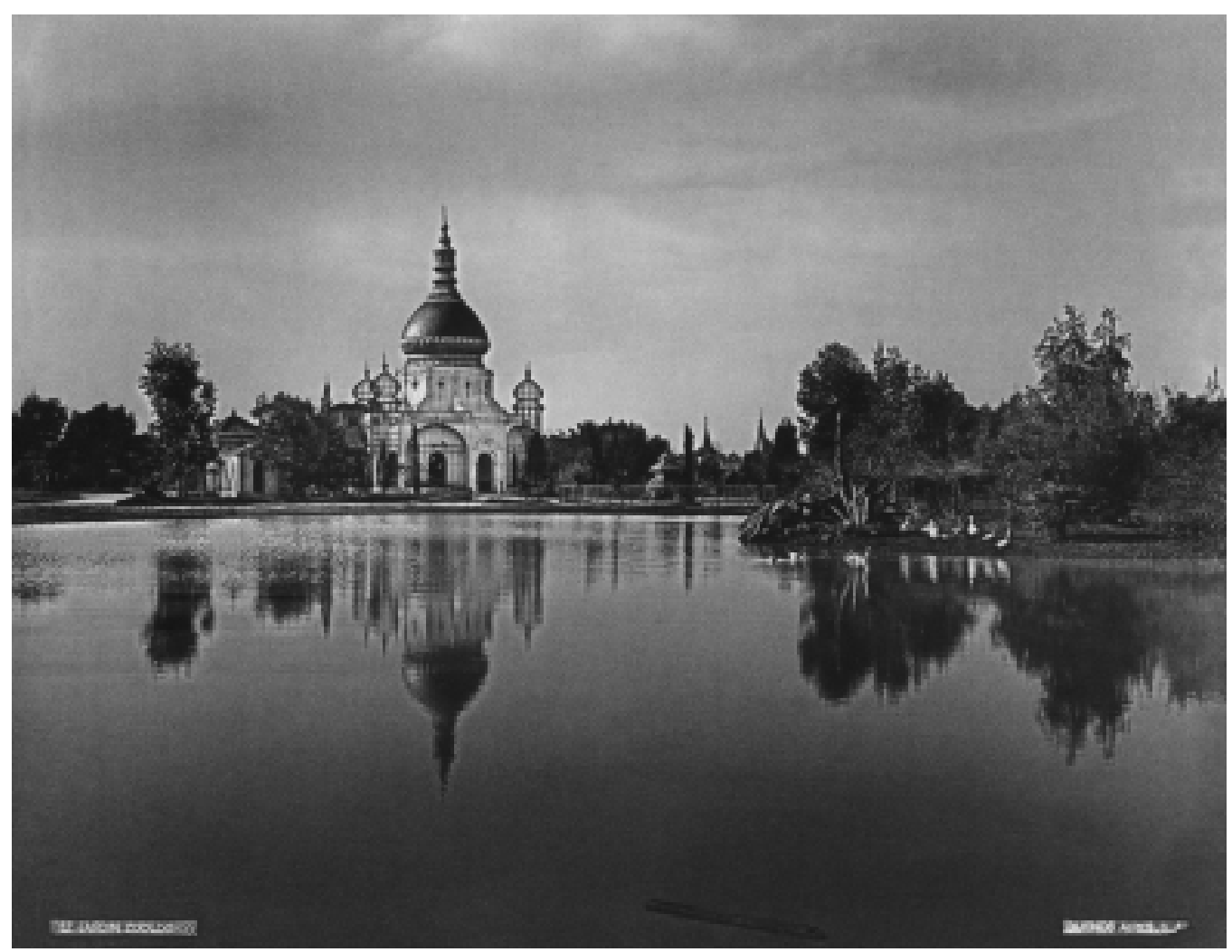

Figura 104 - Parque 3 de Febrero, maior área verde da cidade de Buenos Aires, criado no século XIX e diversas vezes reformado. Vista de um dos lagos.

Fonte: GUTMAN, Margarita (ed.). Buenos Aires 1910: memoria del porvenir. Buenos Aires, Gobierno de la Ciudad de Buenos Aires/ Faculdade de Arquitetura, Design e Urbanismo da Universidade de Buenos Aires/ IIED-America Latina, 1999 


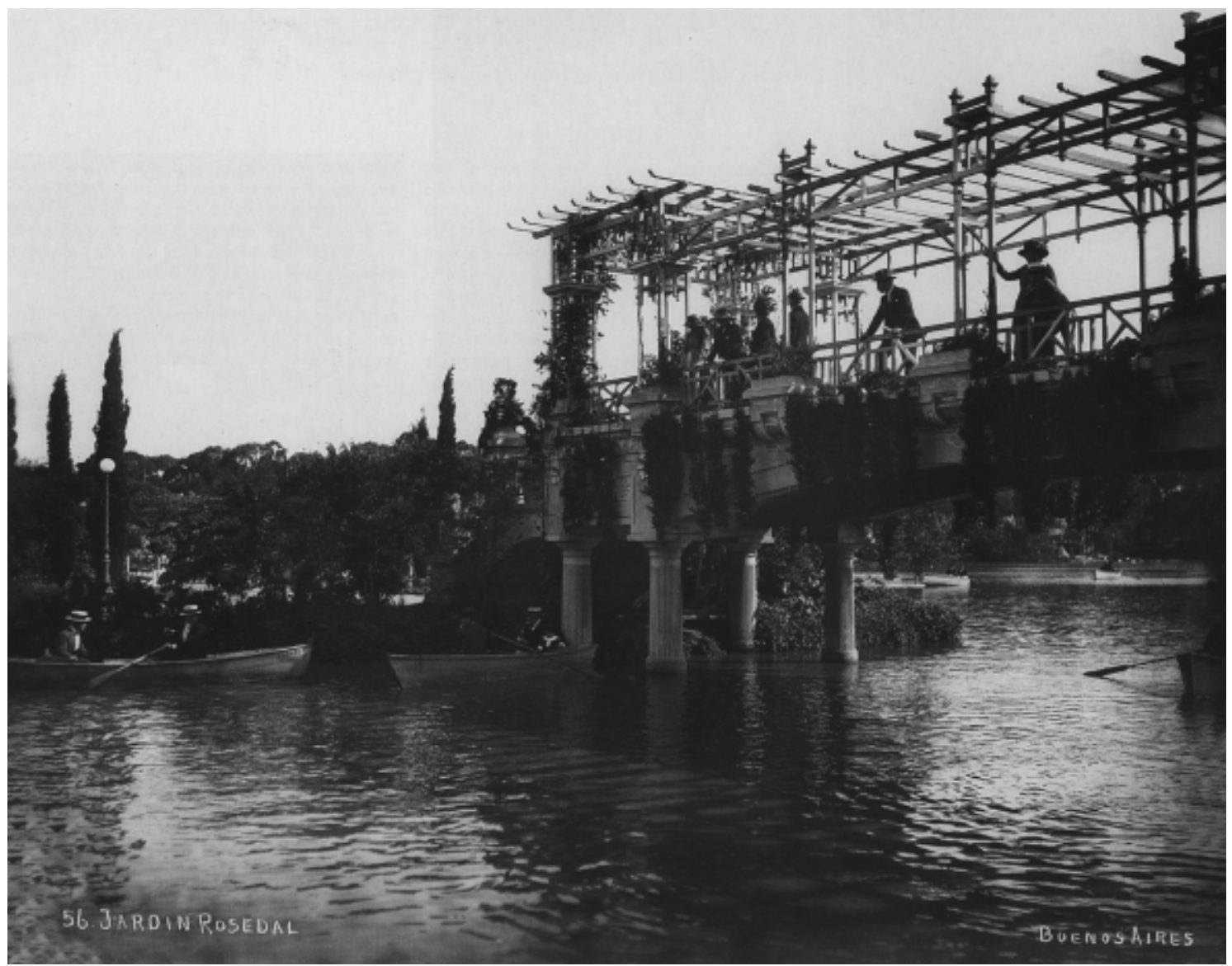

Figura 105 - Jardin Rosedal, localizado no parque 3 de Febrero.

Fonte: GUTMAN, Margarita (ed.). Buenos Aires 1910: memoria del porvenir. Buenos Aires, Gobierno de la Ciudad de Buenos Aires/ Faculdade de Arquitetura, Design e Urbanismo da Universidade de Buenos Aires/ IIED-America Latina, 1999

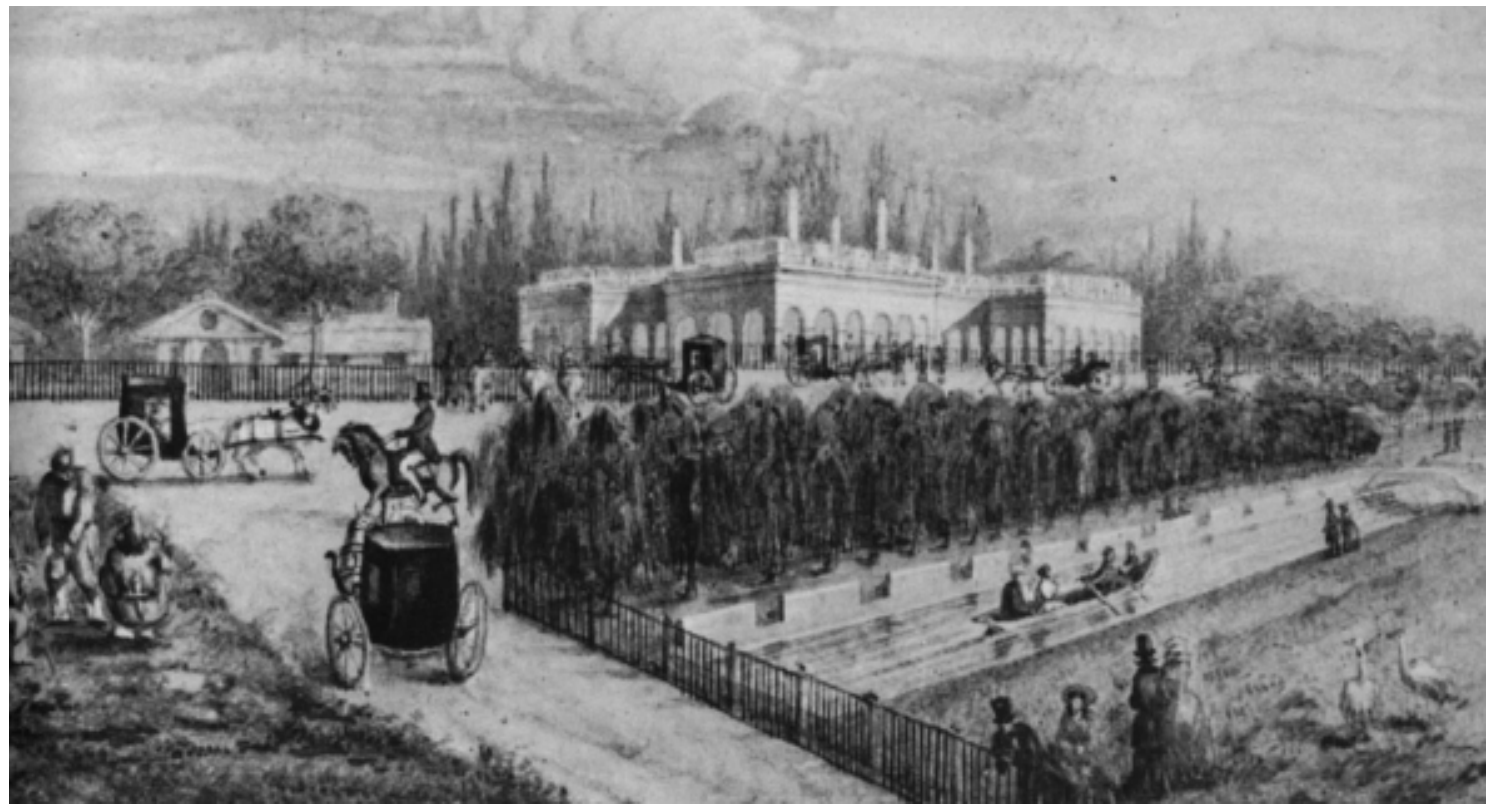

Figura 106 - Esta representação mostra a antiga residência de Juan Manuel de Rosas, na região de Palermo. Esta casa foi derrubada em uma das reformas realizadas no Parque Tres de Febrero.

Fonte: MOLINARI, Ricardo Luis. Buenos Aires 4 siglos. Buenos Aires, TEA, 1980. 
somente em 29 de outubro de $1825 .^{8}$ Sem muitas modificações, em 1838 passa a se chamar Jardim Público.

Desde sua criação, poucas intervenções foram feitas na área. Em 1860, vinte braças de terreno em frente ao jardim foram entregues à Companhia de Estrada de Ferro Inglesa para a construção da estação da estrada que ligava Santos a Jundiaí, ${ }^{9}$ inaugurada em 1867.

O abastecimento de água vinha do ribeirão Saracura, com nascentes nas baixadas da avenida Paulista, e represadas no tanque Reúno. Este abastecimento foi feito de forma precária até 1874 , quando, durante a presidência do Dr. João Theodoro Xavier, foi feita a canalização das águas do tanque Reúno para os chafarizes do bairro de Santa Efigênia e para o Jardim Público.

A partir dessa data foram realizadas intervenções significativas, como a construção da torre do observatório, a colocação de quatro estátuas de mármore representando as estações e outra de Vênus, além do plantio de numerosas espécies. ${ }^{10}$

Nova reforma foi realizada pelo prefeito Antonio Prado (1899-1910), que ficou muito mal impressionado com o seu aspecto ao visitá-lo. Remodelou-o em estilo inglês. Em 1916 recebe a atual denominação de Jardim da Luz.

A partir de meados do século XIX, este jardim passou a ser o principal ponto de encontro da sociedade paulistana. Ali foram realizados grandes eventos, como a ascensão do aeronauta Zeballos em 1876. Também foi realizada a primeira quermesse, entre 1882 e 1884, patrocinada pela colônia francesa ${ }^{11}$. Era também o principal ponto turístico da cidade, para os que vinham de fora.

Diversos viajantes deixaram suas impressões sobre o Jardim da Luz, como Domville-Fife, que em 1909 dizia:

"Os parques - eu chamo de parque aquele que realmente faz jus ao nome - mesmo um exigente inglês não poderia desprezar. Refiro-me ao Jardim da Luz, que não só possui magníficas alamedas de palmeiras onde, no verão, sentados à sombra, os jovens paulistanos passam horas agradáveis; como também ostenta um lago ornamental, com um chafariz no centro, banhando as rochas, e estátuas que refletem sua beleza na espelhante superfície das águas." ${ }^{12}$

\footnotetext{
${ }^{8}$ Naquele então já existia o horto botânico do Pará, criado em 1797. Ver SEGAWA, Hugo. Ao amor do público. Jardins no Brasil. São Paulo, Studio Nobel/Fapesp, 1996.

${ }_{9}$ Era apenas uma pequena construção. O grande edifício da estação da Luz é de 1901.

10 KLIASS, Rosa Grena. A evolução dos parques urbanos na cidade de São Paulo. Dissertação de Mestrado. São Paulo, FAUUSP, 1989, p. 97.

${ }^{11}$ LOUREIRO, Maria Amélia Salgado. A cidade e as áreas verdes. São Paulo, Secretaria de Serviços e Obras da Prefeitura do Município, 1979.

12 BRUNO, Ernani da Silva. Memória da cidade de São Paulo. Depoimentos de moradores e visitantes. 1553-1958. São Paulo, DPH, 1981, p. 148.
} 
Entretanto, a partir da década de 1920 começa sua decadência, sendo preterido por outras áreas da cidade como o parque Villon (atual parque Siqueira Campos), o Anhangabaú, a Praça da República, e mais tarde o Ibirapuera.

Em Buenos Aires, a área que é hoje ocupada pelo Parque Tres de Febrero corresponde a uma região que havia sido destinada, quando da fundação da cidade, para chácaras de cultivo visando o abastecimento. Durante o período da ditadura de Juan Manuel de Rosas, a área foi ocupada pelo caudilho com o objetivo de ali situar sua residência. Como era uma área alagadiça, fez transportar dos bairros de Belgrano e Recoleta milhares de carretas com terra. Nesta superfície de 541 hectares foram plantadas diversas espécies arbóreas, formando uma área que também servia à população, contando inclusive com um pequeno zoológico (figura 106). ${ }^{13}$

Após a queda de Rosas, em 1852, a área é parcialmente abandonada até que em fins de 1875 o presidente Avellaneda decide reformar o parque que então passará a levar o nome Tres de Febrero (data da derrocada de Rosas). Entretanto, alguns anos após a reforma o parque ficou novamente semi-abandonado até que em 1881 o intendente Torquato de Alvear decide iniciar uma nova reforma.

A partir desse momento, e particularmente a partir de 1891 com a nomeação de Charles Thays para a diretoria de passeios, é que o parque irá ganhar um tratamento paisagístico de alta qualidade e consolidada. Com o objetivo de eliminar por completo a memória do ditador Rosas, em 3 de fevereiro de 1899 foi dinamitado o antigo casarão que havia sido sua residência. Em 1893 é ampliada a área do parque, em 1894 começam a ser formados os lagos e em 1900 é realizada uma nova ampliação na direção norte. Sucessivos melhoramentos são realizados nas décadas seguintes dando aos poucos ao parque as atuais feições.

A área ocupada é muito grande, de sorte que é hoje um dos principais parques da cidade. Nas discussões da época, havia quem propusesse que servisse também para recreio das camadas populares, que não contavam com áreas para recreação e ócio. Na prática isto não ocorreu, devido a que na época estava situado em área afastada tanto do centro como dos bairros populares. Outros afirmavam que os mais pobres não possuíam cultura suficiente para aproveitar os benefícios de um parque como aquele. ${ }^{14}$

\section{3 - OUTROS ESPAÇOS}

A Plaza de Mayo e o Parque Tres de Febrero ocupam usualmente um papel de destaque na bibliografia sobre Buenos Aires. Entretanto houve também outras intervenções significativas. Até 1880 já estava consolidado o passeio que ligava a Recoleta com o Parque Lezama, através do Paseo de Julio (chamado Paseo Guarda Nacional), na direção norte, e o Paseo Colón, ao sul.

\footnotetext{
${ }^{13}$ RAMOS, Jorge. El parque Tres de Febrero: de Garay a Noel. In: BERJMAN, Sonia (comp.). El tiempo de los parques. Buenos Aires, IAAIE "Mário Buschiazzo", 1992.

${ }^{14}$ GORELIK, Adrián. La grilla y el parque. Espacio público y cultura urbana en Buenos Aires, 1887-1936. Buenos Aires, Universidad Nacional de Quilmes, 1998.
} 
A partir de Alvear, são realizados um grande lago artificial na Recoleta e uma gruta. Também passam por intervenções a atual praça Miserere (antiga Plaza de las Carretas), a praça Lorea (depois modificada para a construção do Palácio do Congresso) e a Plaza Constitución. Também é criado o Parque do Retiro, como ampliação da Plaza San Martin. Para isto foi necessário a derrubada do quartel onde San Martin organizou o Regimento de Granaderos, em 1813.

Mas talvez a obra de maior envergadura de Alvear tenha sido o Parque de la Convalescencia, onde estavam localizados o Hospital de Inválidos, o das Mercedes, o Asilo de Mujeres Dementes e o Asilo del Buen Pastor, além do viveiro municipal. Este último, criado em 1886, abasteceu com numerosas espécies as principais obras realizadas, na época e anos seguintes. ${ }^{15}$

Em São Paulo, na última década do século XIX são criadas algumas das maiores áreas verdes da cidade, como o Parque da Cantareira (1893), o Horto Florestal (1896) e o Museu do Ipiranga (1890. Os jardins são de 1909).

O Parque da Cantareira têm sua origem ligada à antiga Companhia Cantareira de Águas e Esgotos, que em 1892 foi encampada pelo Governo do Estado. Com o objetivo de proteger os mananciais, o estado criou uma reserva florestal, que tinha uma área de 5.647 hectares. Em fins de 1894 entrou em operação uma pequena linha de Tramways, com o objetivo de transportar material de construção, mas que acabou sendo também utilizada pelo público, que assim obteve um acesso rápido ao parque. Em pouco tempo esta área se transformou no local de lazer preferido dos paulistanos (figura 107). ${ }^{16}$

Não existe um caso semelhante em Buenos Aires, até porque a água era retirada diretamente do Rio da Prata.

Já o Horto Botânico, localizado pouco abaixo do reservatório da Cantareira, foi criado por lei de 10 de fevereiro de 1896. Tratava-se de uma área de 174 hectares, que até hoje é intensamente utilizada pela população. ${ }^{17}$

No início do século XX surgem novos espaços, como o Trianon e a Praça Buenos Aires. Esta última foi construída após a aquisição da área pela prefeitura, e sua construção foi autorizada pela lei $\mathrm{N}^{0} 1626$ de 1912. Chamava-se inicialmente Praça Higienópolis, adquirindo a atual denominação em 1913.

Quando a Avenida Paulista foi aberta, em 1890/91, foi destruída praticamente toda a mata nativa que ali existia. Entretanto, sobraram em duas quadras os tocos da derrubada, que brotaram e recompuseram parcialmente a mata original. Este local foi assim transformado em parque, passando a ser conhecido como Parque Villon, nome do autor do projeto paisagístico.

Em 1911 a prefeitura compra a área, o que deu origem ao Parque Municipal, e em 1930 recebe a atual denominação de Parque Siqueira Campos, embora a população de São Paulo o conheça em geral como Parque Trianon (figura

\footnotetext{
${ }^{15}$ GUTIERREZ, Ramón. Buenos Aires. Evolución Histórica. Buenos Aires, Editorial Escala, 1990.

${ }^{16}$ REIS FILHO, Nestor Goulart. São Paulo e outras cidades: produção social e degradação dos espaços urbanos. São Paulo, Hucitec, 1994.

17 Idem, ibidem.
} 

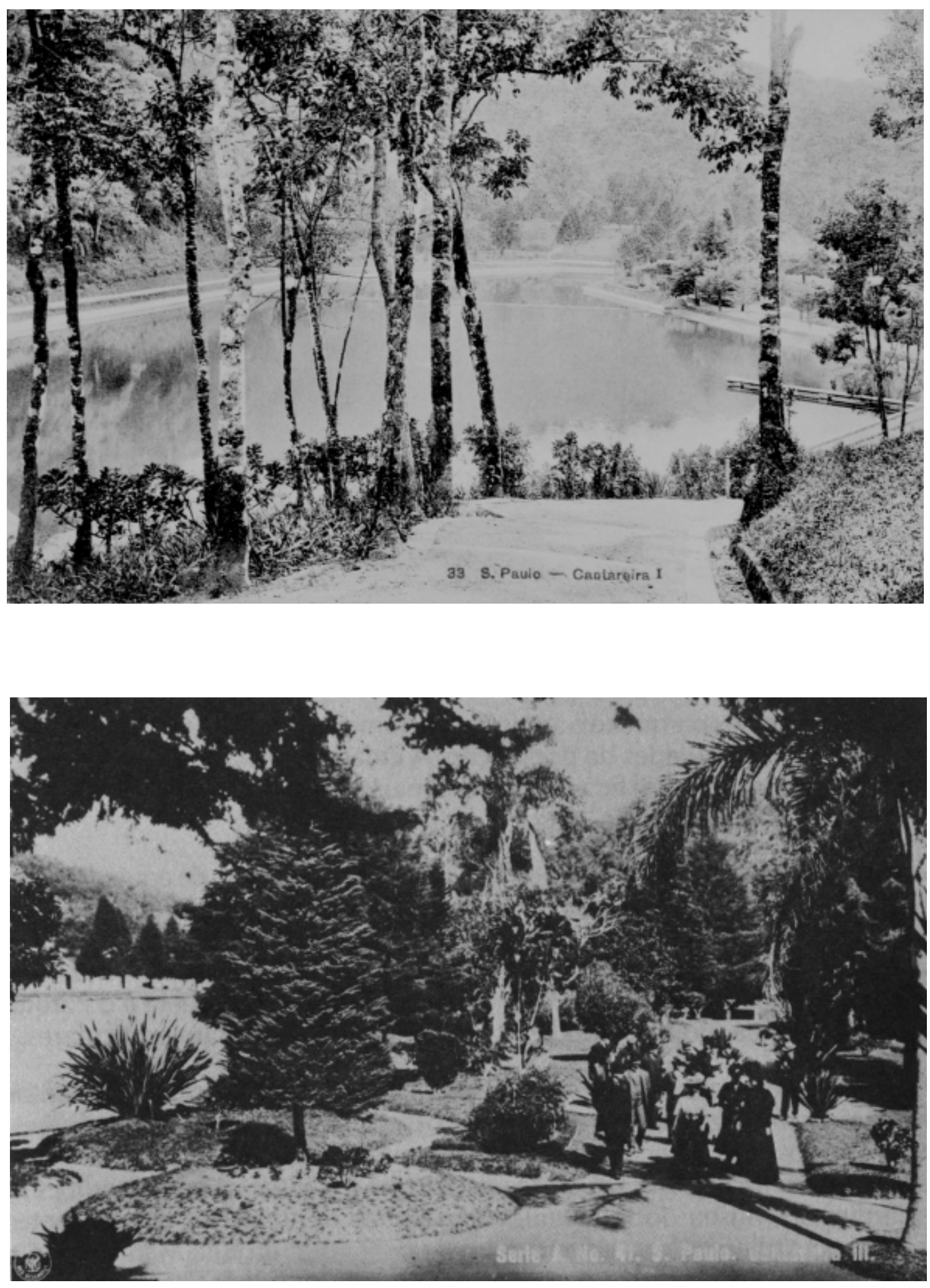

Figura 107 - O parque da Cantareira foi criado com o objetivo de proteger a região dos mananciais. Pouco tempo depois se tornou um dos locais preferidos dos paulistanos.

Fontes: (1) Acervo LAP (2) REIS FILHO, Nestor Goulart. São Paulo e outras cidades: produção social e degradação dos espaços urbanos - São Paulo, Hucitec, 1994. 
108). À sua frente, sobre o Belvedere com vista para o vale do Saracura, está localizado atualmente o Museu de Arte de São Paulo (MASP). ${ }^{18}$

A outra área que servia de passeio e recreio da população de São Paulo era a Praça da República. Passou por várias denominações: Praça da Legião (até 1811), Praça dos Milicianos (até 1817), e Praça, Largo ou Campo dos Curros, onde se realizavam touradas, até 1865. A partir dessa data recebe o nome de Largo 7 de abril, que em 1872 é regularizado e onde em 1879 é instalado um chafariz. A partir da Proclamação da República passa a receber a atual denominação. Em 1894 é inaugurada a Escola Normal, projeto de Ramos de Azevedo. Durante a gestão do prefeito Antonio da Silva Prado foi remodelada, sendo entregue ao público em $1^{\circ}$ de janeiro de 1905. Assim a descreveu Jorge Americano:

"Ali por 1902 a praça da República foi cercada de arame farpado. Vieram carroças, removeu-se terra daqui para ali, fizeram o lago, plantaram árvores, gramaram canteiros e em uma tarde de Ano Bom, com banda de música, foi inaugurado o jardim, com a presença do Presidente do Estado e do Prefeito.

Ajardinada, a praça da República, ao cair da noite, depois do jantar, tornou-se ponto de reunião das famílias dos Campos Elíseos, Vila Buarque e Higienópolis". ${ }^{19}$

Como parte do plano deixado por Bouvard, em 1922 é inaugurado o Parque do Carmo, com projeto de E. F. Cochet. Uma das particularidades desta grande área é estar ao alcance das camadas populares, já que está situada entre os bairros habitados por esta população (Brás, Mooca, Belém) e o "triângulo" central. Ou seja, não se trata de um parque destinado aos mais ricos, como em geral acontece (figura 109).

O procedimento de comprar áreas para realização de parques também existiu em Buenos Aires. Temos, por exemplo, o caso do parque Lezama, que foi formado após a compra da antiga chácara de don José G. Lezama, no ano de 1894, por $800.000 \$ \mathrm{~m} / \mathrm{n}^{20}$

Vitor da Silva Freire cita também o caso da Quinta Hale, situada em plena avenida Alvear, e que estava para ser retalhada e vendida em lotes pelos herdeiros de um rico inglês. A prefeitura comprou esta propriedade, assim como as adjacentes, das famílias Mesquita, Lopez e Fernandez. Nessa área projetou Bouvard um jardim de 16,5 hectares. Neste caso é uma desapropriação em área valorizada, exemplo que utilizou Vitor da Silva Freire para argumentar que o custo dos terrenos não deveria ser um empecilho para a construção de áreas livres em São Paulo. ${ }^{21}$

Mas, uma das maiores diferenças entre ambas cidades é que alguns dos principais parques utilizados pela população paulistana no início do século $X X$ eram iniciativas privadas.

\footnotetext{
18 Idem, ibidem.

${ }^{19}$ BRUNO, Ernani da Silva. Op. cit. p. 125.

${ }^{20}$ Censo General de la Ciudad de Buenos Aires. 1909. Tomo III, p. 558.

${ }^{21}$ FREIRE, Vitor da Silva. Melhoramentos de São Paulo. São Paulo, Revista Polytechnica, Vol. VI, № 33, fevereiro/março de 1911, p. 135.
} 


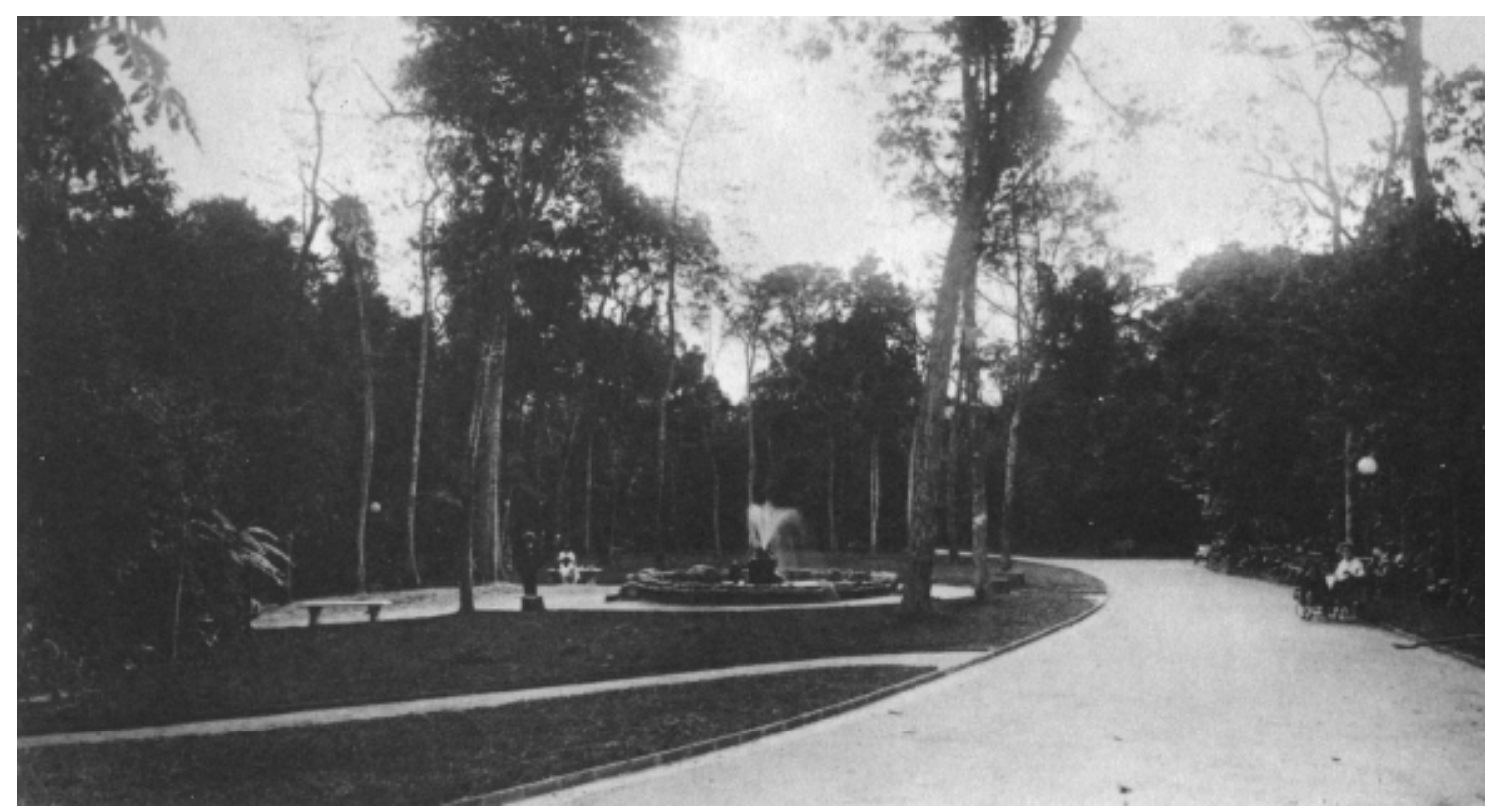

Figura 108 - O parque Siqueira Campos, junto à avenida Paulista. Conhecido como Parque Trianon, foi criado em uma área remanescente, posteriormente comprada pela prefeitura.

Fonte: Acervo LAP

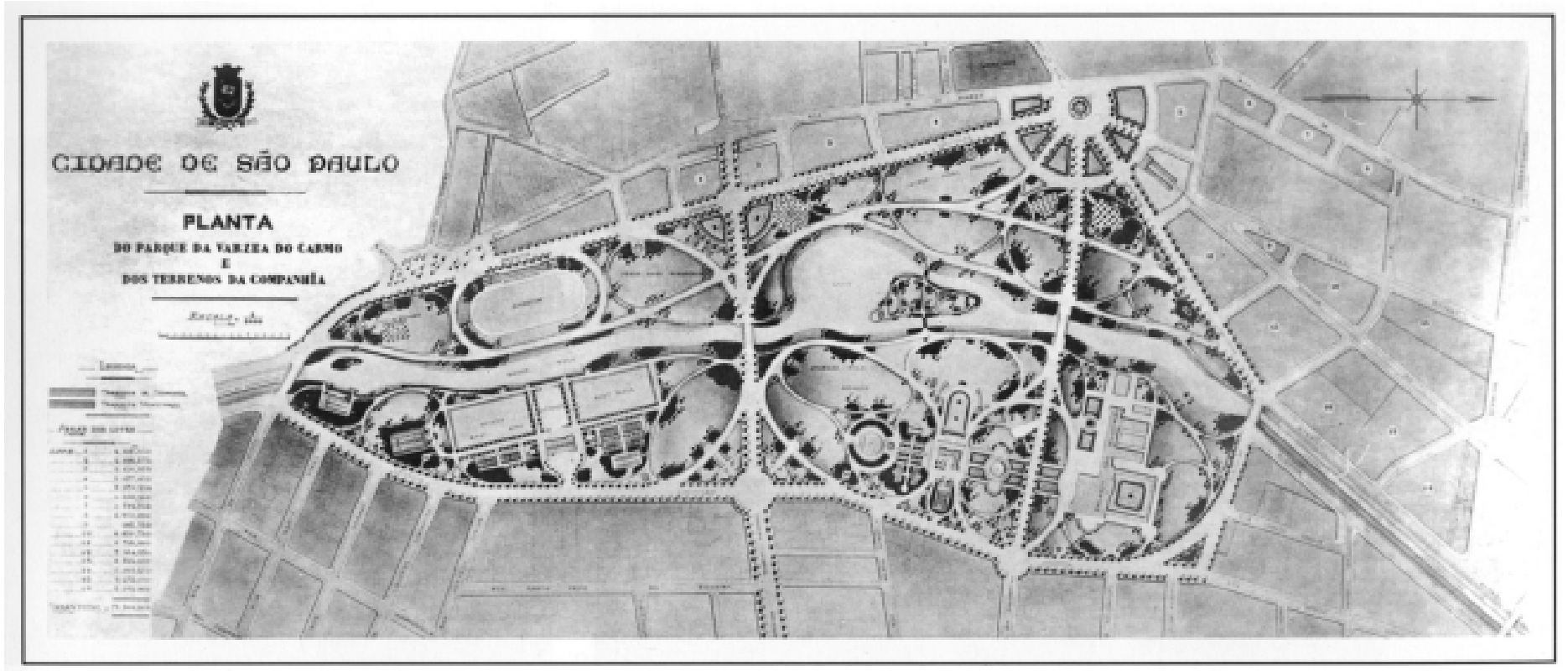

Figura 109 - Projeto de Bouvard para a várzea do Carmo.

Fonte: Acervo LAP 
É o caso do Parque Antártica, na Água Branca, propriedade da Companhia Antártica Paulista (figura 110). Foi aberto no início do século XX, passando a ser um dos lugares de passeio e prática de esportes preferidos da população. Mas em 1916 foi alugado para o Palestra Itália, e em 1920 vendido para o mesmo clube. Hoje abriga o estádio da S. E. Palmeiras. O objetivo da Companhia Antártica com este empreendimento era promover seus produtos. Entretanto, o acesso gratuito também garantia alguns benefícios à empresa, como a isenção de alguns impostos por vinte anos (Lei municipal $\mathrm{N}^{0} 550$, de 1901). ${ }^{22}$

A mesma empresa também foi a responsável pela abertura do Bosque da Saúde (1908), que depois foi loteado dando origem ao atual bairro com essa denominação.

Iniciativa particular também foi o Jardim da Aclimação, obra do Dr. Carlos Botelho. Tendo estudado em Paris, ficou encantado com o "Jardin d'Acclimation", no "Bois de Boulogne", e resolveu criar um jardim semelhante em São Paulo.

Para isto comprou as terras que ficavam no vale do sítio do Tapanhoin, além da Liberdade e Glória, naquele então ainda virgens. Em 1892 implantou no lugar uma granja leiteira, bosque, parque de diversões e zoológico. Parte era aberta ao público, parte era particular. Carlos Botelho era médico e fazendeiro, que procurou utilizar técnicas sofisticadas na agricultura e pecuária. Utilizou esta área para pesquisas, onde instalou em 1898 o primeiro "zootéchnico" de São Paulo. Além do público em geral (que pagava para entrar), também atendia pecuaristas de todo 0 estado (figura 111).

O Jardim da Aclimação teve seu auge na década de 1920. Para chegar lá se pegava o bonde $\mathrm{N}^{0} 28$ na Sé, mas só aos domingos e feriados, já que naquela época ainda era um lugar afastado. Nos anos 1930 os herdeiros de Carlos Botelho iniciaram o retalhamento das terras privadas. Quando pretendiam lotear o Jardim, a prefeitura comprou a área, durante a primeira gestão de Prestes Maia. O preço foi de Rs. 2.850:000\$000. Já estava então decadente, e nessa situação continuou ainda por vários anos. ${ }^{23}$

\section{4 - A VEGETAÇÃO NAS RESIDÊNCIAS}

Embora durante o período colonial a vegetação estivesse praticamente ausente do espaço público, era, entretanto, presente nas residências. No caso da casa colonial brasileira, era comum que no fundo do lote existisse uma área onde eram plantadas diversas espécies de árvores, muitas vezes frutíferas. Também podiam existir hortas (figura 112).

No caso hispano-americano, a Coroa espanhola trouxe para cá um modelo de casa, que possui como uma de suas características mais marcantes o pátio interior, em geral com a presença de vegetação e muitas vezes de água. Além de

\footnotetext{
22 BARTALINI, Vladimir. Op. cit. p. 51.

${ }^{23}$ DOREA, Augusta Garcia Rocha. Aclimação. São Paulo, DPH, 1982.
} 


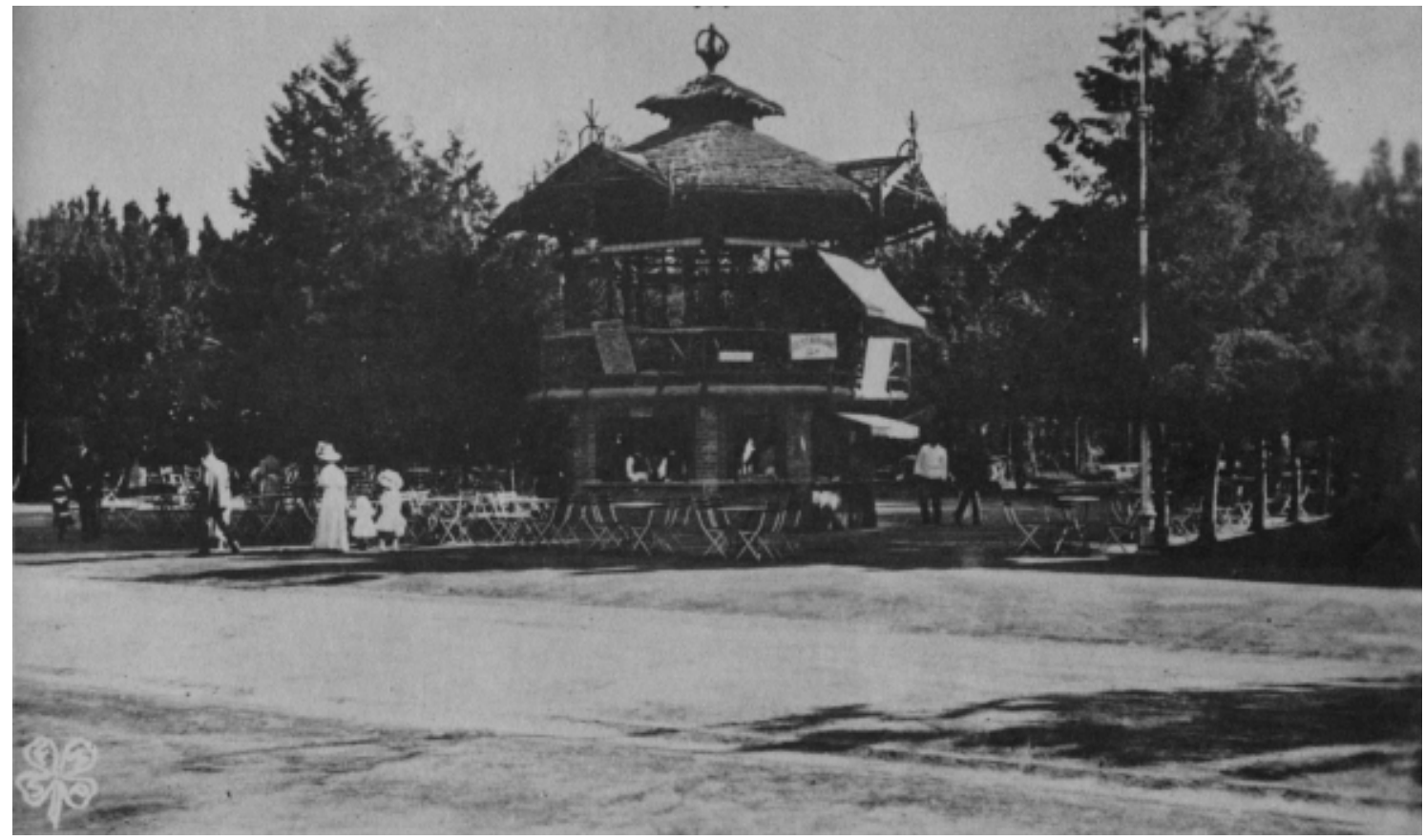

Figura 110 - Parque Antártica, empreendimento privado localizado em uma área mais acessível que o da Cantareira, foi muito usado pelos paulistanos até ser vendido pela Companhia Antártica.

Fonte: Acervo LAP

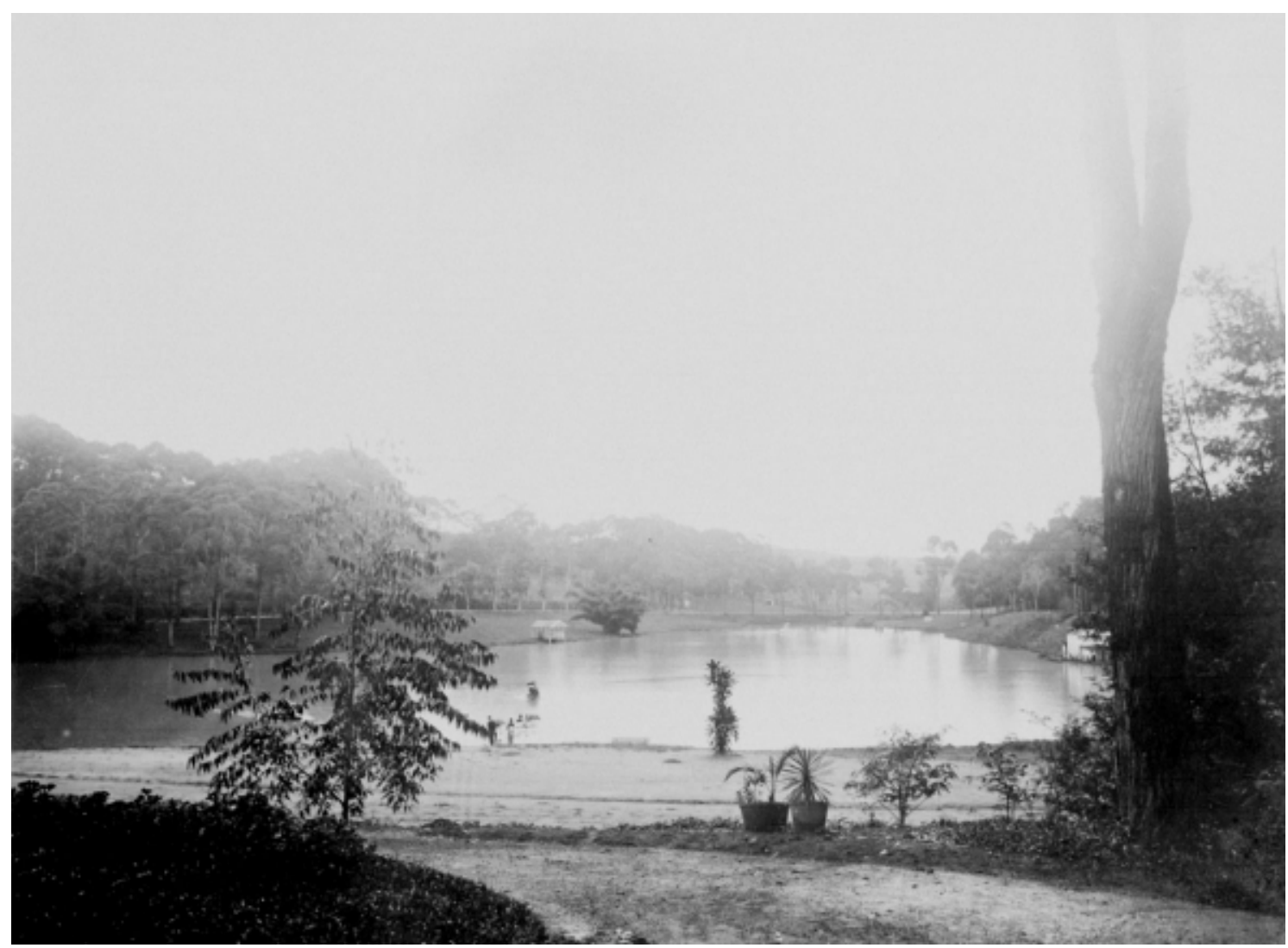

Figura 111 - Outro empreendimento privado foi o parque da Aclimação, iniciativa do Dr. Carlos Botelho, que teve seu auge na década de 1920.

Fonte: Acervo LAP 


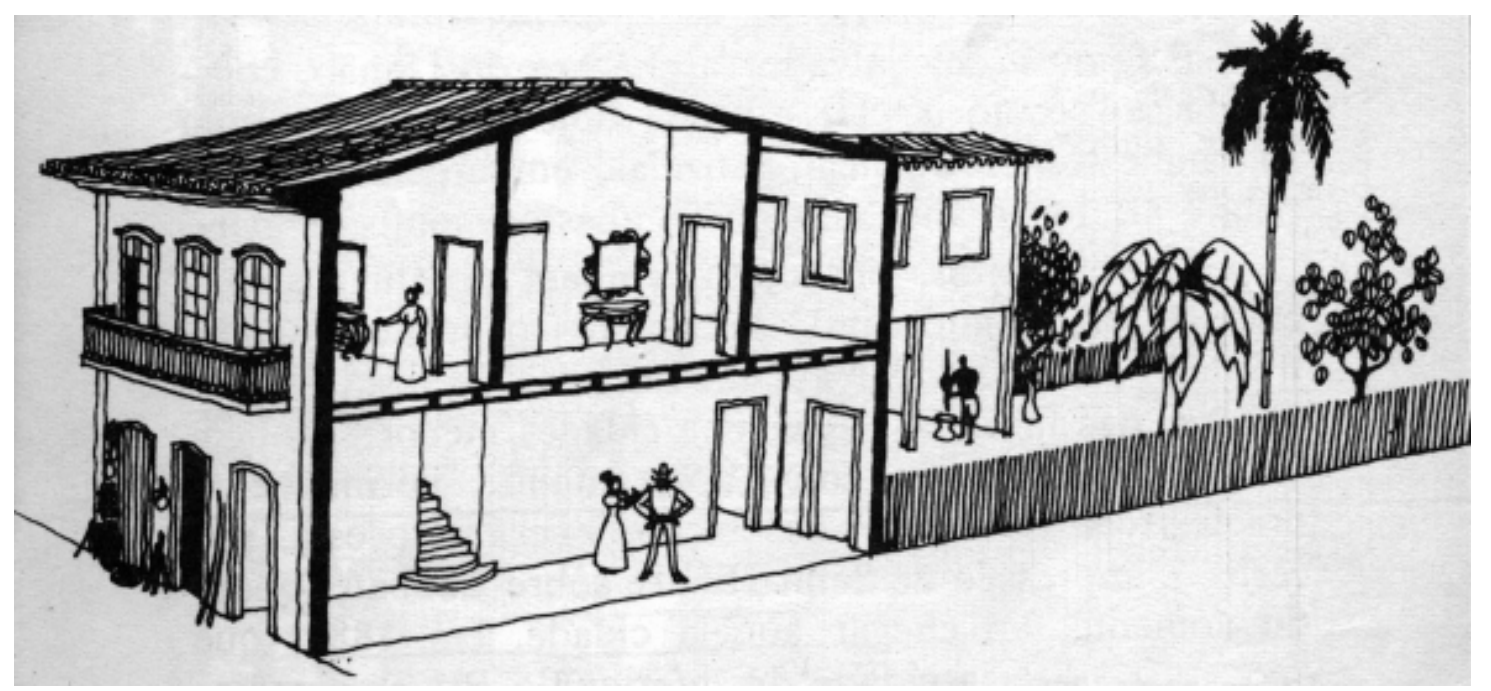

Figura 112 - No desenho acima podemos observar a presença de um jardim na parte posterior da casa colonial brasileira.

Fonte: REIS FILHO, Nestor Goulart. Quadro da Arquitetura no Brasil. - 5ª ed. - São Paulo, Perspectiva, 1983.

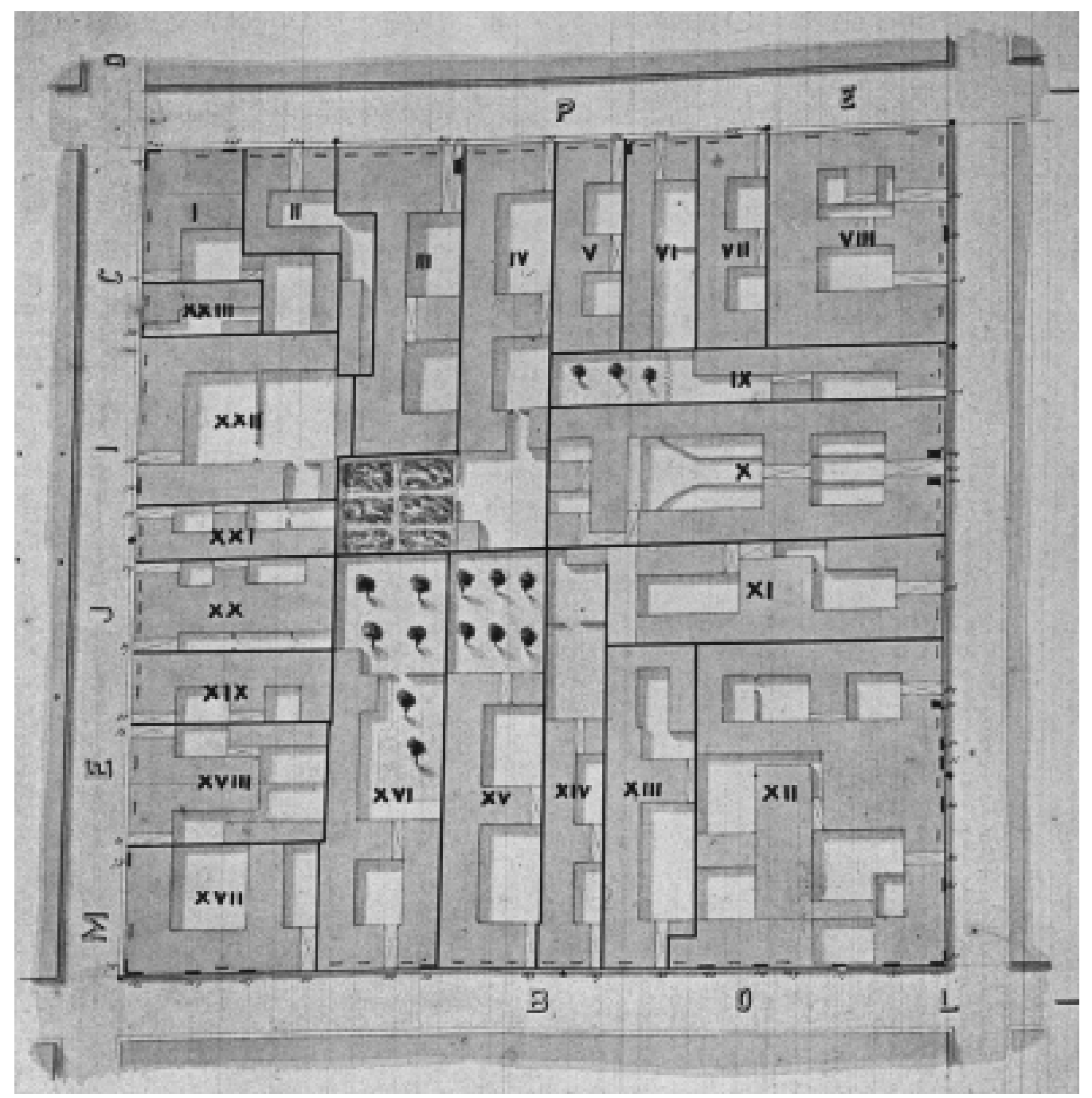

Figura 113 - O plano acima é o "Catastro Beare”, de 1869, onde se pode perceber a presença dos pátios na arquitetura.

Fontes: Instituto Histórico de la ciudad de Buenos Aires; Instituto de Arte Americano e Investigaciones Estéticas “Mario J. Buschiazzo”. 
servir de espaço de integração da residência e de circulação, também fornecia proteção em lugares de clima muito quente (figura 113).

No momento em que se iniciam os grandes fluxos migratórios para a América, estas cidades sofrem um rápido crescimento. Uma das formas em que esta expansão se manifesta é pela ocupação de áreas periféricas. Embora portugueses e espanhóis tenham produzido urbanismos diferentes na América, em ambos casos, São Paulo e Buenos Aires, estas novas áreas apresentam em geral quadras de formato retangular, e lotes estreitos e compridos. Isto gerou uma tipologia particular de moradias, caracterizada pela sucessão de cômodos. Esta, ao contrário do que acontece em muitos países europeus, é extremamente freqüente em ambas cidades. São as chamadas "casa-chorizo" e "casa de porão alto", as quais estudaremos com maiores detalhes adiante.

Há diversos aspectos interessantes que surgem comparando sua arquitetura, mas no momento vamos nos concentrar na presença da vegetação. De fato, embora em ambos casos exista uma circulação lateral, no caso paulistano ela é efetivamente apenas uma passagem. Em Buenos Aires, talvez como herança dos pátios da casa hispano-americana ${ }^{24}$, este espaço recebe um tratamento que inclui plantas em vasos, e uma parreira como cobertura, acompanhando uma estrutura de madeira ou metal (Figura 114). Com o adensamento e a construção de edifícios em altura, muitas destas casas foram substituídas, mas podemos perceber que nas sacadas dos edifícios (o que é usual em Buenos Aires), embora pequenas, as pessoas ainda hoje criam um ambiente parecido com o destes pátios.

Em ambos os casos, em geral na parte posterior dos lotes podiam ser encontrados pomares, além de servir de área para a criação de pequenos animais.

Ao contrário, nas novas tipologias residenciais que passam a ser adotadas pelas camadas mais ricas, a vegetação é abundante. Este processo se inicia no final do século XIX, quando esta população deixa a área central deslocando-se para novos bairros, como Campos Elíseos e Higienópolis, em São Paulo, e avenida Alvear e Recoleta, em Buenos Aires. Uma das características mais marcantes destes bairros é a forma de implantação das casas, que possuem generosos recuos laterais e frontais. Nestes jardins são plantados numerosos espécimes nacionais e estrangeiros, e em muitos casos os projetos possuem um refinado paisagismo, caracterizando um salto de qualidade em relação ao que existia até pouco tempo atrás (figuras 115 e 116).

Não devemos nos esquecer também que ao lado destes jardins, que também era usufruídos por aqueles que utilizavam os passeios, também existia uma intensa arborização nas ruas, cuja largura era maior que o usual no período colonial. Isto, por sua vez, permitia a contemplação das fachadas das casas.

Há diversas descrições da época que se referem aos jardins e ruas destes bairros. Diz L. A. Gaffre, em 1910:

"Não se pode imaginar nada de mais bem traçado e melhor arborizado que as ruas da Liberdade e da Consolação, que leva a esta esplêndida Avenida Paulista, à qual eu não saberia comparar senão certas avenidas de Nova York, onde a fantasia dos milionários americanos encerra, no verde de grandes

\footnotetext{
${ }^{24}$ Segundo alguns estudiosos, a casa-chorizo se forma pela subdivisão ao meio da antiga casa colonial.
} 

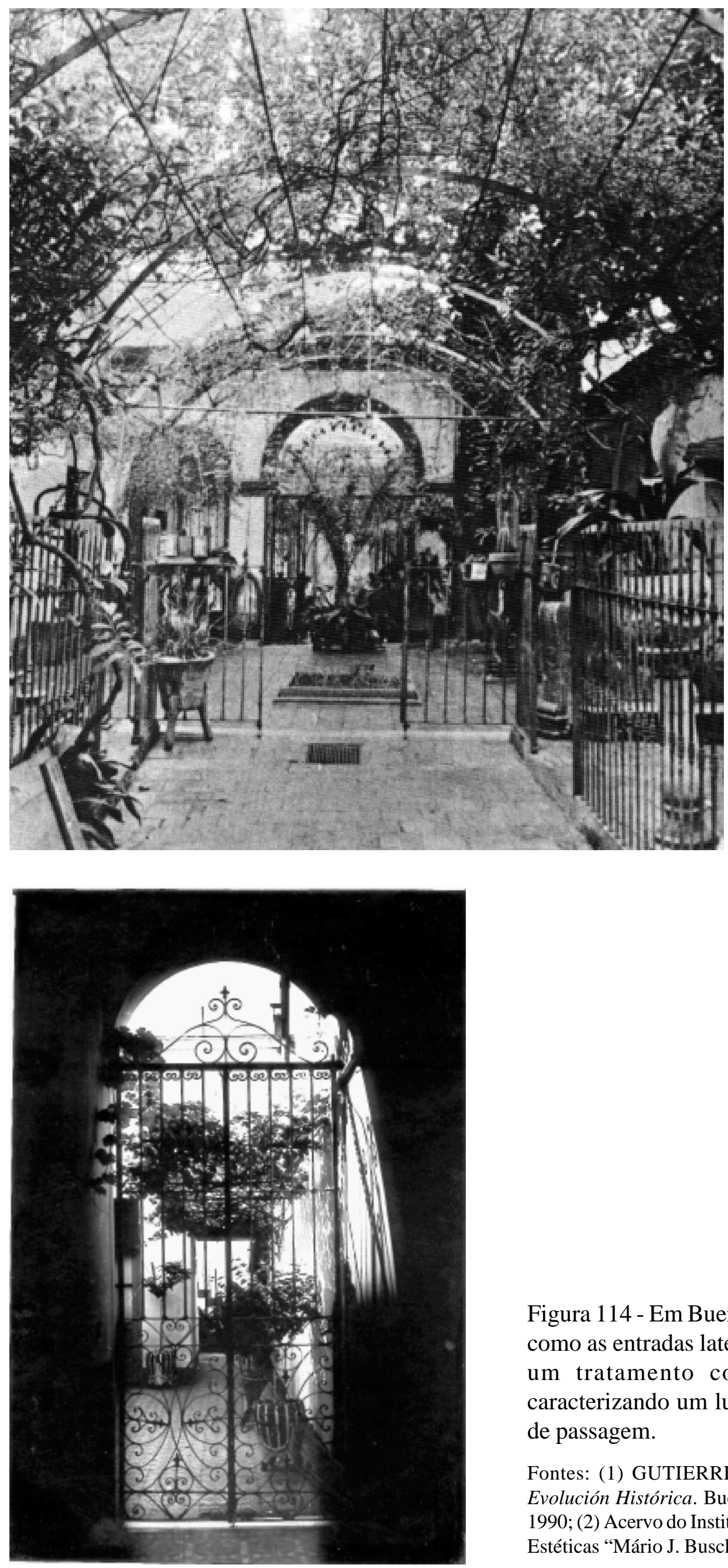

Figura 114 - Em Buenos Aires tanto os pátios como as entradas laterais das casas recebiam um tratamento com vasos e plantas, caracterizando um lugar que não era apenas de passagem.

Fontes: (1) GUTIERREZ, Ramón. Buenos Aires. Evolución Histórica. Buenos Aires, Editorial Escala, 1990; (2) Acervo do Instituto de Arte e Investigaciones Estéticas "Mário J. Buschiazzo" 


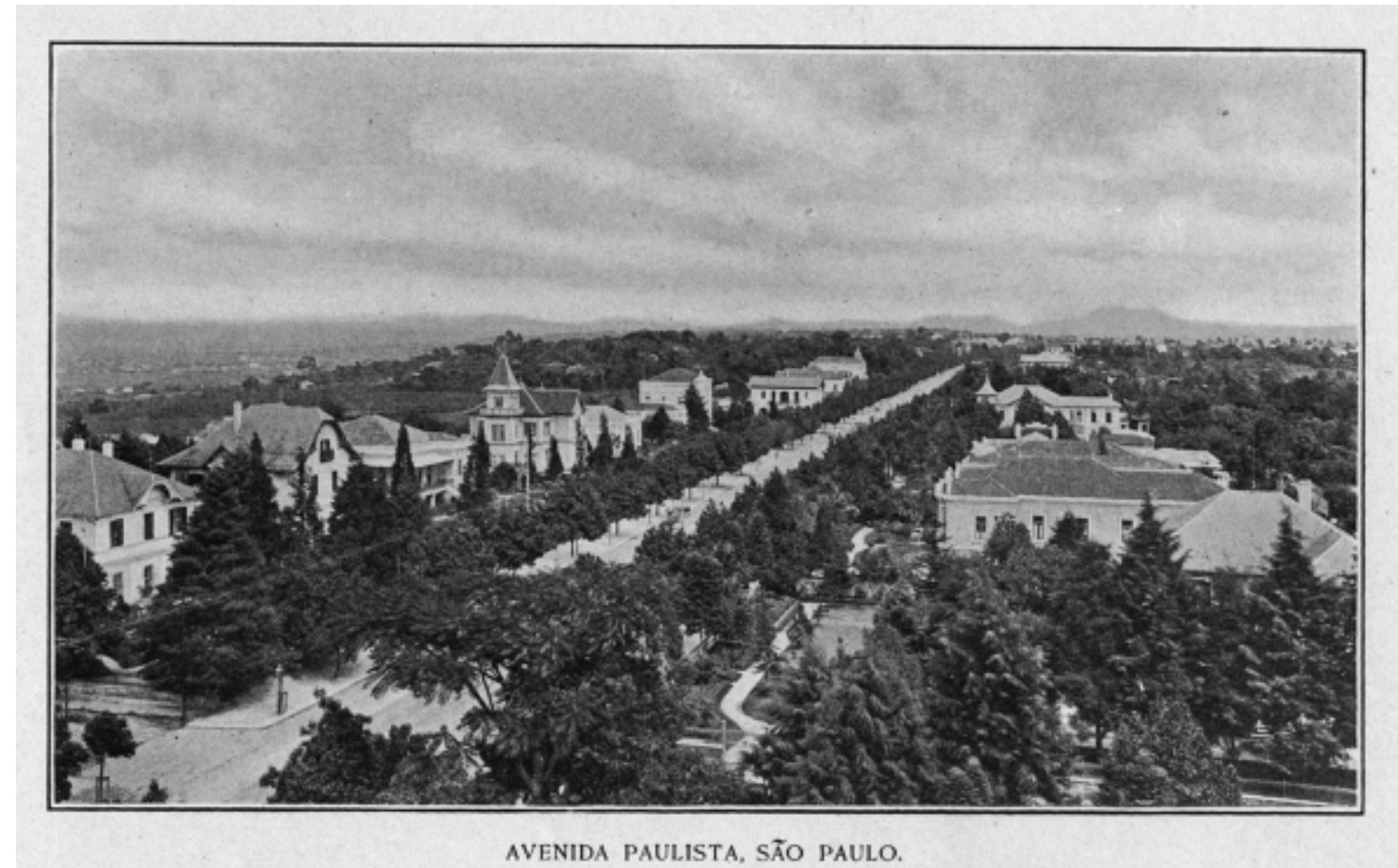

Figura 115 - A Avenida Paulista passa a ser ocupada por grandes residências, que têm como uma de suas características a presença abundante de vegetação.

Fonte: WRIGHT, Marie Robinson. The New Brazil. Its resources and attractions. Philadelphia, George Barrie \& Sons, 1907.

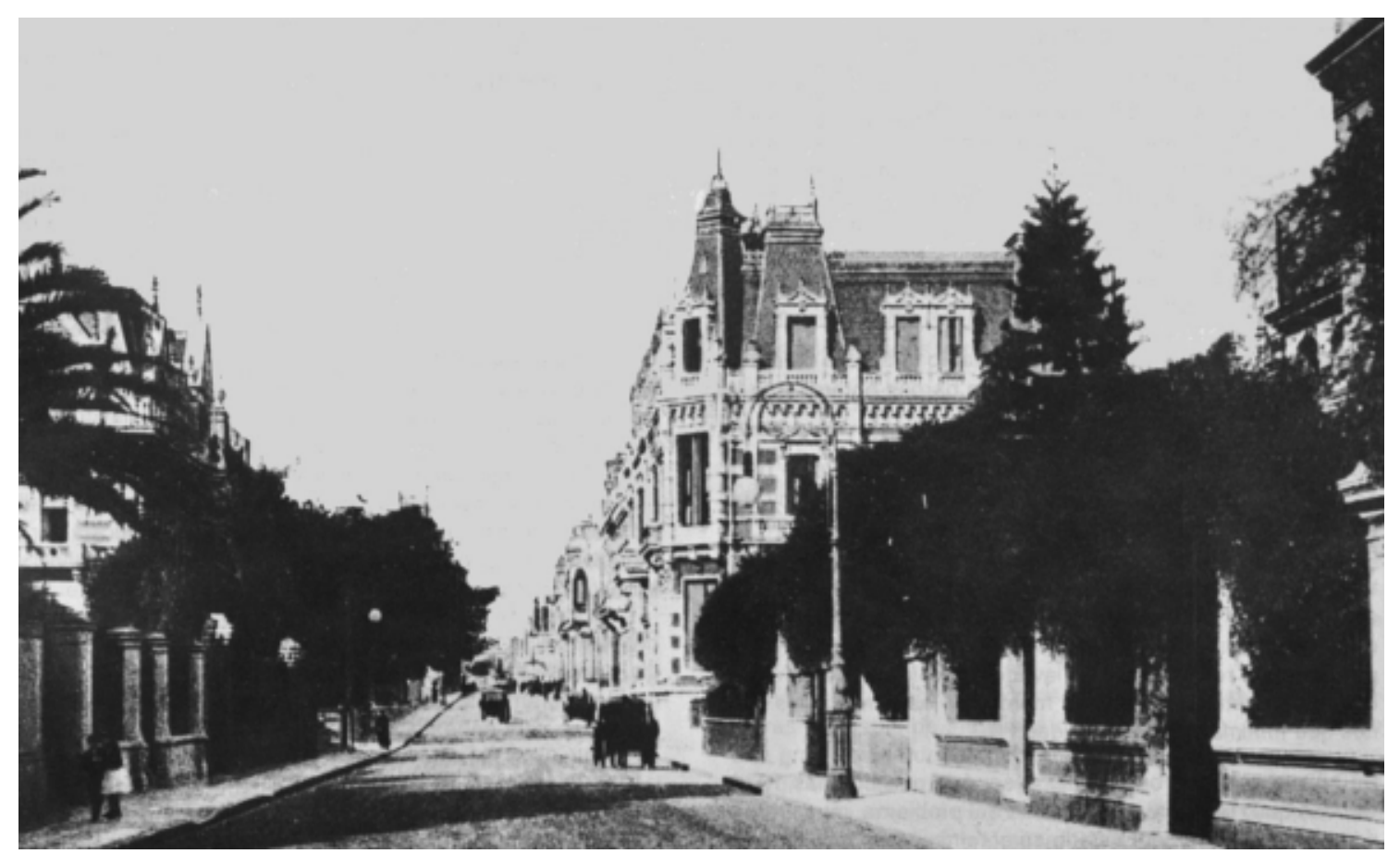

Figura 116 - O mesmo acontece em Buenos Aires, neste caso na Avenida Alvear.

Fonte: GUTIERREZ, Ramón. Buenos Aires. Evolución Histórica. Buenos Aires, Editorial Escala, 1990. 
árvores e na policromia dos canteiros dos jardins, seus palácios de elegantes esculturas, como se encaixa diamante de valor, com múltiplas facetas, nos engastes de esmeraldas e rubis." 25

Já para Alfredo Cusano, em 1911:

"Os bairros elegantes (Higienópolis, Maranhão, Campos Elíseos, Avenida Paulista, Liberdade, etc.) são um verdadeiro triunfo da vegetação e das flores. Toda a luxuriante flora tropical é magnificamente combinada com aquela das zonas temporadas, e passa-se por ruas amplas e majestosas, que são autênticas veredas maravilhosas, nas quais se vêm surgir, a breves intervalos, as mais graciosas casinhas, as mais simpáticas vilas, os mais elegantes palacetes, em uma variedade de cores, de linhas e de estilos, que entretanto têm todos um único fundo de tonalidade italiana, dando idéia expressiva da fantasia e do capricho do amálgama arquitetônico dominante.

Creio que nenhuma cidade do mundo tenha tanto luxo de vegetação, tanta riqueza floral em seu centro urbano e tanta graça arquitetônica nas numerosas vilas, todas orladas de jardins perfumados, que certos bairros de São Paulo."26

Por último, diz Ernesto Bertarelli (1913):

"A Avenida Higienópolis, com alguns palacetes belíssimos e muitas casas bonitas, ricos jardins, arranjos de terreno que eliminam toda a monotonia da cidade, pode competir vitoriosamente com as mais belas ruas modernas das cidades européias. Com a vantagem de que, nos jardins, há uma flora quase tropical e a alegria das corolas multicores, plantas de folhagens régias e a variedade de vivos vegetais de toda a espécie. Outras novas e amplas ruas se entrelaçam, contornadas sempre de casinhas de um a dois andares, edificações ocultas entre os ramos e as flores, alegres habitações de luzes e de cores que irradiam uma aura de doçura e de simplicidade."27

Quanto aos bairros tipo cidade-jardim, em São Paulo o precursor é o Jardim América, projetado por Raymond Unwin e Barry Parker, famosos por vários projetos na Inglaterra. Este bairro começou a ser ocupado na década de $1910 .{ }^{28}$ Não há exemplos similares em Buenos Aires, embora haja tentativas de romper a quadrícula, como em Palermo Chico ou passagem Seaver ${ }^{29}$ Entretanto, muitas ruas de Buenos Aires têm uma densa arborização, graças ao trabalho realizado pelo

\footnotetext{
${ }^{25}$ BRUNO, Ernani da Silva. Op. cit. p. 162.

${ }^{26}$ Idem, ibidem. p. 168.

${ }^{27}$ Idem, ibidem. p. 178.

28 WOLFF, Silvia Ferreira Santos. Jardim América: o primeiro bairro-jardim de São Paulo e sua arquitetura. São Paulo, Edusp, 2001.

${ }_{29}$ Há exemplos posteriores na periferia, como o bairro "Ciudad Jardim", em Palomar, da década de 1940.
} 
paisagista Carlos Thays, que entre 1890 e 1910 plantou mais de 150 mil espécies de árvores em ruas e avenidas.

\section{5 - A ESCOLHA DOS SITIOS}

Uma das grandes dificuldades para a realização de parques em áreas centrais era o problema das desapropriações. Seria muito caro realizar demolições nas áreas mais valorizadas, para um empreendimento sem retorno comercial direto.

No caso da abertura de vias e substituição de edifícios, esta possibilidade existia, já que era viável prever um retorno devido à valorização produzida. No caso das avenidas, assim como realizado em Paris por Haussmann, a idéia era comprar mais terrenos do que o necessário para as obras, vendendo-os após sua valorização e assim pagar os custos da obra. Isto tanto poderia ser estatal (avenida de Mayo, em Buenos Aires) como um empreendimento privado (projeto Alexandre de Albuquerque, em São Paulo).

Apesar disto, esta idéia foi utilizada em São Paulo no caso do parque da Várzea do Carmo. Da área escolhida foram reservados $451.000,00 \mathrm{~m}^{2}$ para o parque, e os 102.346,07 $\mathrm{m}^{2}$ restantes foram divididos em $90.899,95 \mathrm{~m}^{2}$ para comercialização e $11.446,12 \mathrm{~m}^{2}$ para outros fins. A idéia era custear parte das despesas com a construção do parque através da venda de terrenos. Não se tratava, entretanto, de uma área muito valorizada por ser várzea. ${ }^{30}$

Em São Paulo, entretanto, foi criado um considerável parque no vale do Anhangabaú, mesmo situado em área central e sem que fosse utilizado o expediente da reserva de terras para venda. Isto se deve a que, ao contrário de Buenos Aires, onde os projetos realizados reforçam a centralidade da praça maior, em São Paulo o que era o fundo da cidade, passa a ser a entrada, pela cidade nova, formada por loteamentos para as camadas abastadas (Higienópolis, Campos Elíseos). ${ }^{31}$ A entrada agora é pela avenida São João, e não mais pelo Tamanduateí. Com isso, uma área não ocupada, por ser um vale de difícil acesso, e não valorizada pelos motivos acima, passa a ser objeto de um grande projeto, do qual pouco resta nos dias de hoje (figura 117). ${ }^{32}$

O equivalente portenho é a remodelação da Plaza de Mayo. O ciclo de reformas começou quando o jovem pintor e engenheiro Pridiliano Pueyrredón retorna em 1854 a Buenos Aires depois de uma estadia em Paris. Nos anos seguintes à sua chegada projetou e executou uma reforma na Praça Maior alterando substancialmente suas características. As reformas incluíram reconstrução dos monumentos existentes, pavimentação e formação de canteiros de plantas, além do fechamento da praça com postes e correntes para evitar a entrada de animais e veículos. ${ }^{33}$

\footnotetext{
${ }^{30}$ BARTALINI, Vladimir. Op. cit. p. 60.

${ }^{31}$ REIS FILHO, Nestor Goulart. Algumas experiências urbanísticas no início da República: 1890-1920. Cadernos do LAP 1. São Paulo, FAUUSP, 1994.

${ }^{32}$ A respeito dessas discussões, ver capítulo sobre as intervenções nas áreas centrais.

${ }^{33}$ BERJMAN, Sonia. Nuestros paseos públicos a traves del tiempo. In: BERJMAN, Sonia (comp.). Op. cit.
} 


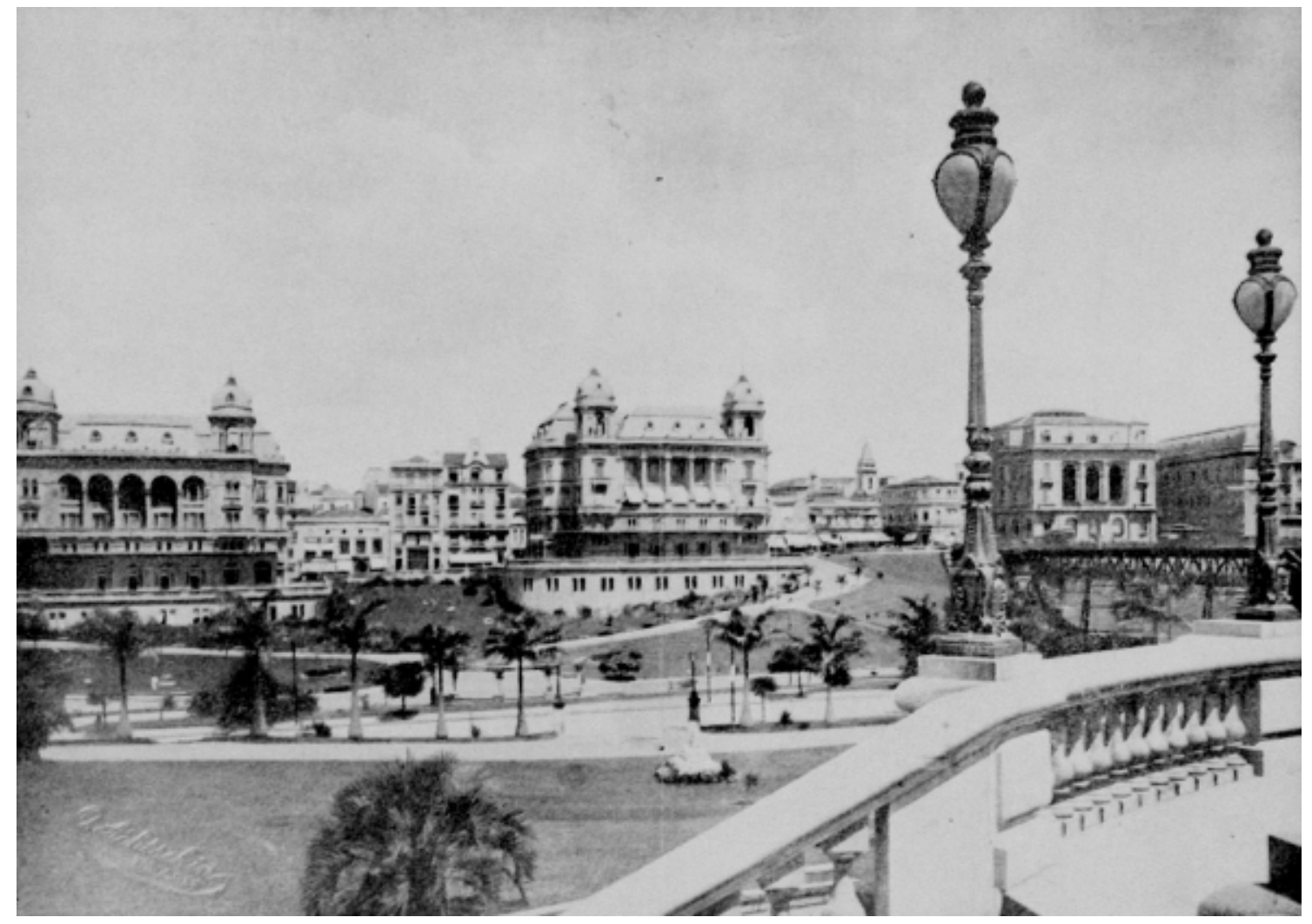

Figura 117 - Nesta figura vemos o parque construído no vale do Anhangabaú, resultado dos projetos propostos na década de 1910, e que passa a ser o “cartão de visitas” da cidade de São Paulo.

Fonte: TOLEDO, Benedito Lima de. Prestes Maia e as origens do urbanismo moderno em São Paulo. São Paulo, Empresa das Artes, 1996.

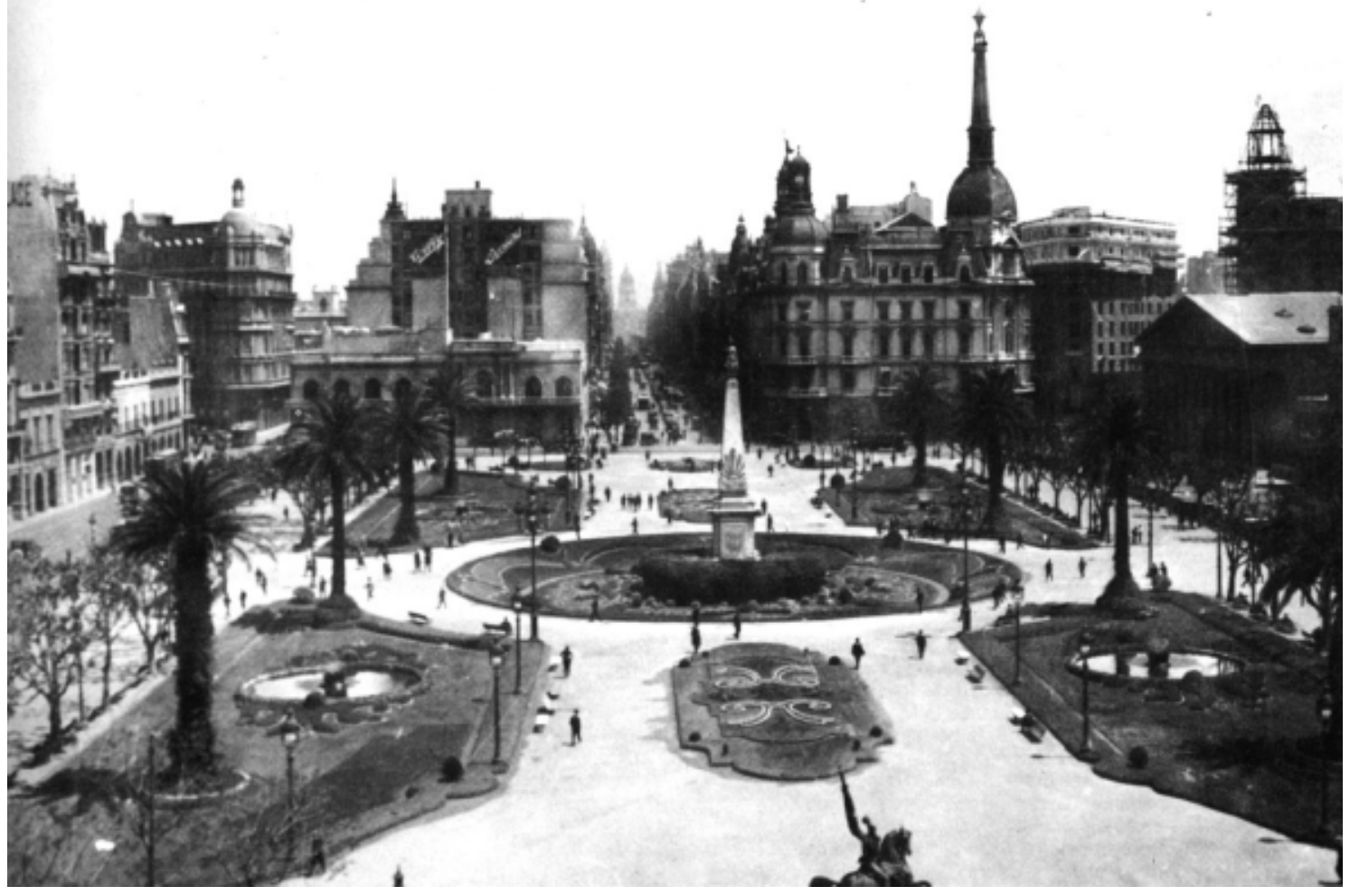

Figura 118 - Neste caso, temos uma foto com o resultado final da junção de praças que resultou na atual "Plaza de Mayo".

Fonte: GUTIERREZ, Ramón. Buenos Aires. Evolución Histórica. Buenos Aires, Editorial Escala, 1990. 
Após isto, em 1884, durante a gestão do intendente Torquato de Alvear, é demolida a "recova", espécie de edifício porticado de dois andares construído em 1803, onde funcionava um mercado, e que separava as praças do Mercado e da Vitória. Estava formada a atual Plaza de Mayo. O objetivo declarado era modernizar e embelezar a cidade, formando um grande espaço em frente à Casa de Governo, que se tornaria um dos eixos focais da futura Avenida de Mayo.

Esta praça tem uma dimensão menor que o parque do Vale do Anhangabaú, é central, mas não significou desapropriações, pois as praças já existiam. $^{34}$ (figura 118).

\section{6 - OS SISTEMAS DE PARQUES}

Em geral, na bibliografia corrente sobre o urbanismo em ambas cidades, o tema das áreas verdes é colocado como parte dos embelezamentos ou ações de higiene. Novamente vamos citar Gorelik, ${ }^{35}$ já que sua posição é diferente. Em sua tese mostra que há a emergência de um espaço público metropolitano baseado em duas figuras: a grelha, configurada pela forma do sistema viário, e um conjunto de parques. Mostra que ao lado das grandes propostas de intervenção e as polêmicas que suscitaram, houve de forma mais silenciosa, vinda de alguns órgãos técnicos da prefeitura, ${ }^{36}$ a realização de um plano com visão global da cidade, publicado em 1904.

Antes, em 1888, haviam sido definidos os atuais limites da capital (correspondente à avenida General Paz), conformando uma área consideravelmente maior que a mancha urbana então existente, e que incorporava dois povoados próximos: Belgrano e Flores. No plano de 1904 já estão traçadas todas as ruas, ou seja, definindo toda a posterior ocupação da cidade, seguindo a mesma grelha de sempre, a despeito das inúmeras discussões a favor e contra o sistema ortogonal. $E$ junto, projetados uma série de parques, que definem a ocupação daquelas fronteiras. Em outras palavras, os órgãos públicos de planejamento projetam e executam um sistema de parques, junto com o sistema viário, a maioria deles situados em áreas ainda não ocupadas. Quase todos foram efetivamente executados mais tarde: Parque del Sur, Parque Chacabuco, Quinta Agronomica, Parque Rancagua, Parque Centenário, Parque Lezica, Parque Patricios, Quinta Moreno e Parque Rivadavia (figura 119).

Não encontramos paralelo em São Paulo a respeito da execução de política semelhante. Entretanto, a idéia de construir sistemas de parques não esteve ausente do debate urbano na capital paulista.

No relatório apresentado por Bouvard em 15 de maio de 1911, não há muitas referências à questão, até porque era um texto relativamente genérico. Entretanto, diz:

\footnotetext{
${ }^{34}$ Procedimento diferente também foi adotado em Manhattam: o Central Park foi construído em área não ocupada, mas de tal forma que mais tarde ocupasse uma posição central, como de fato ocorreu. GORELIK, Adrián. Op. Cit.

${ }^{35}$ Idem, ibidem.

${ }^{36}$ Buenos Aires foi federalizada, isto é, tornou-se a capital da República, em 1880.
} 


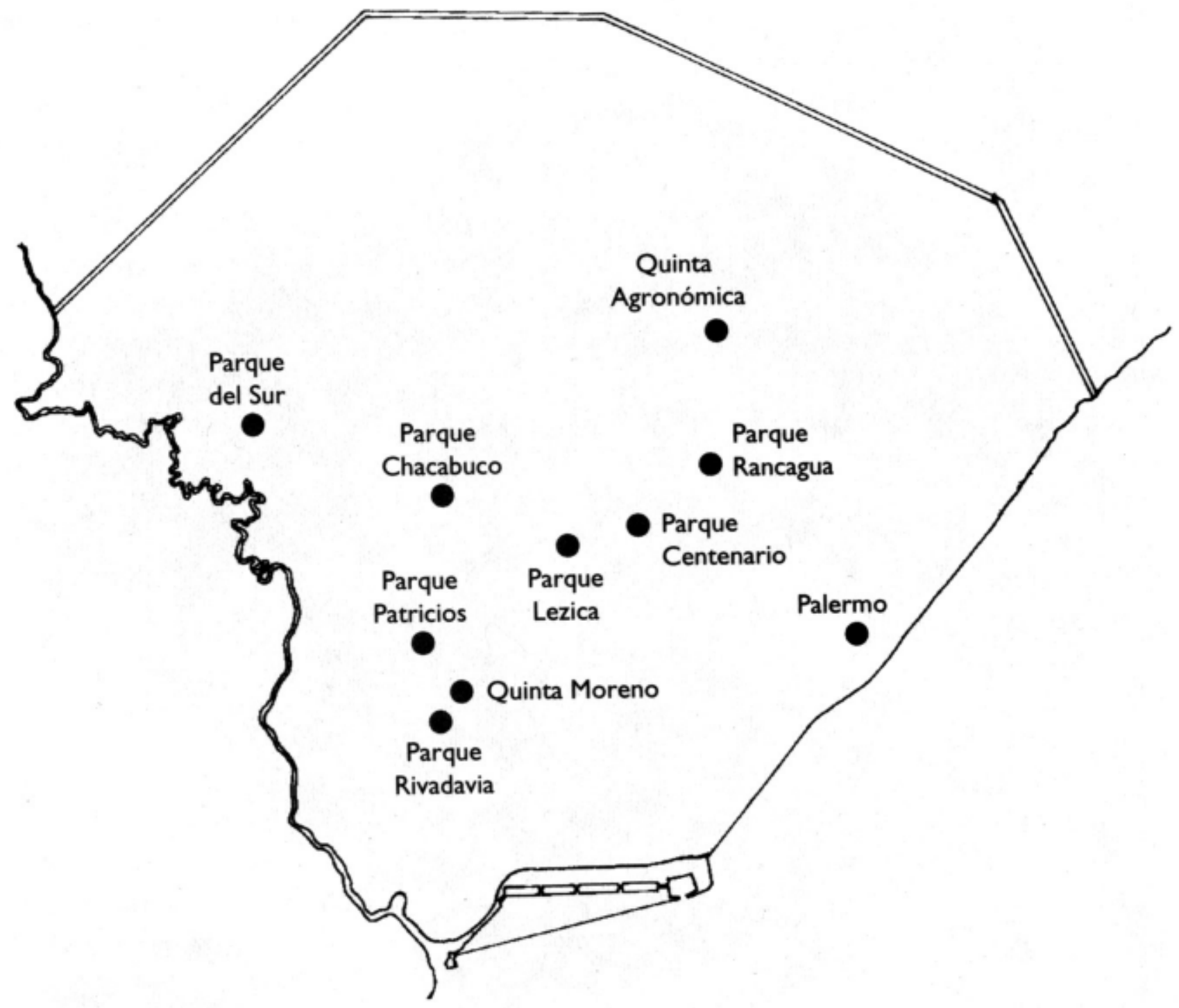

Figura 119 - Esquema com a disposição dos parques propostos para Buenos Aires, de acordo com o plano de 1904.

Fonte: GORELIK, Adrián. La Grilla y el parque. Espacio público y cultura urbana en Buenos Aires, 18871936. Quilmes, Universidad Nacional de Quilmes, 1998. 
"Em todas essas disposições cumpre não esquecer a conservação e criação de espaços livres, de centros de vegetação, de reservatorios de ar. Mais a população aumentará, maior será a densidade da agglomeração, mais crescerá o número de construcções, mais alto subirão os edifícios, maior se imporá a urgencia de espaços livres, de praças públicas, de squares, de jardins, de parques, se impõe.

Foi para tal fim que independentemente dos passeios interiores, de que apresento a collocação nos estudos, tendo em vista o encanto e attração da cidade, aconselho tres grandes parques, logares de passeio para os habitantes, o curso de hygiene e de bem estar, necessarios à saude publica, tanto moral como physica. ${ }^{137}$

Não deixa maiores informações do que sejam esses "passeios interiores".

Pouco antes, em 15 de fevereiro de 1911, em conferência proferida no "Gremio Polytechnico", Vitor da Silva Freire fazia uma série de considerações a respeito dos parques numa cidade. Na ocasião compara Paris com Londres, fazendo notar que existe uma grande diferença entre ambas, já que enquanto em Londres há uma grande quantidade de pequenas áreas verdes, em Paris predominam os grandes parques:

" ... a superioridade de Londres não é tanto na importancia das grandes manchas. Reside ella sobretudo na quantidade das pequenas. Londres está 'crivada' de espaços abertos. E eis o que dirige hoje as municipalidades. Muitos pequenos logradouros, mas dispostos por forma a que todos ali possam ir, descansar, passeiar, sentar-se, respirar., ${ }^{, 38}$

Vitor da Silva Freire acredita que a receita londrina é mais eficiente, apoiado no fato de que os índices de tuberculose são muito maiores em Paris do que em Londres. Preocupado com o crescimento de São Paulo, pergunta:

"Póde a superfície que ella [a cidade de São Paulo] occupa tornar-se duas, tres, quatro vezes maior? Sim, se, como em Londres, houver a precaução de dispôr, na medida do seu crescimento e em proporção à massa das edificações, os espaços abertos, parques e jardins, necessários à sua saúde! Não, se, como em Pariz, permittirmos a accumulação de pedra concentrar-se cada vez mais, invadir dia a dia os antigos terrenos livres, e negligenciarmos de praticar emquanto é tempo, novas clareiras. ${ }^{139}$

Ao criticar o fato de que somente são classificados na categoria de "sanitários" os "espaços ajardinados 'completamente separados e a um abrigo do

\footnotetext{
${ }^{37}$ O relatorio do Sr. Bouvard. Revista de Engenharia. V1. Junho de 1911 a maio de 1912, p. 42-43.

38 FREIRE, Vitor da Silva. Melhoramentos de São Paulo. São Paulo, Revista Polytechnica, Vol. Vi, № 33, fevereiro/março de 1911, p. 130.

39 Idem, ibidem. p. 126.
} 
bulicio, do movimento e da poeira das ruas, por uma espessa cortina de vegetação' ", passa a adotar o conceito de "sistemas de parques". Assim:

"De tudo isso nasceu a noção actual dos "systemas de parques", denominação technica já consagrada e que exprime para cada cidade, a forma por que ella satisfaz a necessidade da distribuição de ar puro, luz, repouso e recreio ao melhor das suas forças vivas, às suas crianças. E não é só. É a salubridade moral que se procura também obter". ${ }^{40}$

Alguns anos depois, entre 1918 e 1919, Barry Parker, que trabalhou no projeto do Jardim América com Raymond Unwin que reformou o parque Villon, deixou também escritos com referências a este tema:

"As autoridades municipais também me encarregaram de desenhar um parque de uns 700 acres [280 ha] num outro distrito. Diante deste pedido fiz notar que este parque deveria fazer parte de um sistema completo de parques, e não ser concebido como uma unidade isolada (...) Chamei a atenção das autoridades municipais de que deveria ser adquirido rapidamente, antes que fosse tarde demais, um cinturão de terras para parques entre a cidade existente e estas aldeias e lugarejos, fazendo um círculo completo em torno da cidade. Minha proposta foi de criar um cinturão largo, com sua faixa interna destinada definitivamente para parque, podendo haver um retorno lucrativo para a cidade com a revenda das terras das faixas externas do anel, graças à valorização que elas teriam com a destinação da faixa interna para parque." ${ }^{, 1}$

Também nos projetos de "Melhoramentos do rio Tietê" há a preocupação com a criação de áreas verdes. A crítica realizada pela Diretoria de Obras da Prefeitura, na figura de Vitor da Silva Freire, ao projeto do Dr. J. a da Fonseca Rodrigues, apresentado em 1922, e elogios ao substitutivo apresentado pouco depois pelo engenheiro J. F. de Ulhoa Cintra tem como pano de fundo, entre outros motivos, o fato de F. Rodrigues não ter supostamente se preocupado com estas questões. ${ }^{42}$

"... considerando sobretudo o atrazo indesculpavel em que se encontra a capital do Estado em matéria de respiradouros, de pulmões para a população, de espaços abertos, em resumo, para me servir da expressão consagrada, - completa o engenheiro Cintra o seu esboço, prevendo a formação, ao longo do futuro canal, de uma série de trechos relvados e ajardinados, constituindo por essa forma solução do conjunto, de tal modo frequente nas cidades modernas e adiantadas até na América, que a ciência da urbanização já Ihe reservou uma denominação especial a de 'parkway' ".43

\footnotetext{
${ }^{40}$ Idem, ibidem. p. 132.

${ }^{41}$ BARTALINI, Vladimir. Op. cit. p. 74. Grifo nosso.

${ }^{42}$ Embora exista um item sobre "Obras de embellezamento". Boletim do Instituto de Engenharia $\mathrm{N}^{0} 19$, janeiro de 1923, p. 194.

${ }^{43}$ Ambos projetos, e os comentários de Vitor da Silva Freire estão publicados no "Boletim do Instituto de Engenharia" $\mathrm{N}^{\circ} 19$, de janeiro de 1923. Também há referências em BRITO, Saturnino de. Obras
} 
Saturnino de Brito incorpora também a idéia da importância destes espaços livres para o "aformoseamento urbano", no projeto que apresenta para o Tietê em 1926 (figura 120).

Poucos anos depois, em 1930, surge o projeto de Prestes Maia intitulado "Estudo de um plano de avenidas para a cidade de São Paulo". ${ }^{44}$ Neste estudo, o tema de parques ocupa um apêndice. Embora sem maiores detalhamentos, reitera a idéia dos "parkways", e propõe uma série de parques novos, divididos em dois tipos.

O primeiro tipo é o dos grandes parques, que seriam: Cabeceiras do Ipiranga, Ibirapuera, Cantareira e Alto da Serra. Os demais seriam os parques médios. Foram previstos os parques Ponte Grande, Pary, Mooca, Tatuapé, Lapa, Butantan e Aclimação.

Como podemos notar, na década de 1920 já se faz sentir o peso das idéias vindas dos Estados Unidos, principalmente na concepção de parques ladeando avenidas ou vias expressas, os chamados "parkways". Ou então a idéia dos grandes cinturões verdes, em detrimento da existência de muitas pequenas áreas livres, como havia sido defendido por Vitor da Silva Freire.

Embora a idéia de criar um sistema de parques tenha perpassado constantemente o discurso sobre as intervenções urbanas na cidade de São Paulo, na prática não houve uma concretização efetiva dessas idéias, como ocorreu em Buenos Aires, segundo a tese de Gorelik.

\section{7 - OS QUADROS PROFISSIONAIS}

Um fato que chama a atenção em ambas cidades é que, a despeito das turbulências políticas do período que estudamos, persistiram por longo tempo os profissionais encarregados de parques e jardins. No caso de São Paulo, o primeiro Inspetor de Jardins foi Antônio Etzel. Ele ficou no cargo por pouco mais de trinta anos, de 1899 (nomeado por Antônio Prado, o $1^{\circ}$ prefeito) até 1930, quando foi substituído por seu filho Arthur Etzel. Durante esse período, a cidade teve 6 prefeitos.

Não foi muito diferente em Buenos Aires: o primeiro encarregado dos parques e jardins, como "Director de Paseos" da cidade, foi Eugène Courtois, que ficou no cargo de 1877 a $1889 .{ }^{45}$ Nesse período a cidade foi governada por uma Comissão Municipal (até 1883) e 4 intendentes. ${ }^{46}$

Completas de Saturnino de Brito. Vol. XIX: Defesa contra as inundações (1925-1929). Rio de Janeiro, Imprensa Nacional, 1944.

44 MAIA, Francisco Prestes. Estudo de um plano de avenidas para a cidade de São Paulo. São Paulo, Companhia Melhoramentos, 1930.

${ }^{45}$ BERJMAN, Sonia. Eugène Courtois, ese desconocido paisajista. Buenos Aires, Anales del IAAIE "Mario Buschiazzo" N 29, 1992-1993, p. 69-85.

${ }^{46} \mathrm{O}$ cargo de intendente equivale em Buenos Aires ao de prefeito em São Paulo. 


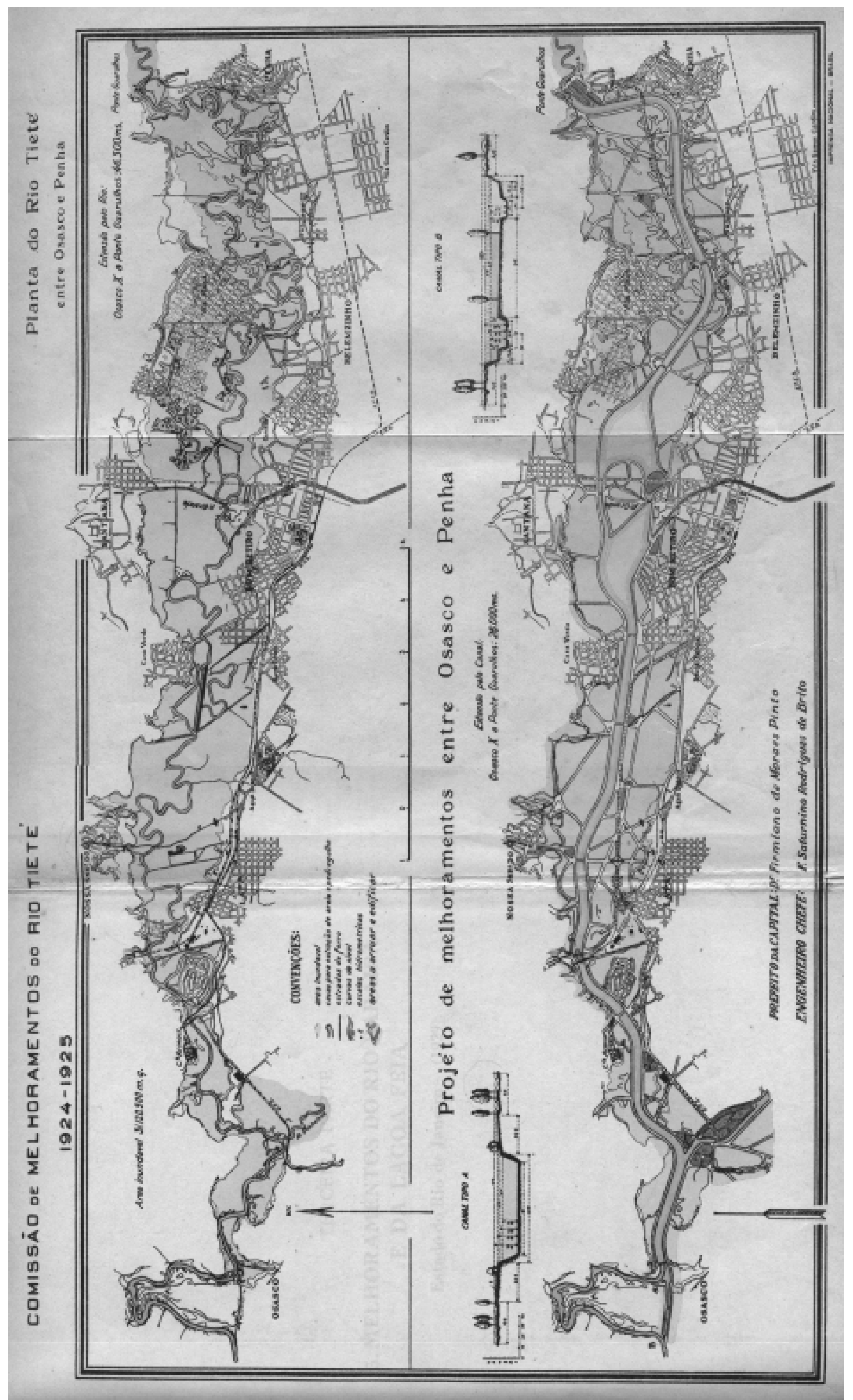

를

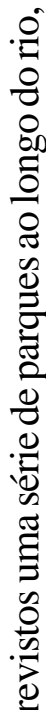

굴

峦

중

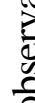

$\checkmark$

0

ํㅗㅇ

ㄱ.

응

৫่

:

으 을

ㅇ

ก)

ฮี ڤั

임

事

जี

议

告 :

ठี हे

임

गั0

드 :

导兽

러

ํํㄹ

ช 꿍

일 
A seguir veio Carlos Thays, que foi diretor de "Parques y Paseos" de 1891 a 1913, durante o qual a cidade teve dez intendentes. Assim como ocorreu em São Paulo, seu filho Carlos Leon Thays irá assumir o cargo alguns anos depois.

Carlos Thays realizou um trabalho notável, tanto no âmbito público como no privado. Por este motivo, vale a pena descrever resumidamente sua biografia.

Nasceu em Paris em 1849, de forma que sua adolescência e juventude transcorreram enquanto o barão de Haussmann realizava as reformas em Paris. Reconhece entre seus principais mestres a Jean Alphand, que projetou entre inúmeras outras obras os jardins dos Campos Elíseos, além de Edouard André, em cujo estúdio trabalhou por alguns anos e participou de obras em vários países europeus. Um fazendeiro portenho chamado Miguel Crisol, radicado em Córdoba depois de muitos anos de residência em Paris, contratou Thays por um ano para realizar diversos trabalhos naquela cidade, por recomendação de Alphand. Thays chegou à Argentina em junho de 1889, onde ficaria até sua morte em 1934. Mesmo sendo pouco conhecido em Buenos Aires, em 1891 venceu um concurso para "Director de Parques y Paseos" desta cidade, onde ficaria até 1913. Com enorme capacidade de trabalho, projetou e executou uma quantidade muito grande de trabalhos não só em Buenos Aires, mas também em inúmeras outras cidades da Argentina e de outros países, tanto no âmbito público como no privado. Realizou inclusive um projeto no Brasil, a praça do Palácio de São Luis do Maranhão (1901). ${ }^{47}$

\section{$6.8-$ CONCLUSÕES}

Nesta parte do trabalho pudemos constatar que existem numerosas diferenças na forma de apropriação, produção, uso e transformação do espaço urbano. Uma dessas diferenças reside na persistência ou não de determinados elementos do urbanismo colonial. É o caso da Praça de Maio, que é objeto de alguns dos mais importantes projetos paisagísticos em Buenos Aires, que reiteram uma centralidade que vem até os dias atuais. Diferente é o caso do antigo "triângulo" paulistano, que embora receba algum tratamento paisagístico, é suplantado neste sentido pelas intervenções realizadas no vale do Anhangabaú.

É importante também constatar que as duas principais áreas verdes existentes no período colonial, o Parque da Luz e o Parque Tres de Febrero, embora nessa época estivessem afastados das áreas centrais, no final do século XIX vêem seu entorno ser ocupado por bairros destinados às camadas mais ricas, que passam a utilizá-los intensamente.

Em relação às residências, verificamos que o padrão adotado nos bairros das elites econômicas não difere muito em ambas cidades, ao contrário das casas das novas camadas médias que, embora tenham semelhanças na implantação e partido, apresentam diferenças no tratamento paisagístico interior.

\footnotetext{
${ }^{47}$ Para um resumo de toda a produção de Thays ver: DE PAULA, Alberto; VILLAMIL, Vicente Rodriguez. Carlos Thays. In: BERJMAN, Sonia (comp.). El tiempo de los parques. Buenos Aires, IAAIE "Mário Buschiazzo", 1992.
} 
Outro aspecto que merece ser considerado refere-se à relação entre os organismos técnicos públicos, os projetos propostos e sua efetiva realização. Neste período já existiam quadros técnicos competentes, com um certo grau de estabilidade se comparado com os cargos políticos. Entretanto isto nem sempre se traduziu em projetos executados.

Isto é particularmente significativo no caso de São Paulo, já que até a inauguração do Parque Ibirapuera em 1954, pouco foi realizado pelos governos municipais, apesar dos inúmeros debates sobre a matéria, ou dos investimentos realizados. Em relação a este último aspecto, é paradigmático o caso do Parque da Ponte Grande (ou da Floresta). A prefeitura comprou em 1912 os terrenos contíguos ao rio Tietê com o objetivo de realizar um grande parque, o qual teria em torno de 300.000 metros quadrados. Não foi realizado, mas consumiu em 1911, entre compras e indenizações, $15 \%$ do total da receita daquele ano. ${ }^{48}$

Ao contrário, algumas das principais áreas de lazer do paulistano foram empreendimentos privados, como o Parque Antarctica, o Bosque da Saúde e o Parque da Aclimação, neste último caso com acesso pago. Duraram enquanto existiu o interesse privado, e somente restou o Parque da Aclimação porque a prefeitura comprou a área.

Como parte do processo de conhecer melhor a organização social do período há o fato de que muitos dos grandes nomes europeus que para cá foram trazidos pelas elites eram paisagistas ou ligados a essa atividade, como Bouvard, Courtois, Thays, Villon, Arsenius Puttomans etc. Isto mostra a importância que estas camadas sociais davam ao assunto, e entender melhor a razão da produção destes espaços pode permitir compreender melhor os projetos sociais e suas contradições, e de que forma eram usados como instrumento de legitimação.

\footnotetext{
${ }^{48}$ BARTALINI, Vladimir.Op. cit. p. 52.
} 
CAPÍTULO 7

\section{TRAÇADO: RUAS, QUADRAS E LOTES}




\section{1 - ANTECEDENTES}

Uma das características mais marcantes e mais evidenciadas por inúmeros pesquisadores é o contraste entre o urbanismo praticado por portugueses e espanhóis no período colonial. De fato, é notável como um modelo extremamente geométrico é repetido à exaustão, no caso espanhol. Isto levou a que alguns pesquisadores (como Robert Smith) concluíssem que os portugueses não conheciam a ordem. É de certa forma o que se apreende no capítulo "O semeador e o ladrilhador", do clássico livro Raízes do Brasil, de Sérgio Buarque de Holanda. ${ }^{1}$

Este tipo de abordagem vêm sendo continuamente superada desde os anos 60, quando à procura de aperfeiçoar os instrumentos teóricos foram substituídas as interpretações baseadas apenas na questão do traçado, passando a se trabalhar com o conceito de projeto social ${ }^{2}$, mostrando que não se trata de conhecer ou não a ordem, mas sim de que políticas colonizadoras diferentes produzem resultados diferentes, projetos estes que devem ser analisados quanto às suas implicações nas diversas escalas.

O projeto espanhol desde cedo é levado adiante sob um rigoroso controle de todo seu processo por parte da Coroa Espanhola. A intenção de povoar, ou seja, ocupar o território, já está presente no século XVI. Pouco tempo se passou desde as primeiras tentativas e a consolidação de um corpo de leis que objetivavam o povoamento, como são as Leyes de Descubrimiento y Población, ditadas por Felipe II em 1573. Esse aspecto está presente, por exemplo, nas ordenanças 32 e 33, que dizem:

“... antes de conceder nuevos descubrimientos, se pueble lo descubierto"3

A preocupação em assegurar o sucesso da empresa leva a um elevado grau de detalhamento do projeto, como neste trecho das ordenanças 88 e 89 :

“...Que dentro del término, que le fuere señalado, por lo ménos tenga treinta vecinos, y cada uno de ellos una casa, diez vacas de vientre, quatro bueyes, ó dos bueyes, y dos novillos, una yegua de vientre, una puerca de vientre, veinte ovejas de vientre de Castilla, $y$ seis gallinas, $y$ un gallo..."

Quem recebia terras era obrigado a tomar posse, erguer a cidade e cuidar de tudo o que fosse necessário para seu sucesso em um prazo determinado, conforme a Ordenança 107:

\footnotetext{
${ }^{1}$ HOLANDA, Sérgio Buarque de. Raízes do Brasil. 6a. ed. Estudos Brasileiros, 1. Rio de Janeiro, José Olympio, 1971.

${ }^{2}$ SCHERER, Rebeca. História, teoria e método nos estudos de urbanização. In: Notas sobre planejamento e método. São Paulo, Cadernos de pesquisa do LAP 10, nov./dez. 1995.

${ }^{3}$ In: Recopilación de Leyes de los Reynos de las Indias. Madrid, 1943. Ed. Fac. de 1791. Vol. II, p. 1.

${ }^{4}$ Idem, ibidem. p. 15.
} 
"Los que aceptaren asiento de caballerías y peonías, se obliguen de tener edificados los solares, poblada la casa, hechas y repartidas las hojas de tierras de labor, y haberlas labrado, puesto de plantas, y poblado de ganados las que fueren de pasto, dentro de tiempo limitado, repartido por sus plazos, y declarando lo que en cada uno ha de estar hecho, pena de que pierdan el repartimiento de solares, y tierras, $y$ mas cierta cantidad de maravedis para la República, con obligación en pública forma, y fianza llana y abonada."

Além destas, há uma quantidade enorme de ordenanças que determinam em detalhes tanto as características físicas como de organização desses núcleos urbanos na América, e que foram obedecidas em geral. ${ }^{6}$

Não é nossa intenção aqui entrar em detalhes quanto ao urbanismo hispano-americano, assunto sobre o qual há uma numerosa bibliografia, mas salientar a clareza e o detalhamento com que foi montado esse projeto. Mostra disso é o fato da Espanha praticar, no mesmo período, urbanismos diferentes na metrópole e nas cidades de nova fundação na América. É o caso das dimensões, tanto das ruas, das praças e dos solares, que na América tem dimensões muito maiores do que na Espanha. ${ }^{7} \mathrm{E}$, ao contrário das cidades espanholas, onde as instituições religiosas e civis ocupam espaços diferentes, na América estão ambas reunidas em torno da Plaza Mayor.

Na figura 121 temos o plano de fundação de Buenos Aires, no qual podemos verificar como de antemão o solo é delimitado no ato da fundação, sendo já destinado aos diferentes povoadores as datas que lhes correspondem.

No caso do Brasil ainda prevalece a idéia de que não havia atividades de planejamento urbano no período colonial, apesar da contribuição de numerosos autores mostrando o contrário. Estas evidências ficam claras ao observamos planos de cidades que desde o século XVII tinham um traçado regular, como é o caso de São Luis do Maranhão (1612) e Belém do Pará (1616) (figuras 122 e 123). ${ }^{8}$

É importante também destacar o papel dos engenheiros militares, que provinham de Portugal e de outros países, mas que desde muito cedo também começaram a ser formados no Brasil: em 1696 na Bahia e em Pernambuco, e depois também no Rio de Janeiro e Pará. Eram profissionais de elevado gabarito, e que responderam com competência às solicitações do projeto da Coroa Portuguesa. ${ }^{9}$

Apesar disto, as regras eram menos detalhadas que as espanholas quanto aos aspectos urbanísticos, caso das Ordenações Filipinas, de 1603. Ou ainda as

\footnotetext{
${ }^{5}$ Idem, ibidem. p. 40.

${ }^{6}$ Existem exceções a essas leis, devido aos mais variados motivos, mas de forma geral a grande maioria as segue, embora não exista nenhuma que rigorosamente tenha as características propostas. É o caso da Plaza Mayor, da qual segundo as ordenanças deveriam sair ruas em cada uma de suas esquinas, além de ruas partindo do centro de cada um dos lados da praça. A realidade mostra que não existe nenhum exemplo construído com essa configuração.

${ }^{7}$ CEHOPU. La ciudad Hispanoamericana. El sueño de un orden. Madrid, Cehopu, s.d.

${ }^{8} \mathrm{O}$ melhor documento para comprovar estas afirmações é o recentemente lançado livro de REIS, Nestor Goulart. Imagens de Vilas e Cidades do Brasil Colonial. São Paulo, Edusp/Imprensa Oficial do Estado, 2001.

9 BUENO, Beatriz Piccolotto Siqueira. Desenho e Desígnio: o Brasil dos Engenheiros Militares (15001822). Tese de Doutorado. São Paulo, FAUUSP, 2001.
} 


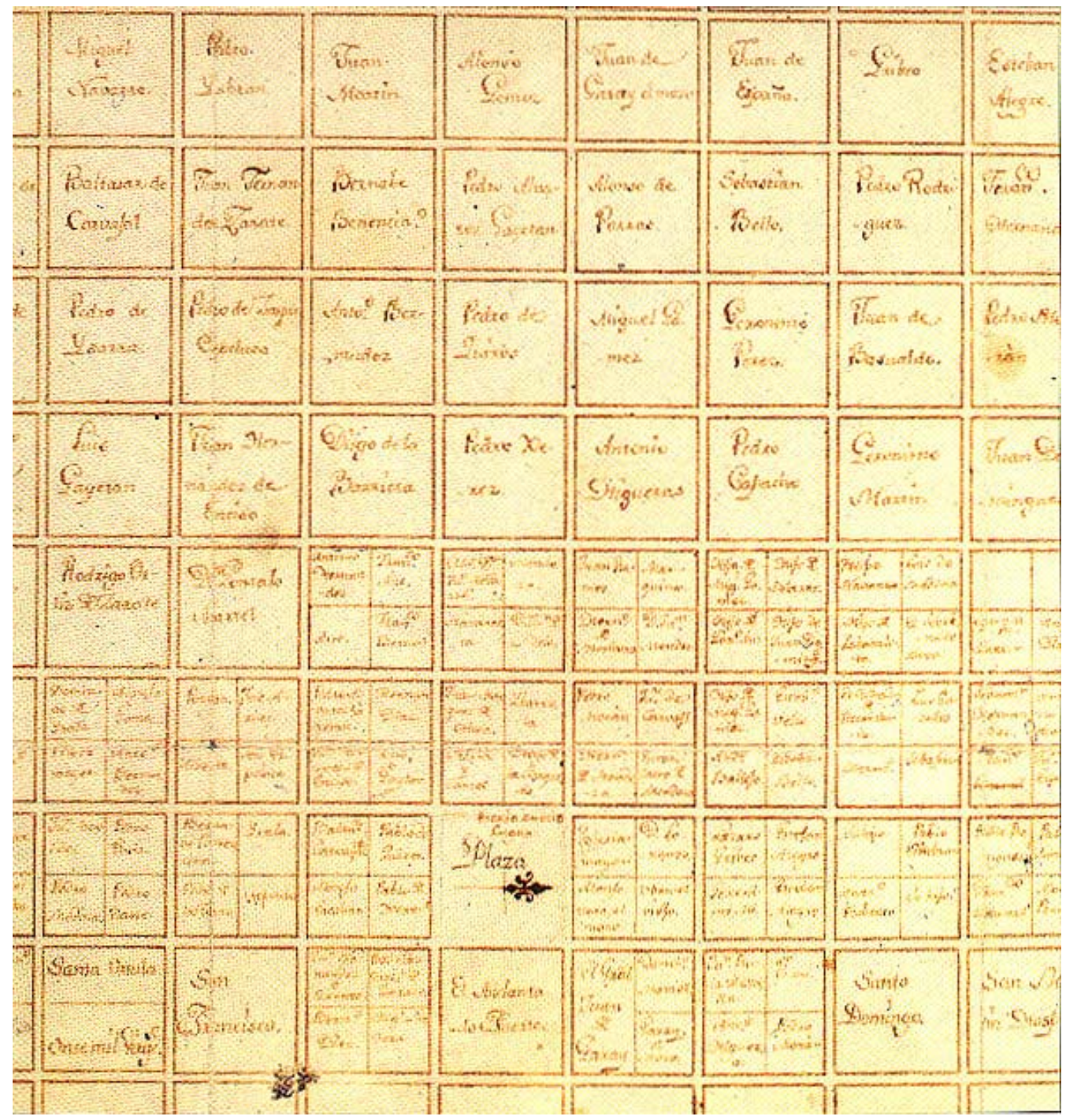

Figura 121 - Plano de fundação da cidade de Buenos Aires (1583).

Fonte: CEHOPU. La ciudad hispanoamericana. El sueño de un orden. Madrid, CEHOPU, 1989

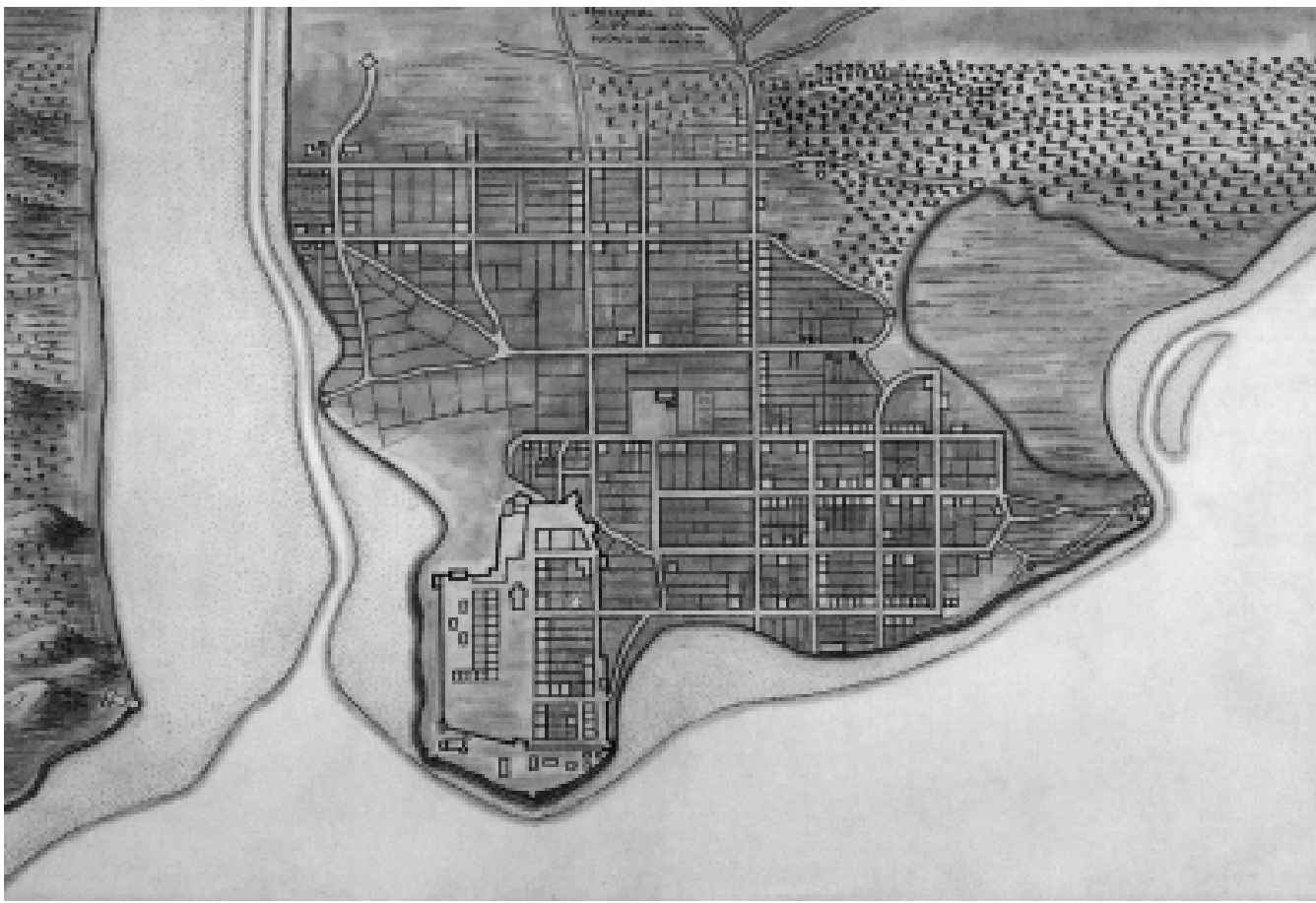

Figura 122 - Planta de 1640 (c.a.) de São Luis do Maranhão. Ao contrário do que afirma a visão mais difundida, já havia no Brasil do século XVII cidades fundadas com traçado regular, neste caso em 1612.

Fonte: REIS, Nestor Goulart. Imagens de Vilas e Cidades do Brasil Colonial. São Paulo, Edusp/ Imprensa Oficial do Estado, 2001. 


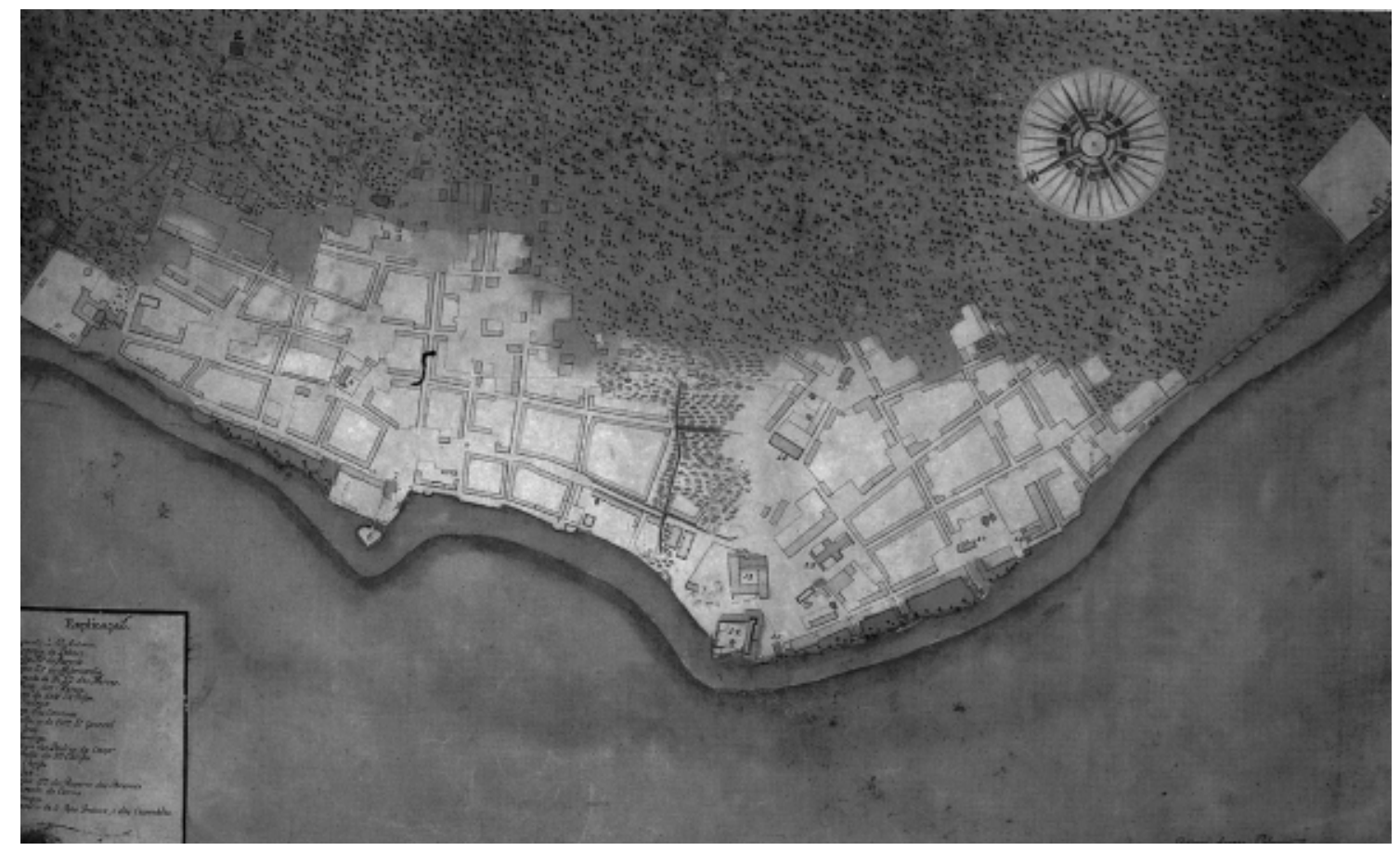

Figura 123 - Cidade de Belém do Pará, em 1753. Outro exemplo de cidade fundada no século XVII (1616) com traçado regular.

Fonte: REIS, Nestor Goulart. Imagens de Vilas e Cidades do Brasil Colonial. São Paulo, 2000

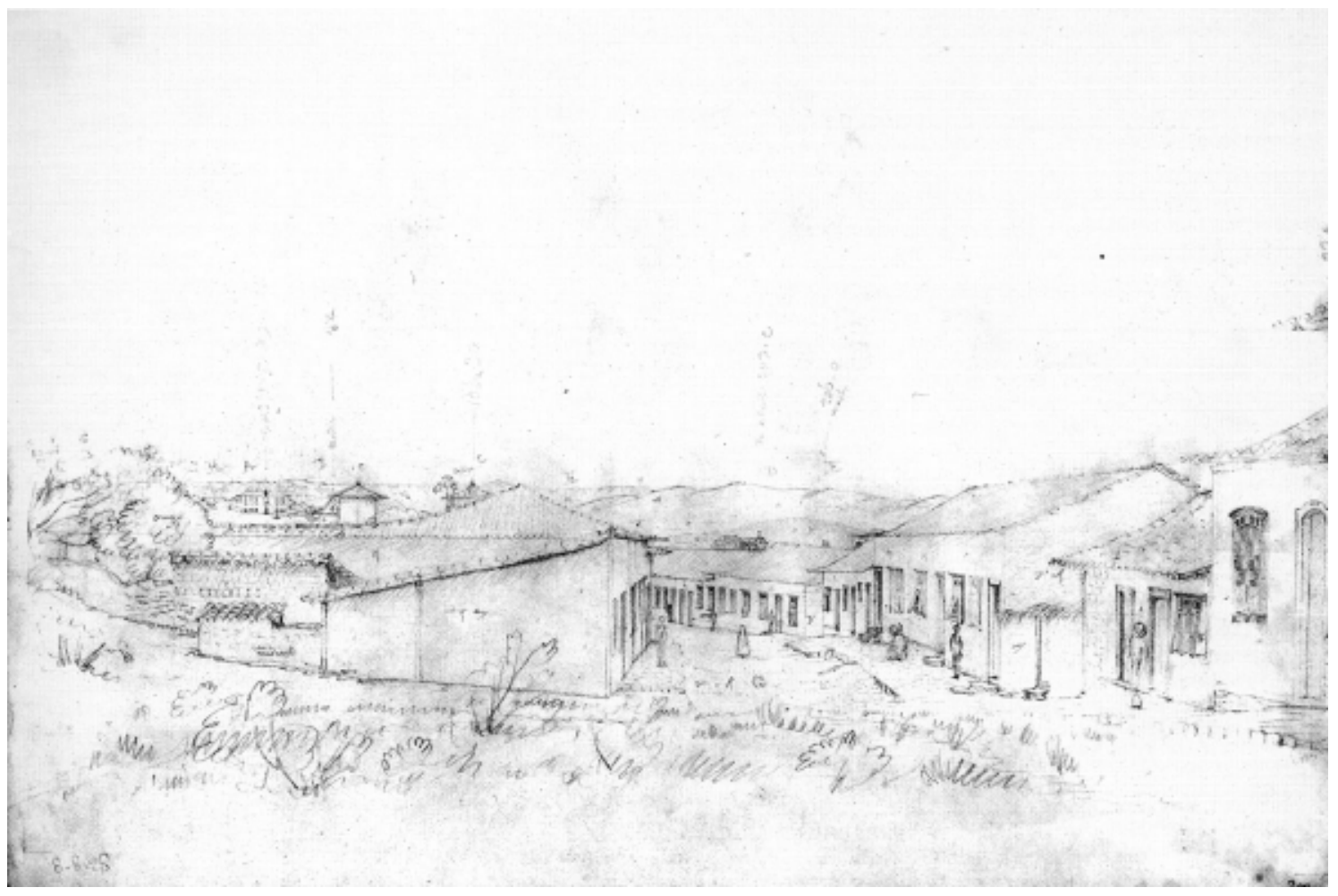

Figura 124 - Aspecto de uma rua no Brasil colonial.

Fonte: FERREZ, Gilberto (org.). O Brasil do Primeiro Reinado visto pelo botânico William John Burchell. 1825/1829. Rio de Janeiro, Fund. João Moreira Salles/Fund. Pró-memória, 1981. 
Constituiçõens primeyras do arcepispado da Bahia, redigidas em $1707 .{ }^{10}$ Tratam-se de normas eclesiásticas, do poder religioso.

Mas, se não há aspectos específicos quanto ao desenho do núcleo há, da mesma forma que no caso da Espanha, a preocupação pela escolha do sítio para a povoação:

"Conforme direito Canônico, as Igrejas se devem fundar, e edificar em lugares decentes, e acommodados, pelo que mandamos, que havendo-se de edificar de novo alguma Igreja parochial em nosso Arcebispado, se edifique em sitio alto, e lugar decente, livre de humidade, e desviado, quanto for possível, de lugares immundos, e sordidos..."11

Há nessas Constituições, no entanto, uma determinação que tem implicações importantes no urbanismo e na arquitetura, e refere-se às características do templo: as igrejas paroquiais deviam estar afastadas das demais construções, permitindo inclusive que as procissões pudessem dar a volta ao templo. Isto leva a arquiteturas bastante diferenciadas, já que aqui todo o volume do edifício deve receber tratamento, enquanto nos núcleos espanhóis é a fachada que cumpre o principal papel simbólico. ${ }^{12}$ Quanto ao urbanismo, no Brasil a igreja funciona como um ponto focal em torno da qual se desenvolve a ocupação, ao contrário do caso espanhol, cujo centro é a Plaza Mayor.

Aqui a igreja é a referência para a instalação do pelourinho e da Casa de Câmara e Cadeia, situada em geral perto, mas em outro espaço. ${ }^{13}$ A Plaza Mayor continua, poderíamos dizer que em muitos casos até os dias de hoje, como o centro principal desses núcleos, incorporando as instituições religiosa e civil. Esses processos levam a uma configuração espacial diferente, associada a projetos coloniais diferentes. Temos portanto, de origem, urbanismos diferentes.

Não é outro o caso das áreas que os habitantes irão ocupar. Na América hispânica, como vimos, ao ser fundada a povoação, já estavam previamente delimitados "os lotes" a serem ocupados por cada um, que eram sempre em número suficiente para viabilizar a empreitada.

Nas cidades luso-brasileiras não ocorre o mesmo. O parcelamento do solo tem estreita relação com as edificações existentes no alinhamento das ruas. Era comum que os núcleos urbanos ficassem em lugares altos, neste caso o lote podia ser extremamente comprido e estender-se até algum limite natural, como um rio.

Como resultado de processos históricos diferentes, o aspecto da rua também é diferente: o que caracterizava uma vila portuguesa era a concentração das edificações, que definiam a rua. Era uma forma de dar "peso" a estas pequenas povoações, que passavam boa parte do tempo semivazias, já que os senhores habitavam nas fazendas e engenhos, em especial antes do início do século XVIII (figura 124).

\footnotetext{
${ }^{10}$ Estas são, segundo Murillo Marx, as "Constituições primeiras porque foram as primeiras codificadas e realmente aplicadas, por mais tempo e por toda parte,..." MARX, Murillo. Cidade no Brasil terra de quem? São Paulo, Edusp/Nobel, 1991, p. 20.

11 idem, ibidem. p. 22.

12 GUTIERREZ, Ramón. Arquitectura y urbanismo en Iberoamérica. Madrid, Cátedra, 1983, p. 71.

13 MARX, Murillo. Op. cit.
} 
"As ruas eram constituídas por fileiras de casas construídas sôbre o alinhamento e sôbre os limites laterais dos terrenos, formando superfícies contínuas. Nos centros menores e nos arrabaldes - por vêzes também nas casas de esquina chegavam os pomares junto às ruas, mas eram ocultos por muros, restabelecendo-se, por meio dêstes, a continuidade das superfícies construídas." ${ }^{14}$

No caso espanhol, pelo fato dos solares já serem definidos de antemão, e da legislação exigir a ocupação e edificação do solar concedido, é outro o aspecto da rua. Esta só passa a apresentar continuidade quando as diversas construções são sucessivamente ampliadas ocupando os limites da quadra (figura 125). Esta quadra, por esse motivo, era de início tanto quintal como ambiente semi-rural, onde havia hortas e criação de animais. Somente mais tarde é que o adensamento e ocupação das quadras irá "fechá-las", conformando os tradicionais pátios, e pequenos quintais (figura 126).

No Brasil, as quadras:

“...quando completamente edificadas, compunham-se de uma linha contínua de construções, dos lados das ruas, com um grande vazio constituído pelos quintais, na parte interior. Os telhados das casas, de duas águas, que as lançavam para a rua e para o interior dos lotes, coroavam o conjunto e, algumas vêzes, formavam uma segunda linha de continuidade. Internamente, porém as dimensões das quadras sendo grandes, estendiam-se os quintais em vazios surpreendentes, que contrastavam, de modo violento, com a aparência de concentração das vias públicas. As suas dimensões e proporções variavam de acôrdo com as condições de topografia e posição das quadras no conjunto." 15

Além das vilas e cidades fundadas pela Coroa, há também uma parte dos núcleos urbanos que surge nas áreas entre glebas rurais, entre sesmarias, embrião das futuras freguesias, vilas e cidades. Esta tese, proposta por Murillo Marx, mostra como aos poucos, em torno da capela, irão se instalando pessoas, famílias, e é com a Igreja que estes primeiros habitantes terão que se relacionar: estes recebem uma pequena área em torno da capela e em geral pagam o foro. A relação de dependência entre eles é o aforamento. Este processo continua sucessivamente até que essa freguesia, ou paróquia, é elevada a vila. ${ }^{16}$

Embora existam significativas diferenças, há também alguns pontos em comum. Ao ser fundada uma cidade espanhola, além do traçado e da distribuição dos solares, era também deixada uma área, o exido ${ }^{17}$, para permitir o futuro crescimento do núcleo. Instância semelhante em nossas vilas é o rossio, que embora em geral não

\footnotetext{
${ }^{14}$ REIS FILHO, Nestor Goulart. Contribuição ao estudo da evolução urbana do Brasil (1500/1720). São Paulo, Pioneira/Edusp, 1968, p. 146.

15 Idem, ibedem. p. 148.

16 MARX, Murillo. Op. cit.

17 Ordenança 129. A própria palavra "foragido" (fora do exido) designa justamente aqueles que estão além desses limites.
} 


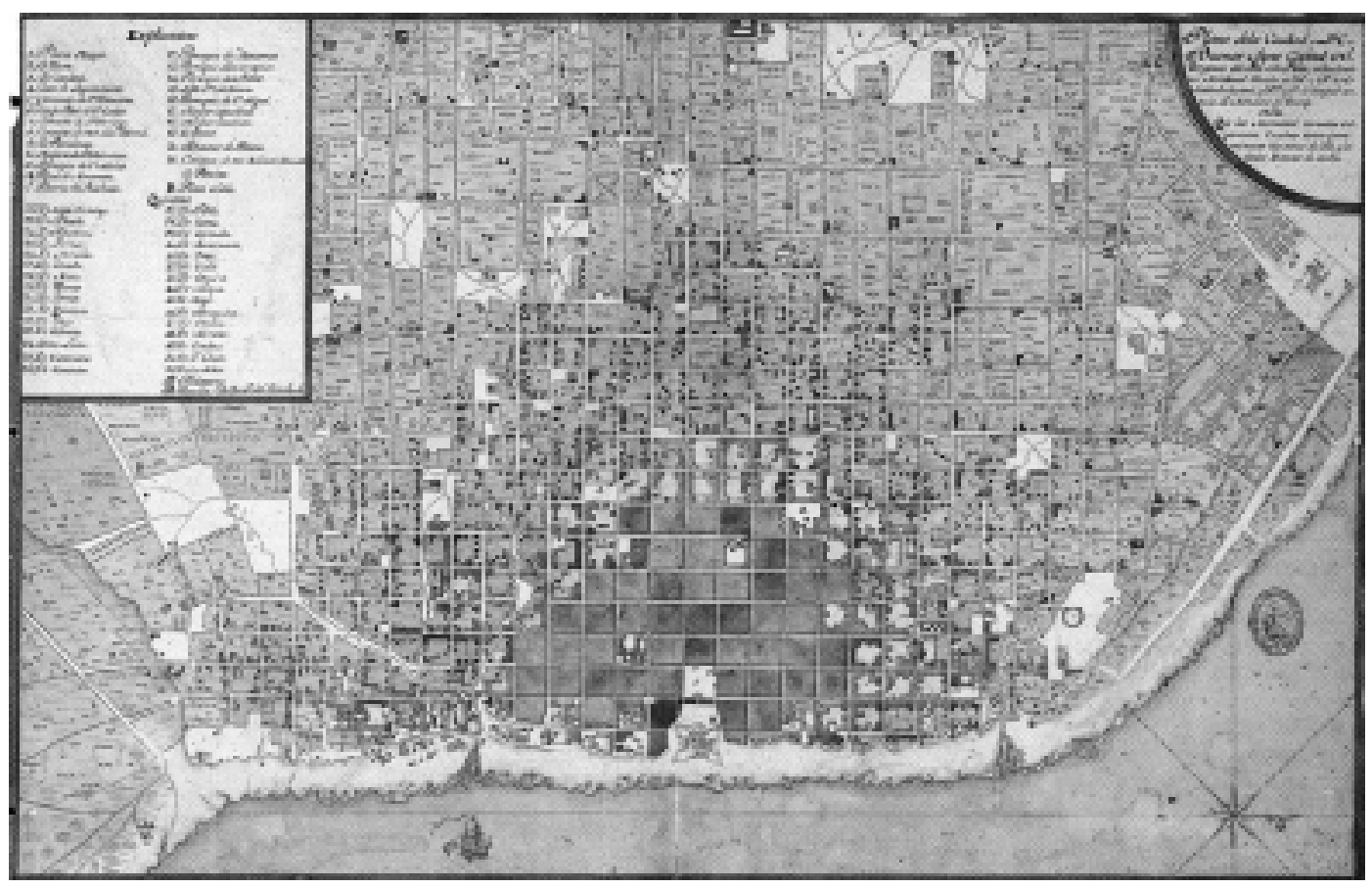

Figura 125 - Buenos Aires em fins do século XVIII.

Fonte: CEHOPU. La ciudad hispanoamericana. El sueño de un orden. Madrid, CEHOPU, 1989

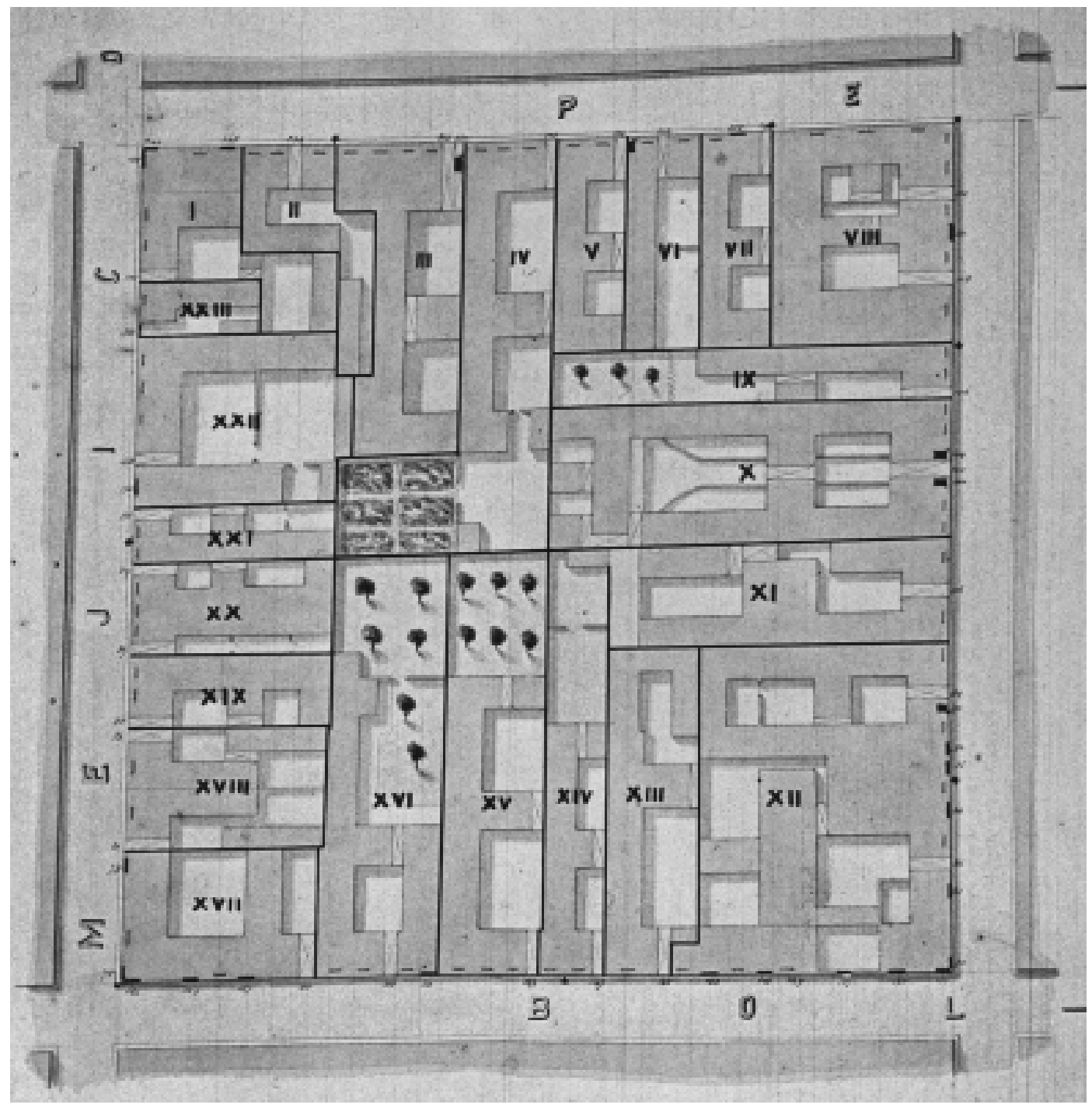

Figura 126 - Adensamento da trama urbana de Buenos Aires, e formação dos tradicionais pátios.

Fontes: Instituto Histórico de la ciudad de Buenos Aires; Instituto de Arte Americano e Investigaciones Estéticas “Mario Buschiazzo”. 
estivesse muito bem definido, tinha o mesmo papel. Há em ambos casos, neste momento, já uma preocupação com o futuro, com as possibilidades de esses núcleos crescerem, permitindo a ocupação do território.

Vimos até agora que há marcantes diferenças entre o urbanismo colonial espanhol e português. É importante, porém, assinalar algumas mudanças que estavam em andamento no século XVIII.

Estudos recentes revelam que, ao menos no caso de Buenos Aires, a obediência àquele urbanismo não era assim tão rigorosa. Em primeiro lugar, assim como no Brasil, em que pese o traçado diferente, também existiam ruas cuja função era servir de escoamento das águas e dos detritos. É o caso, em Buenos Aires, da rua Chile, que segundo relatos da época era um esgoto a céu aberto, exalando um forte cheiro. Suas calçadas, inclusive, tiveram que ser construídas a 1,2 metros de altura, devido ao grande fluxo. ${ }^{18}$ A precariedade (ou inexistência) de instalações punha no mesmo patamar ambos urbanismos nesse sentido, situação que somente melhorou com a instalação de serviços de infraestrutura no final do século XIX, e principalmente no século XX.

Quanto à quadrícula, Novick e Giunta assinalam que é somente no final do século XVIII que se passa

“...de la cuadrícula prevista por la legislación de Indias a una efectiva regularización de la misma y de lo construído en ella."19

Ou seja, estes autores apontam para um fato fundamental: somente a partir deste momento é que de fato vai se controlar mais rigorosamente a obediência a estas normas coloniais. Dois são os fatores essenciais: um é a necessidade de estabelecer uma clara distinção entre o público e o privado. Daí o porquê da intensa atividade de demarcação dos limites entre estas duas esferas.

Outro fator, e necessário para isto, é a presença de profissionais, ou pessoas que tivessem a capacidade de realizar esta tarefa, sendo obrigatória sua participação, assim como passa a ser obrigatória a apresentação de planos. O que se observa na prática, na Buenos Aires desse período, é que o rigor geométrico do urbanismo não era seguido tão estritamente, nem mesmo nas ruas. São inúmeros os casos de pessoas que incorporaram estas aos seus domínios, como mostra este documento de 1796:

“...a fin de exterminar estos desordenes, consiguientes de la unión de cuadras y en tanto interessan al Estado, la Causa Pública, la Religión y la Buena Policía, ordeno y mando que en el perentório término de ocho días desde la publicación de este bando, todos los dueños de Quintas abran las calles..."20

A exigência da presença de profissionais para delimitação existe ao menos desde 1590, mas não obedecida. Não nos devemos esquecer que muito mais do que

\footnotetext{
${ }^{18}$ SCOBIE, James. Buenos Aires. Del centro a los barrios 1870-1910. Buenos Aires, Solar/Hachette, 1977, p. 71.

${ }^{19}$ NOVICK, Alicia; GIUNTA, Rodolfo. La casa de patios y la legislación urbanística. Buenos Aires a fines del siglo XVIII. Buenos Aires, Medio Ambiente y Urbanización, jun. set. 1994. Ano 12. Nºs 47-48 p. 196.

${ }^{20}$ Idem, ibidem. p. 200.
} 
um "desenho urbano", esse urbanismo é quase literal, como nos mostra Angel Rama: não é difícil, a partir do texto da legislação espanhola, realizar o traçado de um núcleo. ${ }^{21} \mathrm{E}$, de fato, isto serviu de base para a fundação de numerosas cidades. $\mathrm{A}$ etapa seguinte, que é a realização de um traçado, com quadras, ruas e praças, é um outro passo, assim como o é sua estrita obediência.

Enfim, segundo esses autores, é a questão do público e do privado que irá determinar a regularização desse traçado, no final do século XVIII:

"Si las ordenanzas, aunque mas no fuere parcialmente, se cumplieron, ello se debió seguramente a la existencia de una 'demanda de regulación' proveniente de la própria sociedad local. Dicha demanda resultó de la necesidad de legitimar jurídicamente la propriedad de las parcelas en un contexto de valorización inmobiliária, motivo central que promovió el cumplimiento de obligaciones urbanísticas y, por esa vía, su impacto sobre las configuraciones habitacionales." 22

Não devemos esquecer também que a necessidade de estabelecer os limites das propriedades será um dos pontos essenciais dos regulamentos e posturas do século XIX, o que pode ser auferido pela importância que assumem, como forma de controle, as atividades de alinhamento.

Essas constatações nos levam a fazer as seguintes reflexões: embora sejam resultado de políticas urbanas coloniais diferentes, há de fato um ponto de inflexão básico na intervenção e na obediências às normas existentes quando se torna necessária a delimitação mais clara entre o que é público e o que é privado, o que ficará mais evidente a partir do final do século XIX. Este é um ponto em comum em ambos casos.

\section{2 - ASPECTOS FORMAIS}

\subsection{1 - O Desenho}

Nesta parte utilizaremos a iconografia e a cartografia para caracterizar em linhas gerais o traçado urbano de ambas cidades, bem como a arquitetura e o urbanismo associado a este.

A primeira observação que podemos fazer comparando diversas plantas é que os rios e córregos são um fator de maior importância no sentido de impedir a ocupação do solo do que os desníveis topográficos, devido às inundações. Tanto em São Paulo como em Buenos Aires as regiões próximas de cursos como o Tietê,

\footnotetext{
${ }^{21}$ RAMA, Angel. A cidade das letras. São Paulo, Brasiliense, 1985.

${ }^{22}$ NOVICK, Alicia; GIUNTA, Rodolfo. Op. cit., p. 199.
} 
Pinheiros, Tamanduateí e Anhangabaú (em São Paulo), e Riachuelo e Maldonado (em Buenos Aires), apresentam baixo nível de ocupação. ${ }^{23}$

A topografia também condicionou a construção das linhas das estradas de ferro, muito mais em São Paulo, onde são obrigadas a seguir de perto as curvas de nível dos vales, e menos em Buenos Aires, cujo terreno quase plano permitiu a construção de vias mais livremente.

Devemos observar, entretanto, que o sitio urbano de Buenos Aires não é completamente plano, e alguns metros de altura de diferença são suficientes para tornar estes lugares mais frescos no forte verão portenho, devido às brisas, lugares estes que foram escolhidos pelas camadas mais ricas para construir suas chácaras de veraneio ou morar, caso de Flores, Belgrano e Devoto.

Outra diferença que podemos observar refere-se à diferença existente no traçado das atuais regiões centrais: Buenos Aires possui o desenho ortogonal característico da maioria das cidades de fundação hispano-americanas, enquanto em São Paulo, como em muitas cidades portuguesas na América, a intenção urbanizadora se manifesta muito menos no plano formal (figuras 127 e 128). No entanto, podemos constatar que os novos loteamentos que são projetados em São Paulo seguem um padrão mais ortogonal, da mesma forma que em Buenos Aires, neste caso como continuação do padrão característico da cidade colonial (figura 129). ${ }^{24}$

Gorelik apresentou recentemente uma tese que coloca em questão algumas das interpretações sobre o processo de expansão urbana da cidade de Buenos Aires. ${ }^{25}$ Mostra que em 1904 é publicado um plano da cidade onde já estão previamente traçadas todas as ruas e avenidas, além de um sistema de parques (figuras 130 e 131). Àquela época a mancha urbana ocupada era bem menor do que a área prevista pelo plano, e este traçado é em grande medida o que efetivamente foi realizado, denotando por parte de alguns órgãos públicos não só a preocupação com o projeto da cidade, como também capacidade de controle deste processo. ${ }^{26}$

No caso de São Paulo, as razões apontadas para a adoção de desenhos mais ortogonais são a maximização dos $\operatorname{lucros}^{27}$, como também a pouca preocupação

\footnotetext{
${ }^{23}$ Isto pode ser observado também hoje, por exemplo, na periferia de São Paulo, onde muitas regiões de relevo extremamente acidentado estão densamente ocupadas, o que ocorre em menor grau nas áreas inundáveis. E não é difícil verificar que em São Paulo o sistema viário acompanha de perto os antigos leitos de córregos, últimos lugares a serem ocupados.

${ }^{24}$ A respeito dos loteamentos em São Paulo, ver GROSTEIN, Marta Dora. A Cidade Clandestina: os Ritos e os Mitos. São Paulo, FAUUSP, 1987.

${ }^{25}$ GORELIK, Adrián. La grilla y el parque. Espacio público y cultura urbana en Buenos Aires, 1887-1936. Buenos Aires, Universidad Nacional de Quilmes, 1998. Neste livro há uma interessante discussão a respeito do traçado em quadrícula. Um artigo sobre este tema foi publicado no Brasil na revista Topos: GORELIK, Adrián. La máquina reformista - indagaciones sobre la cuadrícula moderna en Buenos Aires. Belo Horizonte, Topos $\mathrm{N}^{0} 1$, julho/dezembro 1999.

${ }^{26}$ Anos antes já existia a preocupação em definir um traçado para a cidade. Em 1883 Alvear dizia: "El rápido incremento de la población y el gran número de construcciones que se levantan día a día en el centro de la ciudad en los suburbios hace indispensable proyectar a la mayor brevedad un plan general de ensanche con la apertura y formación de calles cuya dirección y ancho corresponda al mejor ornato e higiene de los barrios nuevos" Citado in: GUTIERREZ, Ramón. Op. Cit., p. 128.

${ }^{27}$ Diz Murillo Marx: "A forma do lote terá - e nisto não há novidade, tão-somente mais explicitação e rigor vantagens em assumir a figura de um quadrado ou retângulo, geralmente deste último, pois a frente ainda guarda seu privilégio, que interessa ao futuro loteiro, ao loteador, ao governo municipal. Tal quadrângulo, retangular e ortogonal, mostra-se como a figura geométrica mais adequada para o retalhamento de uma gleba. A sua área refletirá a que entre a necessidade de atender ao comprador e a de obter o maior lucro possível." MARX, Murillo. Op. Cit.. p. 112.
} 


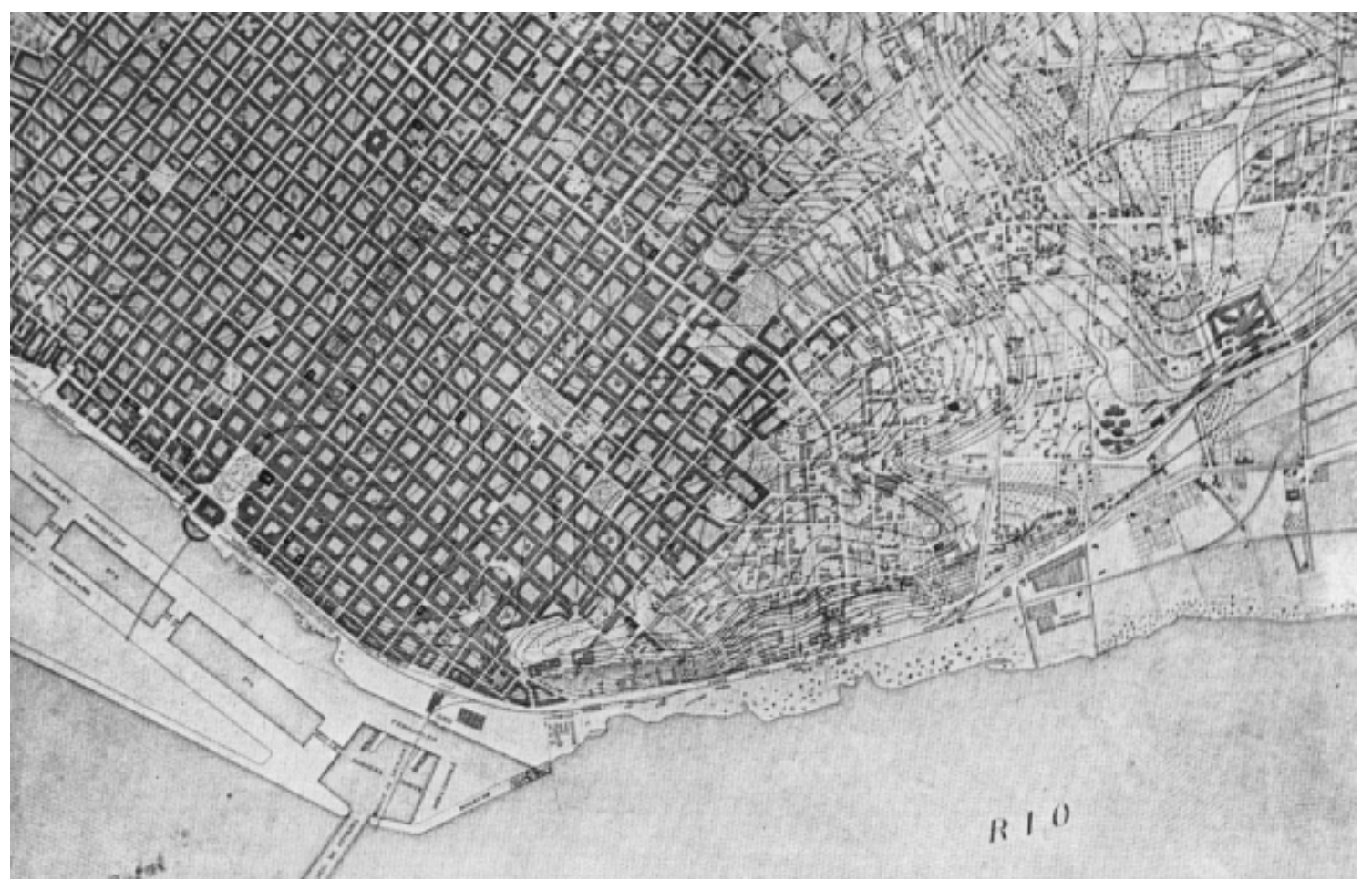

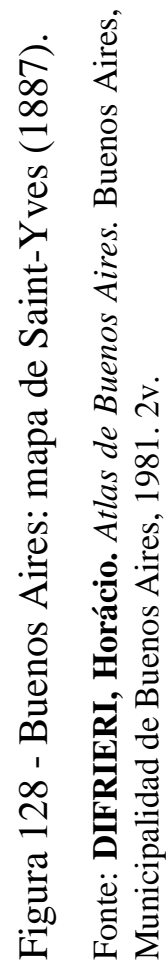
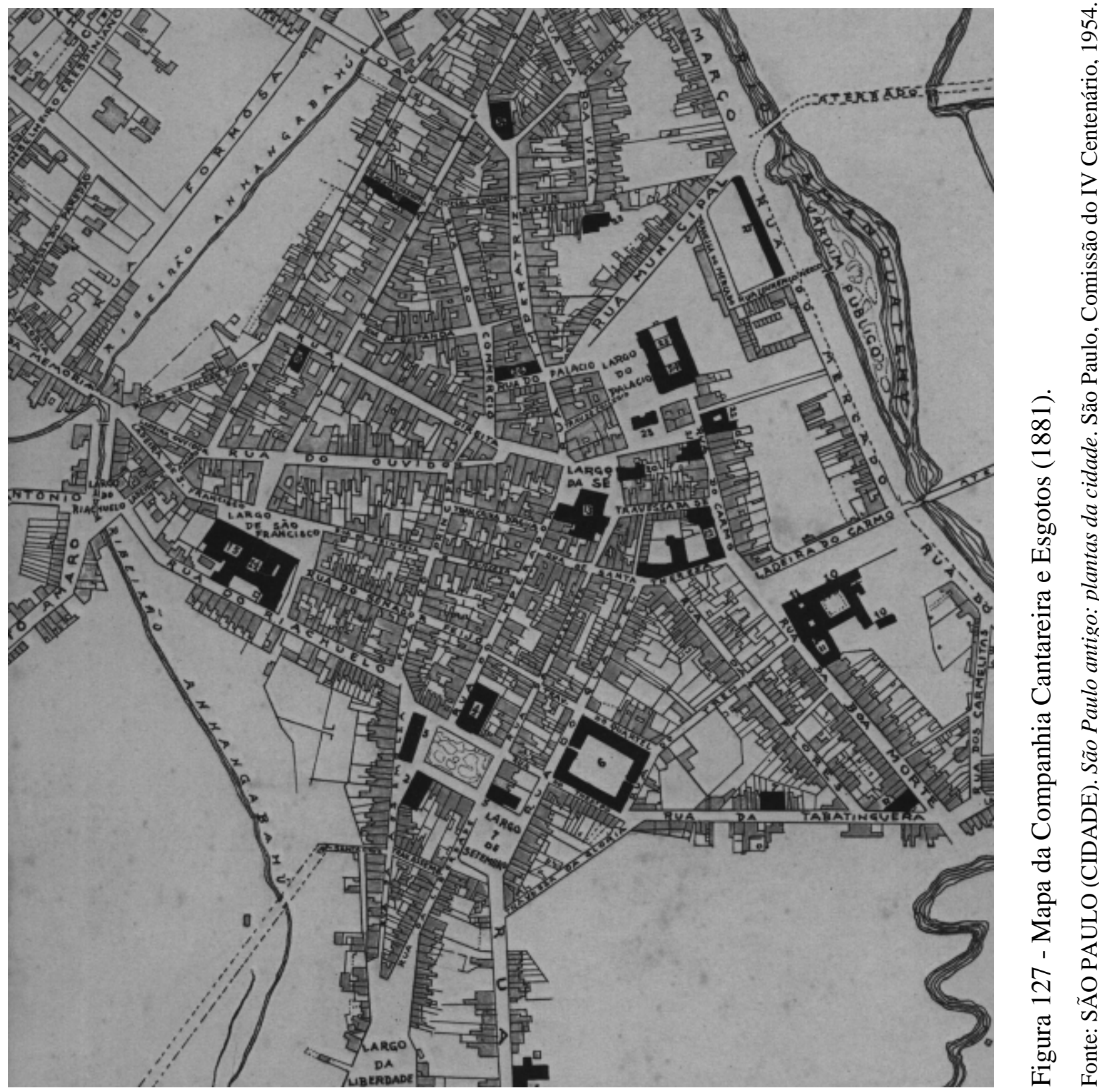


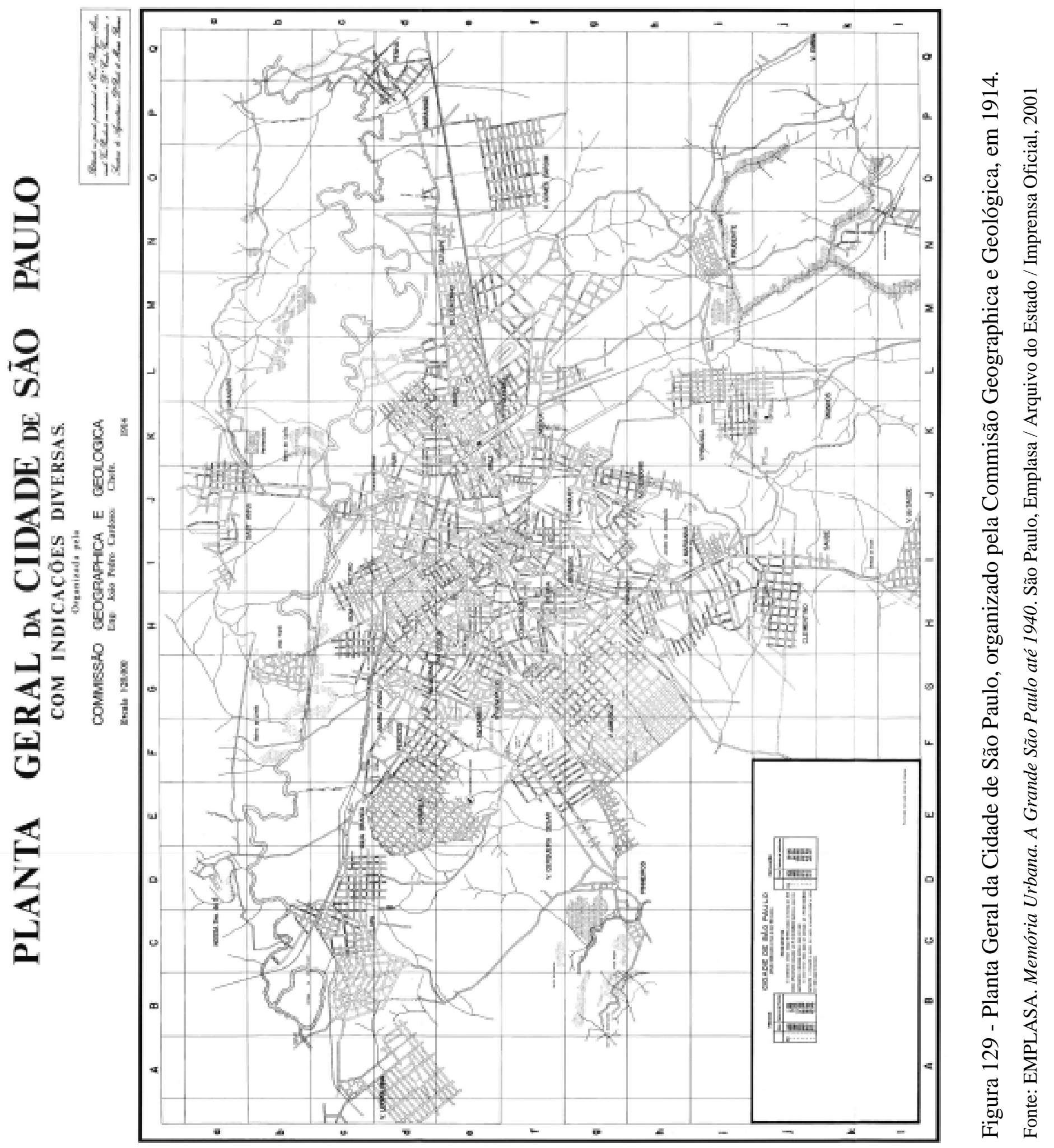




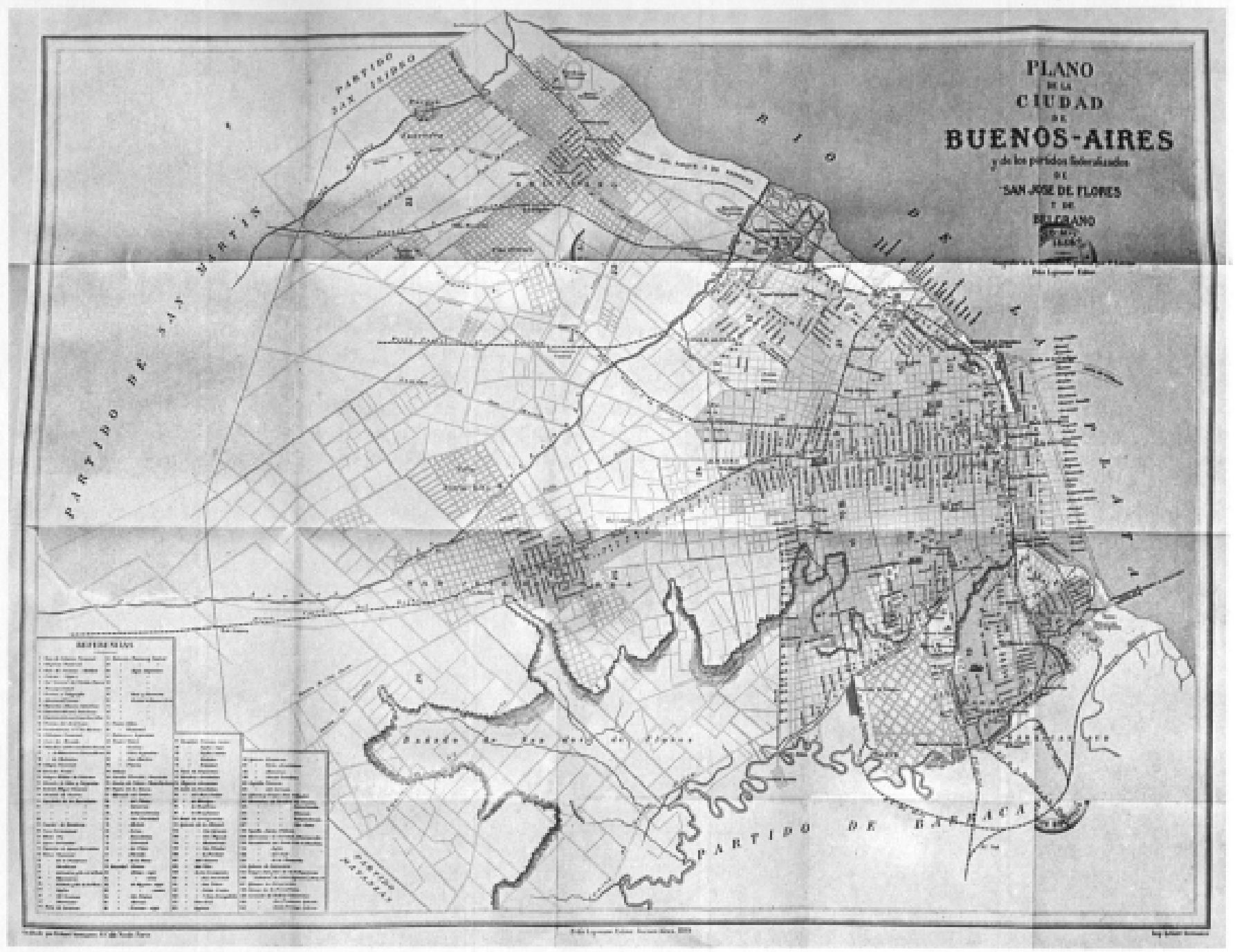

Figura 130 - Plano de la ciudad de Buenos-Aires y de los partidos federalizados de San José de Flores y Belgrano, de 1889. É possível notar que a área ocupada é muito menor que a área que foi definida para a Capital Federal. Ainda não estão desenhados os sistemas viário e de parques que constam do plano de 1904 (próxima figura).

Fonte: DIFRIERI, Horácio. 2v. Atlas de Buenos Aires. Buenos Aires, Municipalidad de Buenos Aires, 1981. 


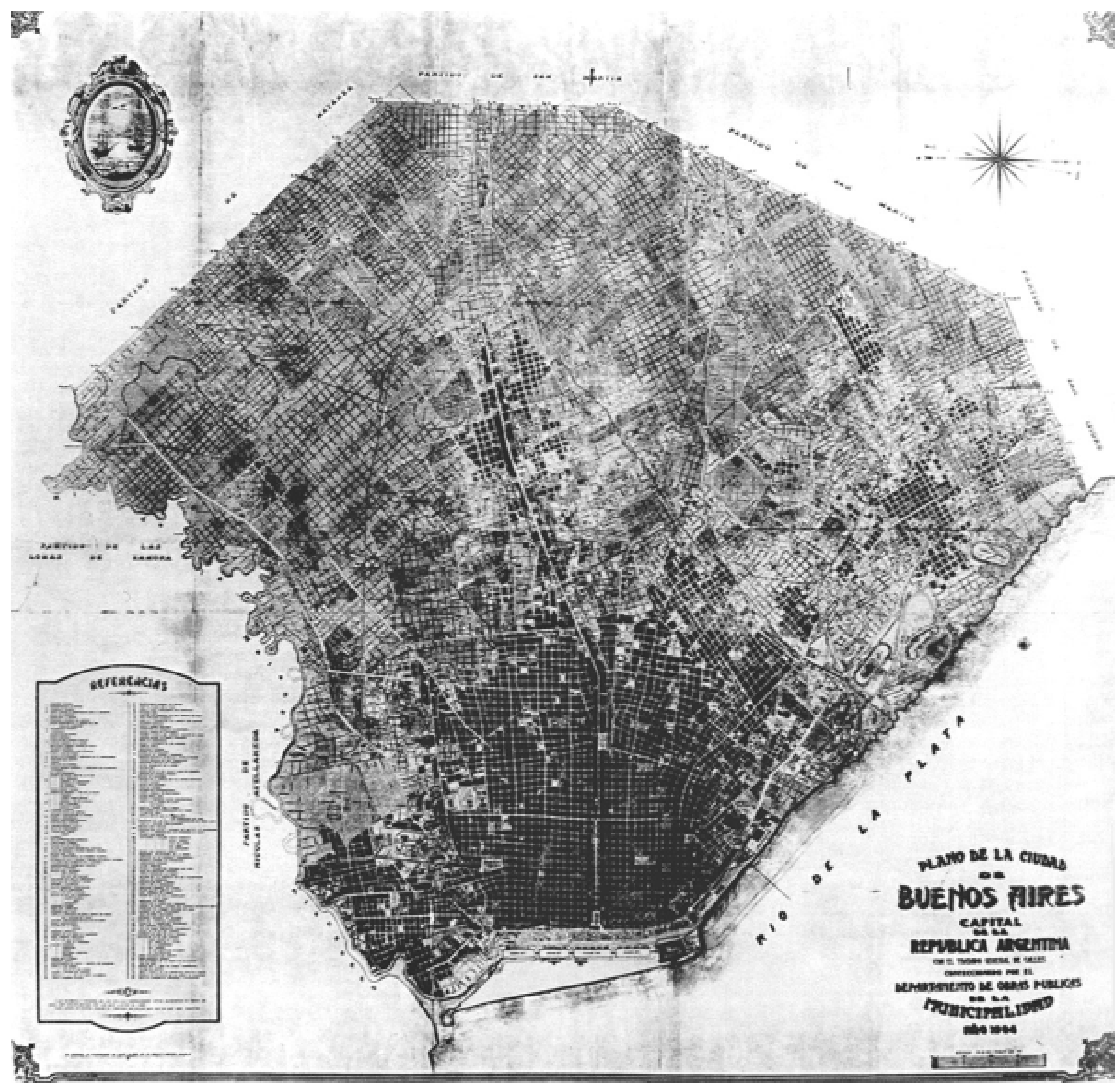

Figura 131 - Neste plano de Buenos Aires, de 1904, podemos observar que o traçado das ruas já está todo pré-definido, mesmo que a área efetivamente ocupada (parte mais oscura) seja ainda bem menor que os limites fixados para a capital.

Fonte: GORELIK, Adrián. La Grilla y el parque. Espacio público y cultura urbana en Buenos Aires, 1887-1936. Quilmes, Universidad Nacional de Quilmes, 1998. 
dos loteadores com a qualidade do projeto, aliado à falta de controle público. De fato, na prática se verifica que muitos destes traçados não correspondiam à topografia, e por esse motivo de execução totalmente impraticável tal como previsto, exigindo adaptações em geral mal resolvidas.

Comparando as plantas das figuras 129 e 131 verificamos que de fato o traçado de características ortogonais predomina em Buenos Aires. Em São Paulo, ao contrário, este tipo de padrão será encontrado em alguns loteamentos, que, entretanto correspondem a apenas uma parte das novas áreas ocupadas. Muitas vezes a expansão se dava pela solicitação de abrir uma ou mais ruas, caracterizando, portanto, empreendimentos de pequena dimensão, que em geral resultavam em um conjunto de vias e quadras com pouca articulação entre si. Nas figuras 132 a 134 temos exemplos de loteamentos em ambas cidades.

Esses loteamentos, que se tornam viáveis após a implantação de linhas de transporte e infra-estrutura sanitária, possuem uma ocupação inicial caracterizada por construções isoladas e afastadas. Já a partir da década de 1910 surgirão em São Paulo diversos empreendimentos cujo traçado segue o padrão das cidades-jardim, destinado principalmente às camadas de maior poder aquisitivo (figura 135). ${ }^{28}$ Embora em Buenos Aires o traçado viário estivesse já previamente definido no início do século $\mathrm{XX}$, também há espaço para alternativas ao desenho ortogonal característico das cidades hispano-americanas visando criar um cenário europeu, como na passagem Seaver (figura 136). Também há exemplos de bairros tipo cidade-jardim, como Palermo Chico, projetado por Charles Thays em 1912.

Um outro aspecto que chama a atenção ao observar o traçado viário de São Paulo e Buenos Aires é que na primeira cidade há uma grande variação tanto na largura das vias como dos passeios. Em Buenos Aires, ao contrário, há maior homogeneidade nestes aspectos. Na figura 137 podemos ver que existem áreas bem definidas onde a largura de ruas é a mesma, e que correspondem a setores com idade de ocupação diferentes. A largura preponderante é a de 20 varas (exceto avenidas), que é a regulamentar a partir de 1875. Portanto isto não ocorre a partir de 1904, mas muito antes.

Esta homogeneidade também pode ser observada nas quadras, que em geral são de formato quadrado. Da mesma forma, também os lotes apresentam maior homogeneidade.

\footnotetext{
28 WOLFF, Silvia Ferreira Santos. Jardim América: o primeiro bairro-jardim de São Paulo e sua arquitetura. São Paulo, Edusp, 2001.
} 

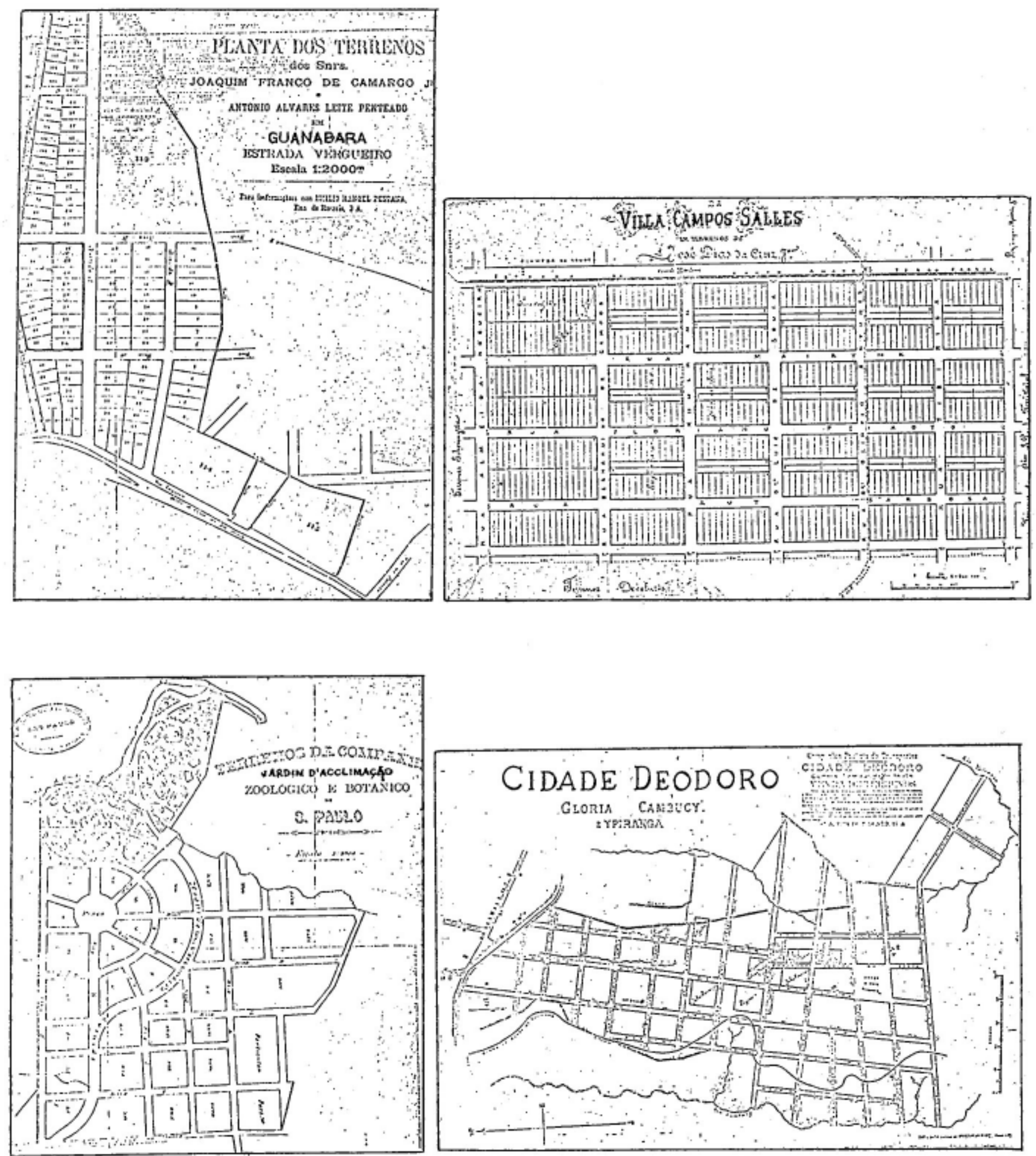

Figura 132 - Exemplos de planos de arruamentos em São Paulo, no período 1890-1900. No traçado prevalece em geral o padrão ortogonal.

Fonte: GROSTEIN, Marta Dora. Tese de Doutorado. A Cidade Clandestina: os Ritos e os Mitos. São Paulo, FAUUSP, 1987. 


\section{MIRA N DOPOIIS}

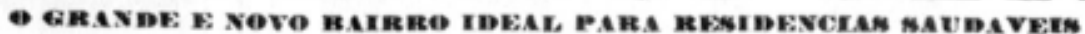

Tendas a vista e a prestap̧ōes desde 5\$OOO por metro quadrado

Magnifica sitnaça no planalto da Saúde, en Villa Marianna, a 800 metros sobre o nivel do mur o a 100 metros

Distancia : a 22 minatos do Centro e a 10 mimutos da Aveuida Paulista.

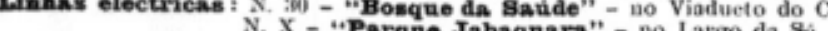

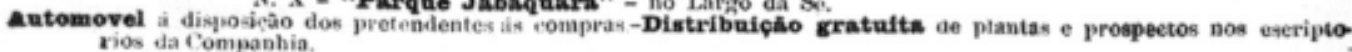

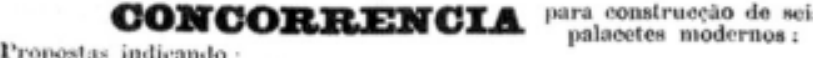

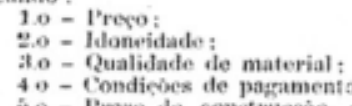

40 - Condicies de pagamento

o - Pruzo de construecio, de accìrto o om as plantas ja spiporadas, atu tio slo eorrente no eseriptorio entral.

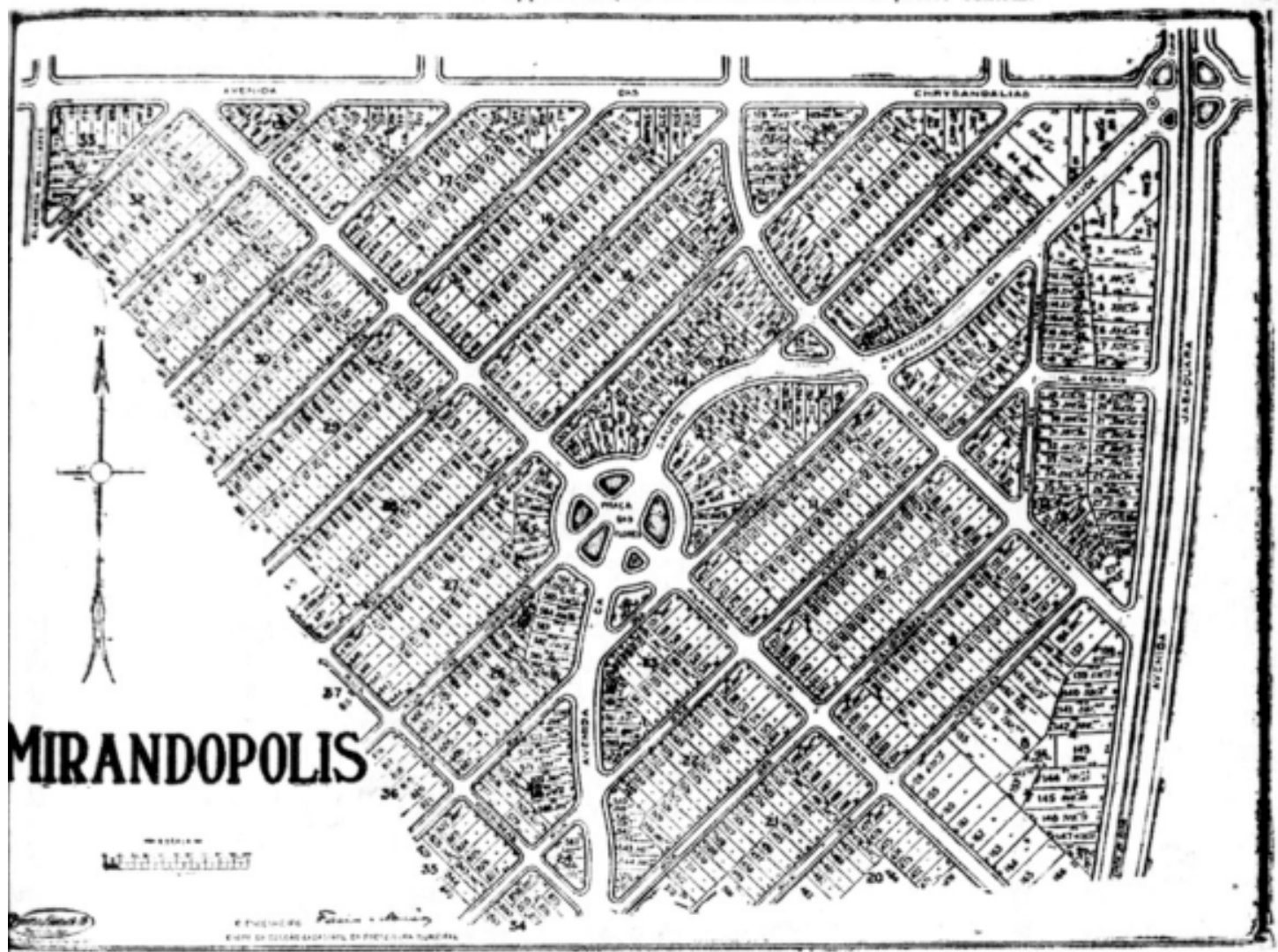

\section{PREDIOS E TERREEHOS}

Quatro linhas de bonds electriesos

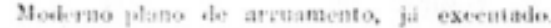

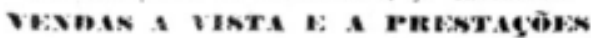

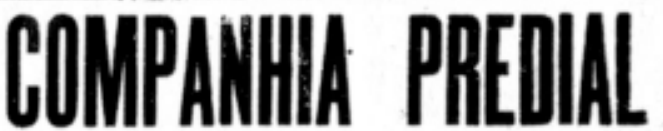

A. CANTPRFTEA

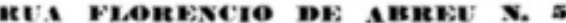
Telephone: Central, 3746 - S. PACLO

vru Zona alta - Xituacho maznifica - Clina salubervimo - Panoramas deslumbrantes

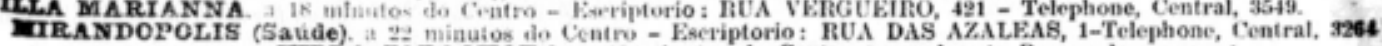

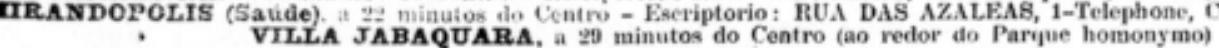

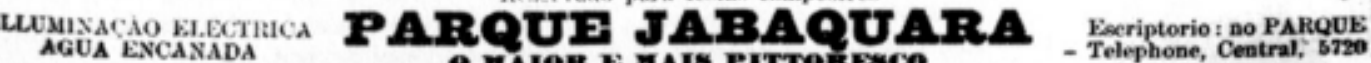

Figura 133 - Anúncio de venda de terrenos no loteamento de Mirandópolis, situado na área dos bairros de Vila Mariana e Saúde.

Fonte: SEGAWA, Hugo. Prelúdio da Metrópole. Arquitetura e urbanismo em São Paulo na passagem do século XIX ao XX. São Paulo, Ateliê Editorial, 2000 


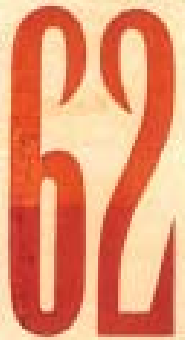
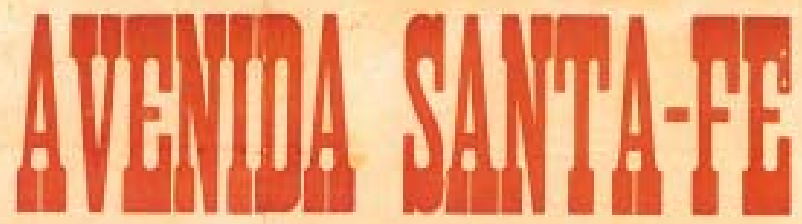 \\ 017 eon frente á Godoy Gruz, Palermo y boulevard Cervifío}

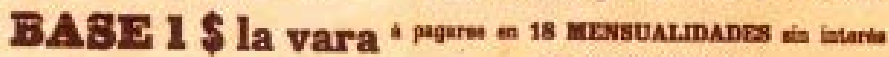
EL DOMINGO 28 DE SETTEMBRE RODOLFO BOLLIMI Y CII

$4 \tan 230 \mathrm{~A}$. Base: 1 \&la vara
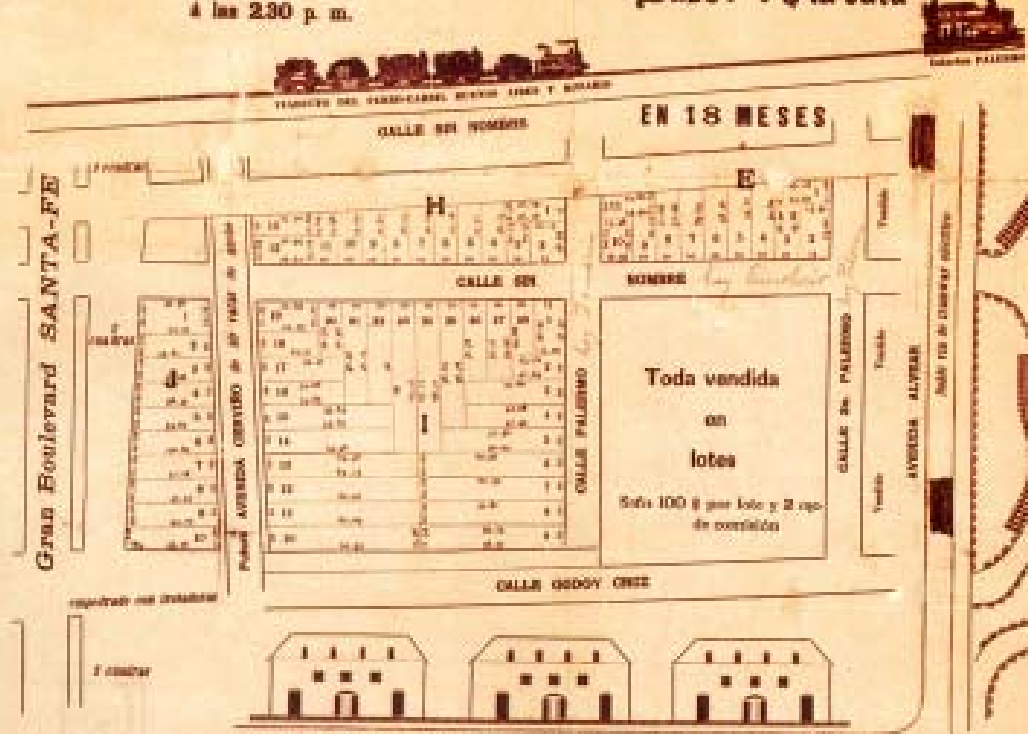

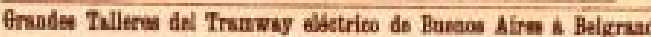

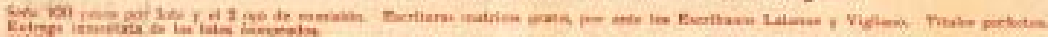

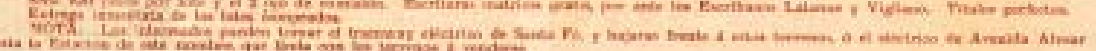

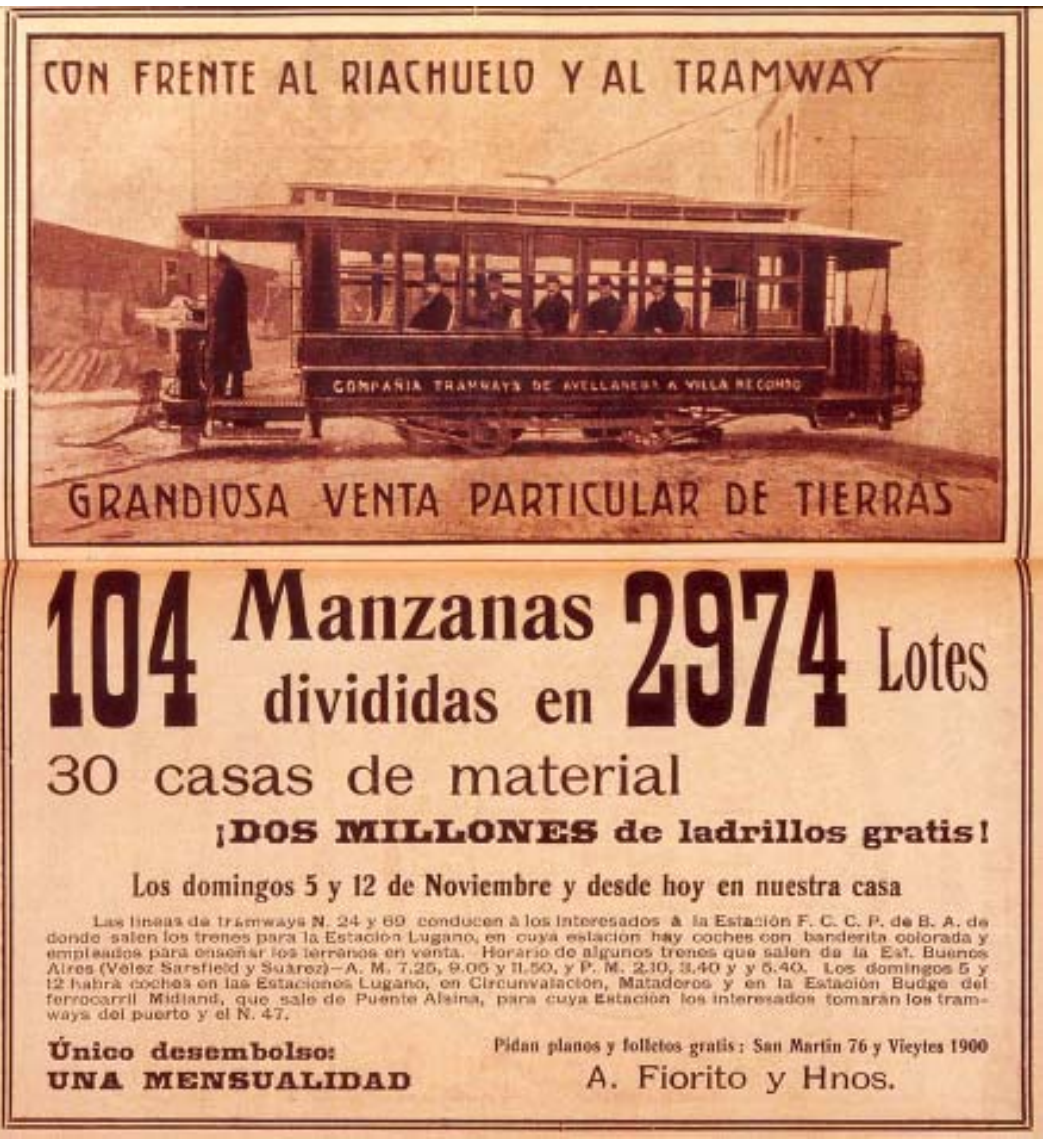

Figura 134 - Exemplos de propagandas para a venda de lotes, em Buenos Aires. No primeiro caso no bairro de Palermo, região norte. No caso ao lado na parte sul da cidade, perto do rio Riachuelo.

Fonte: GUTMAN, Margarita (ed.). Buenos Aires 1910: memoria del porvenir. Buenos Aires, Gobierno de la Ciudad de Buenos Aires/ Faculdade de Arquitetura, Design e Urbanismo da Universidade de Buenos Aires/ IIEDAmerica Latina, 1999 


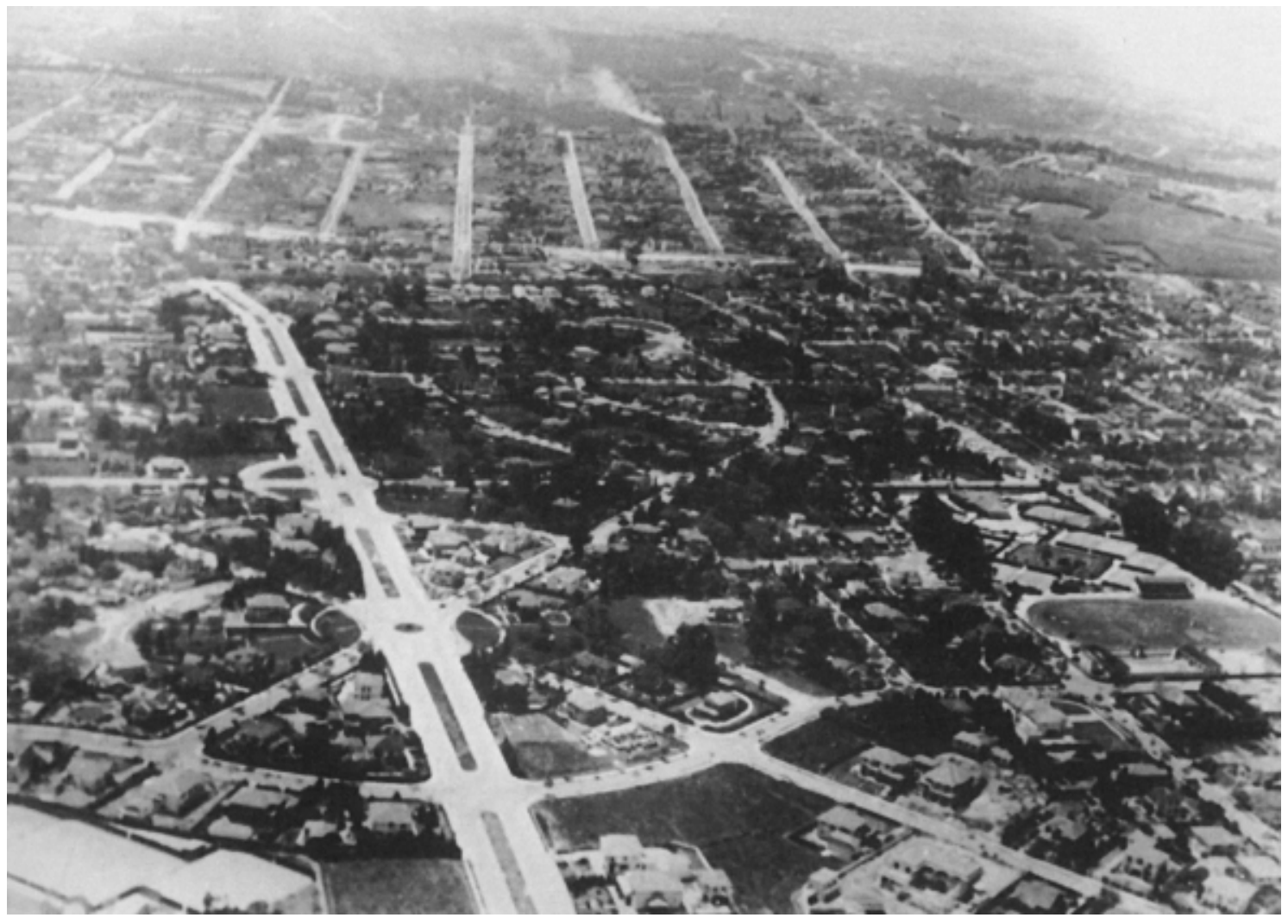

Figura 135 - Vista aérea do Jardim América, primeiro loteamento realizado pela Cia. City em São Paulo. Os primeiros lotes começaram a ser comercializados na década de 1910, e os últimos nos anos 40.

Fonte: WOLFF, Silvia Ferreira Santos. Jardim América: o primeiro bairro-jardim de São Paulo e sua arquitetura. São Paulo, Edusp, 2001

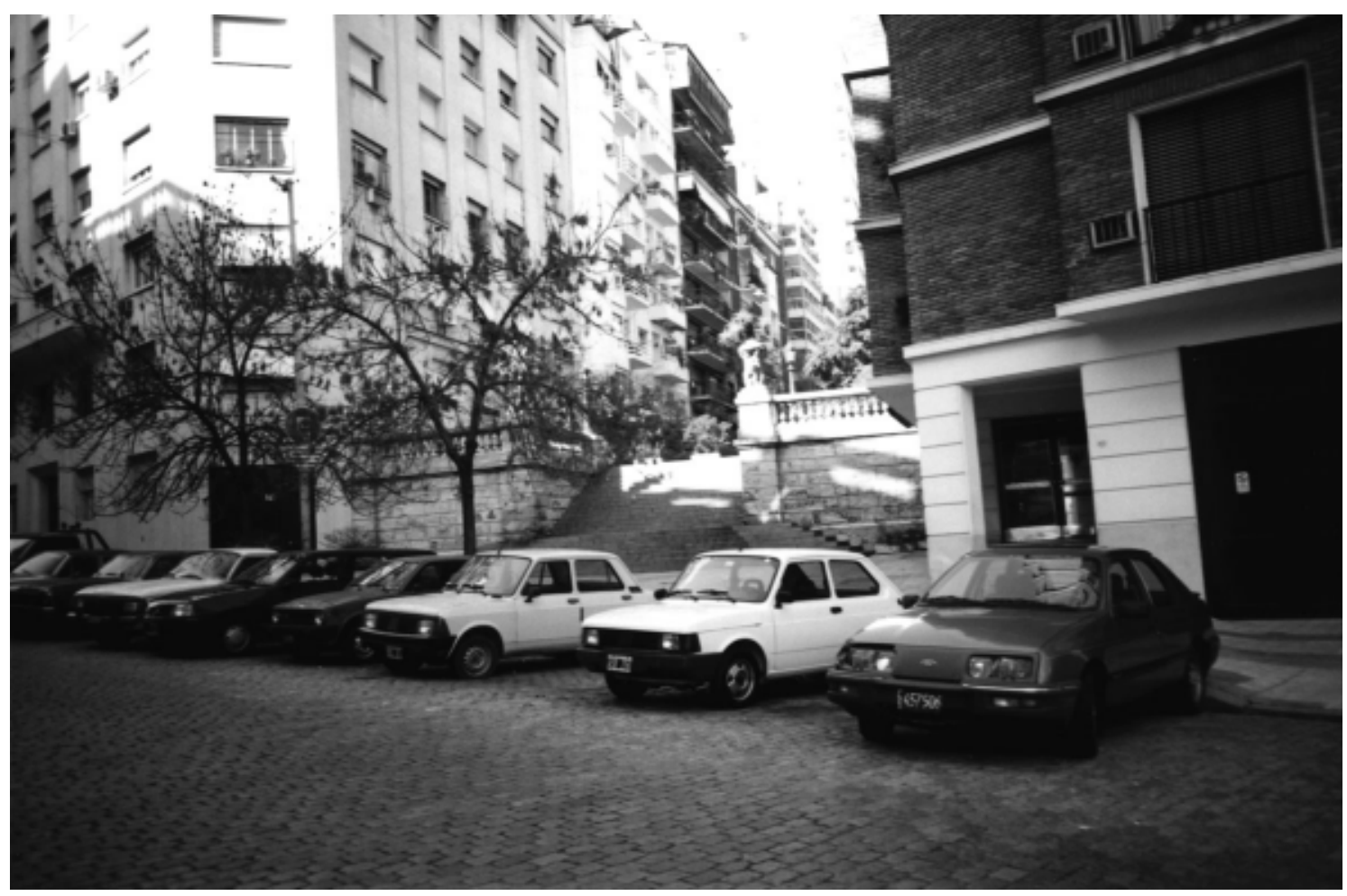

Figura 136 - Escadaria localizada na região norte da cidade de Buenos Aires. Exemplo de intervenção em bairro ocupado pelas camadas sociais mais ricas, procurando criar um cenário europeu.

Fonte: Foto do autor. 


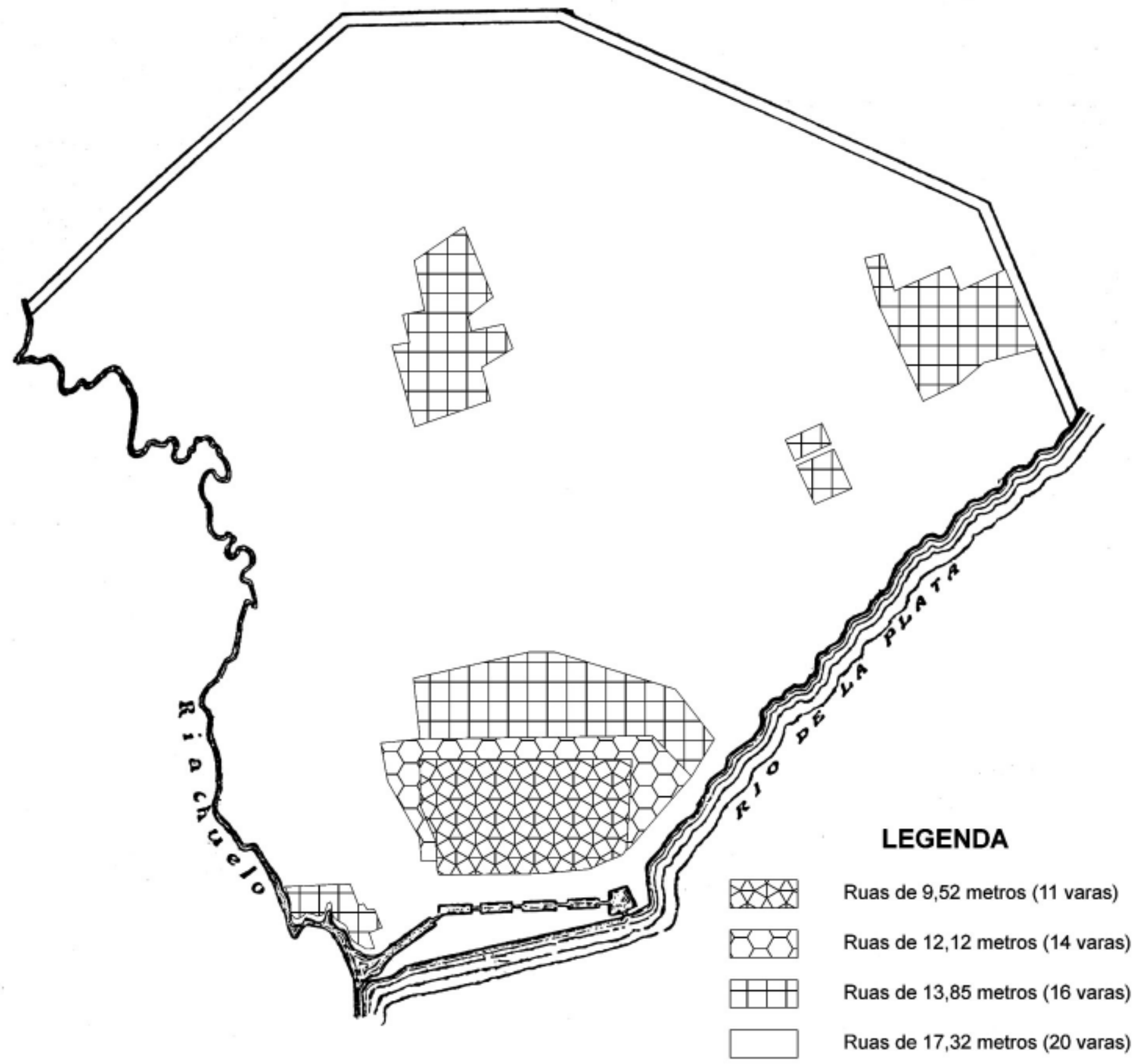

Figura 137 - Mapa mostrando as áreas com mesma largura de ruas em Buenos Aires. Exceto o caso particular de algumas partes mais antigas, prevalece em quase toda a cidade o padrão de 20 varas.

Fonte: Censo General de la Ciudad de Buenos Aires, 1909 


\subsection{2 - A Área Ocupada}

Também é revelador das diferenças existentes a comparação da mancha urbana de ambas cidades. Utilizemos em primeiro lugar mapas de datas próximas: 1882 para Buenos Aires e 1881 para São Paulo ${ }^{29}$, que mostramos na figura 138. Buenos Aires tinha aproximadamente 500 mil habitantes, ${ }^{30}$ e São Paulo 31.000 habitantes em 1881. ${ }^{31}$ Embora os dados já indiquem isto, os mapas permitem confirmar graficamente que à época havia uma diferença significativa em área ocupada e dimensões físicas.

Vamos agora usar os mapas de 1867 (Buenos Aires) e 1897 (São Paulo) ${ }^{32}$, quando as cidades tinham populações da mesma ordem de grandeza: Buenos Aires 200.000 habitantes e São Paulo 196.000 habitantes $^{33}$ (figura 139).

Desta última comparação podemos fazer diversas constatações: embora possa haver imprecisões nestes mapas (por exemplo, no plano de Gomes Cardim estão desenhados loteamentos ainda pouco ou não ocupados por essa data), o fato é que há uma diferença de tamanho físico considerável. Fizemos uma estimativa aproximada da área ocupada e obtivemos os valores de 5.000 hectares para São Paulo, e 1.200 hectares para Buenos Aires. Podemos notar também que São Paulo tem muitos vazios, e provavelmente uma ocupação dos lotes menos compacta que em Buenos Aires. Ou seja, esta proporção é de 1:4 na área ocupada.

Pode-se argumentar que estamos comparando épocas diferentes, e conseqüentemente dinâmicas diferentes. É verdade que podem existir algumas diferenças, mas o fato é que o grande momento de inflexão, quando estas cidades experimentarão um processo de rápida expansão da mancha urbana, somente ocorrerá depois de 1900, ou seja, após as datas dos mapas que estamos comparando.

Nesta etapa, que coincide também com a implantação de linhas de transporte e infra-estrutura, e organização de um sistema de financiamento, estas cidades que até aquele momento viam suas áreas centrais serem continuamente reformadas, verão decair sua densidade em função da ocupação das áreas periféricas. Segundo Villaça, esta em São Paulo irá cair de aproximadamente 150 hab/ha no período colonial para 70-80 hab/ha em 1890. Sofrerá alguma recuperação

\footnotetext{
${ }^{29}$ Ciudad de Buenos Aires. Oficina Municipal de Obras Públicas, 1882; Planta da Cidade de São Paulo. Companhia Cantareira e Esgotos, 1881.

${ }^{30}$ Há divergências quanto à população. Bourdé aponta para esse ano 364.979 habitantes, mas este dado corresponde provavelmente à Capital Federal. Optamos por utilizar os dados fornecidos por Hardoy e Gutman, fazendo uma interpolação por parábola com os dados de 1869, 1895 e 1914. BOURDÉ, Guy. Buenos Aires: Urbanización e Inmigración. Buenos Aires, Ed. Huemul, 1977; GUTMAN, Margarita; HARDOY, Jorge Enrique. Buenos Aires. Coleção Ciudades de Iberoamérica. Madrid, MAPFRE, 1992.

${ }^{31}$ EMPLASA. Memória Urbana. A Grande São Paulo até 1940. São Paulo, Emplasa / Arquivo do Estado / Imprensa Oficial, 2001. Neste caso o município contém toda a mancha urbana.

32 Plano Topográfico de la Ciudad de Buenos Aires y de todo su Municipio. Departamento Topográfico de la Provincia de Buenos Aires, 1867; Planta Geral da Capital de São Paulo. Gomes Cardim, 1897.

33 Para Buenos Aires novamente utilizamos os dados da grande Buenos Aires extraídos de GUTMAN, Margarita; HARDOY, Jorge Enrique. Op. Cit. Para São Paulo interpolamos os dados de 1881, 1905 e 1914 de VILLAÇA, Flávio. A estrutura territorial da metrópole sul brasileira: áreas residenciais e comerciais. Tese de Doutorado. São Paulo, FFCLH, 1978.
} 

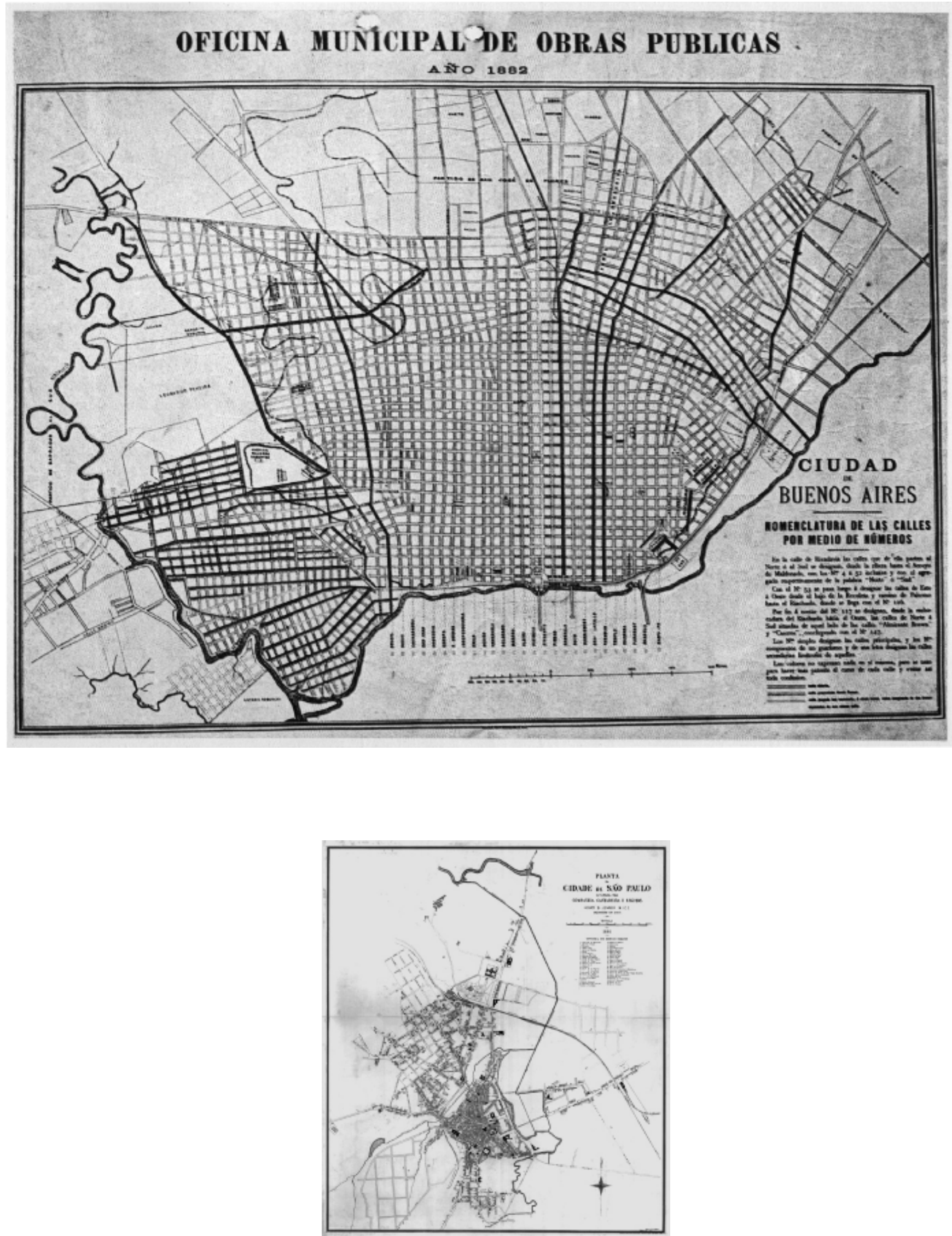

Figura 138 - Planos do mesmo período de Buenos Aires (1882) e São Paulo (1881), na mesma escala. Buenos Aires era bem maior do que São Paulo na época, situação que só irá se reverter na década de 1960.

Fontes: DIFRIERI, Horácio. 2v. Atlas de Buenos Aires. Buenos Aires, Municipalidad de Buenos Aires, 1981; SÃO PAULO (CIDADE). São Paulo antigo: plantas da cidade. São Paulo, Comissão do IV Centenário, 1954. 

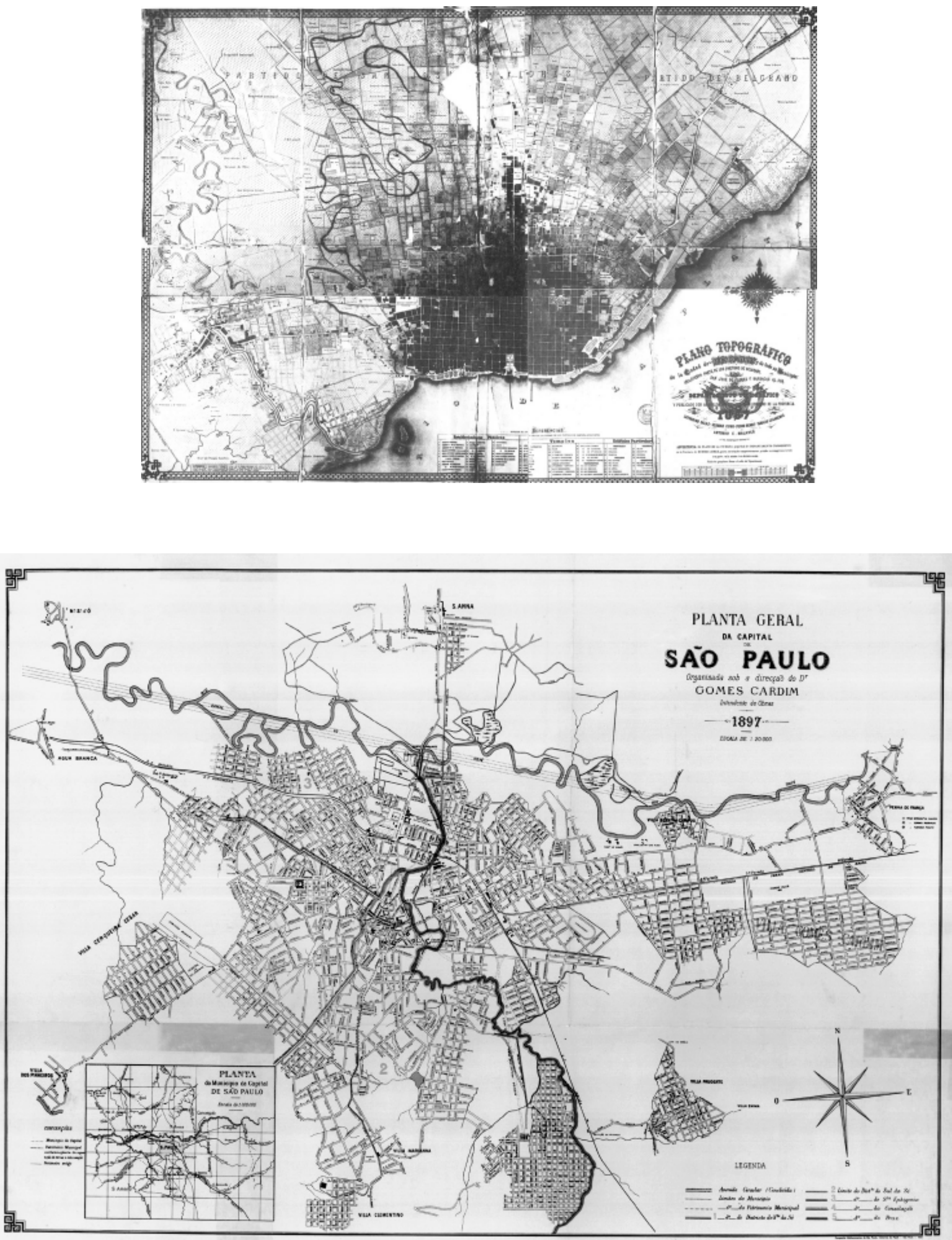

Figura 139 - Planos de Buenos Aires (1867) e São Paulo (1897), colocados na mesma escala, quando ambas cidades tinham aproximadamente a mesma população. Observar que embora com população semelhante, a mancha urbana em São Paulo é significativamente maior.

Fontes: DIFRIERI, Horácio. 2v. Atlas de Buenos Aires. Buenos Aires, Municipalidad de Buenos Aires, 1981; SÃO PAULO (CIDADE). São Paulo antigo: plantas da cidade. São Paulo, Comissão do IV Centenário, 1954. 
em 1914, situando-se em torno de 110 hab/ha. ${ }^{34}$ Segundo Horacio Torres, em Buenos Aires a densidade aumenta no período 1869-1895, e diminui entre 1895 e $1914 .{ }^{35}$

Nas figuras 140 e 141 mostramos a evolução da mancha urbana em ambas cidades. Em primeiro lugar podemos notar que há uma tendência à expansão da área central, com a diferença que em Buenos Aires o centro é deslocado, devido ao Rio da Prata. Também podemos observar claramente que até aproximadamente 1890 (1890 no mapa de São Paulo e 1888 no de Buenos Aires) essa expansão se realiza de forma compacta a partir do núcleo central, e depois disso começam a aparecer ocupações descontínuas, tanto pela ocupação dos novos loteamentos como pelo crescimento e incorporação de pequenos povoados já existentes.

Estas considerações são indicativas, mas mostram que há diferenças significativas na relação entre arquitetura e urbanismo em ambas cidades.

\subsection{3 - Alguns Agentes Sociais}

Em geral enfatiza-se bastante $o$ forte caráter especulativo que caracterizaria a produção do espaço no período. Embora este fator seja relevante, é importante aprofundar seu estudo.

No caso da cidade de São Paulo, há um trabalho de Mônica S. Brito ${ }^{36}$, onde é enfocada a atuação dos setores empresariais. Esta autora fez uma ampla pesquisa de associações anônimas no Diário Oficial, constatando que embora houvessem também iniciativas isoladas, a maior parte destas esteve em mãos de empreendedores. Sua ação era organizada e muitas vezes transcendia a mera atividade loteadora, participando também de empreendimentos na área de materiais, transportes, importação, crédito e serviços.

É interessante notar também que antes do advento da República e da chegada de empresas estrangeiras, este setor empresarial já estava organizado e atuante. Vários autores mostram como desde as regiões de mineração, no século XVIII, existiam formas de capitalismo empresarial, conhecimentos que foram posteriormente utilizados na etapa do café.

Assim, estes dados indicam que a produção do espaço, através de arruamentos e loteamentos, não foi realizada de forma desarticulada.

No caso de Buenos Aires, Gorelik procura questionar a visão de que a produção do espaço é resultado meramente das inovações técnicas e da especulação imobiliária. Procura mostrar que parte de determinados órgãos públicos um desenho da cidade que tem entre outros objetivos frear a especulação imobiliária. Realiza algumas considerações para justificar sua tese, como por exemplo, o fato de terem

\footnotetext{
${ }^{34}$ VILLAÇA, Flávio. Op. cit.

35 TORRES, Horacio A. Evolución de los procesos de estructuración espacial urbana. El caso de Buenos Aires. Buenos Aires, Desarrollo Económico, Vol. 15, Nº 58, julho-setembro 1975.

${ }^{36}$ BRITO, Mônica Silveira. A participação da iniciativa privada na produção do espaço urbano: São Paulo, 1890-1911. Dissertação de Mestrado. São Paulo, FFLCH, 2000. A respeito deste mesmo tema, ver SAMPAIO, Maria Ruth Amaral. O papel da iniciativa privada na formação da periferia paulistana. São Paulo, Revista Espaço \& Debates N ${ }^{\circ} 37,1994$.
} 


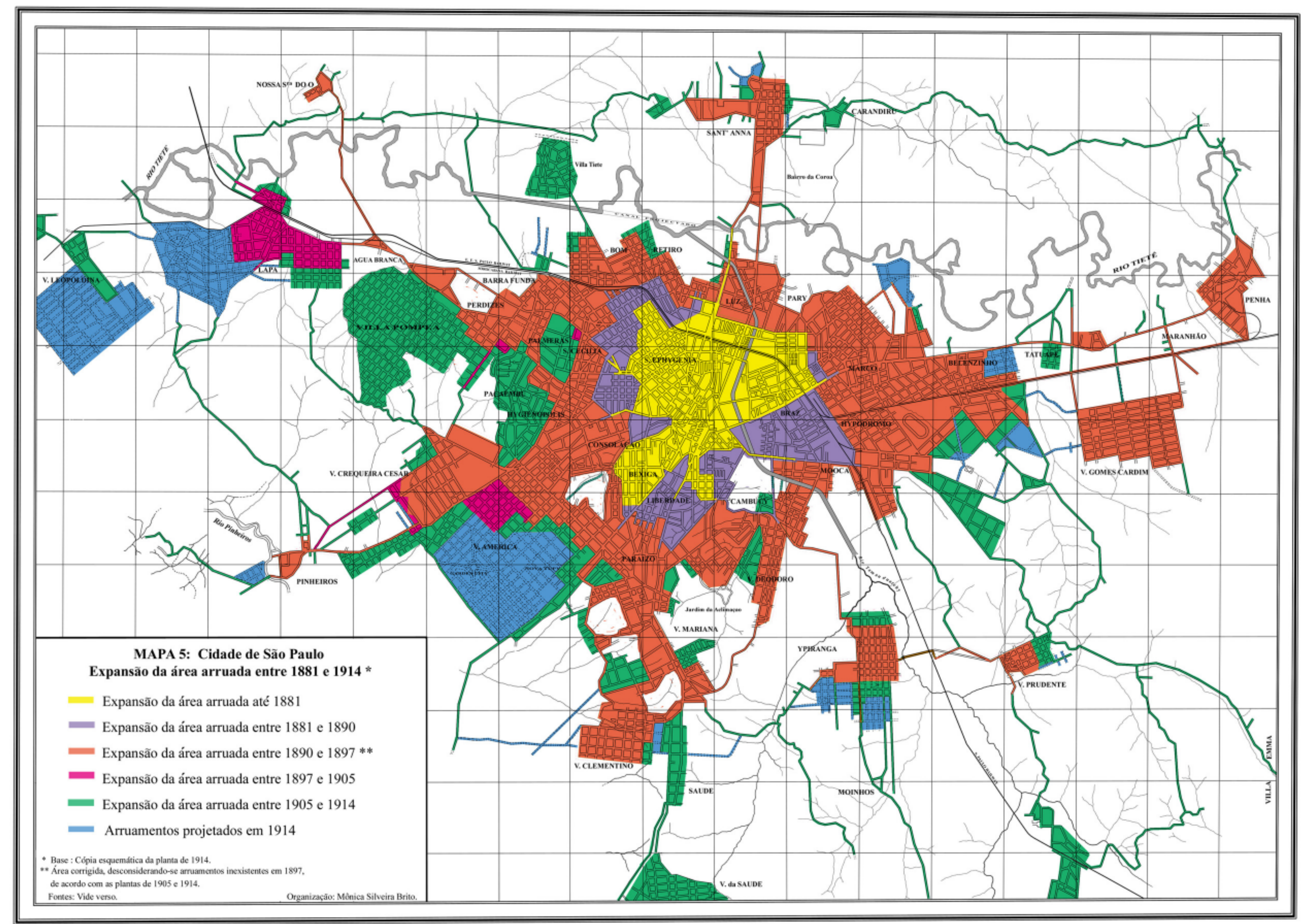

Figura 140 - Cidade de São Paulo: expansão da área arruada entre 1881 e 1914.

Fonte: BRITO, Mônica Silveira. Dissertação de Mestrado. A participação da iniciativa privada na produção do espaço urbano: São Paulo, 1890-1911. São Paulo, FFLCH, 2000. 


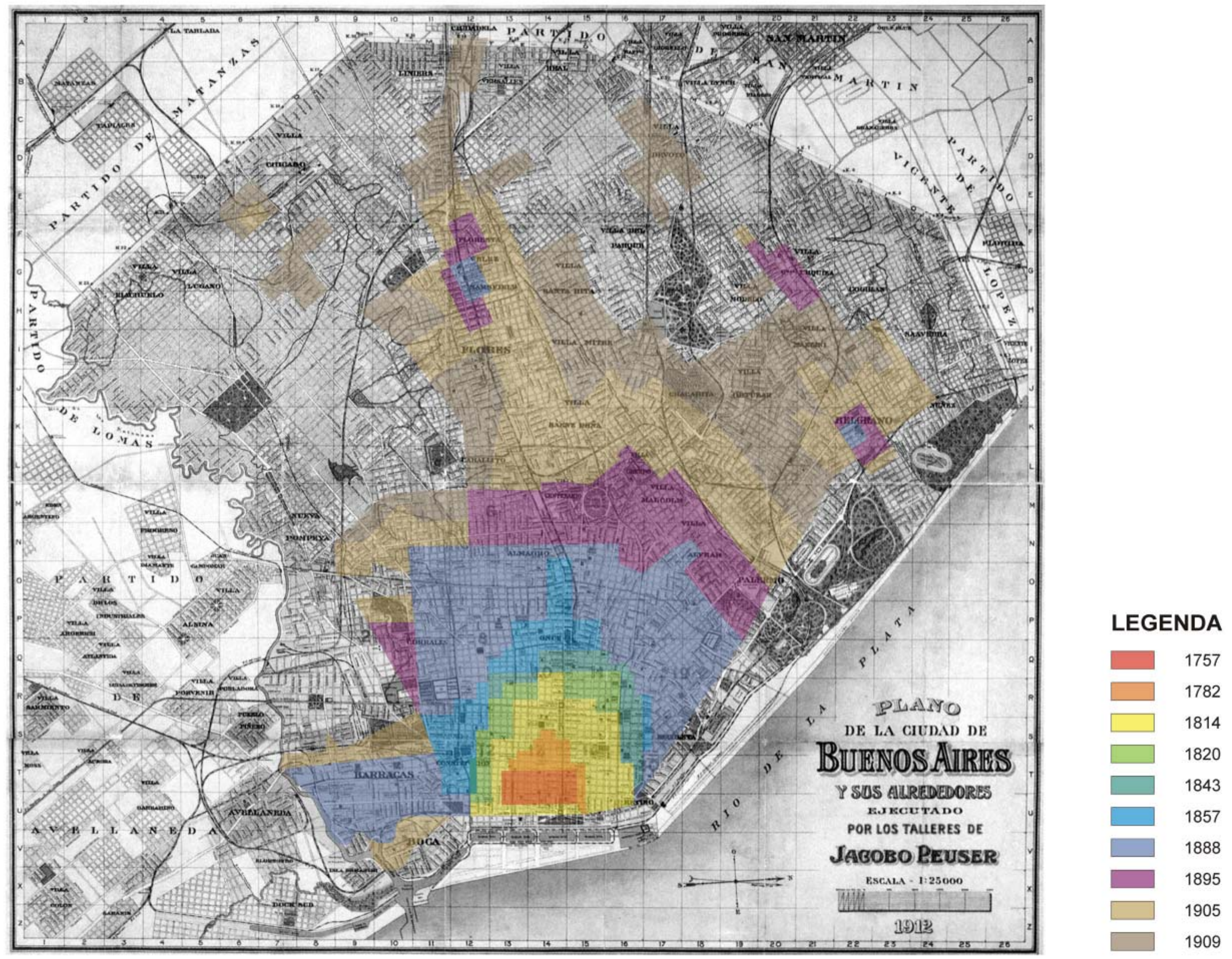

Figura 141 - Evolução da mancha urbana de Buenos Aires (1757-1909).

Fonte: Mapa realizado pelo autor a partir do Censo General de la Ciudad de Buenos Aires, de 1909. 
sido realizadas quadras de formato quadrado, que não é a forma mais rentável (neste sentido a retangular é melhor). Este controle exercido teria permitido a constituição de um espaço público tanto nas ruas como praças e parques projetados naquele então.

"El poder público descubre, al final de un proceso, que una serie de intervenciones puntuales sin vocación global, producto de la superposición institucional, del rol 'natural' del parque como condensador de representaciones, pero también de la impotencia del municipio de intervenir más decididamente en el conjunto de la grilla, han mostrado capacidad de convertir un artefacto pensado originariamente como freno a la urbanización, en un dispositivo capaz de irradiar una cierta cualidad urbana como alternativa a la 'anomia' que produce el mercado librado a sus propios impulsos: la modernización sin cualidad no produce barrio ni ciudad; lo que el poder público comienza a descubrir, en este aspecto, es una nueva capacidad potencial de imponerle modelos al mercado sin necesidad de intervenir en él drásticamente, sino concentrando intervenciones al margen, digamos, del laissez-faire para el cual destina la porción principal de la grilla." ${ }^{\text {,37 }}$

Este autor mostra também que essas idéias estavam presentes no plano de Bouvard (1910), embora pouca gente tenha se concentrado em observar outros aspectos que não as intervenções nas áreas centrais. Isto sugere que os organismos públicos que na prática realizaram a maior parte do plano Bouvard, estavam cientes deste objetivo.

De acordo com os dados disponíveis, não há evidências de procedimentos semelhantes em São Paulo. Entretanto, há diversas indicações vindas das repartições públicas da necessidade de controlar o arruamento. Em 1911 dizia Vitor da Silva Freire:

“.. deveria a municipalidade occupar-se dos novos bairros. Seriam estes criados pelos seus proprietários, obedecendo à planta que para cada caso fosse organisada segundo os dictames da technica de hoje ou, melhor ainda, pela própria municipalidade que, em vez de ter com elles - como succede actualmente - todos os onus e nenhum proveito, faria por esse processo operações multiplamente lucrativas, pecuniária, esthetica e sanitariamente. ${ }^{38}$

Mais tarde, em 1923, o mesmo autor reforçaria estas idéias, que foram utilizadas por Prestes Maia no Plano de Avenidas de 1930, no capítulo sobre a extensão da cidade. Trata-se do elogio à lei de arruamentos de 1923, que já incorpora uma visão urbana, pois exigia que o loteador se submetesse a algumas diretrizes viárias:

"Nos termos de uma lei recente, os que pretenderem abrir vias públicas no município, terão previamente que apresentar a

\footnotetext{
${ }^{37}$ GORELIK, Adrián. Op. Cit., p. 303.

${ }^{38}$ FREIRE, Vitor da Silva. Melhoramentos de São Paulo. São Paulo, Revista Polytechnica, Vol. VI, № 33, fevereiro/março de 1911, p. 101.
} 
planta dos terrenos a aprovar, com curvas de nível de metro em metro. N'essa planta a repartição téchnica marcará o traçado das vias de communicação principaes e a implantação dos espaços livres julgados necessários ao interesse geral ... Ficam por esse modo desde o início assegurados a ligação e encaixe do novo arruamento, no meio da rede geral de viação.

(...)

A recente lei paulista vale pois, como é azado verificar, por verdadeiro programma de urbanização."39

Mas o interessante desta história é que tanto para Vitor da Silva Freire como para Prestes Maia esta medida seria uma inovação no continente:

"Neste sentido acaba a capital paulista de dar o primeiro passo, passo sem precedente entre nós, sem precedente tambem em toda a América do Sul, onde nada nos consta de existir a tal respeito." ${ }^{40}$

É possível levantar duas hipóteses: ou o plano de 1904 citado por Gorelik (que inclusive é mais do que uma lei de arruamentos) era desconhecido por aqui, ou foi deliberadamente omitido. No primeiro caso confirmaria que sua execução foi efetivamente realizada de forma discreta pelos órgãos técnicos locais, que procederam sem fazer estardalhaço, e que por este motivo teve divulgação restrita. Ou então era importante mostrar o pioneirismo de São Paulo, como parte de um projeto de afirmação da importância da capital paulista. Ambas hipóteses merecem um aprofundamento, até porque existia uma razoável troca de informações entre os profissionais de ambos paises. É bom não esquecer que o próprio Vitor da Silva Freire era membro do Museo Social Argentino, entidade particular formada por pessoas da elite que tinha como objetivo exercer um papel intermediário entre o Estado e os conflitos sociais, visando a modernização do país. ${ }^{41}$

\subsection{4 - A Legislação}

cidades.

Vejamos agora, sumariamente, a questão da legislação em ambas

A cidade de Buenos Aires, como grande parte das cidades hispanoamericanas, foi regida durante o período colonial por uma série de normas urbanísticas, que se caracterizavam pelo elevado grau de detalhamento. Estas regras coloniais foram largamente estudadas, ao contrário da legislação nos séculos XIX e $X X^{42}$

\footnotetext{
${ }^{39}$ Citado in: MAIA, Francisco Prestes. Estudo de um Plano de Avenidas para a Cidade de São Paulo. São Paulo, Melhoramentos, 1930, p. 279.

40 Idem, p. 279.

41 BRAGOS, Oscar. O Museo Social Argentino e a formação e difusão das idéias do urbanismo. In: RIBEIRO, Luiz César de Queiroz; PECHMAN, Robert (org.). Cidade, povo e nação. Rio de Janeiro, Civilização Brasileira, 1996.

${ }^{42}$ De fato, é escassa a bibliografia sobre o assunto em Buenos Aires. Em nosso caso iremos nos basear em trabalho de Alicia Novick e Sandra Sanchez, ainda inédito, preparado para o Diccionario Histórico de Arquitectura, Habitat y Urbanismo em la Argentina, dirigido por Jorge Liernur e Fernando Aliata, a ser
} 
Após a Independência, a primeira sistematização mais significativa ocorre em 1872, no "Digesto de Disposiciones Municipales", que se compõe de uma série de normativas com ênfase maior nos aspectos de habitabilidade, higiene e segurança.

Em 21 de junho de 1887 é promulgada a "Ordenanza Reglamentária de Construcciones", cuja redação foi dirigida pelo ing. Juan A. Buschiazzo. Compõe-se de diversos capítulos, abrangendo os seguintes temas: permissões de obra, alinhamentos, alturas, fachadas, demolições, muros, prevenções de incêndios, níveis, obras públicas e passeios. Este documento será modificado em 1898, 1904, 1911 e 1918, sendo substituído em 1928 pelo "Reglamento General de Construcciones".

Neste último, além do conteúdo já existente na ordenança de 1887, há o acréscimo de diretrizes de formas de ocupação do espaço urbano e tipos de configurações edilícias. Um de seus eixos principais é o zoneamento. Este documento está baseado nos pressupostos do chamado "Plan Noel", organizado pela "Comisión de Estética Edilícia de la Intendencia Municipal", em 1925, que por sua vez contém diversos elementos do plano Bouvard, de 1910. Este regulamento vigorará até 1944, quando é promulgado o Código de Edificações.

Assim como na Argentina, também no Brasil há uma série de disposições que vigoram desde os tempos coloniais. Entretanto, ao contrário de Buenos Aires, há muitos autores que se dedicaram a estudar a legislação, talvez devido à importância que assumiu a chamada "ocupação ilegal" quando do intenso processo de urbanização em São Paulo a partir da década de 60 do século passado. ${ }^{43}$

Em 1886 (portanto um ano antes que em Buenos Aires) é promulgado a Código de Posturas. Do ponto de vista urbanístico há apenas algumas disposições sobre a largura de ruas, que deviam ter 16 metros de largura e serem retas.

Surgem também no final do século XIX algumas leis feitas especialmente para determinadas áreas, como a lei 355/1898 para as avenidas Higienópolis e Itatiaia (atual Angélica), com exigências de 6 metros de frente e recuos de 2 metros de lado. Ou ainda a lei 310/1894, para a avenida Paulista, que previa recuo frontal de 10 metros e lateral de 2 metros.

De 1894 é o Código Sanitário, que embora seja mais detalhado que o Código de Posturas, é mais específico quanto às questões de higiene.

Do ponto de vista urbanístico, temos a primeira lei de arruamentos em 1913 (lei 1666/13). Trata-se de uma lei que exigia apenas uma previsão do traçado das ruas. Ao proprietário era deixada a iniciativa de fazer o restante. O objetivo era que houvesse alguma coincidência viária e tentar organizar um pouco melhor 0 sistema viário da cidade em função desses novos loteamentos.

A exigência de apresentar o parcelamento do solo somente virá em 1923 com a lei $2611 / 23$. Essa lei previa também porcentagens para o sistema viário e espaços livres e área mínima para os lotes. São definidos dois tipos de vias: as

publicado pela Sociedad Central de Arquitectos. Ver também SUÁREZ, Odília E. Planes y Códigos para Buenos Aires. 1925-1985. $2^{\text {a }}$ ed. Buenos Aires, Ediciones Fadu, 1994.

${ }^{43}$ Por exemplo, entre outros, GROSTEIN, Marta Dora. Op. Cit. ROLNIK, Raquel. A cidade e a lei. Legislação, política urbana e territórios na cidade de São Paulo. São Paulo, Studio Nobel/FAPESP, 1997. 
públicas, que são abertas pelo poder público ou por particulares, cujos leitos são doados à municipalidade, e as vias particulares, abertas por particulares e que permanecem sob seu domínio e responsabilidade (artigo 23 e 24 da lei no 2611/23). Neste caso o poder público desobriga-se da prestação de serviços.

Em 1929 surge o Código de Obras (consolidado em 1934), conhecido como "Código Arthur Saboya", onde se consolida um documento para a questão edilícia na cidade. Entretanto, do ponto de vista urbanístico, repete-se basicamente o constante da lei de 1923.

Por esta lei o interessado deveria 1) solicitar diretrizes de arruamento 2) executar obras de infra-estrutura urbana 3) doar partes para áreas públicas.

\subsection{5 - As Tipologias Resultantes}

Uma das brechas existentes na legislação paulistana é a possibilidade de abrir ruas particulares, das quais não era exigido o cumprimento das normas dos códigos. Foram largamente utilizadas para obter maior aproveitamento das quadras, já que permitiam a demarcação de lotes com frente para essas vias, no miolo das mesmas.

Estas ruas podiam assumir diversas formas, e tanto podiam atravessar uma quadra como serem fechadas, com apenas um acesso. Para alguns autores, em São Paulo esta legislação permitia garantir a qualidade e valor das áreas ocupadas pelos mais ricos, como também maximizar o lucro dos empreendedores nas áreas mais pobres, através das possibilidades de burla existentes. ${ }^{44}$

Até serem extintas, em 1953 (lei 4371/53), elas tiveram uma grande importância. Basta verificar que em 1951 o número de ruas particulares era três vezes maior que o de vias oficiais. ${ }^{45}$

Podemos localizar exemplos desta forma de ocupação em vários pontos da cidade, hoje conhecidas como "vilas". ${ }^{46}$ Mas justamente por serem em principio não-oficiais (embora o poder público soubesse e tirasse proveito de sua existência) não constam dos mapas oficiais. Por este motivo, para mostrar alguns exemplos, iremos nos valer de um trabalho realizado na Emurb sobre as vilas na área Cura BrásBresser, ${ }^{47}$ e dos mapas produzidos pela empresa Sara Brasil, em 1930.

\footnotetext{
${ }^{44}$ GROSTEIN, Marta Dora. Op. Cit. ROLNIK, Raquel. Op. Cit. Antes disso, Toledo já havia apontado essa característica da legislação, que permitia a "desobrigação da observação da medida": TOLEDO, Benedito Lima de. São Paulo: três cidades em um século. 2ª ed. aum. São Paulo, Duas Cidades, 1983.

45 LEFEVRE, Henrique Neves. Influência da legislação urbanística sobre a estruturação das cidades: aplicação especial ao caso da cidade de São Paulo. Tese de Cátedra. São Paulo, Escola de Engenharia Mackenzie, 1951. Citado em: GROSTEIN, Marta Dora. Op. Cit.

${ }^{46}$ Atualmente estas são muito valorizadas pelas camadas média e média-alta por questões de segurança e existência de uma pequena área semi-pública. Sobre estas vilas ver: ARAGÃO, Solange. Da persistência do ecletismo nas vilas paulistanas. Dissertação de Mestrado. São Paulo, FAUUSP, 2000.

${ }^{47}$ EMURB. Vilas e Conjuntos Habitacionais. Área Cura Brás-Bresser. São Paulo, Emurb, 1977. [Relatório técnico coordenado por Maria Marta Soban Tanaka, realizado na gestão do Dr. Nestor Goulart Reis Filho na vice-presidência técnica da EMURB].
} 
Nas figuras 142 e 143 indicamos com círculos mais claros áreas de ocorrência de vilas. No primeiro mapa podemos observar do lado esquerdo o parque D. Pedro II. Notar, principalmente no segundo plano, a significativa quantidade de vilas existentes (nós marcamos dez círculos, mas certamente há mais casos). O próprio mapa informa a existência de ruas particulares, indicadas por "(n.o.)", abreviação de "não officiaes", e "(a.r.)", que significa "ruas officialisadas não recebidas".

Já nas figuras 144 a 146 mostramos fotos dos espaços resultantes. As áreas internas tanto podiam ser extremamente exíguas, como também amplas a ponto de servirem de praça central ao conjunto. O mesmo pode ser dito dos acessos, que também variavam bastante.

Finalmente, nas figuras 147 e 148 temos a forma de parcelamento do solo em algumas quadras, levantamento realizado no trabalho já citado. Podemos notar a variedade de formas que assumem os lotes, e em muitos casos as exíguas dimensões, já que muitos têm apenas três metros de largura.

Existiram também empreendimentos de maior porte, iniciativa em geral de associações mutuais. Talvez o exemplo mais conhecido seja 0 da Vila Economizadora, construída entre 1908 e 1910 no bairro da Luz (figura 149).

No caso de São Paulo é comum a designação "vilas operárias" para as residências destinadas aos trabalhadores de renda mais baixa. Podiam por um lado ser as construídas pelas próprias indústrias, como por exemplo, a vila Maria Zélia, no Belém, ou a vila Matarazzo, no Brás. Entretanto, em relação ao montante de habitações na cidade, estas representaram muito pouco.

Também eram chamadas de "vilas operárias" os conjuntos de moradias unifamiliares construídas em série, em geral para fins de locação. Atendiam quase sempre trabalhadores mais qualificados, que podiam pagar os aluguéis.

Por último, é também necessário esclarecer que as diferenças entre as vilas operárias, os cortiços e outras tipologias nem sempre eram muito evidentes. $\mathrm{Na}$ prática existia uma infinidade de formas e soluções, que atendiam às diferentes camadas sociais. ${ }^{48}$

A forma de parcelamento do solo em Buenos Aires assume outras características. Em primeiro lugar podemos destacar as quadras, que são em geral de formato quadrado, divididas em lotes que não apresentam grande variedade. Na figura 150 vemos uma típica divisão de quadra. Como podemos observar, os lotes possuem aproximadamente a mesma largura, mas comprimentos variáveis.

Como não existem ruas para acesso ao interior das quadras, são comuns na cidade os edifícios situados no interior da quadra, mas com acesso da rua através de um corredor (figuras 151 e 152). Isto também acontece em São Paulo, mas em geral em cortiços ou casas de cômodos. Em Buenos Aires atendem a uma população variada, que ali tem sua residência. ${ }^{49}$

\footnotetext{
48 BONDUKI, Nabil Georges. Origens da habitação social no Brasil. São Paulo, Estação Liberdade/Fapesp, 1998; REIS, Nestor Goulart. Habitação popular no Brasil: 1880-1920. Cadernos de Pesquisa do LAP 2. São Paulo, FAUUSP, set-out 1994. $2^{a}$ tiragem, 2001.

${ }^{49}$ Esta tipologia é utilizada até os dias de hoje. No bairro de Belgrano, por exemplo, são muito comuns os conjuntos deste tipo, muitos deles construídos nos anos 1940-50, ocupados pelas camadas médias. Em São Paulo existiram algumas construções com essas características, as "vilas comerciais", mas que não
} 


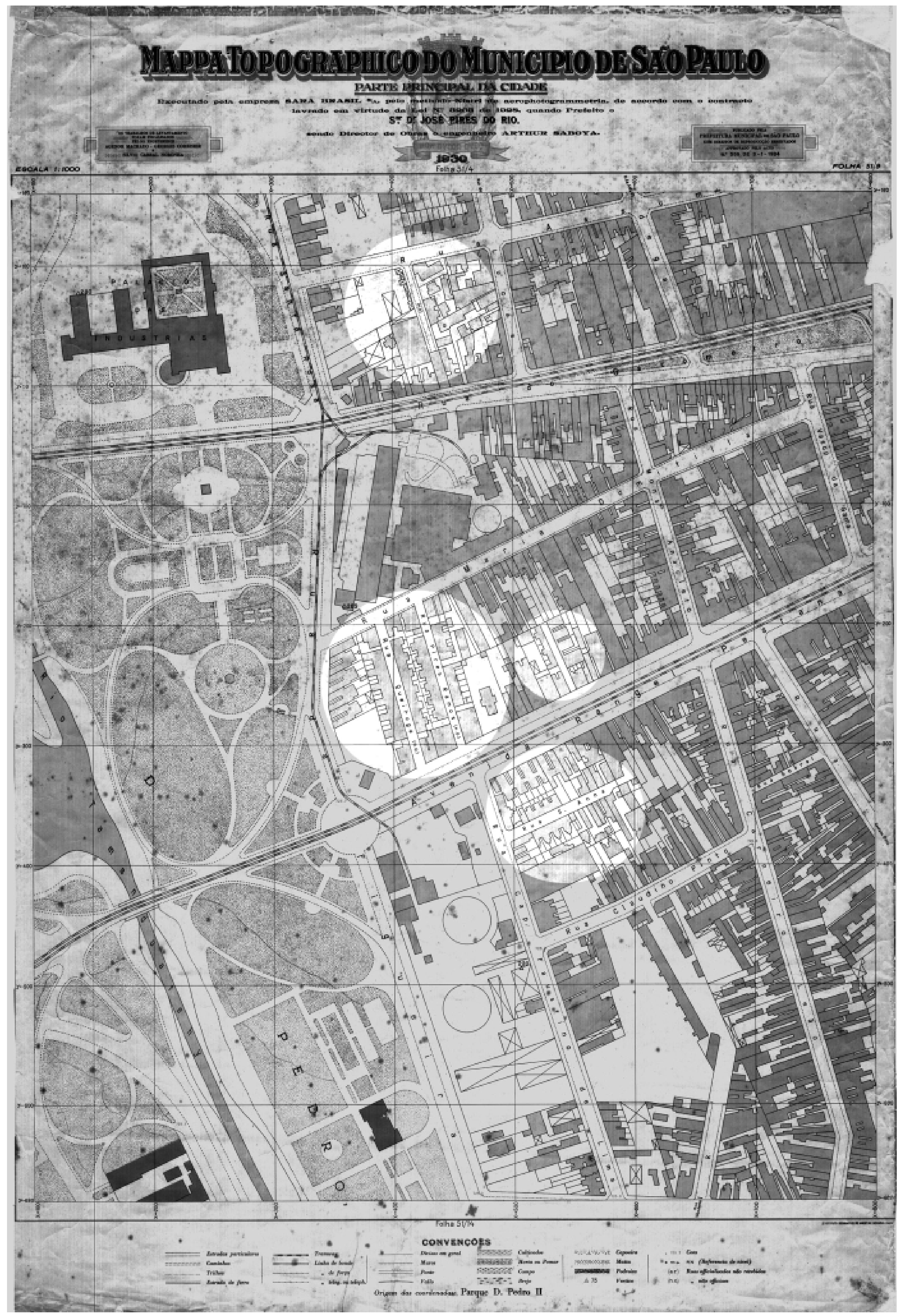

Figura 142 - Mapa de 1930 da região a leste do parque D. Pedro II. As áreas em destaque indicam a presença de ruas particulares. Notar que algumas têm a indicação “(n.o.)”, abreviação de "não officiaes”, ou “(a.r.)”, que significa "ruas officialisadas não recebidas”.

Fonte: SÃO PAULO (cidade). Mappa Topographico do Municipio de São Paulo. São Paulo, Prefeitura Municipal de São Paulo, 1934. Levantamento realizado pela empresa Sara Brasil, em 1930. 


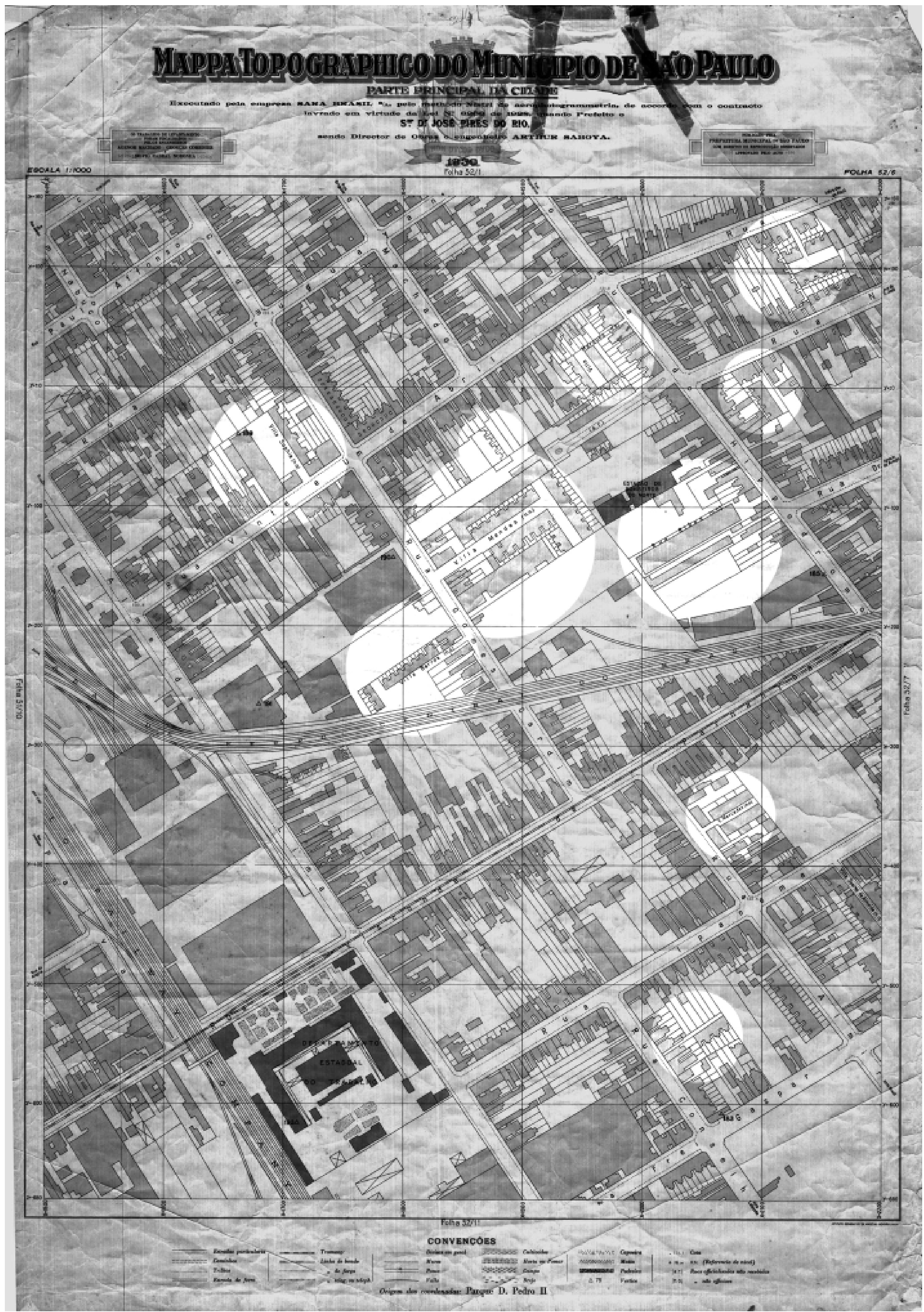

Figura 143 - Região do bairro do Brás. Assim como na figura anterior indicamos nas áreas mais claras a presença de ruas particulares.

Fonte: SÃO PAULO (cidade). Mappa Topographico do Municipio de São Paulo. São Paulo, Prefeitura Municipal de São Paulo, 1934. Levantamento realizado pela empresa Sara Brasil, em 1930. 

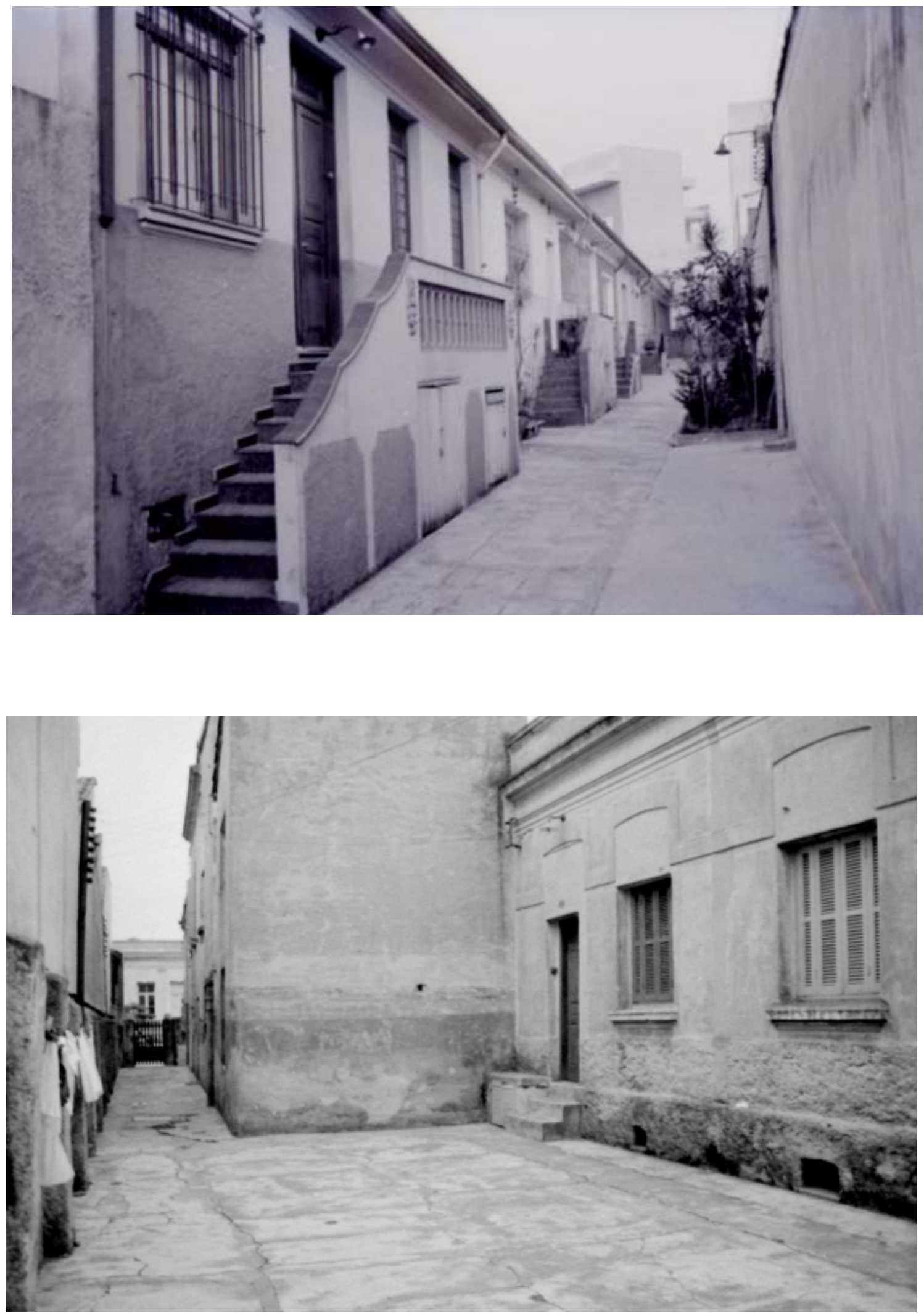

Figura 144 - Na foto superior, detalhe do corredor de circulação de uma vila localizada na rua Maria Joaquina. Embaixo temos uma foto de uma vila situada na rua coronel Antonio Marcel. O acesso é feito através de uma estreita passagem.

Fonte: EMURB. Vilas e Conjuntos Habitacionais. Área Cura Brás-Bresser. São Paulo, Emurb, 1977. 

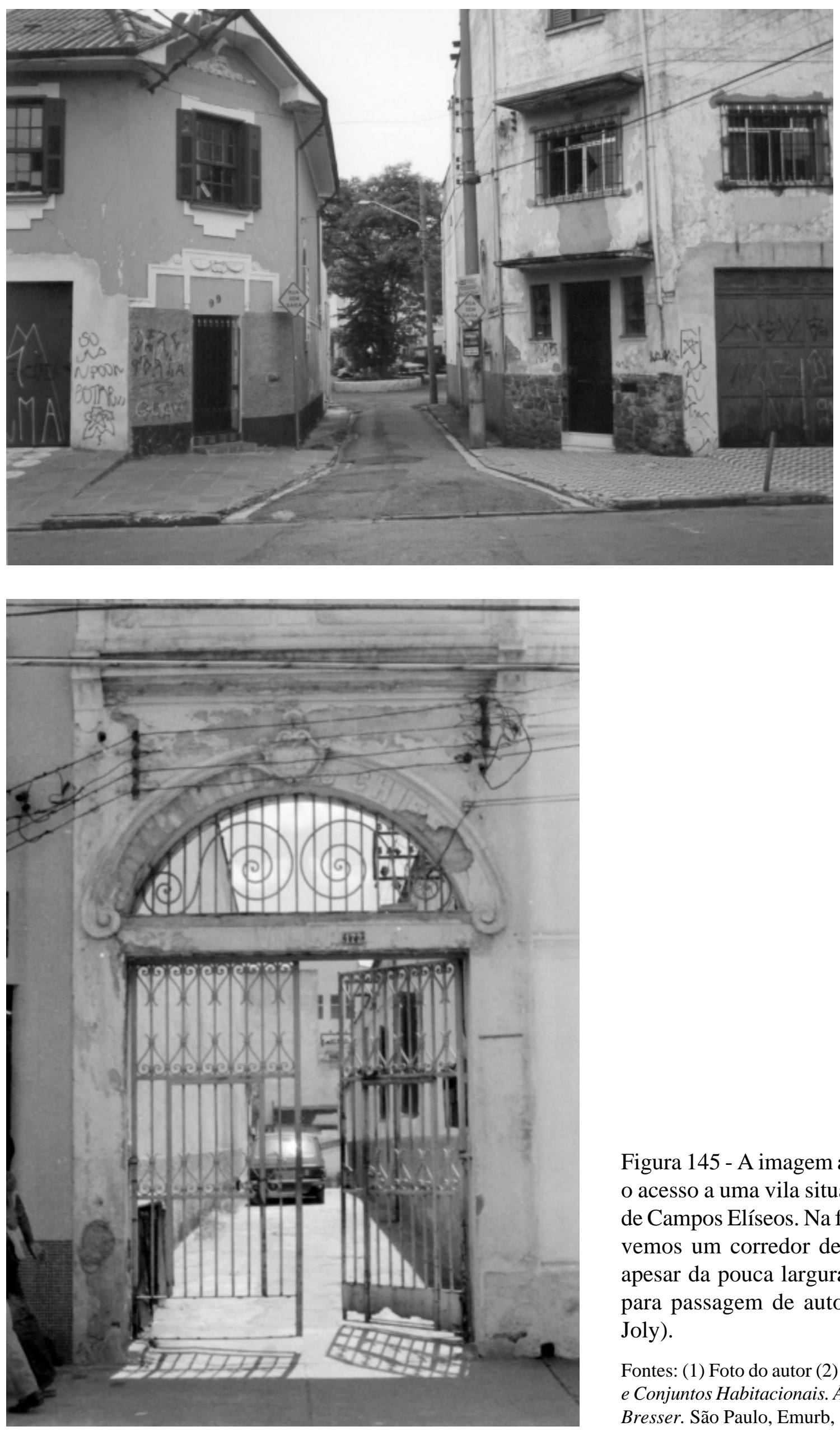

Figura 145 - A imagem acima mostra o acesso a uma vila situada no bairro de Campos Elíseos. Na figura ao lado vemos um corredor de acesso que, apesar da pouca largura, é utilizado para passagem de automóveis (rua Joly).

Fontes: (1) Foto do autor (2) EMURB. Vilas e Conjuntos Habitacionais. Área Cura BrásBresser. São Paulo, Emurb, 1977. 

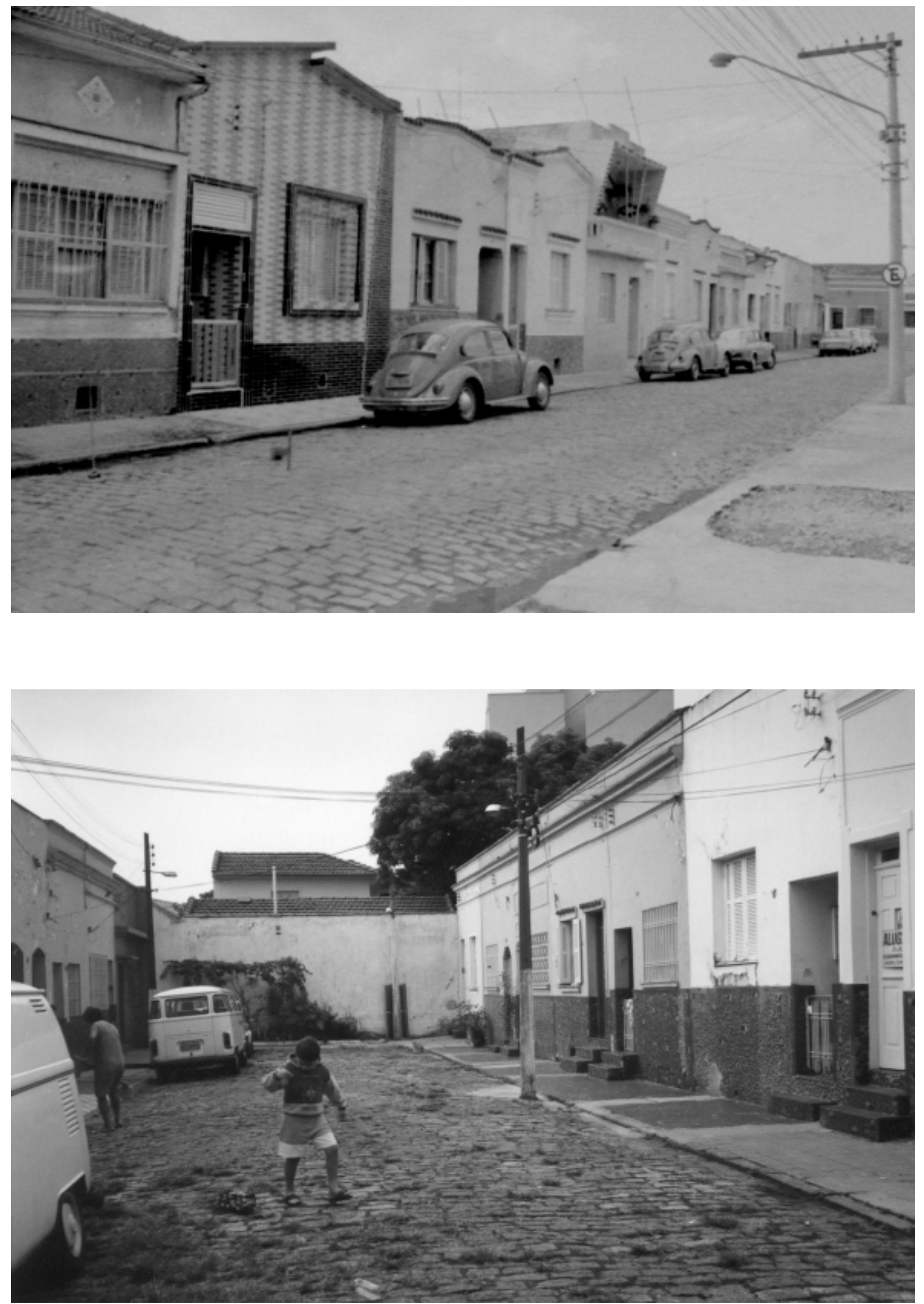

Figura 146 - Nem todas as vilas têm exíguos espaços comuns, como vemos nestes dois exemplos: a Vila Mendes (acima), e uma vila situada no bairro do Pari.

Fontes: (1) EMURB. Vilas e Conjuntos Habitacionais. Área Cura Brás-Bresser. São Paulo, Emurb, 1977. (2) Foto do autor. 


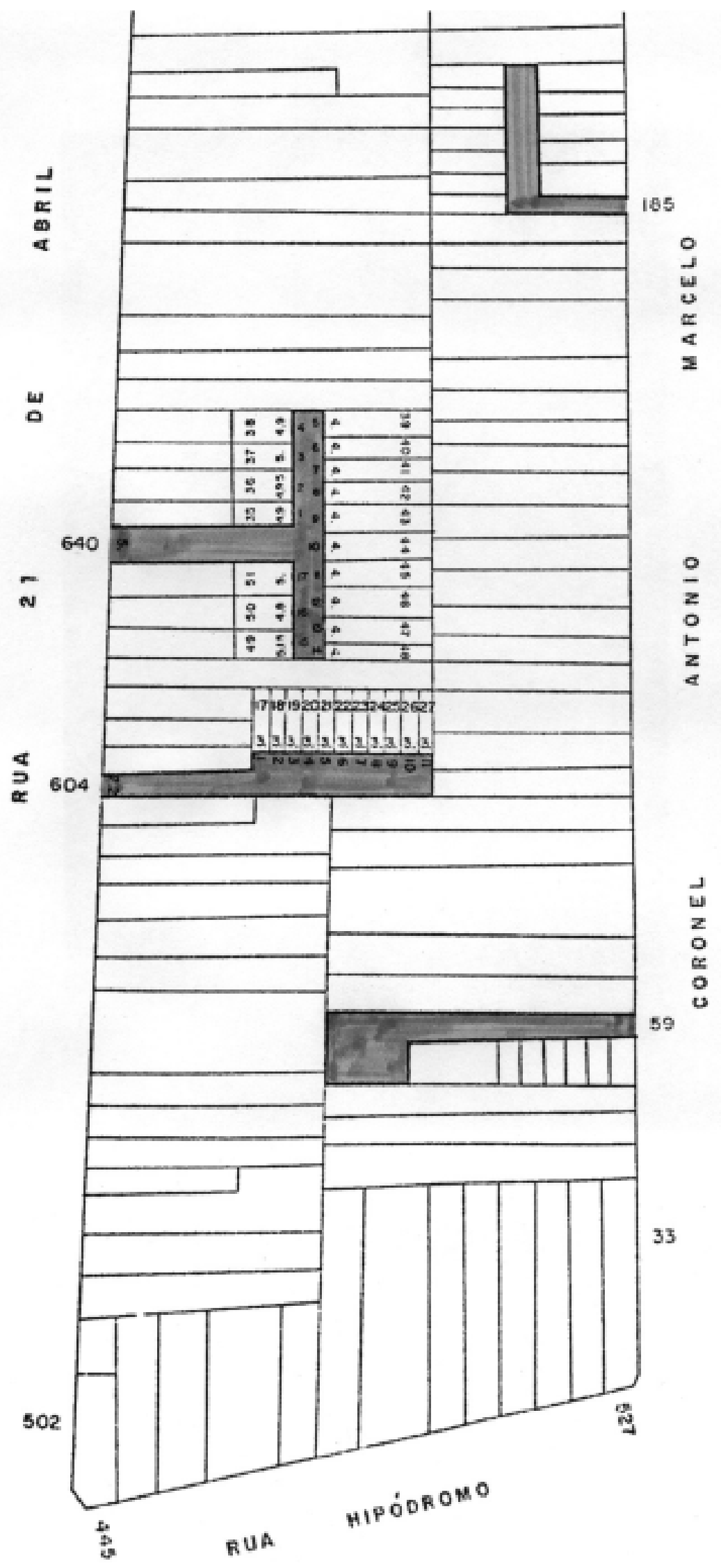

Figura 147 - As vilas, assim como outras formas de abertura de vias, eram consideradas ruas particulares, e por este motivo não precisavam obedecer à legislação urbanística referente a espaços públicos. Este quarteirão, no bairro do Brás, possui várias delas. Notar como em alguns casos os lotes eram extremamente estreitos, como no caso da vila situada na rua 21 de abril No 604, onde a largura é de apenas 3 metros.

Fonte: EMURB. Vilas e Conjuntos Habitacionais. Área Cura Brás-Bresser. São Paulo, Emurb, 1977. 


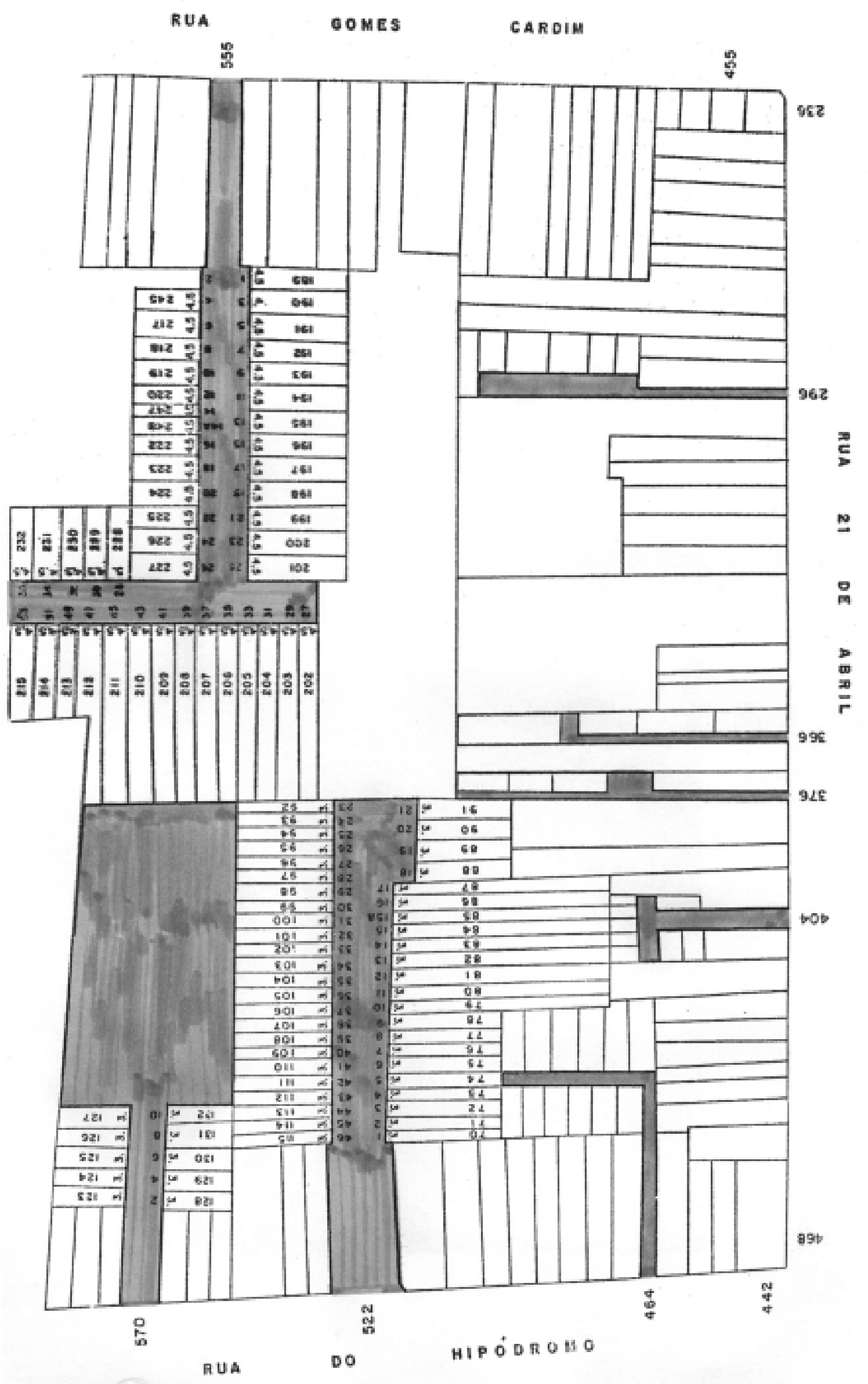

Figura 148 - Esta quadra é particularmente caracterizada pela quantidade de vilas. Assim como na figura anterior, observamos casos onde os lotes têm 3 metros de largura, mas com comprimento maior, de mais de 30 metros. Em outros casos chama a atenção a estreita largura das passagens de entrada e circulação.

Fonte: EMURB. Vilas e Conjuntos Habitacionais. Área Cura Brás-Bresser. São Paulo, Emurb, 1977. 

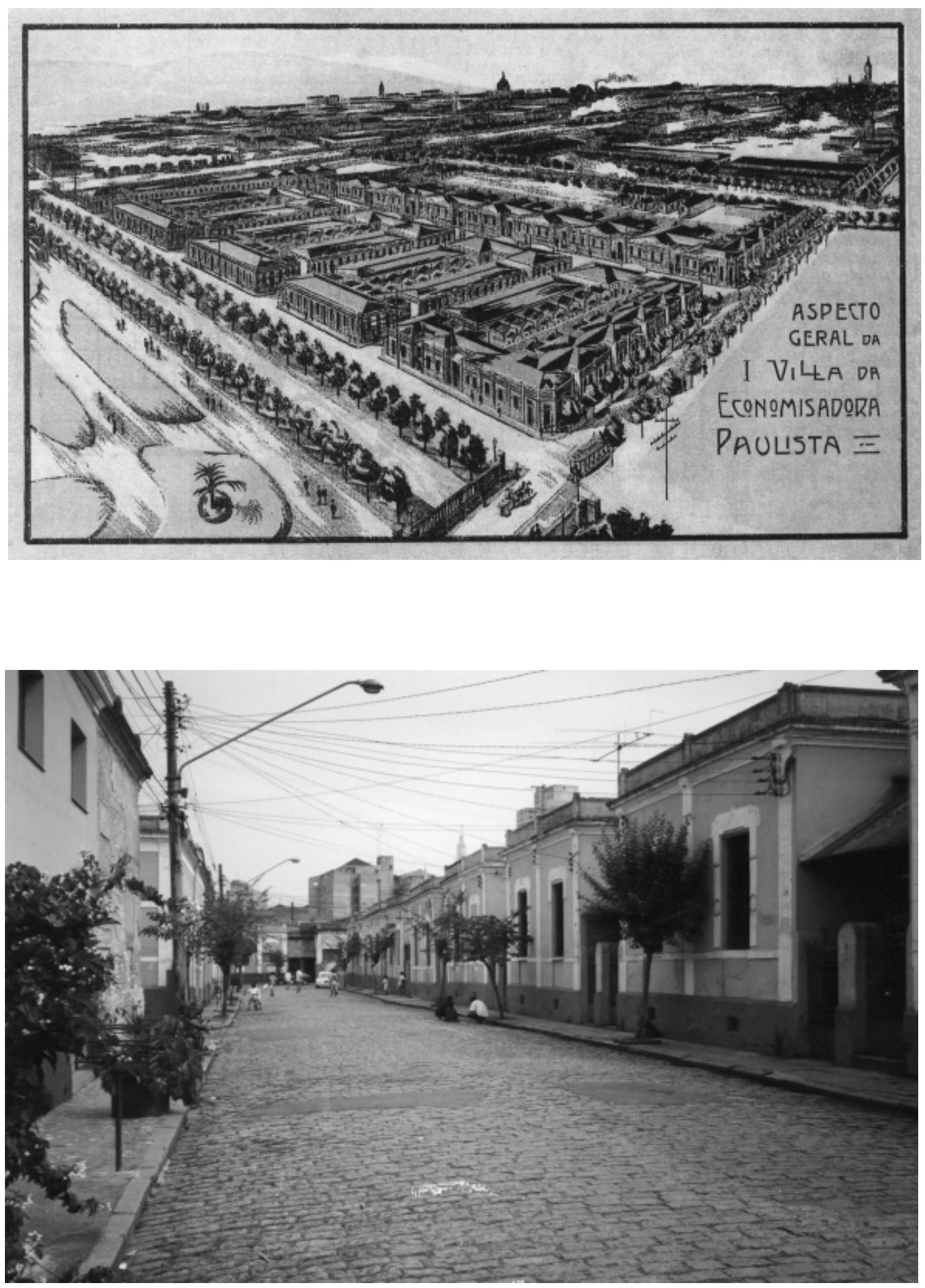

Figura 149 - Na parte superior temos a capa de um álbum de A Economizadora Paulista, mostrando uma vista aérea do conjunto. Embaixo vemos o aspecto de uma das ruas.

Fontes: (1) TOLEDO, Benedito Lima de. Prestes Maia e as origens do urbanismo moderno em São Paulo. São Paulo, Empresa das Artes, 1996. (2) Foto do autor. 


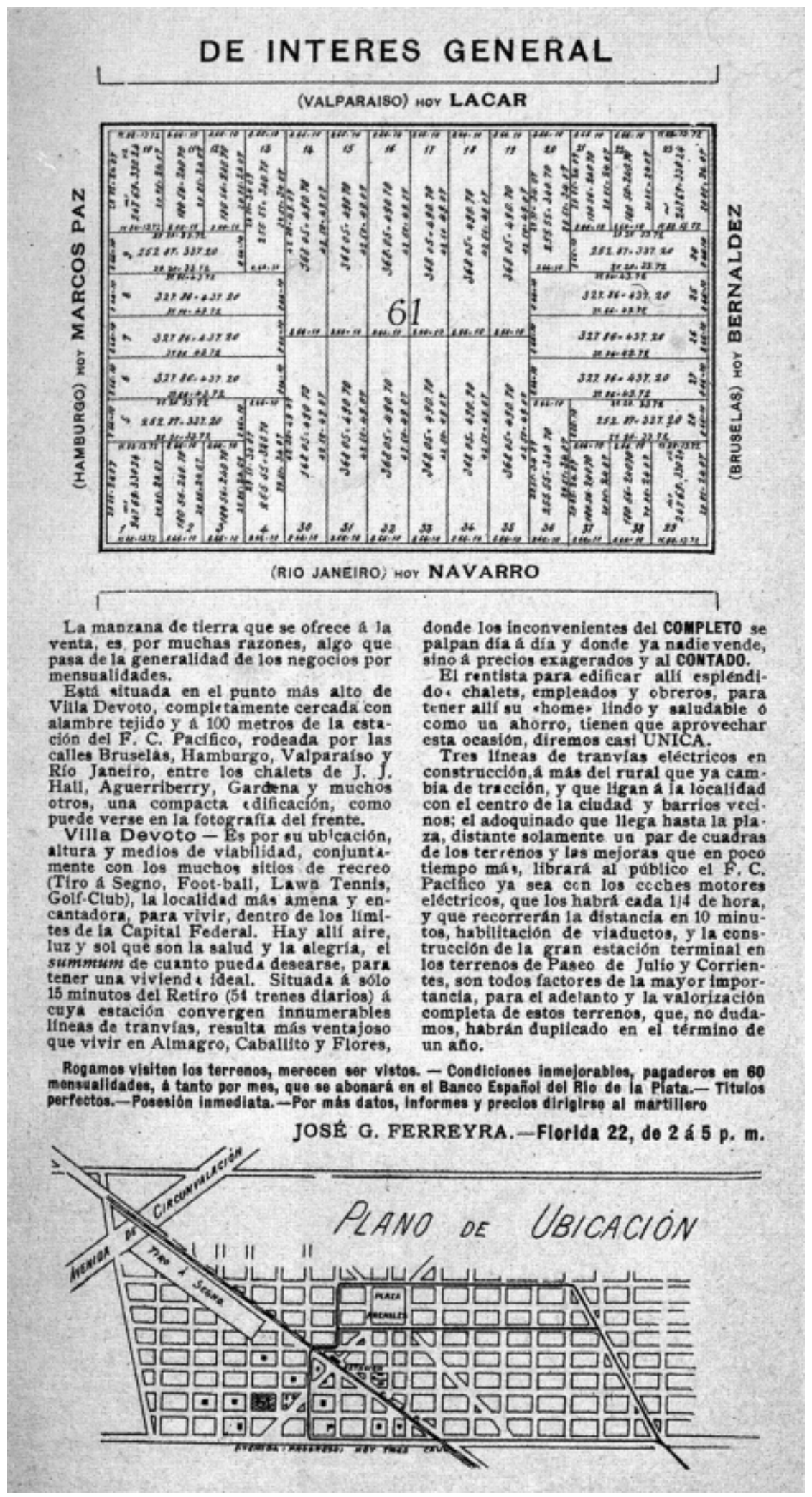

Figura 150 - Prospecto de venda de lotes. Na parte superior vemos uma forma de parcelamento da quadra característica de Buenos Aires.

Fonte: GUTMAN, Margarita (ed.). Buenos Aires 1910: memoria del porvenir. Buenos Aires, Gobierno de la Ciudad de Buenos Aires/ Faculdade de Arquitetura, Design e Urbanismo da Universidade de Buenos Aires/ IIED-America Latina, 1999 

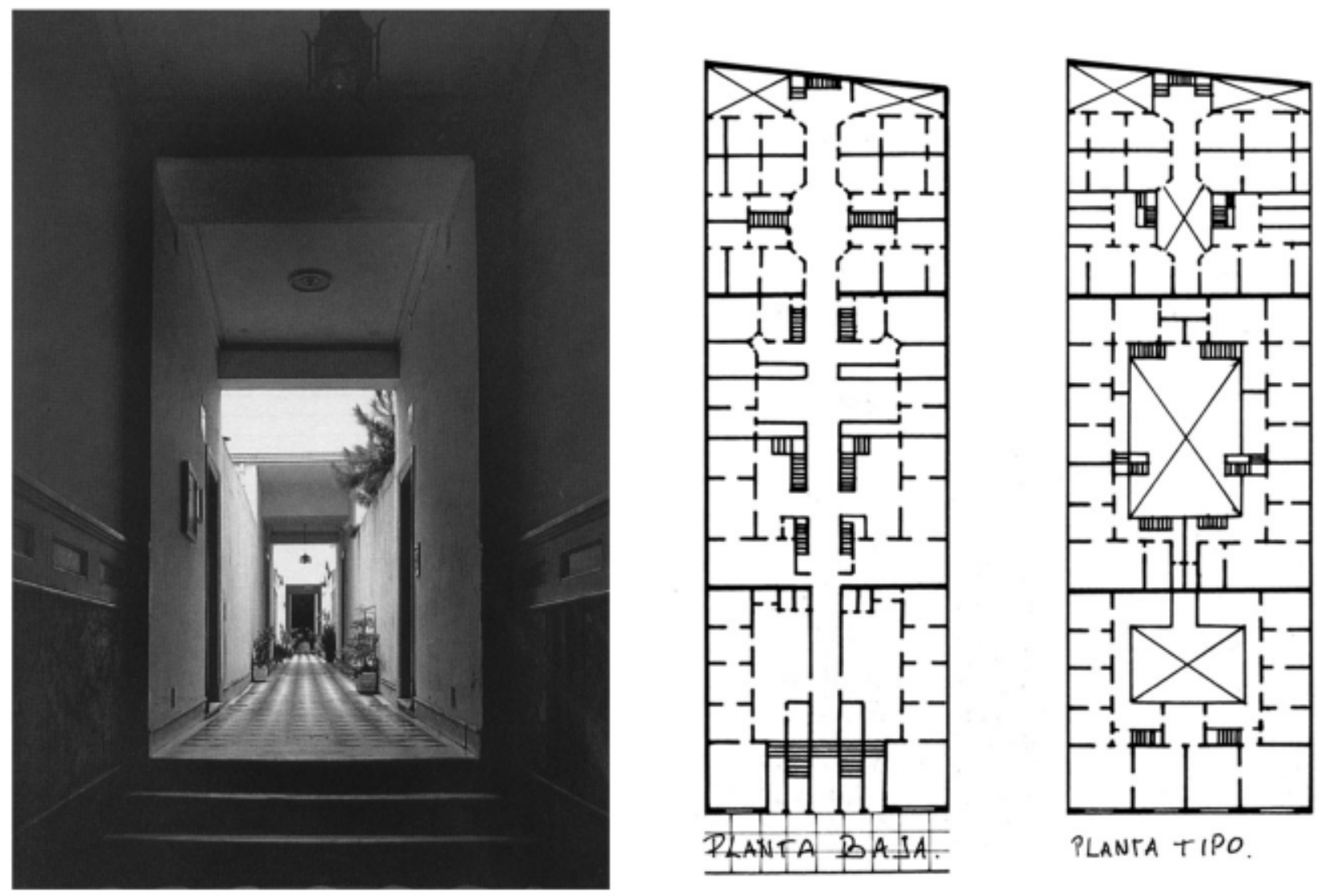

PLANTA TIPO

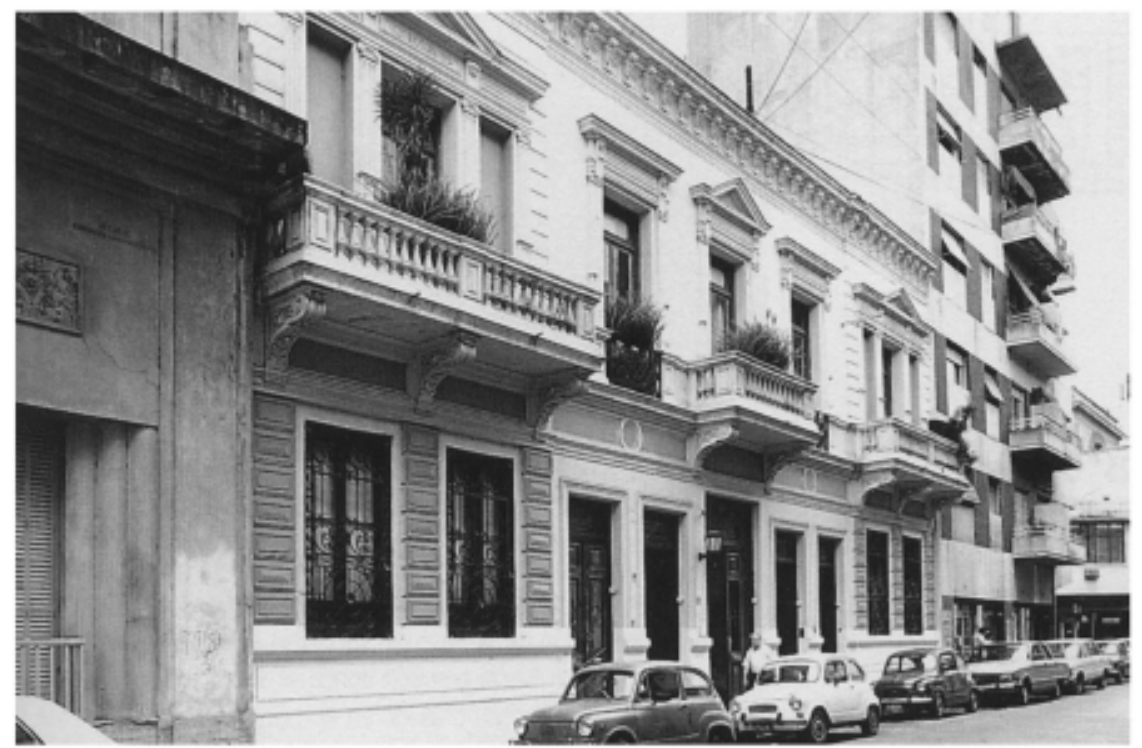

Figura 151 - Moradia coletiva, situada na rua México Nos 470/72/74/76/78, construída em 1898. Exemplo de um conjunto de várias residências, com acesso através de um corredor central. Na fachada observamos uma porta central e mais quatro laterais, que dão acesso às residências situadas no alinhamento do passeio.

Fontes: ASLAN, Liliana et alli. Buenos Aires. Monserrat 1580-1970. Buenos Aires, Faculdade de Arquitetura e Urbanismo da Universidade de Buenos Aires, 1992. PETRINA, Alberto (org.). Buenos Aires. Ocho recorridos por la ciudad. Buenos Aires, Municipalidad de la Ciudad de Buenos Aires; Sevilha, Concejería de Obras Públicas y Transportes, 1994. 


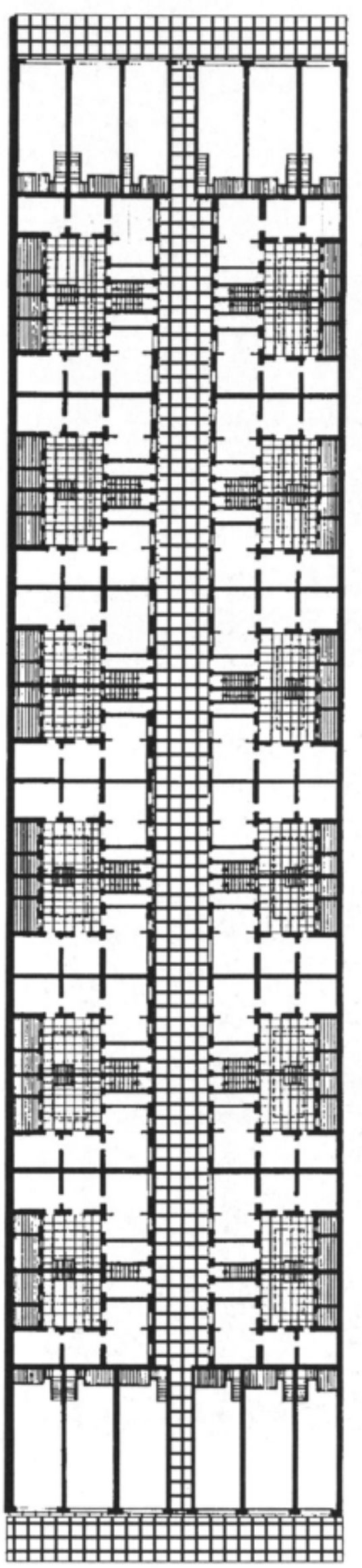

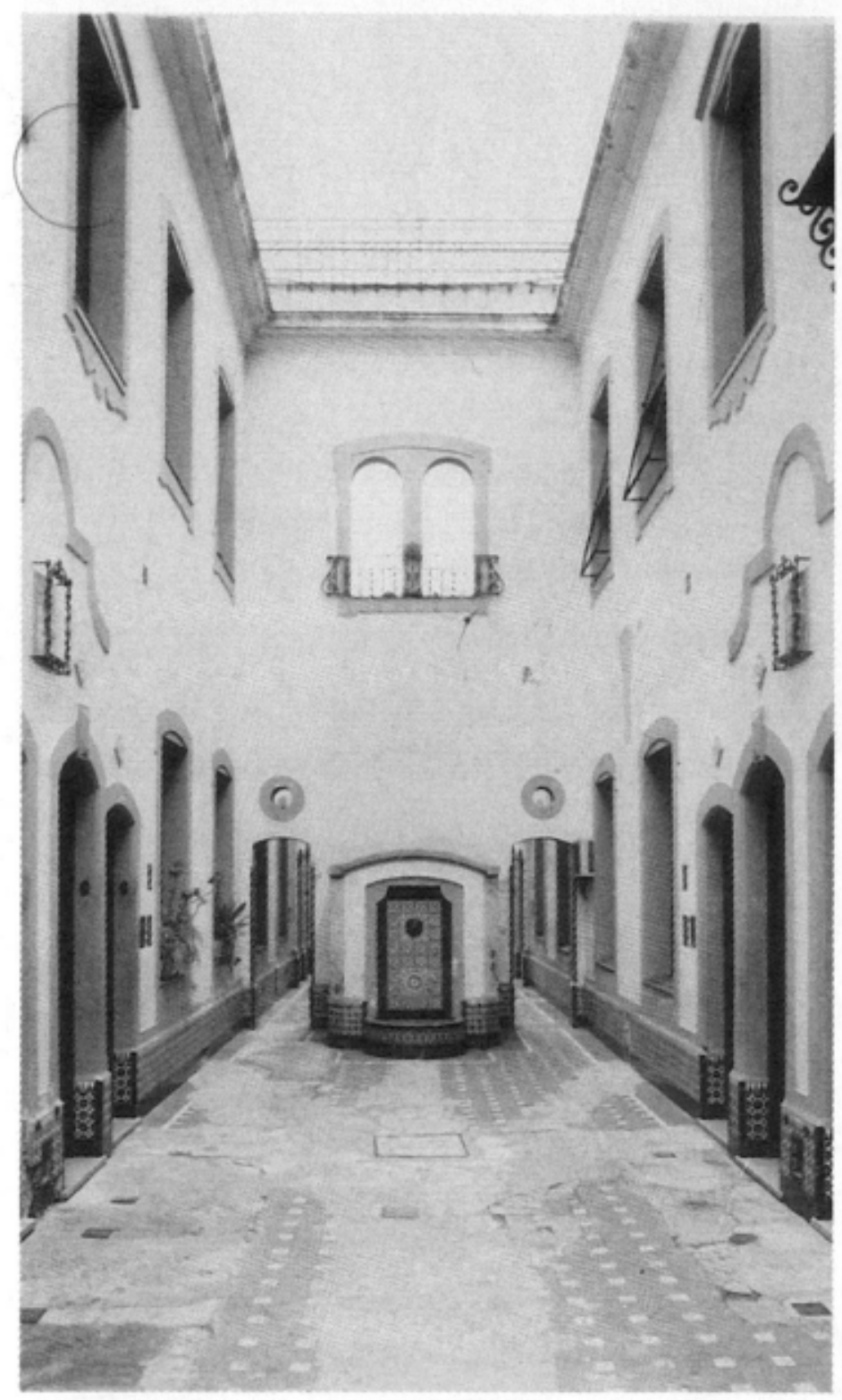

Figura 152 - Neste lote, de 25 metros de largura, foi construído um grande conjunto de residências, além de alguns locais de comércio. Conhecido como "Pasage Sarmiento”, foi construído em 1895 e reformado em 1940.

Fonte: ASLAN, Liliana et alli. Buenos Aires. Balvanera 1817-1970. Buenos Aires, Faculdade de Arquitetura e Urbanismo da Universidade de Buenos Aires, 1992

Planta Baja 
Com isso, o alinhamento frontal das construções costuma ser contínuo. O que muitas vezes denuncia a existência de conjuntos de residências é a existência de uma série de portas na fachada (figura 153). Muitas vezes essa porta é uma entrada independente para o andar superior. Outras vezes é uma porta que dá a um corredor através do qual se dará o acesso às diversas residências situadas no interior da quadra. ${ }^{50}$ Borges assim as descreveu:

"Hacia el confín con Balvanera, hacia el oeste, abundan los caserones con recta sucesión de patios, (...). Cuando las noches impacientes de octubre sacaban sillas y personas a la vereda y las casas ahondadas se dejaban ver hasta el fondo y había amarilla luz en los patios, la calle era confidencial y liviana y las casas huecas eran como linternas en fila." ${ }^{151}$

\section{$7.3-$ CONCLUSÕES}

Nesta etapa realizamos uma série de comparações, enfatizando algumas das categorias de análise da organização do espaço intra-urbano mais importantes, como traçado, lote e implantação.

Neste sentido foi de extrema importância a utilização de material gráfico, através do qual foi possível apreender uma série de aspectos do urbanismo, tarefa que seria muito mais difícil, e provavelmente menos eficiente, se utilizássemos outros meios.

A primeira constatação que realizamos é que embora existam algumas continuidades em relação ao urbanismo colonial, principalmente no caso de Buenos Aires, há de fato um momento de inflexão neste período. Pudemos observar isto ao estudar a evolução da mancha urbana, que a partir aproximadamente de 1890 começa em ambas cidades a apresentar ocupações descontínuas em relação ao núcleo central (figuras 140 e 141). Outro dado interessante, resultado da utilização de material gráfico, é a comparação de mapas de ambas cidades, colocados na mesma escala (figuras 138 e 139). Neste caso pudemos observar que Buenos Aires apresenta um padrão mais compacto, ao contrário de São Paulo, cuja ocupação é mais dispersa.

Um outro aspecto que merece ser considerado é a questão do controle sobre o espaço urbano. No caso de São Paulo parece prevalecer a ação organizada de empresários ligados não apenas à construção civil, mas também a diversas outras atividades correlatas. Já em Buenos Aires de acordo com a tese de Gorelik, o Estado não foi sócio das inversões imobiliárias o que permitiu a criação de um espaço público metropolitano. Trata-se de um indício de que há diferenças na forma de organização

tiveram a mesma difusão que em Buenos Aires, e eram destinadas a uma população de mais baixa renda.

${ }^{50}$ Esta forma de parcelamento também teve ecos posteriormente na arquitetura moderna. Evidentemente não no caso do projeto de Le Corbusier de 1947 que fazia tabula rasa de uma parte da cidade. Mas arquitetos como Antonio Vilar desenvolveram tipologias com o objetivo de superar as limitações da arquitetura tradicional, mas inseridas nestes lotes estreitos, em geral de 8,66 m, e sem recuos laterais.

${ }^{51}$ Do conto "Palermo de Buenos Aires", do livro "Evaristo Carriego". Citado em: GRAU, Cristina. Borges y la arquitectura. Madrid, Cátedra, 1989, p. 30. 

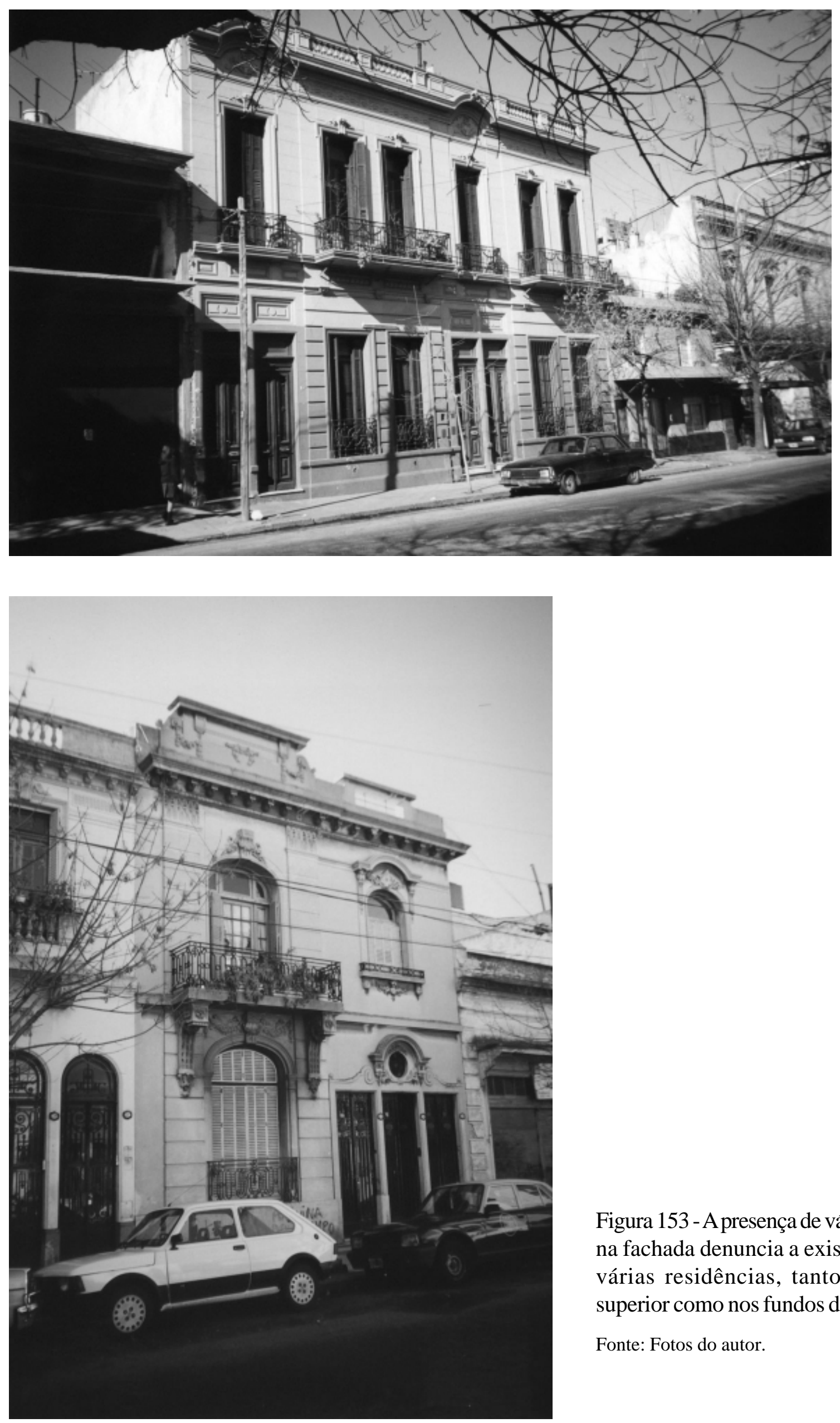

Figura 153 - Apresença de várias portas na fachada denuncia a existências de várias residências, tanto na parte superior como nos fundos do lote.

Fonte: Fotos do autor. 
institucional, que está relacionado a formas de controle sobre o espaço urbano diferentes. Entretanto, esta hipótese exige maiores estudos para a sua confirmação, inclusive porque em ambas cidades havia uma estreita relação entre os ocupantes de cargos públicos e os agentes privados que atuavam na área imobiliária.

No caso da legislação comprovamos que em termos gerais há inúmeras semelhanças, o que também pode ser atribuído ao fato de que em geral esses regulamentos eram baseados naqueles já existentes em outros países, em geral europeus. Entretanto, a legislação paulistana parece possuir mais brechas no sentido de permitir certas formas de parcelamento do solo, como as ruas particulares, por exemplo, que em princípio eram legais, mas das quais não era exigida a obediência aos parâmetros que a lei considerava mínimos para uma boa qualidade urbana.

Por último verificamos que a arquitetura resultante é extremamente variável, embora em cada cidade possamos identificar padrões próprios. Podemos afirmar, entretanto, que em comum têm o fato de ser caracterizada por uma infinidade de soluções de projeto, que procuravam resolver da melhor maneira possível a equação formada por pelos menos três variáveis: implantação nos terrenos disponíveis, custo da obra e possibilidades econômicas dos diferentes demandantes. 
CAPÍTULO 8

A “CASA DE PORÃO ALTO”
E A “CASA-CHORIZO" 


\section{1 - CARACTERIZAÇÃO}

\section{1}

Para entender a urbanização e de que maneira o espaço é parte dos projetos dos diversos grupos sociais, é necessário caracterizar este espaço no período em estudo e suas transformações, já que trabalhamos com processos. Para atingir este objetivo podemos nos valer de descrições ou análises baseadas em dados como censos, relatórios de prefeitos, atas de câmaras etc. Outro meio são as imagens da época, em nosso caso existentes em quantidade significativa, embora esta fonte muitas vezes se caracterize por um enfoque mais voltado para as áreas centrais, ou para aquilo que os grupos dominantes da época pretendiam mostrar. Por último, podemos contar ainda com os muitos edifícios remanescentes do período em estudo, além das vias e quadras, que em geral persistem mesmo quando os edifícios são substituídos.

Para construir modelos teóricos devemos poder generalizar uma explicação. Para isto temos que encontrar regularidades, o que em nossa área de trabalho significa encontrá-las não apenas em elementos construtivos ou detalhes de ornamentação, mas na lógica do projeto. Como já colocamos anteriormente, é próprio do arquiteto que a análise do espaço a partir de um determinado recorte caminhe junto com a possibilidade das questões suscitadas se tornarem efetivas socialmente, isto é, viabilizem a realização de um projeto. Projeto, neste caso, refere-se não apenas ao projeto social, ou seja, à maneira como os diversos grupos sociais se organizam e procedem para concretizar seus objetivos, mas também a todos os elementos, que são próprios da formação do arquiteto, necessários à sua materialização resultando, portanto, em arquitetura e urbanismo.

Desta forma, quando identificamos formas, usos, técnicas, ou maneiras de articulação entre arquitetura e urbanismo que se repetem, é possível a recuperação da dimensão social:

"A arquitetura não é um simples dado das condições de existência social. Ela é realizada pelos agentes sociais, com alvos socialmente definidos... Pode, portanto, adquirir significados contraditórios, segundo os grupos sociais pelos quais é utilizada. Mas sempre e necessariamente, se não é caso particular, isto é, se é utilizada por grupos sociais e tem generalidade, é porque adquiriu significado social para o grupo."

\footnotetext{
${ }^{1}$ REIS FILHO, Nestor Goulart. Quadro da Arquitetura no Brasil. $5^{\frac{a}{a}}$ ed. São Paulo, Perspectiva, 1983, p.
} 186. 


\section{2}

Iremos agora utilizar a iconografia levantada para analisar mais especificamente um determinado padrão arquitetônico utilizado pelas camadas baixas e médias em geral, que é a chamada casa de porão alto e entrada lateral, em São Paulo, ou casa chorizo, ${ }^{2}$ em Buenos Aires. Resumidamente, estas tipologias têm em comum o fato de ocuparem um lote estreito e comprido, e possuírem uma implantação de cômodos em fila. Progressivamente, à medida que aprofundarmos sua caracterização no decorrer dos próximos itens, acrescentaremos maiores detalhes arquitetônicos e urbanísticos (figura 154). antecedentes.

Entretanto, antes de proceder a esta análise, devemos verificar seus

Havia uma certa homogeneidade na aparência de vilas e cidades do Brasil colonial, principalmente a partir do século XVIII, quando tornaram-se correntes exigências quanto a dimensões e número de aberturas, altura dos pavimentos e alinhamentos com as edificações vizinhas.

Também há uma razoável padronização tanto dos lotes como das plantas das residências. Normalmente as edificações formavam uma linha contínua, e suas fachadas alinhadas terminavam por definir a rua.

A grande maioria das residências era térrea ou sobrado. Estes últimos eram um sinal de riqueza, de sorte que quando o térreo não era utilizado para fins residenciais destinava-se aos animais e escravos. Ou então era usado como loja. Quanto ao partido, em geral o pavimento superior era um rebatimento do andar térreo.

A partir do início do século XIX surge um novo padrão arquitetônico, que é a chamada "casa de porão alto". Trata-se de uma evolução da casa colonial urbana, mas contando agora com um pequeno porão sob o nível térreo, que permite a utilização de pisos de madeira, e garante a privacidade naquele nível, o que revaloriza o térreo para fins residenciais (figuras 155 e 156). A implantação, entretanto, continua a mesma do período colonial, prevalecendo a ocupação de ambos os limites laterais do terreno.

Isto começa a mudar a partir de 1850, quando surgem os primeiros recuos laterais. Nas residências maiores este recuo pode comportar um jardim, e muitas vezes ambos os lados possuem recuos, embora em geral somente um deles fosse valorizado, o que permitiu a eliminação das alcovas, que eram cômodos sem qualquer ventilação e iluminação. Entretanto, não há grandes alterações na implantação, exceto a localização da entrada na fachada lateral. Esta situação irá perdurar até aproximadamente a década de 1920.

Como vimos, a chamada "casa de porão alto" refere-se a todas as construções que surgem no século XIX onde o nível térreo está elevado em relação ao passeio. Entretanto, para os fins desta pesquisa, doravante quando nos referimos à "casa de porão alto" estaremos nos referindo ao caso particular caracterizado por um lote exíguo e presença de um estreito corredor lateral.

\footnotetext{
2 A tradução literal seria "casa-linguiça". Muitos autores também a denominam "casa pompeyana", por supostamente guardar semelhanças com as casas existentes na cidade de Pompéia, na Itália.
} 

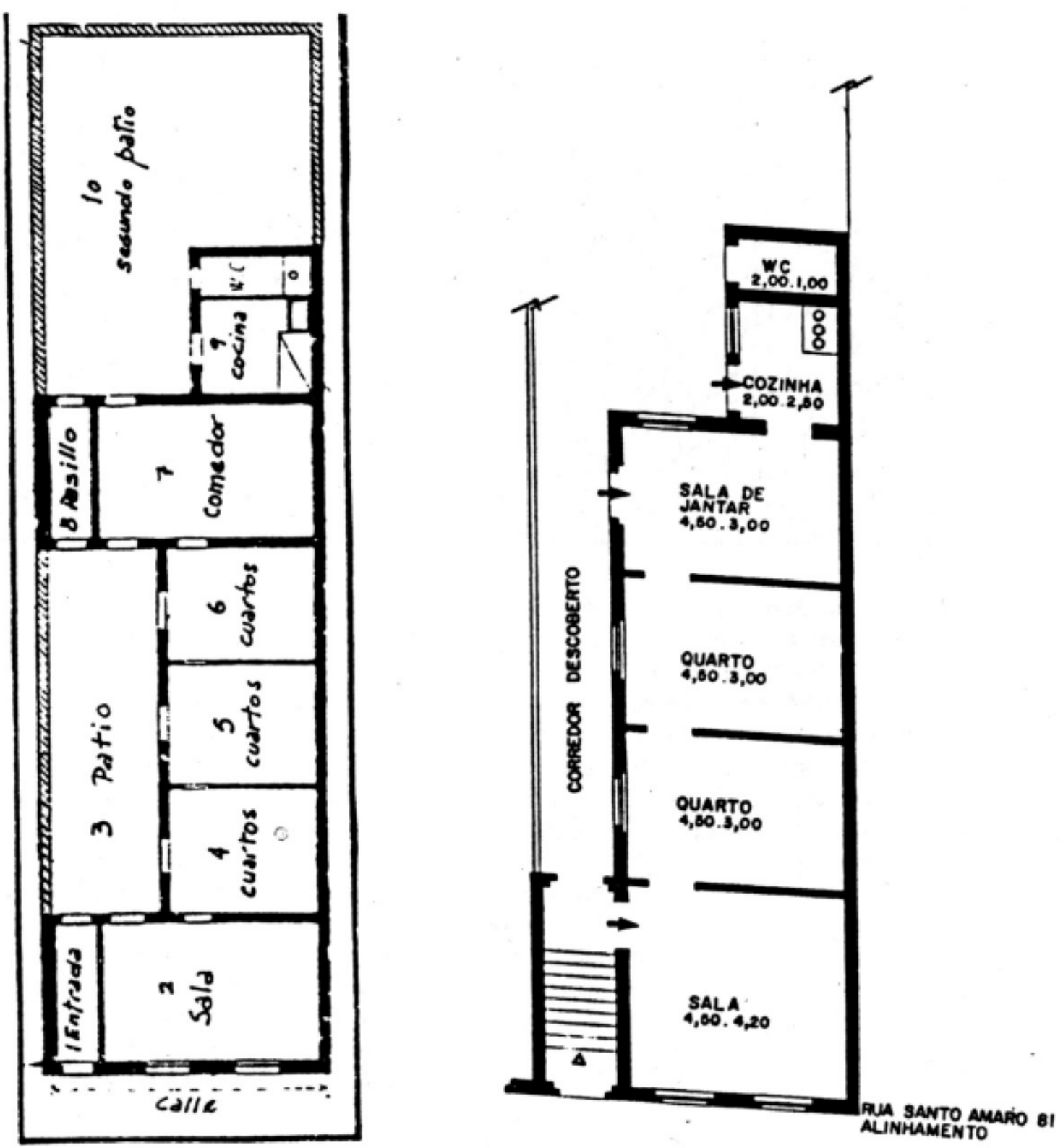

Figura 154 - À esquerda temos a planta de uma "casa chorizo”, e à direita uma "casa de porão alto e entrada lateral”. Notar como a implantação e o partido seguem um disposição parecida.

Fonte: CALDEIRA, Vasco; NOVICK, Alicia. A cidade arquitetural e a arquitetura urbana. O caso de São Paulo e Buenos Aires. São Paulo, Revista Projeto № 85, março 1986 

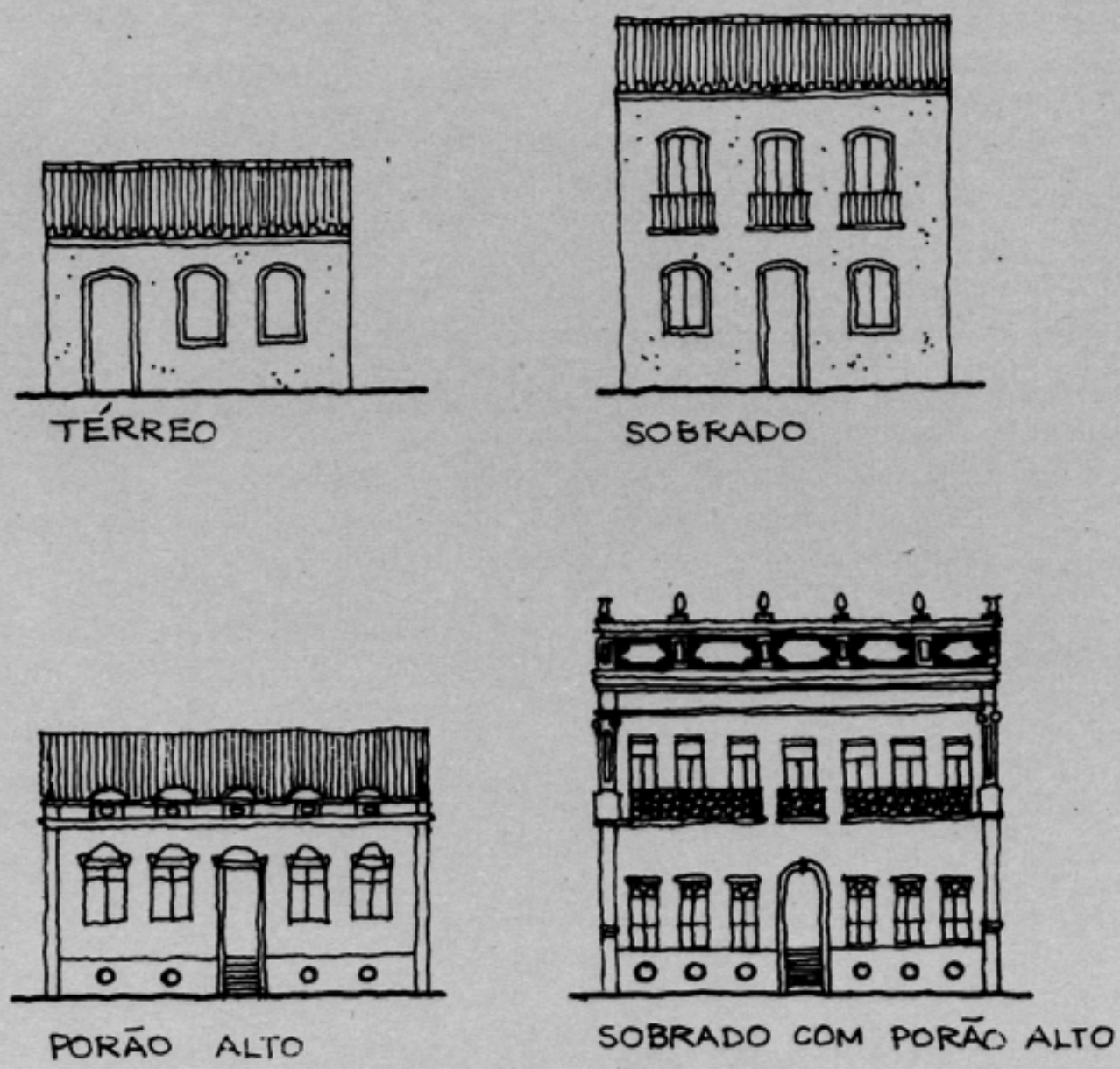

Figura 155 - Esquema de transição ocorrido nas casas coloniais no Brasil, que recebem um porão sob o nível térreo.

Fonte: REIS FILHO, Nestor Goulart. Quadro da Arquitetura no Brasil. 5ª ed. São Paulo, Perspectiva, 1983 

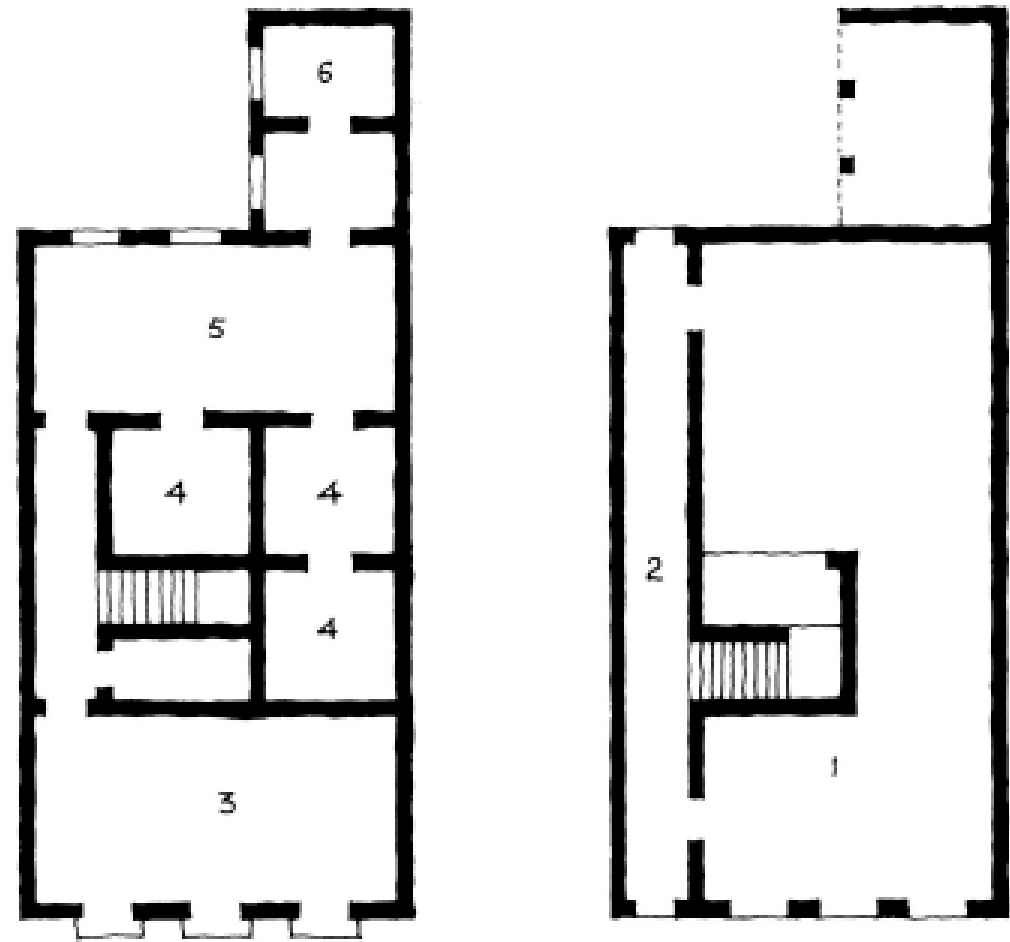

1. loja; 2. corredor de entrada para residência, independente da loja; 3. saläo; 4. alcovas; 5 . sala de viver ou varanda; 6. cozinha e servicos.

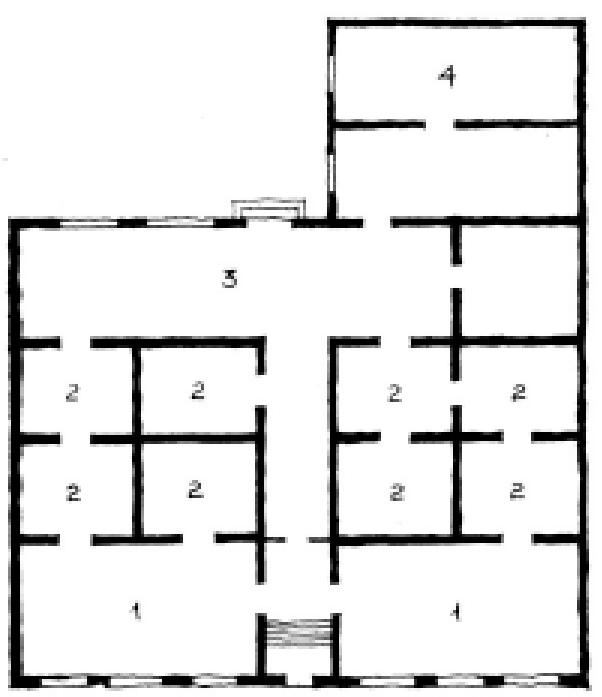

1. who; 2. alcovas; 3. sala de viver ou varanda; 4. cozinha serviços.

Figura 156 - Na parte superior temos uma planta característica da arquitetura colonial no Brasil. Na inferior, a planta de uma "casa de porão alto", padrão surgido no século XIX. Comparando ambas é posível verificar que não há grandes alterações quanto ao partido adotado.

Fonte: REIS FILHO, Nestor Goulart. Quadro da Arquitetura no Brasil. 5ª ed. São Paulo, Perspectiva, 1983 
$\mathrm{Na}$ Argentina, a arquitetura colonial é herdeira de um processo de seleção e síntese da arquitetura espanhola, como em diversas outras partes da América Hispânica. ${ }^{3}$ Uma de suas características mais marcantes é a organização do projeto em torno de um pátio. Vejamos a descrição de um viajante em Buenos Aires em meados do século XIX:

\begin{abstract}
"Algunas residencias de familias pertenecientes a las clases superiores son realmente hermosas como edificios, aunque el efecto que producen pierde mucho debido a la estrechez de las calles. Por lo general, dichas casas pueden considerarse dobles por su disposición: tienen sobre la calle una ancha y maciza puerta que conduce a un patio abierto, encuadrado por los departamentos principales; un zaguán espacioso une este patio con un segundo, destinado a los cuartos de dormir; más adentro se abre otro donde están las cocinas y cuartos de servicio. Estos patios se hallan adornados generalmente con plantas y flores escogidas; a veces un árbol de naranjo ocupa el centro y suele hallarse cubierto todo el patio por una frondosa parra, de la que cuelgan vaciamos purpúreos. Los techos planos llamados azoteas constituyen un delicioso retiro en las tardes de verano cuando los cuartos interiores se ponen sofocantes a causa del excesivo calor."
\end{abstract}

Outro fator importante é que o traçado das ruas e espaços públicos antecedia a ocupação. Assim, o tecido podia ter uma constituição mais dispersa do que no caso brasileiro. E devido à regularidade própria do traçado ortogonal, havia também grande padronização quanto ao tamanho dos lotes, que inicialmente apresentavam formato quadrado, no caso de Buenos Aires. Estes foram aos poucos sendo sub-divididos, assumindo novas formas, em geral retangulares. Quanto à casachorizo, muitos entendem que surge a partir da divisão ao meio da antiga casa colonial. (figura 157 e 158)

Devemos também deixar claro o que significa trabalhar com tipologias. Há na arquitetura uma conhecida linha de análise, utilizada por autores como Aldo Rossi, Giulio Carlo Argan e Carlo Aymonino, que trabalha a partir de tipos. Neste caso, o tipo é a antítese do modelo, que pressupõe sempre a sua imitação. O contrário, para Argan (citando Quatremère de Quincy, de quem estes autores são devedores):

"Um tipo é uma estrutura que dá a possibilidade, não apenas a possibilidade, mas a necessidade de variantes, pois o tipo não tem uma determinação formal, nós devemos lhe dar esta determinação formal."

\footnotetext{
${ }^{3}$ GUTIERREZ, Ramón. El laberinto de la enajenación. La historia de la arquitectura própria escrita con ojos ajenos. In: MARCONDES, Neide; BELLOTTO, Manoel. Laberintos e nós: imagem ibérica em terras da América. São Paulo, Unesp/Imprensa Oficial, 1999, p. 77.

${ }_{5}^{4}$ MacCANN, William. Viaje a caballo por las provincias argentinas. Buenos Aires, 1939.

5 ARGAN, Giulio Carlo. A história na metodologia do projeto. Revista Caramelo $N^{0}$ 6. São Paulo, FAUUSP. p. 158.
} 

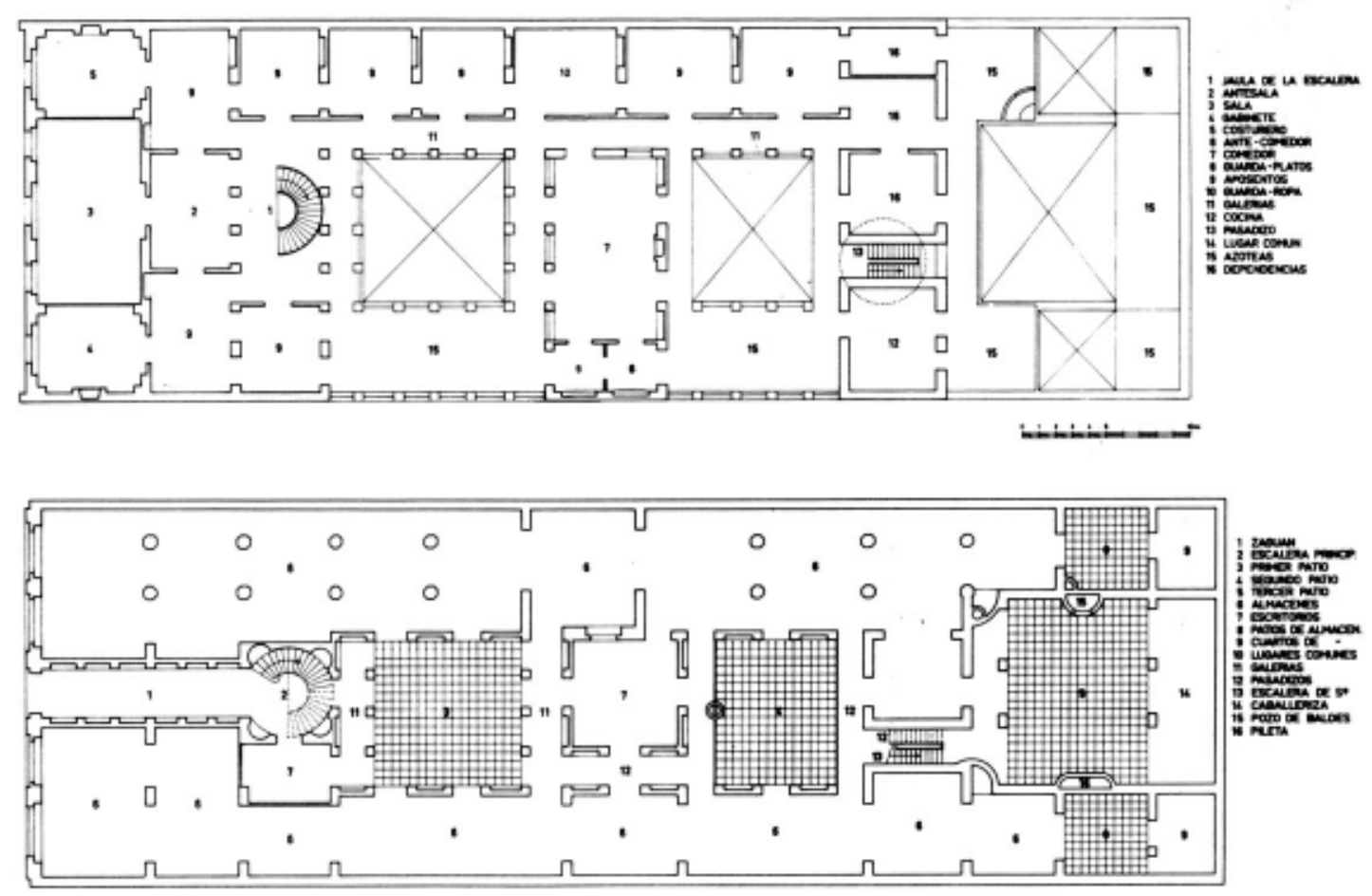

Figura 157 - Plantas dos andares térreo e superior da residência do Gal. Pacheco, em Buenos Aires. A casa se organiza em torno a pátios, herança da arquitetura colonial.

Fonte: LECUONA, Diego E. La vivienda de “criollos” y “extranjeros”en el siglo XIX. Tucumán, Instituto Argentino de Investigaciones de Historia de la Arquitectura y del Urbanismo, 1984
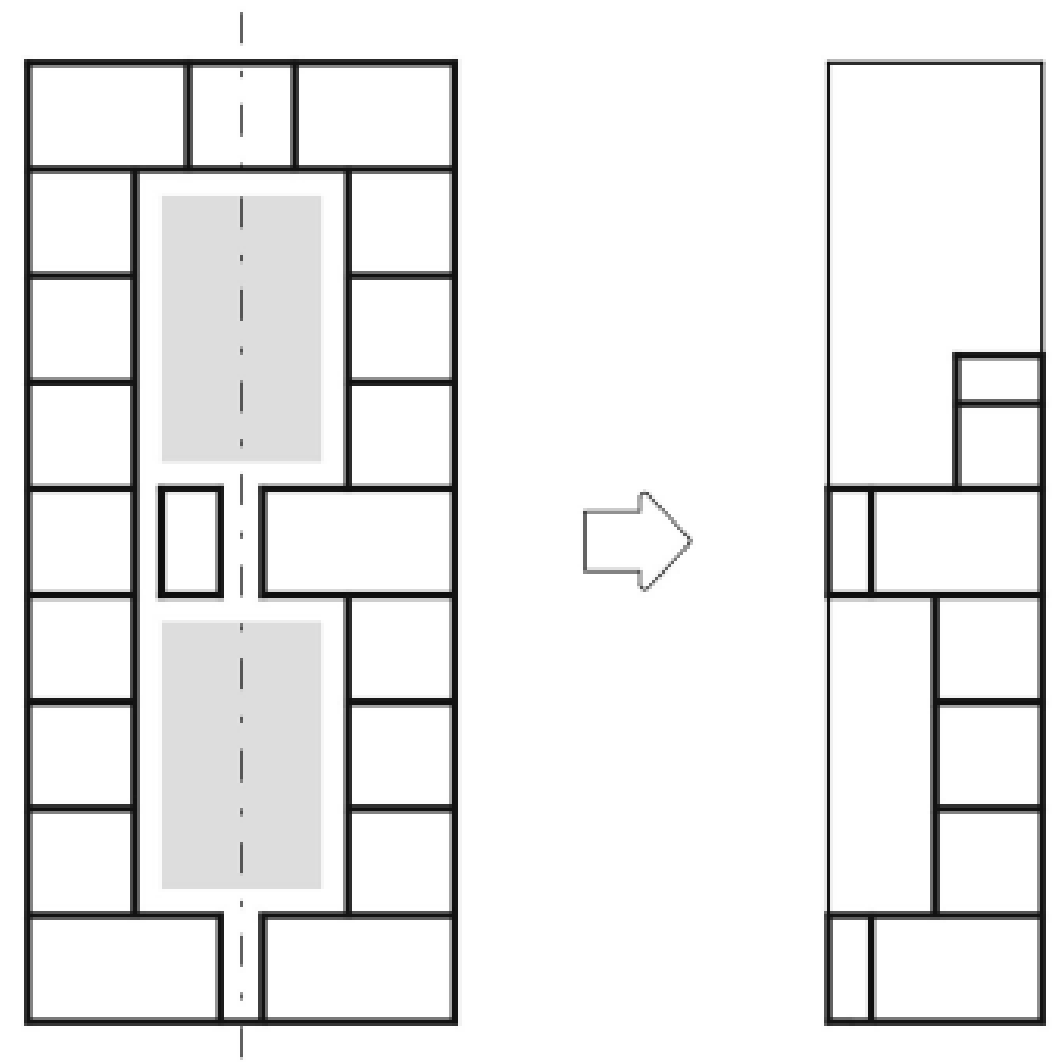

Figura 158 - Desenho esquemático mostrando a subdivisão da casa colonial de pátios, resultando na casa chorizo.

Fonte: Desenho do autor 


\section{Para Rossi, \\ "Nenhum tipo se identifica com uma forma, se bem todas as formas arquitetônicas são remissíveis a tipos."}

Outras variantes, comuns nas ciências sociais em geral, são os "tipos médios", utilizados nas abordagens positivistas, e os "tipos ideais", de extração weberiana.

Nesta análise de tipologias residenciais nosso objetivo é mais modesto, nas questões de método. Tipologia em nosso caso refere-se a determinados padrões arquitetônicos que apresentam significativa freqüência em ambas cidades. Embora existam variações, as quais também apontaremos, são em grau que permitem identificá-las como pertencendo ao mesmo padrão. Nosso objetivo não é encontrar os diversos tipos existentes, nem as formas que assumem no decorrer do tempo, mas definir um recorte que nos permita obter algumas generalizações, a partir de comparações, baseados na sua ocorrência nas cidades que estudamos.

Comecemos por caracterizar algumas variações. No caso de Buenos Aires, um dos autores que estudou as diferentes tipologias e sua evolução foi Diez. ${ }^{7}$ Partindo de uma metodologia próxima à de Aldo Rossi, levantou junto com os alunos de arquitetura da Universidade de Belgrano uma infinidade de situações, a partir das quais define uma série de tipologias. Organiza, assim, esquemas de como um tipo deriva em outro. Quanto à tipologia que nós escolhemos, mostra apenas as variações possíveis, em função do comprimento do lote, as quais já vimos ao analisar o traçado (figura 159).

De qualquer maneira, ao periodizar as diferentes tipologias encontradas, verifica que entre meados do século XIX e aproximadamente 1920 prevalece a "casachorizo" (que ele chama de "casa de $1 / 2$ pátio") em suas diferentes variações. Portanto, nossa escolha é representativa da produção residencial do período que escolhemos.

Em São Paulo, pelo fato do traçado e lotes apresentam maiores variações do que em Buenos Aires, há também maiores diferenças. Não encontramos trabalhos com a abordagem semelhante à de Diez. Entretanto diversos autores fizeram análises das tipologias existentes na cidade de São Paulo, seja através de observação direta como de consulta ao arquivo municipal Washington Luís, o qual contém uma infinidade de documentos com projetos de arquitetura. Na figura 160 temos alguns exemplos das variações que estas tipologias experimentam em São Paulo.

Entretanto não é nosso objetivo estudar exaustivamente todas essas tipologias, mas sim o de obter algumas conclusões para nossa pesquisa. Assim, verificamos que as duas tipologias que escolhemos representam um universo significativo da produção arquitetônica do período. Tão características, que no caso de Buenos Aires chamaram a atenção de Le Corbusier, que nelas enxergou a essência da arquitetura moderna:

\footnotetext{
${ }^{6}$ ROSSI, Aldo. La arquitectura de la ciudad. Barcelona, Gustavo Gili, 1971, p. 68. [Tradução nossa].

7 DIEZ, Fernando E. Buenos Aires y algunas constantes en las transformaciones urbanas. Buenos Aires, Fundación Editorial de Belgrano, 1996.
} 


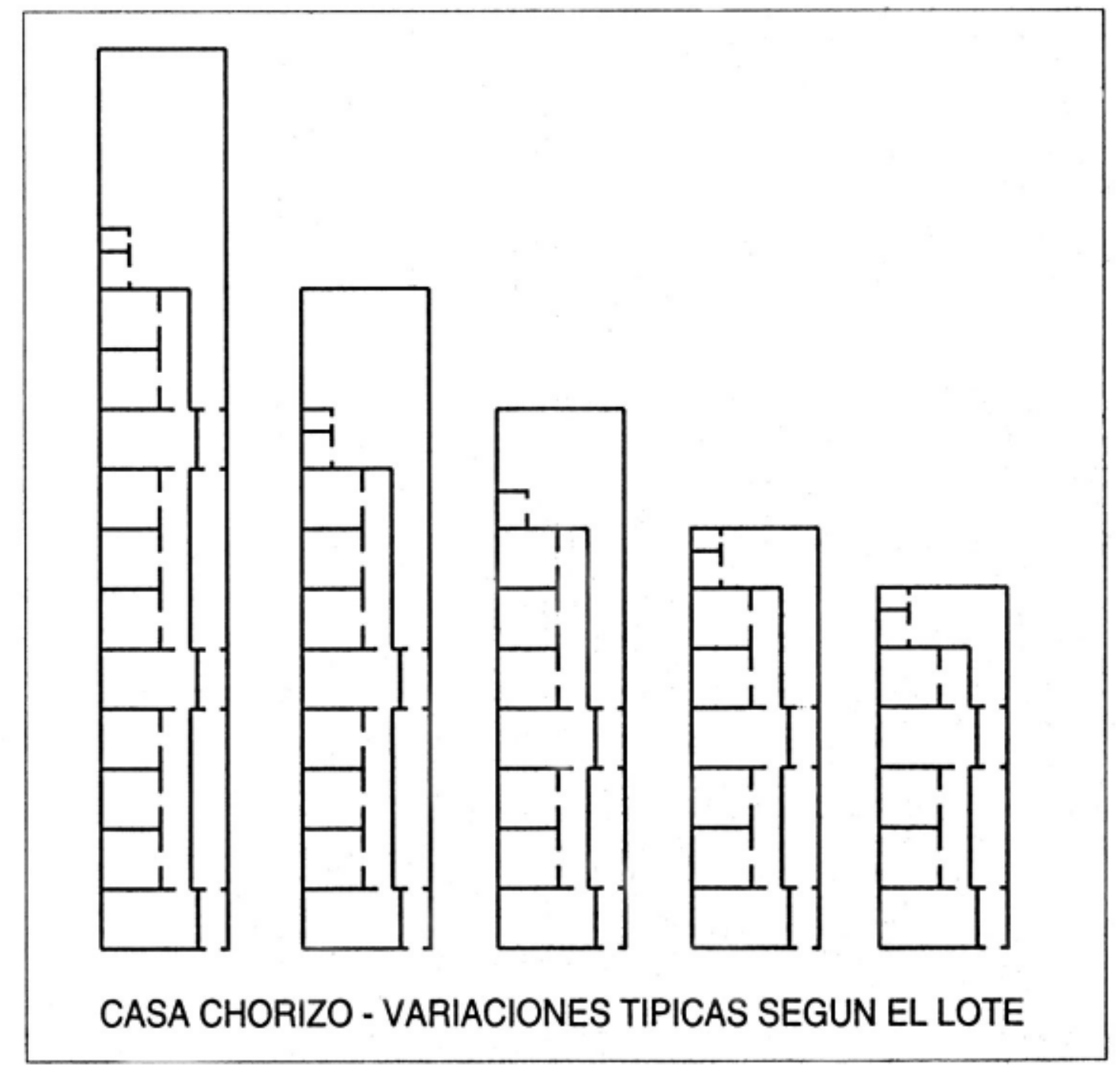

Figura 159 - Algumas das possíveis variações que pode assumir a planta da casa chorizo em função do comprimento do lote.

Fonte: DIEZ, Fernando E. Buenos Aires y algunas constantes en las transformaciones urbanas. Buenos Aires, Fundación Editorial de Belgrano, 1996 


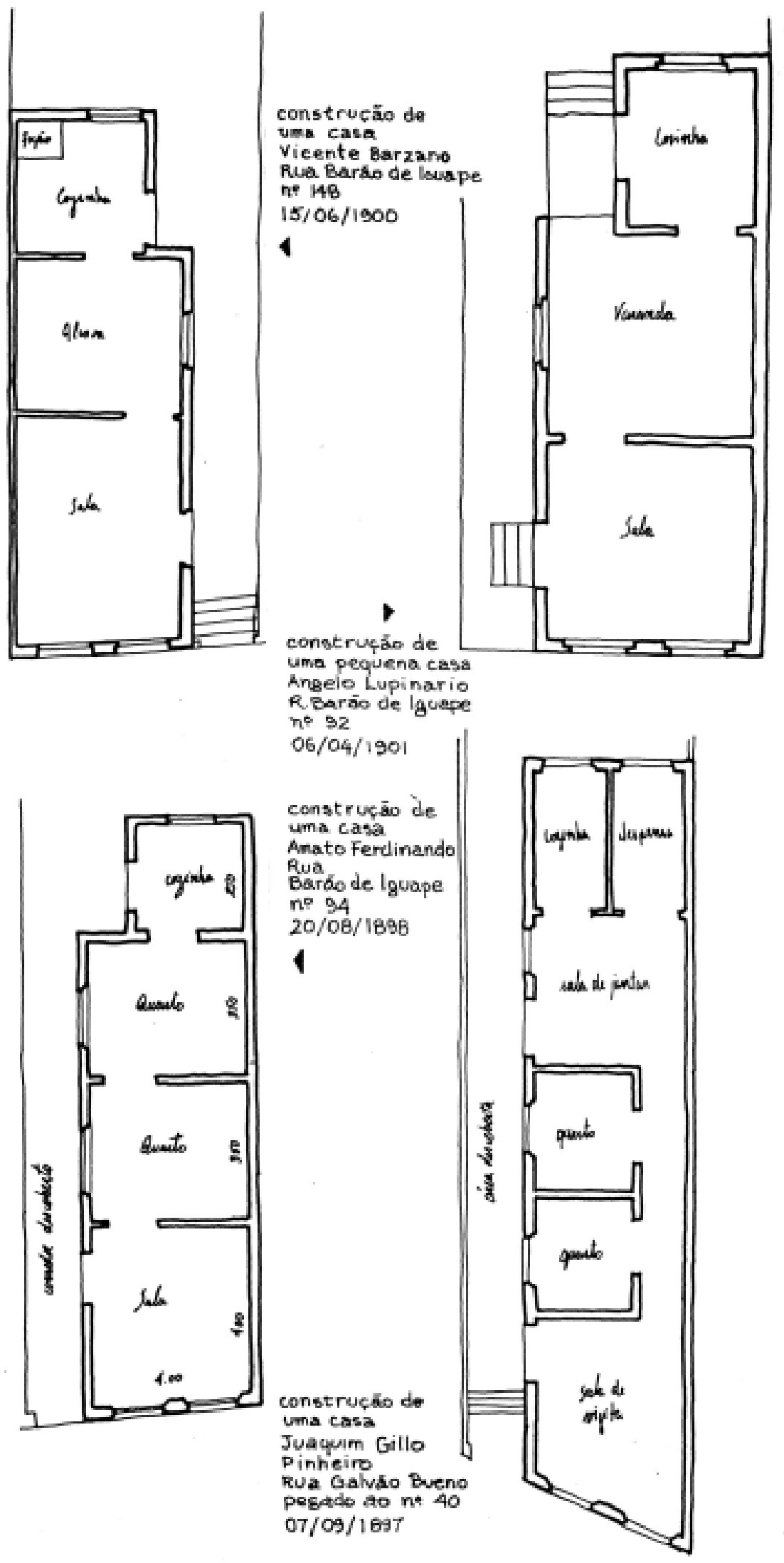

Figura 160 - Luiz Alberto do Prado Passaglia é o autor destes esquemas, resultado de uma ampla pesquisa realizada nos bairros do Brás e Liberdade, na qual levantou e sistematizou uma série de características destas casas.

Fonte: PASSAGLIA, Luiz Alberto do Prado. O Italianizante. A arquitetura no período de 1880 a 1914 na cidade de São Paulo. São Paulo, FAUUSP, 1984 
"Dicen: 'no tenemos nada, nuestra ciudad es muy nueva'. [...] Vean: dibujo un muro de cerramiento, abro una puerta en él, el muro se prolonga por el triangular tejado a la izquierda de un cobertizo con una pequeña ventana en el medio; a la izquierda dibujo una galería bien cuadrada y neta. Sobre la terraza de la casa elevo ese delicioso cilindro: el tanque de agua. Ustedes piensan: ' $C$ aramba, he aquí lo que compone una ciudad moderna!' Nada de eso: he dibujado las casas de Buenos Aires."

Vejamos agora as regularidades: nas figuras 161, 162 e 163 mostramos residências situadas em Campos Elíseos, Brás e Belém. Mostramos também exemplos onde em vez do portão lateral, a fachada é contínua, no alinhamento da rua (figura 164).

Da mesma forma, nas figuras 165 e 166 mostramos a repetição do padrão casa-chorizo, em Buenos Aires, neste caso nos bairros de Nuñez e Abasto.

Encontramos também em Buenos Aires diversos casos de residências térreas já preparadas para receber um segundo andar, não concluído, fato pouco analisado na literatura existente. Encontramos vários casos, principalmente na região sul da cidade, que é a região mais pobre, e onde provavelmente as pessoas não puderam terminar nunca o projeto original (figura 167). Curiosamente, no entanto, encontramos também um caso em Palermo, região mais rica (figura 168), o que pode ser percebido pela ornamentação mais refinada da fachada.

\section{4}

Uma comparação preliminar entre a casa de porão alto paulistana e a casa chorizo foi realizada por Caldeira e Novick. ${ }^{9}$ Neste trabalho destacam que o ponto de encontro é o lote estreito e comprido, e mostram as semelhanças existentes nas plantas deste tipo de construção. No entanto, afirmam que embora aparentemente com esquemas de implantação parecidos, sua origem é diferente: a casa chorizo é a divisão ao meio do antigo solar colonial, enquanto a casa de porão alto é uma ruptura em relação aos padrões coloniais brasileiros de ocupação. Seu porão vem da casa rural, onde servia de depósito e estrebaria. Sublinham também a diferença entre o corredor lateral em São Paulo, usado como circulação, ventilação e iluminação, e os pátios portenhos, já que em Buenos Aires o cotidiano se organiza em torno destes, herança da tradição colonial hispânica. Em São Paulo o espaço de convivência equivalente é o quintal nos fundos do lote.

\footnotetext{
${ }^{8}$ Conferencias de Buenos Aires, en Le Corbusier en Buenos Aires, 1929. Buenos Aires, SCA, 1979, p. 59. Citado em GORELIK, Adrián. La Grilla y el parque. Espacio público y cultura urbana en Buenos Aires, 1887-1936. Quilmes, Universidad Nacional de Quilmes, 1998.

${ }^{9}$ CALDEIRA, Vasco; NOVICK, Alicia. A cidade arquitetural e a arquitetura urbana. O caso de São Paulo e Buenos Aires. São Paulo, Revista Projeto N 85, março 1986.
} 


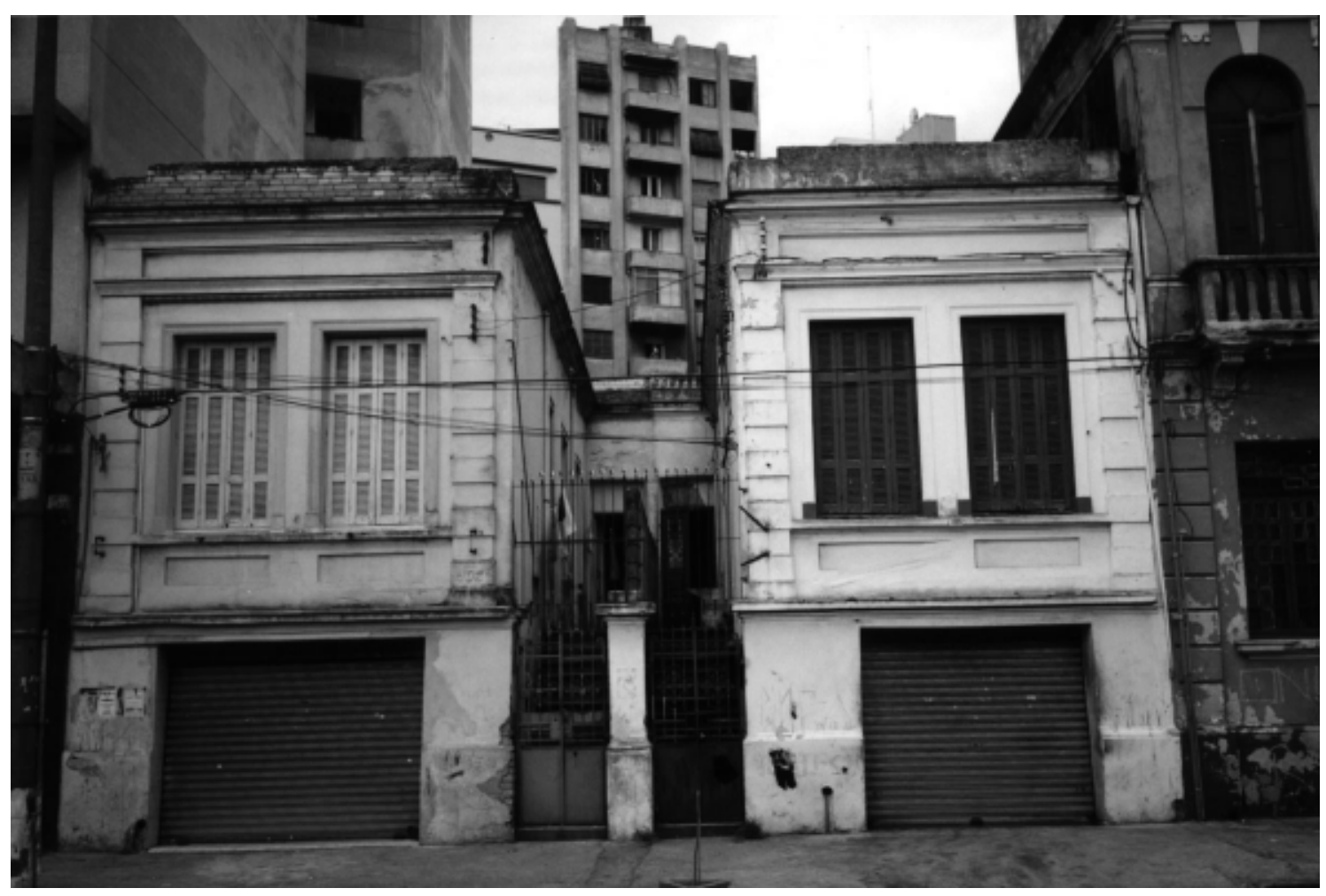

Figura 161 - Casa de porão alto e entrada lateral. Exemplares deste tipo de construção podem ser encontrados em várias regiões da cidade, como os da foto acima, situados no bairro de Campos Elíseos.

Fonte: Foto do autor.

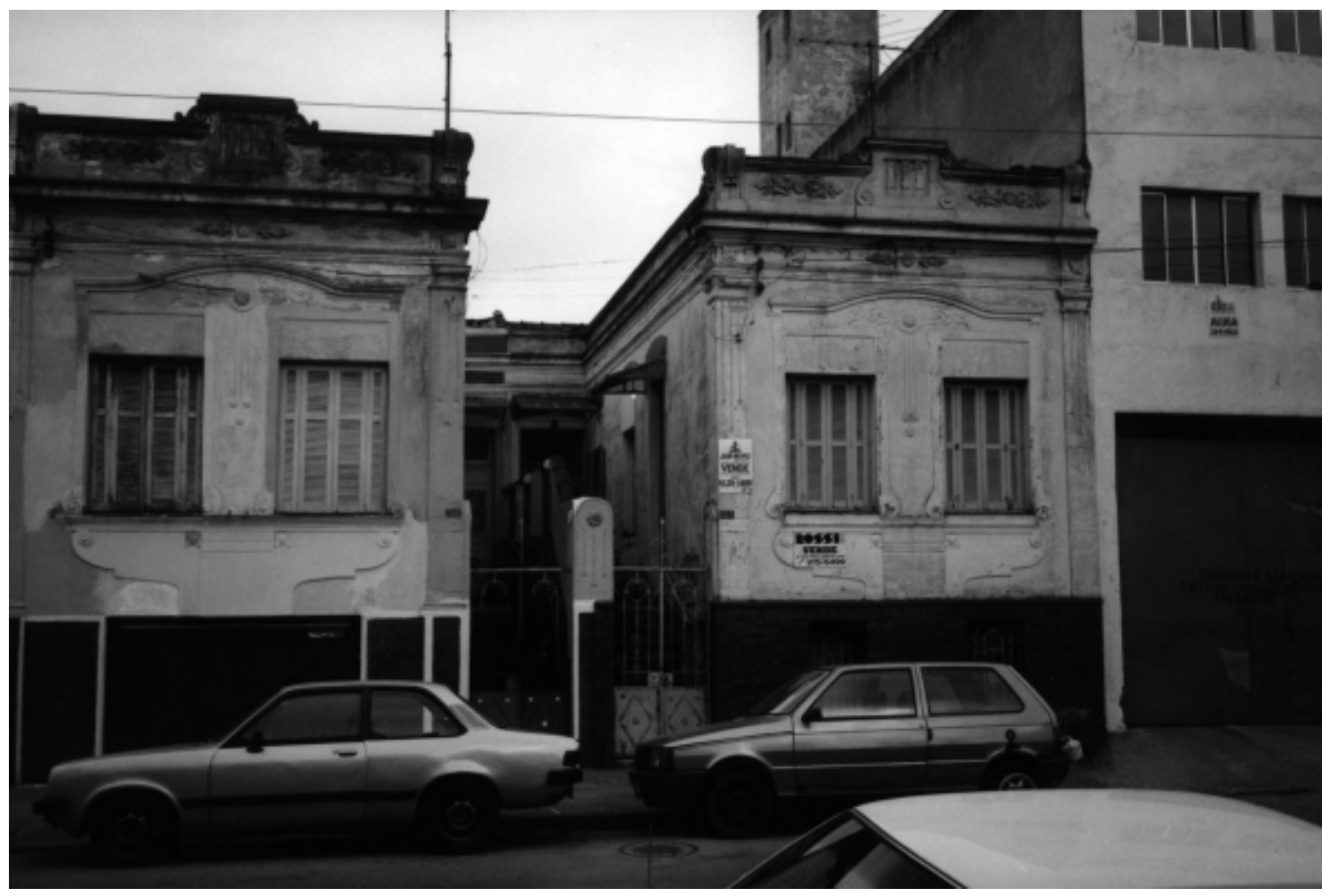

Figura 162 - Neste caso temos duas casas de porão alto e entrada lateral no bairro do Brás. Fonte: Foto do autor. 


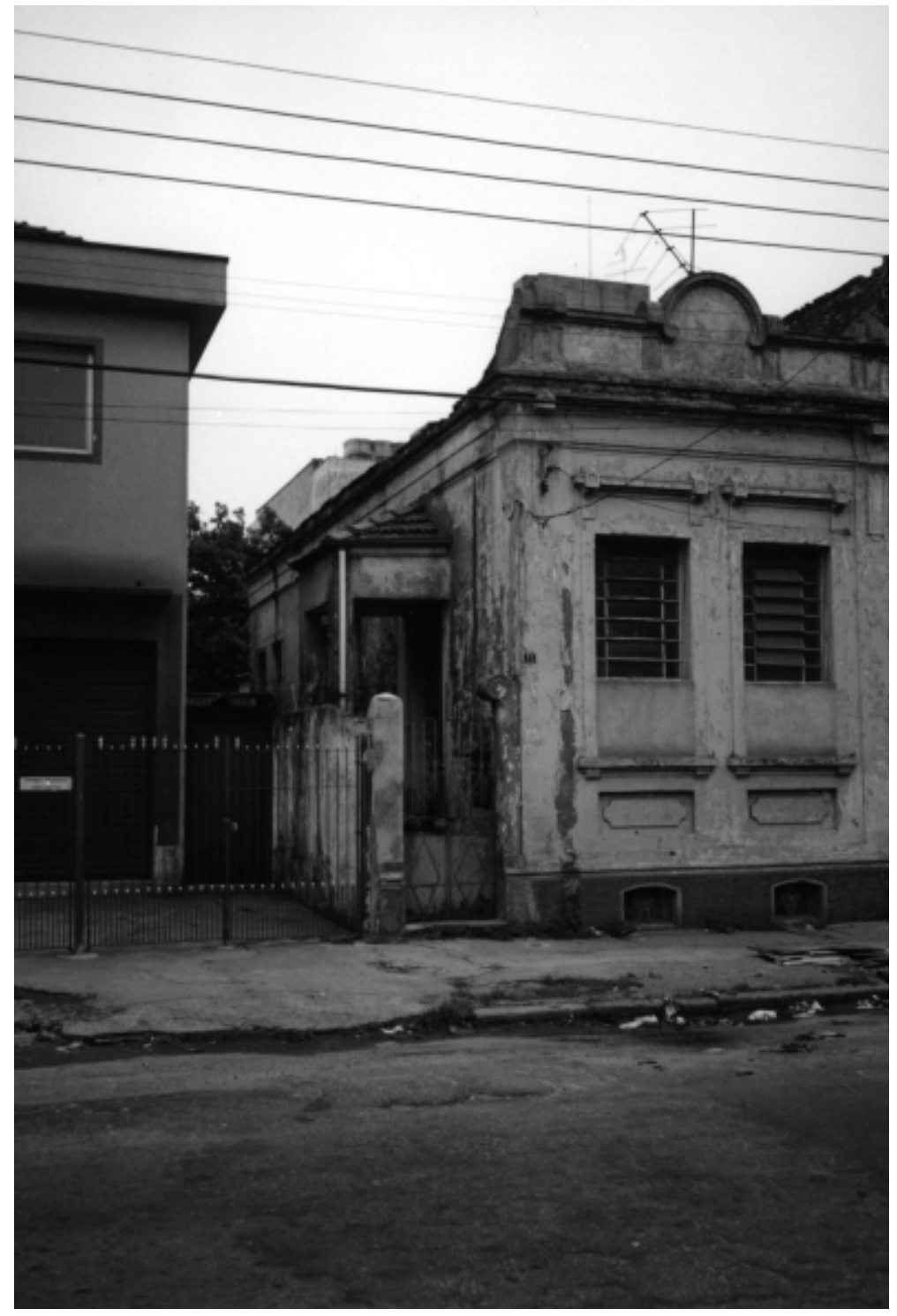

Figura 163 - Este terceiro exemplo está localizado no bairro de Belém.

Fonte: Foto do autor.

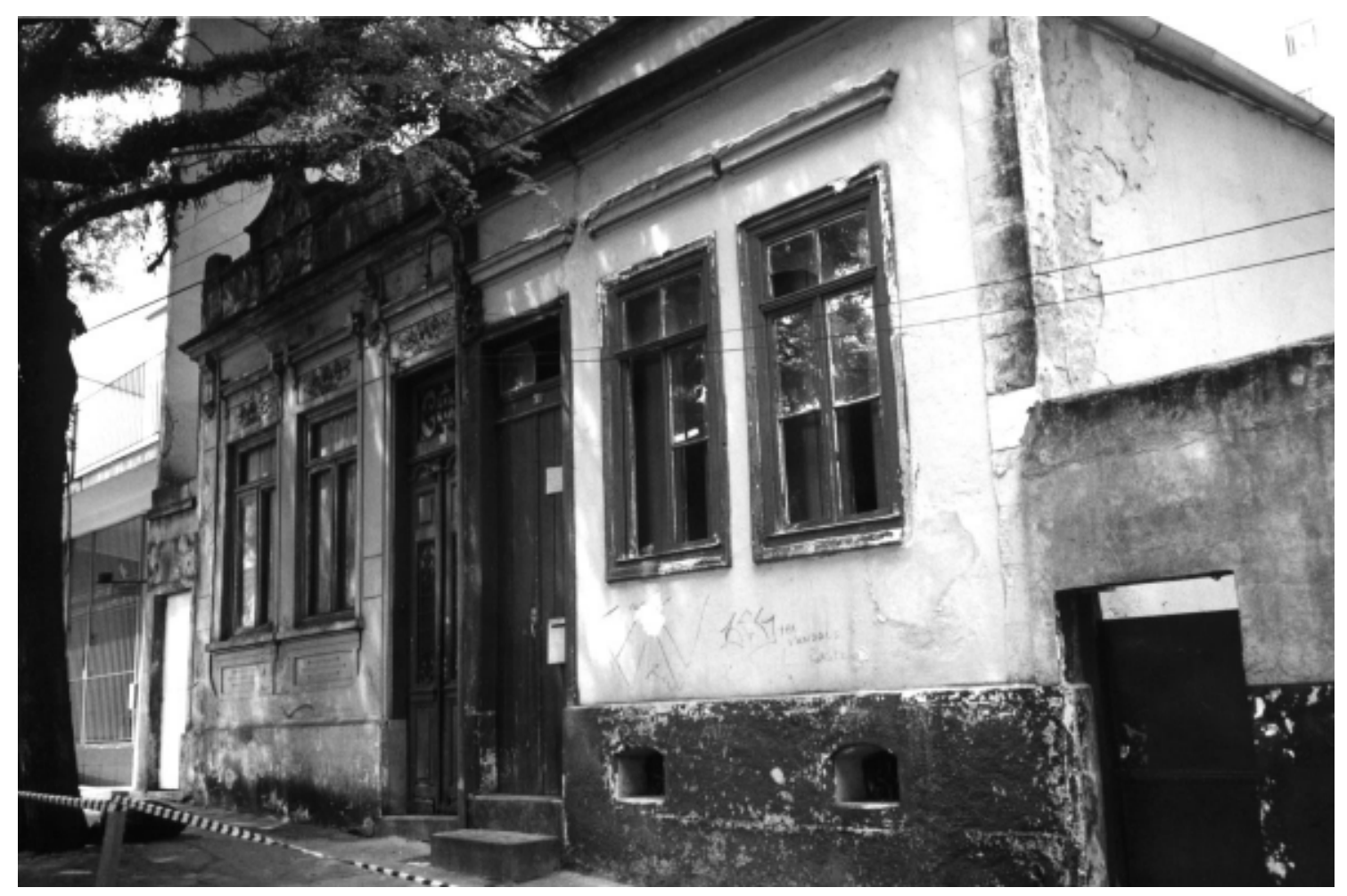

Figura 164 - Existem também diversos casos onde a entrada lateral possui uma porta no alinhamento do passeio, como nesta casa em Higienópolis.

Fonte: Foto do autor. 


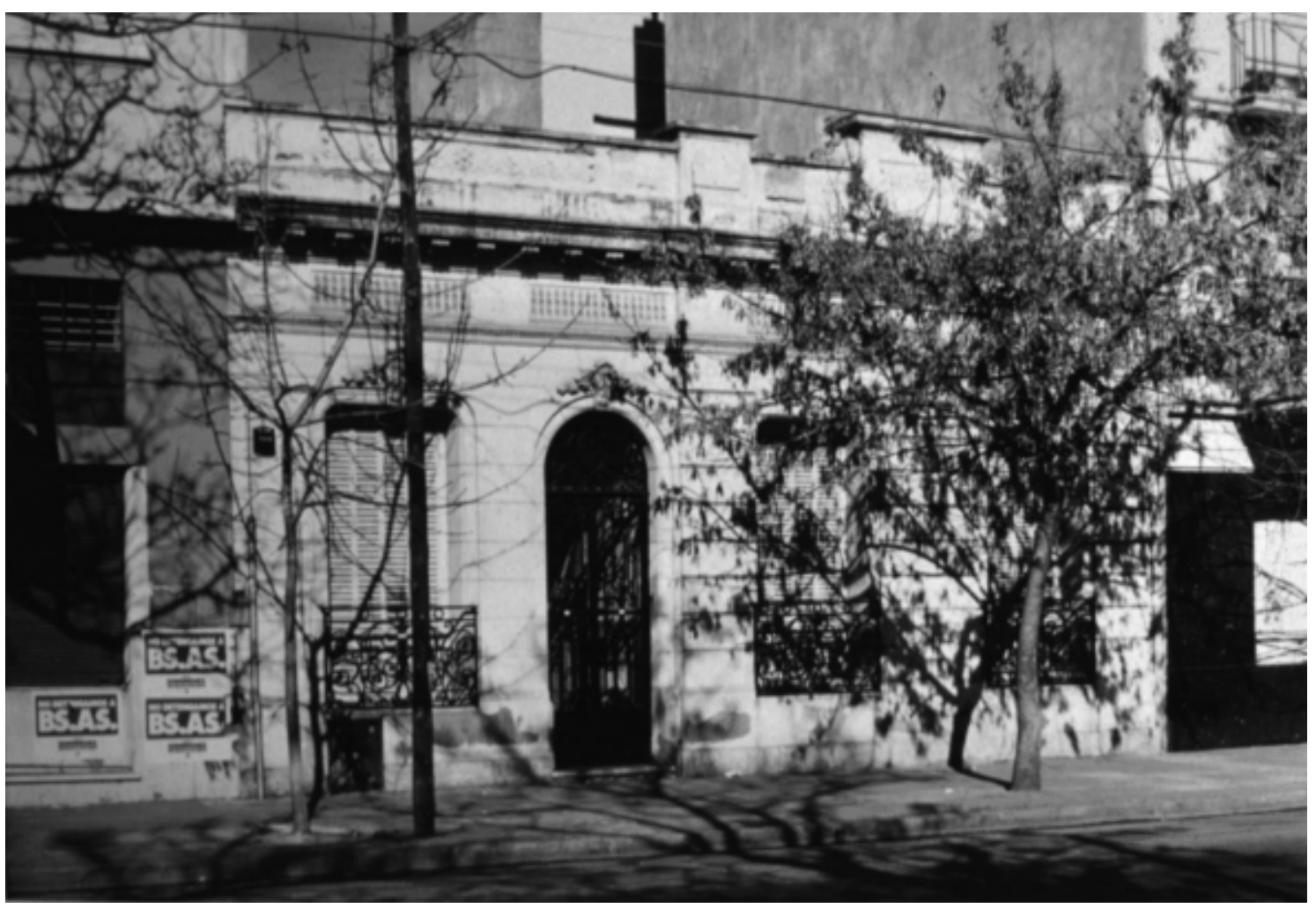

Figura 165 - No caso de Buenos Aires é recorrente a casa chorizo. Esta está situada no bairro de Abasto.

Fonte: Foto do autor.

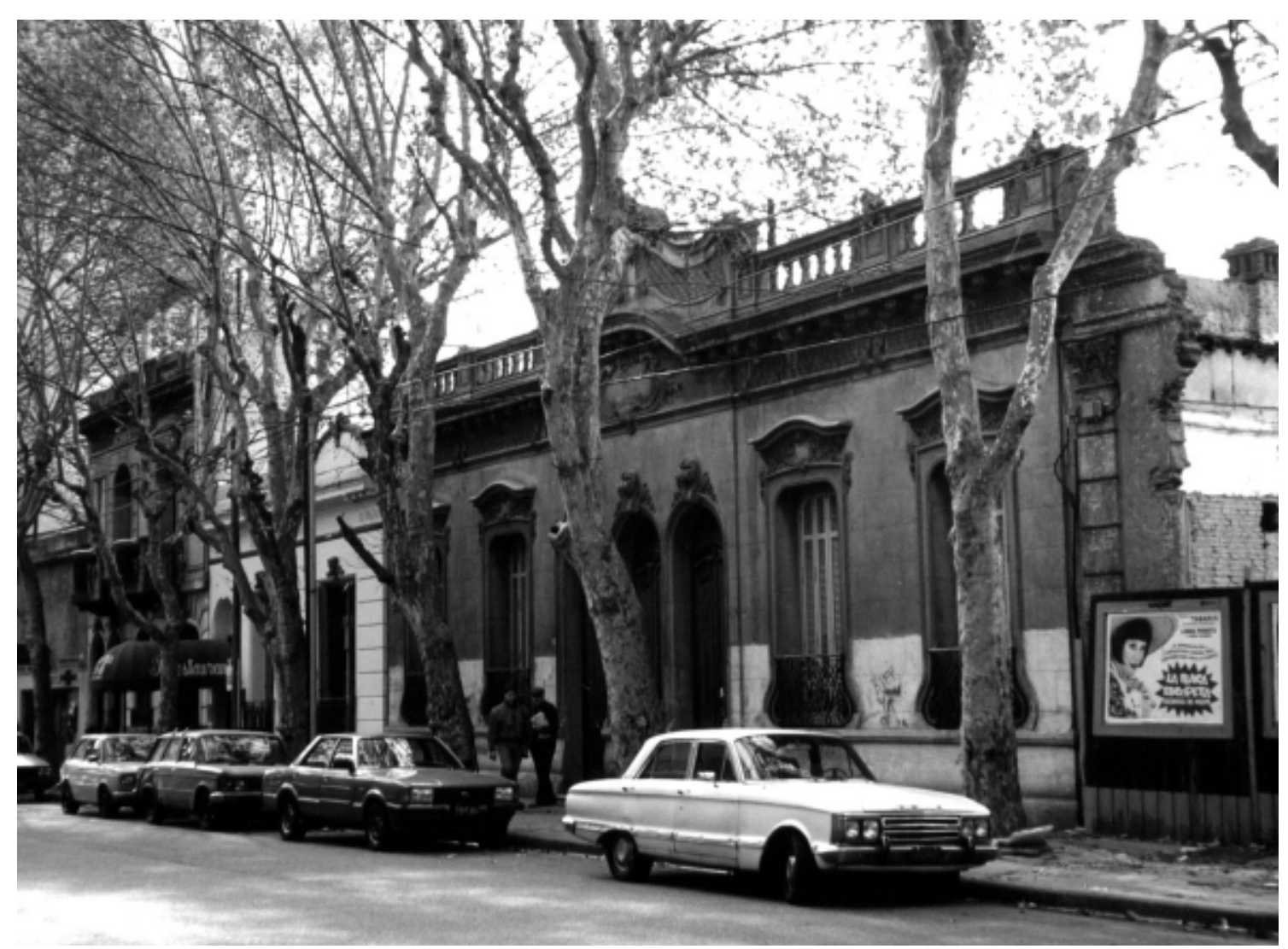

Figura 166 - Frequentemente as casas chorizo formavam um conjunto com mais de uma unidade, e também muitas vezes possuíam um certo refinamento nas fachadas. Bairro de Balvanera.

Fonte: Foto do autor. 


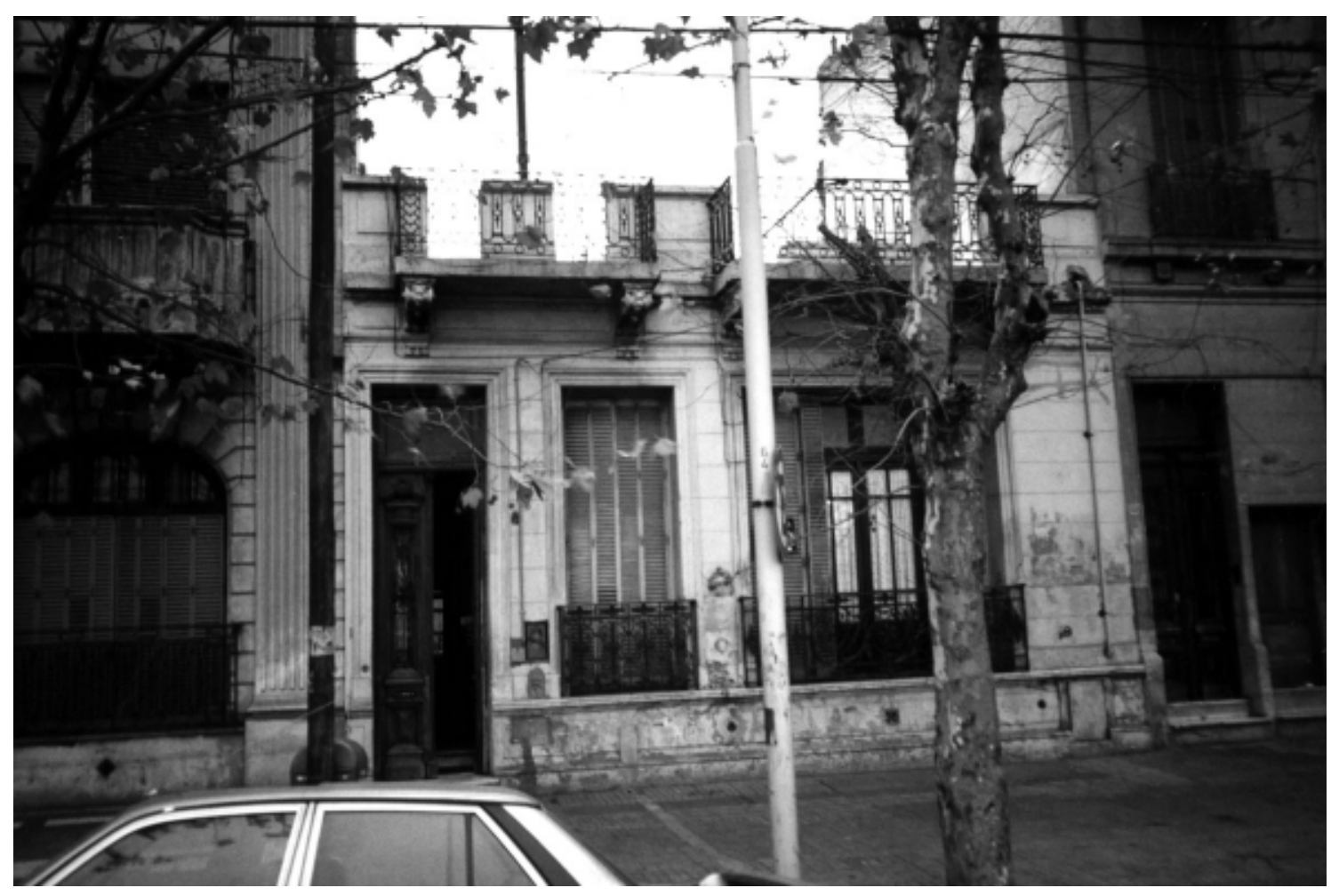

Figura 167 - Também encontramos em Buenos Aires casos de casas térreas onde um andar superior estava previsto, e nunca foi concluído, principalmente na região sul. Esta está localizada no bairro de La Boca.

Fonte: Foto do autor.

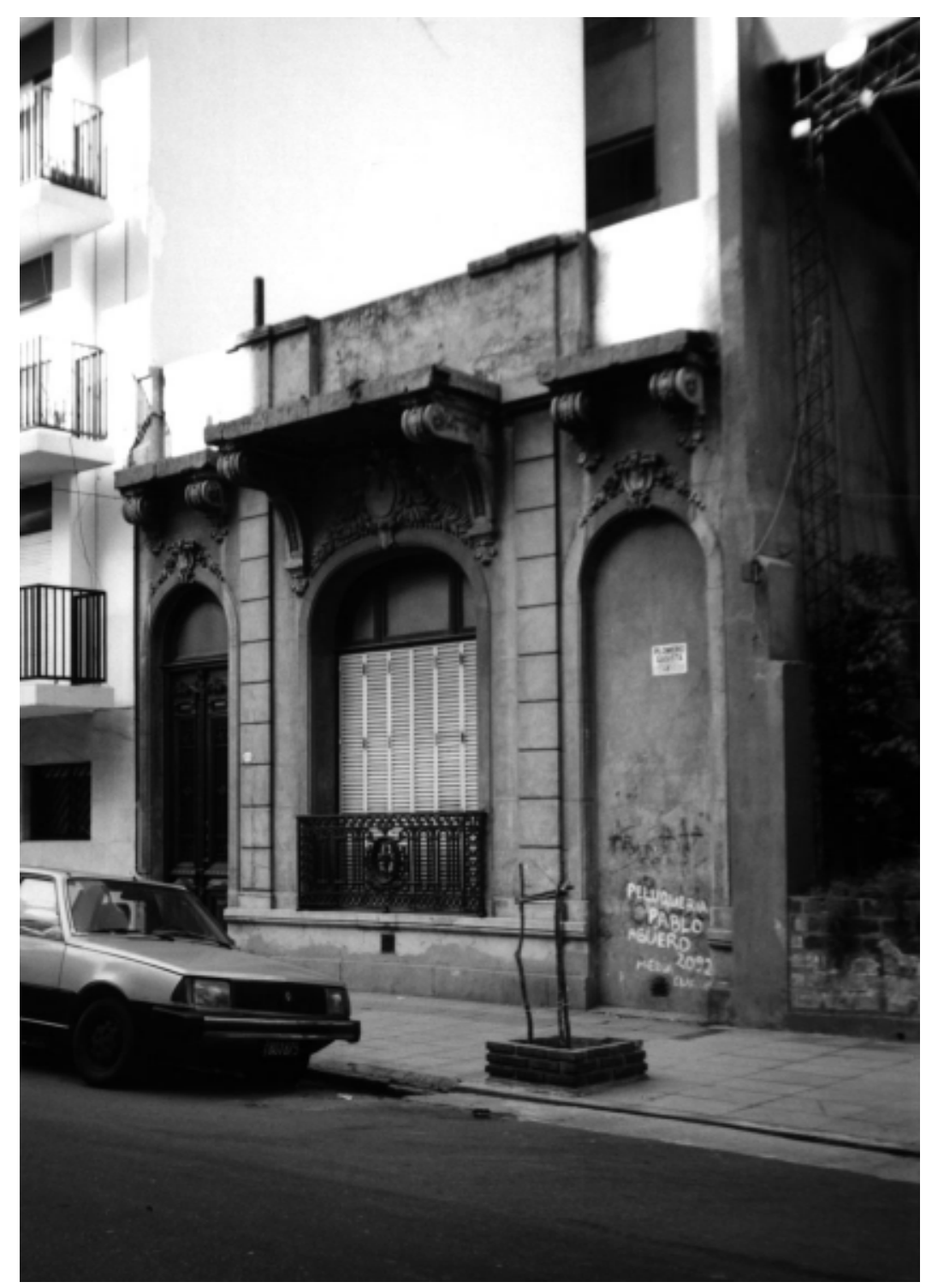

Figura 168 - No entanto, localizamos também exemplares na região norte, como esta residência em Palermo.

Fonte: Foto do autor. 


\section{5}

A partir do material levantado e de nossas observações in situ, vamos agora analisar o que as distingue e as assemelha. Podemos ver na figura 169 que a casa chorizo possui um pequeno espaço sob o solo, para permitir a ventilação do piso de madeira, enquanto as janelas têm um peitoril bastante baixo, permitindo a visão de quem passa pela rua. São ainda características as grades que protegem essas janelas. Já o nível do piso interno da casa paulistana está em geral mais distanciado do nível do passeio caracterizando, em muitos casos, um porão habitável, ajudado inclusive pelos desníveis do terreno. Isto obriga à existência de uma pequena escada de acesso (figura 170).

Outra diferença é que embora a entrada em ambos casos seja lateral, em Buenos Aires mantém-se sempre a fachada contínua entre os limites do lote, ao contrário da casa paulistana, onde esta em geral é recortada com um portão de acesso, muito embora existam também inúmeros exemplos de fachada contínua, como já mostramos.

Nas figuras 171 e 172 mostramos plantas destas casas, uma em São Paulo e outra em Buenos Aires. Podemos verificar ao compará-las que a forma de organização dos cômodos é semelhante: na frente, no alinhamento da rua, ficava a sala. Era a transição entre a casa e a rua, e em geral o cômodo menos usado no dia a dia, cabendo-Ihe o papel de causar boa impressão nas visitas que aí eram recebidas.

Após a sala estão localizados os quartos, em fila, cujo número podia variar, mas que em geral eram dois ou três. Na sequência está a sala de jantar, que servia de fato como sala no cotidiano, ligada por sua vez à cozinha, já como um anexo da casa. Por último aparece o banheiro.

Cabem aqui duas observações: em São Paulo o corredor lateral é mais estreito, servido quase que apenas para circulação. Em Buenos Aires podemos notar que após a entrada, o corredor de acesso se abre, passando a existir um pequeno pátio, utilizado também como estar, muitas vezes coberto por parreiras. E nos fundos há outro pátio, de serviço. Este esquema segue a forma de organização do espaço em torno de pátios, característica da arquitetura colonial hispano-americana. Em São Paulo esta hierarquização é menos clara, já que os espaços livres são o corredor lateral e o quintal nos fundos.

Outra constatação que podemos fazer refere-se à articulação entre arquitetura e urbanismo. Há indícios de que a forma de ocupação dos lotes apresenta diferenças. Já havia nos chamado a atenção uma colocação de Scobie, ${ }^{10}$ atentando para o fato de que era muito comum que as casas portenhas fossem construídas por partes: de início eram realizados os quartos, depois a área de serviço, e em torno de 15 anos após o início da construção a casa era completada com a construção da sala, no alinhamento da rua. Não temos notícias de processos semelhantes em São Paulo, e a observação de mapas da época nos indicam que essa forma de produção do espaço edificado pode efetivamente ter se dado de forma diferente. Na figura 173 encontramos em Buenos Aires bairros em formação com numerosas construções afastadas do alinhamento da rua, o que sugere a forma de ocupação acima

${ }^{10}$ SCOBIE, James R. Buenos Aires. Del centro a los barrios. 1870-1910. Buenos Aires, Solar/Hachette, 1977. 


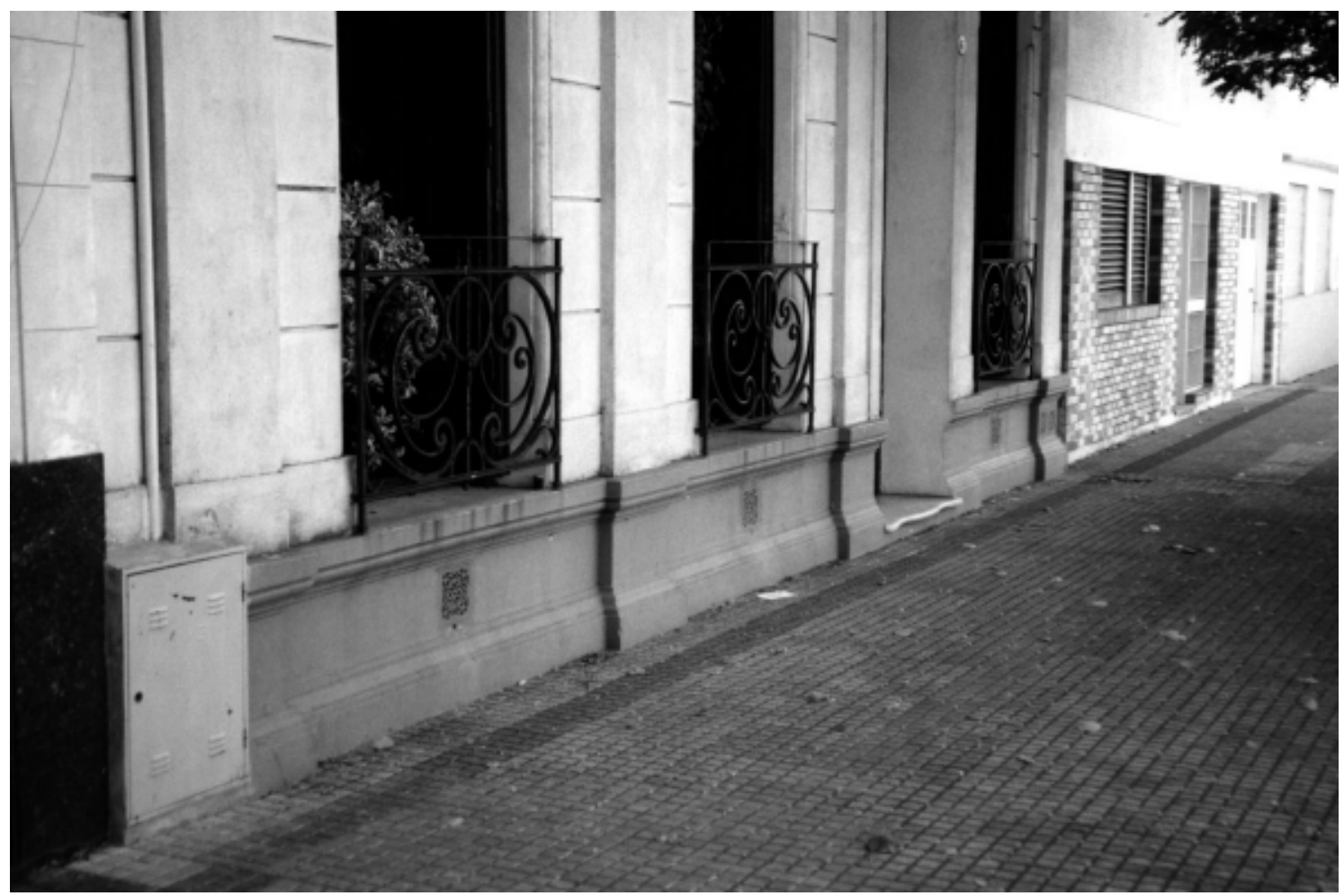

Figura 169 - Exemplo de casa em Buenos Aires, onde a pequena diferença de nível com o passeio permite apenas a ventilação do piso, como vemos nesta imagem.

Fonte: Foto do autor.

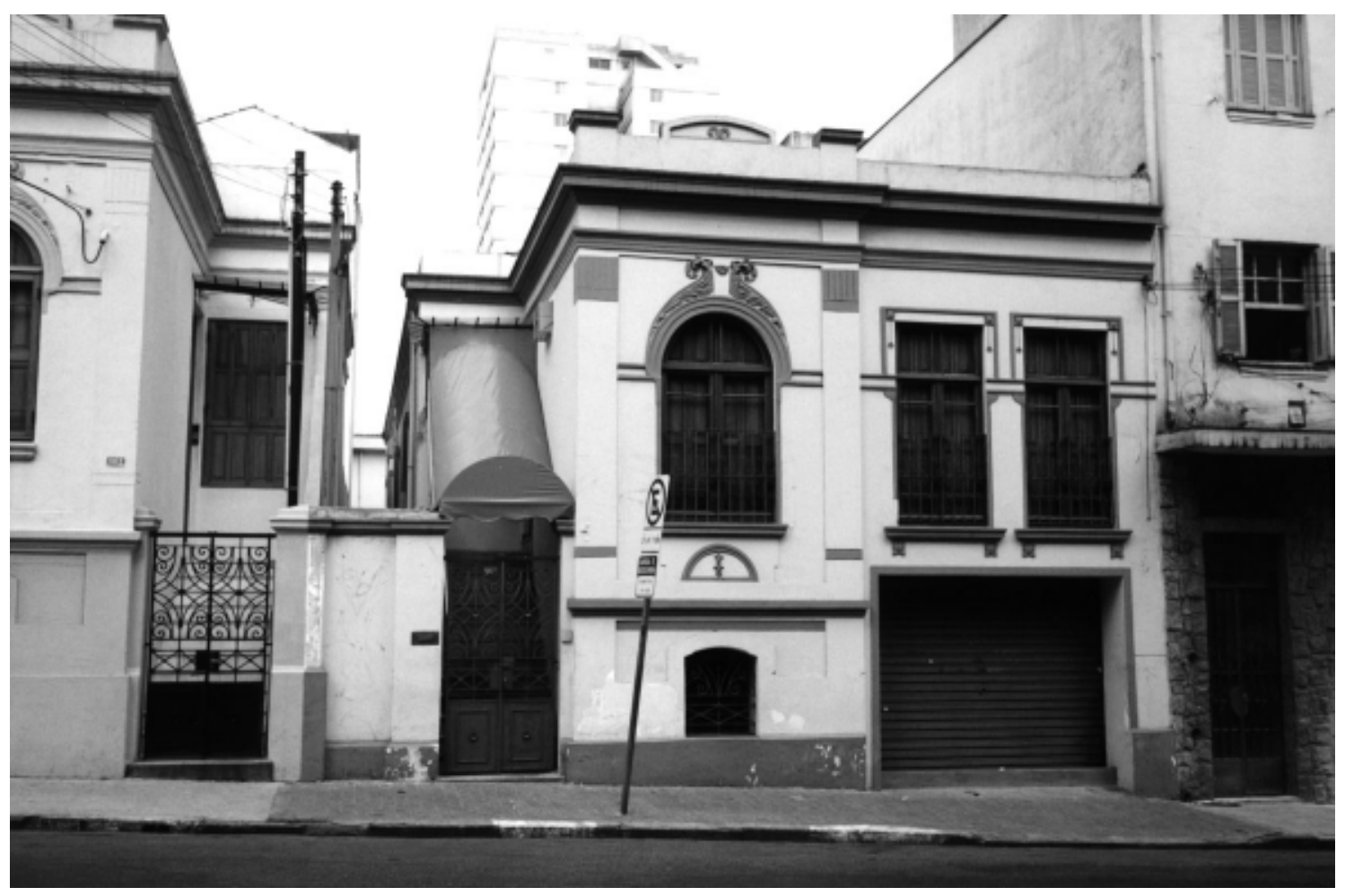

Figura 170 - Já em São Paulo, como o porão tem muitas vezes um pé direito razoável, é necessário uma escada de acesso, como observamos nestas duas residências.

Fonte: Foto do autor. 


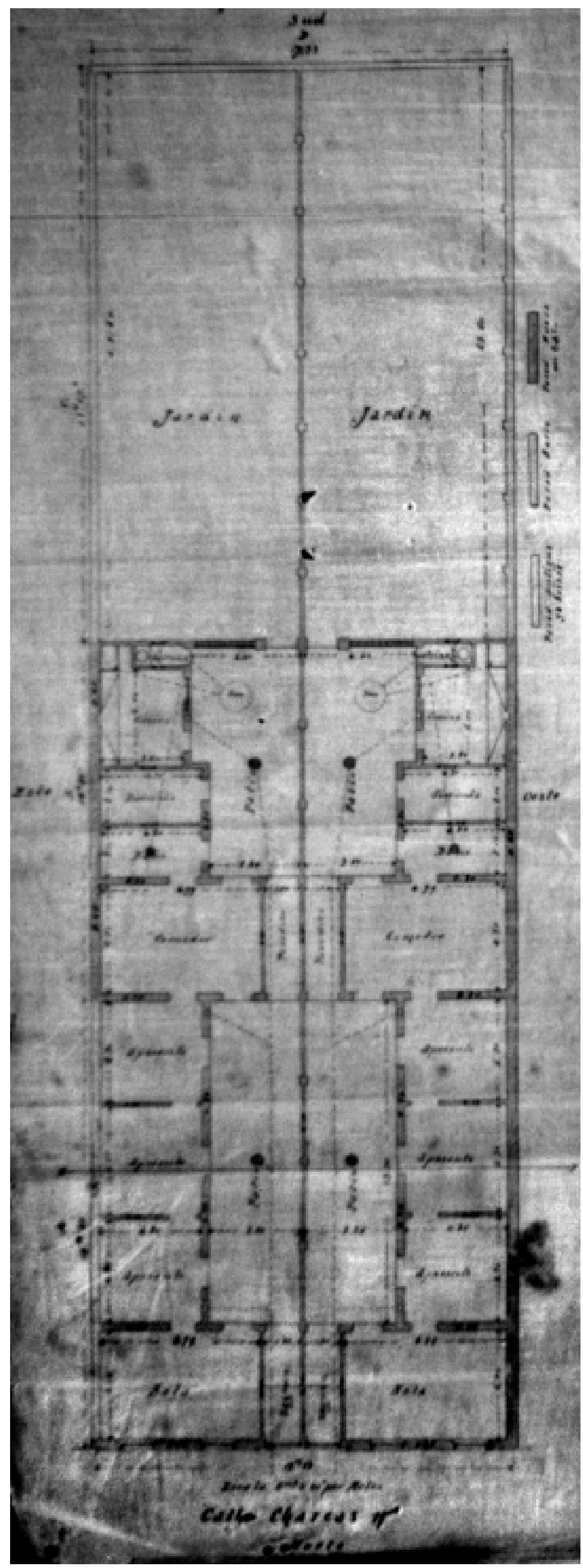

Figura 171 - Casas chorizo germinadas em Buenos Aires. O esquema de implantação é parecido com o encontrado em São Paulo: uma sala de visitas na frente, uma sucessão de quartos, uma sala de estar ligada à cozinha, e por último um banheiro, como anexo.

Fonte: Archivo Historico de la Ciudad de Buenos Aires. 

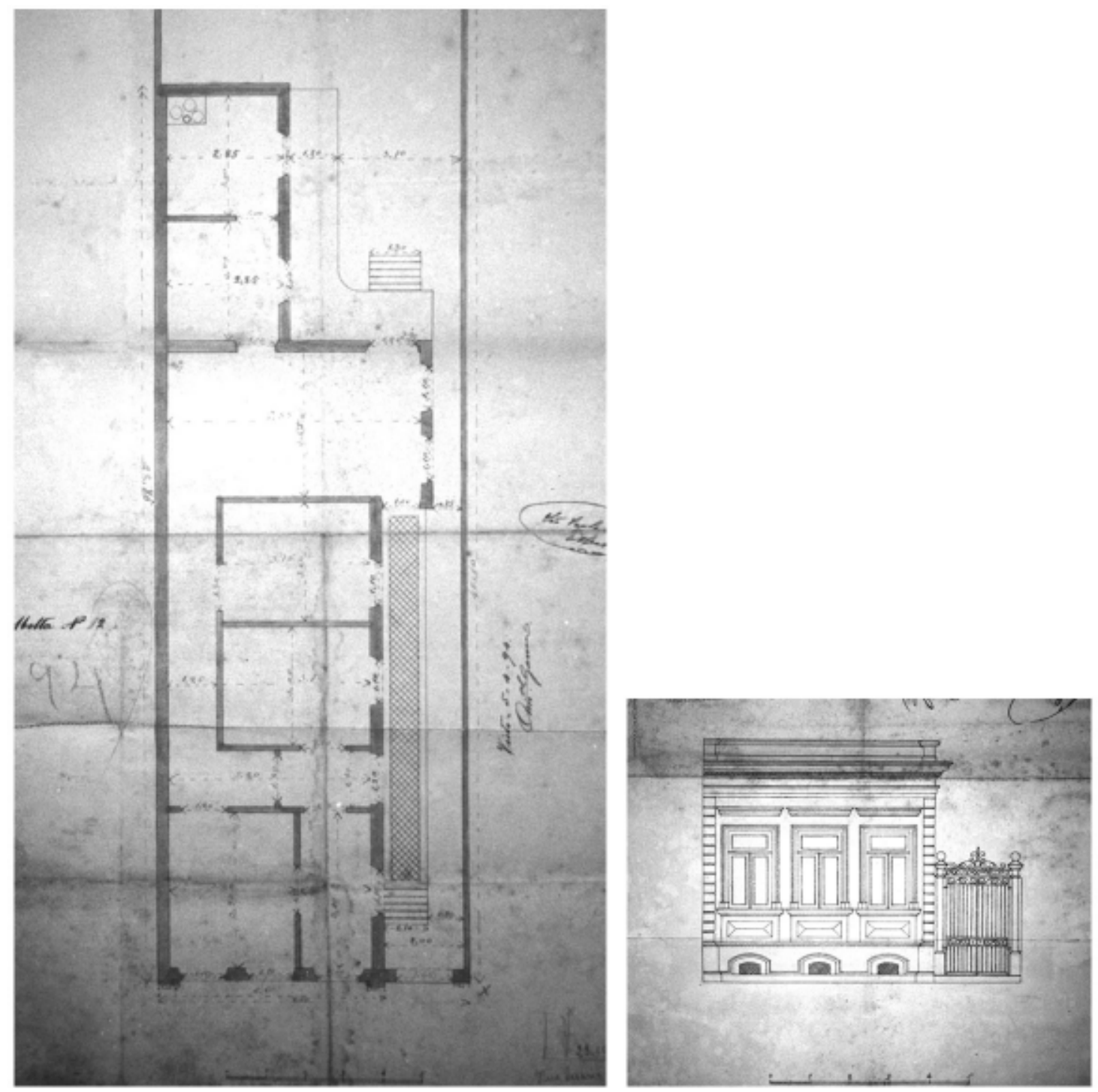

Figura 172 - Planta e fachada de projeto de 1894 de uma casa de porão alto e entrada lateral localizada na rua Cesário Motta No 2, Vila Buarque. Notar a semelhança com o esquema da casa chorizo portenha.

Fonte: Arquivo Municipal de São Paulo 


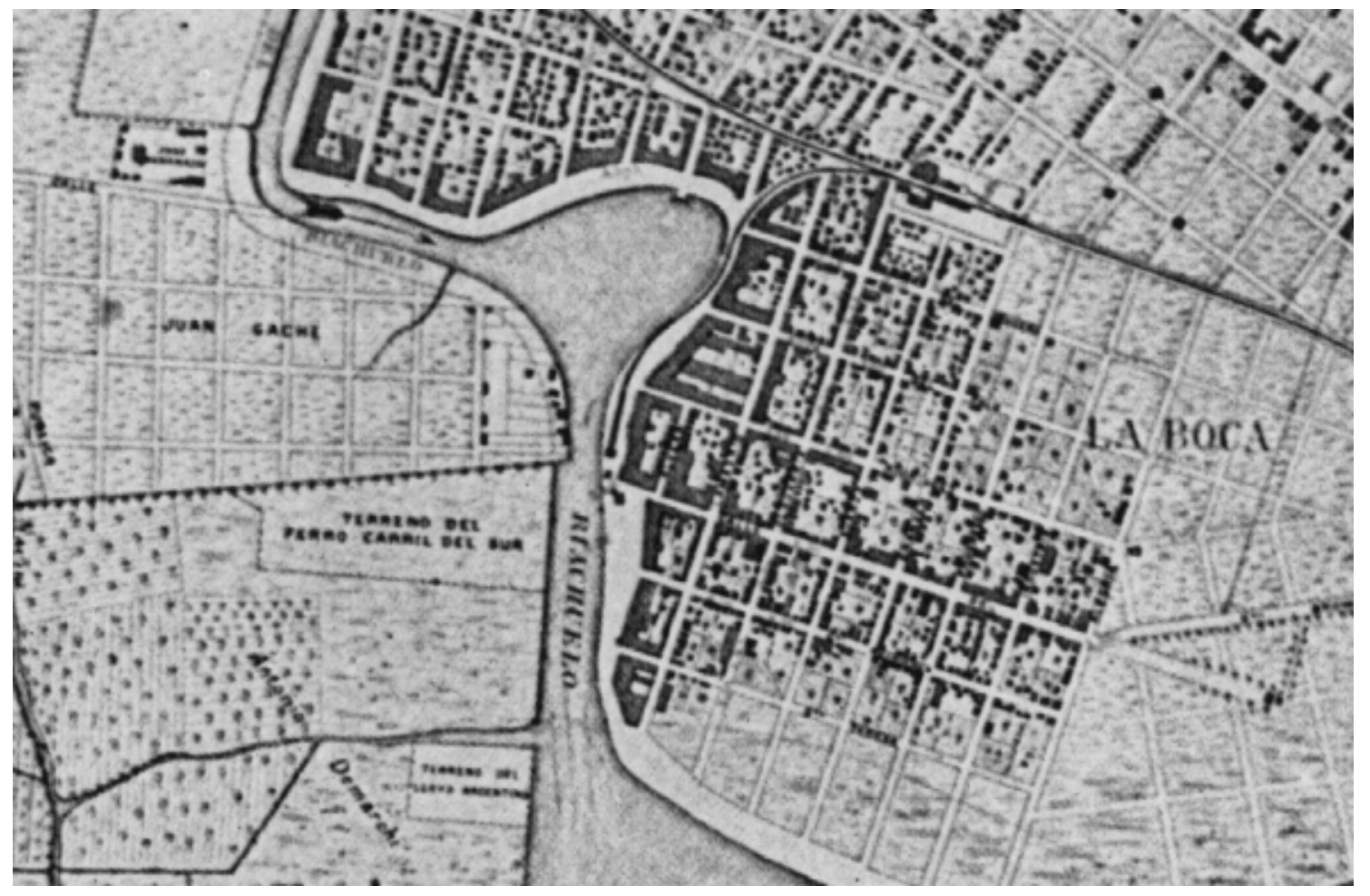

Figura 173 - Em Buenos Aires observamos muitas novas construções sendo implantadas a partir do interior dos terrenos. Mapa de Saint-Yves (1887).

Fonte: DIFRIERI, Horácio. 2v. Atlas de Buenos Aires. Buenos Aires, Municipalidad de Buenos Aires, 1981.

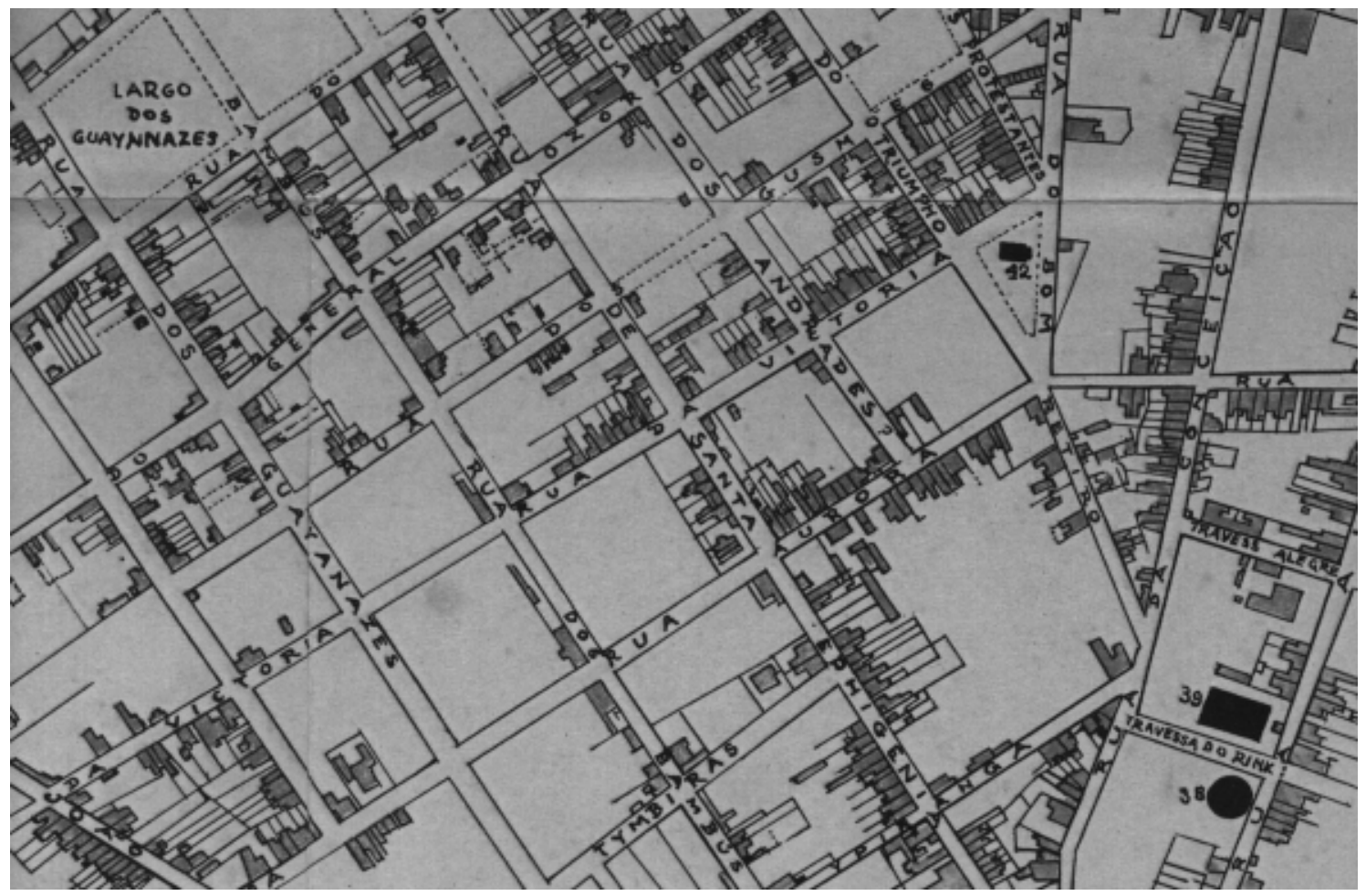

Figura 174 - Em São Paulo, ao contrário, observamos o predomínio da ocupação a partir dos limites do lote com a rua. Companhia Cantareira e Esgotos (1881).

Fonte: SÃO PAULO (CIDADE). São Paulo antigo: plantas da cidade. São Paulo, Comissão do IV Centenário, 1954. 
mencionada. Com base na figura 174 podemos verificar que aparentemente em São Paulo ocorre ao contrário, já que praticamente todas as construções marcadas estão alinhadas com o passeio.

Um outro aspecto interessante é quanto às transformações sofridas pela arquitetura e sua articulação com o espaço urbano. A antiga casa colonial térrea em São Paulo ganha altura em relação ao solo e aos poucos se solta das laterais, configurando uma "transição entre os velhos sobrados e as casas térreas". ${ }^{11}$ Ao mesmo tempo os beirais são eliminados e o telhado escondido atrás de uma platibanda (figura 175). Com isto se obtêm um padrão que permite estabelecer uma diferença com a arquitetura colonial, e ao mesmo tempo impedir a queda da água da chuva no passeio, o que vem ao encontro dos novos requisitos exigidos pela maior dinamização da vida urbana, acompanhada por diversas melhorias (calçamento, redes de esgotos e água, etc.) e introdução de inovações técnicas, como na iluminação pública, conferindo outra qualidade ao espaço da rua. Os materiais também mudam, com a utilização do tijolo no lugar da taipa.

Em Buenos Aires, porém, há enorme quantidade de construções que, em vez de telhado, apresentam terraços em sua parte superior. O censo de 1904 mostra a predominância das casas de "azotea" em Buenos Aires. Notar que de 1895 a 1904 estas diminuem proporcionalmente.

\begin{tabular}{|c||c|c|c|}
\hline \multicolumn{4}{|c|}{ Tipo de cobertura ${ }^{12}$} \\
\hline \hline Ano & Terraço (azotea) & Telha & Ferro/zinco \\
\hline \hline 1895 & 37.327 & 2.498 & 12.159 \\
\hline 1904 & 32.523 & 2.399 & 45.677 \\
\hline
\end{tabular}

Além disso, era muito frequente o uso de madeira e chapa nas construções, como ainda hoje se pode observar no conhecido bairro de La Boca (figuras 176 e 177). Existiam inclusive casos de moradores que construíam suas casas de madeira em terrenos alugados e quando precisavam mudar alugavam um lote próximo e se mudavam com a casa, que era transportada apoiada em roletes ${ }^{13}$. 0 terreno plano evidentemente ajudava nesta operação.

As soluções encontradas com o objetivo de aumentar a área construída também foram diferentes: em São Paulo ocorre um aumento da taxa de ocupação do terreno e o uso do porão, solução muito comum nos cortiços. Em Buenos Aires, ao contrário, o fato de existirem terraços permitiu a construção de ampliações de madeira e chapa nas coberturas (figuras 178 e 179). ${ }^{14}$ Analisando diversas fotografias antigas de São Paulo não encontramos situação semelhante, apenas algumas tentativas de aproveitar o espaço superior, mas sem a importância que isto teve em Buenos Aires (figura 180). Aliás, encontramos raríssimos casos de terraços, como o que podemos

\footnotetext{
${ }^{11}$ REIS FILHO, Nestor Goulart. Op. cit., p. 40.

12 BUENOS AIRES (Cidade). Censo de la capital Federal. 1904.

${ }^{13}$ LIERNUR, Jorge F. Op. cit.

${ }^{14}$ Idem.
} 


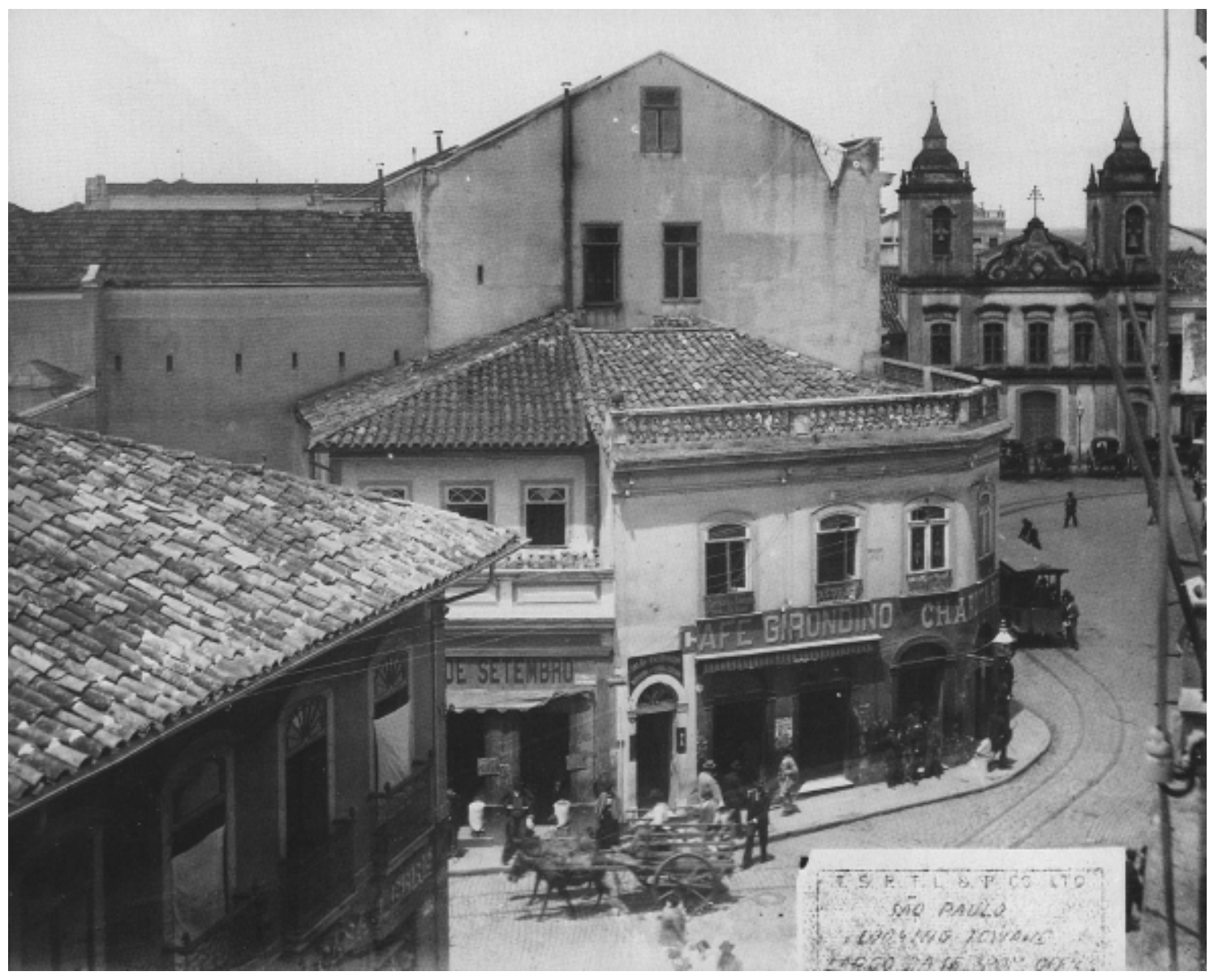

Figura 175 - Em São Paulo o beiral aos poucos é eliminado e cede lugar à platibanda. O esquema da cobertura no entanto permanece o mesmo.

Fonte: ELETROPAULO. A Cidade da Light. 1899/1930. São Paulo, DPH/Eletropaulo, 1990 


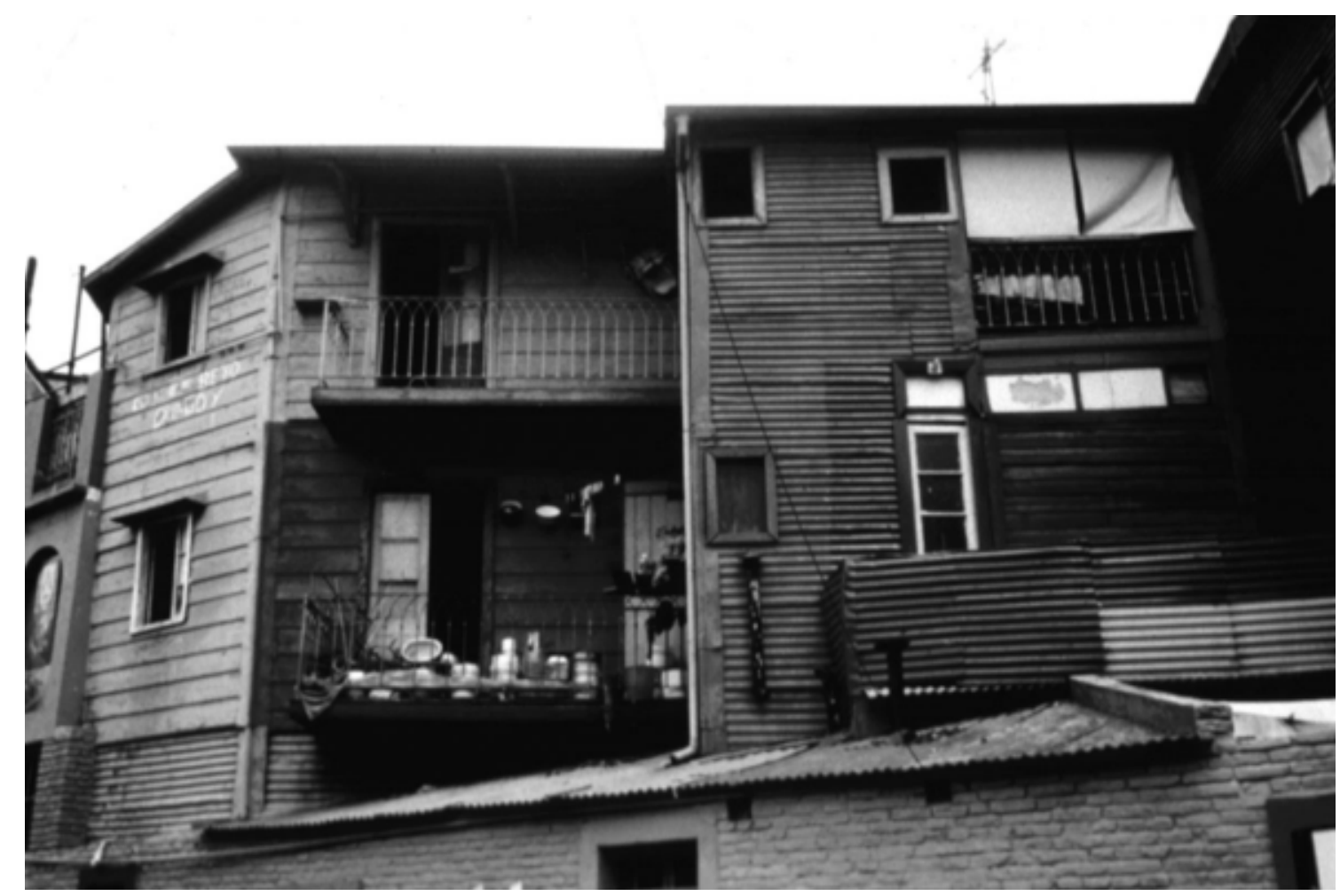

Figura 176 - O bairro de La Boca, em Buenos Aires, é conhecido pelas construções de madeira com fechamentos em chapa.

Fonte: Foto do autor

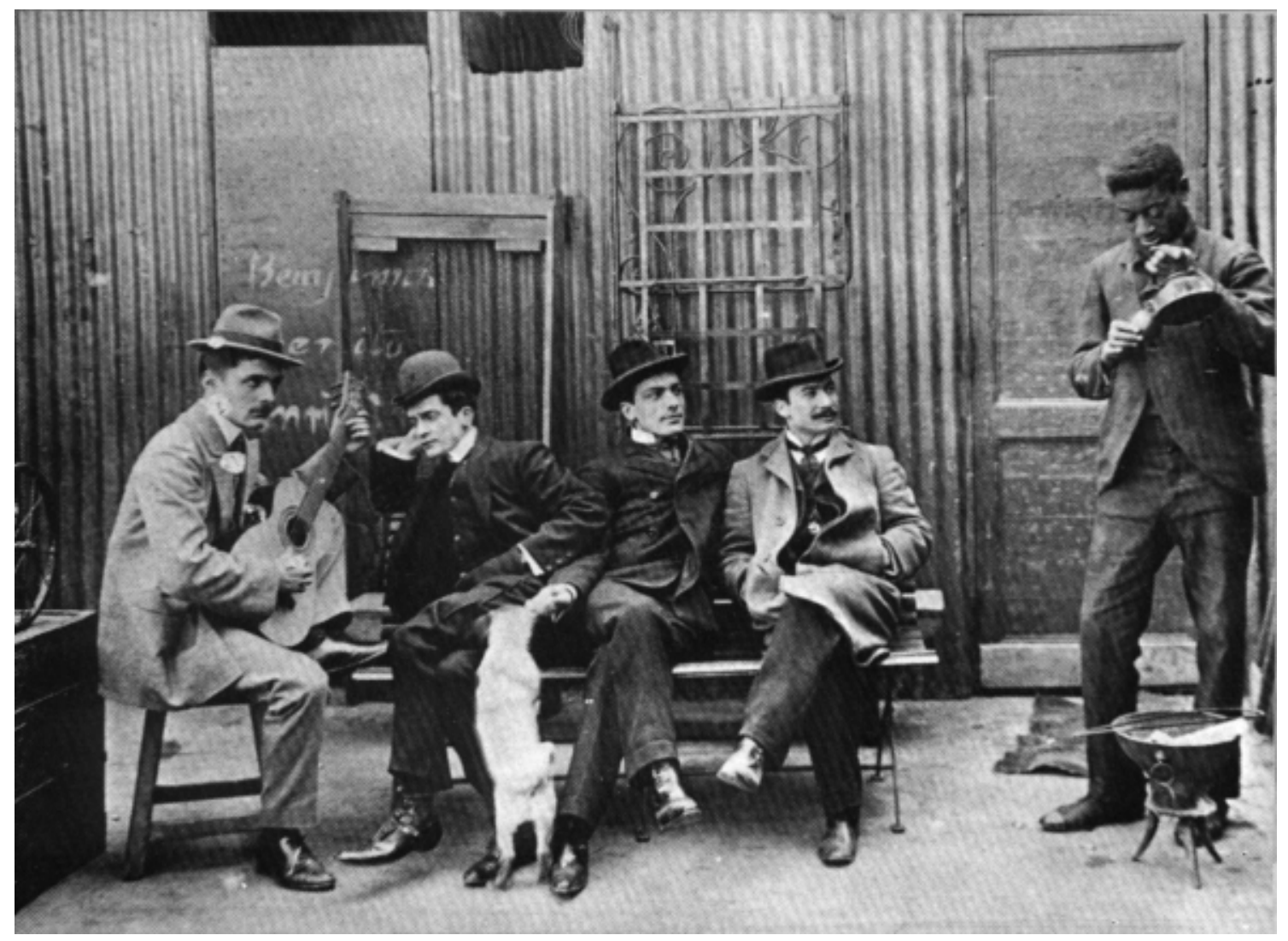

Figura 177 - Cena da boemia em Buenos Aires. Notar o ambiente construído com chapas metálicas.

Fonte: MOLINARI, Ricardo Luis. Buenos Aires 4 Siglos. Buenos Aires, TEA, 1980. 


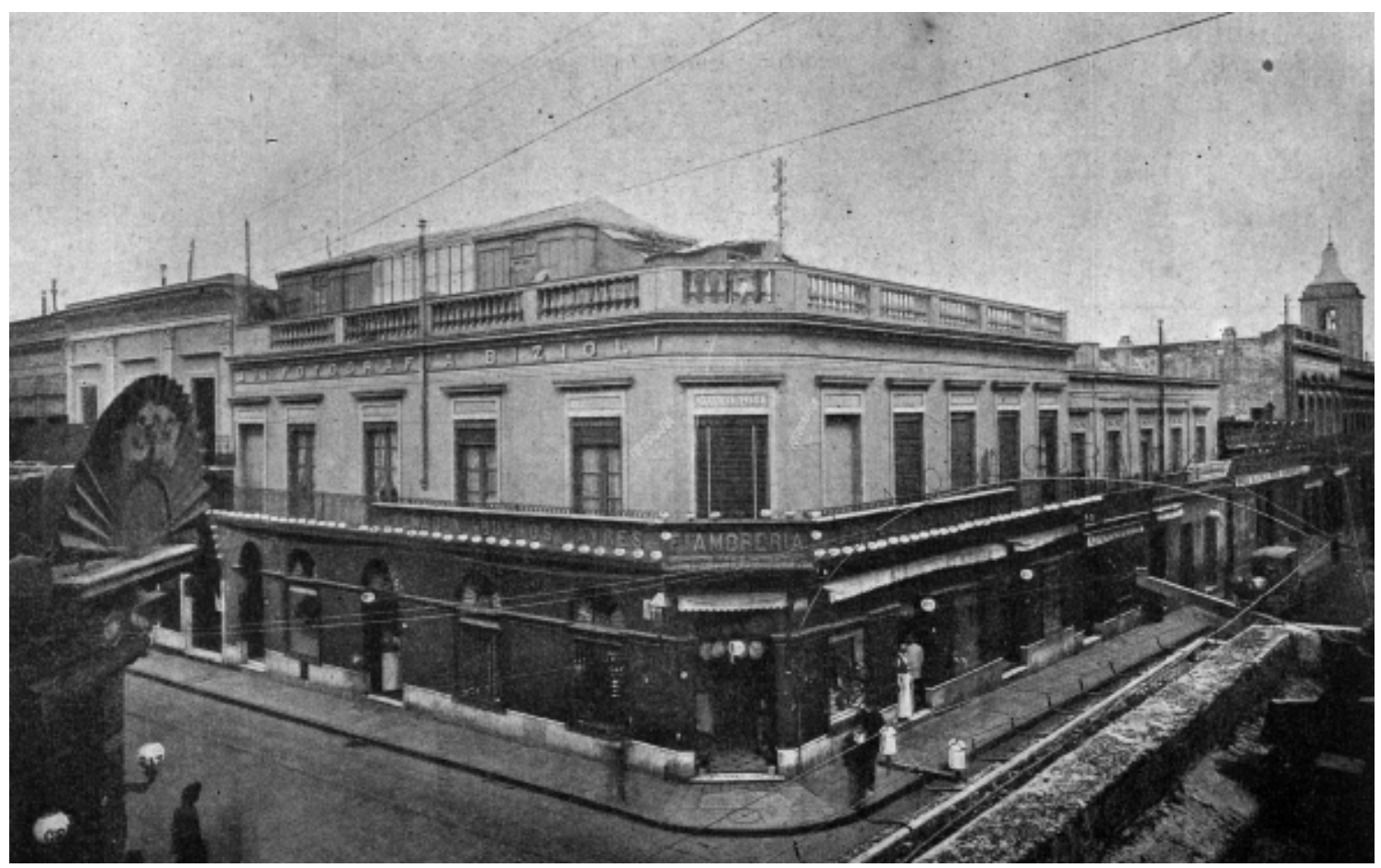

Figura 178 - Uma das formas usuais de adensamento em Buenos Aires foi a ocupação dos terraços com estruturas de madeira e chapa.

Fonte: COMITATO DELLA CAMERA ITALIANA DI COMMERCIO ED ARTI. Gli italiani nella Repubblica Argentina. Buenos Aires, Compañia Sud-Americana de Billetes de Banco, 1898

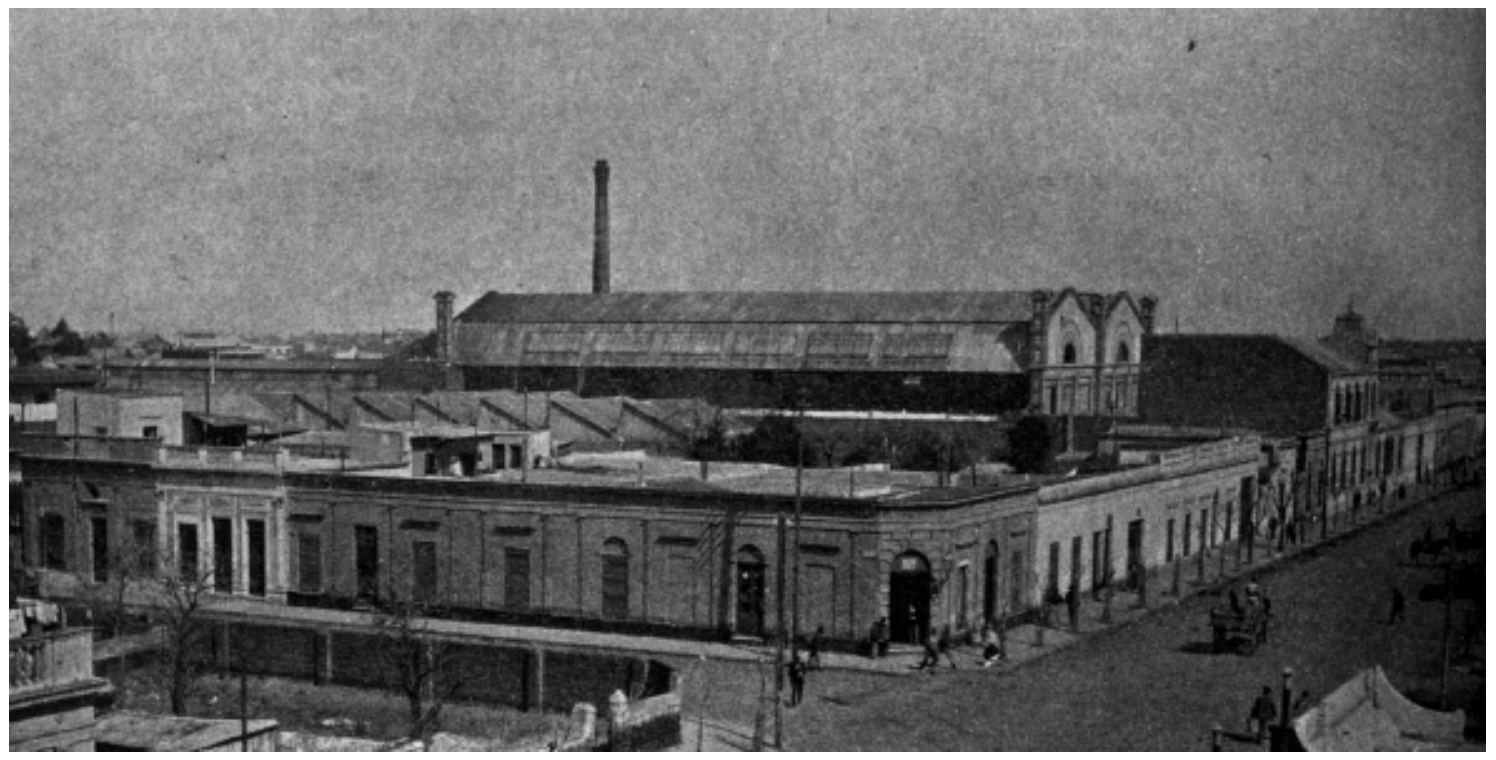

Figura 179 - Temos aqui outro exemplo de lajes de cobertura sendo ocupadas.

Fonte: COMITATO DELLA CAMERA ITALIANA DI COMMERCIO ED ARTI. Gli italiani nella Repubblica Argentina. Buenos Aires, Compañia Sud-Americana de Billetes de Banco, 1898 


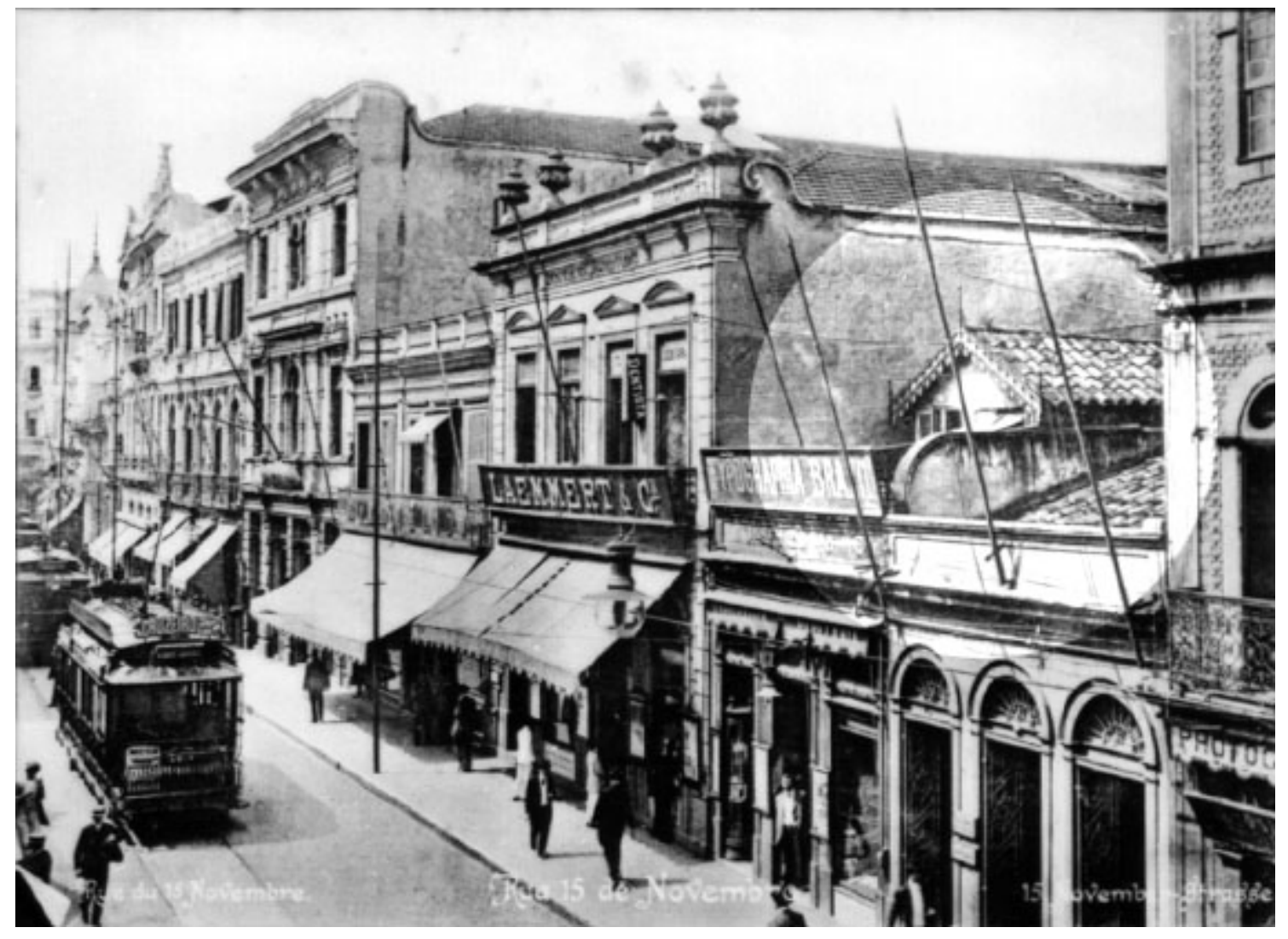

Figura 180 - Em São Paulo são muito raros os casos de ocupação da cobertura, como o que vemos aqui. Predominava sempre o telhado de duas ou mais águas.

Fonte: Biblioteca Municipal Mário de Andrade (Acervo LAP)

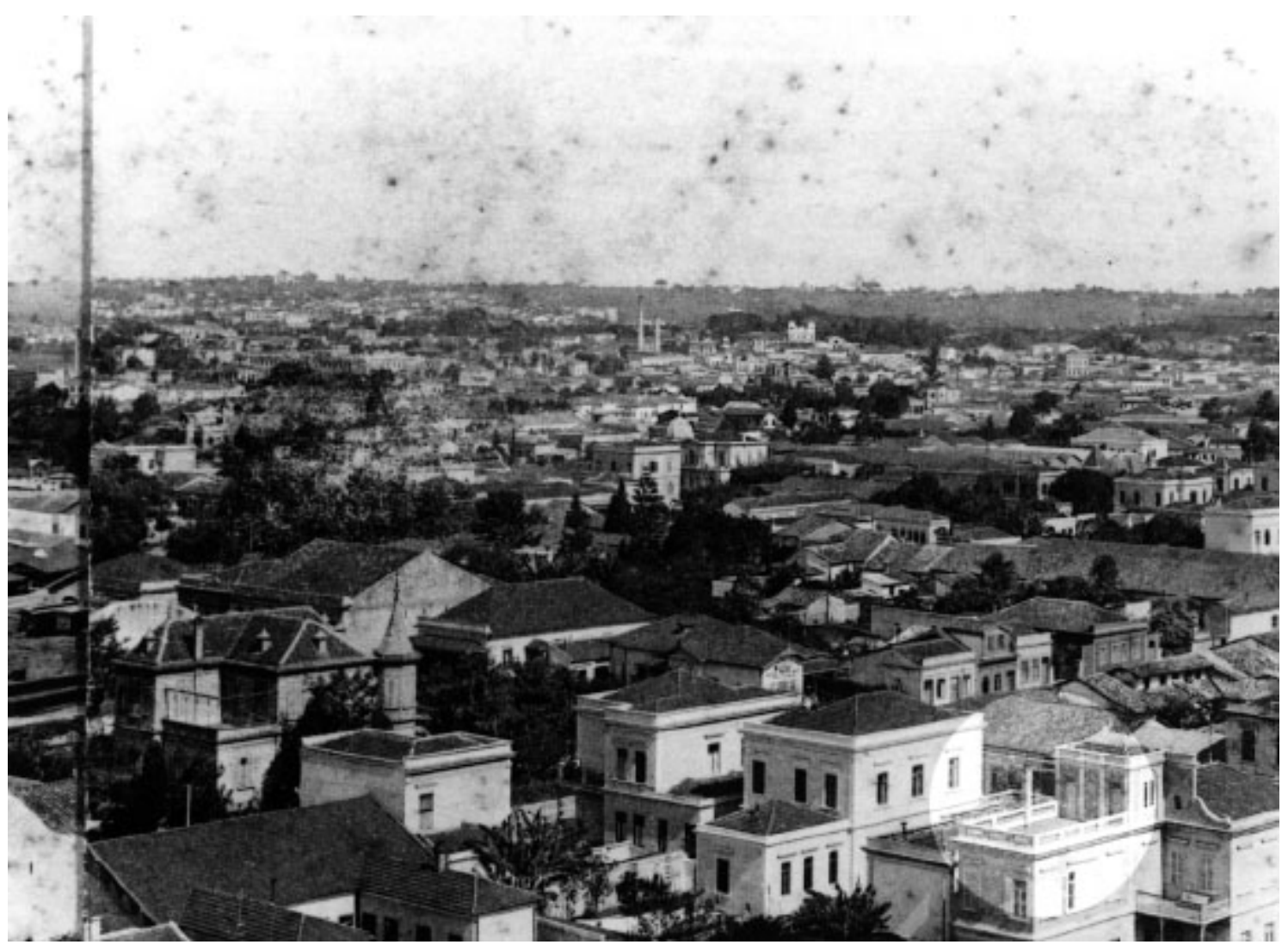

Figura 181 - No canto inferior direito mostramos um dos raros casos de utilização de terraços em São Paulo na época.

Fonte: Biblioteca Nacional do Rio de Janeiro (Acervo LAP) 
ver na figura 181. Estes em geral eram encontrados em residências de pessoas com algum poder aquisitivo, nas quais em muitos casos também eram usadas como área de serviço. Recebiam o nome de açoiteias, semelhante à designação dada em espanhol, azotea.

É interessante notar, entretanto, que antigamente existiram em São Paulo determinadas casas onde se procurava resolver o problema do espaço com a construção de uma espécie de sótão, que em geral servia de depósito, cujo rebatimento na fachada é a existência de pequenas janelas. Não chegavam, entretanto, a configurar um sobrado, embora fossem mais altos que as residências térreas. Exemplares existiram na cidade de São Paulo e chegaram a ser registradas por Militão Augusto de Azevedo, ${ }^{15}$ mas atualmente um dos poucos lugares onde é possível encontrar construções com estas características é em Santana do Parnaíba (figura 182).

Trata-se de um procedimento que não teve continuidade. Entretanto, chama a atenção que também na Espanha encontram-se residências assim, como, por exemplo, as da figura 182, localizadas perto da cidade de Salamanca.

Nos dias de hoje, em São Paulo o antigo porão, mesmo com baixo pédireito, é usado cotidianamente como comércio em diversos lugares (figuras 183 e 184).

Por outro lado ainda hoje é muito usual na Grande Buenos Aires o uso de lajes como cobertura, ao invés de telhado, em geral aproveitadas para colocação de varal ou área de lazer. E é comum que construções novas sejam implantadas sem recuos laterais nos antigos lotes, resultando em uma arquitetura diferente da que é realizada atualmente aqui (figura 185). Já em São Paulo é usual a construção de uma edícula no fundo do lote, talvez reminiscência das antigas senzalas, como podemos observar em muitos projetos realizados ainda em nossos dias (figura 186). Não é comum esta forma de ocupação do lote em Buenos Aires.

\section{6}

Até aqui procuramos caracterizar as diferenças e semelhanças entre as chamadas casa de porão alto e casa chorizo, tipologia de residências ocupadas pelos setores de baixos e médios ingressos. Baseamos nossa análise em categorias de análise da organização do espaço intra-urbano como lote, implantação, fachada, quadra, sistema viário, estrutura, níveis e cobertura, enfocando os processos de transformação. Vamos agora testar a validade de possíveis hipóteses que poderiam explicar esta arquitetura e sua articulação com o urbanismo.

15 AZEVEDO, Militão Augusto de. Album comparativo da cidade de São Paulo/1862-1887. São Paulo, Prefeitura do Município de São Paulo/ Secretaria Municipal de Cultura, 1981. 

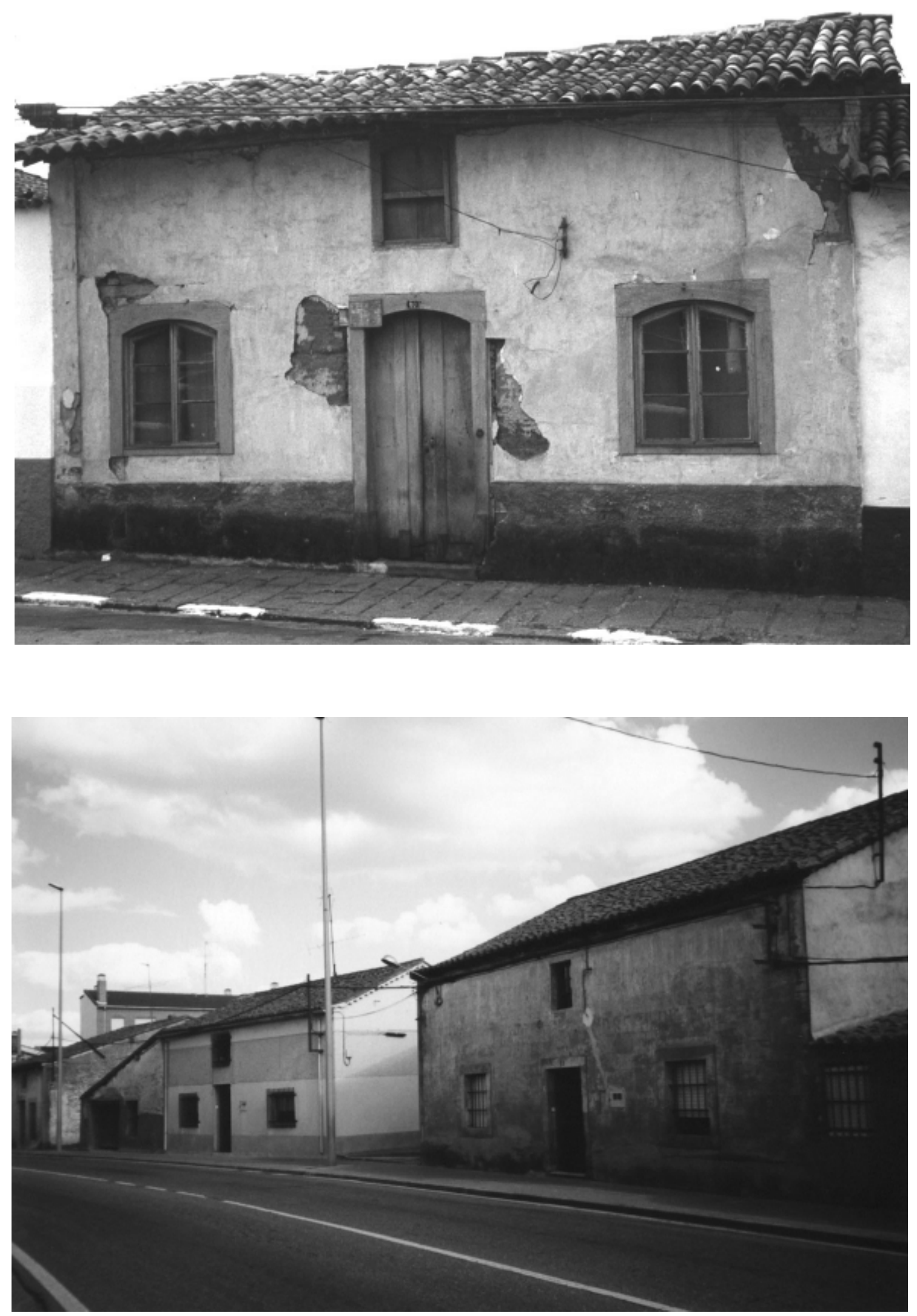

Figura 182 - Na foto superior temos uma casa em Santana de Parnaíba, localizada perto da cidade de São Paulo. Podemos observar que há uma janela logo acima da porta de entrada, que ventila e ilumina um sótão. A casa é mais alta que uma residência térrea, e mais baixa que um sobrado. Solução semelhante pode ser encontrada na Espanha, no caso da foto inferior em um povoado perto de Salamanca.

Fonte: Fotos do autor 


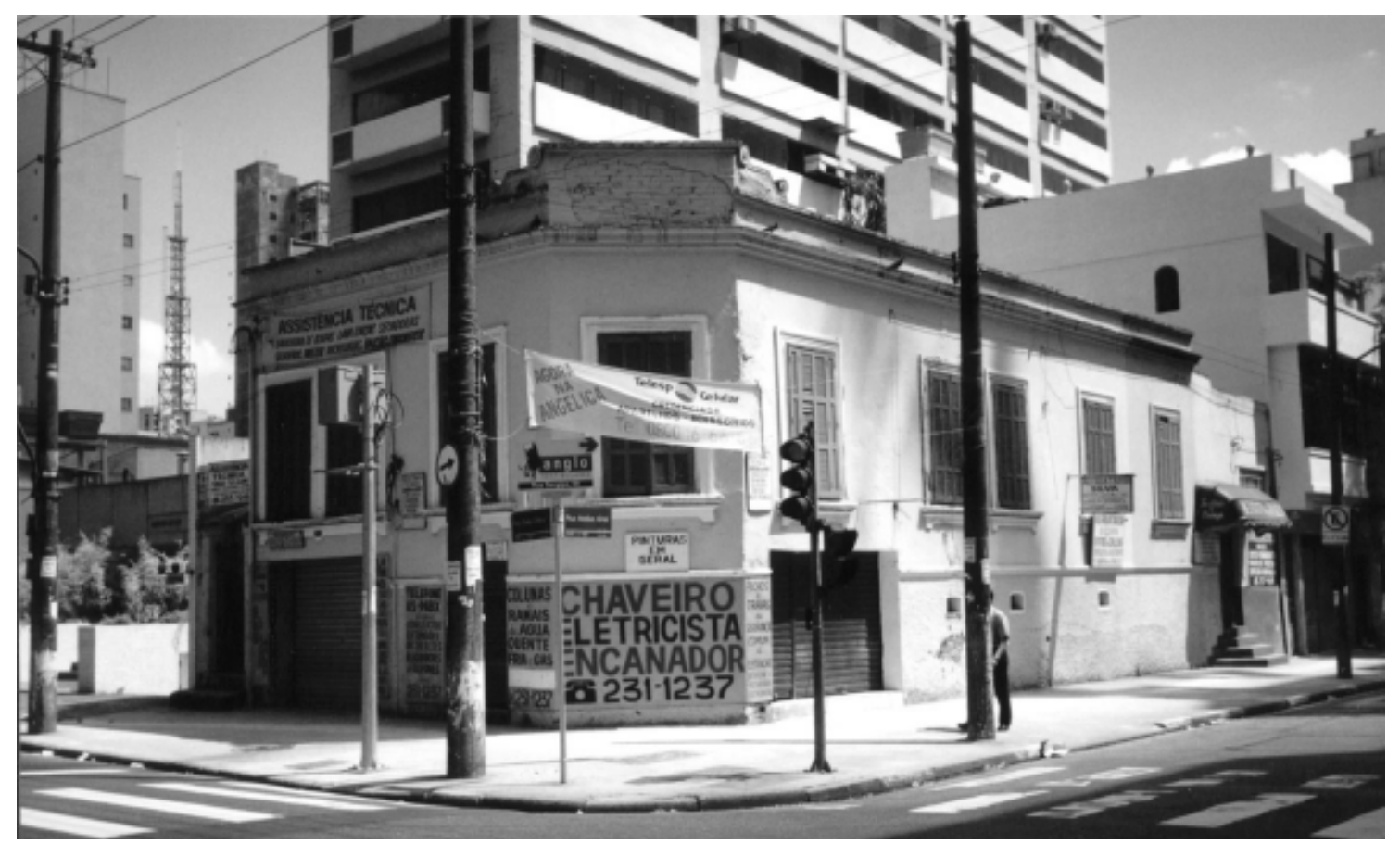

Figura 183 - Os antigos porões são hoje em dia muitas vezes utilizados para comércio, a despeito do seu baixo pé-direito. Esquina da rua Bela Cintra com Mathias Aires, na Bela Vista.

Fonte: Foto do autor

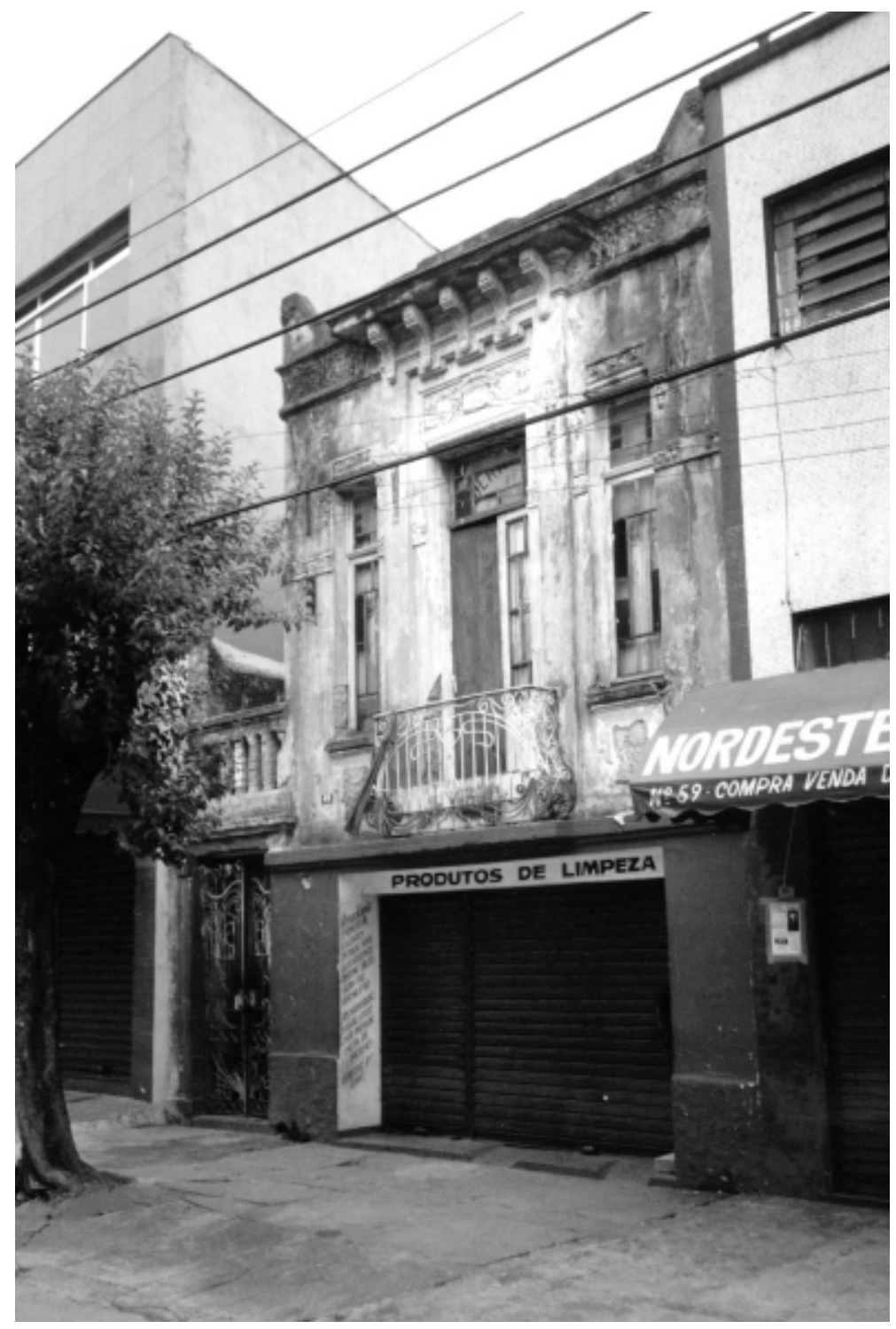

Figura 184 - Neste caso temos uma pequena loja de produtos de limpeza. Bairro do Pari.

Fonte: Foto do autor 


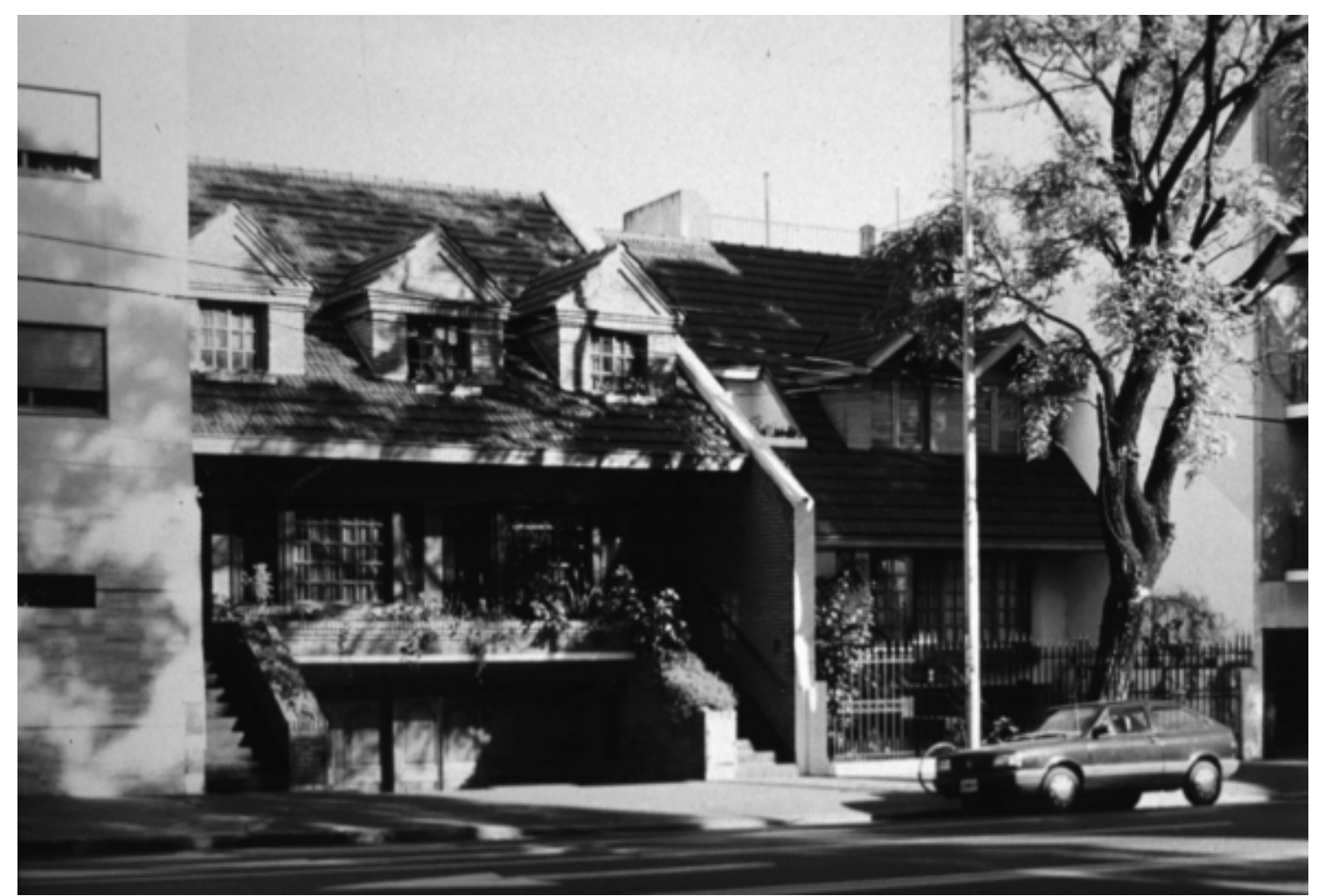

Figura 185 - É comum que as novas construções em Buenos Aires não possuam recuos laterais. Neste caso a passagem ao pátio do fundo se faz através da garagem.

Fonte: Foto do autor

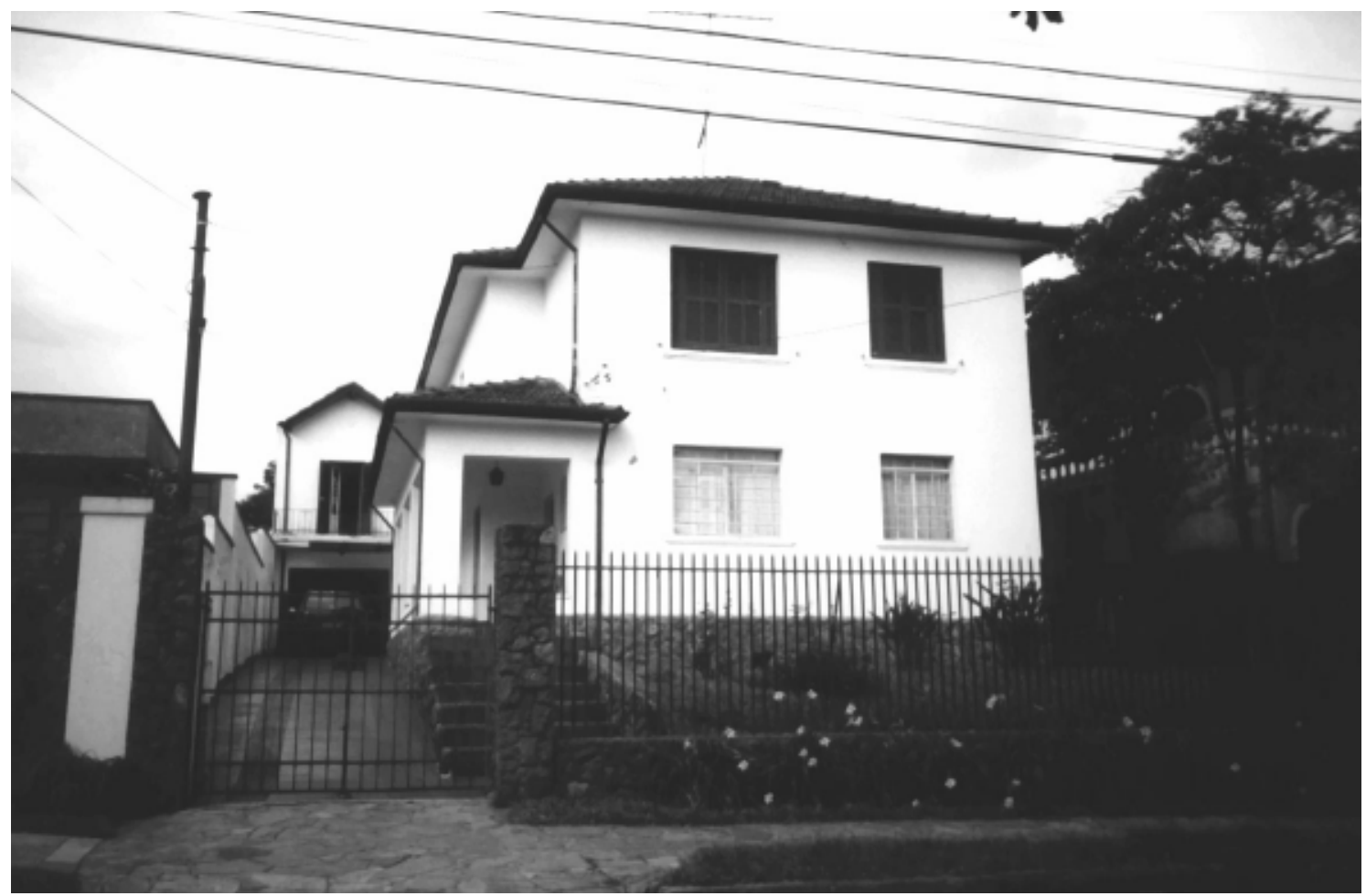

Figura 186 - Em São Paulo ainda hoje é usual um corredor lateral e uma edícula nos fundos. E até os anos 50/60 ainda se fazia lá a garagem, obrigando os carros a percorrerem um longo corredor de acesso.

Fonte: Foto do autor 


\section{$8.2-1^{\underline{a}}$ HIPÓTESE}

\section{Os imigrantes procuram reproduzir no país de destino seus hábitos culturais, construindo suas casas à semelhança das que habitavam no lugar de origem.}

Se levarmos em conta que os imigrantes provinham de muitas regiões da Europa, com hábitos culturais bastante diferentes, seria de esperar, por esta hipótese, também uma grande variedade de tipologias.

No entanto, vimos que as tipologias que estamos estudando apresentam grande regularidade, no sentido de que é possível encontrar, em cada cidade, exemplares semelhantes em diversos bairros.

Vejamos apenas o caso dos italianos, que são o grupo com maior participação no setor da construção em ambas cidades: os dados a seguir mostram a porcentagem sobre o total de imigrantes italianos de acordo com a região de origem:

\begin{tabular}{||c|c|}
\hline \multicolumn{2}{|c|}{ Buenos Aires (1876-1915) ${ }^{16}$} \\
\hline \hline Região de origem & Porcentagem sobre o total \\
\hline Vêneto e Friuli & 23,0 \\
\hline Piamonte & 11,0 \\
\hline Campania & 10,5 \\
\hline Sicília & 9,5 \\
\hline Lombardia & 9,5 \\
\hline
\end{tabular}

${ }^{16}$ NASCIMBENE, Mário C. História de los Italianos en la Argentina. 1835-1920. $2^{\mathrm{a}}$ ed. Buenos Aires, CEMLA, 1987. 


\begin{tabular}{|l|c|}
\hline \multicolumn{2}{|c|}{ São Paulo (1887-1920) ${ }^{17}$} \\
\hline \hline Região de origem & Porcentagem sobre o total \\
\hline Vêneto e Friuli & 29,4 \\
\hline Campânia & 13,2 \\
\hline Calabria & 10,5 \\
\hline Toscana & 6,5 \\
\hline
\end{tabular}

Comparando os dados verificamos que embora haja um pouco mais de grupos do sul da Itália em São Paulo, em ambas cidades o grupo majoritário é o mesmo: Vêneto e Fruli. No entanto, como já mostramos, há diferenças entre a casa de porão alto em São Paulo e a casa-chorizo em Buenos Aires, a despeito da grande participação de mestres-de-obra e arquitetos italianos. Se esta hipótese fosse tão determinante não deveriam existir as significativas diferenças verificadas entre ambas cidades.

Embora possam evidentemente existir elementos trazidos pelos imigrantes, os dados mostram que este fator não parece ter maior importância para explicar os processos de transformação da arquitetura, em especial quanto à relação entre lote e partido.

Ao estudarmos o caso da Espanha, origem de muitos imigrantes que vieram ao Brasil e Argentina, percebemos que há uma grande diferença na forma de ocupação da área urbana. Como já colocamos, foi tal o contingente de pessoas que emigraram daquele país, que as cidades pouco cresceram. E não observamos a formação de bairros de periferia com as características dos que aqui foram implantados.

Vimos que para a maioria das cidades espanholas foram realizados projetos de expansão chamados "ensanches". Mas, no chamado "extraradio", ou seja, além do "ensanche", começaram a surgir aglomerações marginais, com habitações de baixa qualidade e sem serviços. É o caso em Madri de La Guindalera, La Prosperidad, El Parral, etc.

Embora a preocupação pelas condições de vida dessa população marginalizada existisse, pouco foi feito. No Congresso Nacional de Arquitetos, realizado em Madri em 1881, este tema foi bastante discutido. Havia os que eram contra a construção de bairros para operários por considerar que eram focos de doenças e de agitação, sendo portanto preferível que estivessem junto às demais camadas sociais, mas em condições inferiores. Outros achavam que em bairros próprios estariam melhor.

\footnotetext{
${ }^{17}$ Estes dados foram obtidos a partir das informações extraídas da seguinte obra: TRENTO, Angelo. Do outro lado Atlântico. Tradução Mariarosária Fabris (capítulos 2 a 5), Eduardo Brandão (capítulos 1, 6 e 7). São Paulo, Nobel/ Istituto Italiano di Cultura di San Paolo/ Instituto Cultural Ítalo-Brasileiro, 1988.
} 
De qualquer maneira, devido à pouca capacidade de poupança da população e a pouca rentabilidade dos investimentos em casas populares, pouco se fez no período. A primeira "Ley de Casas Baratas", de 1911, que tinha como objetivo resolver este problema foi um fracasso. Em Sevilha, por exemplo, das 24 cooperativas formadas em 1911, não existia mais nenhuma em 1913. E somente em 1921 foi aprovada outra lei. Isto mostra que o fenômeno não assumiu proporções com a dinâmica do aqui produzido.

Verificamos também que na Espanha as tipologias apresentam grande variedade, sem a regularidade que observamos nas cidades que estudamos. É raro encontrar áreas onde haja conjuntos urbanos caracterizados pela repetência de formas de lote e implantação. Em geral, quando isto acontece, trata-se de um conjunto de algumas poucas casas.

Há exceções, como a que encontramos na cidade de Almería, no sul do país. De fato, podemos observar nas figuras 187 e 188 que há um parcelamento do solo com uma divisão em lotes semelhantes, de frente estreita e compridos. Como em nosso caso, também a implantação segue um esquema de cômodos em fila, de forma semelhante à que encontramos aqui. Deve-se notar, entretanto que as soluções de iluminação e ventilação são mais precárias já que os cômodos não têm janelas nem existe o corredor lateral aberto. O empreendimento é de 1887.

$\mathrm{Na}$ figura 189 vemos um conjunto com características urbanas semelhantes, na região do rio Besós, na cidade de Barcelona.

Estas conclusões sugerem que o fenômeno de parcelamento do solo em grandes loteamentos, e em lotes com formato semelhante, é uma característica específica do processo de urbanização das cidades de São Paulo e Buenos Aires. O mesmo parece ocorrer com as tipologias residenciais que estudamos, que também apresentam grande regularidade.

\title{
$8.3-2^{\underline{a}}$ HIPÓTESE
}

\begin{abstract}
As diferenças encontradas nas transformações sofridas pela arquitetura devem-se ao fato de estarem situadas em regiões que foram colônia de duas metrópoles diferentes: Portugal e Espanha.
\end{abstract}

Vimos que em São Paulo o piso interno é elevado em relação ao nível do passeio, e há uma ruptura no padrão de implantação. No entanto, persistem diversos elementos da arquitetura colonial como as coberturas que mantêm o esquema de estrutura de madeira com telhas de cerâmica, de duas ou mais águas. Já os beirais são progressivamente eliminados substituídos por platibandas. Este esquema se repete em diversas cidades brasileiras.

No caso de Buenos Aires destacamos anteriormente o uso freqüente de lajes planas, sistema que também pode ser observado em Montevidéu e em La Plata. Esta solução construtiva pode ser encontrada ao menos um século antes, como 


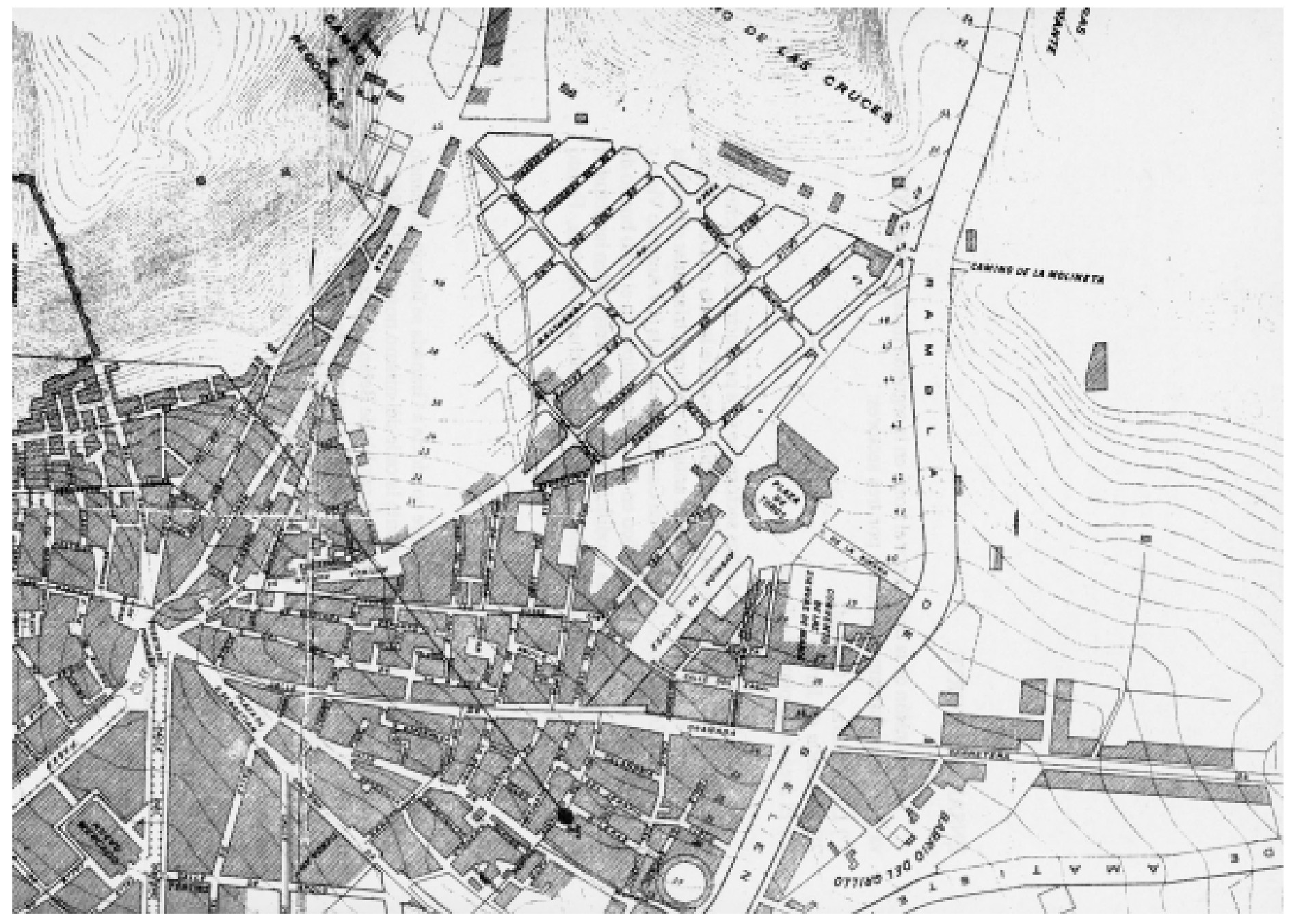

Figura 187 - Neste mapa da cidade de Almeria é possível notar na parte superior um conjunto urbano, cujo traçado se distingue do resto da cidade pela regularidade das quadras.

Fonte: VILLANUEVA MUÑOZ, Emilio Angel. Urbanismo y Arquitectura en la Almería Moderna (1780-1936). Almería, Cajal, 1983.

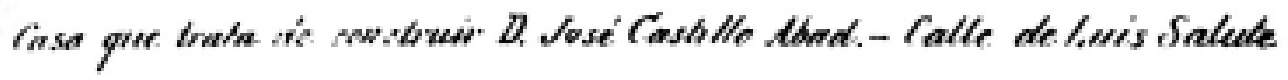

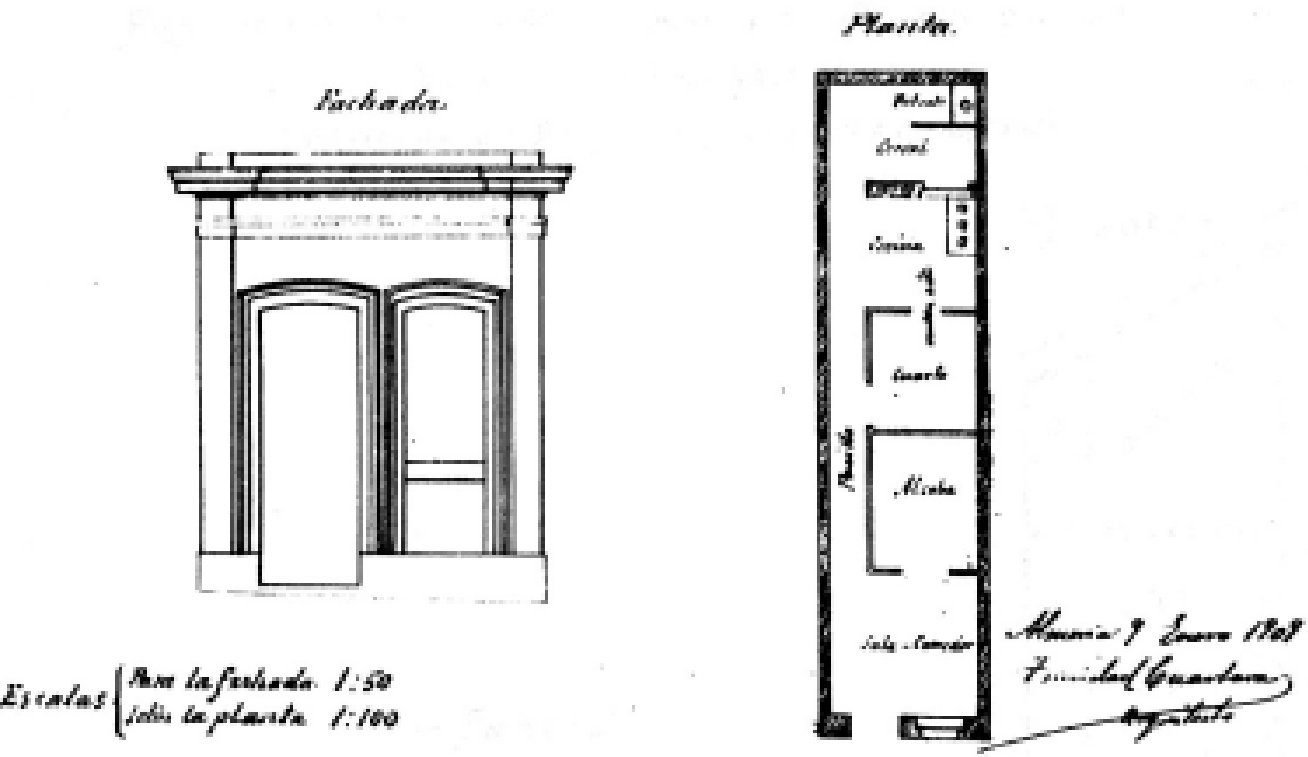

Figura 188 - Exemplo de casa situada na área indicada no mapa acima. Estas construções, cujo padrão se repete, guardam algumas semelhanças com a casa chorizo e com a casa de porão alto pela forma do lote, e disposição interna dos cômodos.

Fonte: VILLANUEVA MUÑOZ, Emilio Angel. Urbanismo y Arquitectura en la Almería Moderna (17801936). Almería, Cajal, 1983. 

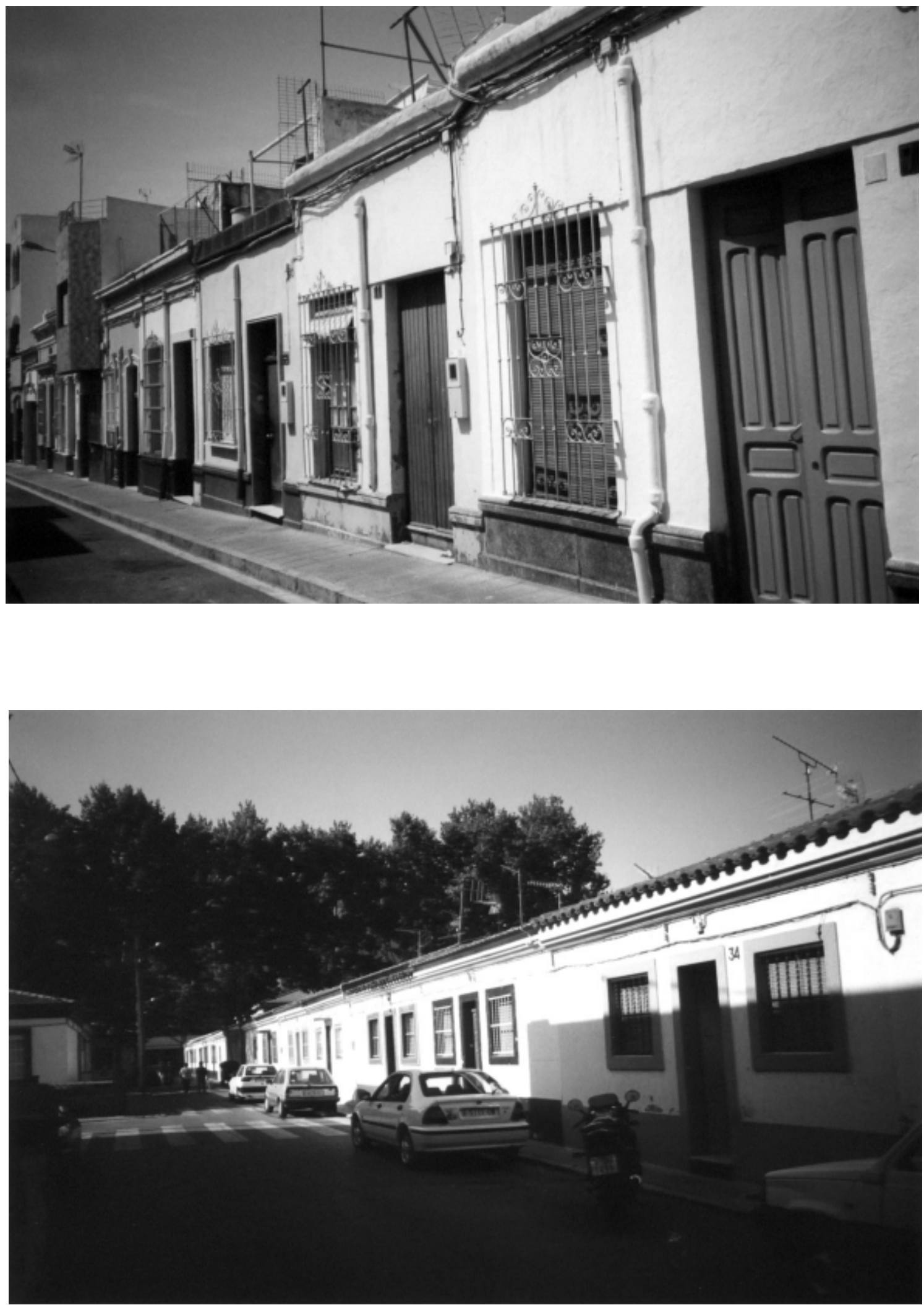

Figura 189 - A foto superior mostra uma rua em Almería, formada por um conjunto de casas semelhantes. O mesmo vemos na foto inferior, mas no bairro de Besòs, em Barcelona. São exemplos singulares no urbanismo da Espanha.

Fonte: Fotos do autor 
podemos ver na figura 190 onde aparece um corte de uma casa de fins do século XVIII.

Este dado nos permite concluir que aparentemente existe uma relação de continuidade ao menos neste aspecto, apenas com um maior refinamento nos acabamentos.

No entanto, se analisarmos outra cidade de colonização hispânica, Santiago do Chile, verificamos que o esquema da cobertura se assemelha muito mais ao de São Paulo que aos da região do Prata, como vemos na figura 191. A imagem mostra que o beiral é substituído por uma platibanda, neste caso porém de madeira ao invés de alvenaria.

Neste caso, verificamos que especificamente estas duas cidades de colonização hispânica apresentam soluções arquitetônicas diferentes.

\section{$8.4-3^{\underline{a}}$ HIPÓTESE}

\section{A arquitetura nos centros econômicos e culturais mais importantes têm influência sobre a praticada em uma determinada área ao redor.}

Para explicar as semelhanças e diferenças encontradas poderíamos tentar localizar determinados centros irradiadores e delimitar a área de influência deste pela observação da repetição de determinadas características. Isto permitiria explicar as semelhanças encontradas em certas cidades, como São Paulo, Porto Alegre e Campinas, ou em Buenos Aires, La Plata e Montevidéu, e as diferenças entre estas últimas e Santiago do Chile, já mais distante.

Mostramos anteriormente que localizamos em Buenos Aires diversas casas já preparadas para receber um andar superior, inconcluso. Isto também pode ser verificado em Montevidéu e La Plata, mas não em Porto Alegre e nem em Santiago, cidades mais distantes. No entanto, encontramos exemplares deste tipo de casa na cidade de Salta, norte da Argentina, a uma distância equivalente à existente entre São Paulo e Buenos Aires (figura 192), e mais longe de Buenos Aires do que Santiago. É o caso também de uma solução comum na região do Prata, a utilização de telhado com inclinação para os fundos da casa ao invés de laje plana. Esta característica pode ser observada também em Jujuy, quase fronteira com a Bolívia, e a uma latitude próxima à de São Paulo (figura 193). significativo.

Ou seja, a distância não parece representar um fator de determinação 


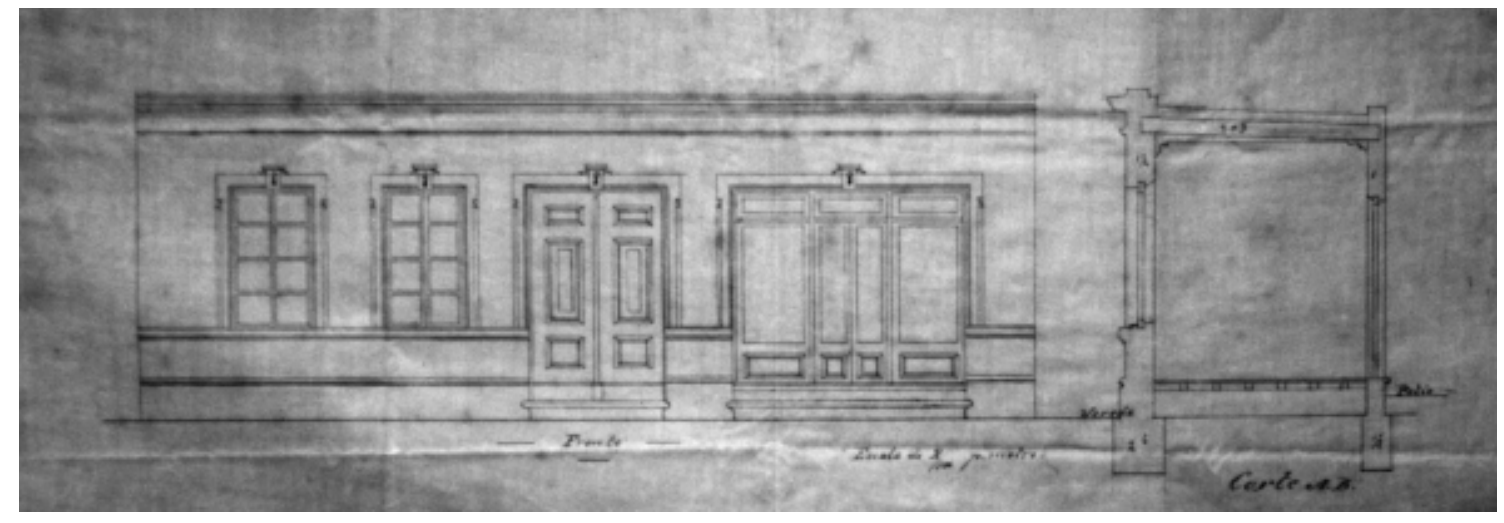

Figura 190 - Fachada e corte de uma residência de fins do século XVIII. Podemos notar que a cobertura é uma laje, com pequena inclinação para os fundos.

Fonte: Archivo Historico de la Ciudad de Buenos Aires.

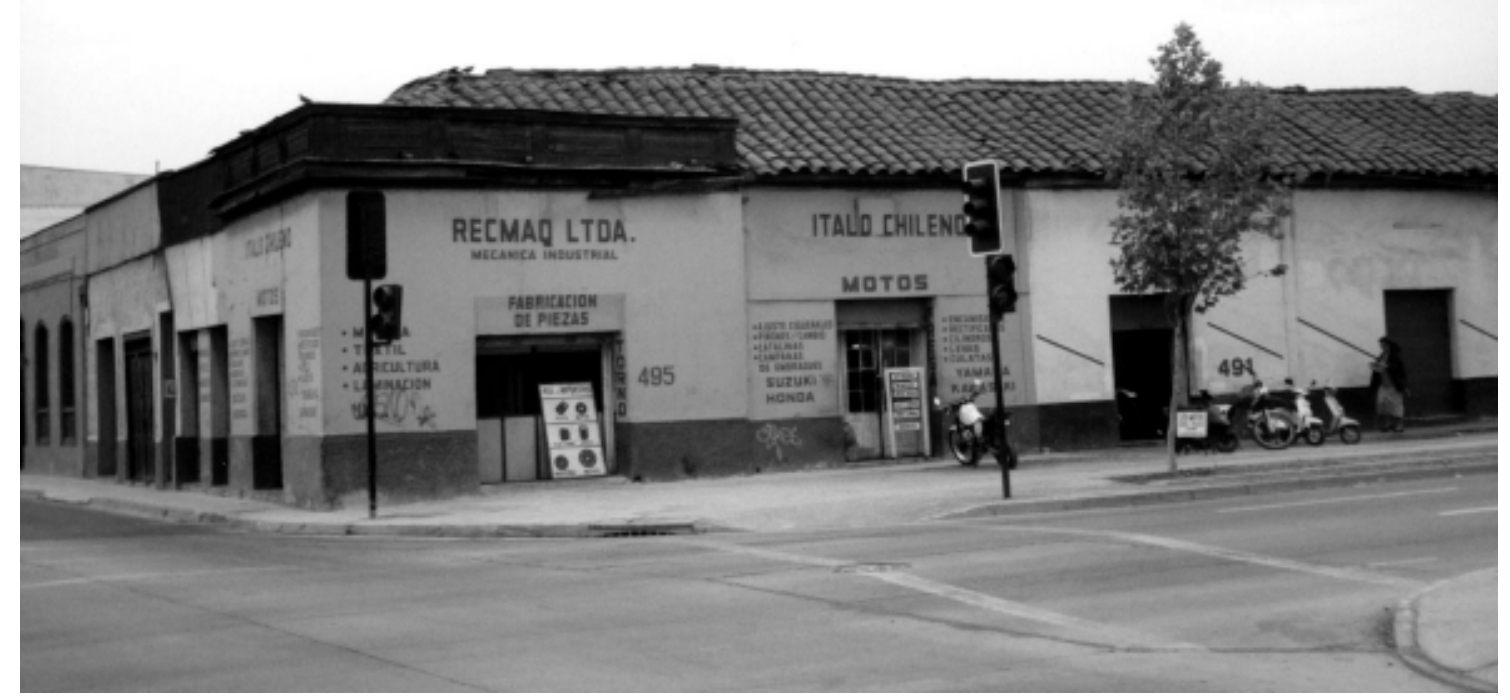

Figura 191 - Em Santiago do Chile o esquema de substituição do beiral pela platibanda é semelhante ao de São Paulo, com a diferença de que é utilizada madeira ao invés de alvenaria.

Fonte: Foto do autor 


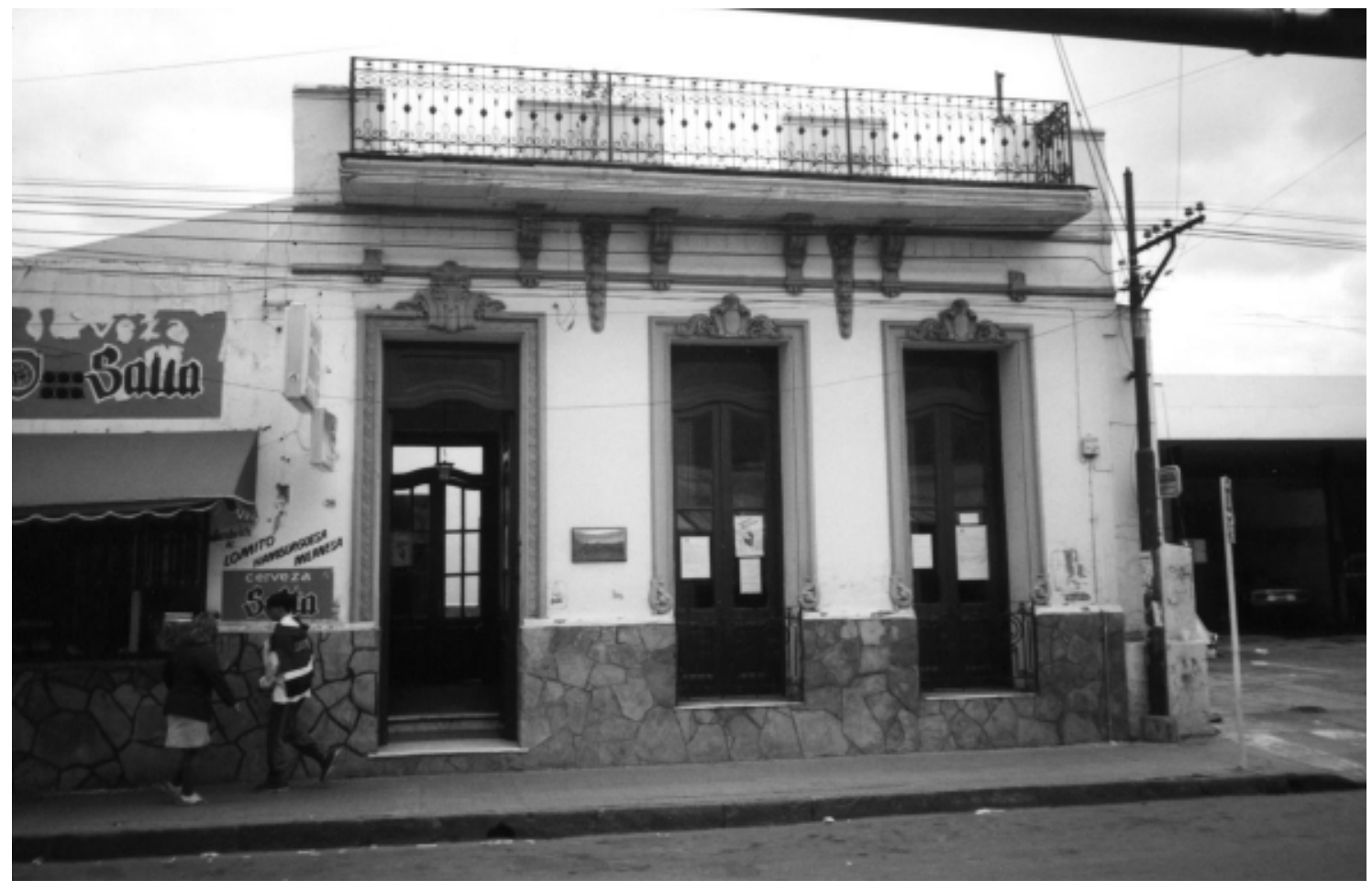

Figura 192 - Embora tão distante de Buenos Aires quanto São Paulo, em Salta (norte da Argentina) também encontramos exemplos de casas térreas preparadas para receber um andar superior, como as observadas na região do Prata.

Fonte: Foto do autor

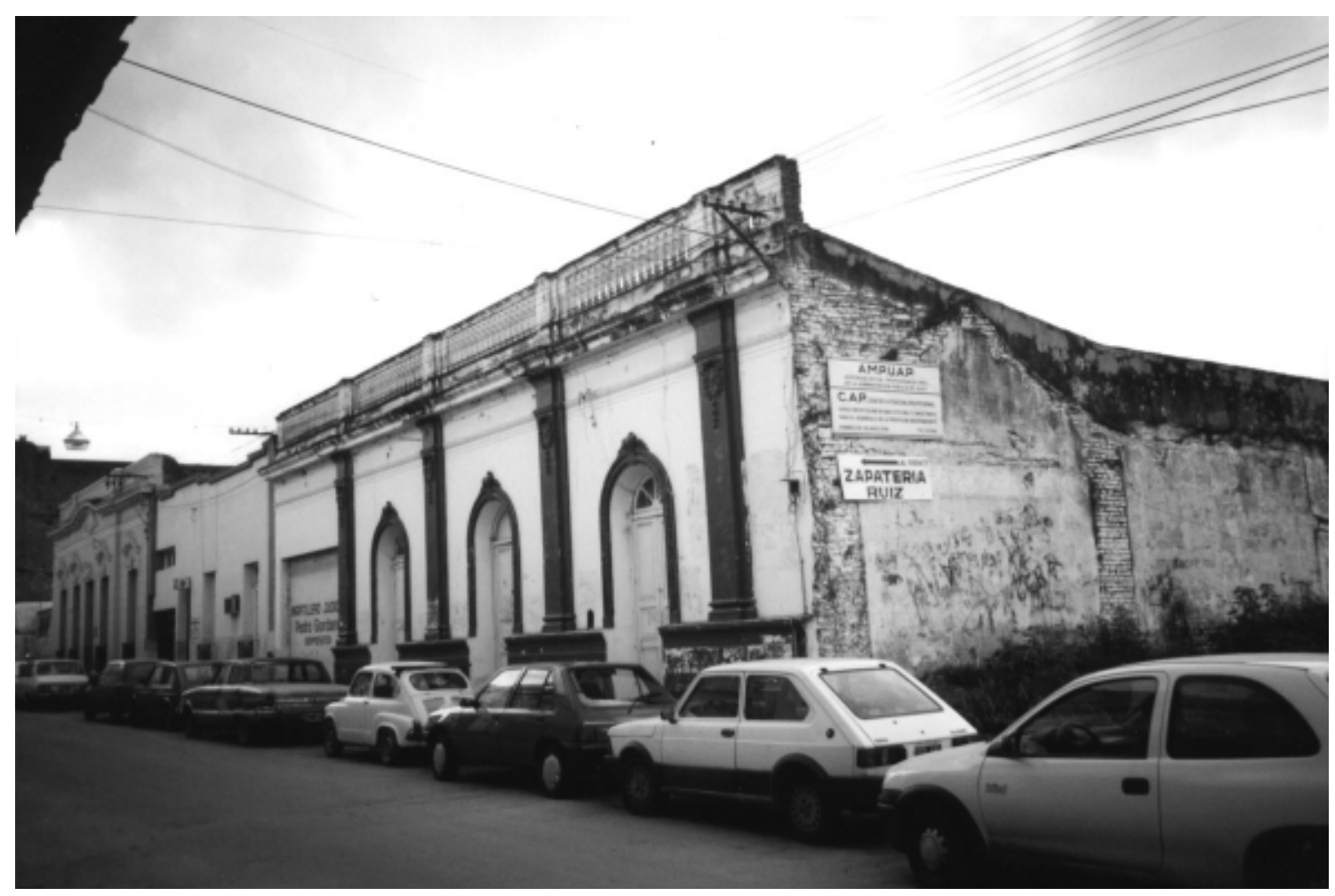

Figura 193 - Da mesma forma em Jujuy, quase fronteira com a Bolívia, a cobertura possui inclinação para os fundos, ao contrário do que observamos em cidades brasileiras e em Santiago do Chile.

Fonte: Foto do autor 


\section{$8.5-4^{\mathrm{a}}$ HIPÓTESE}

\section{As diferenças na arquitetura estão relacionadas também a diferenças na organização social.}

O uso do porão alto, como vimos, é comum tanto em São Paulo como em outras cidades brasileiras. Nas figuras 194, 195 e 196 vemos exemplares também em Porto Alegre, Campinas e Belém. No período colonial a parte baixa dos sobrados também servia de porão, já que abrigava animais, escravos e servia de depósito. Neste caso, porém, estamos tratando do progressivo aumento do pé-direito do porão da casa térrea, até chegar a constituir quase um andar completo, e utilizado tal qual, como já mostramos.

A existência destes porões é atribuída à necessidade de proteger a intimidade e alojar serviçais ou servir de depósito. Diz Lemos, referindo-se às casas cujos proprietários possuíam um certo poder aquisitivo:

"Todas essas casas invariavelmente possuíam porão que a lei vigente exigia para afastar o soalho da umidade do solo. Essa providência possuía também outros méritos, pois evitava fossem os cômodos dianteiros devassados por quem passasse pela calçada, o que acontecia com as antigas construções terreiras de taipa..."18

\section{Segundo Reis Filho:}

“... as casas conservavam uma altura discreta da rua, protegendo a intimidade e aproveitando simultaneamente os porões para alojamento de empregados e locais de serviço."19

Para o objetivo de lograr um certo grau de privacidade é suficiente uma elevação em torno de 1 metro do nível do passeio. Mas quando encontramos casos onde esta altura é bem maior, então evidentemente a intenção é utilizar este espaço para diversos fins, como depósito ou moradia.

Vimos que para este tipo de casa que estamos tratando, não encontramos um porão semelhante em Buenos Aires, já que é deixado apenas um espaço para ventilar o piso de madeira. Na verdade, é possível encontrar casos onde está presente um porão com pé-direito maior, mas em edifícios públicos ou construções de pessoas mais abastadas (figura 197).

Uma primeira tentativa de explicar esta diferença pode ser associar a utilização do porão às necessidades surgidas com o adensamento, o que em São Paulo se manifesta pela ocupação cada vez maior dos porões, e em Buenos Aires, como já comentamos, com a ocupação com estrutura de madeira e chapa das lajes planas de cobertura.

\footnotetext{
${ }^{18}$ LEMOS, Carlos Alberto Cerqueira. Op. cit., p. 98 e 99.
}

${ }^{19}$ REIS FILHO, Nestor Goulart. Op. cit., p. 4. 


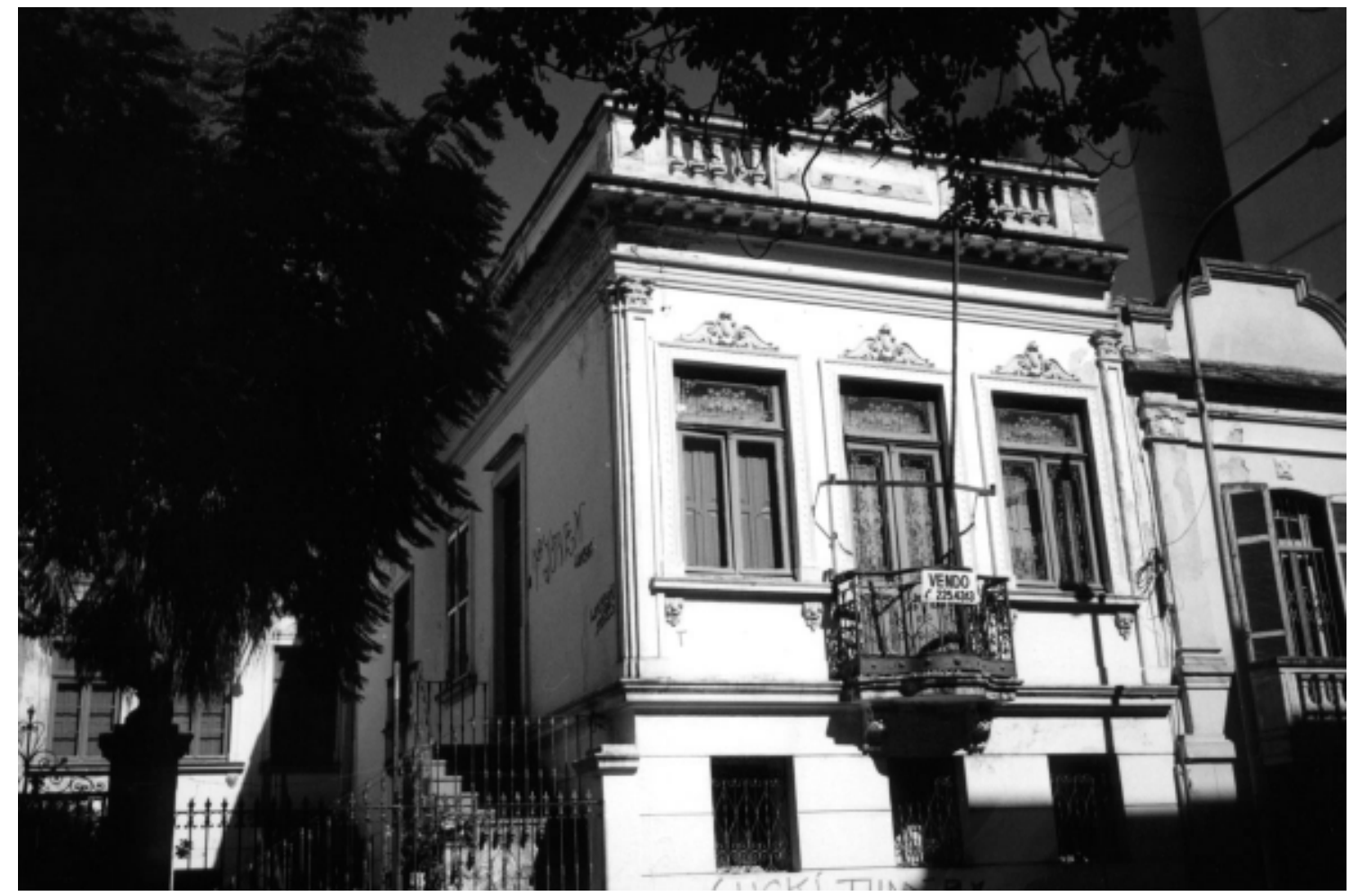

Figura 194 - As casas com porão alto e entrada lateral são comuns em muitas cidades brasileiras, como este exemplar em Porto Alegre.

Fonte: Foto do autor

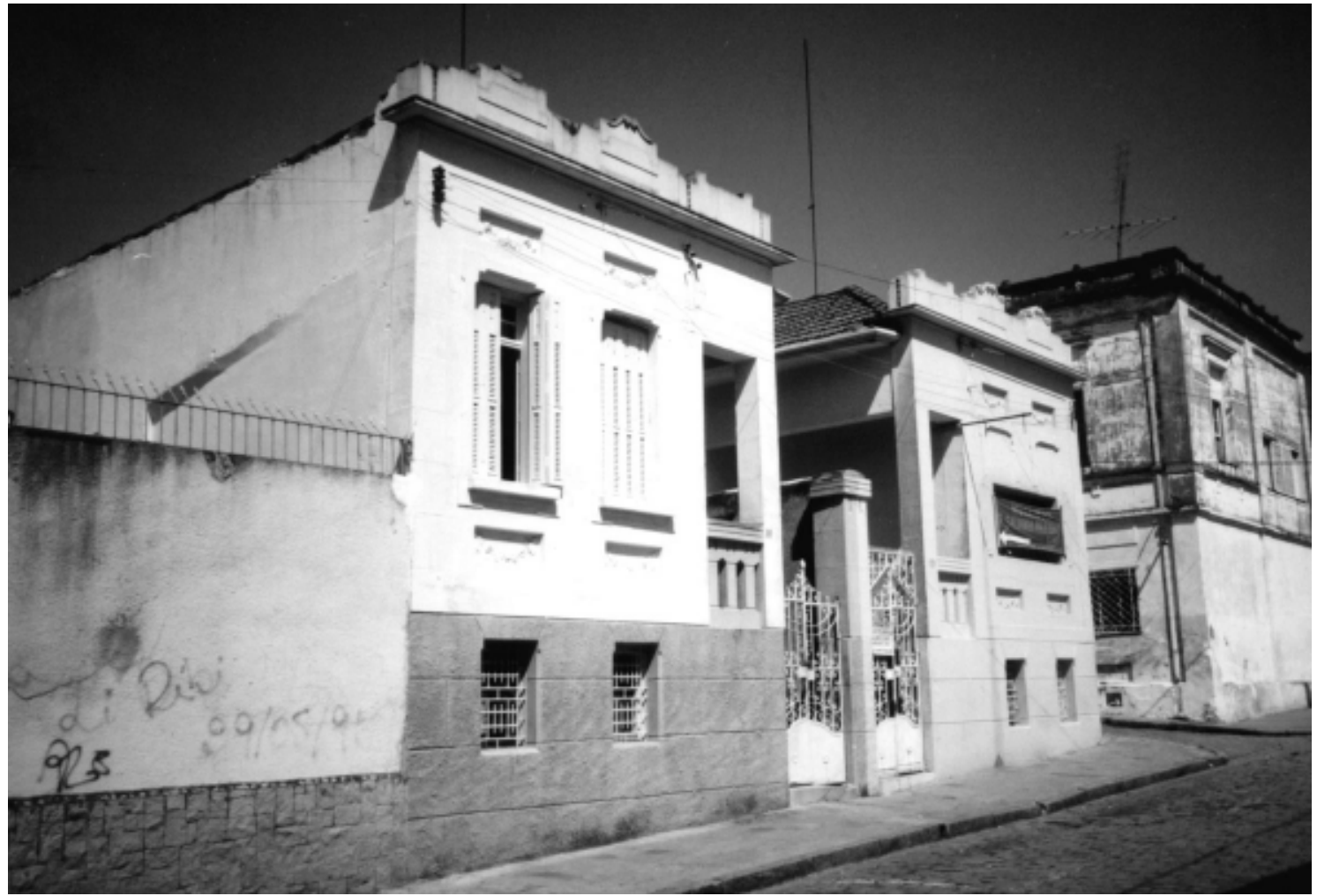

Figura 195 - Outro exemplo da regularidade com que é encontrada a tipologia da casa de porão alto e entrada lateral, neste caso em Campinas (SP).

Fonte: Foto do autor 


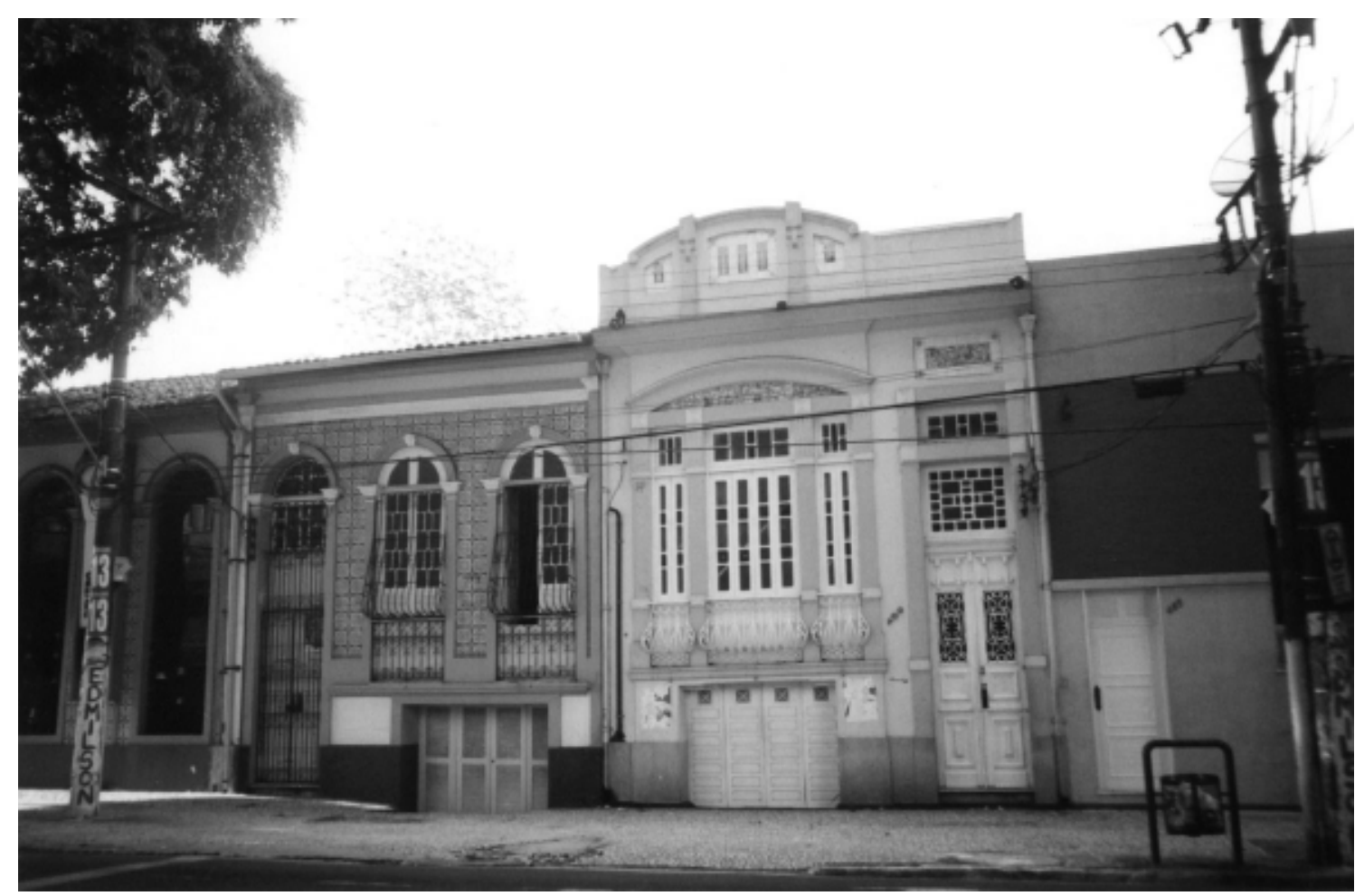

Figura 196 - Casas com porão alto também podem ser encontradas no norte do Brasil. Estas duas casas estão localizadas em Belém.

Fonte: Foto do autor

Figura 197 - Em Buenos Aires é possível encontrar construções com porão, mas apenas em edifícios institucionais ou em residências pertencentes às camadas mais abastadas.

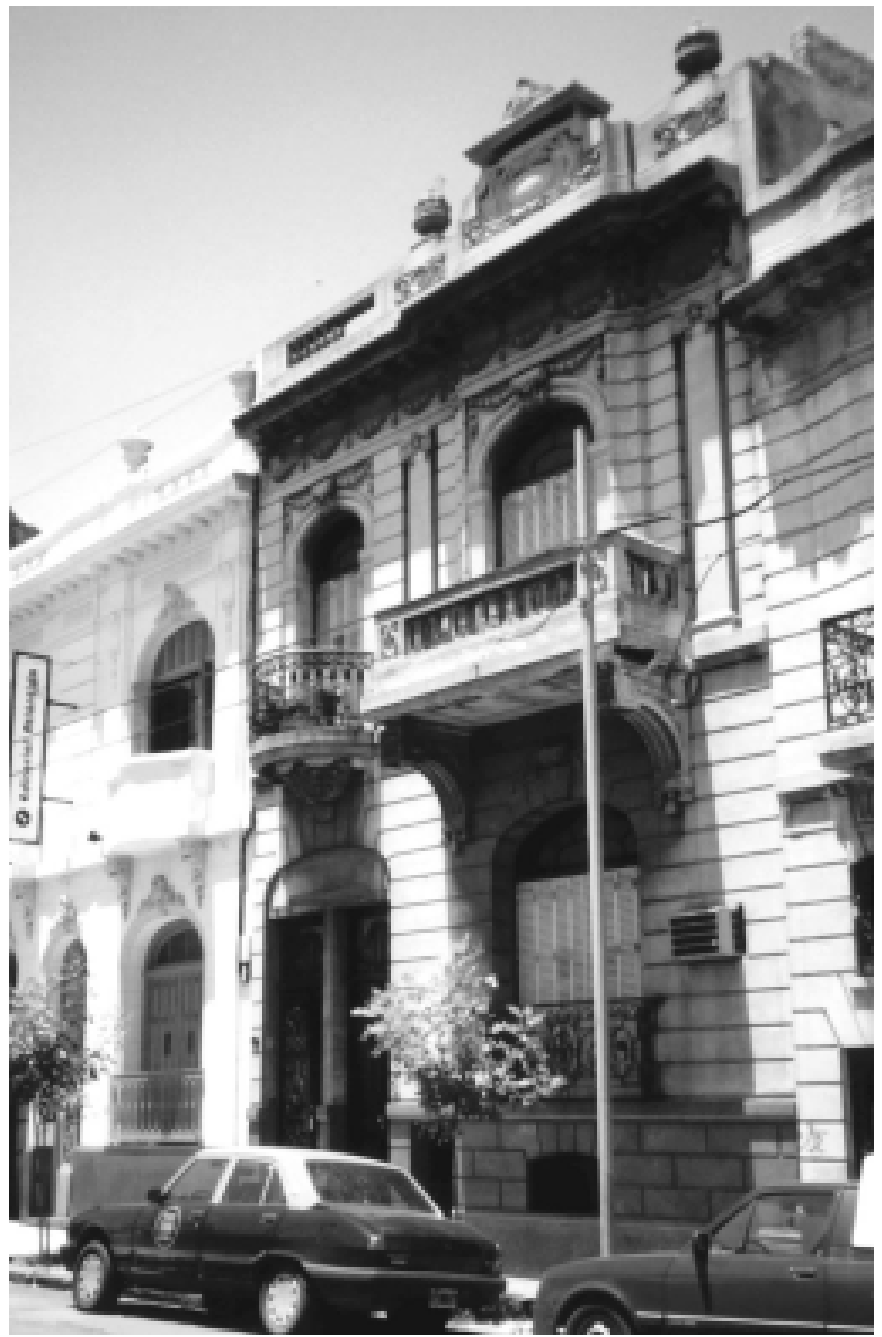


Dadas as semelhanças encontradas até o momento entre Buenos Aires e Montevidéu, seria de esperar que esta explicação fosse verdadeira também para esta última cidade. Mas ao comparar com as imagens obtidas em Montevidéu constatamos com surpresa que nesta cidade há exemplos onde coexistem ambas soluções, ou seja, tanto as lajes planas similares às de Buenos Aires passam a ser ocupadas como, ao contrário desta última cidade, encontramos também muitos casos de porões com altura suficiente para serem habitáveis, com a diferença em relação a São Paulo que em geral têm nível inferior ao do passeio (figuras 198 e 199). ${ }^{20}$

Uma pista plausível para explicar este fenômeno pode estar na forma de organização destas sociedades. Vejamos alguns dados da população destas cidades:

\begin{tabular}{|l|c|}
\hline \multicolumn{2}{|c|}{ São Paulo $(1872)^{21}$} \\
\hline \hline \multicolumn{1}{|c|}{ População } & Habitantes \\
\hline Brancos & 18.834 \\
\hline Negros e Mulatos & 11.679 \\
\hline Índios & 872 \\
\hline Total & 31.385 \\
\hline
\end{tabular}

\begin{tabular}{|c|c|}
\hline \multicolumn{2}{|c|}{ Buenos Aires (1887) 22} \\
\hline População & Habitantes \\
\hline Negros e mulatos & 8.005 \\
\hline Total & 430.000 \\
\hline
\end{tabular}

${ }^{20}$ Em relação às casas com o segundo pavimento inconcluso, em Montevidéu há uma crença popular que diz que as casas nunca devem ficar completamente finalizadas, já que isto provoca azar.

${ }^{21}$ ROLNIK, Raquel. A cidade e a lei. Legislação, política urbana e territórios na cidade de São Paulo. São Paulo, Studio Nobel/FAPESP, 1997, p. 62. Baseado no Recenseamento da População do Império do Brasil, de 10 de agosto de 1872.

${ }^{22}$ MOLAS, Ricardo Rodriguez. Intinerário de los negros en el Rio de la Plata. Buenos Aires. Revista Todo es Historia, $\mathrm{N}^{0} 162$. Nov/1980. 


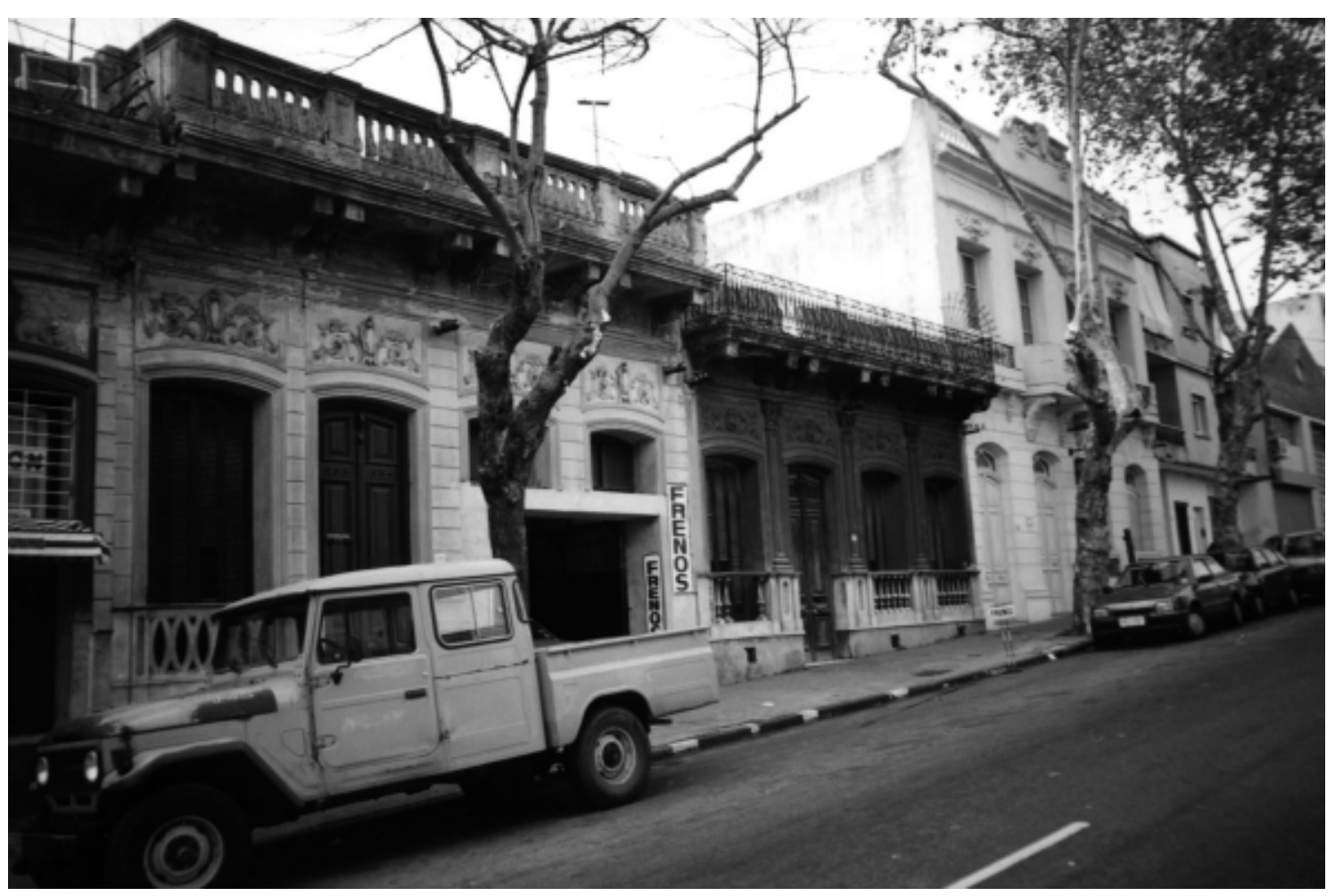

Figura 198 - Assim como em Buenos Aires, também é usual encontrar em Montevidéu residências térreas sem o andar superior concluído.

Fonte: Foto do autor

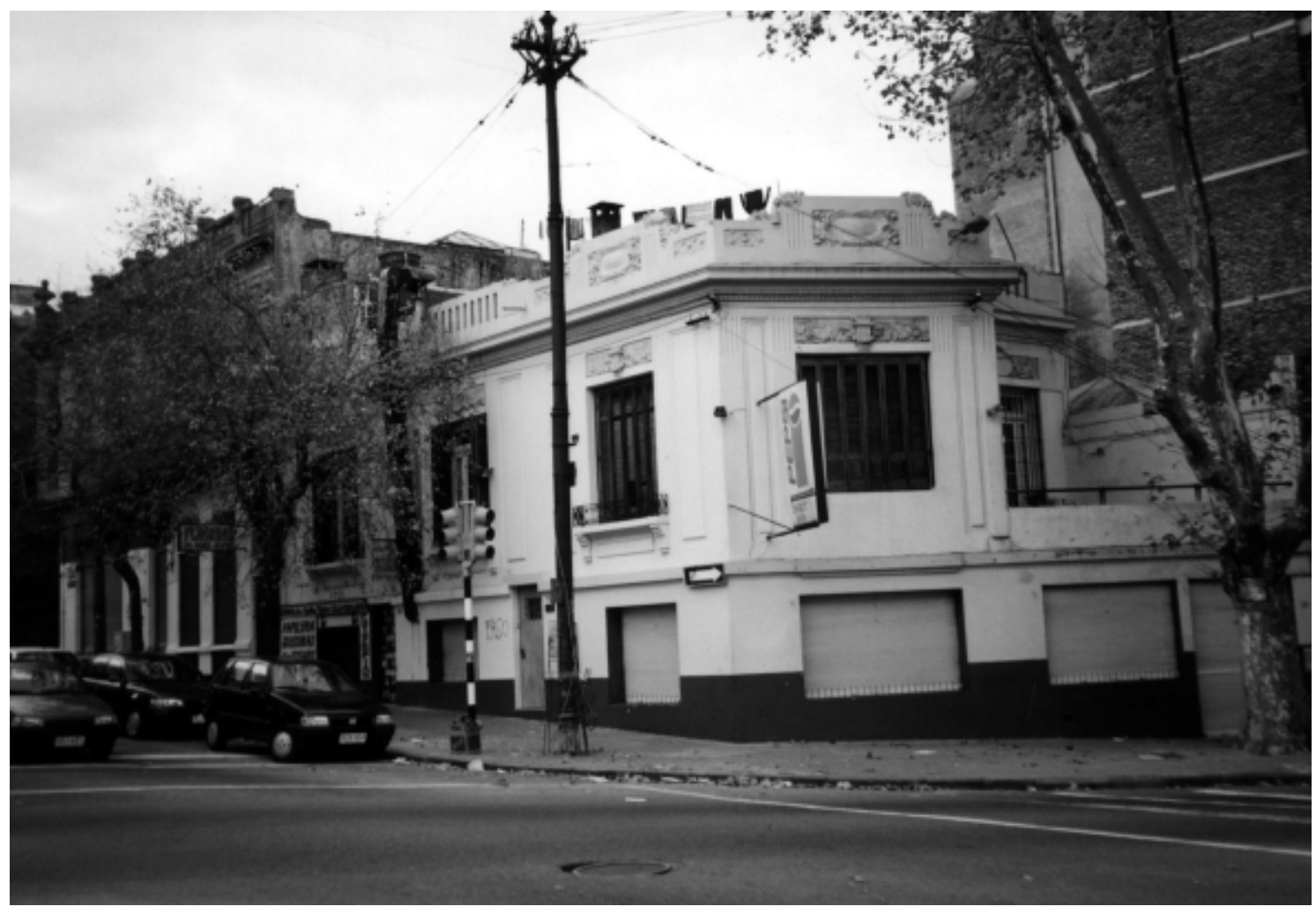

Figura 199 - No entanto, também é comum encontrar porões altos, como neste exemplo. Notar que em Montevidéu, ao contrário de Buenos Aires, podem existir simultaneamente tanto o porão como a laje plana, neste caso sendo utilizada como varal.

Fonte: Foto do autor 
seguir:

No estado de São Paulo a situação é parecida, como vemos na tabela a

População do estado de São Paulo (1836-1940) ${ }^{23}$

\begin{tabular}{|c||c||c||c|}
\hline \hline Ano & Brancos & Negros e Mulatos & Total \\
\hline \hline 1836 & $52,5 \%$ & $47,2 \%$ & 283.750 \\
\hline 1872 & $51,8 \%$ & $48,3 \%$ & 837.354 \\
\hline 1890 & $63,1 \%$ & $37,0 \%$ & 1.384 .753 \\
\hline 1940 & $84,9 \%$ & $12,0 \%$ & 7.180 .316 \\
\hline
\end{tabular}

Estes dados nos indicam que há grande diferença na composição étnica, já que enquanto em 1872 em São Paulo 40\% da população é negra, mulata e índia, a população de negros e mulatos em Buenos Aires em 1887 é de apenas $1,8 \%{ }^{24}$

É possível encontrar na bibliografia corrente algumas referências a respeito da relação entre esta população marginalizada e habitação. Vejamos esta descrição sobre a Barra Funda:

"O caráter da camada inferior da população foi estabelecida pela avidez de lucros dos novos proprietários e procuradores que exploravam os cortiços e casas de cômodos. É preciso lembrar que as velhas casas da Barra, com raríssimas exceções, tinham sido construídas sobre porões.

(..)

Ora, considerando a presente inutilidade dos porões e, ao mesmo tempo, a demanda da residência barata, os proprietários das pensões e cortiços decidiram sublocá-los. E foi assim que vieram os negros para a Barra Funda.

(..)

Estabeleceu-se uma enorme colônia negra, vastíssimo quilombo instalado nos porões. ${ }^{25}$

Ou ainda esta, sobre o bairro da Consolação:

"Bem cedo, contudo, esse arrabalde da Consolação aceitaria, depois da Abolição, contingente de escravos alforriados e recém-

${ }^{23}$ ANDREWS, George Reid. Negros e Brancos em São Paulo (1888-1988). Bauru, SP, Edusc, 1998, p. 377.

${ }^{24}$ Embora esta população tenha sido significativa no período colonial. Por exemplo, em 1778 os negros correspondiam a 28,4\% da população da cidade, e em 1822 estes ainda eram 26,0\%. GOLDBERG, Marta Beatriz. Nuestros negros: ¿desaparecidos o ignorados? Buenos Aires, Revista Todo es Historia, $N^{\circ} 393$. Abr/2000, p. 27.

${ }^{25}$ BRANCO, Fernando. Tristezas da Barra Funda. O Estado de São Paulo, 5 jan. 1963. Suplemento Literário, p. 2. Citado in: BORTOLONI, Giacomo. Violão: a imagem que fez escola. São Paulo 1900-1960. Tese de Doutorado. Assis, Unesp, 2000, p. 108. 
libertos que, ao buscarem espaços livres para morar com suas famílias, alcançaram a parte alta da Bela Vista e se posicionaram no eixo das ruas Frei Caneca e Bela Cintra. Ocuparam casas de modesta construção levantadas por imigrantes italianos para fins de locação e apresentando um outro característico habitacional irradiado por toda a São Paulo - os porões.

(...) A despeito de inadequadas condições de habitabilidade - falta de luz e ventilação, umidade e mínimos recursos sanitários neles se promiscuíram gentes, resultando nos chamados cortiços." ${ }^{.26}$

Sobre Montevidéu, entramos em contato com pesquisadores locais, que nos informaram que não existem dados confiáveis a esse respeito, mas que com certeza a população de negros em Montevidéu era maior que em Buenos Aires. ${ }^{27}$

Um dos raros trabalhos enfocando a população negra foi realizado por Carlos Altezor. ${ }^{28}$ Este autor procurou localizar em que áreas da cidade de Montevidéu morava esta população, e em que condições. Embora os dados sobre os negros sejam escassos, sabe-se que em $1803,22 \%$ da população da cidade era formada por escravos. Poucos anos depois, com o fim da escravidão, esta população irá se concentrar nos bairros na região sul da cidade velha (Barrio Sur e Palermo), em cortiços e casas de inquilinato.

A importância da cultura negra nesta cidade é atestada pela história do cortiço "Médio Mundo", construído em 1883, e que foi tradicional assento da população negra e sua cultura. Pouco antes de ser demolido, em 1979, houve uma grande festa ao som de tambores, mostra de manifestações culturais que ainda hoje persistem na cidade de Montevidéu.

Em geral, a população negra nas cidades latino-americanas possui uma condição social extremamente precária e têm enormes dificuldades para se incorporar às mudanças do sistema capitalista (são marginalizados), ao contrário de uma quantidade considerável dos imigrantes, que se bem chegam aqui sem nada além dos braços para o trabalho, em pouco tempo ascendem socialmente.

Um dos estudos pioneiros sobre a população negra em São Paulo foi realizado por Florestan Fernandes. ${ }^{29}$ Mostra como a abolição na prática levou a um processo de exclusão, já que esta população não estava preparada para a nova forma de vida, principalmente nas cidades:

“... percebe-se que o negro perdera a segurança de material e moral que porventura lograsse, como propriedade, no regime

\footnotetext{
${ }^{26}$ ATHAYDE, Jorge Clovis. Consolação. Uma reportagem histórica. História dos Bairros de São Paulo $\mathrm{N}^{0}$ 22. São Paulo, DPH, s.d.

${ }^{27}$ Devemos agradecer particularmente a Adela Pellegrino, que se prontificou rapidamente em responder nossa solicitação a respeito dessa questão. Nos informou também que esta é atualmente objeto de uma grande revisão da historiografia uruguaia, já que até hoje o Uruguai sempre foi considerado um país formado apenas por imigrantes europeus.

28 ALTEZOR, Carlos. Esclavitud urbana y topologías habitacionales en Montevideo. Estudos Iberoamericanos. Porto Alegre, PUCRS, XVI (1,2):17-27, jul. e dez., 1990.

${ }^{29}$ FERNANDES, Florestan. A integração do negro na sociedade de classes. São Paulo, Edusp/Dominus, 1965.
} 
escravista. Mas não adquirira, senão parcial e imperfeitamente, a segurança material do trabalhador livre e estava longe de poder garantir-se a segurança moral da pessoa, consagrada pelo código civil e pela Constituição republicanos. ${ }^{30}$

Existia inclusive uma diferenciação de gênero, já que aqueles que haviam trabalhado realizando serviços para os patrões (negros da casa grande) estavam mais preparados do que os que trabalhavam no cultivo (negros da lavoura). No primeiro caso eram maioria as mulheres, que por este motivo conseguiram uma inserção maior que os homens. Em 1893, 42\% da ocupação doméstica estava na mão das "nacionais".

Também diversas fontes, particularmente as da história oral, registram uma série de diferenças no comportamento dos ex-escravos e os imigrantes. ${ }^{31}$ Enquanto estes últimos faziam todo tipo de sacrifício para ascender socialmente, os primeiros estiveram durante um bom tempo procurando gozar aquilo que thes era mais precioso: a liberdade.

A diferença entre a organização social destas três cidades é a diferença na participação percentual dos diversos segmentos na população total, e as possibilidades sociais de ascensão social, o que pode justificar as diferenças encontradas em Montevidéu. No caso, há uma diferença qualitativa na utilização do porão e das lajes como espaços habitáveis. Talvez também explique porque em São Paulo é necessário aumentar a altura do peitoril, já que a relação entre o grupo social que ocupa estas casas e os demais é diferente em ambas cidades, portanto a maneira de caracterizar essa diferença, ou as desigualdades, exige soluções arquitetônicas diferentes.

\section{$8.6-$ DISCUSSÃO}

\section{1}

Analisando um determinado padrão arquitetônico, a casa de porão alto em São Paulo, e a casa chorizo em Buenos Aires, constatamos que são tipologias bastante difundidas em ambas cidades, apesar da significativa participação de imigrantes oriundos de regiões culturalmente distintas da Europa na composição social.

Por outro lado, embora o grupo predominante nas atividades ligadas à construção seja de origem italiana, e o grupo majoritário ser o mesmo em ambas as cidades (Vêneto e Friuli), encontramos numerosas diferenças na arquitetura entre ambas cidades, as quais podem ser associadas à persistência de certas práticas

\footnotetext{
30 Idem, p. 56.

31 Por exemplo: BERNARDO, Teresinha. Memória em branco e negro. Olhares sobre São Paulo. São Paulo, Educ/Unesp, 1998; BOSI, Ecléa. Memória e Sociedade. Lembranças de velhos. São Paulo, Companhia das Letras, 1994.
} 
arquitetônicas do período colonial, como são os pátios como elementos organizadores da casa portenha, ou o esquema da cobertura e a divisão bem definida entre frente e fundo da residência em São Paulo.

Assim, verificamos que as possibilidades de reprodução dos hábitos culturais de origem dos imigrantes são estreitas, enquanto há, em maior grau, espaço para a continuidade dos sistemas arquitetônicos da colônia. Isto também pode ser constatado pelas diferenças que encontramos entre a forma de parcelamento do solo, implantação e partido em São Paulo e Buenos Aires, e as cidades espanholas. Espanhóis que junto com os italianos formam a maior parte do contingente que imigrou.

Entretanto, estas continuidades também têm limites definidos pela presença de elementos comuns em ambas as tipologias, tais como a forma de parcelamento do solo (quadras regulares, lotes estreitos e longos) e o partido arquitetônico. Isto significa, entre outras coisas, que a casa chorizo não pode apenas ser apontada como resultado da divisão ao meio da antiga casa colonial, já que guarda semelhanças com a casa de porão alto, que por sua vez não tem precedentes equivalentes.

Estas transformações podem ser associadas ao processo de urbanização em suas diversas escalas. Conseqüentemente mudam as formas locais de produção do espaço, às quais devemos associar aos projetos dos diversos grupos sociais.

No entanto, dentro das novas condições de apropriação, produção, uso e transformação do espaço, a presença dos imigrantes permitiu um salto qualitativo e um refinamento nas técnicas e práticas da arquitetura, graças à sua maior qualificação em relação aos profissionais e à mão-de-obra até então utilizados nesta atividade, em especial no Brasil onde esta última foi formada por escravos até avançado o século XIX.

\section{2}

Verificamos também ser questionável uma generalização baseada numa associação direta da arquitetura e do urbanismo deste período com a das exmetrópoles.

A primeira razão é que o espaço colonial não era homogêneo, já que as políticas urbanas de Portugal e Espanha variaram no tempo e no território. No Brasil, estas sempre estiveram ligadas às políticas mais gerais de Portugal, como aos interesses de seus parceiros comerciais. Foi assim desde o século XVI, com a extração do Pau-brasil, passando pela produção de açúcar e mais adiante, no século XVIII, com a mineração, que alterou profundamente a estrutura urbana do Brasil e de Portugal. Com a ascensão ao poder do marquês de Pombal na segunda metade do século XVIII, passa a haver espaço também para projetos próprios em cada região da colônia. O maior ou menor controle sobre aspectos formais do urbanismo dependia das exigências contidas nas estratégias dos projetos adotados nestas políticas. ${ }^{32}$

32 REIS FILHO, Nestor Goulart. Notas sobre o Urbanismo no Brasil - Primeira parte: período colonial. Cadernos do LAP 8. São Paulo, FAUUSP, julho-agosto 1995; REIS FILHO, Nestor Goulart. Notas sobre 0 Urbanismo no Brasil - Segunda parte: séculos XIX e XX. Cadernos do LAP 9. São Paulo, FAUUSP, setembro-outubro 1995. 
Não é diferente o caso da Espanha. As cidades fundadas entre os séculos XVI e XVII em território espanhol são completamente diferentes das fundadas na América na escala das quadras, praças e lote, sendo neste último caso significativamente maiores. É imposto um modelo rígido de cidade, seguido em linhas gerais por todo o território. ${ }^{33}$ Como os interesses espanhóis na Europa e América eram diferentes, há para cada caso uma política urbana específica. Isto mostra claramente que o urbanismo colonial espanhol não é meramente voluntarista, mas responde a um projeto muito bem organizado. Regionalmente também havia diferenças, já que durante muito tempo os centros de interesse maior foram as áreas de mineração, enquanto regiões como o Rio da Prata permaneceram marginalizadas até o início do século XIX.

O período de grandes transformações do início do século XX nas cidades de São Paulo e Buenos Aires está associado a atividades econômicas que se iniciam algumas décadas antes. No caso de São Paulo, a ocupação das terras do sudeste do país com a cana-de-açúcar, e posteriormente com o café, que criaram as condições iniciais para a expansão urbana. E em Buenos Aires a produção de carne e cereais, que escoava pelo seu porto, o que provocou também um grande crescimento urbano.

Da mesma forma, os dados levantados e apresentados neste trabalho mostram que em nosso período de estudo existem continuidades com as práticas arquitetônicas e urbanísticas coloniais, que são determinantes na produção do espaço neste momento de transição. Verificamos também que a arquitetura apresenta diferenças no território, o que pode ser associado a diferenças no processo de urbanização, ligado tanto à organização do espaço colonial, que como vimos não era homogêneo, como também a diferenças na relação entre os projetos dos novos grupos dominantes locais e internacionais.

Portanto entender o processo de urbanização neste período exige ter consciência da especificidade, o que significa assumir a importância dos diversos sistema sociais, desde os locais aos mais gerais, e o desenvolvimento de instrumentos teóricos que permitam explicá-los. ${ }^{34}$

\section{3}

É considerável a quantidade de trabalhos que procuram explicar a arquitetura e o urbanismo a partir de uma análise da estética do espaço produzido, e os processos a partir de mudanças nesta. ${ }^{35}$

${ }^{33}$ CEHOPU. La ciudad hispanoamericana. El sueño de un orden. Madrid, CEHOPU, 1989.

34 Sobre a questão da especificidade e a América Latina citamos novamente SCHERER, Rebeca. $A$ consciência da especificidade e a formação de uma rede de conhecimentos sobre integração regional na América Latina. In: SCHERER, Rebeca. Notas sobre planejamento e método. Cadernos de Pesquisa do LAP 10. São Paulo, FAUUSP, nov/dez 1995.

35 Integralmente ou parcialmente em obras como: SALMONI, Anita; DEBENEDETTI, Emma. Arquitetura italiana em São Paulo. São Paulo, Perspectiva, 1981; FABRIS, Annateresa (org.). Ecletismo na Arquitetura Brasileira. São Paulo, Nobel/Edusp, 1987; LEMOS, Carlos Alberto Cerqueira. Alvenaria Burguesa: breve história da arquitetura residencial de tijolos em São Paulo a partir do ciclo econômico liderado pelo café. $2^{\mathrm{a}}$ ed. São Paulo, Nobel, 1989; ANDRADE, Carlos Roberto Monteiro. Camillo Sitte, Camille Martin e Saturnino de Brito: traduções e transferências de idéias urbanísticas; BULLRICH, Francisco. (1) Classicismo Romântico; (2) Ecletismo. In: ROMERO, José Luis; ROMERO, Luis Alberto (org.). Buenos Aires. Historia de cuatro siglos. 2 v. Buenos Aires, Abril, 1983; BRANDARIZ, Gustavo A. El aporte italiano a la arquitectura argentina. Buenos Aires, Todo es Historia N ${ }^{\circ} 344$, março 1996. 
No caso de São Paulo e Buenos Aires, estas análises em geral se detêm ao estudo de quais obras ou autores influenciaram a produção do espaço. $\mathrm{Na}$ arquitetura é comum uma classificação em estilos arquitetônicos (Neoclassicismo, Ecletismo, Art Nouveau, etc.), ao passo que nas intervenções são procuradas as cidades que serviram de modelo (Paris, Viena, Londres, etc.), ou os autores de obras e/ou livros que serviram de base para estas, como Haussmann, Camilo Sitte, Eugène Hénard, Joseph Stübben, etc. Quase sempre as referências são européias, pelo menos até as décadas de 20 e 30 do século XX.

As análises a partir do conceito de influência não são exclusivas deste período: uma das mais conhecidas obras sobre a arte colonial sul-americana é de autoria de Bayón. ${ }^{36}$ Discípulo de Francastel, um dos expoentes do estudo das mentalidades, procura caracterizar as obras de arte a partir do maior ou menor grau com que estas se aproximam de obras consideradas originais.

Nós trabalhamos com o conceito de que o investimento realizado no aspecto interior ou exterior das construções está ligado aos processos de dominação social, e têm o papel de caracterizar as desigualdades. Assumem portanto um determinado valor. Podemos também afirmar que estas formas de caracterização são particularmente significativas em etapas de mudanças, quando a mobilidade social é grande, como é o caso do período que estudamos.

$\mathrm{Na}$ arquitetura estes processos podem se dar de várias maneiras: as novas camadas em ascensão irão assumir os valores que as elites aceitam como socialmente superiores. Já os grupos de imigrantes com mesma origem poderão ressaltar suas características culturais próprias, quando isto for importante para a afirmação do grupo, e assim por diante. Os diferentes grupos irão utilizar o valor para se posicionar na sociedade, como parte dos processos de dominação frente às transformações em curso.

Por estes motivos, utilizamos a análise de estilos ou fachadas apenas para tentar identificar na sociedade os grupos e seus projetos, e o papel do espaço nestes. Um exemplo claro de como funcionavam estes mecanismos na época é Clube Espanhol, em Buenos Aires: um de seus salões é ricamente decorado com motivos provenientes do sul da Espanha. Esta estética, neste caso, passa a representar os espanhóis frente a outros grupos de imigrantes, apesar de ser um grupo formado por indivíduos de características culturais diversas. Trata-se aqui apenas de uma fachada, até porque o arquiteto contratado para fazer o projeto era, curiosamente, holandês! (figura 200). ${ }^{37}$

Não é diferente o caso do urbanismo: são realizadas intervenções com o objetivo de construir uma paisagem à semelhança de algumas cidades européias, como afirmação dos grupos dominantes, urbanismo este balizado por edifícios públicos que também seguem em geral modelos europeus.

Já nos espaços ocupados pelas novas camadas médias, é encontrado com regularidade o modelo de casa que já analisamos, a casa de porão alto e a casa

${ }^{36}$ BAYÓN, Damián. Sociedad y Arquitectura Colonial en Sudamérica. Barcelona, Gustavo Gili, 1974.

37 GIUNTA, Rodolfo. Un holandés diseña el Club Español. In: BRAUN, Clara; CACCIATORE, Julio. Arquitectos Europeos y Buenos Aires. 1860-1940. Buenos Aires, TIAU, 1996. Embora a arquitetura do Clube Espanhol esteja baseada em um "estilo árabe", encontrado principalmente no sul da Espanha, em geral a comunidade espanhola escolheu as referências catalãs para representá-la. Ver na mesma obra: GUTIERREZ, Ramón. La vuelta de España a América. 


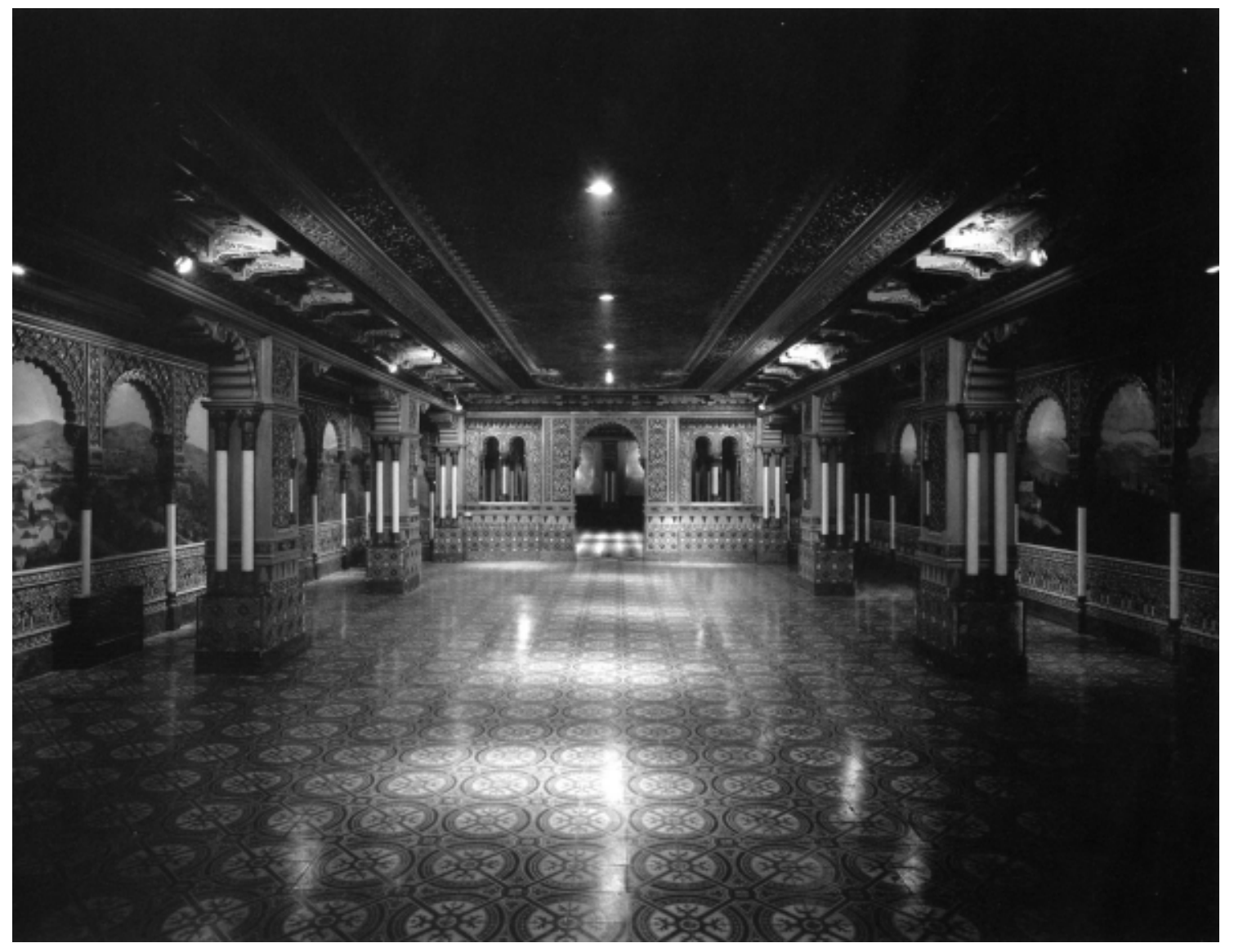

Figura 200 - Clube Espanhol. Neste caso específico, a arquitetura do sul da Espanha passa a representar a comunidade espanhola em Buenos Aires. O autor do projeto é holandês.

Fonte: BRAUN, Clara; CACCIATORE, Julio. Arquitectos Europeos y Buenos Aires. 1860-1940. Buenos Aires, TIAU, 1996. 
chorizo. O que nossos dados indicam é que não há uma relação direta entre distância e a ocorrência de determinadas tipologias, como mostramos ao observar exemplos com características semelhantes em Salta, Jujuy e a região do Prata, características estas que não encontramos em cidades mais próximas de Buenos Aires, como Porto Alegre e Santiago do Chile.

Os grandes edifícios e as residências das camadas mais ricas têm sua lógica de projeto ligada a profissionais estrangeiros ou formada no exterior, e a modelos, técnicas e materiais importados. Por este motivo são recorrentes em muitas cidades latino-americanas, e não diferem muito entre si quanto aos aspectos formais.

Não é o caso das duas tipologias que estudamos. O fato de termos encontrado certas diferenças e semelhanças significa que há diferentes relações entre espaço e sociedade no território, e o seu estudo pode nos ajudar a entender melhor diversas dimensões da sociedade, como as cultural e econômica, e particularmente neste caso, em relação ao espaço, as dimensões técnica e política, já que trata-se de uma etapa de mudança na inserção destes países na rede urbana internacional, e de consolidação dos projetos dos grupos que irão tomar o poder no Brasil a partir da República, e na Argentina com a chamada geração dos 80.

\section{4}

Outro dado interessante que obtivemos ao comparar Buenos Aires, São Paulo e Montevidéu foi a presença nesta última de formas arquitetônicas intermediárias, no caso porões e lajes de cobertura, o que indica que as diferenças na composição destas sociedades são relevantes. Também mostra que é necessário ampliar o estudo das populações marginalizadas, como os ex-escravos, ao contrário do que vem sido feito até agora, já que existe normalmente maior ênfase na abordagem dos imigrantes. ${ }^{38}$ Enquanto estes, ainda que em geral fossem pobres e provenientes do campo, rapidamente se incorporam ao sistema capitalista vigente, e ascendem socialmente. O mesmo não acontece com uma porcentagem da população, significativa principalmente em São Paulo, que permanece à margem deste sistema. No entanto, a arquitetura, como constatamos, não pode ser explicada sem este setor da sociedade.

Isto também pode contribuir para ampliar o estudo da sociedade no sentido de identificar as relações entre todos os setores da sociedade, inclusive entre esta população marginalizada e as camadas médias. Entender, por exemplo, que papel pode ter desempenhado a locação de espaços nas residências (como os porões) para o processo de acumulação daquelas novas camadas.

38 Uma exceção é ROLNIK, Raquel. Op. cit. Neste trabalho a autora também estuda o território dos descendentes de africanos. 


\section{7- CONCLUSÕES}

Finalizando esta etapa, vamos elencar algumas diretrizes que possam contribuir ao aperfeiçoamento dos modelos teóricos sobre o processo de urbanização no Brasil, Argentina e outros países da América Latina, entre o final do século XIX e início do XX. Esperamos com isto poder subsidiar o conjunto de elementos teóricos necessários ao projeto dos espaços urbanos da atualidade.

Ao analisar categorias como quadra, lote, implantação e técnicas construtivas, aplicadas ao caso da produção de espaços destinados às novas camadas médias que são formadas no período, verificamos que em São Paulo e Buenos Aires há determinadas semelhanças quanto ao desenho dos novos loteamentos, forma dos lotes e implantação, o que indica que existe um certo grau de controle sobre este espaço que transcende as relações sociais locais, ligada portanto a determinações mais gerais do processo de urbanização. Estas determinações, entretanto, parecem estar restritas à América Latina, já que as regularidades que identificamos em São Paulo e Buenos Aires não são verificáveis na Espanha. Neste caso, o estudo de outros núcleos urbanos latino-americanos pode permitir verificar em que medida se repete esta regularidade e assim entender melhor este processo nas suas diversas escalas.

No entanto, ao lado das semelhanças, observamos também algumas diferenças na arquitetura e no urbanismo, que identificamos como continuidade de práticas arquitetônicas usuais já existentes. Isto não significa que o passado colonial em comum das cidades de fundação portuguesa e espanhola faça com que este processo de transição seja igual. Pelo contrário, nossos dados indicam que há variações entre as várias cidades estudadas, o que pode ser atribuído ao fato de 0 espaço colonial não ser homogêneo, e a diferenças nos projetos dos grupos locais, já que se trata de um período de grandes mudanças sociais, marcado pela construção das nações latino-americanas e dos grupos que irão consolidar o poder em fins do século XIX. Diante desta regularidade, é possível reforçar a idéia de que o estudo de outros núcleos urbanos latino-americanos exige a consciência da especificidade das relações sociais, e sua relação com a arquitetura e o urbanismo. 
CAPÍTULO 9

CONSIDERAÇÕES FINAIS 
No transcorrer deste trabalho realizamos uma série de comparações entre São Paulo e Buenos Aires, de aspectos da arquitetura e do urbanismo, através da utilização de categorias de análise da organização do espaço intra-urbano.

No capítulo 6 verificamos que nesse período começa a ser dada maior importância à presença da vegetação, seja em residências e edifícios, seja no espaço público. No primeiro caso através da incorporação de espécies vegetais e projetos paisagísticos nas residências das pessoas mais ricas e ambientação de alguns edifícios públicos. No segundo caso pela criação ou reforma de praças e parques. Mas constatamos também que as políticas públicas tiveram orientações diferentes em relação a estes últimos. Em Buenos Aires foi criado um sistema de parques públicos propostos, segundo Gorelik, em plano de 1904. Em São Paulo, ao contrário, não há evidências de um projeto sistemático como esse, embora os sistemas de parques tenham sido sugeridos por alguns autores. Além disso, algumas das principais áreas deste tipo foram particulares, como o Parque Antártica, Bosque da Saúde e Jardim da Aclimação.

Em relação ao traçado (capítulo 7), pudemos constatar diversas diferenças. Uma refere-se à forma de ocupação do solo, já que segundo a comparação de mapas que fizemos, Buenos Aires apresenta um padrão mais compacto do que São Paulo. Além disso, em Buenos Aires também houve maior controle na forma e dimensões de ruas e quadras. Não se trata de fazer um juízo de valor a respeito desse procedimento, mas evidenciar que foi diverso o papel das instituições ligadas ao urbanismo. Relacionada a este aspecto também está a questão da legislação, cuja burla em São Paulo era freqüente e muitas vezes legal, como é o caso das ruas particulares, das quais não era exigida a obediência à largura mínima prevista pelos códigos então vigentes. Por último mostramos também que projetos de conjuntos de residências ocupando o miolo da quadra apresentam soluções diferentes em cada cidade. Em São Paulo são comuns as vilas, conjuntos de casas em torno de uma rua (com ou sem saída). Em Buenos Aires é usual a construção de conjuntos de residências, com acesso feito através de um corredor interno.

Analisamos ainda a produção residencial referente às novas camadas médias, que se viabiliza quando há disponibilidade de transporte barato e estas famílias passam a dispor de algumas possibilidades de poupança, suficientes para a compra parcelada de lotes e a construção de pequenas residências (capítulo 8). As tipologias mais comuns (embora não exclusivas desses extratos sociais) são a chamada "casa de porão alto" em São Paulo, e a "casa-chorizo" em Buenos Aires. Verificamos que embora existam algumas semelhanças quanto às dimensões e formato do lote, e partido adotado, se analisadas com maiores detalhes apresentam diferenças que atribuímos a especificidades nas sociedades locais, e em alguma medida a tradições arquitetônicas diferentes.

Ao abordar os grandes planos propostos (capítulo 4), que quando executados o foram principalmente nas áreas centrais, procuramos mostrar que as propostas realizadas apenas em parte explicam os fenômenos urbanos no período. Sua característica preponderante é a construção de cenários, baseados em elementos formais europeus, particularmente franceses. Exemplos de intervenções com estas 
características cenográficas podem ser encontrados em ambos países, como exemplificamos com os casos da avenida de Mayo e a avenida Central, e ainda em outros países, como a Gran Via de Madri.

No caso das residências das camadas mais ricas acontece o mesmo fenômeno, que é o da utilização de modelos estéticos importados (capítulo 5). Importados também eram os projetos, os materiais e em muitos casos a mão-de-obra. Em grande medida significa o transplante de uma arquitetura, cujo significado tem sentido principalmente como atribuição de valor, de caracterização de uma posição social pelas camadas mais abastadas.

Por outro lado verificamos que a ocupação do solo urbano pelas camadas médias foi realizada por meio de loteamentos e através do desenvolvimento de uma arquitetura que guarda uma relação mais direta tanto com as possibilidades econômicas destas, como também com as possibilidades técnicas efetivamente disponíveis. Também constatamos que esta forma de ocupação do solo e esta arquitetura não são freqüentes na Espanha, onde o crescimento das cidades no período foi extremamente baixo, comparado com o das cidades latino-americanas. Outros estudos comparativos podem confirmar, mas esta forma de projeto não parece ter ocorrido da mesma forma nas cidades européias e seria uma característica própria das cidades latino-americanas. Neste caso é legítimo propor que este urbanismo e esta arquitetura sejam considerados como patrimônio, por serem uma contribuição original e guardar a lógica de como estas sociedades projetaram seus espaços, dentro de um quadro de mudanças rápidas e intensas.

Estas mesmas razões mostram as limitações da análise realizada através da identificação das influências ou referências, que embora permitam entender alguns aspectos formais e de que forma são utilizados socialmente pelas elites, referem-se a apenas uma parte das relações sociais e do espaço produzido.

\section{2}

Um outro dado importante refere-se à qualidade de vida e infra-estrutura instalada. Algumas cidades latino-americanas naquele período possuíam padrões de vida comparáveis e às vezes melhores (inclusive salários) que muitas cidades européias. O mesmo acontecia com a infra-estrutura instalada, transportes, saneamento e iluminação, também comparável às cidades da Europa. Se aqui havia problemas, as cidades do velho continente também os padeceram durante muito tempo. Exemplo disto é o fato de que na Inglaterra de 1885 a média dos inquilinos de uma casa de cômodos dispunham de muito menos espaço do que o prescrito para os encarcerados em prisões ou reformatórios. Em Berlim, ainda em 1916, 79\% das moradias só dispunham de um ou dois quartos aquecíveis. ${ }^{1}$

Buenos Aires foi a cidade latino-americana que naquele período melhor representou o sonho de "fazer a América", e se converteu em paradigma para outras cidades, não apenas em nosso continente. É o caso de Barcelona. Vejamos esta história: Frederick Starck Pearson foi quem organizou e montou a "The São Paulo Tramway Light and Power Co. Ltd.", empresa que foi a principal concessionária de energia elétrica e transportes em São Paulo, e sua similar no Rio de Janeiro, a "The

\footnotetext{
${ }^{1}$ HALL, Peter. Cidades do amanhã. São Paulo, Perspectiva, 1995, p. 24 e 36.
} 
Rio de Janeiro Tramway Light and Power Co. Ltd." Começaram a funcionar respectivamente em 1899 e 1905. Não é um fato muito conhecido mas Pearson em 1911 partiu para Barcelona com o objetivo de realizar um trabalho semelhante e instalou a "Barcelona Traction Light and Power". Ao chegar, subiu na colina de Tibidabo, de onde é possível avistar toda a cidade, e disse: "Faremos de Barcelona uma cidade tão grande como Buenos Aires". ${ }^{2}$

A existência de uma relação econômica assimétrica entre os países mais desenvolvidos e o Brasil e a Argentina deveria pressupor uma igual assimetria nas condições de vida em ambos continentes, o que, entretanto não se observa na realidade.

Nem o café brasileiro, nem a carne e os cereais argentinos, teriam na época suficiente importância que pudesse explicar a quantidade e a qualidade do processo de urbanização no período. O fato é que se observado este processo do ponto de vista da apropriação, produção, uso e transformação do espaço, Brasil e Argentina não são apenas fornecedores de matérias-primas, mas parte importante do desenvolvimento da urbanização e do capitalismo no mundo ocidental do período, consolidado através da incorporação de milhões de pessoas ao mundo urbano e pela obtenção de enormes lucros por parte principalmente das empresas dos países mais desenvolvidos. Isto mostra que a urbanização não pode ser analisada a partir da mesma lógica usada para análise das relações macroeconômicas.

Esta linha de explicação já havia sido proposta por Reis Filho ao discutir a "influência" do urbanismo dos paises industrializados:

"A magnitude das realizações e das transformações e o pequeno intervalo de tempo em que ocorrem nos permitem reiterar que sua viabilidade dependia necessariamente de uma integração crescente de algumas das economias, dos dois lados do Atlântico, bem como de seus sistemas produtivos e de uma ampla articulação dos interesses dos grupos dominantes e, mesmo, dos setores de renda média."

\section{3}

Explicar a urbanização na América Latina implica necessariamente estudar as especificidades e as generalidades. Neste trabalho procuramos mostrar que a arquitetura e o urbanismo em São Paulo e Buenos Aires são o resultado de diferentes racionalidades. Em outras palavras, significa que não são apenas uma conseqüência direta da nova divisão internacional do trabalho, mas que resultam de outros determinantes relacionados a outras escalas e às suas respectivas formas de organização social. Não basta a generalidade, é necessário estudar a especificidade.

\footnotetext{
${ }^{2}$ CALVO, Ángel. Frank Pearson y la Barcelona Traction Light and Power. In: SÁNCHEZ, Alejandro. Barcelona 1888-1929. Madrid, Alianza, 1992.

${ }^{3}$ REIS, Nestor Goulart. Urbanização e modernidade: entre o passado e o futuro (1808-1945). In: MOTA, Carlos Guilherme (org). Viagem incompleta. A experiência brasileira. A grande transação. São Paulo, SENAC São Paulo, 2000. Pág. 108. Ver também REIS FILHO, Nestor Goulart. Memória do transporte rodoviário. Desenvolvimento das atividades rodoviárias de São Paulo. São Paulo, CPA, s.d.Rodovias e História; REIS FILHO, Nestor Goulart. Cultura e Estratégias de Desenvolvimento. Cadernos do LAP 23. São Paulo, FAUUSP, janeiro-fevereiro 1998.
} 
Identificar o que é geral e o que é particular serve tanto para estudar a urbanização na América Latina como para avaliar os modelos de explicação para cada núcleo urbano. No primeiro caso através da identificação de regularidades existentes no sistema urbano do continente. Essas mesmas regularidades gerais permitem avaliar os modelos teóricos desenvolvidos para um núcleo urbano em outro, já que dadas as mesmas condições devem valer as mesmas explicações. Os resultados desta avaliação, ou seja, aquilo que é descrito com precisão e aquilo que não é, permitirá aperfeiçoar tanto os modelos mais gerais como os mais específicos.

Neste trabalho, procuramos contribuir para estudar a urbanização na América Latina a partir das especificidades, com ênfase particular na arquitetura e no urbanismo.

Em relação à rede urbana internacional também é possível tirar algumas conclusões. A primeira é que é necessário estudar melhor a relação entre a rede urbana latino-americana e a rede internacional, principalmente estudando-a como uma relação de dois sentidos, e não apenas aceitando que uma é conseqüência da outra. $E$ mais, assim como tanto a rede urbana latino-americana como a européia apresentam inúmeros aspectos heterogêneos, é necessário assumir essa complexidade e transcender a simples dicotomia Europa-América.

Neste sentido, os estudos históricos mostram claramente que esta situação nunca existiu. Desde o período colonial ambos continentes formam parte de uma realidade intrinsecamente ligada. Basta lembrar o papel que a prata e ouro extraídos na América tiveram sobre a sociedade européia. Reis Filho mostrou estas relações na rede urbana colonial brasileira, ao provar que não é possível explicar a rede urbana colonial no Brasil sem levar em conta a rede internacional. ${ }^{4}$ Também mostrou Gutierrez que não é possível explicar a arquitetura e o urbanismo colonial na América Latina apenas a partir de referenciais europeus, mas que há um processo de seleção e síntese. ${ }^{5}$ Se no passado as explicações só foram possíveis a partir de uma visão que levasse em conta estes múltiplos movimentos, porque o estudo do período que abordamos prescindiria desta abordagem?

Há ainda uma questão que deve ser destacada: normalmente estudamos o impacto que as migrações tiveram na América Latina, mas não o impacto que tiveram na rede européia. Ou mais precisamente, o que teria acontecido se esta enorme população não tivesse migrado. É necessário estudar o que foi e o que não foi. Ou como disse Ernesto Sábato, esta aproximação pode ser feita estudando tanto a pedra que cai como a lua que não cai. O resultado é o mesmo.

\footnotetext{
${ }^{4}$ REIS FILHO, Nestor Goulart. Contribuição ao estudo da evolução urbana do Brasil (1500-1720). São Paulo, Pioneira, 1968.

${ }^{5}$ GUTIERREZ, Ramón. El laberinto de la enajenación. La historia de la arquitectura própria escrita con ojos ajenos. In: MARCONDES, Neide; BELLOTTO, Manoel. Laberintos e nós: imagem ibérica em terras da América. São Paulo, Unesp/Imprensa Oficial, 1999.
} 


\section{4}

Existe atualmente um discurso, que tem uma certa hegemonia, que pressupõe a preponderância do fator econômico na produção do espaço. Isto é aceito inclusive por alguns arquitetos. ${ }^{6}$

Vejamos, por exemplo, os atuais estudos sobre a globalização (ou mundialização). Com a suposta perda de poder dos estados-nação, as cidades ganham nova evidência. Entretanto, costuma ser dada maior ênfase à relação entre espaço e mercado financeiro, daí o destaque para as chamadas cidades globais. No caso, o objetivo é localizar os centros de poder e controle do mundo globalizado. ${ }^{7}$ Como reflexo, há massiva divulgação de projetos realizados em determinadas áreas de cidades como Paris, Nova York, Berlim, Tokyo, São Paulo (centro, Paulista, Berrini), Buenos Aires (Puerto Madero, Retiro), entre outras. Castells, em seu livro "A era da Informação", dedica um capítulo à arquitetura, mas na verdade refere-se apenas ao que se convencionou chamar arquitetura pós-moderna. ${ }^{8}$

Neste panorama, a arquitetura acabou assumindo uma extraordinária evidência, visto a grande divulgação editorial de determinadas obras ou intervenções (por exemplo Baltimore, Docklands, Bilbao, Barcelona, Puerto Madero, etc.). Estas tornaram-se ponto de atração turística e passam a ser um modelo para intervenções em outros lugares. ${ }^{9}$

Deste ponto de vista, em Buenos Aires serão valorizadas principalmente as intervenções na área de Puerto Madero, com seus projetos assinados por arquitetos famosos como César Pelli, Santiago Calatrava e Rafael Viñoli. Mas serão deixados de lado outros fenômenos importantes, como as conseqüências das autoestradas construídas nos anos 1990 e dos condomínios nas periferias, que lá são um fenômeno recente. O mesmo pode ser dito sobre São Paulo, cuja análise corre o risco de ficar restrita às obras na área central, como a Estação Julio Prestes, o Centro Cultural Banco do Brasil, a Pinacoteca, a Praça do Patriarca, etc.

A questão não é meramente teórica, mas essencial para a formulação de projetos. Agir dentro de um paradigma dominado pela instância econômica exige como prioridade o enfrentamento dessa instância macro (por exemplo a globalização), o que implica neste caso que o projeto arquitetônico e urbanístico têm um peso menor e só terão importância após esse desenlace. Outra visão, a qual compartilhamos, pressupõe que as diversas instâncias são igualmente importantes, exigindo outras formas de ação, inclusive no papel representado pela arquitetura e pelo urbanismo.

\footnotetext{
${ }^{6}$ Por exemplo Ermínia Maricato, que afirma: "O quadro macroeconômico determina, não totalmente, mas em grande parte, a produção e apropriação do ambiente construído". MARICATO, Ermínia. "As idéias fora do lugar e o lugar fora das idéias. In. ARANTES, Otília; VAINER, Carlos; MARICATO, Ermínia. A cidade do pensamento único. Desmanchando consensos. $2^{\text {a }}$ ed. Petrópolis, Vozes, 2000, p. 170.

${ }^{7}$ Os critérios para definir as cidades globais são essencialmente econômicos e políticos. Saskia Sassen, por exemplo, propõe que além de funções de longa direção como centros do comércio mundial e da atividade bancária, as cidades globais devem ser: 1 - Pontos de comando na organização da economia mundial; 2 - lugares e mercados fundamentais para as indústrias de destaque do atual período, isto é, as finanças e os serviços especializados destinados às empresas; 3 - lugares de produção fundamentais para essas indústrias, incluindo a produção de inovações. SASSEN, Saskia. As cidades na economia mundial. São Paulo, Studio Nobel, 1998, p. 16.

${ }^{8}$ CASTELLS, Manuel. La era de la información. Economía, sociedad y cultura. 3v. Madrid, Alianza, 1997.

9 Expressando, em última instância, relações de dominação. Qualquer semelhança com o período que estudamos não é mera coincidência.
} 
Em outras palavras, estes dois paradigmas pressupõem diferentes formulações de projetos sociais.

Neste trabalho mostramos que apesar de existir entre o final do século XIX e início do XX uma nova divisão internacional do trabalho, caracterizada por forte assimetria econômica, o grau de determinação desta instância na arquitetura e no urbanismo de ambas cidades é relativo, existindo espaço para que fossem possíveis projetos próprios. Conseqüentemente, do ponto de vista da formulação de projetos sociais, permitiu mostrar que o quadro macro-econômico não foi impedimento para que fossem trilhados em ambas cidades caminhos diferentes. Trazendo esta questão para os nossos dias, a pergunta que deve ser formulada é: em que medida estas possibilidades também existem no presente?

\section{5}

Borges dizia que o texto definitivo só tem sentido na religião e no cansaço. Esta tese é resultado deste último. Nossa formação como arquiteto exige confirmar no espaço cada afirmação, o que implicou em considerável esforço, que entretanto somente permitiu abordar alguns aspectos. Comparar duas cidades como São Paulo e Buenos Aires é uma tarefa que ainda exige muito trabalho, tanto empírico quanto teórico. Nosso desejo é que o que aqui fizermos, longe de esgotar o assunto, possa ser útil ao apontar um caminho para a realização de outros trabalhos semelhantes, tanto entre estas duas como entre outras cidades latino-americanas. Ou, ao menos, induzir idéias novas no leitor.

Ficaremos satisfeitos também se este trabalho, feito a partir do ponto de vista do arquiteto, puder ser útil a pesquisadores de outras áreas, cujos trabalhos, por sua vez, são imprescindíveis para melhorar o projeto de arquitetura e de urbanismo. E assim contribuir para obter uma visão mais articulada das especificidades e generalidades da América Latina. Conseqüentemente, desenvolver modelos teóricos mais precisos sobre a urbanização e assim cumprir nosso papel social como pesquisadores. 


\section{REFERÊNCIAS BIBLIOGRÁFICAS}


ALIATA, Fernando. La cantera de la historia. Mario Palanti y la construcción de una poética ecléctica en Argentina. Cuadernos de Historia 8. Buenos Aires, IAAIE "Mario J. Buschiazzo", junho de 1997.

ALMEIDA, Fernando Lopes (org.). A Questão Urbana na América Latina. Rio de Janeiro, Forense-Universitária, 1978.

ALOMAR, Gabriel (coord.). De Teotihuacán a Brasilia. Estudios de História Urbana Iberoamericana y Filipina. Madrid, Instituto de Estudios de Administración Local, 1987.

ALTEZOR, Carlos. Esclavitud urbana y topologías habitacionales en Montevideo. Estudos Iberoamericanos. Porto Alegre, PUCRS, XVI (1,2):17-27, jul. e dez., 1990.

AMERICANO, Jorge. São Paulo naquele tempo (1895-1915). São Paulo, Saraiva, 1957.

ANDRADA, et alli. Las casas de madera y chapa del barrio de La Boca. Resistencia, DANA N ${ }^{\circ} 25,1988$.

ANDRADE, Carlos Roberto Monteiro. Camillo Sitte, Camille Martin e Saturnino de Brito: traduções e transferências de idéias urbanísticas. In: RIBEIRO, Luiz César de Queiroz; PECHMAN, Robert (org.). Cidade, povo e nação. Rio de Janeiro, Civilização Brasileira, 1996.

A peste e o plano: o urbanismo sanitarista do engenheiro Saturnino de Brito. Dissertação de Mestrado. São Paulo, Fauusp, 1992.

ANDREWS, George Reid. Negros e Brancos em São Paulo (1888-1988). Bauru, SP, Edusc, 1998.

ANGULO IÑIGUEZ, D.; MARCO DORTA, E.; BUSCHIAZZO, Mario J. Historia de arte hispano-americano. 3v. Barcelona, Salvat, 1945-1956.

ANTOLA, Susana; PONTE, Cecilia. El edificio de renta como tipo arquitectónico generador de ciudad. Montevidéu, Faculdade de Arquitetura da Universidade da República, 1997.

ARAGÃO, Solange. Da persistência do ecletismo nas vilas paulistanas. Dissertação de Mestrado. São Paulo, FAUUSP, 2000.

ARANTES, Otília; VAINER, Carlos; MARICATO, Ermínia. A cidade do pensamento único. Desmanchando consensos. $2^{a}$ ed. Petrópolis, Vozes, 2000.

ARGAN, Giulio Carlo. História da arte como história da cidade. São Paulo, Martins Fontes, 1993.

A história na metodologia do projeto. Revista Caramelo $N^{0}$ 6. São Paulo, FAUUSP.

ARMUS, Diego (comp.). Mundo Urbano y Cultura Popular. Buenos Aires, Sudamericana, 1990.

ASENCIO, Miguel et alli. La Avenida de Mayo. Buenos Aires, Ayuntamiento de Madrid/Municipalidad de la Ciudad de Buenos Aires/Manrique Zago ed./Eudeba, 1988.

ASLAN, Liliana et alli. Buenos Aires. Monserrat 1580-1970. Buenos Aires, Faculdade de Arquitetura e Urbanismo da Universidade de Buenos Aires, 1992. 
Buenos Aires. Balvanera 1817-1970. Buenos Aires, Faculdade de Arquitetura e Urbanismo da Universidade de Buenos Aires, 1992.

Buenos Aires. San Telmo 1580-1970. Buenos Aires, Faculdade de Arquitetura e Urbanismo da Universidade de Buenos Aires, 1992.

ATHAYDE, Jorge Clovis. Consolação. Uma reportagem histórica. História dos Bairros de São Paulo $\mathrm{N}^{0}$ 22. São Paulo, DPH, s.d.

AZEVEDO, Aroldo de. A cidade de São Paulo. Estudos de geografia urbana. 4 v. São Paulo, Companhia Editora Nacional, 1954.

AZEVEDO, Militão Augusto de. Album comparativo da cidade de São Paulo/18621887. São Paulo, Prefeitura do Município de São Paulo/ Secretaria Municipal de Cultura, 1981.

São Paulo em três tempos. São Paulo, Imprensa Oficial do Estado, 1982.

BACCI, Massimo Livi. Historia de la Población Europea. Barcelona, Crítica, 1999.

BAIROCH, Paul. De Jericó a México. Historia de la urbanización. México, Trillas, 1990.

BALMORI, Diana; STUART, F.; WORTMAN, Miles. Las alianzas de familias y la formación del país en América Latina. México, Fondo de Cultura Econômica, 1990.

BARSKY, Osvaldo; GELMAN, Jorge. Historia del Agro Argentino. Desde la Conquista hasta fines del siglo XX. Buenos Aires, Grijalbo, 2001

BARTALINI, Vladimir. Parques públicos municipais de São Paulo. Tese de Doutorado. São Paulo, Fauusp, 1999.

BAYÓN, Damián. Sociedad y Arquitectura Colonial en Sudamérica. Barcelona, Gustavo Gili, 1974.

BERJMAN, Sonia. Eugène Courtois, ese desconocido paisajista. Buenos Aires, Anales del IAAIE "Mario Buschiazzo" N² 29, 1992-1993. Págs. 69-85. (comp.). El tiempo de los parques. Buenos Aires, IAAIE "Mário Buschiazzo", 1992.

BERNARDO, Teresinha. Memória em branco e negro. Olhares sobre São Paulo. São Paulo, Educ/Unesp, 1998.

BETHELL, Leslie (ed.). Historia de América Latina. Vol. 7: América Latina: Economía y Sociedad, 1870-1930. Barcelona, Crítica, 2000.

BLAY, Eva Alterman. Eu não tenho onde morar: vilas operárias na cidade de São Paulo. São Paulo, Nobel, 1985.

BOLETIM DO INSTITUTO DE ENGENHARIA. "Obras de embellezamento". N ${ }^{0} 19$, janeiro de 1923, p. 194.

BONDUKI, Nabil Georges. Origens do Problema da Habitação Popular em São Paulo Primeiros Estudos. São Paulo, Espaço \& Debates, Ano 2, № 5, março/junho de 1982. p. 81-111.

Origens da habitação social no Brasil. São Paulo, Estação Liberdade/Fapesp, 1998.

BORJA, Jordi; CASTELLS, Manuel. Local y Global. La gestión de las ciudades en la era de la información. Madrid, Taurus, 1997. 
BORTOLONI, Giacomo. Violão: a imagem que fez escola. São Paulo 1900-1960. Tese de Doutorado. Assis, Unesp, 2000.

BOSI, Ecléa. Memória e Sociedade. Lembranças de velhos. São Paulo, Companhia das Letras, 1994.

BOURDÉ, Guy. Buenos Aires: Urbanización e Inmigración. Buenos Aires, Ed. Huemul, 1977

BRAGOS, Oscar. Ciudades, sueños, planes. La emergencia del urbanismo en la Argentina y los primeros planes para la ciudad de Rosario. IV Seminário de História da Cidade e do Urbanismo Rio de Janeiro, 1996.

O Museo Social Argentino e a formação e difusão das idéias do urbanismo. In: RIBEIRO, Luiz César de Queiroz; PECHMAN, Robert (org.). Cidade, povo e nação. Rio de Janeiro, Civilização Brasileira, 1996.

BRANDARIZ, Gustavo A. El aporte italiano a la arquitectura argentina. Buenos Aires, Todo es Historia $N^{\circ}$ 344, março 1996.

BRAUN, Clara; CACCIATORE, Julio. Arquitectos Europeos y Buenos Aires. 18601940. Buenos Aires, TIAU, 1996.

BRESCIANI, Stella (org.). Imagens da cidade. Séculos XIX e XX. São Paulo, Marco Zero, 1994.

BRITO, Mônica Silveira. A participação da iniciativa privada na produção do espaço urbano: São Paulo, 1890-1911. Dissertação de Mestrado. São Paulo, FFLCH, 2000.

BRITO, Saturnino de. Obras Completas de Saturnino de Brito. Vol. XIX: Defesa contra as inundações (1925-1929). Rio de Janeiro, Imprensa Nacional, 1944.

BRUNO, Ernani da Silva. História e Tradições da Cidade de São Paulo. 3 Vol. $3^{\text {a }}$ ed. São Paulo, Hucitec, 1984.

. Memória da cidade de São Paulo. Depoimentos de moradores e visitantes. 1553-1958. São Paulo, DPH, 1981.

BUENO, Beatriz Piccolotto Siqueira. Desenho e Desígnio: o Brasil dos Engenheiros Militares (1500-1822). Tese de Doutorado. São Paulo, Fauusp, 2001.

BUENOS AIRES (Cidade). Censo General de la Ciudad de Buenos Aires. 1909. Tomo III.

BUENOS AIRES (Cidade). Plano topográfico de la ciudad de Buenos Aires y de todo su municipio. Departamento Topográfico de la Provincia de Buenos Aires, 1867.

BULLRICH, Francisco. (1) Classicismo Romântico; (2) Ecletismo. In: ROMERO, José Luis; ROMERO, Luis Alberto (org.). Buenos Aires. Historia de cuatro siglos. 2 v. Buenos Aires, Abril, 1983.

BUNGE, Alejandro. Una nueva Argentina. Buenos Aires, Ed. Guillermo Kraft, 1940.

BUSCHIAZZO, Mário J. La Arquitectura en la República Argentina 1810-1930. 2v. Buenos Aires, Mac Gaul, 1971.

CALDEIRA, Vasco; NOVICK, Alicia. A cidade arquitetural e a arquitetura urbana. $O$ caso de São Paulo e Buenos Aires. $2^{\mathrm{a}}$ parte. São Paulo, Revista Projeto $\mathrm{N}^{0}$ 85, março 1986. 
CAMPOS, Candido Malta. Os rumos da cidade. Urbanismo e modernização em São Paulo. São Paulo, Senac, 2002.

CANO, Wilson. Raízes da Concentração Industrial em São Paulo. Rio de Janeiro, Difel, 1977

CARMONA, Liliana; GÓMEZ, Maria Julia. Montevideo. Proceso Planificador y Crecimientos. Montevidéu, Facultad de Arquitectura de la Univesidad de la República, 1999.

CARPINTERO, Antonio Carlos Cabral. Brasília: prática e teoria urbanística no Brasil. 1956-1998. Tese de Doutorado. São Paulo, FAUUSP, 1998.

CARPINTÉRO, Marisa Varanda T. A construção de um sonho. Os engenheirosarquitetos e a formulação da política habitacional no Brasil (São Paulo 19171940). Campinas, Editora da Unicamp, 1997.

CARRION, Fernando; LINDA, Mario; CORAGGIO, José Luis. La Investigacion Urbana en América Latina: Caminos Recorridos y por Recorrer. 3v. Quito, CIUDAD, 1989-1990. vol. 3

CARR-SAUNDERS, M. Población Mundial. Mexico, Fondo de Cultura Economica, 1939.

CARS, Jean; PINON, Pierre. Paris-Haussmann: le pari d'Haussmann. Paris, Picard, 1991.

CASTELLS, Manuel. La era de la información. Economía, sociedad y cultura. 3v. Madrid, Alianza, 1997.

Problemas de investigación en sociologia urbana. Buenos Aires, Siglo XXI, 1972.

CEDEX. La Ciudad Iberoamericana. Madrid, MOPU, 1987.

CEDODAL. Fotografía Latinoamericana. Colección Cedodal. Buenos Aires, Cedodal, 2001.

CEHOPU. La ciudad Hispanoamericana. El sueño de un orden. Madrid, Cehopu, s.d.

CHEVALIER, Françoise. América Latina. De la Independencia a nuestros días. México, Fondo de Cultura Económica, 1999.

CIPOLLA, Carlo M. História Econômica da População Mundial. Rio de Janeiro, Zahar, 1977.

COMITATO DELLA CAMERA ITALIANA DI COMMERCIO ED ARTI. Gli italiani nella Repubblica Argentina. Buenos Aires, Compañia Sud-Americana de Billetes de Banco, 1898.

CORAGGIO, José Luis. Hacia una revisión de la teoría de los polos de desarrollo. Santiago, Revista Eure, março 1972. Vol. II. Nº 4.

Politica social y economía del trabajo. Buenos Aires, Miño y Dávila, 1999.

CUNHA, Euclides. Os Sertões. São Paulo, Nova Cultural, 2002.

D'AleSSIO, Vito; SOUKEF, Antonio; ALBARELLO, Eduardo. Avenida Paulista. São Paulo, Dialeto Latin American Documentary, 2002.

DEAN, Warren. A Industrialização de São Paulo (1880-1945). São Paulo, Difel/Edusp, 1971. 
DEL BRENNA, Giovanna Rosso. O Rio de Janeiro de Pereira Passos: uma cidade em questão. Rio de Janeiro, Index, 1985.

DELLE DONNE, Marcella. Teorias sobre a cidade. Lisboa, Edições 70, 1979.

DIEZ, Fernando E. Buenos Aires y algunas constantes en las transformaciones urbanas. Buenos Aires, Fundación Editorial de Belgrano, 1996.

DIFRIERI, Horácio. Atlas de Buenos Aires. 2v. Buenos Aires, Municipalidad de Buenos Aires, 1981.

DONGHI, Túlio Halperin. História da América Latina. Rio de Janeiro, Paz e Terra, 1975.

DOREA, Augusta Garcia Rocha. Aclimação. São Paulo, DPH, 1982.

ECO, Umberto. Era uma vez um milênio... São Paulo, jornal O Estado de São Paulo, 13 de junho de 1999.

ELETROPAULO. Evolução Urbana da Cidade de São Paulo. Estruturação de uma Cidade Industrial: 1872-1945. São Paulo, Eletropaulo, 1989.

História \& Energia, 3: O Metrô da Light. São Paulo, Departamento de Patrimônio Histórico/Eletropaulo, 1986.

A Cidade da Ligth. 1899/1930. Departamento de Patrimônio Histórico/Eletropaulo, 1990.

EMPLASA. Memória Urbana. A Grande São Paulo até 1940. São Paulo, Emplasa / Arquivo do Estado / Imprensa Oficial, 2001.

EMURB. Vilas e Conjuntos Habitacionais. Área Cura Brás-Bresser. São Paulo, Emurb, 1977. Relatório técnico coordenado por Marta Maria Soban Tanaka, realizado na gestão do Dr. Nestor Goulart Reis Filho na vice-presidência técnica da EMURB.

EULÁLIO, Joaquim. Impressões do Brazil no século vinte: sua história, seu povo, commercio, indústrias e recursos. Londres, Lloyd's \& Walter Britain Publishing Company Ltd., 1913.

FABRIS, Annateresa (org.). Ecletismo na Arquitetura Brasileira. São Paulo, Nobel/Edusp, 1987.

FAORO, Raymundo. A questão nacional: a modernização. São Paulo, Revista Estudos Avançados 6(14), 1992.

FAUSTO, Boris (org). Fazer a América. $2^{\mathrm{a}}$ ed. São Paulo, Edusp, 2000.

Brasil: estrutura social e política da $1^{a}$ República. In: BETHELL, Leslie (org). Historia da América Latina: de 1870 a 1930. Volume V. São Paulo, Edusp/Imprensa Oficial; Brasília, Fundação Alexandre de Gusmão, 2002.

FERNANDES, Ana; GOMES, Marco Aurélio A. de Filgueiras (org.). Cidade \& História. Modernização das cidades brasileiras nos séculos XIX e XX. Salvador, UFBA; Faculdade de Arquitetura; ANPUR, 1992.

FERNANDES, Florestan. A integração do negro na sociedade de classes. São Paulo, Edusp/Dominus, 1965.

FERREZ, Gilberto (org.). O Brasil do Primeiro Reinado visto pelo botânico William John Burchell. 1825/1829. Rio de Janeiro, Fund. João Moreira Salles/Fund. Pró-memória, 1981. 
FERREZ, Gilberto. Bahia. Velhas fotografias 1858/1900. Rio de Janeiro, Kosmos Ed.; Salvador, Banco da Bahia Investimentos, 1989.

FERREZ, Marc. O Álbum da Avenida Central. Rio de Janeiro, João Fortes Eng./ Ex Libris, 1982.

FRANCO, Herta. Modernização e melhoramentos urbanos em São Paulo: a gestão do presidente de província João Theodoro (1872-1875). Tese de Doutorado. São Paulo, Fauusp, 2002.

FREIRE, Vitor da Silva. Melhoramentos de São Paulo. São Paulo, Revista Polytechnica, Vol. VI, № 33, fevereiro/março de 1911.

. A planta de Bello Horisonte. São Paulo, Revista Polytechnica Nº 52, 1916.

. A cidade salubre. São Paulo, Revista Polytechnica N 48, out-nov 1914.

FURTADO, Celso Monteiro. Formação Econômica do Brasil. São Paulo, Nacional, 1985.

GADELHA, Maria Regina D'Aquino Fonseca. Os núcleos coloniais e o processo de acumulação cafeeira (1850-1920): contribuição ao estudo da colonização em São Paulo. Tese de Doutorado. São Paulo, FFLCH, 1982.

GARCIA VERDUGO, Francisco R.; MARTÍNEZ LOPEZ, Cristina. Cartografia y fotografia de un siglo de urbanismo en Cordoba. Córdoba, Ayuntamiento de Córdoba, 1994.

GARRABOU, Ramón (ed.). La crisis agrária de fines del siglo XIX. Barcelona, Crítica, 1988.

GIDDENS, Anthony. As conseqüências da modernidade. São Paulo, Unesp, 1991.

GOLDBERG, Marta Beatriz. Nuestros negros: ¿desaparecidos o ignorados? Buenos Aires, Revista Todo es Historia, $N^{0} 393$. Abr/2000.

GOMES, Francisco de Assis Magalhães. A Eletrificação no Brasil. São Paulo, Eletropaulo, outubro de 1986. Revista História \& Energia $\mathrm{N}^{\circ} 2$.

GONZÁLEZ MARTÍNEZ, Elda Evangelina. O Brasil como país de destino para os migrantes espanhóis. In: FAUSTO, Boris (org). Fazer a América. $2^{\mathrm{a}}$ ed. São Paulo, Edusp, 2000.

GORELIK, Adrián; SILVESTRI, Graciela. Imágenes al sur. Sobre algunas hipótesis de James Scobie para el desarrollo de Buenos Aires. In: Buenos Aires, Anales del Instituto de Arte Americano e Investigaciones Esteticas "Mario J. Buschiazzo" N² 27-28, 1989-1991, p. 93-104.

GORELIK, Adrián. La grilla y el parque. Espacio público y cultura urbana en Buenos Aires, 1887-1936. Buenos Aires, Universidad Nacional de Quilmes, 1998.

La máquina reformista - indagaciones sobre la cuadrícula moderna en Buenos Aires. Belo Horizonte, Topos N 1, julho/dezembro 1999.

GOTTDIENER, Mark. A produção social do espaço urbano. São Paulo, Edusp, 1993.

GRAU, Cristina. Borges y la arquitectura. Madrid, Cátedra, 1989.

GRAVAGNUOLO, Benedetto. La progettazione urbana in Europa. 1750-1960. $2^{\mathrm{a}}$ ed. Roma/Bari, Gius. Laterza \& Figli, 1994. 
GROSS, Patrício. Los planes de transformación de Santiago entre finales del siglo XIX y princípios del siglo XX. In: CEDEX. La Ciudad Iberoamericana. Madrid, MOPU, 1987, p. 351-362.

GROSTEIN, Marta Dora. A Cidade Clandestina: os Ritos e os Mitos. Tese de Doutorado. São Paulo, FAUUSP, 1987.

GUÀRDIA, Manuel; MONCLÚS, Francisco Javier; OYÓN, José Luis (dir.). Atlas Histórico de Ciudades Europeas. Vol. I: Península Ibérica. Barcelona, CCCB/Salvat, 1994.

GUTIERREZ, Ramón; TARTARINI, Jorge. El Banco de Boston. La casa central en la Argentina. 1917-1997. Buenos Aires, Fundación Banco de Boston, 1996.

GUTIERREZ, Ramón; GUTMAN, Margarita. Vivienda: ideas y contradicciones (19161956). Resistencia, Instituto Argentino de Investigaciones de Historia de la Arquitectura y del Urbanismo, 1988.

GUTIERREZ, Ramón; MARTíN, Marcelo. Bibliografía iberoamericana de revistas de arquitectura y urbanismo. Madrid, Instituto Español de Arquitectura; Ediciones de las Universidades de Alcala y Valladolid, 1993

GUTIERREZ, Ramón; MÉNDEZ, Patricia. Bibliografía de arquitectura y urbanismo en Iberoamérica, 1980-1993. Alcalá de Henares, Instituto Español de Arquitectura, Universidad de Alcalá y Valladolid; Buenos Aires, Centro de Documentación de Arquitectura Latinoamericana (CEDODAL), 1996

GUTIERREZ, Ramón. Notas para uma bibliografia hispanoamericana de arquitectura. 1526-1875. Resistência, Universidad Nacional del Nordeste, 1972.

. La historiografía de la arquitectura americana. Entre el desconcierto y la dependencia cultural. 1870-1985. Buenos Aires, Revista Summa 215/216, agosto 1985.

Arquitectura y urbanismo en Iberoamérica. Madrid, Cátedra, 1983.

. Arquitetura latino-americana. Textos para reflexão e polêmica. São Paulo, Nobel, 1989

Buenos Aires. Evolución Histórica. Buenos Aires, Editorial Escala, 1990.

. (coord.). Arquitectura latinoamericana en el siglo XX. Barcelona, Lunwerg, 1998.

El laberinto de la enajenación. La historia de la arquitectura própria escrita con ojos ajenos. In: MARCONDES, Neide; BELLOTTO, Manoel. Laberintos e nós: imagem ibérica em terras da América. São Paulo, Unesp/Imprensa Oficial, 1999.

GUTMAN, Margarita; HARDOY, Jorge Enrique. Buenos Aires. Coleção Ciudades de Iberoamérica. Madrid, MAPFRE, 1992.

GUTMAN, Margarita (ed.). Buenos Aires 1910: memoria del porvenir. Buenos Aires, Gobierno de la Ciudad de Buenos Aires/ Faculdade de Arquitetura, Design e Urbanismo da Universidade de Buenos Aires/ IIED-America Latina, 1999.

HADFIELD, William. Brazil, the River Plate and the Falkland Islands; with the Cape Horn Route to Australia. Including notices of Lisbon, Madeira, the Canaries, and Cape Verds. Londres, Longman, Brown, Green and Longmans, 1854.

HALL, Peter. Cidades do amanhã. São Paulo, Perspectiva, 1995. 
HARDOY, Jorge E.; TOBAR, Carlos. La urbanización em América Latina. Buenos Aires, Editorial del Instituto, 1969.

HARDOY, Jorge E.; SCHAEDEL, Richard P. Las ciudades de América Latina y sus áreas de influencia a través de la historia. Buenos Aires, SIAP, 1975.

HARDOY, Jorge Enrique. Ciudades Precolombinas. Buenos Aires, Ed. Infinito, 1964.

Teorias y practicas urbanísticas en Europa entre 1850 y 1930. Su traslado a América Latina. Resistencia, DANA N ${ }^{\text {os }} 37 / 38,1995$, p. 12-30.

HARDOY, Jorge Enrique; LANGDON, María E. El pensamiento regional en Argentina y Chile entre 1850 y 1930. México, Revista Interamericana de Planificación. Vol. XIV. N ${ }^{\text {os }} 55 / 56$. Set/dez. 1980.

HARDOY, Jorge Enrique e MORSE, Richard P. Repensando la ciudad de América Latina. Buenos Aires, Grupo Editor Latinoamericano, 1988.

Nuevas perspectivas en los estudios sobre historia urbana latinoamericana. Buenos Aires, Grupo Editor Latinoamericana, 1989.

HARVEY, David. Condição pós-moderna. São Paulo, Loyola, 1998.

. A justiça social e a cidade. São Paulo, Hucitec, 1980.

Do gerenciamento ao empresariamento: a transformação da administração urbana no capitalismo tardio. São Paulo, Revista Espaço \& Debates, 1996.

HECK, Marina (coord.). Grandes Metrópolis de América Latina. São Paulo, Fondo de Cultura Económica/ Memorial da América Latina, 1993.

HOBSBAWM, Eric J. A era dos Impérios. 1875-1914. $7^{\mathrm{a}}$ ed. Rio de Janeiro, Paz e Terra, 1988.

HOBSBAWM, Eric J. Tempos interessantes. Uma vida no século $X X$. São Paulo, Companhia das Letras, 2002.

HOLANDA, Sérgio Buarque de. Raízes do Brasil. Estudos Brasileiros, 1. 6ª . ed. Rio de Janeiro, José Olympio, 1971.

HOMEM, Maria Cecília Naclério. O palacete paulistano e outras formas urbanas de morar da elite cafeeira 1867-1918. São Paulo, Martins Fontes, 1996.

HUGON, Paul. Demografia Brasileira. São Paulo, Atlas/Edusp, 1973.

IANNI, Octavio. Teorias da globalização. $8^{a}$ ed. Rio de Janeiro, Civilização Brasileira, 2000.

IOKOI, Zilda Márcia Gricoli (org.). Bibliografia Comentada: Urbanização, Industrialização e Migrações em São Paulo - Séculos XIX e XX. São Paulo, FFLCH-USP, 1995.

KLIASS, Rosa Grená. A evolução dos parques urbanos na cidade de São Paulo. Dissertação de Mestrado. São Paulo, FAUUSP, 1989.

KORN, Francisco. La gente distinguida. In: ROMERO, José Luis; ROMERO, Luis Alberto (org.). Buenos Aires. Historia de cuatro siglos. 2 v. Buenos Aires, Abril, 1983.

KORN, Francis; TORRE, Lidia de la. La vivienda en Buenos Aires 1887-1914. Buenos Aires, Desarrollo Económico, julho-setembro 1985. Vol. 25. № 98. 
KÜHL, Beatriz Mugayar. Arquitetura do Ferro e arquitetura ferroviária em São Paulo. Reflexões sobre a sua preservação. São Paulo, Ateliê Editorial/Fapesp/Secretaria da Cultura, 1998.

LECUONA, Diego E. La vivienda de "criollos" y "extranjeros"en el siglo XIX. Tucumán, Instituto Argentino de Investigaciones de Historia de la Arquitectura y del Urbanismo, 1984.

LEFEBVRE, Henri. El Materialismo Dialéctico. Buenos Aires, Ed. La Pleyade, 1971.

LEME, Maria Cristina da Silva. Revisão do Plano de Avenidas: um Estudo de Planejamento Urbano, 1930. Tese de Doutorado. São Paulo, FAUUSP, 1990.

(coord.). Urbanismo no Brasil 1895-1965. São Paulo, Studio Nobel/FAUUSP/Fupam, 1999.

A formação do urbanismo como disciplina e profissão: São Paulo na primeira metade do século XX. In: RIBEIRO, Luiz César de Queiroz; PECHMAN, Robert (org.). Cidade, povo e nação. Rio de Janeiro, Civilização Brasileira, 1996.

LEMOS, Amalia Ines Geraiges de. Modernidade e Metrópoles Latino-americanas. Rio de janeiro e Buenos Aires. Tese de Livre-docência. São Paulo, FFLCH-USP, 1996.

LEMOS, Carlos Alberto Cerqueira. Cozinhas, etc.: um estudo sobre as zonas de serviço da casa paulista. São Paulo, Perspectiva, 1978.

Alvenaria Burguesa: breve história da arquitetura residencial de tijolos em São Paulo a partir do ciclo econômico liderado pelo café. $2^{2}$ ed. São Paulo, Nobel, 1989.

. Ramos de Azevedo e seu escritório. São Paulo, Pini, 1993.

LIERNUR, Jorge F. e SILVESTRI, Graciela. El umbral de la metrópolis. Transformaciones técnicas y cultura en la modernización de Buenos Aires (1870-1930). Buenos Aires, Editorial Sudamericana, 1993.

LIERNUR, Jorge Francisco. Arquitectura em la Argentina del siglo XX. La construcción de la modernidad. Buenos Aires, Fondo Nacional de las Artes, 2001.

LOUREIRO, Maria Amélia Salgado. A cidade e as áreas verdes. São Paulo, Secretaria de Serviços e Obras da Prefeitura do Município, 1979.

LOUSTAU, César J. Influencia de Italia en la arquitectura uruguaya. Montevidéu, Istituto Italiano di Cultura, 1998.

LOVE, Joseph L. A República brasileira: federalismo e regionalismo (1889-1937). In: BETHELL, Leslie (org). Historia da América Latina: de 1870 a 1930. Volume V. São Paulo, Edusp/Imprensa Oficial; Brasília, Fundação Alexandre de Gusmão, 2002.

LUNA, Félix. Breve Historia de los Argentinos. Buenos Aires. Editorial Planeta Argentina, 1993.

MacCANN, William. Two thousand mile's ride through the Argentine Provinces: Being an account of the natural products of the country, and habits of the people; with a historical retrospect of the Rio de la Plata, Montevideo, and Corrientes. Londres, Smith, Elder \& Co., 1853. 
MACHADO, António de Alcântara. Brás, Bexiga e Barra Funda: notícias de São Paulo. Ed. Fac-similar. São Paulo, Imprensa Oficial do Estado/Arquivo do Estado, 1982.

MADERO, Guillermo. Historia del Puerto de Buenos Aires. Buenos Aires, Companía Impresora, 1955.

MAIA, Francisco Prestes; CINTRA, João Florense de Ulhôa. Os grandes melhoramentos de São Paulo. São Paulo, Boletim do Instituto de Engenharia N0 29, julho a outubro de 1925. p. 192.

MAIA, Francisco Prestes. Estudo de um Plano de Avenidas para a Cidade de São Paulo. São Paulo, Melhoramentos, 1930.

MARCONDES, Neide; BELLOTTO, Manoel. Laberintos e nós: imagem ibérica em terras da América. São Paulo, Unesp/Imprensa Oficial, 1999.

MARICATO, Ermínia. As idéias fora do lugar e o lugar fora das idéias. In. ARANTES, Otília; VAINER, Carlos; MARICATO, Ermínia. A cidade do pensamento único. Desmanchando consensos. $2^{\mathrm{a}}$ ed. Petrópolis, Vozes, 2000.

MARTIN, Jules. São Paulo antigo e São Paulo moderno: álbum de fotografias. São Paulo, s.n., 1905.

MARTINS, Antônio Egidio. São Paulo antigo (1554 a 1910). São Paulo, Conselho Estadual de Cultura, s.d., p. 311.

MARTÍNEZ, Elda Evangelina González. O Brasil como país de destino para os migrantes espanhóis. In: FAUSTO, Boris (org). Fazer a América. $2^{\mathrm{a}}$ ed. São Paulo, Edusp, 2000.

MARX, Murillo. Cidade Brasileira. São Paulo, Melhoramentos/Edusp, 1980.

. Cidade no Brasil terra de quem? São Paulo, Edusp/Nobel, 1991.

. Cidade no Brasil. Em que termos? São Paulo, Studio Nobel, 1999.

MARX, Karl. Formações Econômicas Pré-capitalistas. $2^{a}$ ed. Introdução de Eric Hobsbawm. Rio de Janeiro, Paz e Terra, 1977.

MATOS, Odilon Nogueira de. A cidade de São Paulo no século XIX. São Paulo, Revista de História, 1955.

MEDRANO, Ricardo Hernán. Arquitetura e urbanismo em São Paulo e Buenos Aires na virada do século XIX: algumas considerações preliminares. In: MACHADO, Denise Pinheiro (org.). Anais do IV Seminário de História da Cidade e do Urbanismo. Rio de Janeiro, UFRJ/Prourb, 1996.

Resumos das aulas do Prof. Nestor Goulart Reis Filho na disciplina AUH 237 Urbanização e Urbanismo no Brasil I. Cadernos de Pesquisa do LAP 19. São Paulo, FAUUSP, 1997.

MEYER, Regina Maria Prosperi. Metrópole e urbanismo: São Paulo anos 50. Tese de Doutorado. São Paulo, FAUUSP, 1991.

MOLAS, Ricardo Rodríguez. Intinerário de los negros en el Rio de la Plata. Buenos Aires. Revista Todo es Historia, Nº 162. Nov/1980.

MOLINARI, Ricardo Luis. Buenos Aires 4 Siglos. Buenos Aires, TEA, 1980.

MONBEIG, Pierre. Pioneiros e fazendeiros de São Paulo. São Paulo, Hucitec/Polis, 1984. 
MORSE, Richard M. Formação Histórica de São Paulo. São Paulo, Difusão Européia do Livro, 1970.

MOTA, Carlos Guilherme (org). Viagem incompleta. A experiência brasileira. Formação: histórias. São Paulo, SENAC São Paulo, 2000.

(org). Viagem incompleta. A experiência brasileira. A grande transação. São Paulo, SENAC São Paulo, 2000.

(org). Brasil em perspectiva. São Paulo, Difel, 1968.

. Ideologia da cultura brasileira. São Paulo, Ática, 1998.

. América Latina: em busca da memória comum. Ciência e Cultura 38(1).

MOTTA, Cesário et alli. Relatório da Comissão de Exame e Inspecção das Habitações Operárias e Cortiços no Districto de Santa Ephigênia. São Paulo, Tipographia Vanordem \& Comp., 28 de março de 1894.

MOURA, Paulo Cursino de Almeida. São Paulo de Outrora (evocações da metrópole). Belo Horizonte, Ed. Itatiaia; São Paulo, Ed. da Universidade de São Paulo, 1980.

NASCIMBENE, Mário C. História de los Italianos en la Argentina. 1835-1920. $2^{\mathrm{a}}$ ed. Buenos Aires, CEMLA, 1987.

NOVICK, Alicia. La traza de las grandes residências en la Recoleta, Buenos Aires (1880-1920). In: Buenos Aires, Anales del Instituto de Arte Americano e Investigaciones Esteticas "Mario J. Buschiazzo" N² 26, 1988. p. 63-69.

NOVICK, Alicia; GIUNTA, Rodolfo. La casa de patios y la legislación urbanística. Buenos Aires a fines del siglo XVIII. Buenos Aires, Medio Ambiente y Urbanización, jun. set. 1994. Ano 12. N ${ }^{\text {os }} 47-48$.

NOVICK, Alicia; PICCIONI, Raúl. Carlos Maria Della Paolera o la amnésia del urbanismo argentino. Buenos Aires, Anales del Instituto de Arte Americano e Investigaciones Esteticas "Mario J. Buschiazzo" Nº 30, 1994-95. p. 77-100.

ORTIZ, Federico F.; MANTERO, Juan C.; GUTIERREZ, Ramón; LEVAGGI, Abelardo. La arquitectura del liberalismo en la Argentina. Buenos Aires, Ed. Sudamericana, 1968.

ORTIZ, Renato. Mundialização e Cultura. São Paulo, Brasiliense, 1994.

ORTIZ, Ricardo M. Historia Económica de la Argentina. $4^{\underline{a}}$ ed. Buenos Aires, Plus Ultra, 1974.

OSELLO, Marco Antonio. Planejamento urbano em São Paulo (1899-1961): introdução ao estudo dos planos e realizações. Dissertação de Mestrado 4a. ed. São Paulo, EAESP/FGV, 1983.

OTTONI, Dácio Araújo Benedicto. São Paulo Rio de Janeiro. Séculos XIX-XX. Aspectos da formação dos seus espaços centrais. Tese de Doutorado. São Paulo, FAUUSP, 1972.

PASSAGLIA, Luiz Alberto do Prado. O Italianizante. A arquitetura no período de 1880 a 1914 na cidade de São Paulo. São Paulo, FAUUSP, 1984.

PAULA, Alberto S. J. de. Una modificación del diseño urbano porteño proyectada en 1875. Buenos Aires, Anales del IAAIE "Mário J. Buschiazzo" №19, 1966. p. 71 a 77. 
La ciudad de La Plata. Sus tierras y su arquitectura. Buenos Aires, Ediciones del Banco de la Provincia de Buenos Aires, 1987.

PEREIRA, Luiz. Urbanização "sociopática" e tensões sociais na América Latina. In: ALMEIDA, Fernando Lopes (org.). A Questão Urbana na América Latina. Rio de Janeiro, Forense-Universitária, 1978.

PEREIRA, Paulo César Xavier. Espaço, Técnica e Construção: o desenvolvimento das técnicas construtivas e a urbanização do morar em São Paulo. São Paulo, Nobel, 1988.

PESCUMA, Augusto. Las águas de Buenos Aires. Buenos Aires, Revista Encrucijadas UBA, março de 1997. Ano 3, Nº 5, p. 88-89.

PETRINA, Alberto. Buenos Aires. Guia de Arquitectura. Buenos Aires, Municipalidad de la ciudad de Buenos Aires; Sevilha, Consejería de Obras Públicas y Transportes, 1994.

PINTO, Adolpho Augusto. História da viação pública de São Paulo. São Paulo, Governo do Estado de São Paulo, 1977.

PINTO, Maria Inez Machado Borges. Cotidiano e sobrevivência: a vida do trabalhador pobre na cidade de São Paulo (1890-1914). São Paulo, Edusp, 1994.

PRADO JUNIOR, Caio. Evolução política do Brasil e outros estudos. São Paulo, Brasiliense, 1961.

História Econômica do Brasil. $3^{\mathrm{a}}$ ed. São Paulo, Brasiliense, 1953.

QUEIROZ, Suely Robles Reis de. São Paulo. Coleção Ciudades de Iberoamérica. Madrid, MAPFRE, 1992.

RADOVANOVIC, Elisa. Planos de Buenos Aires - Siglos XIX y XX. Buenos Aires, Cedodal, 2001.

RAMA, Angel. A cidade das letras. São Paulo, Brasiliense, 1985.

RAMOS, Jorge. El parque Tres de Febrero: de Garay a Noel. In: BERJMAN, Sonia (comp.). El tiempo de los parques. Buenos Aires, IAAIE "Mário Buschiazzo", 1992.

RECOPILACIÓN DE LEYES DE LOS REYNOS DE LAS INDIAS. Vol. II. Madrid, 1943. Ed. Fac. de 1791.

REIS FILHO, Nestor Goulart. Urbanização e Teoria. São Paulo, Edição do autor, 1967.

Contribuição ao estudo da evolução urbana do Brasil (1500-1720). São Paulo, Pioneira, 1968.

. Quadro da Arquitetura no Brasil. 5a ed. São Paulo, Perspectiva, 1983.

. Aspectos da História da Engenharia Civil em São Paulo 1860-1960. São Paulo, Kosmos, 1989.

Algumas experiências urbanísticas no início da República: 1890-1920. Cadernos do LAP 1. São Paulo, FAUUSP, 1994.

- São Paulo e outras cidades: produção social e degradação dos espaços urbanos. São Paulo, Hucitec, 1994. 
Memória do transporte rodoviário. Desenvolvimento das atividades rodoviárias de São Paulo. São Paulo, CPA, s.d.

Algumas Raízes. Origens dos trabalhos regulares de pesquisa sobre História da Arquitetura, da Urbanização e do Urbanismo no Brasil. O Estudo da História na Formação do Arquiteto. São Paulo, Revista Pós Número Especial, 1994.

Notas sobre o Urbanismo no Brasil - Primeira parte: período colonial. Cadernos do LAP 8. São Paulo, FAUUSP, julho-agosto de 1995.

- Notas sobre o Urbanismo no Brasil - Segunda parte: séculos XIX e XX. Cadernos do LAP 9. São Paulo, FAUUSP, setembro-outubro de 1995.

Campos Elíseos. A casa e o bairro. A tecnologia da construção civil em 1900. São Paulo, Secretaria da Ciência, Tecnologia e Desenvolvimento Econômico, s.d.

Racionalismo e Proto-Modernismo na obra de Victor Dubugras. São Paulo, FBSP, 1997.

Notas sobre História da Arquitetura e aparência das vilas e cidades. Cadernos de Pesquisa do LAP 20. São Paulo, FAUUSP, julho-agosto de 1997.

Cultura e Estratégias de Desenvolvimento. Cadernos do LAP 23. São Paulo, FAUUSP, janeiro-fevereiro 1998.

Notas sobre a evolução dos estudos de História da Urbanização e do Urbanismo no Brasil. Cadernos do LAP 29. São Paulo, FAUUSP, jan. jun. 1999

Urbanização e modernidade: entre o passado e o futuro (1808-1945). In: MOTA, Carlos Guilherme (org). Viagem incompleta. A experiência brasileira. A grande transação. São Paulo, SENAC São Paulo, 2000, p.. 108.

. Imagens de Vilas e Cidades do Brasil Colonial. São Paulo, Edusp/Imprensa Oficial do Estado, 2001.

REVISTA DE ENGENHARIA. Melhoramentos de São Paulo. A primeira secção do plano Bouvard. Os "blocos" do valle Anhangabahú. São Paulo, Revista de Engenharia, Vol.1, № 4, 10 de setembro de 1911.

REVISTA DE ENGENHARIA. O relatorio do Sr. Bouvard. V1. Junho de 1911 a maio de 1912, p. 42-43.

RIBEIRO, Luiz César de Queiroz; PECHMAN, Robert (org.). Cidade, povo e nação. Rio de Janeiro, Civilização Brasileira, 1996.

ROBLEDO, Ricardo. Crisis agrária y éxodo rural: emigración española a ultramar, 1880-1920. In: GARRABOU, Ramón (ed.). La crisis agrária de fines del siglo XIX. Barcelona, Crítica, 1988.

ROFMAN, Alejandro Boris. Dependência, estructura de poder y formación regional en América Latina. $2^{\text {a }}$ ed. México, Siglo Veintiuno Editores, 1977.

ROFMAN, Alejandro B.; ROMERO, Luis A. Sistema Socioeconomico y estructura regional en la Argentina. $2^{\mathrm{a}}$ ed. Buenos Aires, Amorrortu, 1997.

ROLNIK, Raquel. A cidade e a lei. Legislação, política urbana e territórios na cidade de São Paulo. São Paulo, Studio Nobel/FAPESP, 1997. 
ROMERO, José Luis; ROMERO, Luis Alberto (org.). Buenos Aires. Historia de cuatro siglos. 2 v. Buenos Aires, Abril, 1983.

ROMERO, José Luis. Latinoamérica: las ciudades y las ideas. $4^{\mathrm{a}}$ ed. Buenos Aires, Siglo XXI, 1986.

ROSSI, Aldo. La arquitectura de la ciudad. Barcelona, Gustavo Gili, 1971.

SALAS, Jonás Figueroa. La ciudad lineal en Chile (1910-1930). Resistencia, DANA N ${ }^{\text {os }}$ 37/38, 1995. p. 64-70.

SALGADO, Ivone. Condições sanitárias das cidades brasileiras de fins do período colonial (1777-1822): teorias e práticas em debate. In: Colóquio Internacional Universo Urbanístico Português 1415-1822. Actas ... Lisboa, CNCDP, 2001.

SALMONI, Anita; DEBENEDETTI, Emma. Arquitetura italiana em São Paulo. São Paulo, Perspectiva, 1981.

SAMPAIO, Maria Ruth Amaral de (Coord.). Catálogo Bibliográfico. Transformações Urbanas e Mercado de Trabalho em São Paulo 1870/1954. São Paulo, FAUUSP, 1994.

SAMPAIO, Maria Ruth Amaral de. O papel da iniciativa privada na formação da periferia paulistana. São Paulo, Revista Espaço \& Debates N ${ }^{0} 37,1994$.

SÁNCHEZ, Alejandro. Barcelona 1888-1929. Madrid, Alianza, 1992.

SANCHEZ-ALBERNOZ, Nicolás. La población de América Latina, 1859-1930. In: BETHELL, Leslie (ed.). História de América Latina. Vol. 7: América Latina: Economia y Sociedad. 1870-1930. Barcelona, Crítica, 2000.

SALGUEIRO, Heliana Angotti (org.). Cidades Capitais do Século XIX. São Paulo, Edusp, 2001.

SANTOS, Carlos José Ferreira dos. Nem tudo era italiano. São Paulo e pobreza (1890-1915). São Paulo, Annablume, 1998.

SANTOS, Milton. Espaço e Método. São Paulo, Nobel, 1985.

SÃO PAULO (Cidade). Mappa Topographico do Municipio de São Paulo. São Paulo, Prefeitura Municipal de São Paulo, 1934. Levantamento realizado pela empresa Sara Brasil, em 1930.

SÃO PAULO (Cidade). Museu Histórico da Imagem Fotográfica da Cidade de São Paulo. São Paulo, 1979.

SÃO PAULO (Cidade). São Paulo antigo: plantas da cidade. São Paulo, Comissão do IV Centenário, 1954.

SÃO PAULO (Cidade). Planta da Cidade de São Paulo. Companhia Cantareira e Esgotos, 1881.

SÃO PAULO (Cidade). Planta Geral da Capital de São Paulo. Gomes Cardim, 1897.

SÃO PAULO (ESTADO). Annuario Demographico. Estado de São Paulo. Secção de Estatística Demographo-Sanitaria. 1914.

SÃo PAULO. São Paulo Antigo, São Paulo Moderno: Álbum Comparativo. São Paulo, Melhoramentos, 1953.

SARMIENTO, Domingo Faustino. Facundo: civilização e barbárie. Petrópolis, Vozes, 1996.

SASSEN, Saskia. As cidades na economia mundial. São Paulo, Studio Nobel, 1998. 
SCHERER, Rebeca. Descentralização e Planejamento Urbano no Município de São Paulo. Tese de Doutorado. São Paulo, FAUUSP, 1987.

. Notas sobre Planejamento e Método. Cadernos de Pesquisa do LAP 10. São Paulo, FAUUSP, nov. dez. 1995.

Sistematização Crítica do Conjunto dos Trabalhos. Tese de Livre Docência. São Paulo, FAUUSP, 1994.

SCHIAFFINO, Eduardo. Urbanizacion de Buenos Aires. Buenos Aires, Manuel Gleizer ed., 1927.

SCHTEINGART, Martha e TORRES, Horácio. Processos Sociais e Estruturação Metropolitana na América Latina (Estudo de Casos). In: ALMEIDA, Fernando Lopes (org.). A Questão Urbana na América Latina. Rio de Janeiro, ForenseUniversitária, 1978.

SCHWARZER, Jorge. La implantación industrial. In: ROMERO, José Luis; ROMERO, Luis Alberto (org.). Buenos Aires. Historia de cuatro siglos. 2 v. Buenos Aires, Abril, 1983.

SCOBIE, James R. Buenos Aires. Del centro a los barrios. 1870-1910. Buenos Aires, Solar/Hachette, 1977.

SEBRELI, Juan José. Buenos Aires, vida cotidiana y alienación. $15^{\mathrm{a}}$ ed. Buenos Aires, Ediciones Siglo Veinte, 1990.

Secretaria Municipal de Planejamento. Bens Culturais Arquitetônicos no Município e na Região Metropolitana de São Paulo. São Paulo, 1984.

SEGAWA, Hugo. Ao amor do público. Jardins no Brasil. São Paulo, Studio Nobel/Fapesp, 1996.

. Arquiteturas no Brasil. 1900-1990. São Paulo, Edusp, 1997.

. Prelúdio da Metrópole. Arquitetura e urbanismo em São Paulo na passagem do século XIX ao XX. São Paulo, Ateliê Editorial, 2000.

SICA, Paolo. Historia del Urbanismo. El siglo XIX. 2 vol. $2^{\text {a }}$ ed. Madrid, Instituto de Estudios de Administración Local, 1981.

SILBERSTEIN, Carina Frid de. A imigração espanhola na Argentina. In: FAUSTO, Boris (org). Fazer a América. 2a ed. São Paulo, Edusp, 2000.

SILVA, Geraldo Gomes da. Arquitetura do ferro no Brasil. São Paulo, Nobel, 1987.

SIMÕES JUNIOR, José Geraldo. O Setor de Obras Públicas e as Origens do Urbanismo na Cidade de São Paulo. Dissertação de Mestrado. São Paulo, Fundação Getúlio Vargas, 1990.

Anhangabaú - História e Urbanismo. Tese de Doutorado. São Paulo, Fauusp, 1995.

SINGER, Paul Israel. Economia Política da Urbanização. $2^{\mathrm{a}}$ ed. São Paulo, Brasiliense, 1975.

SOJA, Edward W. Geografias Pós-Modernas. A reafirmação do espaço na teoria social crítica. Rio de Janeiro, Jorge Zahar, 1993.

SOLSONA, Justo et alli. La Avenida de Mayo. Un proyecto inconcluso. Buenos Aires, FADU-UBA, 1990. 
SOMEKH, Nadia. A cidade vertical e o urbanismo modernizador. São Paulo, Studio Nobel/Edusp/Fapesp, 1997.

SOUKEF, Antonio; MAZZOCO, Maria Inês Dias; ALBARELLO, Eduardo. Cem anos Luz. São Paulo, Dialeto Latin American Documentary, 2000.

SOUZA, Maria Adelia Aparecida de. Identidade da metrópole: a verticalização em São Paulo. São Paulo, Hucitec/Edusp, 1994.

STIEL, Waldemar Correa. História dos transportes coletivos em São Paulo. São Paulo, McGraw-Hill/Edusp, 1978.

SUÁREZ, Odília E. Planes y Códigos para Buenos Aires. 1925-1985. $2^{a}$ ed. Buenos Aires, Ediciones Fadu, 1994.

TARANTINI, Jorge. La polemica Bouvard-Jaeschke (Buenos Aires 1907-1911). Resistencia, DANA № 30, 1991.

Arquitectura Ferroviária. Buenos Aires, Ediciones Colihue, 2001.

TAUNAY, Affonso de Escragnolle. História da Cidade de São Paulo. São Paulo, Melhoramentos, 1954.

TEIXEIRA, Palmira Petratti. A instituição da São Paulo Railway. São Paulo, Kid's, 2000.

TELLA, GUILLERMO. Reglamentación Edilicia y zonificación urbana. Buenos Aires 1880/1900. Buenos Aires, 1993.

TERÁN, Fernando de. Historia del urbanismo en España. Siglos XIX y XX. Madri, Cátedra, 1999.

TOCA, Antonio. Nueva arquitectura em América Latina: presente y futuro. México, Gustavo Gili, 1990.

TOLEDO, Benedito Lima de. Prestes Maia e as origens do urbanismo moderno em São Paulo. São Paulo, Empresa das Artes, 1996.

São Paulo: três cidades em um século. $2^{\underline{a}}$ ed. aum. São Paulo, Duas Cidades, 1983.

TORRES, Horacio A. Evolución de los procesos de estructuración espacial urbana. El caso de Buenos Aires. Buenos Aires, Desarrollo Económico, Vol. 15, N 58 , julho-setembro 1975.

TOURAINE, Alain. Crítica da Modernidade. $6^{\text {a }}$ ed. Petrópolis, Vozes, 1999.

TRENTO, Ângelo. Do outro lado Atlântico; tradução Mariarosária Fabris (capítulos 2 a 5), Eduardo Brandão (capítulos 1, 6 e 7). São Paulo, Nobel/Istituto Italiano di Cultura di San Paolo/ Instituto Cultural Ítalo-Brasileiro, 1988.

TRIFILO, S. Samuel. La Argentina vista por los viajeros ingleses 1810-1860. Buenos Aires, Ed. Gure, 1959.

VAZQUEZ RIAL, Horácio (org.). Buenos Aires 1880-1930. La capital de un império imaginário. Madrid, Alianza, 1996.

VILLAÇA, Flávio. A estrutura territorial da metrópole sul brasileira: áreas residenciais e comerciais. Tese de Doutorado. São Paulo, FFCLH, 1978.

. Espaço intra-urbano no Brasil. São Paulo, Studio Nobel/ Fapesp/ Lincoln Institute, 1998. 
. Efeitos do espaço sobre o social na metrópole brasileira. In: CEDESP. Metropolização e globalização: conhecendo a cidade de São Paulo. São Paulo, CEDESP, 1999.

VILLANUEVA MUÑOZ, Emilio Angel. Urbanismo y arquitectura en la Almería moderna (1780-1936). Almería, Cajal, 1983.

VIÑUALES, Graciela Maria. Viviendas en Buenos Aires. Ideas y realidades de la arquitectura residencial en Buenos Aires a fines del siglo XIX. Resistencia, DANA N ${ }^{0}$ 13, maio 1982.

VRIES, J. de. La Urbanización de Europa 1500-1800. Barcelona, Crítica, 1987.

WAISMAN, Marina (coord.). Documentos para una historia de la arquitectura argentina. Buenos Aires, Ediciones Summa, 1988.

WEBER, Max. The city. Tradução e edição de Don Martindale e Gertrud Neuwirth. Glencoe III, Free Press, 1958.

WOLFF, Silvia Ferreira Santos. Jardim América: o primeiro bairro-jardim de São Paulo e sua arquitetura. São Paulo, Edusp, 2001.

WRIGHT, Marie Robinson. The New Brazil. Its resources and attractions. Philadelphia, George Barrie \& Sons, 1907.

YUJNOVSKY, Oscar. Politicas de vivienda en la ciudad de Buenos Aires (1880-1914). Buenos Aires, Desarrollo Economico vol. 14. N 54, julho/setembro 1974. 


\section{ACERVOS CONSULTADOS}

Em São Paulo:

- Bibliotecas da Universidade de São Paulo: Faculdade de Arquitetura e Urbanismo, Faculdade de Filosofia, Letras e Ciências Humanas, Faculdade de Economia e Administração, Escola Politécnica e Instituto de Estudos Brasileiros.

- Acervo do LAP - Laboratório de Estudos da Urbanização, Arquitetura e Preservação.

- Biblioteca Municipal Mário de Andrade.

- Arquivo Histórico Municipal.

Em Buenos Aires:

- Archivo General de la Nación:

- Legislatura (antigo Consejo Deliberante):

- Instituto de Arte Americano e Investigaciones Estéticas "Mário Buschiazzo", na Facultad de Arquitectura, Diseño y Urbanismo, da Universidade de Buenos Aires.

- CEDODAL

- Museo Mitre

- Museo Histórico de la Ciudad de Buenos Aires

- Instituto Histórico de la Ciudad de Buenos Aires

- Archivo Histórico de la Ciudad de Buenos Aires

\section{Em Barcelona:}

- Faculdade de Arquitetura e Urbanismo da Universidade Politécnica da Catalunha (UPC).

- Colégio de Arquitetos.

- Arquivo histórico (Casa de L'Ardiaca)

- Instituto de Estudios Almerienses.

- Consejería de Cultura e Consejería de Obras Pública y Vivienda da Junta de Andaluzia.

Em Montevidéu:

- Faculdade de Arquitetura da Universidade da República. 


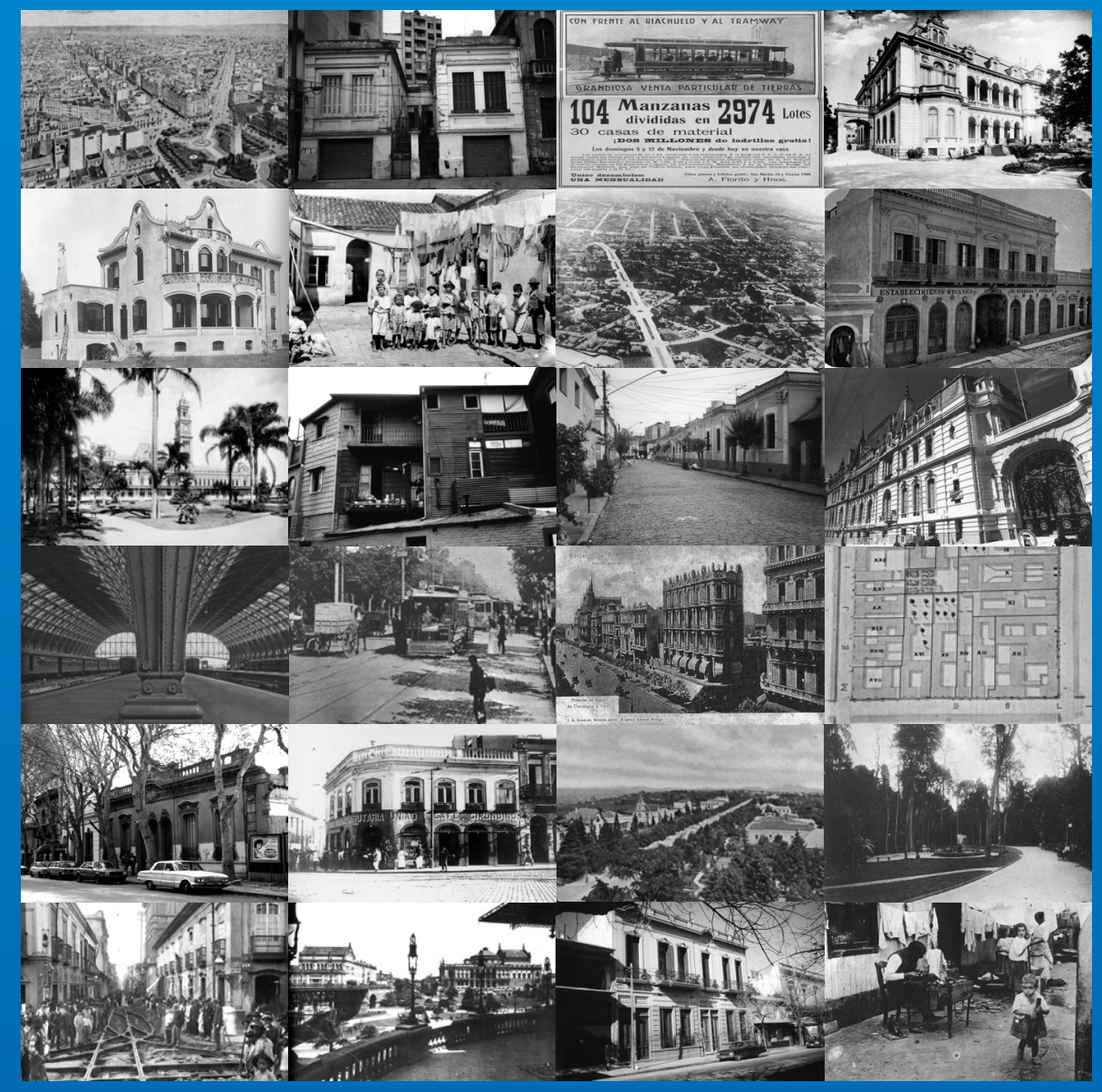

